\section{Pacific Northwest}

National Laboratory

Operated by Battelle for the

U.S. Department of Energy

\section{Data Package for Past and Current Groundwater Flow and Contamination Beneath Single-Shell Tank Waste Management Areas}

D. G. Horton

January 2007

Prepared for CH2M HILL Hanford Group, Inc. and the U.S. Department of Energy under Contract DE-AC05-76RL01830 


\title{
Data Package for Past and Current Groundwater Flow and Contamination Beneath Single-Shell Tank Waste Management Areas
}

\author{
D. G. Horton
}

January 2007

Prepared for CH2M HILL Hanford Group, Inc.

and the U.S. Department of Energy

under Contract DE-AC05-76RL01830

Pacific Northwest National Laboratory

Richland, Washington 99352 


\section{Summary}

Past Hanford Site operations caused large changes in the uppermost aquifer beneath the site in terms of both hydrologic properties and water quality. Disposal of large volumes of liquid waste formed groundwater mounds up to about $26 \mathrm{~m}$ above the pre-Hanford Site water table (Last et al. 1994). The groundwater mounds caused increases in flow velocity and large changes in flow direction that moved contamination throughout the unconfined aquifer in many localized places. Historical water-level measurements were used to reconstruct flow directions through time in the 200 East and 200 West Areas. Today, groundwater flow directions are generally toward the east below most of the 200 West Area except where influenced by pump-and-treat operations. Groundwater flow directions are more variable in 200 East Area due to residual influences of B Pond. There is considerable uncertainty in the flow direction in the northern part of 200 East Area because of thinning of the aquifer against basalt subcrops and the extremely low gradient.

Aquifer testing has shown that vertical hydraulic gradients exist in some wells in the 200 West Area. Vertical flow is upward in some places and downward in other places. The reason for the vertical flow is not known for certain. Nevertheless, vertical flow has important implications pertaining to (1) the representativeness of groundwater samples collected from monitoring wells and (2) the vertical distribution of contaminants in the aquifer.

The major contaminants of concern in the groundwater below and locally adjacent to all single-shell tank waste management areas (WMAs) in 200 West Area are carbon tetrachloride, technetium-99, and nitrate. Chromium and tritium are contaminants present at WMAs T, TX-TY, and S-SX; iodine-129 is of concern at WMA TX-TY and fluoride is of concern at WMA T. The groundwater contaminants of concern below all single-shell tank WMAs in 200 East Area are nitrate, technetium-99, and tritium. Sulfate, uranium, cobalt-60, and cyanide are also of concern at WMA B-BX-BY, and cyanide is of concern at WMA C.

Vertical concentration gradients are known to exist in the upper unconfined aquifer at several singleshell tank WMAs:

- Around WMA T, maximum technetium-99 concentrations occur at the water table in some wells and $10 \mathrm{~m}$ below the water table in other wells east of the WMA.

- Around WMA TX-TY, maximum concentrations of nitrate, technetium-99, and iodine-129 are within $1 \mathrm{~m}$ of the water table in the high concentration plume east of the WMA.

- Around WMA S-SX, chromium, nitrate, and technetium-99 are present throughout the upper $23 \mathrm{~m}$ of the unconfined aquifer near the center of the plume south of the WMA. Technetium-99 and nitrate decrease rapidly with depth in the aquifer at a well near the northern edge of the plume.

- Around WMA B-BX-BY, the concentration of tritium increases with increasing depth at one well. The concentrations of technetium-99 and nitrate are high in a zone at the base of the aquifer in another well at WMA B-BX-BY. 
The vertical concentration gradients are probably a function of several characteristics including distance to source area, salinity of waste fluids, and vertical hydraulic flow in the wells.

Comparing the nitrate, technetium-99, and chromium concentrations in groundwater with concentrations in pore water representing leaked tank fluids suggests that tank waste has influenced groundwater at WMA T and WMA S-SX. Similar comparisons at WMA TX-TY and WMA B-BX-BY do not show similarities between groundwater, pore water and estimated tank fluid composition. 


\section{Acknowledgments}

The author wishes to acknowledge F. M. Mann at CH2M HILL Hanford Group, Inc. (Richland, Washington) for providing project funding and technical guidance. Technical reviews were greatly appreciated and provided by R. J. Serne, K. M. Krupka, R. W. Bryce, and C. P. Beus (Pacific Northwest National Laboratory), M. I. Wood (Fluor Hanford, Inc.), and D. A. Myers (CH2M HILL Hanford Group, Inc.). Dr. A. G. Law, of Richland, Washington, provided an excellent, independent, technical review of the entire document. Thanks go to L. F. Morasch (Pacific Northwest National Laboratory) for completing the editorial review and to K. R. Neiderhiser (Pacific Northwest National Laboratory) for final formatting of this technical report. 


\section{Contents}

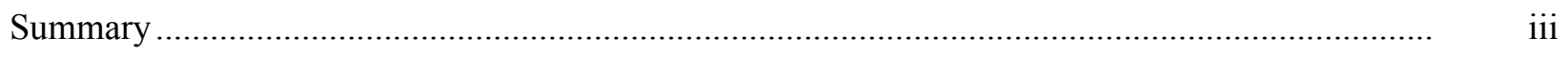

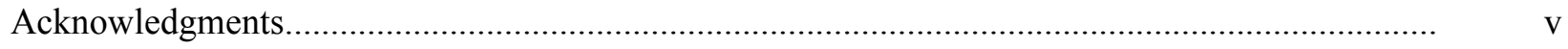

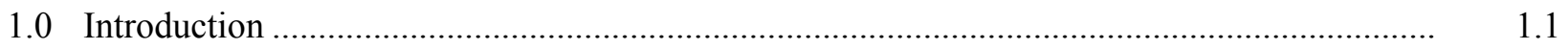

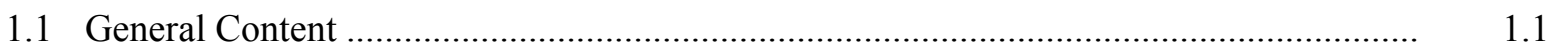

1.2 Definition and Description of the Uppermost Aquifer................................................. 1.4

2.0 Aquifer Properties for the Unconfined Aquifer Beneath the 200 West Area ......................... 2.1

2.1 Existing Hydrologic Properties Beneath the 200 West Area Single-Shell Tank Waste Management Areas............................................................................................. 2.1

2.2 Historical Changes in Groundwater Flow Direction and Gradient Beneath 200 West Area Single-Shell Tank Waste Management Areas ................................................... 2.16

3.0 Aquifer Properties for the Unconfined Aquifer Beneath the 200 East Area .......................... 3.1

3.1 Existing Hydrologic Properties Beneath the 200 East Area Single-Shell Tank Waste Management Areas.................................................................................................

3.2 Historical Changes in Groundwater Flow Direction and Gradient Beneath 200 East Area Single-Shell Tank Waste Management Areas ...................................................... 3.8

4.0 Groundwater Geochemistry Beneath Single-Shell Waste Management Areas ....................... 4.1

4.1 Hanford Site Groundwater Background.................................................................

4.1.1 Hanford Site Background ............................................................................. 4.1

4.1.2 Hanford Site Background as Determined from Wells 699-19-88 and 699-49-100C

4.2 Groundwater Geochemistry Beneath Single-Shell Tank Waste Management Areas

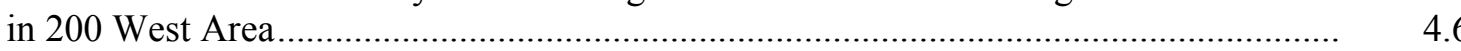

4.2.1 Background Groundwater Composition Beneath Waste Management Area S-SX

4.2.2 Groundwater Contamination Beneath Waste Management Area S-SX ................ 4.8

4.2.3 Comparison of Groundwater, Vadose Zone Pore Water, and Tank Leak Chemical Compositions at Waste Management Area S-SX

4.2.4 Background Groundwater Composition Beneath Waste Management Area T......

4.2.5 Groundwater Contamination Beneath Waste Management Area T .

4.2.6 Background Groundwater Composition Beneath Waste Management Area TX-TY

4.2.7 Groundwater Contamination Beneath Waste Management Area TX-TY...

4.2.8 Background Groundwater Composition Beneath Waste Management Area U .....

4.2.9 Groundwater Contamination Beneath Waste Management Area U...................... 4.66

4.3 Groundwater Geochemistry Beneath Single-Shell Tank Waste Management Areas in 200 East Area

4.3.1 Background Groundwater Composition Beneath Waste Management Area A-AX 
4.3.2 Groundwater Contamination Beneath Waste Management Area A-AX.

4.3.3 Background Groundwater Composition Beneath Waste Management Area B-BX-BY

4.3.4 Groundwater Contamination Beneath Waste Management Area B-BX-BY .

4.3.5 Background Groundwater Composition Beneath Waste Management Area C

4.3.6 Groundwater Contamination Beneath Waste Management Area C

\section{Figures}

1.1 Location Map for the Seven Single-Shell Tank Waste Management Areas on the Hanford Site.

1.2 Generalized Geologic Cross-Section through the Hanford Site.....

2.1 Well Location Map for Single-Shell Tank Waste Management Area S-SX...

2.2 Well Location Map for Single-Shell Tank Waste Management Area T .

2.3 Well Location Map for Single-Shell Tank Waste Management Area TX-TY......

2.4 Well Location Map for Single-Shell Tank Waste Management Area U.

2.5 Hanford Site and Outlying Areas Water Table Map, March 2005.

2.6 Discharge History for the T Pond and U Pond...

2.7 Hydrographs of Selected Wells in the Area of Waste Management Areas T and TX-TY, 200 West Area

2.8 Hydrographs from Selected Wells in the Area of Waste Management Area S-SX, 200 West Area.

2.9 Hydrographs of Selected Wells in the Area of Waste Management Area U, 200 West Area.....

2.10 Groundwater Flow Directions in the North Part of the 200 West Area Near the T, TX, and TY Tank Farms

2.11 Groundwater Flow Directions at Waste Management Area U between 1992 and 2005

2.12 Groundwater Flow Directions Beneath the S and SX Tank Farms

3.1 Well Location Map for Waste Management Area A-AX ................................................... 3.2

3.2 Well Location Map for Waste Management Area B-BX-BY ................................................ 3.3

3.3 Well Location Map for Waste Management Area C …........................................................... 3.4

3.4 Discharge History for the B Pond and the Gable Mountain Pond Systems ...........................

3.5 Hydrographs of Selected Wells in the Area of Waste Management Area B-BX-BY, 200 East Area

3.6 Hydrographs from Selected Wells in the Area of Waste Management Area C, 200 East Area 
3.7 Hydrographs of Selected Wells in the Vicinity of Waste Management Area A-AX, 200 East Area

3.8 Groundwater Flow Directions in the Northern Part of the 200 East Area Near the B, BX, and BY Tank Farms....

3.9 Groundwater Flow Directions in the Vicinity of the C Tank Farm.....

3.10 Groundwater Flow Directions at the A and AX Tank Farms from 1990 to 2003

4.1 Modified Stiff Diagram Depicting Major Cation and Anion Compositions for Background Groundwater, Top of the Aquifer in the Hanford Site's Unconfined Aquifer

4.2 Modified Stiff Diagrams Depicting Major Cation and Anion Compositions for Groundwater from the Groundwater Performance Assessment Project's Quality Control Wells.

4.3 Major Cation and Anion Composition of Groundwater from Upgradient Wells at WMA S-SX

4.4 Carbon Tetrachloride, Nitrate, Technetium-99, and Chromium Concentrations versus Depth in the Aquifer in Well 299-W22-47 at Waste Management Area S-SX.

4.5 Wellbore-Fluid Specific Conductance Measurements Collected in Well 299-W23-19 at Waste Management Area S-SX.

4.6 Average FY 2005 Tritium Concentrations in the 200-UP-1 Operable Unit, Top of the Aquifer....

4.7 Average FY 2005 Carbon Tetrachloride Concentrations in Groundwater Beneath 200 West Area, Top of the Aquifer

4.8 Average FY 2005 Nitrate Concentrations at Waste Management Area S-SX, Top of the Aquifer

4.9 Average FY 2005 Chromium Concentrations at Waste Management Area S-SX, Top of the Aquifer

4.10 Average FY 2005 Technetium-99 Concentration at Waste Management Area S-SX, Top of the Aquifer

4.11 Nitrate and Technetium-99 Concentrations versus Time in Wells 299-W22-48 and 299-W22-44 East of the S Tank Farm.

4.12 Nitrate, Technetium-99, and Chromium Concentrations versus Time in Wells at the Plume South of the SX Tank Farm.

4.13 Major Cation and Anion Composition of Groundwater from Upgradient Wells at Waste Management Area T

4.14 Specific Conductance versus Depth below the Water Table in Well 299-W10-28

4.15 Specific Conductance versus Depth below the Water Table in Well 299-W11-42 .................

4.16 Nitrate Concentration in Well Pair 299-W10-24 and 299-W11-27 and Well Pair 299-W11-42 and 299-W11-28 Downgradient of Waste Management Area T.

4.17 Technetium-99 Concentrations in Well Pair 299-W10-24 and 299-W11-27 and Well Pair 299-W11-23 and 299-W11-39 at the Northeast Corner of T Tank Farm.

4.18 Depth Distribution of Key Contaminants in Well 299-W10-24.

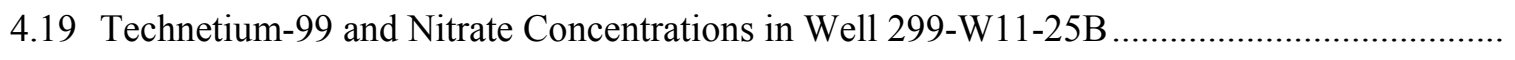

4.20 Technetium-99 and Nitrate Concentrations in Well 299-W11-45. 
4.21 Average FY 2005 Concentrations of Tritium in the Northern Part of 200 West Area, Top of the Unconfined Aquifer

4.22 Average FY 2005 Concentrations of Nitrate in the Northern Part of 200 West Area, Top of the Unconfined Aquifer

4.23 Nitrate Concentration versus Time in Wells West and Southwest of Waste Management Area T .

4.24 Average FY 2005 Chromium Concentrations near Waste Management Areas T and TX-TY, Top of the Unconfined Aquifer

4.25 Chromium Concentration versus Time for Selected Wells West and Southwest of Waste Management Area T.

4.26 Chromium Concentration versus Time for Selected Wells North of Waste Management Area T.

4.27 Average FY 2005 Technetium-99 Concentrations near Waste Management Areas T and TX-TY, Top of the Unconfined Aquifer.

4.28 Gross Beta Contamination in Wells West and Southwest of Waste Management Area T.......

4.29 Technetium-99/Nitrate Composition Ratios for Groundwater and Estimated Tank Leaks at Waste Management Area T.

4.30 Technetium-99/Nitrate Composition Ratios for Pore Water at the Tank T-106 Leak and Pumped Samples from Two New Monitoring Wells at Waste Management Area T........

4.31 Major Cation and Anion Composition of Groundwater from Upgradient Wells at WMA TX-TY

4.32 Specific Conductance versus Depth in Well 299-W14-13

4.33 Technetium-99 Concentration in Wells 299-W14-12 and 299-W14-13 in Waste Management Area TX-TY.

4.34 Nitrate Concentrations in Wells 299-W14-12 and 299-W14-13 at Waste Management Area TX-TY.....

4.35 Tritium Concentrations in Wells 299-W14-12 and 299-W14-13 at Waste Management Area TX-TY.

4.36 Distribution of Technetium-99 in the Aquifer at Well 299-W14-11, Waste Management Area TX-TY.

4.37 Distribution of Nitrate in the Aquifer at Well 299-W14-11, Waste Management Area TX-TY

4.38 Distribution of Iodine-129 in the Aquifer at Well 299-W14-11, Waste Management Area TX-TY .....

4.39 Contaminant Distributions in Samples Collected During Drilling of Well 299-W14-14 ........

4.40 Nitrate Concentration in Groundwater versus Depth in Well 299-W15-44 ...........................

4.41 Results of Multi-Depth Sampling of Well 299-W14-13

4.42 Average FY 2006 Iodine-129 Concentrations in the Vicinity of Waste Management Area TX-TY, Top of the Aquifer

4.43 Technetium-99 Concentration in Selected Wells South and West of the Waste Management Area TX-TY.

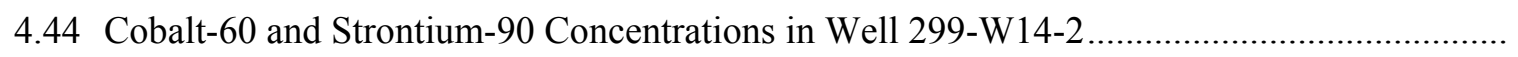


4.46 Major Cation and Anion Composition of Groundwater from Upgradient Wells at Waste Management Area U

4.47 Concentrations versus Time for Technetium-99 and Nitrate at Two Well Pairs Downgradient of Waste Management Area U.

4.48 Average FY 2005 Nitrate and Technetium-99 Concentrations at Waste Management Area U, Top of the Aquifer

4.49 Nitrate Concentration in Downgradient Well 299-W19-12 at Waste Management Area U

4.50 Technetium-99 Concentrations in Monitoring Wells at Waste Management Area U

4.51 Nitrate Concentrations in Monitoring Wells at Waste Management Area U.

4.52 Technetium-99 Concentration Ratios at Waste Management Area U.

4.53 Major Cation and Anion Composition of Groundwater from Upgradient Wells at Waste Management Area A-AX.

4.54 June 2005 Sulfate Concentrations in the Vicinity of Waste Management Area A-AX, Top of the Aquifer

4.55 June 2005 Nitrate Concentrations in the Vicinity of Waste Management Area A-AX, Top of the Aquifer

4.56 Nitrate Concentration versus Time in Selected Wells from Waste Management Area A-AX

4.57 June 2005 Technetium-99 Concentrations in the Vicinity of Waste Management Area A-AX, Top of the Aquifer

4.58 Technetium-99 Concentration versus Time in Selected Wells at Waste Management Area A-AX

4.59 Concentration versus Time for Several Contaminants in Groundwater from Well 299-E25-1 and 299-E25-2 at Waste Management Area A-AX...

4.60 Major Cation and Anion Composition of Groundwater from Upgradient Wells at Waste Management Area B-BX-BY

4.61 Depth Distribution of Tritium in Well 299-E33-334.

4.89

4.62 Depth Distribution of Technetium-99 and Nitrate in Well 299-E33-44...

4.63 Average FY 2005 Nitrate Concentration in the Area of Waste Management Area B-BX-BY, Top of the Aquifer.

4.64 Nitrate Concentrations in Selected Wells at Waste Management Area B-BX-BY .

4.65 Average FY 2005 Technetium-99 Concentrations in the Area of Waste Management Area B-BX-BY, Top of the Aquifer

4.66 Technetium Concentrations in Selected Wells in the Vicinity of Waste Management Area B-BX-BY

4.67 Historic Cobalt-60 Concentrations in Selected Wells in the Vicinity of Waste Management Area B-BX-BY.

4.68 Cobalt-60 Concentrations at the 216-B-45 Crib near Waste Management Area B-BX-BY

4.69 Cobalt-60 Concentrations in Selected Wells East of Waste Management Area B-BX-BY and at the BY Cribs 
4.70 Average FY 2005 Uranium Concentrations in Groundwater in the Vicinity of Waste Management Area B-BX-BY, Top of the Aquifer

4.71 Uranium Concentrations in Selected Wells at Waste Management Area B-BX-BY

4.72 Average FY 2005 Tritium Concentrations South of Waste Management Area B-BX-BY, Top of the Aquifer

4.73 Tritium Concentration in Wells along the South Border of Waste Management Area B-BX-BY

4.74 Uranium Isotopic Data for Vadose Zone Contamination in Well 299-E33-45 and 299-E33-46 and in Groundwater Samples from Wells in the Waste Management Area B-BX-BY Monitoring Network

4.75 Major Cation and Anion Composition of Groundwater from Upgradient Wells at Waste Management Area C

4.76 Specific Conductance and Concentrations of Nitrate and Technetium-99 versus Depth below the Water Table in Well 299-E27-22.

4.77 Average FY 2005 Tritium Concentration in the Area of Waste Management Area C, Top of the Aquifer

4.78 Average FY 2005 Iodine-129 Concentration in the Area of Waste Management Area C, Top of the Aquifer.

4.79 Average June 2005 Nitrate Concentrations in the Area of Waste Management Area C, Top of the Aquifer

4.80 Average FY 2006 Technetium-99 Concentrations in the Area of Waste Management Area C, Top of the Aquifer.

4.81 Nitrate, Sulfate, and Technetium-99 Concentrations in Upgradient Well 299-W27-7 at Waste Management Area C

4.82 Sulfate, Nitrate, and Technetium-99 Concentrations in Selected Downgradient Wells at Waste Management Area C

4.83 Technetium-99/Nitrate and Technetium-99/Sulfate Relationships for Selected Wells at Waste Management Area C

4.84 Cyanide Concentration in Wells at Waste Management Area C

4.85 Selected Compositional Relationships between Groundwater Samples from Wells at Waste Management Area C and C4297 Pore Water ....

\section{Tables}

1.1 Major Sources for Groundwater Data .....

2.1 Thickness of the Unconfined Aquifer Beneath the 200 West Area

2.2 Summary of the Thickness of the Unconfined Aquifer Beneath the 200 West Area Single-Shell Tank Waste Management Areas

2.3 Current Groundwater Flow Directions and Flow Rates for Single-Shell Tank Waste Management Areas in the 200 West Area 
2.4 Groundwater Flow Characterization Results for Tank Farm Wells in the 200 West Area Based on Trend Surface Analyses .....

2.5 In-Well, Vertical, Flow-Velocity Summary for Wells at 200 West Area Single-Shell Tank Waste Management Areas.

2.6 Hydraulic Properties from Slug and Constant Rate Pumping Tests and Calculated Flow Velocities at 200 West Area Single-Shell Tank Waste Management Areas

2.7 Multi Test/Depth Slug Test Characterization in Well 299-W11-25B at Single-Shell Waste Management Area T

2.8 Results from Tracer-Dilution and Tracer-Pumpback Tests in Wells at 200 West Area Single-Shell Tank Waste Management Areas

2.9 Results of Pre-1997 Slug Testing at Single-Shell Tank Farms in the 200 West Area.

2.10 Water-Level Changes Beneath the 200 West Single-Shell Tank Farms

2.11 Historical Water-Level Data, Groundwater Flow Directions, and Water-Table Gradients for the T, TX, and TY Tank Farm Areas...

2.12 Historical Water-Level Data, Groundwater Flow Directions, and Water-Table Gradients for the U Tank Farm Area

2.13 Historical Water-Level Data, Groundwater Flow Directions, and Water-Table Gradients for the S and SX Tank Farm Areas.

3.1 Thickness of the Unconfined Aquifer Beneath the 200 East Area....

3.2 General Groundwater Flow Directions and Flow Rates for Single-Shell Tank Waste Management Areas in the 200 East Area

3.3 Results from Recent Slug Testing of Wells at 200 East Area Single-Shell Tank Farms

3.4 Results of Pre-1997 Slug Testing at Single-Shell Tank Waste Management Areas in the 200 East Area.

3.5 Historical Water Level Changes Beneath the 200 East Area Single-Shell Tank Farms

3.6 Historical Water Levels, Groundwater Flow Directions, and Water-Table Gradients in the Area of Waste Management Area B-BX-BY

3.7 Water Levels, Groundwater Flow Directions, and Water-Table Gradients in the Area of Waste Management Area C from 1958 to 2003.

3.8 Water Levels, Groundwater Flow Directions, and Water-Table Gradients in the Area of Waste Management Area A-AX from 1992 to 2003

4.1 Hanford Site Groundwater Background Concentrations.

4.2 Average FY 2005 Composition of Groundwater from Wells 699-49-100C and 699-19-88

4.3 Average FY 2005 Groundwater Composition in Upgradient Wells at Waste Management Area S-SX...

4.4 Depth Distribution of Selected Contaminants during Drilling of Well 299-W22-50.....

4.5 Vertical Variation of Groundwater Composition Measured in Well 299-W23-19 and Estimated for the Adjacent Aquifer on September 23, 2003.

4.6 Technetium-99/Nitrate Concentration Ratios Estimated for Tank Leaks and Measured in Groundwater from Waste Management Area S-SX Wells.

4.7 Technetium-99/Nitrate Concentration Ratios from Pore Water Samples of Well 299-W23-19 and Groundwater from Waste Management Area S-SX Wells. 
4.8 Average FY 2005 Groundwater Composition in Upgradient Wells at Waste Management Area T .

4.9 Average Concentration of Mobile Contaminants in Groundwater in the Vicinity of Waste Management Areas T for FY $2005 .$.

4.10 Average FY 2005 Groundwater Composition in Waste Management Area TX-TY Upgradient Wells

4.11 Average Concentration of Mobile Contaminants in Groundwater in the Vicinity of Waste Management Area TX-TY for FY 2005.

4.12 Technetium-99/Nitrate Concentration Ratios for Contaminated Groundwater Downgradient of Waste Management Area TX-TY and Pore Water from Borehole C3831

4.13 Average FY 2005 Groundwater Composition in Waste Management Area U Upgradient Wells

4.14 Average Concentration of Selected Contaminants in Groundwater in the Vicinity of Waste Management Area U for FY 2005.

4.15 Average FY 2005 Groundwater Composition in Upgradient Wells at Waste Management Area A-AX.

4.16 Average FY 2005 Concentrations of Mobile Contaminants in Groundwater in the Vicinity of Waste Management Area A-AX

4.17 Comparison of Technetium-99/Nitrate Composition Ratios in Groundwater and Estimated Tank Leak Fluids

4.18 Average FY 2005 Groundwater Composition in Waste Management Area B-BX-BY Upgradient Wells

4.19 Average Concentration of Selected Mobile Contaminants in the Vicinity of Waste Management Area B-BX-BY for FY 2005

4.20 Ratios of Tank Waste Mobile Contaminants in Groundwater, Pore Water, and Perched Water at Waste Management Area B-BX-BY

4.21 Ratios of Selected Mobile Contaminants in Groundwater and Pore Water from Well 299-E33-46

4.22 Average FY 2005 Groundwater Composition in Upgradient Wells at Waste Management Area C.

4.23 Depth-Discrete Water Sampling Results from Well 299-E27-22

4.24 Average Concentration of Mobile Contaminants in Groundwater in the Vicinity of Waste Management Areas C for FY 2005

4.25 Concentration Ratios for Selected Constituents in Estimated Tank Leaks, Groundwater, and Pore Water from Waste Management Area C 


\subsection{Introduction}

The Hanford Federal Facility Agreement and Consent Order (Ecology et al. 1989) Milestone M-045-55 requires that a Resource Conservation and Recovery Act (RCRA) Facility Investigation report be submitted to the Washington State Department of Ecology. The RCRA Facility Investigation report will provide a detailed description of the state of knowledge needed for tank farm risk assessments. This document provides the detailed technical information about groundwater contamination to support the RCRA Facility Investigation report.

Groundwater monitoring and characterization are ongoing activities associated with RCRA and Comprehensive Environmental Response, Compensation, and Liability Act (CERCLA) projects. In addition, a number of vadose zone activities are ongoing or planned to be done by the Tank Farm Vadose Zone Project, the results of which may relate to current or future possible groundwater contamination. This report is current through early 2006 and can be updated, if necessary, as the results of current and future studies become available.

This document summarizes historic and recent groundwater data collected from the uppermost aquifer beneath the 200 East and 200 West Areas. Although the area of interest is the Hanford Site Central Plateau, most of the information discussed in this document is at the scale of individual singleshell tank waste management areas (WMAs). This is because the geologic, and thus the hydraulic, properties and the geochemical properties (i.e., groundwater composition) are different in different parts of the Central Plateau. Figure 1.1 is a map showing the locations of the seven single-shell tank WMAs.

\subsection{General Content}

The information discussed in this document includes historic and current water-table elevations; hydraulic properties including hydraulic conductivity, effective porosity, specific yield, and transmissivity; historic and current groundwater flow directions and flow rates as determined by measured hydraulic properties; and the concentrations and distributions of contaminants in the unconfined aquifer.

The water-level data used in this document were obtained from field measurements using electrical tapes or steel tapes. McDonald et al. (1999) describe the methods and procedures for collecting waterlevel measurements, management of water-level data, and analysis and reporting of water-level data at the Hanford Site. Water-level data are stored and are available from the HYDRODAT database maintained by Pacific Northwest National Laboratory. They are also available on the CD included in Hartman et al. (2006).

The values for hydraulic properties (e.g., hydrologic conductivity, specific yield, transmissivity, measured flow velocities) were obtained from aquifer testing and are documented in the published reports cited in this document. The types of aquifer tests include slug tests, constant rate pumping tests, and tracer tests. Calculated groundwater flow velocities listed in these reports use the hydrologic properties obtained from the aquifer tests. 


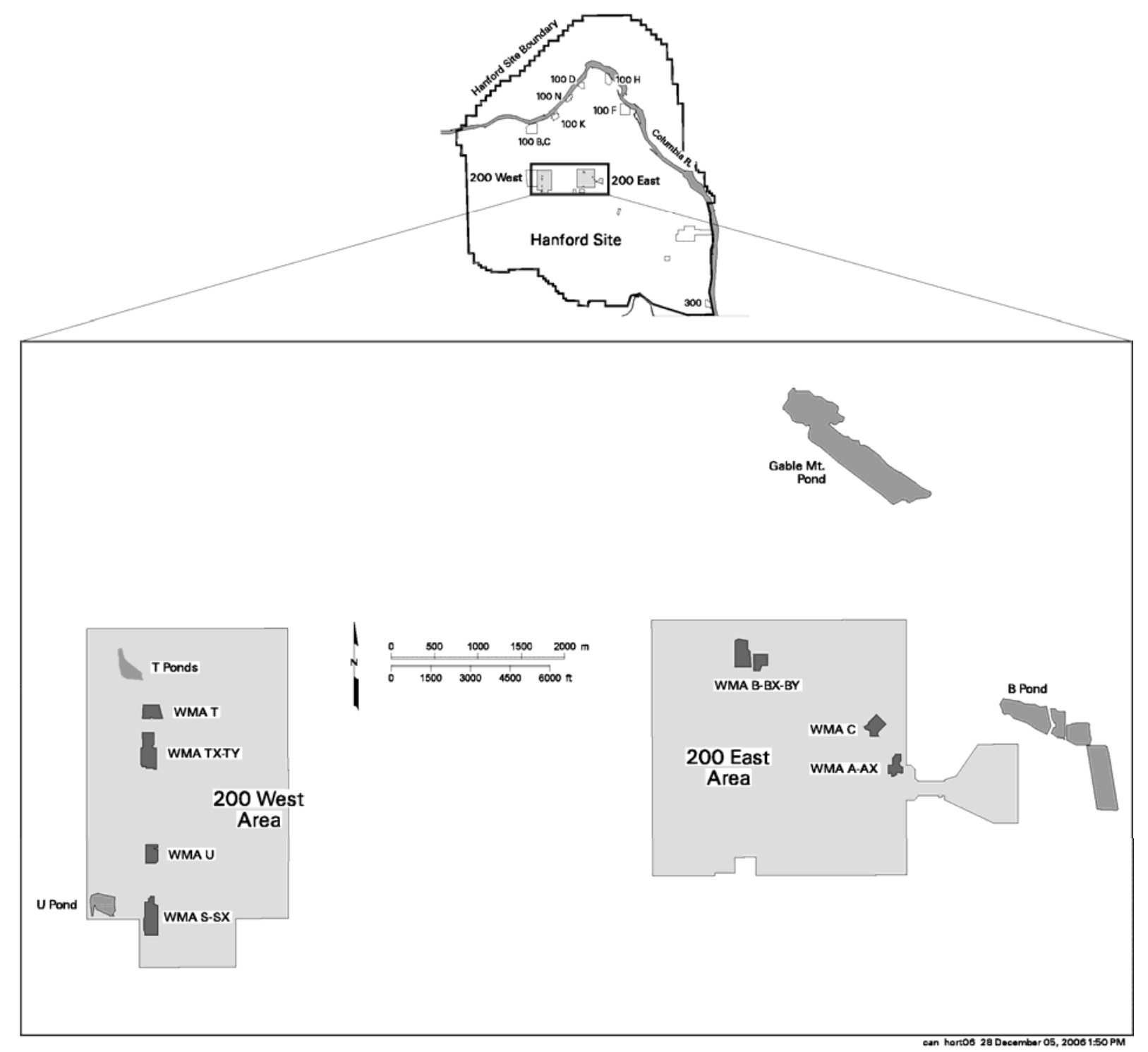

Figure 1.1. Location Map for the Seven Single-Shell Tank Waste Management Areas on the Hanford Site 
Unless otherwise specified, all groundwater chemistry data are from the Hanford Environmental Information System data base (HEIS 1994) and are available from Flour Hanford, Inc. Most groundwater chemistry data collected since the mid 1980s were collected under strict regulatory requirements for the RCRA or CERCLA. Hartman (2000) describes the sampling methods, analytical methods, and quality control and data management practices used to collect and evaluate these data. Groundwater data collected before the mid 1980s are not as well documented and, in a general way, the older the data, the less is known about the data quality.

Most of the information presented and discussed in this document is updated from previously published sources by including the latest analytical results from groundwater sampling. Table 1.1 lists the most used sources of groundwater hydrology and geochemistry information.

Table 1.1. Major Sources for Groundwater Data

\begin{tabular}{|c|}
\hline $\begin{array}{l}\text { - Hanford Site Groundwater Monitoring for Fiscal Year 2005. MJ Hartman, LF Morasch, and } \\
\text { WD Webber (eds.). 2006. PNNL-15670. (This is the most recent in a series of annual reports.) }\end{array}$ \\
\hline $\begin{array}{l}\text { - Geology, Hydrogeology, Geochemistry, and Mineralogy Data Package. SP Reidel, DG Horton, } \\
\text { Y Chien, DB Barnett, and K Singleton. 2006. RPP-23748. }\end{array}$ \\
\hline - Field Investigation Report for Waste Management Area S-SX. AJ Knepp. 2002a. RPP-7884, Rev. 0. \\
\hline $\begin{array}{l}\text { - Field Investigation Report for Waste Management Area B-BX-BY. AJ Knepp. 2002b. RPP-10098, } \\
\text { Rev. } 0\end{array}$ \\
\hline $\begin{array}{l}\text { - Characterization of Vadose Zone Sediments Below the T Tank Farm: Boreholes C4104, C4105, } \\
\text { 299-W10-196, and RCRA Borehole 299-W11-39. RJ Serne et al. 2004b. PNNL-14849. }\end{array}$ \\
\hline $\begin{array}{l}\text { - Characterization of Vadose Zone Sediments Below the TX Tank Farm: Boreholes C3830, C3831, } \\
\text { C3832 and RCRA Borehole 299-W10-27. RJ Serne et al. 2004a. PNNL-14594. }\end{array}$ \\
\hline - Hanford Site Background: Part 3, Groundwater Background. DOE. 1997. DOE/RL-96-61, Rev. 0. \\
\hline $\begin{array}{l}\text { - Field Investigation Report for Waste Management Areas T and TX-TY. DA Myers. } 2005 . \\
\text { RPP-23752, Rev. 0. }\end{array}$ \\
\hline $\begin{array}{l}\text { - Subsurface Conditions Description of the C and A-AX Waste Management Areas. MI Wood et al. } \\
\text { 2003. RPP-14430. }\end{array}$ \\
\hline $\begin{array}{l}\text { - Subsurface Conditions Description of the U Waste Management Area. MI Wood and TE Jones. } \\
\text { 2003. RPP-15808, Rev. } 0 .\end{array}$ \\
\hline $\begin{array}{l}\text { - Hanford Environmental Information System. HEIS. 1994, Hanford Information System Department, } \\
\text { Fluor Hanford, Inc. }\end{array}$ \\
\hline
\end{tabular}

This document is arranged in five major sections following this introduction. Section 2.0 describes the aquifer properties of single-shell tank WMAs in the 200 West Area. Section 3.0 describes the aquifer properties of the WMAs in 200 East Area. Section 4.0 describes the current and historical magnitude and distribution of contamination for each single-shell tank WMA in 200 West and 200 East. A comparison of groundwater contamination, vadose zone contamination, and estimated tank leak fluid compositions is included in Section 4.0 for WMAs for which data are available. Section 5.0 contains brief conclusions based on the previous sections and Section 6.0 is the reference list. 


\subsection{Definition and Description of the Uppermost Aquifer}

Both confined and unconfined aquifers exist beneath the Hanford Site. The regional, confined aquifer system consists of saturated transmissive units within the Columbia River Basalt Group and extends from western Idaho through eastern Washington and northeastern Oregon (Thorne 2004). Basalt-confined aquifers beneath the Hanford Site are grouped into three separate hydrogeologic units corresponding to three distinct basalt formations which are, from deepest to shallowest, the Grande Ronde, Wanapum, and Saddle Mountains (DOE 1988). The basalt-confined aquifers are composed of flow tops and pillowed bases of individual basalt flows and sedimentary interbeds (the Ellensburg Formation) between basalt flows. These aquifers are confined between the relatively impermeable interiors of basalt flows (Thorne 2004). The overlying, local flow system exists within fluvial, lacustrine, and glaciofluvial sediments deposited on top of the Columbia River Basalts within the Pasco Basin. A detailed discussion of the geology of the multi-aquifer system is in Appendix E of this document (Reidel et al. 2006).

The local flow system overlying the basalt aquifers is the suprabasalt aquifer system. The suprabasalt aquifers are the uppermost aquifers beneath the Hanford Site. Groundwater within this aquifer system is contained within the glaciofluvial sands and gravels of the Hanford formation and the fluvial-lacustrine sediments of the Ringold Formation. The position of the water table beneath the western portion of the Hanford Site is generally within the coarse-grained gravel units of the Ringold Formation. In the northern and eastern portions of the Hanford Site, the water table is generally within the Hanford formation. Hydraulic conductivities for the glaciofluvial Hanford formation are much greater than those of the poorly sorted, frequently cemented, coarse-grained gravel units of the Ringold Formation (Williams et al. 2002).

The suprabasalt aquifer system is approximately $180 \mathrm{~m}$ thick near the center of the Cold Creek syncline. Laterally, anticlinal basalt ridges that extend above the water table bound the aquifer system. A generalized east-west geologic cross section showing the position of the water table and major stratigraphic units beneath the Hanford Site is shown in Figure 1.2.

The base of the unconfined aquifer generally is regarded as the basalt surface and, where this is the case, the suprabasalt aquifer consists entirely of the unconfined aquifer. Where the Ringold Formation is present in the suprabasalt aquifer, the silt and clay horizon of the formation's hydrogeologic unit 8 (lower mud unit) forms a confining layer that separates the suprabasalt aquifer into the uppermost and unconfined aquifer and an underlying confined or semi-confined aquifer in the Ringold Formation. The hydrogeologic unit 8 is elevated at or above the water table east of the 200 East Area and in an area between the 200 East and 200 West Areas. This geologic structure creates a thinning of the unconfined aquifer and a barrier to eastward groundwater flow in very localized areas.

Glaciofluvial floods, during the Pleistocene, eroded channels into the Ringold Formation and removed the hydrogeologic unit 8 in places. These eroded areas, located primarily north of the 200 Areas, through Gable Gap, and across the northeast portion of 200 East Area, typically were filled with younger, more permeable Hanford formation sand and gravel. In the areas where hydrogeologic unit 8 was removed, the entire suprabasalt aquifer consists of the unconfined aquifer.

The general direction of groundwater flow is primarily from natural recharge areas on the basalt ridges west of the Hanford Site to discharge along the Columbia River. The general west-to-east flow was interrupted locally by the now subsiding groundwater mounds in the 200 Areas, which were created by past-practice liquid disposal activities. Since cessation of non-permitted liquid discharges to the 
ground, the flow directions of the unconfined aquifer are returning to pre-Hanford Site directions toward the east. There is also a component of groundwater flow and contaminant transport to the north, between Gable Mountain and Gable Butte.

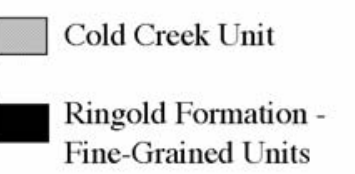

West (A)
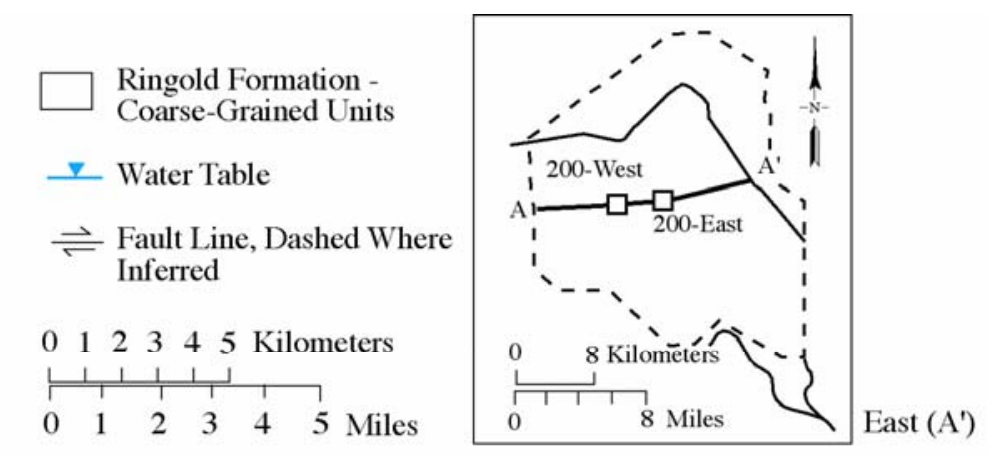

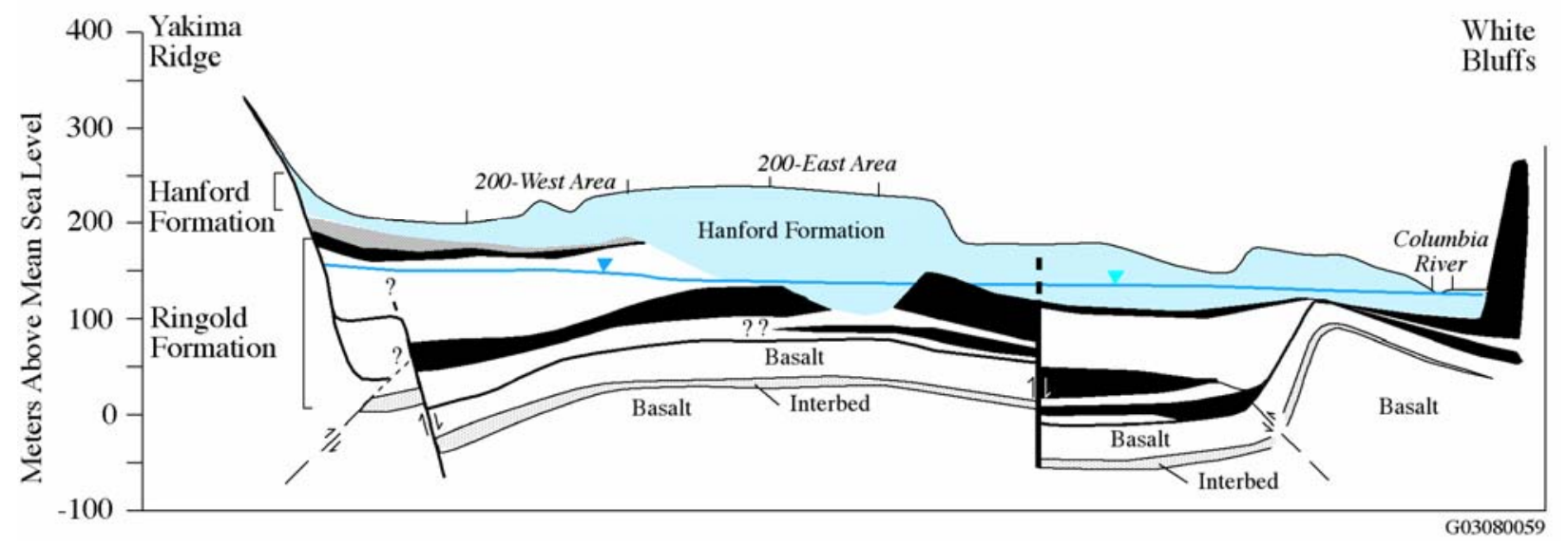

Figure 1.2. Generalized Geologic Cross-Section through the Hanford Site. (Location of crosssection A-A' is shown as west-east line on outline of Hanford site in upper right.)

Significant water-level changes have occurred on the Hanford Site. Water levels in the unconfined aquifer have risen because of artificial recharge from liquid waste disposal operations active since the 1940s. Artificial recharge created large water-table mounds, primarily below the 200 East and 200 West Areas, but some mounding also occurred below the 100 Areas. Recharge from the 200 Areas wastewater disposal sites was estimated to be approximately 10 times the natural recharge on the Hanford Site. Since cessation of non-permitted discharge to the ground, the water table has declined about $12 \mathrm{~m}$ in the 200 West Area and about $6 \mathrm{~m}$ in the 200 East Area from the highest, historic water levels. The declining water table also has caused changes in groundwater flow direction in some places. Many monitoring wells have gone dry because of the declining water table, and many replacement wells have been installed to maintain adequate monitoring networks and to account for changes in flow direction.

Recharge from agricultural activities offsite and west of the Hanford Site has affected the groundwater. The continued use of irrigation upgradient of the Hanford Site is expected to sustain recharge to the unconfined aquifer. 


\subsection{Aquifer Properties for the Unconfined Aquifer Beneath the 200 West Area}

This section describes the aquifer properties beneath the 200 West Area single-shell tank WMAs including hydraulic properties, aquifer thickness, and current flow directions and flow rates. The section also describes historic changes in the aquifer properties due to past fuel processing operations and waste management. Changes in the aquifer properties during the past 60 years have significant implications for direction and rate of contaminant movement in the aquifer and for residual vadose zone contamination where the water table has decreased elevation. Most of the information in this section is from Reidel et al. (2006) and updated using the latest groundwater sampling results.

Figures 2.1 through 2.4 show the single-shell tank WMAs in 200 West Area along with the locations for most of the wells discussed in this section. The locations of wells not on the figures are described in the main text of this document.

\subsection{Existing Hydrologic Properties Beneath the 200 West Area Single-Shell Tank Waste Management Areas}

The base of the unconfined aquifer beneath the 200 West Area single-shell tank WMAs is the top of the Ringold Formation lower mud unit (hydrogeologic unit 8 of Thorne et al. [1993]). This unit forms a confining layer that separates the suprabasalt aquifer into the uppermost unconfined aquifer and the underlying confined aquifer in the Ringold Formation (Williams et al. 2002). Thus, the unconfined aquifer in the area of interest extends from the water table down to the hydrogeologic unit 8 and consists of variably cemented and compacted coarse sands and gravels of the Ringold Formation, member of Wooded Island, unit E (Lindsey 1996), which is hydrogeologic unit 5 of Thorne et al. (1993).

Several wells extend through the unconfined aquifer in the 200 West Area and can be used to determine the thickness of the aquifer. Table 2.1 lists some of the wells that penetrate the entire thickness of the unconfined aquifer, March 2005 water levels from those wells, and determined aquifer thickness. The data in the table show that the uppermost aquifer beneath the 200 West Area ranges from about 45 to $72 \mathrm{~m}$ in thickness. Williams et al. (2002) used similar data to make an isopach map of the aquifer thickness in the 200 West Area. Table 2.2 summarizes those results for each WMA in the 200 West Area. The information in both Tables 2.1 and 2.2 indicate a general thickening of the aquifer from north to south. This is the result of a higher water table in the southern part of 200 West Area due to the residual groundwater mound under 216-U-10 pond (U Pond). (See discussion in Section 2.2 for the effects of U Pond on the water table.)

Figure 2.5 is the general water-table map for the entire Hanford Site (Hartman et al. 2006) and shows that the general flow direction is toward the east beneath 200 West Area. Current groundwater flow directions and flow rates specific to each single-shell tank WMA in the 200 West Area are given in Table 2.3 (Hartman et al. 2006). Except where influenced by pump-and-treat operations, the flow directions at the single-shell tank WMA is in agreement with the generalized map. 


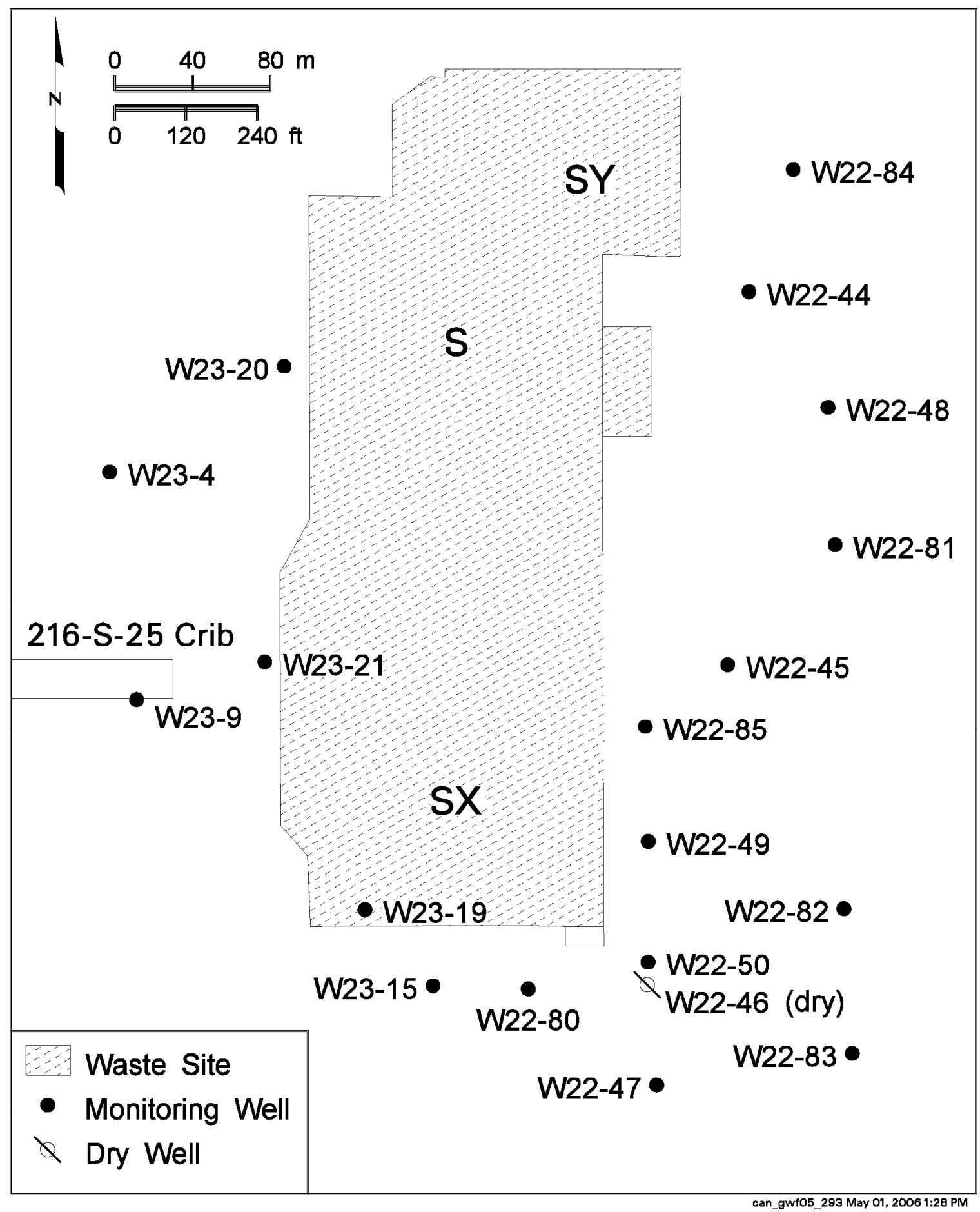

Figure 2.1. Well Location Map for Single-Shell Tank Waste Management Area S-SX (modified from Hartman et al. 2006) 


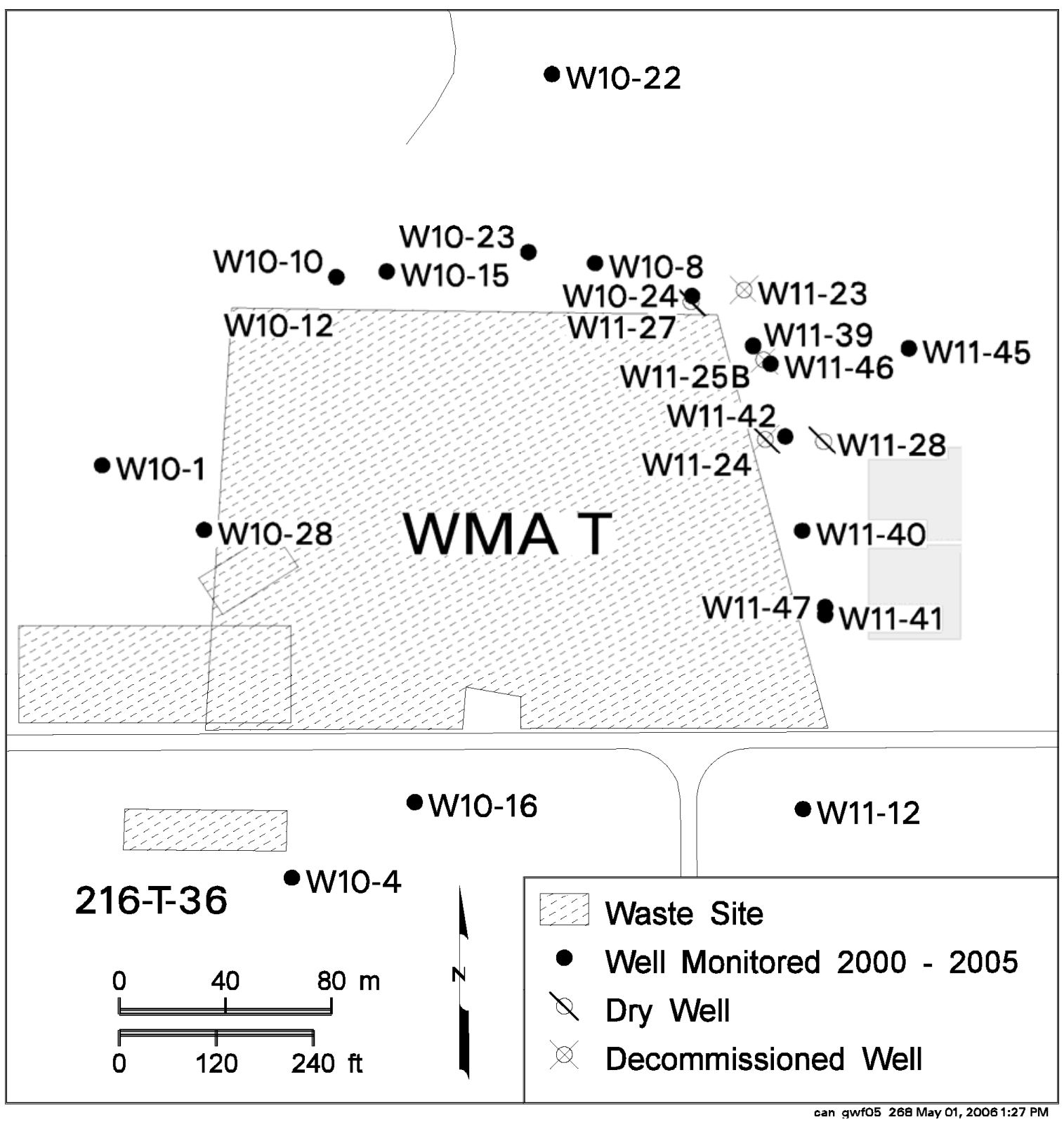

Figure 2.2. Well Location Map for Single-Shell Tank Waste Management Area T (modified from Hartman et al. 2006) 


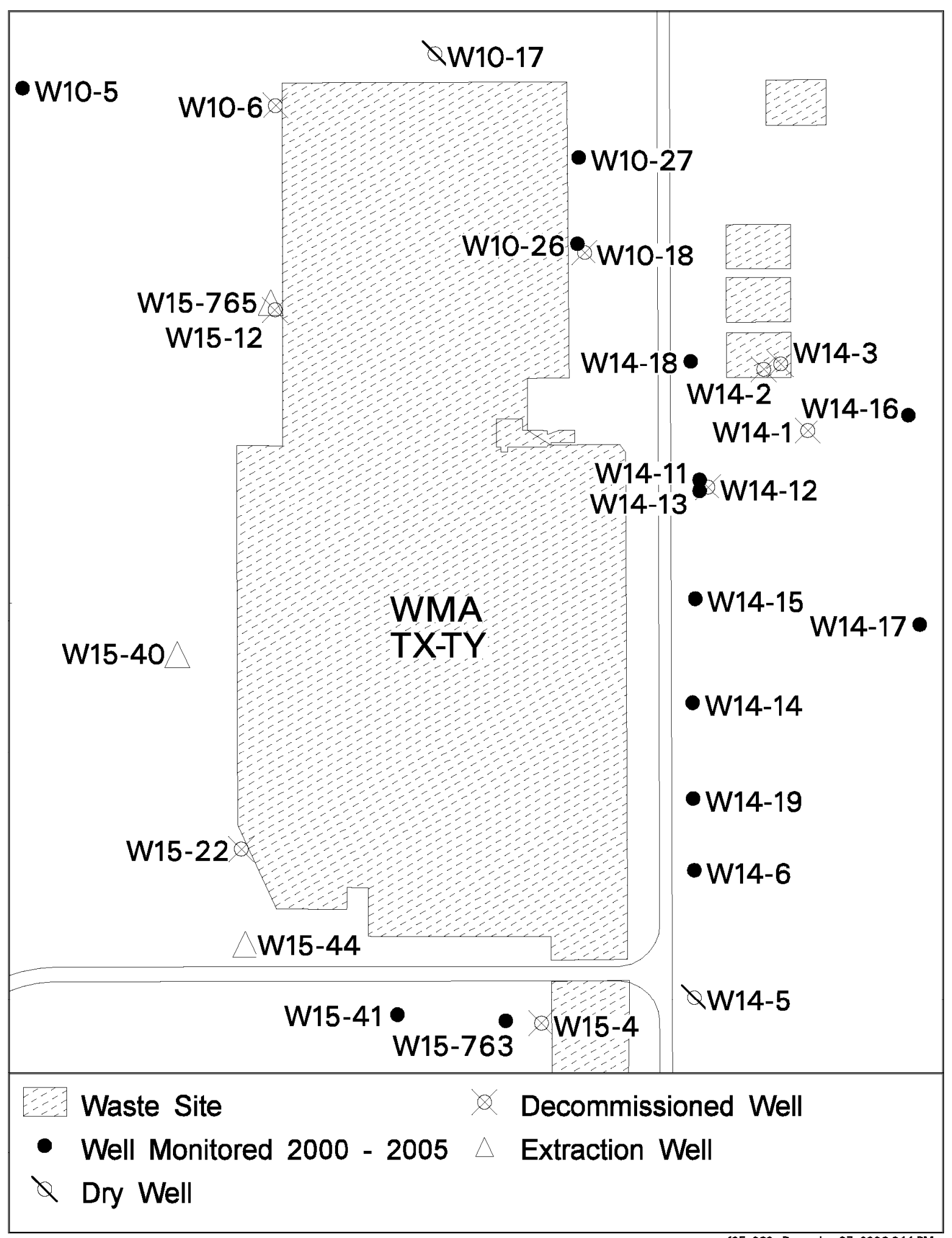

can_gwf05_269c Docember 07, 2006 6:14 PM

Figure 2.3. Well Location Map for Single-Shell Tank Waste Management Area TX-TY (modified from Hartman et al. 2006) 


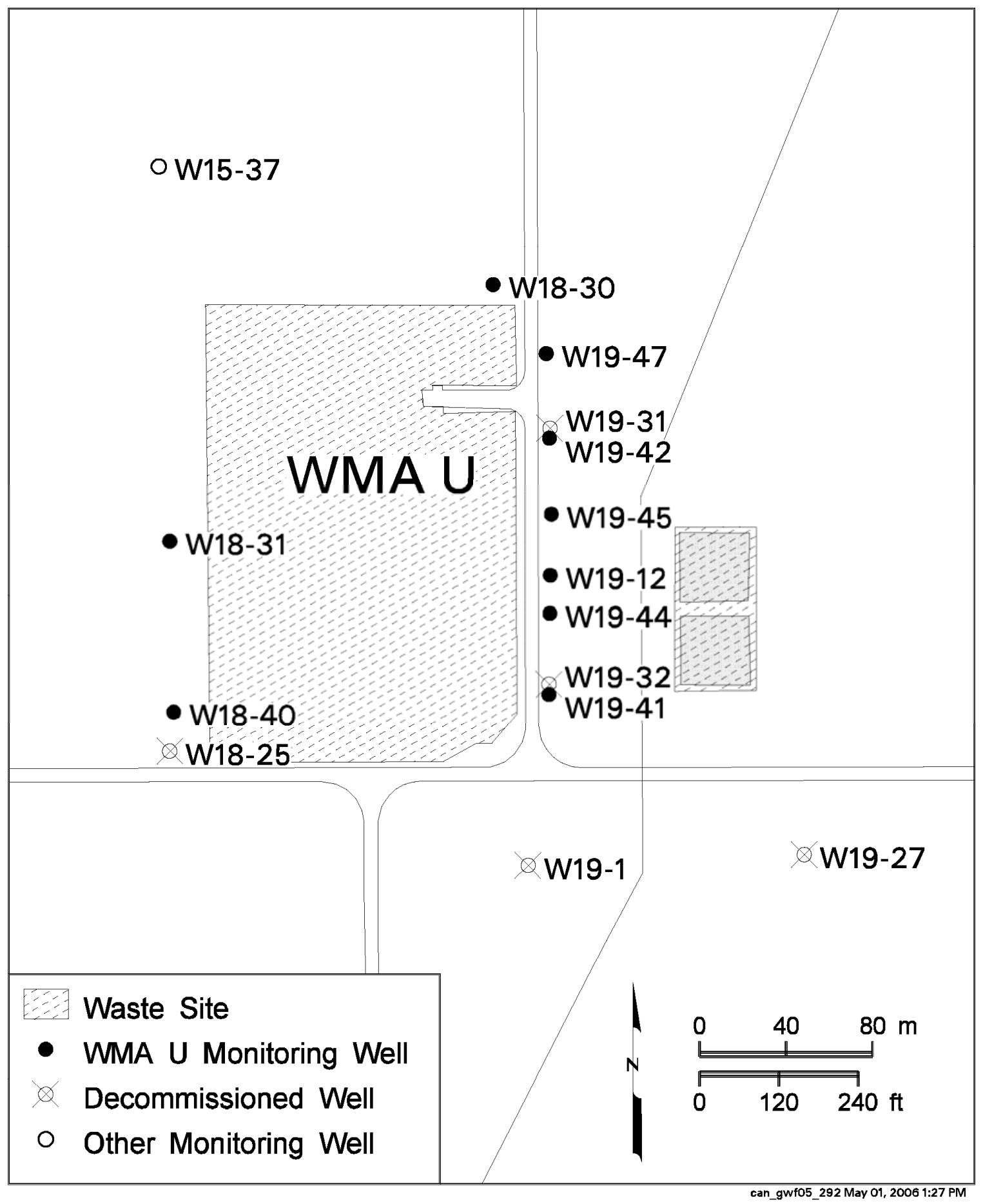

Figure 2.4. Well Location Map for Single-Shell Tank Waste Management Area U (modified from Hartman et al. 2006) 
Table 2.1. Thickness of the Unconfined Aquifer Beneath the 200 West Area

\begin{tabular}{|c|c|c|c|c|}
\hline Well Name & Well Location & $\begin{array}{c}\text { Elevation of } \\
\text { Aquifer Bottom } \\
(\mathrm{m}) \\
(\mathrm{m} \text { amsl })\end{array}$ & $\begin{array}{c}\text { Elevation of } \\
\text { Water Table }^{(\mathbf{b})} \\
(\mathrm{m} \text { amsl })\end{array}$ & $\begin{array}{c}\text { Aquifer } \\
\text { Thickness } \\
(\mathrm{m})\end{array}$ \\
\hline 299-W6-3 & $\sim 550 \mathrm{~m}$ northeast of WMA T & 90.22 & 135.398 & 45.18 \\
\hline 299-W10-14 & $\sim 600 \mathrm{~m}$ west of WMA T & 77.72 & 137.075 & 59.36 \\
\hline 299-W10-24 & Northeast corner of WMA T & 86.26 & 135.931 & 49.67 \\
\hline 299-W11-25B & East side of WMA T & 86.0 & 135.95 & 49.95 \\
\hline 299-W14-14 & East side of WMA TX-TY & 81.99 & 135.782 & 53.79 \\
\hline 299-W15-46 & $\sim 450 \mathrm{~m}$ south of WMA TX-TY & 76.47 & $135.487^{(\mathrm{c})}$ & 59.02 \\
\hline 299-W18-22 & $\sim 650 \mathrm{~m}$ west of WMA U & 68.88 & 137.401 & 68.58 \\
\hline 299-W19-4 & $\sim 1,100$ m east of WMA $U$ & 83.51 & $134.518^{(\mathrm{d})}$ & 52.01 \\
\hline 299-W22-50 & Southeast corner of WMA S-SX & 64.31 & 135.905 & 71.70 \\
\hline \multicolumn{5}{|c|}{$\begin{array}{l}\text { (a) Williams et al. (2002). } \\
\text { (b) March } 2005 \text { data except where noted. } \\
\text { (c) August } 2005 . \\
\text { (d) September } 2005 \text {. } \\
\text { amsl = above mean sea level. }\end{array}$} \\
\hline
\end{tabular}

Table 2.2. Summary of the Thickness of the Unconfined Aquifer Beneath the 200 West Area SingleShell Tank Waste Management Areas (Data from Williams et al. 2002)

\begin{tabular}{||l|c||}
\hline \multicolumn{1}{|c|}{ Waste Management Area } & $\begin{array}{c}\text { Aquifer Thickness } \\
(\mathrm{m})\end{array}$ \\
\hline \hline $\mathrm{T}$ & $50-55$ \\
\hline TX-TY & $50-58$ \\
\hline $\mathrm{U}$ & $60-70$ \\
\hline $\mathrm{S}-\mathrm{SX}$ & $70-75$ \\
\hline
\end{tabular}

Several trend-surface analyses of the water table have been done at selected wells at all 200 West Area tank farms during the past five years. The results of those analyses are given in Table 2.4. The flow directions given in Table 2.4 differ from well to well due to heterogeneous aquifer properties, remnants of past practice disposal to ponds, cribs, and ditches, and proximity to ongoing pump-and-treat operations.

Results from borehole tracer dilution and tracer pumpback tests have been published for tests conducted in 15 new RCRA monitoring wells at the 200 West Area single-shell tank WMAs between fiscal years (FY) 1999 and 2002 (Spane et al. 2001a, 2001b, 2002, 2003). Additional tests were done in 2005 but the results of those tests are not yet available. The tracer tests permitted some inferences about flow rate as well as aquifer homogeneity. The tests allowed direct observation of the effect of lateral groundwater flow through the screened interval of the wells, and thus provided an indication of the variability of flow through the screened intervals. Details of the test methods, computations, and the results are included in:

- Results of Detailed Hydrologic Characterization Tests - Fiscal Year 1999 (Spane et al. 2001a)

- Results of Detailed Hydrologic Characterization Tests - Fiscal Year 2000 (Spane et al. 2001b)

- Results of Detailed Hydrologic Characterization Tests - Fiscal Year 2001 (Spane et al. 2002)

- Results of Detailed Hydrologic Characterization Tests - Fiscal Year 2002 (Spane et al. 2003). 


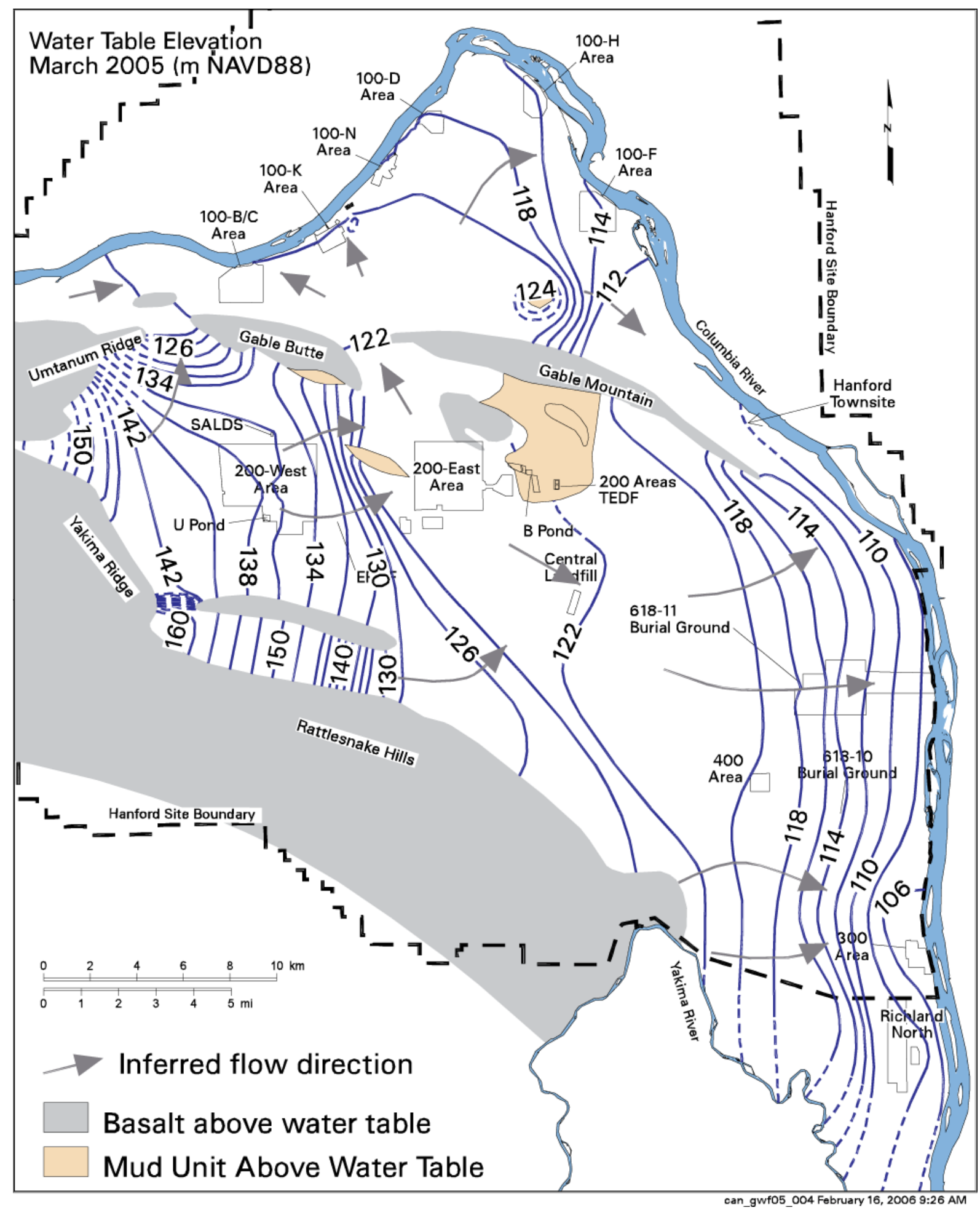

Figure 2.5. Hanford Site and Outlying Areas Water Table Map, March 2005 (modified from Hartman et al. 2006) 
Table 2.3. Current Groundwater Flow Directions and Flow Rates for Single-Shell Tank Waste Management Areas in the 200 West Area ${ }^{(a)}$

\begin{tabular}{||l|l|c|c|c|}
\hline $\begin{array}{c}\text { Waste } \\
\text { Management Area }\end{array}$ & \multicolumn{1}{|c|}{$\begin{array}{c}\text { Groundwater Flow } \\
\text { Direction }\end{array}$} & Gradient & $\begin{array}{c}\text { Hydraulic } \\
\text { Conductivity (m/d) }\end{array}$ & $\begin{array}{c}\text { Groundwater } \\
\text { Flow Rate } \\
\text { (m/d) }\end{array}$ \\
\hline \hline S-SX & E to ESE & 0.0018 to 0.0019 & 0.58 to 17.2 & 0.009 to 0.36 \\
\hline T & $5^{\circ} \mathrm{N}$ of E to $8^{\circ} \mathrm{S}$ of E & 0.001 & 1 to 28 & 0.003 to 0.024 \\
\hline TX-TY & $\begin{array}{l}18^{\circ} \text { to } 43^{\circ} \text { E of S (north } \\
\text { half) }\end{array}$ & 0.001 & 0.05 to 4.9 & 0.0007 to 0.246 \\
\cline { 2 - 5 } & S to SSW (south half) & 0.001 & 14.2 to 19.9 & 0.29 \\
\hline U & E & 0.0021 & 6.12 & 0.008 to 0.2 \\
\hline
\end{tabular}

(a) All information is from Hartman et al. (2006).

(b) Groundwater flow rates are calculated using the Darcy equation (flow rate $=$ (hydraulic conductivity $\mathrm{x}$ hydraulic gradient)/effective porosity.

Table 2.4. Groundwater Flow Characterization Results for Tank Farm Wells in the 200 West Area Based on Trend Surface Analyses (data from Spane et al. 2001a, 2001b, 2002, and 2003)

\begin{tabular}{|c|c|c|c|c|}
\hline Well & Measurement Date & $\begin{array}{c}\text { Groundwater Flow } \\
\text { Direction } \\
\text { Azimuth }\end{array}$ & Hydraulic Gradient & $\begin{array}{c}\text { Wells Used in } \\
\text { Analysis }\end{array}$ \\
\hline \multicolumn{5}{|c|}{ Waste Management Area S-SX } \\
\hline 299-W22-48 & $5 / 17 / 00$ & $88^{\circ}$ & 0.0018 & $\begin{array}{l}299-W 22-45 \\
299-W 22-48 \\
299-W 23-13\end{array}$ \\
\hline 299-W22-49 & $5 / 31 / 00$ & $89^{\circ}$ & 0.00206 & $\begin{array}{l}\text { 299-W22-49 } \\
299-W 22-50 \\
299-W 23-14 \\
299-W 23-15\end{array}$ \\
\hline \multirow[t]{2}{*}{ 299-W22-50 } & $5 / 17 / 00$ & $91^{\circ}$ & 0.00204 & $\begin{array}{l}299-W 22-49 \\
299-W 22-50 \\
299-W 23-14 \\
299-W 23-15\end{array}$ \\
\hline & $5 / 31 / 00$ & $89^{\circ}$ & 0.00206 & $\begin{array}{l}299-W 22-49 \\
299-W 22-50 \\
299-W 23-14 \\
299-W 23-15\end{array}$ \\
\hline \multirow[t]{2}{*}{ 299-W22-80 } & $6 / 26 / 01$ & $97^{\circ}$ & 0.00207 & $\begin{array}{l}299-W 22-46 \\
299-W 22-48 \\
299-W 22-50 \\
299-W 22-80 \\
299-W 23-15\end{array}$ \\
\hline & $6 / 29 / 01$ & $96^{\circ}$ & 0.00209 & $\begin{array}{l}\text { 299-W22-46 } \\
\text { 299-W22-48 } \\
\text { 299-W22-50 } \\
\text { 299-W22-80 } \\
\text { 299-W23-15 }\end{array}$ \\
\hline
\end{tabular}


Table 2.4. (contd)

\begin{tabular}{|c|c|c|c|c|}
\hline Well & Measurement Date & $\begin{array}{c}\text { Groundwater Flow } \\
\text { Direction } \\
\text { Azimuth }\end{array}$ & Hydraulic Gradient & $\begin{array}{c}\text { Wells Used in } \\
\text { Analysis }\end{array}$ \\
\hline 299-W22-81 & $7 / 13 / 01$ & $82^{\circ}$ & 0.00164 & $\begin{array}{l}299-W 22-45 \\
299-W 22-48 \\
299-W 22-81 \\
299-W 23-20 \\
299-W 23-21\end{array}$ \\
\hline 299-W22-81 & $7 / 23 / 01$ & $82^{\circ}$ & 0.00164 & $\begin{array}{l}299-W 22-45 \\
299-W 22-48 \\
299-W 22-81 \\
299-W 23-20 \\
299-W 23-21\end{array}$ \\
\hline \multirow[t]{2}{*}{ 299-W22-84 } & $8 / 14 / 02$ & $115^{\circ}$ & 0.00183 & $\begin{array}{l}299-W 22-48 \\
299-W 22-84 \\
299-W 23-20\end{array}$ \\
\hline & $8 / 19 / 02$ & $114^{\circ}$ & 0.00182 & $\begin{array}{l}\text { 299-W22-48 } \\
\text { 299-W22-84 } \\
299-W 23-20\end{array}$ \\
\hline \multicolumn{5}{|c|}{ Waste Management Area U } \\
\hline 299-W-19-42 & $5 / 20 / 99$ & $76^{\circ}$ & 0.00184 & $\begin{array}{l}299-W 18-25 \\
299-W 18-30 \\
299-W 18-31 \\
299-W 19-12 \\
299-W 19-31 \\
299-W 19-32 \\
299-W 19-42\end{array}$ \\
\hline \multicolumn{5}{|c|}{ Waste Management Area T } \\
\hline 299-W10-24 & $4 / 21 / 99$ & $85^{\circ}$ & 0.00172 & $\begin{array}{c}299-W 10-8 \\
299-W 10-12 \\
299-W 10-22 \\
299-W 10-24 \\
299-W 11-23 \\
299-W 11-27\end{array}$ \\
\hline 299-W11-39 & $9 / 4 / 01$ & $98^{\circ}$ & 0.00115 & $\begin{array}{c}299-W 10-1 \\
299-W 10-4 \\
299-W 10-24 \\
299-W 11-40 \\
299-W 11-41 \\
299-W 11-42\end{array}$ \\
\hline \multicolumn{5}{|c|}{ Waste Management Area T } \\
\hline 299-W11-39 & $9 / 18 / 01$ & $96^{\circ}$ & 0.00114 & $\begin{array}{c}299-W 10-1 \\
299-W 10-4 \\
299-W 10-24 \\
299-W 11-40 \\
299-W 11-41 \\
299-W 11-42\end{array}$ \\
\hline
\end{tabular}


Table 2.4. (contd)

\begin{tabular}{|c|c|c|c|c|}
\hline Well & Measurement Date & $\begin{array}{c}\text { Groundwater Flow } \\
\text { Direction } \\
\text { Azimuth }\end{array}$ & Hydraulic Gradient & $\begin{array}{l}\text { Wells Used in } \\
\text { Analysis }\end{array}$ \\
\hline 299-W11-40 & $8 / 9 / 01$ & $96^{\circ}$ & 0.00132 & $\begin{array}{c}299-W 10-1 \\
299-W 10-4 \\
299-W 10-24 \\
299-W 11-39 \\
299-W 11-41 \\
299-W 11-42\end{array}$ \\
\hline \multicolumn{5}{|c|}{ Waste Management Area TX-TY } \\
\hline 299-W14-13 & $5 / 3 / 99$ & $162^{\circ}$ & 0.00073 & $\begin{array}{l}299-W 10-17 \\
299-W 10-18 \\
299-W 14-12 \\
299-W 15-12 \\
299-W 15-22\end{array}$ \\
\hline \multirow[t]{2}{*}{ 299-W14-14 } & $7 / 12 / 02$ & $132^{\circ}$ & 0.00114 & $\begin{array}{l}299-W 14-13 \\
299-W 14-15 \\
299-W 14-16 \\
299-W 14-17\end{array}$ \\
\hline & $7 / 22 / 02$ & $133^{\circ}$ & 0.00109 & $\begin{array}{l}\text { 299-W14-13 } \\
299-W 14-15 \\
299-W 14-16 \\
299-W 14-17\end{array}$ \\
\hline \multirow[t]{2}{*}{ 299-W14-15 } & $7 / 30 / 01$ & $121^{\circ}$ & 0.00135 & $\begin{array}{l}299-W 14-13 \\
299-W 14-14 \\
299-W 14-16 \\
299-W 14-17\end{array}$ \\
\hline & $8 / 2 / 01$ & $116^{\circ}$ & 0.00140 & $\begin{array}{l}299-W 14-13 \\
299-W 14-14 \\
299-W 14-16 \\
299-W 14-17\end{array}$ \\
\hline 299-W10-26 & $5 / 3 / 99$ & $162^{\circ}$ & 0.00073 & $\begin{array}{l}299-W 10-17 \\
299-W 10-18 \\
299-W 14-12 \\
299-W 15-12 \\
299-W 15-22\end{array}$ \\
\hline
\end{tabular}

A significant feature of the tracer dilution test results is evidence for upward or downward, vertical hydraulic gradients within the upper portion of the aquifer in seven of the wells tested. Vertical flow in three of these wells (wells 299-W22-49, 299-W10-26, and 299-W14-13) was first noted by electromagnetic flowmeter surveys (Waldrop and Pearson 2000). Vertical flow in these wells was confirmed and vertical flow was identified in four additional wells by tracer-dilution studies and later (at two of the wells) by vertical tracer tests specifically designed to detect vertical flow within a borehole (Spane et al. 2001a). Most recently, Newcomer ${ }^{1}$ measured vertical flow in three wells with the electromagnetic borehole flowmeter. Data from all tests are shown in Table 2.5.

\footnotetext{
${ }^{1}$ Newcomer DR. 2005. Preliminary Electromagnetic Borehole Flowmeter Survey Results for Hydrologic Assessment Task Characterization Wells 299-W14-11, 299-W22-47, and 299-W22-80. Letter report from DR Newcomer to FA Spane, Project F8245, Pacific Northwest National Laboratory, Richland, Washington.
} 
Table 2.5. In-Well, Vertical, Flow-Velocity Summary for Wells at 200 West Area Single-Shell Tank Waste Management Areas ${ }^{(a)}$

\begin{tabular}{|c|c|c|c|c|c|c|}
\hline \multirow[b]{2}{*}{ Test Well ${ }^{(\mathrm{c})}$} & \multicolumn{2}{|c|}{ Tracer-Dilution Profile } & \multicolumn{2}{|c|}{ Vertical Tracer Test ${ }^{(\mathbf{b})}$} & \multicolumn{2}{|c|}{$\begin{array}{c}\text { Electromagnetic Flow-Meter } \\
\text { Survey }\end{array}$} \\
\hline & $\begin{array}{c}\text { Range } \\
(\mathrm{m} / \mathrm{min})^{(\mathrm{d})}\end{array}$ & $\begin{array}{l}\text { Average } \\
(\mathrm{m} / \mathrm{min})^{(\mathrm{d})}\end{array}$ & $\begin{array}{c}\text { Range } \\
(\mathrm{m} / \mathrm{min})^{(\mathrm{d})}\end{array}$ & $\begin{array}{l}\text { Average } \\
(\mathrm{m} / \mathrm{min})^{(\mathrm{d})}\end{array}$ & $\begin{array}{c}\text { Range } \\
(\mathrm{m} / \mathrm{min})^{(\mathrm{d})}\end{array}$ & $\begin{array}{l}\text { Average } \\
(\mathrm{m} / \mathrm{min})^{(\mathrm{d})}\end{array}$ \\
\hline \multicolumn{7}{|c|}{ Waste Management Area T } \\
\hline 299-W11-39 & $\begin{array}{c}0.0003-0.002 \\
\downarrow\end{array}$ & $\begin{array}{c}0.001 \\
\downarrow\end{array}$ & ND & ND & ND & ND \\
\hline 299-W11-40 & $\begin{array}{c}0.011-0.020 \\
\downarrow\end{array}$ & $\begin{array}{c}0.017 \\
\downarrow\end{array}$ & ND & ND & ND & ND \\
\hline \multicolumn{7}{|c|}{ Waste Management Area S-SX } \\
\hline 299-W22-47 & ND & ND & ND & ND & $\begin{array}{c}0.005-0.011 \\
1 \uparrow\end{array}$ & ND \\
\hline 299-W22-49 & $\begin{array}{c}0.010-0.015 \\
\uparrow\end{array}$ & $\begin{array}{c}0.012 \\
\uparrow\end{array}$ & ND & ND & $\begin{array}{c}0.002-0.017 \\
\uparrow\end{array}$ & $\begin{array}{c}0.010 \\
\uparrow\end{array}$ \\
\hline 299-W22-80 & $\begin{array}{c}0.023-0.044 \\
\uparrow\end{array}$ & $\begin{array}{c}0.032 \\
\uparrow\end{array}$ & ND & ND & $\begin{array}{c}0.028-0.043 \\
\uparrow\end{array}$ & ND \\
\hline \multicolumn{7}{|c|}{ Waste Management Area TX-TY } \\
\hline 299-W10-26 & $\begin{array}{c}0.002-0.004 \\
\downarrow \\
\end{array}$ & $\begin{array}{c}0.003 \\
\downarrow\end{array}$ & $\begin{array}{c}0.004-0.008 \\
\downarrow \\
\end{array}$ & $\begin{array}{c}0.005 \\
\downarrow\end{array}$ & $\begin{array}{c}0.003-0.006 \\
\downarrow \\
\end{array}$ & $\begin{array}{c}0.004 \\
\downarrow\end{array}$ \\
\hline 299-W14-11 & ND & ND & ND & ND & $\begin{array}{c}0.014-0.027 \\
\uparrow\end{array}$ & ND \\
\hline 299-W14-13 & $\begin{array}{c}0.008-0.015 \\
\downarrow \\
\end{array}$ & $\begin{array}{c}0.011 \\
\downarrow\end{array}$ & $\begin{array}{c}0.013-0.014 \\
\downarrow \\
\end{array}$ & $\begin{array}{c}0.012 \\
\downarrow\end{array}$ & $\begin{array}{c}0.012-0.013 \\
\downarrow \\
\end{array}$ & $\begin{array}{c}0.012 \\
\downarrow\end{array}$ \\
\hline 299-W14-14 & $\begin{array}{c}0.0054-0.0058 \\
\downarrow\end{array}$ & $\begin{array}{c}0.0056 \\
\downarrow\end{array}$ & ND & ND & ND & ND \\
\hline \multicolumn{7}{|c|}{$\begin{array}{l}\text { (a) Data from Spane (2001a, 2001b, 2002, 2003); Waldrop and Pearson (2000); Letter report from DR Newcomer } \\
\text { to FA Spane. 2005. Preliminary Electromagnetic Borehole Flowmeter Survey Results for Hydrologic } \\
\text { Assessment Task Characterization Wells 299-W14-11, 299-W22-47, and 299-W22-80. Project F8245, Pacific } \\
\text { Northwest National Laboratory, Richland, Washington. } \\
\text { (b) In-well, vertical, flow-velocity range determined from tracer peak arrival method for selected sensor depth, } \\
\quad \text { while the average was determined using the center-of-mass technique. } \\
\text { (c) All tests conducted in hydrologic unit } 5 \text { (Ringold Formation gravel unit E). } \\
\text { (d) } \downarrow \text { Directional symbol indicating vertical flow direction. } \\
\text { ND = Not determined. }\end{array}$} \\
\hline
\end{tabular}

The existence of vertical flow in a well does not necessarily reflect actual groundwater flow conditions within the surrounding aquifer, but its presence implies a vertical flow gradient and has implications pertaining to the representativeness of groundwater samples collected from the wells. For example, upward vertical flow of relatively uncontaminated water in a well south of WMA S-SX (well 299-W22-80) may be diluting contamination near the water table such that nearby contaminants are not detectable in pumped samples from the well (McDonald et al. 2006). Also, Serne et al. (2004a) suggested that contamination found near the water table in a well east of WMA TX-TY (well 299-W14-13) may be carried deeper in the aquifer due to downward vertical flow. 
The reason for vertical flow is not known for certain. In some areas, such at WMAs T and TX-TY, vertical flow is dominantly downward, whereas near WMA S-SX, vertical flow is dominantly upward. However, in well 299-W14-13, east of WMA TX-TY, downward flow was measured in the well bore (Spane et al. 2001a) and at well 299-W14-11, located only about $3 \mathrm{~m}$ from, and screened slightly deeper than well 299-W14-13, upward flow was measured Newcomer. ${ }^{2}$ Whatever the mechanism for vertical flow, such flow may have impacts on observed contaminant distribution patterns.

Table 2.6 shows hydraulic conductivities, transmissivities, and specific yields for the unconfined aquifer beneath the 200 West Area single-shell tank WMAs as determined by slug tests and constant rate pumping tests conducted in the screened interval of the completed wells (Spane et al. 2001a, 2001b, 2002, 2003). Calculated velocities using the Darcy equation also are shown in Table 2.6. Most calculated flow velocities are between about 0.01 and $0.3 \mathrm{~m} /$ day but the total range in calculated velocities spans three orders of magnitude. This variation is due to differences in formation permeability among wells and influences of nearby 200-ZP-1 pump-and-treat operations.

Table 2.6. Hydraulic Properties from Slug and Constant Rate Pumping Tests and Calculated Flow Velocities at 200 West Area Single-Shell Tank Waste Management Areas ${ }^{(a)}$

\begin{tabular}{|c|c|c|c|c|c|}
\hline Well $^{(\mathrm{b})}$ & $\begin{array}{c}\text { Hydraulic } \\
\text { Conductivity } \\
(\mathrm{m} / \text { day })\end{array}$ & $\begin{array}{l}\text { Hydraulic } \\
\text { Conductivity }^{(\mathbf{d})} \\
(\mathrm{m} / \text { day })\end{array}$ & $\begin{array}{l}\text { Transmissivity } \\
\left(\mathrm{m}^{2} / \text { day }\right)\end{array}$ & $\begin{array}{l}\text { Specific } \\
\text { Yield }^{(\mathrm{d})}\end{array}$ & $\begin{array}{c}\text { Calculated Flow } \\
\text { Rate } \\
\text { (m/day) }\end{array}$ \\
\hline \multicolumn{6}{|c|}{ Waste Management Area S-SX } \\
\hline 299-W22-45 & $2.14-2.38$ & ND & ND & ND & $0.024^{(\mathrm{e})}$ \\
\hline 299-W22-46 & $2.43-3.37$ & ND & ND & ND & $0.034^{(\mathrm{e})}$ \\
\hline 299-W22-48 & $1.42-1.86$ & 1.78 & 125 & 0.09 & $0.007^{(\mathrm{f})}$ \\
\hline 299-W22-49 & $6.04-7.97$ & 7.59 & 550 & 0.09 & $0.089^{(\mathrm{g})}$ \\
\hline 299-W22-50 & $4.24-5.70$ & 5.24 & 385 & 0.11 & $0.018^{(\mathrm{f})}$ \\
\hline 299-W22-80 & $11.3-15.4$ & 14.4 & 1035 & 0.12 & $0.128^{(\mathrm{g})}$ \\
\hline 299-W22-81 & $1.77-2.25$ & 1.63 & 112 & 0.12 & $0.056^{(\mathrm{f})}$ \\
\hline 299-W22-82 & $1.16-1.45$ & ND & ND & ND & $0.015^{(\mathrm{e})}$ \\
\hline 299-W22-83 & $0.78-1.00$ & ND & ND & ND & $0.010^{(\mathrm{e})}$ \\
\hline 299-W22-84 & $1.15-1.51$ & 1.33 & 91 & 0.09 & $0.076^{(\mathrm{f})}$ \\
\hline 299-W22-85 & $5.69-7.73$ & ND & ND & ND & $0.077^{(\mathrm{e})}$ \\
\hline 299-W23-15 & $1.55-1.58$ & ND & ND & ND & $0.016^{(\mathrm{e})}$ \\
\hline 299-W23-20 & $16.9-17.2$ & ND & ND & ND & $0.172^{(\mathrm{e})}$ \\
\hline 299-W23-21 & $0.58-0.73$ & ND & ND & ND & $0.007^{(\mathrm{e})}$ \\
\hline \multicolumn{6}{|c|}{ Waste Management Area T } \\
\hline 299-W10-23 & $1.62-2.35$ & ND & ND & ND & $0.024^{(\mathrm{e})}$ \\
\hline 299-W10-24 & $1.04-1.68$ & 1.22 & 66 & 0.11 & $0.023^{(\mathrm{f})}$ \\
\hline
\end{tabular}

\footnotetext{
${ }^{2}$ Newcomer DR. 2005. Preliminary Electromagnetic Borehole Flowmeter Survey Results for Hydrologic Assessment Task Characterization Wells 299-W14-11, 299-W22-47, and 299-W22-80. Letter report from DR Newcomer to FA Spane, Project F8245, Pacific Northwest National Laboratory, Richland, Washington.
} 
Table 2.6. (contd)

\begin{tabular}{|c|c|c|c|c|c|}
\hline Well $^{(b)}$ & $\begin{array}{c}\text { Hydraulic } \\
\text { Conductivity } \\
\text { (m/day) }\end{array}$ & $\begin{array}{c}\text { Hydraulic } \\
\text { Conductivity } \\
\text { (m/day) }\end{array}$ & $\begin{array}{c}\text { Transmissivity } \\
\left(\mathrm{m}^{2} / \text { day }\right)\end{array}$ & $\begin{array}{l}\text { Specific } \\
\text { Yield }^{(d)}\end{array}$ & $\begin{array}{c}\text { Calculated Flow } \\
\text { Rate } \\
(\mathrm{m} / \text { day })\end{array}$ \\
\hline 299-W10-28 & $27.9^{(\mathrm{h})}$ & ND & ND & ND & $0.28^{(\mathrm{e})}$ \\
\hline 299-W11-39 & $1.31-1.69$ & 0.85 & 44 & 0.1 & $0.01^{(\mathrm{g})}$ \\
\hline 299-W11-40 & $3.56-4.58$ & 2.02 & 103 & 0.1 & $0.046^{(\mathrm{g})}$ \\
\hline 299-W11-41 & $7.57-7.78$ & ND & ND & ND & $0.078^{(\mathrm{e})}$ \\
\hline 299-W11-42 & $28.1^{(\mathrm{h})}$ & ND & ND & ND & $0.28^{(\mathrm{e})}$ \\
\hline \multicolumn{6}{|c|}{ Waste Management Area TX-TY } \\
\hline 299-W10-26 & $1.39-1.95$ & 1.49 & 82 & 0.14 & $0.014^{(\mathrm{g})}$ \\
\hline 299-W10-27 & $0.05-0.07$ & ND & ND & ND & $0.0007^{(\mathrm{e}, \mathrm{f})}$ \\
\hline 299-W14-13 & $1.66-2.43$ & 2.45 & 135 & 0.12 & $0.020^{(\mathrm{g})}$ \\
\hline 299-W14-14 & $2.31-3.22$ & 2.21 & 121 & 0.12 & $0.027^{(\mathrm{g})}$ \\
\hline 299-W14-15 & $3.52-4.92$ & 4.09 & 225 & 0.01 & $2.46^{(\mathrm{f})}$ \\
\hline 299-W14-16 & $3.90-5.08$ & ND & ND & ND & $0.051^{(\mathrm{e})}$ \\
\hline 299-W14-17 & $3.71-4.89$ & ND & ND & ND & $0.489^{(\mathrm{e})}$ \\
\hline 299-W14-18 & $0.39-0.54$ & ND & ND & ND & $0.005^{(\mathrm{e})}$ \\
\hline 299-W15-40 & $0.88-1.22$ & ND & ND & ND & $0.012^{(\mathrm{e})}$ \\
\hline 299-W15-41 & $14.2-19.9$ & 19.6 & 1130 & 0.12 & $0.29^{(\mathrm{f})}$ \\
\hline 299-W15-763 & $0.71-0.93$ & ND & ND & ND & $0.009^{(\mathrm{e})}$ \\
\hline \multicolumn{6}{|c|}{ Waste Management Area U } \\
\hline 299-W19-41 & $1.18-1.69$ & ND & ND & ND & $0.169^{(\mathrm{e})}$ \\
\hline 299-W19-42 & $7.06-9.50$ & 6.12 & 345 & 0.17 & $0.352^{(\mathrm{f})}$ \\
\hline \multicolumn{6}{|c|}{$\begin{array}{l}\text { (a) Data from Spane et al. (2001a, 2001b, 2002, 2003). } \\
\text { (b) All hydrologic tests conducted in hydrologic unit } 5 \text { (Ringold formation gravel unit E). } \\
\text { (c) Slug test data. } \\
\text { (d) Constant rate pumping test data. } \\
\text { (e) Estimated using maximum hydraulic conductivity value, a gradient of } 0.001 \text { and effective porosity values of } \\
0.1 . \\
\text { (f) Estimated using maximum hydraulic conductivity value, a gradient of } 0.001 \text {, and effective porosity value } \\
\text { from Table } 2.8 \text {. } \\
\text { (g) Estimated using maximum hydraulic conductivity value, a gradient of } 0.001 \text {, and specific yield from this } \\
\text { table. Specific yield was used because vertical flow in the well resulted in uncertain effective porosity. } \\
\text { (h) Indicates average hydraulic conductivity obtained from high-permeability, non-linear type-curve analysis } \\
\text { method. } \\
\mathrm{ND}=\text { Not determined. }\end{array}$} \\
\hline
\end{tabular}

The data in Table 2.7 illustrate the ranges in hydraulic conductivity that can be expected within a single well. The data in Table 2.7 were obtained from slug tests completed at discrete depth intervals during drilling of well 299-W11-25B. The data show that hydraulic conductivity can be expected to vary by as much as an order of magnitude within a single well. This is the only well in 200 West Area where such data have been reported and more data of this type are needed before making general conclusions about vertical variability in hydraulic conductivity. 
Table 2.7. Multi Test/Depth Slug Test Characterization in Well 299-W11-25B at Single-Shell Waste Management Area $\mathrm{T}^{\text {(a) }}$

\begin{tabular}{||c|c|c||}
\hline $\begin{array}{c}\text { Test Zone Depth } \\
(\mathrm{b} \text { below water table) }\end{array}$ & $\begin{array}{c}\text { Type Curve Analysis Method }- \\
\text { Hydraulic Conductivity }(\mathrm{m} / \mathrm{d})\end{array}$ & $\begin{array}{c}\text { Specific Storage } \\
\left(\mathrm{m}^{-1}\right)\end{array}$ \\
\hline \hline $8.55-11.59$ & $2.59-3.02$ & $3.0 \mathrm{E}-5-5.0 \mathrm{E}-5$ \\
\hline $11.59-14.63$ & Outer zone 0.73 & $1.0 \mathrm{E}-5$ \\
\hline $14.34-17.38$ & Outer zone $1.60-1.81$ & $1.0 \mathrm{E}-6$ \\
\hline $23.51-26.55$ & 3.89 & Not available \\
\hline $32.93-35.97$ & $7.34-8.21$ & $1.0 \mathrm{E}-4-1.0 \mathrm{E}-5$ \\
\hline \multicolumn{3}{|c||}{} \\
\hline $\begin{array}{l}\text { (a) Data from Spane, FA. 2005. Interim Report: Preliminary Slug Test Characterization Results for Multi- } \\
\text { Test/Depth Intervals Conducted During the Drilling of WMA T Well 299-W11-25B (C4669). Letter Report to } \\
\text { DG Horton, March 16, 2005. } \\
\text { (b) All hydrologic tests conducted in hydrologic unit 5 (Ringold Formation gravel Unit E). }\end{array}$ \\
\hline \hline
\end{tabular}

Table 2.8 shows effective porosity and horizontal groundwater flow velocities determined from tracer pumpback tests conducted in wells at the 200 West Area single-shell WMAs (Spane et al. 2001a, 2001b, 2002, 2003). The largest differences in flow velocities between those in Tables 2.6 and 2.8 are for wells with vertical, in-well flow. The vertical, in-well flow probably resulted in overestimation of measured flow velocities in column 3 in Table 2.8 .

Table 2.8. Results from Tracer-Dilution and Tracer-Pumpback Tests in Wells at 200 West Area SingleShell Tank Waste Management Areas ${ }^{(a)}$

\begin{tabular}{|c|c|c|c|}
\hline Well & $\begin{array}{l}\text { Effective } \\
\text { Porosity }{ }^{(b)}\end{array}$ & $\begin{array}{c}\text { Groundwater }^{(\mathrm{b})} \text { Flow } \\
\text { Velocity } \\
(\mathrm{m} / \text { day })\end{array}$ & $\begin{array}{c}\text { Average In-Well Flow } \\
\text { Velocity }^{(\mathrm{c})}(\mathrm{m} / \text { day })\end{array}$ \\
\hline \multicolumn{4}{|c|}{ Waste Management Area S-SX } \\
\hline 299-W22-48 & 0.257 & 0.013 & 0.007 \\
\hline $299-W 22-49^{(\mathrm{d})}$ & 0.671 & 0.022 & 0.086 \\
\hline $299-\mathrm{W} 22-50^{(\mathrm{e})}$ & $0.354,0.272$ & $0.030,0.040$ & $0.066,0.046$ \\
\hline $299-W 22-80^{(\mathrm{d})}$ & 0.167 & 0.179 & 0.482 \\
\hline 299-W22-81 & 0.040 & 0.067 & 0.035 \\
\hline 299-W22-84 & 0.020 & 0.121 & 0.090 \\
\hline \multicolumn{4}{|c|}{ Waste Management Area T } \\
\hline 299-W10-24 & 0.072 & 0.029 & 0.012 \\
\hline $299-W 11-39^{(f)}$ & 0.045 & 0.022 & 0.014 \\
\hline $299-\mathrm{W} 11-40^{(\mathrm{g})}$ & 1.1 & 0.002 & 0.176 \\
\hline \multicolumn{4}{|c|}{ Waste Management Area TX-TY } \\
\hline $299-\mathrm{W} 10-26^{(\mathrm{f})}$ & 0.010 & 0.124 & 0.086 \\
\hline $299-\mathrm{W} 14-13^{(\mathrm{g})}$ & 0.009 & 0.191 & ND \\
\hline
\end{tabular}


Table 2.8. (contd)

\begin{tabular}{|c|c|c|c|}
\hline Well & $\begin{array}{l}\text { Effective } \\
\text { Porosity }{ }^{(b)}\end{array}$ & $\begin{array}{c}\text { Groundwater }{ }^{(\mathrm{b})} \text { Flow } \\
\text { Velocity } \\
\text { (m/day) }\end{array}$ & $\begin{array}{l}\text { Average In-Well Flow } \\
\text { Velocity }^{(\mathrm{c})}(\mathrm{m} / \text { day })\end{array}$ \\
\hline $299-\mathrm{W} 14-14^{(\mathrm{f})}$ & 0.020 & 0.122 & 0.041 \\
\hline 299-W14-15 & 0.002 & 1.1 & 0.119 \\
\hline 299-W15-41 & 0.068 & 0.374 & 0.311 \\
\hline \multicolumn{4}{|c|}{ Waste Management Area U } \\
\hline 299-W19-42 & 0.027 & 0.419 & 0.170 \\
\hline \multicolumn{4}{|c|}{$\begin{array}{l}\text { (a) Data from Spane et al. (2001a, 2001b, 2002, 2003). } \\
\text { (b) Data from tracer pump back tests. } \\
\text { (c) Data from tracer dilution tests. } \\
\text { (d) Significant upward vertical flow, data highly uncertain. } \\
\text { (e) Two tests were conducted. } \\
\text { (f) Slight downward vertical flow, data uncertain. } \\
\text { (g) Significant downward vertical flow, data highly uncertain. }\end{array}$} \\
\hline
\end{tabular}

The hydrologic properties in Tables 2.5 through 2.8 are derived from relatively recent (post-1997) aquifer testing. Several slug tests were done prior to about 1997 at wells around the single-shell tank farms. Table 2.9 gives the resulting hydraulic conductivity and transmissivity data from those tests. In most cases, the analyses of the data from pre-1977 tests are less well documented than are the analyses for the data given in Tables 2.5 through 2.8. The original source for the data should be consulted for details of testing and analysis.

Table 2.9. Results of Pre-1997 Slug Testing at Single-Shell Tank Farms in the 200 West Area $^{(a)}$

\begin{tabular}{|c|c|c|}
\hline Well Name & $\begin{array}{l}\text { Hydraulic } \\
\text { Conductivity } \\
(\mathrm{m} / \text { day }) \\
\end{array}$ & $\begin{array}{c}\text { Transmissivity } \\
\left(\mathrm{m}^{2} / \text { day }\right)\end{array}$ \\
\hline \multicolumn{3}{|c|}{ Waste Management Area S-SX } \\
\hline 299-W23-13 & 27 & 167 \\
\hline 299-W23-14 & 0.4 & 2.5 \\
\hline \multicolumn{3}{|c|}{ Waste Management Area T } \\
\hline 299-W10-15 & 10.0 & 50 \\
\hline 299-W10-16 & 10.0 & 50 \\
\hline \multicolumn{3}{|c|}{ Waste Management Area TX-TY } \\
\hline 299-W10-17 & 79 & 464 \\
\hline 299-W10-18 & 43 & 232 \\
\hline 299-W15-22 & 15 & 93 \\
\hline \multicolumn{3}{|c|}{ Waste Management Area U } \\
\hline 299-W18-25 & 6.1 & 37 \\
\hline 299-W19-31 & 36 & 223 \\
\hline 299-W19-32 & 0.3 & 1.8 \\
\hline
\end{tabular}


Taken as a whole, the geologists' logs, geophysical logs, development pumping data, and the hydrologic testing data all indicate heterogeneity in the aquifer properties within the screened intervals of individual wells and among wells at the 200 West Area single-shell tank WMAs. No widespread trends have been identified.

\subsection{Historical Changes in Groundwater Flow Direction and Gradient Beneath 200 West Area Single-Shell Tank Waste Management Areas}

Water levels in the unconfined aquifer have risen as much as $26 \mathrm{~m}$ beneath the 200 West Area (Hodges and Chou 2000) because of artificial recharge from liquid waste disposal operations active from the mid 1940s to 1995 . The largest volumes of discharge were to the 216-T pond (T Pond) system and U Pond. (See Figure 1.1 for locations of T Pond and U Pond.) Figure 2.6 shows the liquid discharge history for the two ponds. The T Pond system is estimated to have received approximately 42.5 billion $\mathrm{L}$ of effluent and the U Pond to have received about 162 billion $\mathrm{L}$ of effluent (see references listed for Figure 2.6). These large volumes disposed to the ponds (and lesser volumes to cribs and ditches) artificially recharged the unconfined aquifer creating large water-table mounds. The increase in watertable elevation was most rapid from 1949 to 1956 and was somewhat stabilized between the late 1960s and the late 1980s. Water levels began to decline in the late 1980s when wastewater discharges in the 200 West Area were reduced.

Liquid Waste Discharges to 200-West Area Ponds

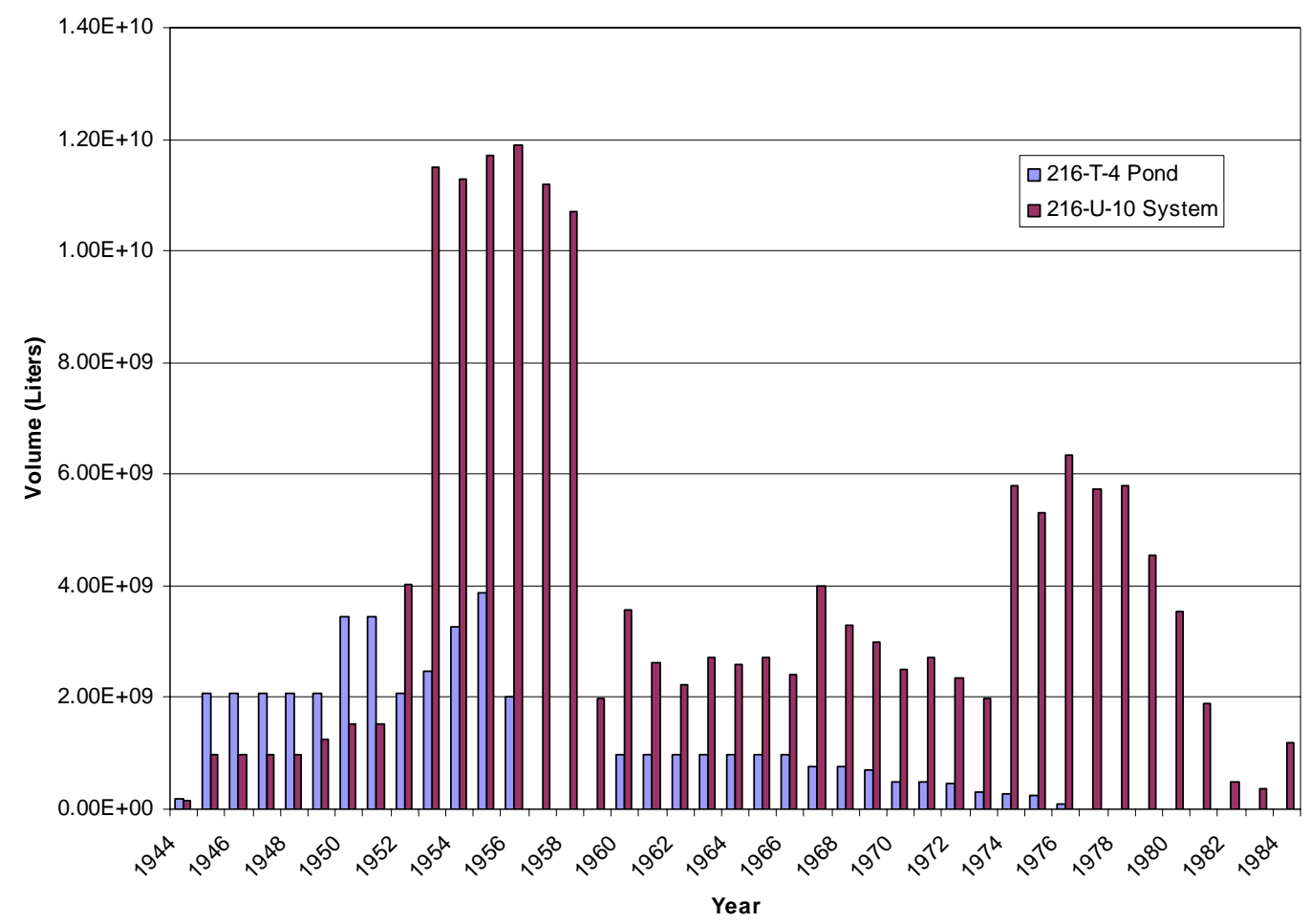

Figure 2.6. Discharge History for the T Pond and U Pond. (Data from Anderson 1976; Mirabella 1977; Anderson and Poremba 1978, 1979; Sliger 1980, 1982, 1983; Aldrich and Sliger 1981; and Aldrich 1984, 1985.) 
Figures 2.7 through 2.9 show hydrographs for the areas of the 200 West Area single-shell tank WMAs. The hydrographs illustrate the changes in water-table elevations that have occurred beneath the tank farms since at least the 1950s. All data used to make the hydrographs were obtained from HydroDat (see data files on compact disc [CD] included in Hartman et al. 2006). HydroDat is a database of waterlevel measurements maintained by the Hanford Groundwater Performance Assessment Project at Pacific Northwest National Laboratory.

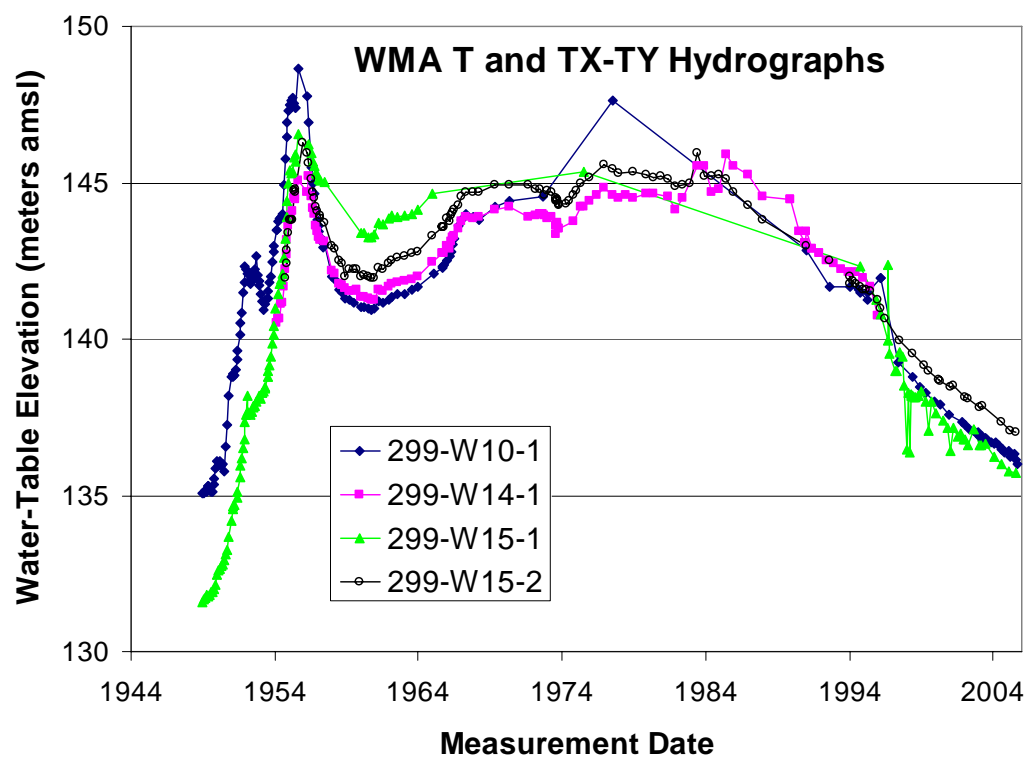

Figure 2.7. Hydrographs of Selected Wells in the Area of Waste Management Areas T and TX-TY, 200 West Area. (The location of well 299-W14-1 is shown on Figure 2.3; well 299-W15-1 is located about $200 \mathrm{~m}$ southwest of Waste Management Area TX-TY; well 299-W15-2 is located about 610 m east of the TY Tank Farm; the location of well 299-W10-1 is shown on Figure 2.2.)

Figure 2.7 shows hydrographs from wells in the area of WMAs T and TX-TY. The hydrographs show an initial and very rapid rise in the water table due to discharges to the T Pond in the late 1940s and early 1950s. The water table was at its highest elevation in about 1956 after having risen about $18 \mathrm{~m}$. This is followed by a sharp decline in the water table until about 1960. At that time, the water table began a slow increase in elevation that lasted until the mid 1980s when discharges to the subsurface began to be curtailed. Since the mid 1980s, the water table has declined, and the rate of decline became greater in 1995 when all non-permitted discharges to the ground were stopped.

Figure 2.8 shows hydrographs for the area around WMA S-SX. The water levels show the large influence of $U$ Pond on the water table in the area. The data do not extend far enough back in time to show any influence from T Pond, although WMA S-SX is fairly far south of the T Pond and may not have been influenced greatly by the pond. Between the early 1950s and mid 1960s, the water table beneath the $\mathrm{S}$ and SX Tank Farms had risen at least $11 \mathrm{~m}$ in response to the discharges to the U Pond. The watertable elevation remained fairly steady between 1965 and 1984 when discharge to U Pond ceased. Water levels began to rapidly decline in 1985 and that decline is continuing today. Water levels have decreased by about $12 \mathrm{~m}$ in the S and SX Tank Farm area since 1985. 


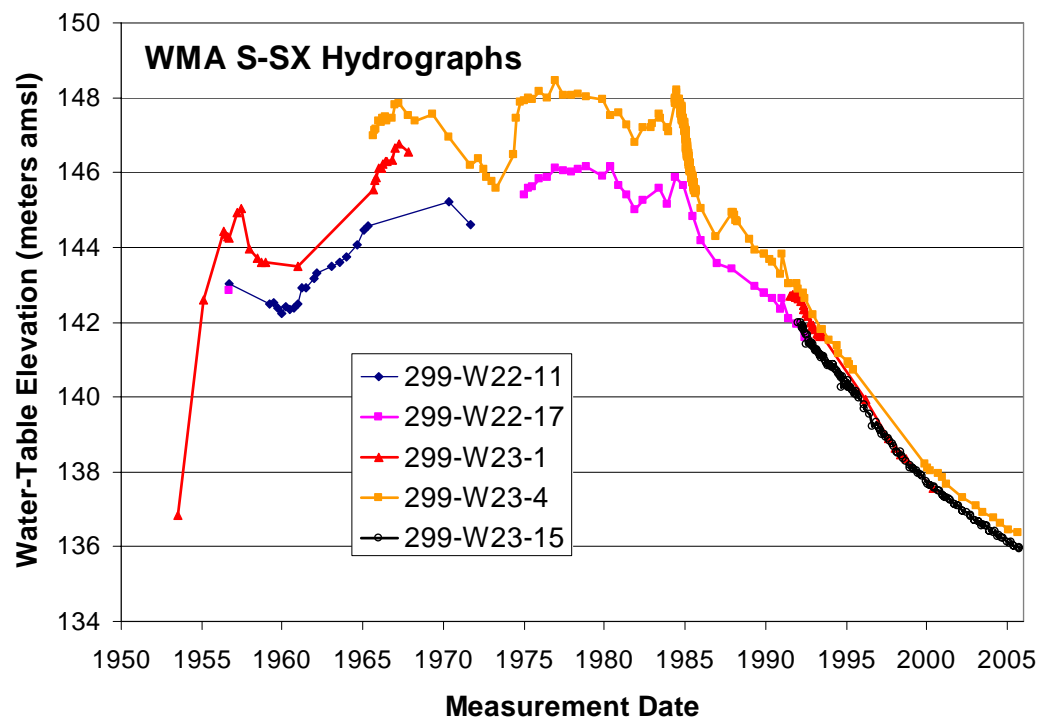

Figure 2.8. Hydrographs from Selected Wells in the Area of Waste Management Area S-SX, 200 West Area. (Wells 299-W22-11 and 299-W22-17 are very near each other and can be considered as a continuum in water-level elevation. Wells 299-W22-11 and 299-W22-17 are located about 150 m east of Waste Management Area S-SX, near the 216 S-1, 2 cribs; well 299-W23-1 is located inside the S Tank Farm; well 299-W23-3 is located just inside the southern fence of the SX Tank Farm; well 299-W23-15 is located just south of the SX Tank Farm.)

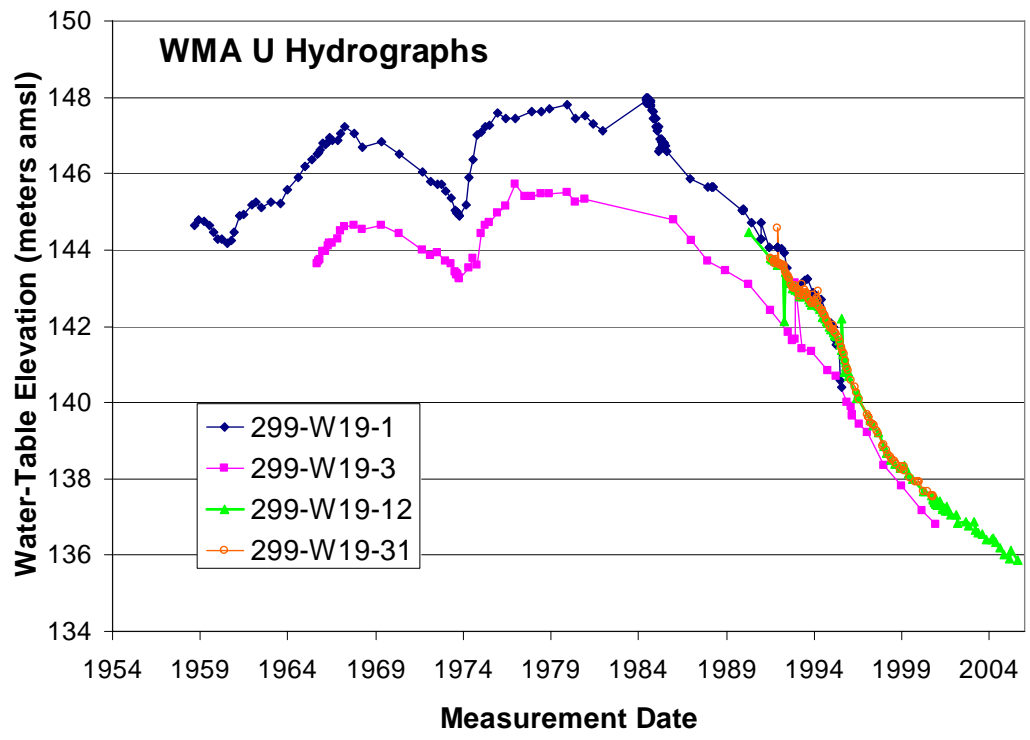

Figure 2.9. Hydrographs of Selected Wells in the Area of Waste Management Area U, 200 West Area. (Well 299-W19-3 is located about 450 m east of the southeast corner of the U Tank Farm; all other wells are shown on Figure 2.4.) 
Only two wells in the area of WMA U have water-level measurements from the 1960s or earlier (Figure 2.9). Water-level measurements from these wells clearly show the influence of U Pond on the local water table, but the measurements began long after the water table had risen several meters due to discharges to the pond. In about 1984, the water table beneath U Tank Farm began to decline and that decline is continuing today after dropping about $12 \mathrm{~m}$.

In all three sets of hydrographs (Figures 2.7, 2.8, and 2.9), there is a minimum in the water-table elevation in the 1973 to 1975 time frame. This minimum corresponds to a minimum in discharges to both T Pond and U Pond (Figure 2.6).

The pre-Manhattan Project maximum water table was at approximately $123 \mathrm{~m}$ above sea level (Kipp and Mudd 1974). Bergeron and Wurstner (2000) more recently modeled the elevation of the water table beneath the Hanford Site for the Immobilized Low-Activity Waste Performance Assessment. Their model, however, resulted in a water-table elevation of about 128 to $132 \mathrm{~m}$ above sea level in the 200 West Area after all influences from the Hanford Site have dissipated. Bergeron and Wurstner's analysis considered recharge from agricultural activities, just west of the Hanford Site, which did not exist at the time of Kipp and Mudd's analysis. Bergeron and Wurstner assumed that the agricultural irrigation would continue after Hanford Site influences on the water table stopped. The assumed continuing agricultural input to the unconfined aquifer probably accounts for the differences in the pre-Hanford Site water-table elevation and the predicted future water-table elevation.

Since all non-permitted discharges of liquid effluent to the ground were stopped, rapid changes have occurred in the water-table elevation. Table 2.10 gives the average rate of water-table decline in wells at each WMA during the past five years. The average rate of decline was obtained by averaging the rate of decline in each monitoring well in the RCRA monitoring network at each WMA between March 2000 and March 2005. All data used are from the HydroDat database (see data files on CD included in Hartman et al. 2006). For wells drilled between 1999 and 2002, the water-table decline during the entire life of the well was used; wells drilled after January 2002 were not used because they would bias the water-level change toward low values. The data in Table 2.10 show that the water table beneath all the 200 West single-shell tank farms is declining at a rate of about $0.3 \mathrm{~m} /$ year. At the current rate of decline, the water table should reach the estimated post-Hanford water-table elevation (Bergeron and Wurstner 2000) in approximately 14 to 17 years.

Accompanying the changes in water level were changes in groundwater flow direction. Pre-Hanford Site groundwater flow direction was generally toward the east (Kipp and Mudd 1974). The groundwater flow direction began to change in the late 1940s as a result of discharges to the T Pond system. In the mid-1950s, groundwater flow direction changed a second time due to the increasing influence of the groundwater mound under U Pond and a decreasing influence of the mound under T Pond. Discharges to T Pond ended in 1976 but continued at U Pond until 1984. After 1984, the groundwater mound beneath U Pond slowly dissipated. Consequently, the flow direction changed again starting in about 1996 when all non-permitted discharges to the ground ceased and the influence of the U Pond mound on the groundwater in 200 West Area diminished. At that time, flow direction began to return toward the preHanford direction. 
Table 2.10. Water-Level Changes Beneath the 200 West Single-Shell Tank Farms

\begin{tabular}{|c|c|c|c|c|c|}
\hline $\begin{array}{c}\text { Waste } \\
\text { Management } \\
\text { Area }\end{array}$ & $\begin{array}{l}\text { Approximate } \\
\text { Pre-Hanford } \\
\text { Water-Table } \\
\text { Elevation }^{(\mathbf{a})} \\
\text { (m amsl) }\end{array}$ & $\begin{array}{l}\text { Estimated Post- } \\
\text { Hanford Water- } \\
\text { Table } \\
\text { Elevation }^{(\mathbf{b})} \\
\text { (m amsl) }\end{array}$ & $\begin{array}{l}\text { Approximate Maximum } \\
\text { Water-Table Elevation } \\
\text { (m amsl) and Date of } \\
\text { Measurement }\end{array}$ & $\begin{array}{l}\text { Approximate } \\
\text { Current Water- } \\
\text { Table } \\
\text { Elevation }^{(c)} \\
\text { (m amsl) }\end{array}$ & $\begin{array}{c}\text { Approximate } \\
\text { Rate of Decline } \\
\text { in the Past } \\
5 \text { Years } \\
(\mathrm{m} / \mathrm{yr})\end{array}$ \\
\hline $\mathrm{T}$ & $123-125$ & $130-132$ & $\begin{array}{c}148.6-\text { Aug } 1955 \\
\quad(299-W 10-1)\end{array}$ & $135.7-136.0$ & 0.32 \\
\hline TX-TY & $123-125$ & $130-132$ & $\begin{array}{l}145.9 \text { - June } 1985 \\
(299-W 14-1)\end{array}$ & $135.2-136.1$ & 0.32 \\
\hline $\mathrm{U}$ & $123-125$ & $130-132$ & $\begin{array}{l}147.9-\text { June } 1984 \\
\quad(299-W 19-1)\end{array}$ & $135.8-136.4$ & 0.30 \\
\hline S-SX & $123-125$ & $130-132$ & $\begin{array}{c}148.2 \text { - July } 1984 \\
(299-W 23-4)\end{array}$ & $135.5-136.1$ & $0.29^{(\mathrm{d})}$ \\
\hline \multicolumn{6}{|c|}{$\begin{array}{l}\text { (a) Kipp and Mudd (1974). } \\
\text { (b) Bergeron and Wurstner (2000). } \\
\text { (c) Hartman et al. (2006). } \\
\text { (d) Includes data from four wells drilled in mid 2001, which slightly bias the rate of decline to a rate slightly lower } \\
\text { than a } 5 \text { year rate. } \\
\text { amsl = Above mean sea level. }\end{array}$} \\
\hline
\end{tabular}

Tables 2.11 through 2.13 give historical groundwater flow directions and water-table gradients beneath each of the 200 West Area tank farms. The flow directions and gradients were calculated using the three-point analysis method (Lahee 1961) and water-level measurements taken from the HydroDat database (see data files on CD included in Hartman et al. 2006).

For the three point analyses, wells located appropriately to the WMAs were first identified. Ideally, appropriately placed wells would form an equilateral triangle with the WMA at the center. This configuration could be met for the recent years but not for the 1950s to 1970s time frame for most WMAs. Thus, wells were chosen that most closely approached this configuration. Second, wells were chosen that had historical data as far into the past as possible. Water levels were recorded regularly in very few wells in the 1940s to 1980s. What data do exist were extracted from the HydroDat database. Third, water levels from all three wells should be measured on the same day to alleviate potential atmospheric pressure effects. This requirement would eliminate most water-level measurements in the HydroDat database older than about 1990. Thus, the requirement was relaxed and water-level measurements taken within at least one month of each other were used when necessary to get a good water-level history. The length of time between the first and third measurement for each three-point analysis is given in Tables 2.11 through 2.13 .

In addition to atmospheric pressure effects, several other potential sources of error affect the analysis of groundwater flow direction and water-table gradient. These include (1) the straightness of the wells, (2) the relatively flat water table coupled with measurement error, (3) the communication between the aquifer and the screened part of the well, (4) differences in lithology, and (5) periodic and local influence from nearby liquid disposal facilities. Also, several different well triplets were used for each single-shell tank WMA. Use of more than one well triplet assumes that the geometry of the wells, the straightness of the wells, and other well attributes are identical among triplets. This is almost certainly not the case. 
Table 2.11. Historical Water-Level Data, Groundwater Flow Directions, and Water-Table Gradients for the T, TX, and TY Tank Farm Areas (from Reidel et al. 2006)

\begin{tabular}{|c|c|c|c|c|c|c|c|c|c|c|}
\hline $\begin{array}{l}\text { Duration }^{(a)} \\
\text { (days) }\end{array}$ & Start Date & End Date & Well 1 & Well 2 & Well 3 & $\begin{array}{c}\text { Water } \\
\text { Level } 1 \\
\text { (m amsl) }\end{array}$ & $\begin{array}{c}\text { Water } \\
\text { Level } 2 \\
(\mathrm{~m} \text { amsl) }\end{array}$ & $\begin{array}{c}\text { Water } \\
\text { Level } 3 \\
(\mathrm{~m} \text { amsl) }\end{array}$ & $\begin{array}{c}\text { Groundwater } \\
\text { Flow } \\
\text { Direction }^{(b)}\end{array}$ & $\begin{array}{c}\text { Water-Table } \\
\text { Gradient }\end{array}$ \\
\hline 1 & $09 / 16 / 54$ & $09 / 16 / 54$ & 299-W10-1 & 299-W14-1 & $299-W 15-2^{(\mathrm{c})}$ & 145.766 & 142.219 & 141.944 & 183.76 & 0.0088 \\
\hline 1 & $10 / 22 / 54$ & $10 / 22 / 54$ & 299-W10-1 & 299-W14-1 & 299-W15-2 & 146.464 & 142.716 & 142.410 & 183.86 & 0.0093 \\
\hline 2 & $11 / 18 / 54$ & $11 / 19 / 54$ & 299-W10-1 & 299-W14-1 & 299-W15-2 & 146.915 & 143.142 & 142.831 & 183.88 & 0.0094 \\
\hline 1 & $12 / 22 / 54$ & $12 / 22 / 54$ & 299-W10-1 & 299-W14-1 & 299-W15-2 & 147.314 & 143.648 & 143.392 & 183.55 & 0.0090 \\
\hline 1 & $01 / 28 / 55$ & $01 / 28 / 55$ & 299-W10-1 & 299-W14-1 & 299-W15-2 & 147.500 & 143.831 & 143.822 & 181.73 & 0.0088 \\
\hline 1 & $02 / 10 / 55$ & \begin{tabular}{|l|l|}
$02 / 10 / 55$ \\
\end{tabular} & 299-W10-1 & 299-W14-1 & 299-W15-2 & 147.607 & 143.974 & 143.812 & 182.88 & 0.0089 \\
\hline 1 & $03 / 25 / 55$ & $03 / 25 / 55$ & 299-W10-1 & 299-W14-1 & $299-W 15-2$ & 147.744 & 144.108 & 143.791 & 184.01 & 0.0090 \\
\hline 1 & $04 / 28 / 55$ & $04 / 28 / 55$ & 299-W10-1 & 299-W14-1 & 299-W15-2 & 147.516 & 144.505 & 144.742 & 179.43 & 0.0071 \\
\hline 1 & $05 / 31 / 55$ & $05 / 31 / 55$ & 299-W10-1 & 299-W14-1 & 299-W15-2 & 147.391 & 144.459 & 144.705 & 179.27 & 0.0069 \\
\hline 1 & $06 / 23 / 55$ & $06 / 23 / 55$ & 299-W10-1 & 299-W14-1 & 299-W15-2 & 147.406 & 144.550 & 144.776 & 179.41 & 0.0067 \\
\hline 1 & $03 / 21 / 56$ & $03 / 21 / 56$ & 299-W10-1 & 299-W14-1 & 299-W15-2 & 147.769 & 144.688 & 145.976 & 168.34 & 0.0065 \\
\hline 2 & $05 / 21 / 56$ & $05 / 22 / 56$ & 299-W10-1 & 299-W14-1 & 299-W15-2 & 146.933 & 145.209 & 145.605 & 174.78 & 0.0038 \\
\hline 1 & $08 / 08 / 56$ & $08 / 08 / 56$ & 299-W10-1 & 299-W14-1 & 299-W15-2 & 145.492 & 144.557 & 145.102 & 162.15 & 0.0019 \\
\hline 1 & $09 / 18 / 56$ & $09 / 18 / 56$ & 299-W10-1 & 299-W14-1 & 299-W15-2 & 144.977 & 144.194 & 144.699 & 159.71 & 0.0016 \\
\hline 1 & $10 / 16 / 56$ & $10 / 16 / 56$ & 299-W10-1 & 299-W14-1 & 299-W15-2 & 144.657 & 143.999 & 144.523 & 153.54 & 0.0013 \\
\hline 1 & $11 / 26 / 56$ & $11 / 26 / 56$ & 299-W10-1 & 299-W14-1 & 299-W15-2 & 144.080 & 143.642 & 144.248 & 129.18 & 0.0009 \\
\hline 1 & $12 / 26 / 56$ & $12 / 26 / 56$ & 299-W10-1 & 299-W14-1 & 299-W15-2 & 143.791 & 143.462 & 144.096 & 110.75 & 0.0008 \\
\hline 3 & $03 / 13 / 57$ & $03 / 15 / 57$ & 299-W10-1 & 299-W14-1 & 299-W15-2 & 143.258 & 143.170 & 143.943 & 65.47 & 0.0010 \\
\hline 1 & $06 / 18 / 57$ & $06 / 18 / 57$ & 299-W10-1 & 299-W14-1 & 299-W15-2 & 143.014 & 143.112 & 143.730 & 45.12 & 0.0010 \\
\hline 1 & $12 / 27 / 57$ & $12 / 27 / 57$ & 299-W10-1 & 299-W14-1 & 299-W15-2 & 142.023 & 142.197 & 142.986 & 41.86 & 0.0014 \\
\hline 1 & $03 / 21 / 56$ & $03 / 21 / 56$ & 299-W10-1 & 299-W14-1 & 299-W15-2 & 147.769 & 144.688 & 145.976 & 168.34 & 0.0065 \\
\hline 2 & $05 / 21 / 56$ & $05 / 22 / 56$ & 299-W10-1 & 299-W14-1 & 299-W15-2 & 146.933 & 145.209 & 145.605 & 174.78 & 0.0038 \\
\hline 1 & $08 / 08 / 56$ & $08 / 08 / 56$ & 299-W10-1 & 299-W14-1 & 299-W15-2 & 145.492 & 144.557 & 145.102 & 162.15 & 0.0019 \\
\hline 1 & $09 / 18 / 56$ & $09 / 18 / 56$ & 299-W10-1 & 299-W14-1 & 299-W15-2 & 144.977 & 144.194 & 144.699 & 159.71 & 0.0016 \\
\hline 1 & $10 / 16 / 56$ & $10 / 16 / 56$ & 299-W10-1 & 299-W14-1 & 299-W15-2 & 144.657 & 143.999 & 144.523 & 153.54 & 0.0013 \\
\hline 1 & $11 / 26 / 56$ & $11 / 26 / 56$ & 299-W10-1 & 299-W14-1 & 299-W15-2 & 144.080 & 143.642 & 144.248 & 129.18 & 0.0009 \\
\hline
\end{tabular}


Table 2.11. (contd)

\begin{tabular}{|c|c|c|c|c|c|c|c|c|c|c|}
\hline $\begin{array}{c}\text { Duration }^{(a)} \\
\text { (days) }\end{array}$ & Start Date & End Date & Well 1 & Well 2 & Well 3 & $\begin{array}{c}\text { Water } \\
\text { Level } 1 \\
\text { (m amsl) } \\
\end{array}$ & $\begin{array}{c}\text { Water } \\
\text { Level } 2 \\
(\mathrm{~m} \text { amsl) } \\
\end{array}$ & $\begin{array}{c}\text { Water } \\
\text { Level } 3 \\
(\mathrm{~m} \text { amsl) } \\
\end{array}$ & $\begin{array}{c}\text { Groundwater } \\
\text { Flow } \\
\text { Direction }^{(b)} \\
\end{array}$ & $\begin{array}{c}\text { Water-Table } \\
\text { Gradient }\end{array}$ \\
\hline 1 & $12 / 26 / 56$ & $12 / 26 / 56$ & 299-W10-1 & 299-W14-1 & $299-W 15-2$ & 143.791 & 143.462 & 144.096 & 110.75 & 0.0008 \\
\hline 3 & $03 / 13 / 57$ & $03 / 15 / 57$ & 299-W10-1 & 299-W14-1 & 299-W15-2 & 143.258 & 143.170 & 143.943 & 65.47 & 0.0010 \\
\hline 1 & $06 / 18 / 57$ & $06 / 18 / 57$ & 299-W10-1 & 299-W14-1 & 299-W15-2 & 143.014 & 143.112 & 143.730 & 45.12 & 0.0010 \\
\hline 1 & $12 / 27 / 57$ & $12 / 27 / 57$ & 299-W10-1 & 299-W14-1 & 299-W15-2 & 142.023 & 142.197 & 142.986 & 41.86 & 0.0014 \\
\hline 1 & $03 / 20 / 58$ & $03 / 20 / 58$ & 299-W10-1 & 299-W14-1 & 299-W15-2 & 141.904 & 142.103 & 142.895 & 40.39 & 0.0015 \\
\hline 1 & $06 / 25 / 58$ & $06 / 25 / 58$ & 299-W10-1 & 299-W14-1 & 299-W15-2 & 141.587 & 141.765 & 142.526 & 41.21 & 0.0014 \\
\hline 1 & $09 / 05 / 58$ & $09 / 05 / 58$ & 299-W10-1 & 299-W14-1 & 299-W15-2 & 141.477 & 141.704 & 142.435 & 37.79 & 0.0014 \\
\hline 1 & $12 / 09 / 58$ & $12 / 09 / 58$ & 299-W10-1 & 299-W14-1 & 299-W15-2 & 141.322 & 141.618 & 142.011 & 25.30 & 0.0011 \\
\hline 2 & $03 / 24 / 59$ & $03 / 25 / 59$ & 299-W10-1 & 299-W14-1 & 299-W15-2 & 141.270 & 141.554 & 142.249 & 34.11 & 0.0015 \\
\hline 2 & $06 / 29 / 59$ & $06 / 30 / 59$ & 299-W10-1 & 299-W14-1 & 299-W15-2 & 141.148 & 141.551 & 142.230 & 28.75 & 0.0017 \\
\hline 2 & $12 / 28 / 59$ & $12 / 29 / 59$ & 299-W10-1 & 299-W14-1 & 299-W15-2 & 141.011 & 141.353 & 141.993 & 30.28 & 0.0016 \\
\hline 1 & $04 / 04 / 60$ & $04 / 04 / 60$ & 299-W10-1 & 299-W14-1 & 299-W15-2 & 141.023 & 141.359 & 142.063 & 31.91 & 0.0016 \\
\hline 1 & $07 / 05 / 60$ & $07 / 05 / 60$ & 299-W10-1 & 299-W14-1 & 299-W15-2 & 140.956 & 141.286 & 142.011 & 32.59 & 0.0016 \\
\hline 1 & $09 / 27 / 60$ & $09 / 27 / 60$ & 299-W10-1 & 299-W14-1 & 299-W15-2 & 140.932 & 141.249 & 141.968 & 33.05 & 0.0016 \\
\hline 1 & $12 / 07 / 60$ & $12 / 07 / 60$ & 299-W10-1 & 299-W14-1 & 299-W15-2 & 140.978 & 141.265 & 141.962 & 34.01 & 0.0015 \\
\hline 2 & $03 / 23 / 61$ & $03 / 24 / 61$ & 299-W10-1 & 299-W14-1 & 299-W15-2 & 141.200 & 141.579 & 142.267 & 29.84 & 0.0017 \\
\hline 1 & $07 / 07 / 61$ & $07 / 07 / 61$ & 299-W10-1 & 299-W14-1 & 299-W15-2 & 141.161 & 141.533 & 142.252 & 30.75 & 0.0017 \\
\hline 1 & $12 / 14 / 61$ & $12 / 14 / 61$ & 299-W10-1 & 299-W14-1 & 299-W15-2 & 141.270 & 141.697 & 142.432 & 29.06 & 0.0019 \\
\hline 1 & $03 / 05 / 62$ & $03 / 05 / 62$ & 299-W10-1 & 299-W14-1 & 299-W15-2 & 141.337 & 141.765 & 142.508 & 29.19 & 0.0019 \\
\hline 1 & $07 / 12 / 62$ & $07 / 12 / 62$ & 299-W10-1 & 299-W14-1 & 299-W15-2 & 141.432 & 141.816 & 142.602 & 31.58 & 0.0018 \\
\hline 1 & $01 / 17 / 63$ & $01 / 17 / 63$ & 299-W10-1 & 299-W14-1 & 299-W15-2 & 141.462 & 141.865 & 142.654 & 30.94 & 0.0019 \\
\hline 1 & $08 / 02 / 63$ & $08 / 02 / 63$ & 299-W10-1 & 299-W14-1 & 299-W15-2 & 141.602 & 141.923 & 142.727 & 34.44 & 0.0017 \\
\hline 1 & $12 / 26 / 63$ & $12 / 26 / 63$ & 299-W10-1 & 299-W14-1 & 299-W15-2 & 141.697 & 141.990 & 142.800 & 35.79 & 0.0017 \\
\hline 1 & $08 / 26 / 65$ & $08 / 26 / 65$ & 299-W10-1 & 299-W14-1 & 299-W15-2 & 142.297 & 142.746 & 143.593 & 30.40 & 0.0021 \\
\hline 1 & $09 / 23 / 65$ & $09 / 23 / 65$ & 299-W10-1 & 299-W14-1 & 299-W15-2 & 142.313 & 142.755 & 143.587 & 30.37 & 0.0020 \\
\hline 2 & $10 / 20 / 65$ & $10 / 21 / 65$ & 299-W10-1 & 299-W14-1 & 299-W15-2 & 142.355 & 142.758 & 143.599 & 31.86 & 0.0019 \\
\hline 1 & $01 / 03 / 66$ & $01 / 03 / 66$ & 299-W10-1 & 299-W14-1 & 299-W15-2 & 142.529 & 142.981 & 143.852 & 30.71 & 0.0021 \\
\hline
\end{tabular}


Table 2.11. (contd)

\begin{tabular}{|c|c|c|c|c|c|c|c|c|c|c|}
\hline $\begin{array}{c}\text { Duration }^{(a)} \\
\text { (days) }\end{array}$ & Start Date & End Date & Well 1 & Well 2 & Well 3 & $\begin{array}{c}\text { Water } \\
\text { Level } 1 \\
\text { (m amsl) } \\
\end{array}$ & $\begin{array}{c}\text { Water } \\
\text { Level } 2 \\
(\mathrm{~m} \text { amsl) } \\
\end{array}$ & $\begin{array}{c}\text { Water } \\
\text { Level } 3 \\
(\mathrm{~m} \text { amsl) } \\
\end{array}$ & $\begin{array}{c}\text { Groundwater } \\
\text { Flow } \\
\text { Direction }^{(b)} \\
\end{array}$ & $\begin{array}{c}\text { Water-Table } \\
\text { Gradient }\end{array}$ \\
\hline 1 & $03 / 04 / 66$ & $03 / 04 / 66$ & 299-W10-1 & 299-W14-1 & $299-W 15-2$ & 142.639 & 142.886 & 143.761 & 38.99 & 0.0017 \\
\hline 1 & $04 / 11 / 66$ & $04 / 11 / 66$ & 299-W10-1 & 299-W14-1 & 299-W15-2 & 142.800 & 143.100 & 143.971 & 36.44 & 0.0018 \\
\hline 1 & $05 / 19 / 66$ & $05 / 19 / 66$ & 299-W10-1 & 299-W14-1 & 299-W15-2 & 143.023 & 143.252 & 144.053 & 38.83 & 0.0015 \\
\hline 1 & $07 / 12 / 66$ & $07 / 12 / 66$ & 299-W10-1 & 299-W14-1 & 299-W15-2 & 143.215 & 143.322 & 144.117 & 46.50 & 0.0013 \\
\hline 3 & $11 / 01 / 66$ & $11 / 03 / 66$ & 299-W10-1 & 299-W14-1 & 299-W15-2 & 143.626 & 143.554 & 144.297 & 63.88 & 0.0010 \\
\hline 1 & $12 / 28 / 66$ & $12 / 28 / 66$ & 299-W10-1 & 299-W14-1 & 299-W15-2 & 143.828 & 143.749 & 144.553 & 64.00 & 0.0011 \\
\hline 1 & $04 / 07 / 67$ & $04 / 07 / 67$ & 299-W10-1 & 299-W14-1 & 299-W15-2 & 143.980 & 143.929 & 144.675 & 61.29 & 0.0010 \\
\hline 1 & $10 / 24 / 67$ & $10 / 24 / 67$ & 299-W10-1 & 299-W14-1 & 299-W15-2 & 143.916 & 143.874 & 144.702 & 59.76 & 0.0011 \\
\hline 3 & $03 / 19 / 68$ & $03 / 21 / 68$ & 299-W10-1 & 299-W14-1 & 299-W15-2 & 143.831 & 143.913 & 144.702 & 48.36 & 0.0013 \\
\hline 1 & $04 / 25 / 69$ & $04 / 25 / 69$ & 299-W10-1 & 299-W14-1 & 299-W15-2 & 144.221 & 144.124 & 144.919 & 66.25 & 0.0010 \\
\hline 1 & $05 / 14 / 70$ & $05 / 14 / 70$ & 299-W10-1 & 299-W14-1 & 299-W15-2 & 144.413 & 144.221 & 144.934 & 81.99 & 0.0008 \\
\hline 5 & $04 / 13 / 73$ & $04 / 17 / 73$ & $299-\mathrm{W} 10-2^{(\mathrm{d})}$ & 299-W14-1 & 299-W15-2 & 144.026 & 143.898 & 144.715 & 69.70 & 0.0010 \\
\hline 4 & $07 / 13 / 73$ & $07 / 16 / 73$ & 299-W10-2 & 299-W14-1 & 299-W15-2 & 143.770 & 143.371 & 144.529 & 90.82 & 0.0013 \\
\hline 1 & $08 / 14 / 73$ & $08 / 14 / 73$ & 299-W10-2 & 299-W14-1 & 299-W15-2 & 143.700 & 143.642 & 144.422 & 61.82 & 0.0010 \\
\hline 1 & $08 / 29 / 73$ & $08 / 29 / 73$ & 299-W10-2 & 299-W14-1 & 299-W15-2 & 143.724 & 143.727 & 144.477 & 55.32 & 0.0011 \\
\hline 1 & $09 / 13 / 73$ & $09 / 13 / 73$ & 299-W10-2 & 299-W14-1 & 299-W15-2 & 143.648 & 143.648 & 144.419 & 55.63 & 0.0011 \\
\hline 1 & $10 / 02 / 73$ & $10 / 02 / 73$ & 299-W10-2 & 299-W14-1 & 299-W15-2 & 143.535 & 143.514 & 144.279 & 57.81 & 0.0011 \\
\hline 1 & $10 / 16 / 73$ & $10 / 16 / 73$ & 299-W10-2 & 299-W14-1 & 299-W15-2 & 143.553 & 143.545 & 144.321 & 56.44 & 0.0011 \\
\hline 1 & $10 / 18 / 74$ & $10 / 18 / 74$ & 299-W10-2 & 299-W14-1 & 299-W15-2 & 143.715 & 143.770 & 144.608 & 50.86 & 0.0013 \\
\hline 1 & $04 / 14 / 75$ & $04 / 14 / 75$ & 299-W10-2 & 299-W14-1 & 299-W15-2 & 144.032 & 144.236 & 144.992 & 39.54 & 0.0014 \\
\hline 1 & $12 / 03 / 75$ & $12 / 03 / 75$ & 299-W10-2 & 299-W14-1 & 299-W15-2 & 144.227 & 144.441 & 145.160 & 38.33 & 0.0014 \\
\hline 1 & $12 / 08 / 76$ & $12 / 08 / 76$ & 299-W10-2 & 299-W14-1 & 299-W15-2 & 144.468 & 144.849 & 145.583 & 30.70 & 0.0018 \\
\hline 1 & $07 / 01 / 77$ & $07 / 01 / 77$ & 299-W10-2 & 299-W14-1 & 299-W15-2 & 144.282 & 144.614 & 145.443 & 34.39 & 0.0018 \\
\hline 1 & $12 / 07 / 77$ & $12 / 07 / 77$ & 299-W10-2 & 299-W14-1 & 299-W15-2 & 144.184 & 144.526 & 145.288 & 32.79 & 0.0017 \\
\hline 1 & $12 / 01 / 78$ & $12 / 01 / 78$ & 299-W10-2 & 299-W14-1 & 299-W15-2 & 144.175 & 144.514 & 145.333 & 33.93 & 0.0018 \\
\hline 1 & $12 / 01 / 79$ & $12 / 01 / 79$ & 299-W10-2 & 299-W14-1 & 299-W15-2 & 144.270 & 144.666 & 145.269 & 27.28 & 0.0016 \\
\hline 1 & $06 / 01 / 80$ & $06 / 01 / 80$ & 299-W10-2 & 299-W14-1 & 299-W15-2 & 144.263 & 144.654 & 145.169 & 25.18 & 0.0015 \\
\hline
\end{tabular}


Table 2.11. (contd)

\begin{tabular}{|c|c|c|c|c|c|c|c|c|c|c|}
\hline $\begin{array}{c}\text { Duration }^{(a)} \\
\text { (days) }\end{array}$ & Start Date & End Date & Well 1 & Well 2 & Well 3 & $\begin{array}{c}\text { Water } \\
\text { Level 1 } \\
\text { (m amsl) } \\
\end{array}$ & $\begin{array}{c}\text { Water } \\
\text { Level } 2 \\
(\mathrm{~m} \text { amsl) } \\
\end{array}$ & $\begin{array}{c}\text { Water } \\
\text { Level } 3 \\
(\mathrm{~m} \text { amsl) } \\
\end{array}$ & $\begin{array}{c}\text { Groundwater } \\
\text { Flow } \\
\text { Direction }^{(b)} \\
\end{array}$ & $\begin{array}{c}\text { Water-Table } \\
\text { Gradient }\end{array}$ \\
\hline 1 & $06 / 01 / 81$ & $06 / 01 / 81$ & 299-W10-2 & 299-W14-1 & $299-W 15-2$ & 144.075 & 144.578 & 145.117 & 22.28 & 0.0018 \\
\hline 1 & $12 / 01 / 81$ & $12 / 01 / 81$ & 299-W10-2 & 299-W14-1 & 299-W15-2 & 143.971 & 144.154 & 144.901 & 40.68 & 0.0014 \\
\hline 1 & $06 / 01 / 82$ & $06 / 01 / 82$ & 299-W10-2 & 299-W14-1 & 299-W15-2 & 144.093 & 144.502 & 144.946 & 22.46 & 0.0015 \\
\hline 1 & $06 / 01 / 83$ & $06 / 01 / 83$ & 299-W10-2 & 299-W14-1 & 299-W15-2 & 144.254 & 145.517 & 145.934 & 9.80 & 0.0034 \\
\hline 1 & $12 / 01 / 83$ & $12 / 01 / 83$ & 299-W10-2 & 299-W14-1 & 299-W15-2 & 144.294 & 145.526 & 145.205 & 353.77 & 0.0027 \\
\hline 1 & $06 / 01 / 84$ & $06 / 01 / 84$ & 299-W10-2 & 299-W14-1 & 299-W15-2 & 144.263 & 144.697 & 145.224 & 24.02 & 0.0016 \\
\hline 1 & $12 / 01 / 84$ & $12 / 01 / 84$ & 299-W10-2 & 299-W14-1 & 299-W15-2 & 144.376 & 144.788 & 145.275 & 23.65 & 0.0015 \\
\hline 9 & $06 / 12 / 85$ & $06 / 20 / 85$ & 299-W10-2 & 299-W14-1 & 299-W15-2 & 144.507 & 145.904 & 145.139 & 343.52 & 0.0029 \\
\hline 2 & $12 / 17 / 85$ & $12 / 18 / 85$ & 299-W10-2 & 299-W14-1 & 299-W15-2 & 144.190 & 145.541 & 144.691 & 340.34 & 0.0027 \\
\hline 5 & $12 / 11 / 87$ & $12 / 15 / 87$ & 299-W10-2 & 299-W14-1 & 299-W15-2 & 143.294 & 144.550 & 143.810 & 341.91 & 0.0025 \\
\hline 11 & $12 / 10 / 90$ & $12 / 20 / 90$ & 299-W10-2 & 299-W14-1 & 299-W15-2 & 142.916 & 143.075 & 142.975 & 340.34 & 0.0003 \\
\hline 14 & $06 / 09 / 92$ & $06 / 22 / 92$ & $299-W 10-14^{(\mathrm{e})}$ & 299-W10-2 & 299-W14-12 & 142.196 & 142.17 & 142.645 & 357.75 & 0.0013 \\
\hline 20 & $08 / 14 / 92$ & $09 / 02 / 92$ & 299-W10-1 & 299-W10-14 & 299-W14-12 & 141.671 & 142.141 & 142.621 & 7.22 & 0.0023 \\
\hline 16 & 08/18/92 & $09 / 02 / 92$ & 299-W10-1 & 299-W14-12 & 299-W15-2 & 141.671 & 142.621 & 142.508 & 359.88 & 0.0021 \\
\hline 14 & $12 / 04 / 92$ & $12 / 17 / 92$ & 299-W10-14 & 299-W10-2 & 299-W14-12 & 141.988 & 141.965 & 142.554 & 358.27 & 0.0017 \\
\hline 10 & $06 / 16 / 93$ & $06 / 25 / 93$ & 299-W10-14 & 299-W10-2 & 299-W14-12 & 141.894 & 141.901 & 142.41 & 359.87 & 0.0016 \\
\hline 15 & $12 / 02 / 93$ & $12 / 16 / 93$ & 299-W10-14 & 299-W10-2 & 299-W14-12 & 141.632 & 141.725 & 142.316 & 3.25 & 0.0022 \\
\hline 15 & $12 / 28 / 93$ & $01 / 11 / 94$ & 299-W10-1 & 299-W14-12 & 299-W15-2 & 141.689 & 142.346 & 141.996 & 344.58 & 0.0013 \\
\hline 15 & $01 / 11 / 94$ & $01 / 25 / 94$ & 299-W10-1 & 299-W10-14 & 299-W14-12 & 141.689 & 141.656 & 142.325 & 346.73 & 0.0013 \\
\hline 7 & $06 / 16 / 94$ & $06 / 22 / 94$ & 299-W10-14 & 299-W10-2 & 299-W14-12 & 141.559 & 141.709 & 142.298 & 4.98 & 0.0024 \\
\hline 13 & $09 / 07 / 94$ & $09 / 19 / 94$ & 299-W10-1 & 299-W10-14 & 299-W14-12 & 141.576 & 141.489 & 142.112 & 341.82 & 0.0011 \\
\hline 13 & $09 / 07 / 94$ & $09 / 19 / 94$ & 299-W10-1 & 299-W14-12 & 299-W15-2 & 141.576 & 142.112 & 141.658 & 331.44 & 0.0010 \\
\hline 14 & $12 / 01 / 94$ & $12 / 14 / 94$ & 299-W10-14 & 299-W10-2 & 299-W14-12 & 141.428 & 141.542 & 141.993 & 4.95 & 0.0018 \\
\hline 15 & $03 / 14 / 95$ & $03 / 28 / 95$ & 299-W10-1 & 299-W10-14 & 299-W14-12 & 141.263 & 141.312 & 141.984 & 351.81 & 0.0015 \\
\hline 33 & $05 / 15 / 97$ & $06 / 16 / 97$ & 299-W10-1 & 299-W14-12 & 299-W15-2 & 139.233 & 139.195 & 139.942 & 65.78 & 0.0010 \\
\hline 2 & $06 / 10 / 98$ & $06 / 11 / 98$ & 299-W10-1 & 299-W10-14 & 299-W14-12 & 138.812 & 139.355 & 138.408 & 113.57 & 0.0010 \\
\hline 5 & $06 / 11 / 98$ & $06 / 15 / 98$ & 299-W10-1 & 299-W14-12 & 299-W15-2 & 138.812 & 138.408 & 139.521 & 96.83 & 0.0014 \\
\hline
\end{tabular}


Table 2.11. (contd)

\begin{tabular}{|c|c|c|c|c|c|c|c|c|c|c|}
\hline $\begin{array}{c}\text { Duration }^{(a)} \\
\text { (days) }\end{array}$ & Start Date & End Date & Well 1 & Well 2 & Well 3 & $\begin{array}{c}\text { Water } \\
\text { Level } 1 \\
(\mathrm{~m} \text { amsl) } \\
\end{array}$ & $\begin{array}{c}\text { Water } \\
\text { Level } 2 \\
(\mathrm{~m} \text { amsl) } \\
\end{array}$ & $\begin{array}{c}\text { Water } \\
\text { Level } 3 \\
(\mathrm{~m} \text { ams } 1) \\
\end{array}$ & $\begin{array}{c}\text { Groundwater } \\
\text { Flow } \\
\text { Direction }^{(b)} \\
\end{array}$ & $\begin{array}{c}\text { Water-Table } \\
\text { Gradient }\end{array}$ \\
\hline 14 & $11 / 14 / 01$ & $11 / 27 / 01$ & 299-W10-14 & 299-W10-28 & 299-W14-13 & 138.035 & 137.219 & 136.997 & 88.28 & 0.0012 \\
\hline 8 & $09 / 17 / 02$ & $09 / 24 / 02$ & 299-W10-14 & 299-W10-28 & 299-W14-13 & 137.88 & 136.958 & 136.721 & 86.98 & 0.0013 \\
\hline 14 & $03 / 12 / 03$ & $03 / 25 / 03$ & 299-W10-14 & 299-W10-28 & 299-W14-13 & 137.733 & 136.76 & 136.566 & 81.94 & 0.0014 \\
\hline $\begin{array}{l}\text { (a) Duratio } \\
\text { (b) Ground } \\
\text { (c) Well 2S } \\
\text { (d) Well 2S } \\
\text { (e) Well 2S }\end{array}$ & $\begin{array}{l}\mathrm{n} \text { is the num } \\
\text { water flow d } \\
9-\mathrm{W} 15-2 \text { is } \\
9-\mathrm{W} 10-2 \text { is } \\
9-\mathrm{W} 10-14 \text { is }\end{array}$ & $\begin{array}{l}\text { ber of days } t \\
\text { irection is g } \\
\text { located abou } \\
\text { located abou } \\
\text { located abc }\end{array}$ & $\begin{array}{l}\text { tween the start } \\
\text { en in degrees a } \\
600 \text { m west of } \\
25 \text { m southwes } \\
\text { t } 700 \text { m west o }\end{array}$ & $\begin{array}{l}\text { ate and the end } \\
\text { muth clockwise } \\
\text { X Tank Farm. } \\
\text { f the southwes } \\
\text { Tank Farm. }\end{array}$ & $\begin{array}{l}\text { te. } \\
\text { rom north }\left(0^{\circ}\right) \text {. } \\
\text { orner of T Tan }\end{array}$ & arm. & & & & \\
\hline
\end{tabular}

Table 2.12. Historical Water-Level Data, Groundwater Flow Directions, and Water-Table Gradients for the U Tank Farm Area (updated from Reidel et al. 2006)

\begin{tabular}{|c|c|c|c|c|c|c|c|c|c|c|}
\hline $\begin{array}{c}\text { Duration }^{(a)} \\
\text { (days) }\end{array}$ & Start Date & End Date & Well 1 & Well 2 & Well 3 & $\begin{array}{c}\text { Water } \\
\text { Level } 1 \\
(\mathrm{~m} \text { amsl) } \\
\end{array}$ & $\begin{array}{c}\text { Water } \\
\text { Level } 2 \\
(\mathrm{~m} \text { amsl) } \\
\end{array}$ & $\begin{array}{c}\text { Water } \\
\text { Level } 3 \\
(\mathrm{~m} \text { amsl) }\end{array}$ & $\begin{array}{c}\text { Groundwater } \\
\text { Flow } \\
\text { Direction }^{(b)}\end{array}$ & $\begin{array}{c}\text { Water-Table } \\
\text { Gradient }\end{array}$ \\
\hline 1 & $01 / 23 / 92$ & $01 / 23 / 92$ & 299-W18-25 & 299-W18-30 & 299-W19-12 & 144.133 & 143.642 & 143.596 & 85.60 & 0.002955 \\
\hline 1 & $02 / 27 / 92$ & $02 / 27 / 92$ & 299-W18-25 & 299-W18-30 & 299-W19-12 & 144.127 & 143.612 & 143.611 & 79.25 & 0.002744 \\
\hline 1 & $05 / 22 / 92$ & $05 / 22 / 92$ & 299-W18-25 & 299-W18-30 & 299-W19-12 & 143.74 & 143.401 & 143.413 & 76.19 & 0.001719 \\
\hline 3 & 06/17/92 & 06/19/92 & 299-W18-25 & 299-W18-30 & 299-W19-12 & 143.627 & 143.35 & 143.346 & 80.21 & 0.001501 \\
\hline 1 & 08/19/92 & 08/19/92 & 299-W18-25 & 299-W18-30 & 299-W19-12 & 143.435 & 143.215 & 143.209 & 81.16 & 0.001213 \\
\hline 1 & $09 / 16 / 92$ & $09 / 16 / 92$ & 299-W18-25 & 299-W18-30 & 299-W19-12 & 143.344 & 143.139 & 143.135 & 80.59 & 0.001118 \\
\hline 1 & $10 / 22 / 92$ & $10 / 22 / 92$ & 299-W18-25 & 299-W18-30 & 299-W19-12 & 143.139 & 142.978 & 142.974 & 80.98 & 0.000885 \\
\hline 1 & $12 / 17 / 92$ & $12 / 17 / 92$ & 299-W18-25 & 299-W18-30 & 299-W19-12 & 143.161 & 143.042 & 143.029 & 86.53 & 0.000731 \\
\hline 1 & $01 / 26 / 93$ & $01 / 26 / 93$ & 299-W18-25 & 299-W18-30 & 299-W19-12 & 143.033 & 142.941 & 142.928 & 88.34 & 0.000589 \\
\hline 1 & $02 / 26 / 93$ & $02 / 26 / 93$ & 299-W18-25 & 299-W18-30 & 299-W19-12 & 142.92 & 142.792 & 142.782 & 84.63 & 0.000755 \\
\hline 1 & $03 / 26 / 93$ & $03 / 26 / 93$ & 299-W18-25 & 299-W18-30 & 299-W19-12 & 142.92 & 142.874 & 142.861 & 94.78 & 0.00035 \\
\hline 1 & $04 / 21 / 93$ & $04 / 21 / 93$ & 299-W18-25 & 299-W18-30 & 299-W19-12 & 142.85 & 142.831 & 142.821 & 102.02 & 0.000187 \\
\hline 1 & $05 / 20 / 93$ & $05 / 20 / 93$ & 299-W18-25 & 299-W18-30 & 299-W19-12 & 142.828 & 142.798 & 142.779 & 104.24 & 0.000325 \\
\hline
\end{tabular}


Table 2.12. (contd)

\begin{tabular}{|c|c|c|c|c|c|c|c|c|c|c|}
\hline $\begin{array}{l}\text { Duration }^{(a)} \\
\text { (days) }\end{array}$ & Start Date & End Date & Well 1 & Well 2 & Well 3 & $\begin{array}{c}\text { Water } \\
\text { Level } 1 \\
\text { (m amsl) }\end{array}$ & $\begin{array}{c}\text { Water } \\
\text { Level } 2 \\
(\mathrm{~m} \text { amsl) } \\
\end{array}$ & $\begin{array}{c}\text { Water } \\
\text { Level } 3 \\
(\mathrm{~m} \text { amsl) } \\
\end{array}$ & $\begin{array}{c}\text { Groundwater } \\
\text { Flow } \\
\text { Direction }^{(b)}\end{array}$ & $\begin{array}{l}\text { Water-Table } \\
\text { Gradient }\end{array}$ \\
\hline 1 & $12 / 15 / 93$ & $12 / 15 / 93$ & 299-W18-25 & 299-W18-30 & 299-W19-12 & 142.545 & 142.588 & 142.587 & 257.22 & 0.000222 \\
\hline 1 & $06 / 22 / 94$ & $06 / 22 / 94$ & 299-W18-25 & 299-W18-30 & 299-W19-12 & 142.298 & 142.368 & 142.395 & 278.30 & 0.000597 \\
\hline 1 & $12 / 09 / 94$ & $12 / 09 / 94$ & 299-W18-25 & 299-W18-30 & 299-W19-12 & 141.81 & 141.917 & 141.907 & 250.78 & 0.000503 \\
\hline 1 & $06 / 21 / 95$ & $06 / 21 / 95$ & 299-W18-25 & 299-W18-30 & 299-W19-12 & 141.408 & 141.536 & 141.499 & 226.29 & 0.000497 \\
\hline 1 & $12 / 19 / 95$ & $12 / 19 / 95$ & 299-W18-25 & 299-W18-30 & 299-W19-12 & 140.85 & 140.801 & 140.673 & 117.62 & 0.001495 \\
\hline 1 & $06 / 14 / 96$ & $06 / 14 / 96$ & 299-W18-25 & 299-W18-30 & 299-W19-12 & 140.357 & 140.225 & 140.1 & 108.87 & 0.001831 \\
\hline 14 & $03 / 13 / 97$ & $03 / 26 / 97$ & 299-W18-25 & 299-W18-30 & 299-W19-12 & 139.674 & 139.448 & 139.536 & 31.09 & 0.000861 \\
\hline 9 & $05 / 13 / 97$ & $05 / 21 / 97$ & 299-W18-25 & 299-W18-30 & 299-W19-12 & 139.683 & 139.378 & 139.377 & 79.35 & 0.001628 \\
\hline 4 & $12 / 12 / 97$ & $12 / 15 / 97$ & 299-W18-25 & 299-W18-30 & 299-W19-12 & 139.232 & 138.845 & 138.868 & 74.05 & 0.001901 \\
\hline 1 & $05 / 18 / 98$ & $05 / 18 / 98$ & 299-W18-25 & 299-W18-30 & 299-W19-12 & 138.915 & 138.546 & 138.505 & 86.64 & 0.002272 \\
\hline 15 & $11 / 24 / 98$ & $12 / 08 / 98$ & 299-W18-25 & 299-W18-30 & 299-W19-12 & 138.598 & 138.205 & 138.289 & 56.83 & 0.001612 \\
\hline 36 & $05 / 13 / 99$ & $06 / 17 / 99$ & 299-W18-25 & 299-W18-30 & 299-W19-12 & 138.494 & 138.028 & 138.118 & 59.49 & 0.001951 \\
\hline 2 & $09 / 07 / 00$ & $09 / 08 / 00$ & 299-W18-25 & 299-W18-30 & 299-W19-12 & 137.907 & 137.53 & 137.576 & 67.82 & 0.00171 \\
\hline 1 & $10 / 19 / 00$ & $10 / 19 / 00$ & 299-W18-25 & 299-W18-30 & 299-W19-12 & 137.837 & 137.453 & 137.458 & 78.06 & 0.002006 \\
\hline 1 & $12 / 07 / 00$ & $12 / 07 / 00$ & 299-W18-25 & 299-W18-30 & 299-W19-12 & 137.809 & 137.417 & 137.412 & 80.08 & 0.002119 \\
\hline 1 & $01 / 17 / 01$ & $01 / 17 / 01$ & 299-W18-25 & 299-W18-30 & 299-W19-12 & 137.737 & 137.29 & 137.293 & 78.57 & 0.002355 \\
\hline 1 & $03 / 21 / 01$ & $03 / 21 / 01$ & 299-W18-25 & 299-W18-30 & 299-W19-12 & 137.69 & 137.515 & 137.296 & 111.75 & 0.002952 \\
\hline 14 & $11 / 1 / 01$ & $11 / 14 / 01$ & 299-W18-30 & 299-W18-40 & 299-W19-12 & 137.074 & 137.500 & 137.055 & 82.32 & 0.002462 \\
\hline 1 & $3 / 20 / 02$ & $3 / 20 / 02$ & 299-W18-30 & 299-W18-40 & 299-W19-12 & 136.890 & 137.238 & 136.854 & 86.06 & 0.002159 \\
\hline 1 & $8 / 21 / 02$ & $8 / 21 / 02$ & 299-W18-30 & 299-W18-40 & 299-W19-12 & 136.909 & 137.220 & 136.869 & 87.51 & 0.001988 \\
\hline 1 & $3 / 21 / 03$ & $3 / 21 / 03$ & 299-W18-30 & 299-W18-40 & 299-W19-12 & 136.695 & 137.036 & 136.674 & 83.46 & 0.002012 \\
\hline 2 & $8 / 6 / 03$ & $8 / 7 / 03$ & 299-W18-30 & 299-W18-40 & 299-W19-12 & 136.546 & 136.915 & 136.552 & 77.84 & 0.001982 \\
\hline 1 & $5 / 11 / 04$ & $5 / 11 / 04$ & 299-W18-30 & 299-W18-40 & 299-W19-12 & 136.362 & 136.724 & 136.349 & 81.72 & 0.00207 \\
\hline 1 & $3 / 28 / 05$ & $3 / 28 / 05$ & 299-W18-30 & 299-W18-40 & 299-W19-12 & 136.038 & 136.430 & 136.118 & 59.34 & 0.001721 \\
\hline 4 & $8 / 22 / 05$ & $8 / 25 / 05$ & 299-W18-30 & 299-W18-40 & 299-W19-12 & 135.902 & 136.397 & 135.857 & 85.31 & 0.003025 \\
\hline \multicolumn{11}{|c|}{$\begin{array}{l}\text { (a) Duration is the length of time between the start date and the end date. } \\
\text { (b) Groundwater flow directions are degrees azimuth clockwise from north }\left(0^{\circ}\right) .\end{array}$} \\
\hline
\end{tabular}


Table 2.13. Historical Water-Level Data, Groundwater Flow Directions, and Water-Table Gradients for the S and SX Tank Farm Areas (from Reidel et al. 2006)

\begin{tabular}{|c|c|c|c|c|c|c|c|}
\hline $\begin{array}{c}\text { Duration }^{(a)} \\
\text { (days) }\end{array}$ & Start Date & End Date & \multicolumn{3}{|c|}{ Water Level (m amsl) } & $\begin{array}{c}\text { Groundwater } \\
\text { Flow Direction }\end{array}$ & $\begin{array}{c}\text { Water-Table } \\
\text { Gradient }\end{array}$ \\
\hline \multicolumn{8}{|c|}{$\begin{array}{ll}\text { Northern Part of Waste Management Area S-SX } \\
\end{array}$} \\
\hline & & & 299-W22-44 & $299-W 23-13^{(c)}$ & $299-W 23-14^{(d)}$ & & \\
\hline 3 & $02 / 27 / 92$ & $02 / 29 / 92$ & 142.511 & 142.926 & 142.444 & 145.038 & 0.003839 \\
\hline 1 & $05 / 22 / 92$ & $05 / 22 / 92$ & 142.286 & 142.651 & 142.249 & 143.931 & 0.003249 \\
\hline 1 & $08 / 19 / 92$ & $08 / 19 / 92$ & 142.091 & 142.362 & 142.060 & 144.178 & 0.002433 \\
\hline 1 & $11 / 25 / 92$ & $11 / 25 / 92$ & 141.765 & 141.999 & 141.725 & 145.206 & 0.002178 \\
\hline 1 & $02 / 25 / 93$ & $02 / 25 / 93$ & 141.603 & 141.801 & 141.573 & 144.861 & 0.00182 \\
\hline 1 & $05 / 20 / 93$ & $05 / 20 / 93$ & 141.560 & 141.746 & 141.524 & 145.596 & 0.001756 \\
\hline 1 & $08 / 20 / 93$ & $08 / 20 / 93$ & 141.567 & 141.731 & 141.499 & 148.903 & 0.001764 \\
\hline 1 & $03 / 18 / 94$ & $03 / 18 / 94$ & 141.381 & 141.453 & 141.280 & 157.185 & 0.001216 \\
\hline 1 & $05 / 12 / 94$ & $05 / 12 / 94$ & 141.143 & 141.295 & 141.112 & 145.772 & 0.001444 \\
\hline 1 & $11 / 14 / 94$ & $11 / 14 / 94$ & 140.805 & 140.954 & 140.807 & 141.556 & 0.001228 \\
\hline 14 & $02 / 01 / 95$ & $02 / 14 / 95$ & 140.780 & 140.804 & 140.673 & 164.721 & 0.000877 \\
\hline 2 & $05 / 23 / 95$ & $05 / 24 / 95$ & 140.448 & 140.688 & 140.564 & 126.413 & 0.001387 \\
\hline 6 & $08 / 04 / 95$ & $08 / 09 / 95$ & 140.360 & 140.588 & 140.369 & 140.963 & 0.001846 \\
\hline 1 & $12 / 19 / 95$ & $12 / 19 / 95$ & 139.988 & 140.228 & 140.137 & 119.430 & 0.001244 \\
\hline 7 & $02 / 07 / 96$ & $02 / 13 / 96$ & 139.994 & 140.131 & 140.055 & 128.091 & 0.000816 \\
\hline 5 & $08 / 08 / 96$ & $08 / 12 / 96$ & 139.351 & 139.756 & 139.689 & 105.235 & 0.001804 \\
\hline 6 & $11 / 07 / 96$ & $11 / 12 / 96$ & 139.296 & 139.567 & 139.475 & 117.117 & 0.001362 \\
\hline 1 & $02 / 04 / 97$ & $02 / 04 / 97$ & 139.143 & 139.420 & 139.344 & 113.008 & 0.001327 \\
\hline 7 & $05 / 07 / 97$ & $05 / 13 / 97$ & 138.988 & 139.262 & 139.235 & 99.923 & 0.001177 \\
\hline 1 & $08 / 07 / 97$ & $08 / 07 / 97$ & 138.842 & 139.164 & 139.085 & 111.047 & 0.001511 \\
\hline 2 & $11 / 11 / 97$ & $11 / 12 / 97$ & 138.625 & 139.024 & 138.988 & 99.236 & 0.001707 \\
\hline 7 & $02 / 05 / 98$ & $02 / 11 / 98$ & 138.464 & 138.796 & 138.735 & 106.620 & 0.001496 \\
\hline 1 & $08 / 06 / 98$ & $08 / 06 / 98$ & 138.214 & 138.616 & 138.585 & 98.142 & 0.001709 \\
\hline
\end{tabular}


Table 2.13. (contd)

\begin{tabular}{|c|c|c|c|c|c|c|c|}
\hline $\begin{array}{l}\text { Duration }^{(a)} \\
\text { (days) }\end{array}$ & Start Date & End Date & \multicolumn{3}{|c|}{ Water Level $(\mathrm{m}$ amsl) } & $\begin{array}{c}\text { Groundwater } \\
\text { Flow Direction }\end{array}$ & $\begin{array}{c}\text { Water-Table } \\
\text { Gradient }\end{array}$ \\
\hline \multicolumn{8}{|c|}{ Northern Part of Waste Management Area S-SX (contd) } \\
\hline & & & 299-W22-44 & 299-W23-13 & 299-W23-14 & & \\
\hline 1 & $02 / 17 / 99$ & $02 / 17 / 99$ & 137.991 & 138.412 & 138.457 & 81.771 & 0.001712 \\
\hline 5 & 05/13/99 & $05 / 17 / 99$ & 137.875 & 138.250 & 138.235 & 94.978 & 0.00157 \\
\hline 6 & $08 / 05 / 99$ & $08 / 10 / 99$ & 137.760 & 138.201 & 138.168 & 97.950 & 0.001873 \\
\hline 1 & 03/29/00 & $03 / 29 / 00$ & 137.437 & 137.829 & 137.796 & 98.734 & 0.001672 \\
\hline 2 & $06 / 20 / 00$ & $06 / 21 / 00$ & 137.352 & 137.814 & 137.756 & 102.114 & 0.002012 \\
\hline 1 & $12 / 20 / 00$ & $12 / 20 / 00$ & 137.155 & 137.585 & 137.577 & 93.112 & 0.001787 \\
\hline 1 & $03 / 20 / 01$ & $03 / 20 / 01$ & 137.061 & 137.585 & 137.471 & 109.095 & 0.002413 \\
\hline 3 & $06 / 25 / 01$ & $06 / 27 / 01$ & 136.979 & 137.395 & 137.384 & 93.799 & 0.001734 \\
\hline \multicolumn{8}{|c|}{ Southern Part of Waste Management Area S-SX } \\
\hline & & & $299-W 22-39^{(\mathrm{e})}$ & 299-W23-14 & 299-W23-15 & & \\
\hline 1 & $02 / 27 / 92$ & $02 / 27 / 92$ & 141.691 & 142.444 & 141.974 & 107.620 & $3.61 \mathrm{E}-03$ \\
\hline 1 & $05 / 22 / 92$ & $05 / 22 / 92$ & 141.532 & 142.249 & 141.812 & 106.180 & $3.44 \mathrm{E}-03$ \\
\hline 1 & $08 / 19 / 92$ & $08 / 19 / 92$ & 141.395 & 142.060 & 141.642 & 108.060 & $3.18 \mathrm{E}-03$ \\
\hline 1 & 09/17/92 & $09 / 17 / 92$ & 141.261 & 141.911 & 141.520 & 105.400 & $3.12 \mathrm{E}-03$ \\
\hline 1 & $11 / 25 / 92$ & $11 / 25 / 92$ & 141.103 & 141.725 & 141.358 & 104.270 & 2.99E-03 \\
\hline 1 & $02 / 25 / 93$ & $02 / 25 / 93$ & 140.975 & 141.573 & 141.209 & 106.100 & $2.87 \mathrm{E}-03$ \\
\hline 1 & $05 / 20 / 93$ & $05 / 20 / 93$ & 140.917 & 141.524 & 141.130 & 110.090 & $2.90 \mathrm{E}-03$ \\
\hline 1 & $08 / 19 / 93$ & $08 / 19 / 93$ & 140.883 & 141.499 & 141.090 & 111.560 & $2.94 \mathrm{E}-03$ \\
\hline 1 & $11 / 23 / 93$ & $11 / 23 / 93$ & 140.612 & 141.195 & 140.843 & 105.620 & $2.80 \mathrm{E}-03$ \\
\hline 1 & $03 / 18 / 94$ & $03 / 18 / 94$ & 140.673 & 141.280 & 140.861 & 114.170 & $2.90 \mathrm{E}-03$ \\
\hline 1 & $05 / 12 / 94$ & $05 / 12 / 94$ & 140.508 & 141.112 & 140.712 & 111.390 & $2.89 \mathrm{E}-03$ \\
\hline 1 & 08/16/94 & $08 / 16 / 94$ & 140.402 & 140.984 & 140.590 & 112.850 & $2.78 \mathrm{E}-03$ \\
\hline 1 & $11 / 14 / 94$ & $11 / 14 / 94$ & 140.249 & 140.807 & 140.435 & 111.830 & $2.67 \mathrm{E}-03$ \\
\hline 1 & $03 / 23 / 95$ & $03 / 23 / 95$ & 140.115 & 140.652 & 140.273 & 115.700 & $2.57 \mathrm{E}-03$ \\
\hline 1 & $05 / 23 / 95$ & $05 / 23 / 95$ & 140.021 & 140.564 & 140.200 & 112.200 & $2.59 \mathrm{E}-03$ \\
\hline 1 & $08 / 09 / 95$ & $08 / 09 / 95$ & 139.841 & 140.369 & 140.139 & 89.970 & $2.71 \mathrm{E}-03$ \\
\hline 2 & $02 / 07 / 96$ & $02 / 08 / 96$ & 139.621 & 140.055 & 139.776 & 109.470 & $2.07 \mathrm{E}-03$ \\
\hline
\end{tabular}


Table 2.13. (contd)

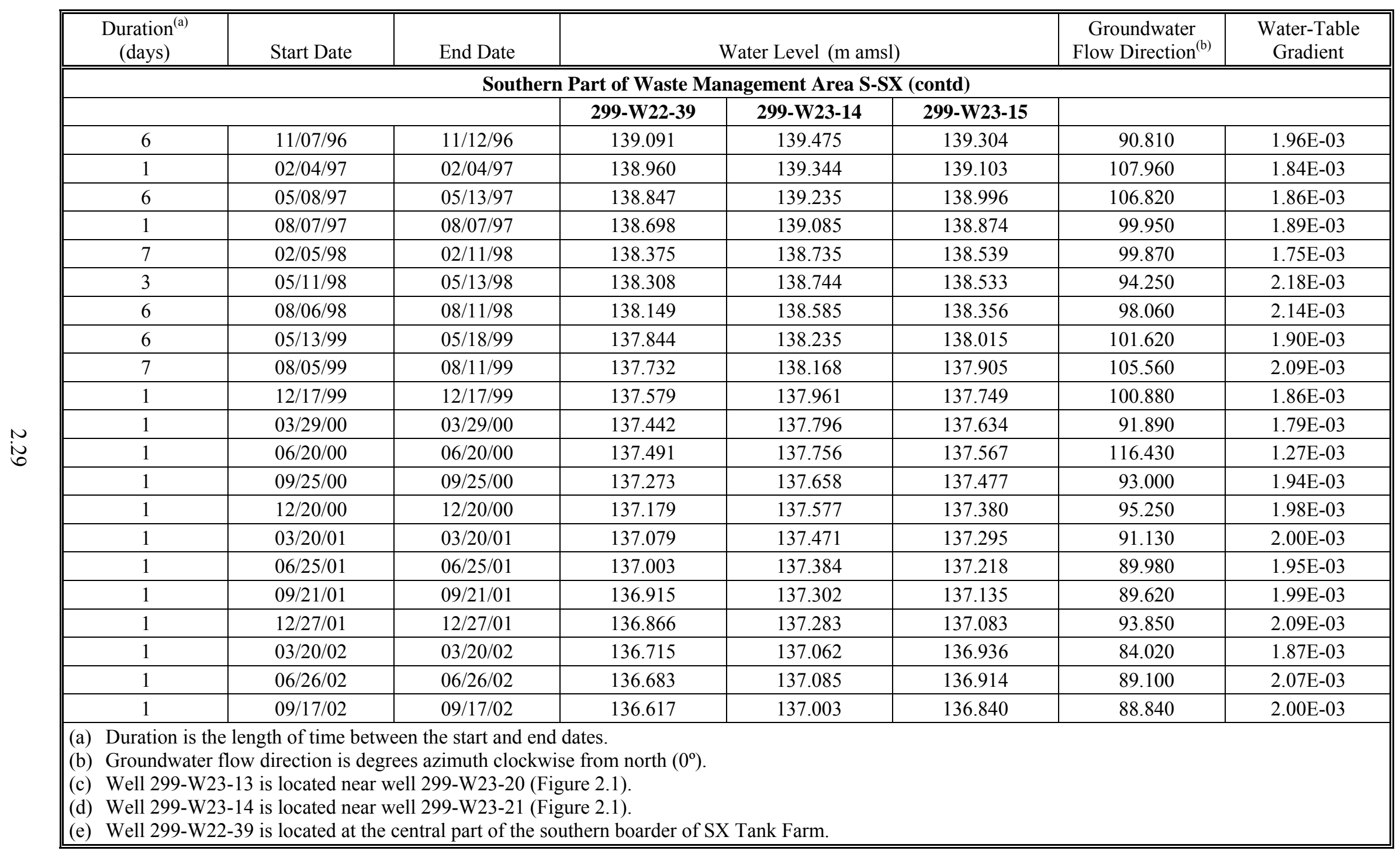


Finally, in order to find usable wells with historic information back into the 1950s, regionally located wells were used where available. This means that determined flow directions are generally applicable to a broad area that includes the applicable WMA, but small local variations immediately beneath the WMAs might have been noted if the appropriate local wells would have existed.

Despite the numerous sources for potential error, there is relatively good agreement among the large number of measurements through time. That, and the agreement of the resulting flow directions with historical Hanford Site operations, suggest that the calculated groundwater flow directions and watertable gradients generally represent past conditions. The general flow directions and changes in flow directions during the period of Hanford Site operations is illustrated by rose diagrams in Figures 2.10 through 2.12. The rose diagrams contain "petals" that point in the azimuth direction of the calculated groundwater flow and the length of the "petals" reflect the percentage of flow direction measurements at the indicated azimuth.

Table 2.11 gives the calculated flow directions and water-table gradients for single-shell tank WMAs $\mathrm{T}$ and TX-TY. Six different well triplets were used and 100 flow directions calculated. Figure 2.10 plots the results as rose diagrams that show the changes in groundwater flow direction beneath the T, TX, and TY Tank Farms through time. The figure shows that that groundwater flowed toward the south in the area by the early 1950s as a result of disposal of large volumes of liquid to the T Pond system (Figure 2.10A). In 1956, groundwater flow direction changed again and started flowing towards the northeast due to the increasing influence of the groundwater mound under U Pond (Figure 2.10B). Discharges to T Pond ended in 1976 but continued at U Pond until 1984. As discharges to the U Pond declined in the early 1980s, groundwater flow shifted to a more northerly direction as the groundwater mound began to decrease. The northerly shift to the groundwater flow direction between early 1980s and mid 1990s (Figure 2.10C) may be the result of the continued discharges to the 216-U-14 ditch or other past practice facilities as discharges to U Pond diminished and stopped. All non-permitted discharges to the ground ceased and the influence of the $\mathrm{U}$ Pond mound on the groundwater beneath the T Tank Farm diminished in 1995. Consequently, the flow direction changed again in about 1996 and began to return toward a pre-Hanford Site easterly direction (Figure 2.10D).

Table 2.12 gives historical water levels, groundwater flow directions, and water-table gradients for the U Tank Farm area. No appropriately located well triplets in the area of WMA U were found that have historical water-level measurements before about 1990. Thus, the data in Table 2.12 are from 1992 to 2005. Two well triplets and 38 measurements are included in the table. The rose diagram in Figure 2.11 displays the data from Table 2.12. Those data show that the groundwater flow direction has been fairly consistent and to the east since the very early 1990s except between 1993 and 1995. The flow direction beneath WMA U was reversed and shifted toward the west between 1993 and 1995. This change was the result of major effluent discharges to the 216-U-14 ditch, located east of WMA U, during 1991 to 1993 (Hodges and Chou 2000). The relatively short term change in flow direction is indicated by the west pointing petals on Figure 2.11.

Wood et al. (1999) show a series of historical water table maps indicating that groundwater flow direction was toward the south in the area of the S and SX Tank Farms during the early 1950s as a result of discharges to T Pond. In about 1955, flow direction had begun to shift toward the southeast and east under the influence of U Pond. Table 2.13 presents water-level data, groundwater flow directions, and water-table gradients since 1992. Johnson and Chou (2002) noted differences in hydraulic conductivity in 

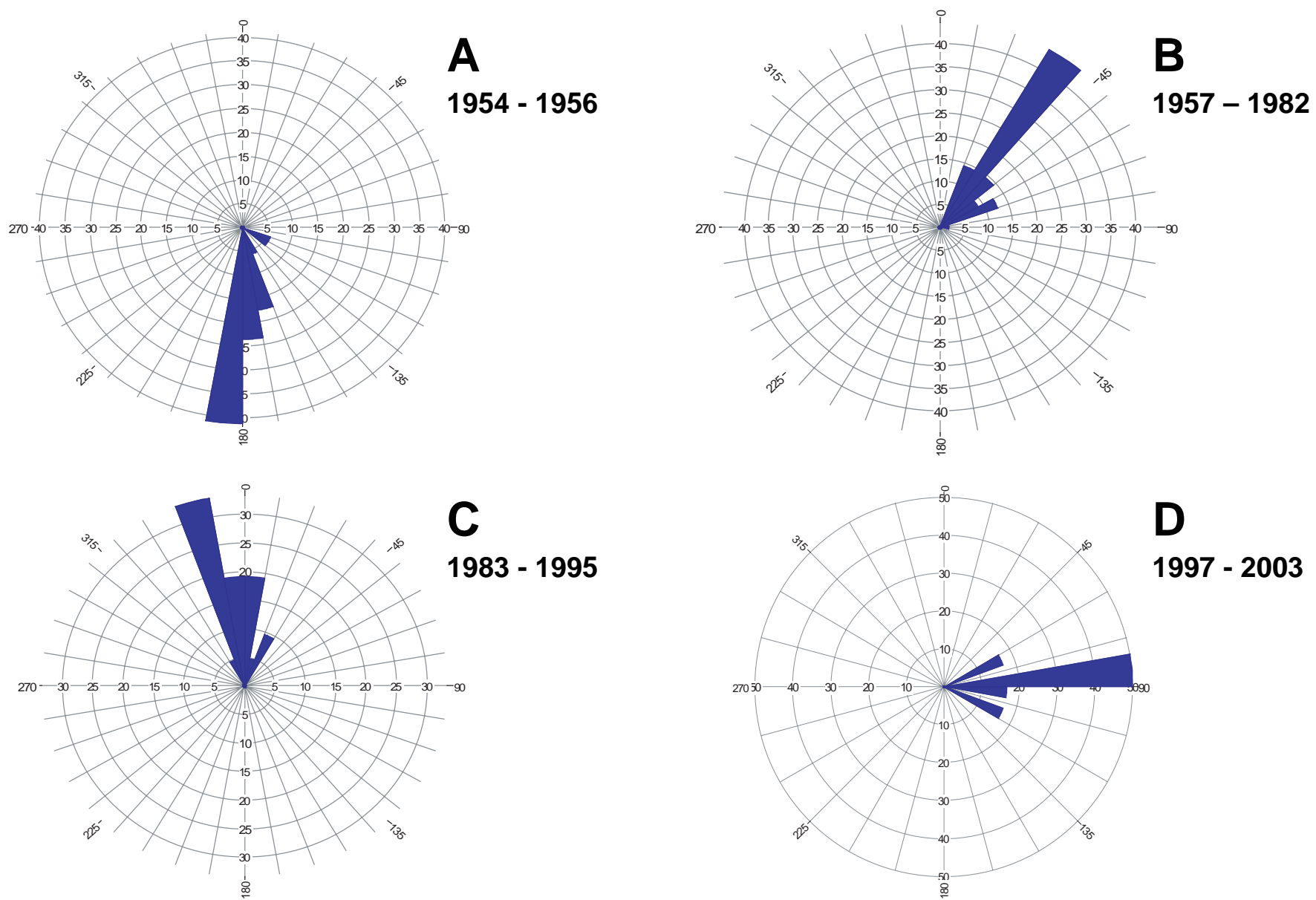

D

$1997-2003$

$1983-1995$

Figure 2.10. Groundwater Flow Directions in the North Part of the 200 West Area Near the T, TX, and TY Tank Farms. A. 1954 to 1956, one well triplet, 17 measurements; B. 1957 to 1982, two well triplets, 56 measurements; C. 1983 to 1995, four well triplets, 21 measurements; D. 1997 to 2003, three well triplets, 6 measurements (from Reidel et al. 2006). 


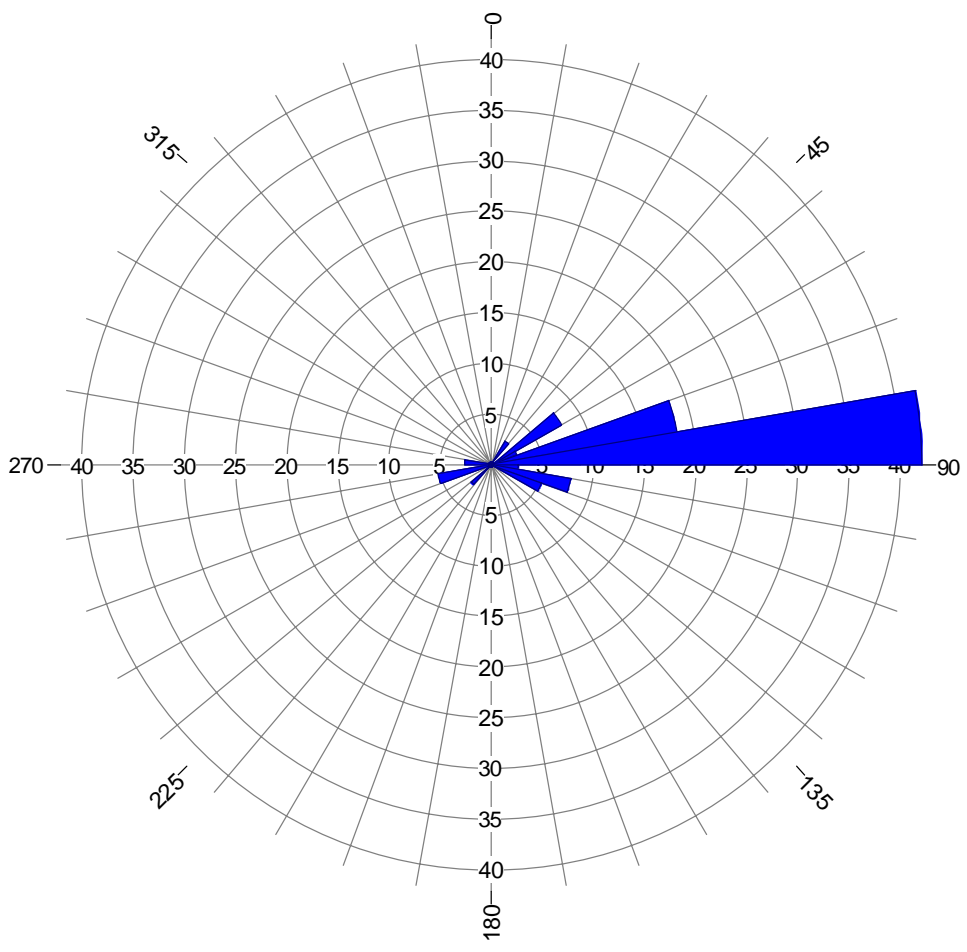

Figure 2.11. Groundwater Flow Directions at Waste Management Area U between 1992 and 2005. Two well triplets, 38 measurements (updated from Reidel et al. 2006).

wells beneath the S Tank Farm in the north and the SX Tank Farm in the south. Therefore, the data in Table 2.13 are separated into two parts: northern and southern. The northern (S Tank Farm) area is represented by one well triplet and 31 data points; the southern (SX Tank Farm) area is represented by one well triplet and 38 data points. Figure 2.12 shows rose diagrams of the groundwater flow directions for both parts. The data in Table 2.13 for both parts of Figure 2.12 show that, as the data become more recent, the flow direction shifts from southeast to east.

The large changes in groundwater flow directions that have occurred throughout the 200 West Area (Figures 2.10 through 2.12) have important impacts on contaminant dispersal in the unconfined aquifer. These large changes are, in part, responsible for the wide distribution of some contaminants such as nitrate and carbon tetrachloride beneath the 200 West Area. 

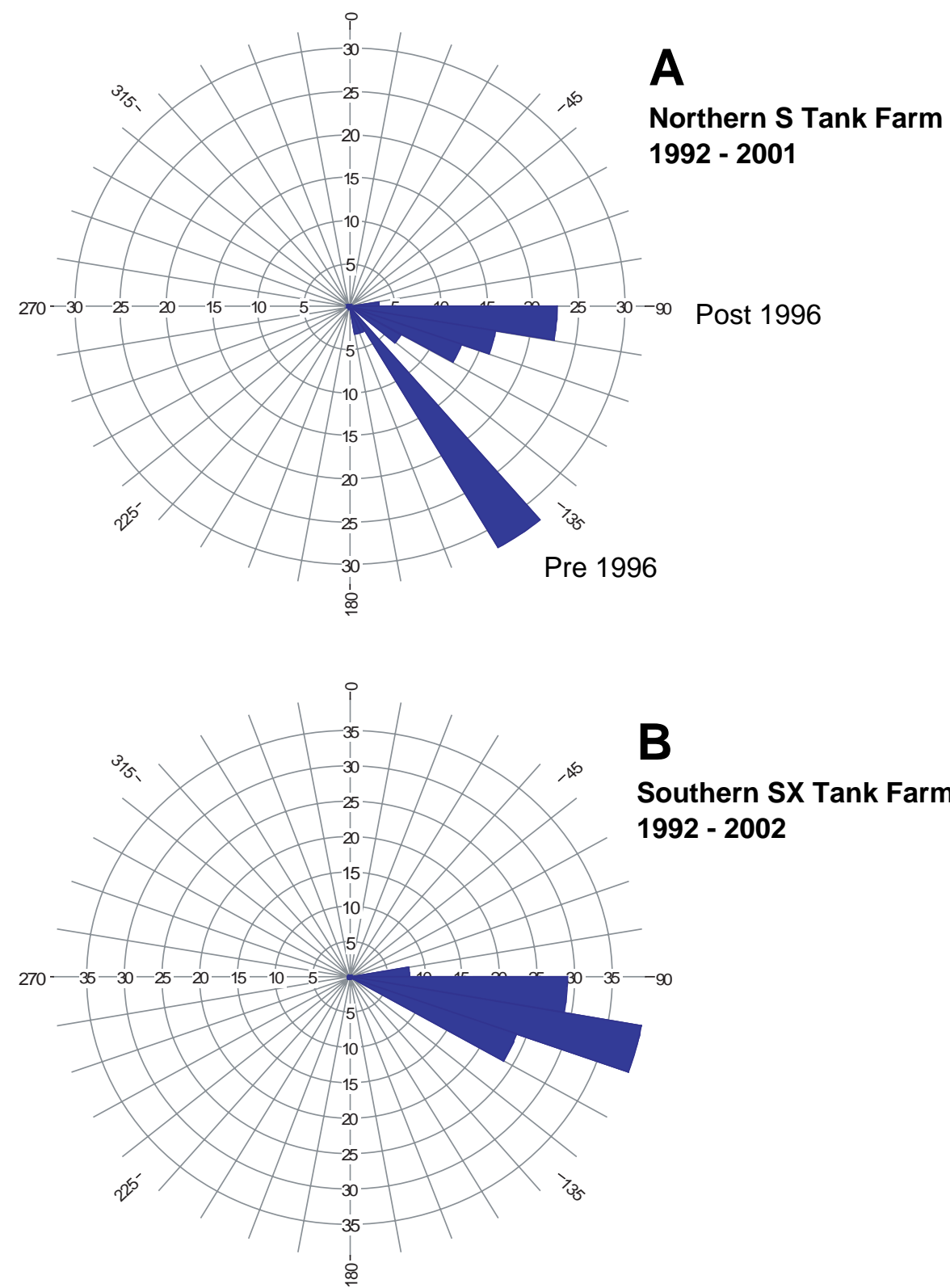

B

Southern SX Tank Farm

$1992-2002$

Figure 2.12. Groundwater Flow Directions Beneath the S and SX Tank Farms. A. The northern S Tank Farm (1992 to 2001, one well triplet, 31 measurements); B. The southern SX Tank Farm (1992 to 2002, one well triplet, 38 measurements) (from Reidel et al. 2006). 


\subsection{Aquifer Properties for the Unconfined Aquifer Beneath the 200 East Area}

This section describes the aquifer properties beneath the 200 East Area single-shell tank WMAs including hydraulic properties, aquifer thickness, and current flow directions and flow rates. This section also describes historic changes in the aquifer conditions due to past fuel processing operations and associated waste disposal to cribs and ponds. Changes in the aquifer properties during the past 60 years have large implications for direction and rate of contaminant movement in the aquifer and for residual vadose zone contamination where the water table has decreased in elevation. Most of the information in this section is from Reidel et al. (2006).

Figures 3.1 through 3.3 show the single-shell tank WMAs in the 200 East Area along with the locations for most of the wells discussed in this section. The locations of wells not on the figures are described in the text.

\subsection{Existing Hydrologic Properties Beneath the 200 East Area Single-Shell Tank Waste Management Areas}

The base of the unconfined aquifer in most of the 200 East Area is generally regarded as the basalt surface, and the suprabasalt aquifer system consists entirely of the unconfined aquifer. Where the Ringold Formation is present in the suprabasalt aquifer, the silt and clay beds of the formation's hydrogeologic unit 8 (lower mud unit) form a confining layer that separates the suprabasalt aquifer into the uppermost unconfined aquifer and an underlying confined aquifer (Williams et al. 2000). These aquifers have separate and distinct flow regimes.

The unconfined aquifer consists primarily of hydrogeologic unit 1 (undifferentiated Hanford formation and coarse-grained Cold Creek unit deposits) and hydrogeologic unit 9 (Ringold Formation unit A) beneath the single-shell tank WMAs in the 200 East Area. Whereas hydrogeologic unit 8 is present beneath most of 200 West Area, it has been removed from beneath almost all of the 200 East Area and is not present beneath any of the single-shell tank farms in the area. Therefore, the following discussion focuses on the unconfined aquifer that extends from the water table to the top of basalt.

Several wells extend through the unconfined aquifer in the 200 East Area to the top of basalt and can be used to determine the thickness of the aquifer. Table 3.1 contains a list of wells near 200 East Area single-shell tank WMAs that penetrate through the entire unconfined aquifer and have March 2005 water level measurements. Also in Table 3.1 are calculated thicknesses for the unconfined aquifer. There are very little data for WMAs A-AX and C and many data for WMA B-BX-BY. This primarily is due to the thin aquifer at WMA B-BX-BY compared to the other WMAs. The data in Table 3.1 show that the thickness of the uppermost aquifer generally increases from north to south as the top of basalt dips into the Cold Creek syncline. The unconfined aquifer beneath the single-shell tank WMAs in the 200 East Area ranges from between 0 and $7 \mathrm{~m}$ beneath WMA B-BX-BY, to about 9 to $10 \mathrm{~m}$ beneath WMA C, to about $27 \mathrm{~m}$ beneath WMA A-AX. 


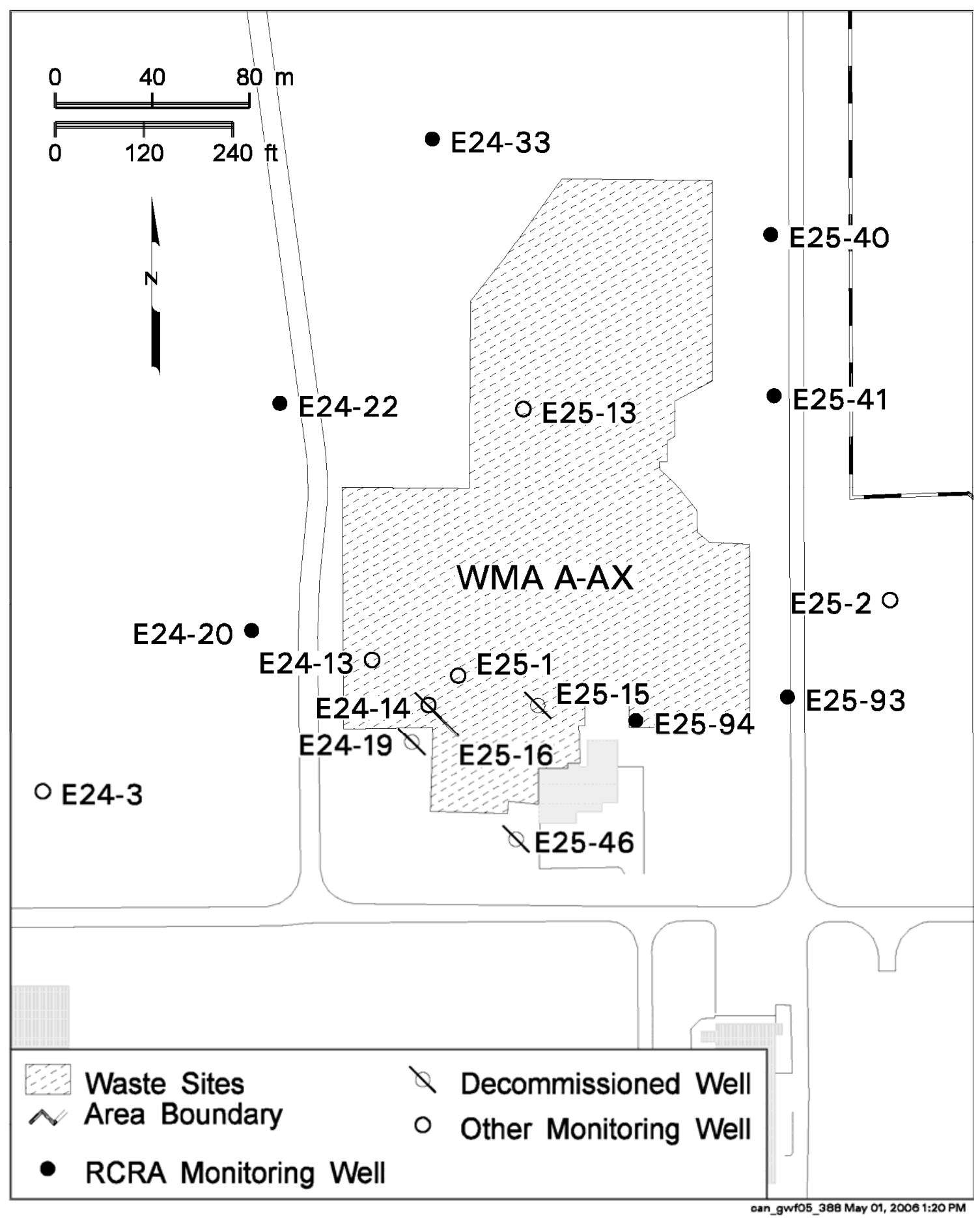

Figure 3.1. Well Location Map for Waste Management Area A-AX (modified from Hartman et al. 2006) 


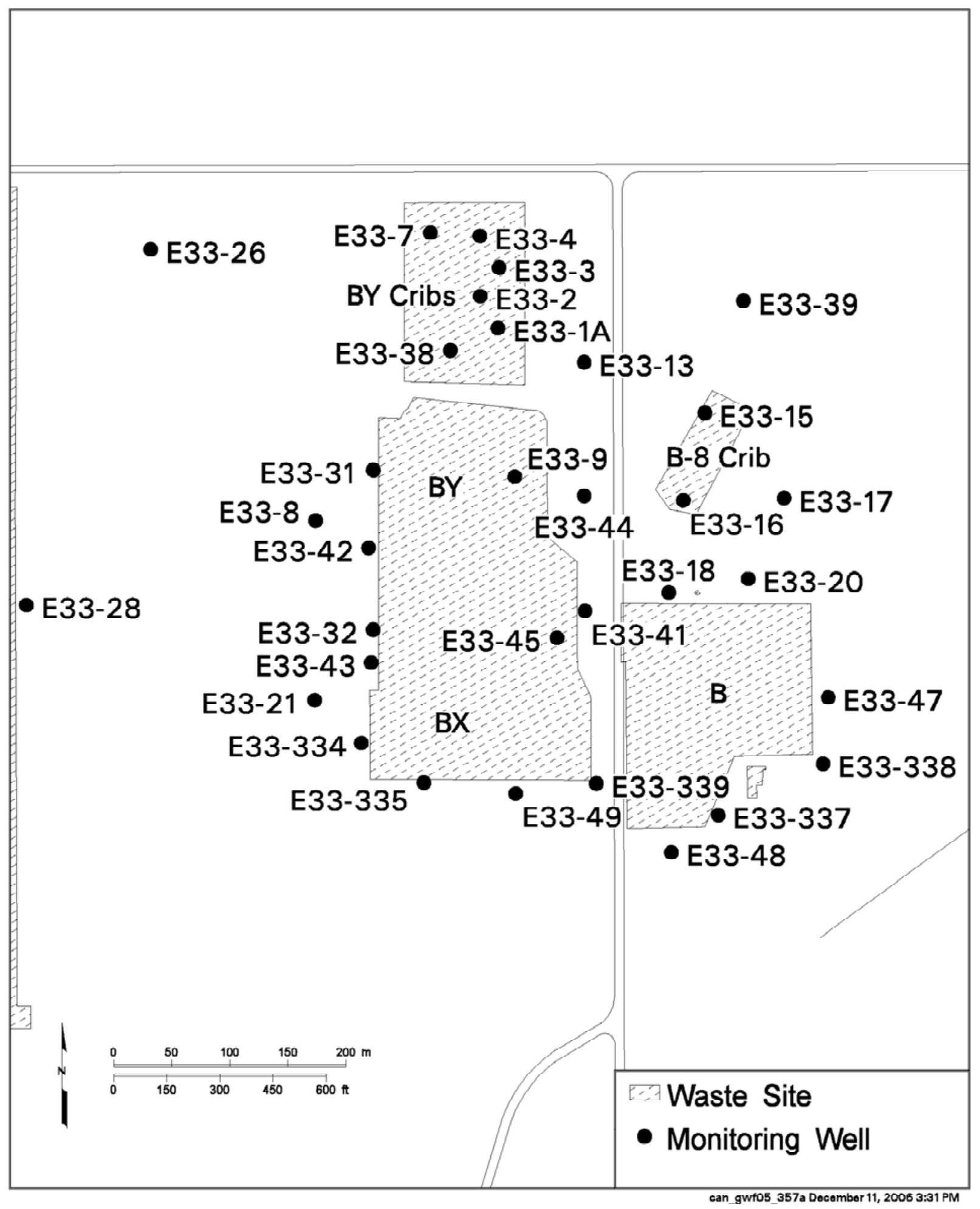

Figure 3.2. Well Location Map for Waste Management Area B-BX-BY (modified from Hartman et al. 2006) 


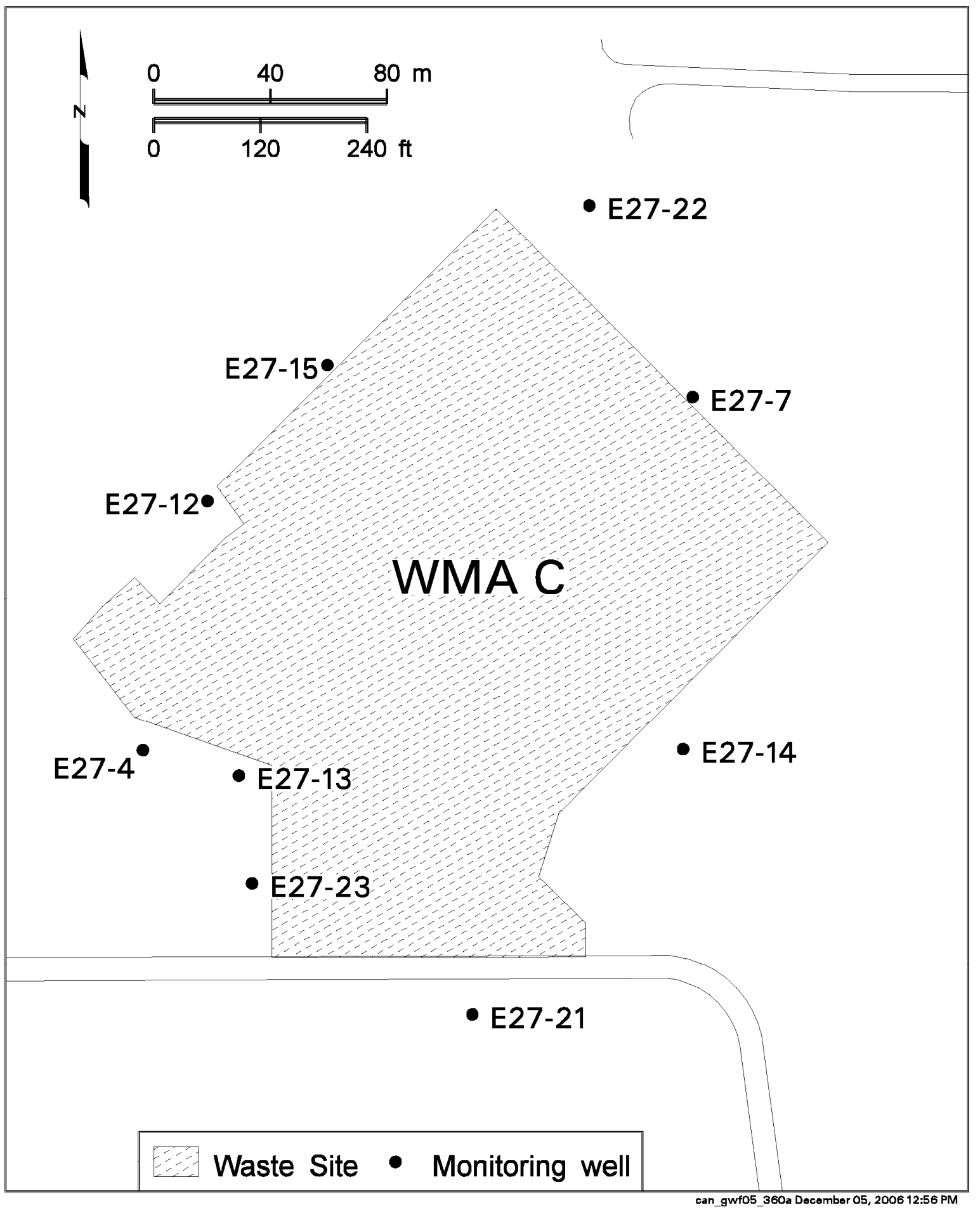

Figure 3.3. Well Location Map for Waste Management Area C (modified from Hartman et al. 2006) 
Table 3.1. Thickness of the Unconfined Aquifer Beneath the 200 East Area

\begin{tabular}{|c|c|c|c|c|}
\hline Well Name & Well Location & $\begin{array}{c}\text { Elevation of Top } \\
\text { of Basalt }{ }^{(\mathrm{a})} \\
(\mathrm{m} \text { amsl) }\end{array}$ & $\begin{array}{c}\text { Elevation of } \\
\text { Water Table }^{(\mathrm{b})} \\
(\mathrm{m} \text { amsl) }\end{array}$ & $\begin{array}{c}\text { Aquifer } \\
\text { Thickness } \\
\text { (m) }\end{array}$ \\
\hline \multicolumn{5}{|c|}{ Waste Management Area A-AX } \\
\hline 299-E25-2 & East side of WMA A-AX & 94.49 & 122.13 & 27.64 \\
\hline 299-E24-8 & $\sim 550$ m southwest of WMA C & 95.71 & 122.12 & 26.41 \\
\hline \multicolumn{5}{|c|}{ Waste Management Area B-BX-BY } \\
\hline 299-E27-17 & $\sim 700$ m east southeast of WMA B-BX-BY & 118.87 & 122.13 & 3.26 \\
\hline 299-E28-8 & $\sim 125$ m south of WMA B-BX-BY & 114.24 & $122.19^{(\mathrm{c})}$ & 7.95 \\
\hline 299-E33-6 & At the BY cribs & $\sim 120.5$ & Well is dry & 0 \\
\hline 299-E33-7 & At the BY cribs & 121.07 & 122.14 & 1.07 \\
\hline 299-E33-14 & $\sim 300$ m northeast of WMA B-BX-BY & 120.36 & 122.14 & 1.78 \\
\hline 299-E33-15 & At the B26-B-8 crib & 118.75 & $122.16^{(\mathrm{c})}$ & 3.41 \\
\hline 299-E33-16 & At the $216-\mathrm{B}-8 \mathrm{crib}$ & 120.43 & $122.08^{(\mathrm{c})}$ & 1.65 \\
\hline 299-E33-17 & East side of the 216-B- 8 crib & 119.12 & $122.14^{(\mathrm{c})}$ & 3.02 \\
\hline 299-E33-18 & North side of the B Tank Farm & 115.88 & $122.38^{(\mathrm{c})}$ & 6.50 \\
\hline 299-E33-20 & North side of the B Tank Farm & 118.63 & $122.13^{(\mathrm{d})}$ & 3.50 \\
\hline 299-E33-21 & West side of the BX Tank Farm & 117.26 & $122.24^{(\mathrm{c})}$ & 4.98 \\
\hline 299-E33-26 & West of the BY cribs & 119.30 & $121.82^{(\mathrm{c})}$ & 2.52 \\
\hline 299-E33-31 & West side of the BY Tank Farm & 119.51 & $122.14^{(\mathrm{c})}$ & 2.63 \\
\hline 299-E33-32 & West side of the BX Tank Farm & 118.32 & $122.09^{(\mathrm{c})}$ & 3.77 \\
\hline 299-E33-33 & $\sim 175$ m east of the B Tank Farm & 118.48 & 122.12 & 3.64 \\
\hline 299-E33-36 & $\sim 175$ m east of the B Tank Farm & 115.84 & 121.68 & 5.84 \\
\hline 299-E33-38 & At the BY cribs & 120.49 & 122.14 & 1.65 \\
\hline 299-E33-39 & East of the BY cribs & 120.34 & 122.15 & 1.81 \\
\hline 299-E33-41 & Between the B and BX Tank Farms & 118.48 & $122.15^{(\mathrm{c})}$ & 3.67 \\
\hline 299-E33-42 & West side of the BY Tank Farm & 120.15 & $122.13^{(\mathrm{c})}$ & 1.98 \\
\hline 299-E33-44 & East side of the BY Tank Farm & 120.58 & $122.12^{(\mathrm{d})}$ & 1.54 \\
\hline 299-E33-47 & East side of the B Tank Farm & 117.28 & 122.16 & 4.88 \\
\hline 299-E33-48 & South side of the B Tank Farm & 115.57 & 122.16 & 6.59 \\
\hline 299-E33-49 & South side of the BX Tank Farm & 116.83 & 122.15 & 5.32 \\
\hline \multicolumn{5}{|c|}{$\begin{array}{l}\text { Waste Management Area C } \\
\end{array}$} \\
\hline 299-E26-8 & $\sim 300$ m east of WMA C & $\begin{array}{r}113.02 \\
\end{array}$ & 122.00 & 8.98 \\
\hline 299-E27-22 & North corner of WMA C & 112.38 & 122.18 & 9.80 \\
\hline \multicolumn{5}{|c|}{$\begin{array}{l}\text { (a) Top of basalt elevation from Horton and Narbutovskih (2001); Narbutovskih and Horton (2001); Williams } \\
\text { et al. (2000); Wood et al. (2003); Hanford Well Information System. } \\
\text { (b) March 2005 data except where noted. } \\
\text { (c) May } 2005 . \\
\text { (d) July } 2005 . \\
\text { amsl = Above mean sea level. }\end{array}$} \\
\hline
\end{tabular}


Current general groundwater flow directions and general flow rates are given in Table 3.2 for each of the WMAs in the 200 East Area (Hartman et al. 2006). Because the water table is very flat over all of the 200 East Area, comparison of the flow directions in Table 3.2 with the latest water-table map (Figure 2.5) is unproductive. The flow directions given in Table 3.2 were estimated using in situ methods and plume tracking in addition to interpreting water level data on a local scale.

Table 3.2. General Groundwater Flow Directions and Flow Rates for Single-Shell Tank Waste Management Areas in the 200 East Area $^{(a)}$

\begin{tabular}{|c|c|c|c|c|}
\hline $\begin{array}{c}\text { Waste } \\
\text { Management } \\
\text { Area }\end{array}$ & $\begin{array}{c}\text { Groundwater Flow } \\
\text { Direction }\end{array}$ & Gradient & $\begin{array}{l}\text { Hydraulic } \\
\text { Conductivity } \\
(\mathrm{m} / \mathrm{d})\end{array}$ & $\begin{array}{l}\text { Groundwater } \\
\text { Flow Rate }{ }^{(b)} \\
\text { (m/day) }\end{array}$ \\
\hline A-AX & SE & 0.00016 & 1,981 & 0.8 to 1.0 \\
\hline \multirow[t]{2}{*}{ B-BX-BY } & WSW (north half) & \multirow{2}{*}{0.00002} & \multirow[t]{2}{*}{73 to 2,520} & 0.005 to 0.17 \\
\hline & SSE to SE (south half) & & & \\
\hline $\mathrm{C}$ & SW & 0.0001 & & 0.7 to 2.4 \\
\hline $\begin{array}{l}\text { (a) Informatior } \\
\text { (b) Groundwat } \\
\text { conductivit }\end{array}$ & $\begin{array}{l}\text { om Hartman et al. (200 } \\
\text { flow rates are calculate } \\
\text { hydraulic gradient)/eft }\end{array}$ & $\begin{array}{l}\text { ng the } D \\
\text { ve poros }\end{array}$ & (1) & (hydraulic \\
\hline
\end{tabular}

No recent published results of detailed hydrologic testing (e.g., tracer dilution tests, tracer pumpback tests, constant rate pumping tests) are available for wells at single-shell tank WMAs in the 200 East Area. However, recent data are available from slug testing at nine wells. Table 3.3 gives the results of those tests.

The calculated groundwater flow rates for WMA A-AX given in Table 3.3 are significantly greater than those in Table 3.2. This is because the flow rates in Table 3.2 were calculated using hydraulic conductivities measured from constant rate pumping tests over relatively large vertical sections of the aquifer (Last et al. 1989). The range of hydraulic conductivities given in Last et al. (1989) is about 427 to $2,042 \mathrm{~m} /$ day. This is in contrast to the relatively low hydraulic conductivities measured by slug testing to calculate the velocities in Table 3.3. The range of velocities for WMA C is the same in Tables 3.2 and 3.3 because the same hydraulic conductivity values were used.

Multi-stress slug tests have been done at specific depth intervals in one well at WMA B-BX-BY and one well at WMA C. The results of those tests (Table 3.3) indicate the ranges in hydraulic conductivity that can be expected within a single well. The data show that the hydraulic conductivity and the calculated flow velocity can be expected to vary by several orders of magnitude within a single well. One similar test was done at WMA T in 200 West Area (Table 2.7) in a well where the aquifer sediments were hydrogeologic unit 5 (Ringold Formation, member of Wooded island unit E). The range of hydrologic conductivity in that well was 0.73 to $8.21 \mathrm{~m} /$ day. The aquifer in the tested 200 East Area wells is hydrogeologic unit 1 (Hanford formation) and the magnitude and range of the hydraulic conductivities is much larger than that found for hydrogeologic unit 5 . 
Table 3.3. Results from Recent Slug Testing of Wells at 200 East Area Single-Shell Tank Farms ${ }^{(a)}$

\begin{tabular}{|c|c|c|c|}
\hline Well $^{(\mathrm{b})}$ & $\begin{array}{l}\text { Hydraulic } \\
\text { Conductivity } \\
\text { (m/day) }\end{array}$ & $\begin{array}{l}\text { Specific Storage } \\
(\mathrm{m})\end{array}$ & $\begin{array}{c}\text { Calculated } \\
\text { Groundwater Flow } \\
\text { Rate } \\
\text { (m/day) }\end{array}$ \\
\hline \multicolumn{4}{|c|}{ Waste Management Area A-AX } \\
\hline 299-E24-22 & $85.0-109^{(\mathrm{c})}$ & NA & $0.058^{(\mathrm{d})}$ \\
\hline 299-E25-93 & 49.3 & NA & $0.026^{(\mathrm{d})}$ \\
\hline \multicolumn{4}{|c|}{ Waste Management Area B-BX-BY } \\
\hline 299-E33-44 & $22.0-24.2$ & $3.3 \mathrm{E}-5$ & $0.002^{(\mathrm{e})}$ \\
\hline 299-E33-334 & $41.8-44.5$ & $2.0 \mathrm{E}-5$ & $0.003^{(\mathrm{e})}$ \\
\hline 299-E33-335 & $49.3-52.1$ & $2.0 \mathrm{E}-5$ & $0.0045^{(\mathrm{e})}$ \\
\hline 299-E33-338 & 89.3 & NA & $0.006^{(\mathrm{e})}$ \\
\hline $\begin{array}{l}\text { 299-E33-49 } 9^{(\mathrm{f,g})} \\
(81.58-83.00)\end{array}$ & 1,780 & NA & $0.119^{(\mathrm{e})}$ \\
\hline $\begin{array}{l}\text { 299-E33-49 } \\
(83.10-83.76)\end{array}$ & 58 & NA & 0.004 \\
\hline $\begin{array}{l}299-E 33-49 \\
(83.76-84.52)\end{array}$ & 2,520 & NA & 0.168 \\
\hline $\begin{array}{l}\text { 299-E33-49 } \\
(84.98-85.89) \\
\end{array}$ & 1,430 & NA & 0.095 \\
\hline $\begin{array}{l}299-E 33-49 \\
(85.89-86.08)\end{array}$ & 83 & NA & 0.006 \\
\hline \multicolumn{4}{|c|}{ Waste Management Area C } \\
\hline $\begin{array}{l}\text { 299-E27-22 } \\
(75.1-75.9)\end{array}$ & $1900-2100^{(\mathrm{c})}$ & NA & $0.7^{(\mathrm{i})}$ \\
\hline $\begin{array}{l}\text { 299-E27-22 } 2^{(\mathrm{g}, \mathrm{h})} \\
(76.8-77.4)\end{array}$ & $0.04^{(\mathrm{c})}$ & NA & $0.0 .00003^{(\mathrm{i})}$ \\
\hline $\begin{array}{l}\text { 299-E27-22(g,h) } \\
(81.4-81.7)\end{array}$ & $6000-6900^{(\mathrm{c})}$ & NA & $2.3^{(\mathrm{i})}$ \\
\hline $299-E 27-23^{(a)}$ & $100-108^{(\mathrm{c})}$ & NA & $0.036^{(\mathrm{i})}$ \\
\hline $\begin{array}{l}\text { (a) Spane et al. } \\
\text { (b) All hydrolo } \\
299-E 33-33 \\
\text { gravel). } \\
\text { (c) High K (osc } \\
\text { (d) Estimated u } \\
\text { and hydraul } \\
\text { (e) Estimated u } \\
\text { and hydraul } \\
\text { (f) Data for we } \\
\text { Characteriz } \\
\text { WMA B-BX- } \\
\text { (g) Numbers in } \\
\text { (h) Williams an } \\
\text { (i) Estimated u } \\
\text { and hydraul } \\
\text { NA = Not availa }\end{array}$ & $\begin{array}{l}\text { of } 0.00016 \text { from } \\
\text { num hydraulic co } \\
\text { of } 0.00002 \text { from } \\
-49 \text { from Spane } \\
\text { lts for Multi-Test } \\
99-E 33-49 \text { (C42 } \\
\text { es are depth inter } \\
\text { vskih (2004). } \\
\text { num hydraulic co } \\
\text { of } 0.0001 \text { from }\end{array}$ & $\begin{array}{l}\text { n et al. (2006). } \\
\text { ity from this table a } \\
\text { n et al. (2006). } \\
\text { DR Newcomer. } 20 \\
\text { Intervals Conductec } \\
\text { tober } 8,2004 \text { letter } \\
\text { ed (meters below } \\
\text { ity from this table a } \\
\text { et al. (2006). }\end{array}$ & $\begin{array}{l}\text { ere noted. } \\
\text { except for wells } \\
\text { nit } 3 \text { (Cold Creek unit } \\
\text { ective porosity of } 0.3 \\
\text { ective porosity of } 0.3 \\
\text { lug Test } \\
\text { ng the Drilling of } \\
\text { to JV Borghese. } \\
\text { surface). } \\
\text { ective porosity of } 0.3\end{array}$ \\
\hline
\end{tabular}


Several slug tests were done prior to 1997 in wells near 200 East Area single-shell tank farms. Table 3.4 gives the resulting hydraulic conductivity and transmissivity data from those tests. In most cases, the analyses of the data from these tests are less well documented than are more recent analyses. The original source for the data should be consulted for details of testing and analysis. The hydraulic conductivities obtained from the earlier slug test (Table 3.4) are generally lower than those measured in the more recent tests (Table 3.3).

The differences in hydraulic properties among wells and within single wells illustrate the difficulty in assigning accurate values to specific hydrogeologic units in the 200 East (and 200 West) Area. The differences are due to different testing and analysis methods used through time, different assumed values for certain parameters such as effective porosity, and natural variation in lithologic properties that affect the hydraulic properties. As more hydrologic data become available, perhaps the relatively large ranges of some hydraulic properties will decrease. Until then, the existing data set must be considered plausible within the uncertainties in the analyses.

Table 3.4. Results of Pre-1997 Slug Testing at Single-Shell Tank Waste Management Areas in the 200 East Area

\begin{tabular}{||c|c|c|c||}
\hline Well Name & $\begin{array}{c}\text { Hydraulic Conductivity } \\
(\mathrm{m} / \text { day })\end{array}$ & $\begin{array}{c}\text { Transmissivity } \\
\left(\mathrm{m}^{2} / \mathrm{day}\right)\end{array}$ & Source \\
\hline \hline \multicolumn{4}{|c||}{ Waste Management Area A-AX } \\
\hline $299-E 24-19$ & 33.5 & 158 & Caggiano 1993 \\
\hline $299-E 25-40$ & 21.3 & 102 & Caggiano 1993 \\
\hline $299-E 25-41$ & 7.3 & 31 & Caggiano 1993 \\
\hline \multicolumn{4}{|c||}{ Waste Management Area B-BX-BY } \\
\hline $299-E 33-33$ & 97.5 & 502 & Caggiano 1993 \\
\hline \multicolumn{5}{|c|}{ Waste Management Area C } \\
\hline $299-E 27-13$ & 54.9 & 232 & Caggiano 1993 \\
\hline $299-E 27-14$ & 48.8 & 242 & Caggiano 1993 \\
\hline $299-E 27-15$ & 118.9 & Caggiano 1993 \\
\hline (a) Transmissivity calculated by multiplying hydraulic conductivity by thickness of test interval. \\
\hline
\end{tabular}

\subsection{Historical Changes in Groundwater Flow Direction and Gradient Beneath 200 East Area Single-Shell Tank Waste Management Areas}

Water levels beneath 200 East Area rose as much as $9 \mathrm{~m}$ (well 699-45-42, located near 216-B pond [B Pond]) because of artificial recharge from liquid waste disposal operations. The largest volumes of discharge were to the B Pond system east of the 200 East Area, the 216-A-25 (Gable Mountain) pond system north of the 200 East Area, and several of the Plutonium Uranium Extraction (PUREX) Plant cribs east and south of WMA A-AX and WMA C. Figure 3.4 shows the liquid discharge history for the two pond systems. (See Figure 1.1 for locations of the B Pond and Gable Mountain pond systems.) The Gable Mountain pond system is estimated to have received approximately 307 billion L of effluent and B Pond to have received about 240 billion L of effluent (DOE 1993). These large volumes disposed to the ponds (and, lesser volumes to cribs and ditches) artificially recharged the unconfined aquifer creating 
large water-table mounds. The increase in water-table elevation was most rapid from 1954 to 1963, increasing as much as $0.6 \mathrm{~m} /$ year at times. The water table declined somewhat in the late $1960 \mathrm{~s}$ and early 1970s, then increased again in the early 1980s before a final decline beginning in 1988 and continuing throughout the 1990s when wastewater discharges in the 200 East Area were reduced.

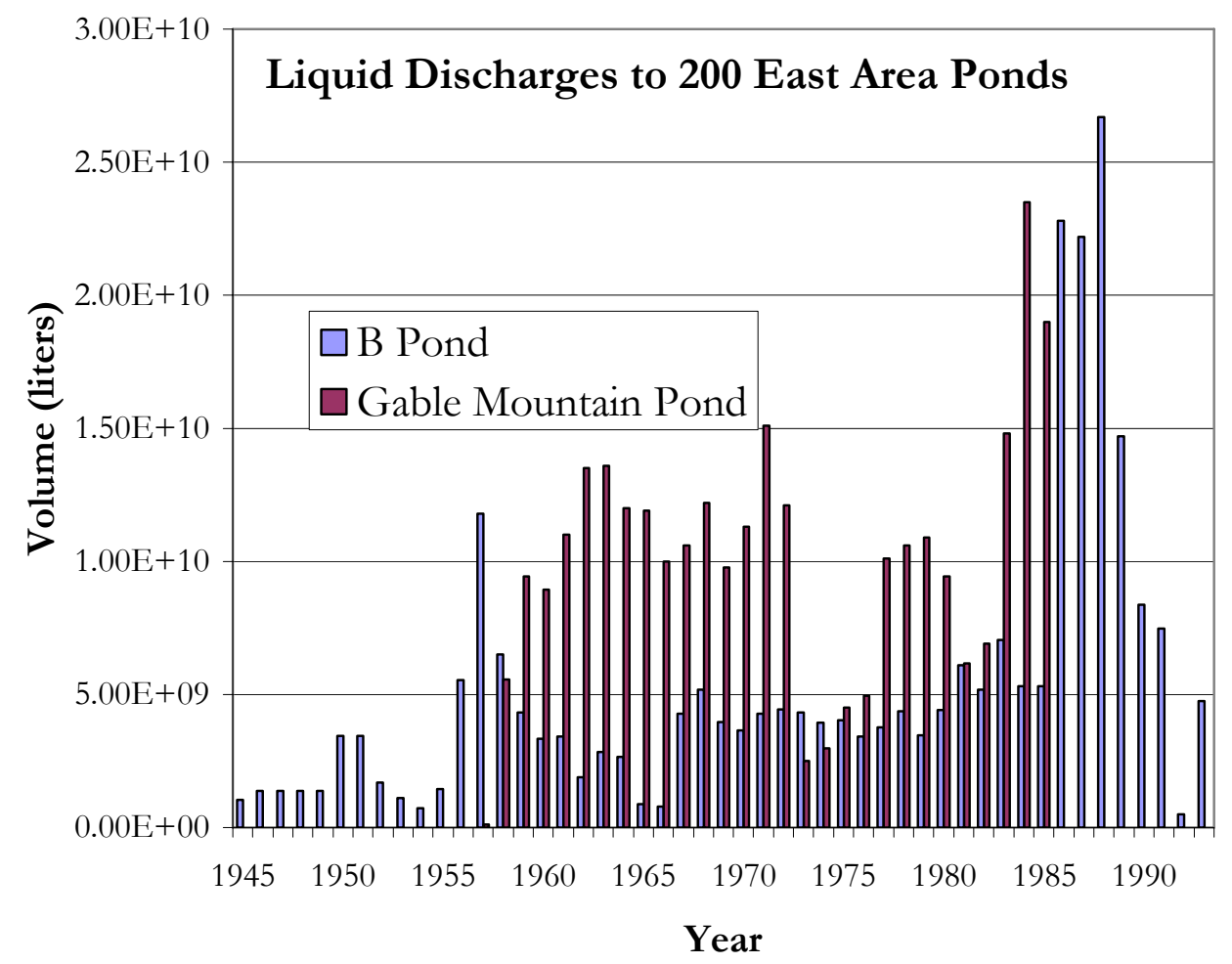

Figure 3.4. Discharge History for the B Pond and the Gable Mountain Pond Systems

Figures 3.5 through 3.7 show hydrographs for the areas around each of the 200 East Area single-shell tank WMAs. The hydrographs illustrate the changes in water-table elevation that have occurred since at least the mid 1950s. All data used to make the hydrographs were obtained from the HydroDat database (see data files on CD included in Hartman et al. 2006).

All three figures show similar changes in water levels beneath the WMAs. All the hydrographs show a maximum in water-table elevation in about 1968 that corresponds to a time of high discharge to Gable Mountain pond (Figure 3.4). This maximum is followed by a minimum, centered around 1978, that corresponds to a minimum in the discharges to both pond systems. Finally, a second maximum is seen in 1986 to 1987 corresponding to peak discharge to the B Pond system.

Table 3.5 summarizes the changes in water-level elevations that have occurred beneath the 200 East Area single-shell tank WMAs since the beginning of the Hanford Site operations. The pre-Manhattan Project water table was at approximately $118 \mathrm{~m}$ above sea level in 200 East Area (Kipp and Mudd 1974). Bergeron and Wurstner (2000), more recently modeled the elevation of the water table beneath the Hanford Site for the Immobilized Low-Activity Waste Performance Assessment. Their model resulted in a water-table elevation of about 116 to $118 \mathrm{~m}$ above sea level in the 200 East Area after all influences from the Hanford Site have dissipated. 


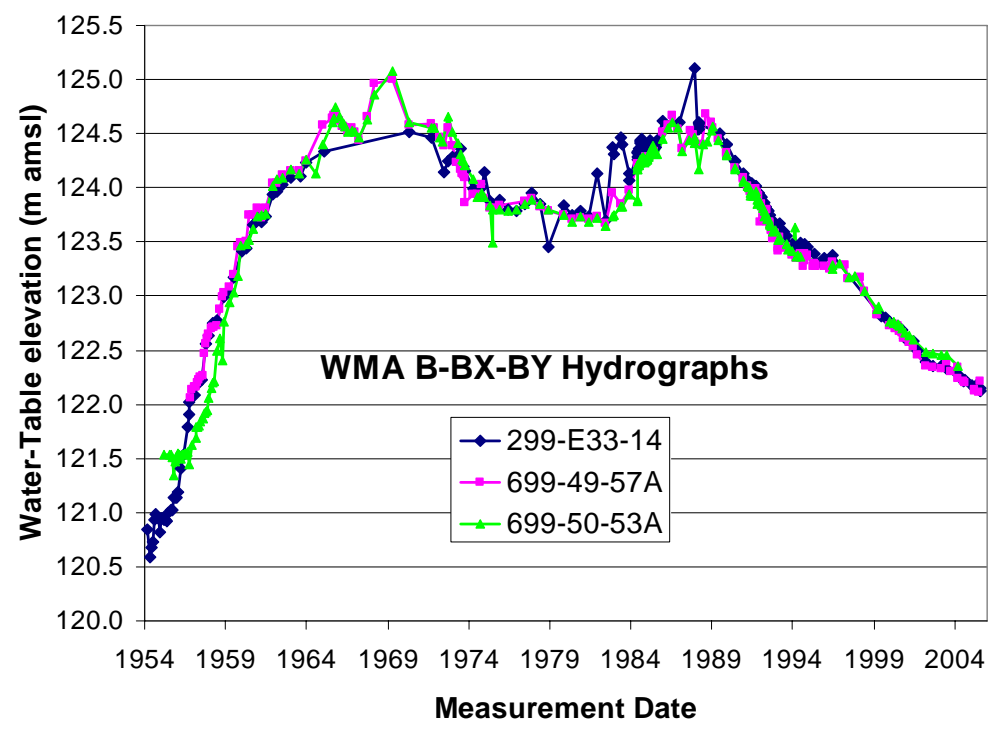

Figure 3.5. Hydrographs of Selected Wells in the Area of Waste Management Area B-BX-BY, 200 East Area. (Well 299-E33-14 is located about 250 m east of the northeast corner of the BY Tank Farm; well 699-49-57A is located about $1.5 \mathrm{~km}$ northwest of the BY Tank Farm; well 266-50-53A is located about $1.5 \mathrm{~km}$ north of the BY Tank Farm.)

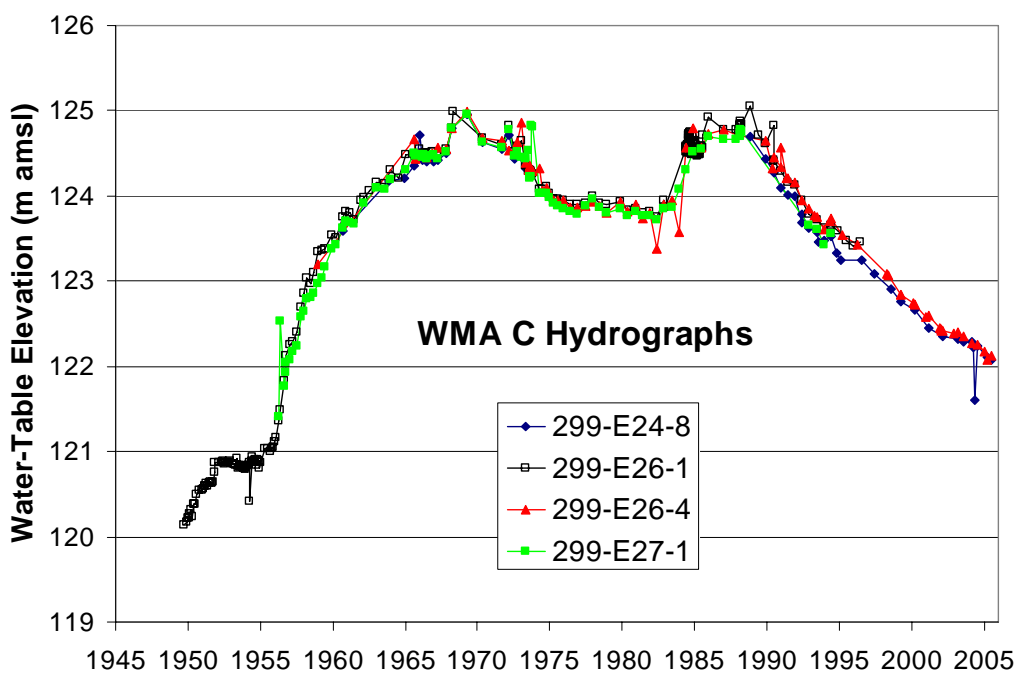

Measurement Date

Figure 3.6. Hydrographs from Selected Wells in the Area of Waste Management Area C, 200 East Area. (Well 299-E24-8 is located about 650 m south-southwest of C Tank Farm; well 299-E26-1 is located about 450 m north of the C Tank Farm; well 299-E26-4 is located about $500 \mathrm{~m}$ southeast of the C Tank Farm; well 299-W27-1 is located about 500 m west of the C Tank Farm.) 


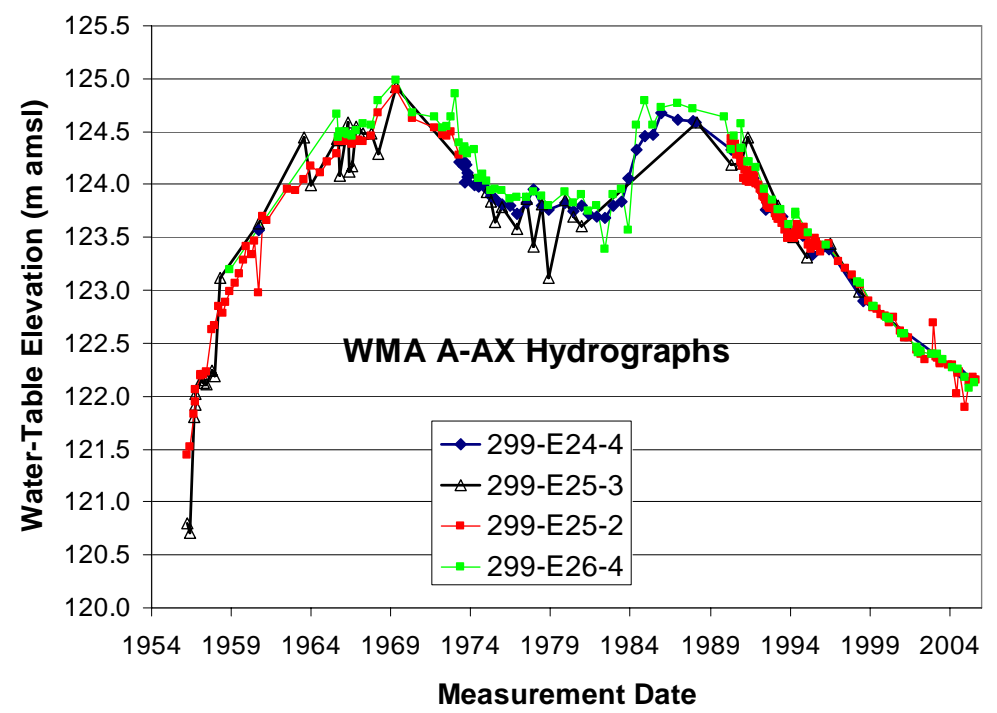

Figure 3.7. Hydrographs of Selected Wells in the Vicinity of Waste Management Area A-AX, 200 East Area. (Well 299-E24-4 is located about 175 m west of Waste Management Area (WMA) A-AX; well 299-E25-2 is located about 60 m east of the Waste Management Area; well 299-E25-3 is located about 350 m south of the WMA; well 299-E26-4 is located about 1,000 m northeast of the WMA.)

Table 3.5. Historical Water Level Changes Beneath the 200 East Area Single-Shell Tank Farms

\begin{tabular}{|c|c|c|c|c|c|}
\hline $\begin{array}{c}\text { Waste } \\
\text { Management } \\
\text { Area }\end{array}$ & $\begin{array}{l}\text { Approximate Pre- } \\
\text { Hanford Water- } \\
\text { Table Elevation } \\
(\mathrm{m} \mathrm{amsl})^{(\mathrm{a})}\end{array}$ & $\begin{array}{l}\text { Estimated Post- } \\
\text { Hanford Water- } \\
\text { Table Elevation } \\
(\mathrm{m} \mathrm{amsl})^{(\mathrm{b})}\end{array}$ & $\begin{array}{c}\text { Approximate } \\
\text { Maximum Water- } \\
\text { Table Elevation } \\
\text { ( } \mathrm{m} \text { amsl) and Date of } \\
\text { Measurement }\end{array}$ & $\begin{array}{l}\text { Approximate } \\
\text { Current Water- } \\
\text { Table Elevation } \\
\quad(\mathrm{m} \mathrm{amsl})^{(\mathrm{c})}\end{array}$ & $\begin{array}{c}\text { Approximate } \\
\text { Yearly Rate of } \\
\text { Decline During } \\
\text { the Past } 5 \text { Years } \\
\text { (m/yr) }\end{array}$ \\
\hline A-AX & $\begin{array}{c}120 \\
116-118\end{array}$ & $116-118$ & $\begin{array}{l}125.9 \text { Dec. } 1985 \\
(299-E 25-4)\end{array}$ & $122.12-122.18$ & 0.11 \\
\hline B-BX-BY & $\begin{array}{c}120 \\
116-118\end{array}$ & $116-118$ & $\begin{array}{l}\text { 125.0 April } 1969 \\
(299-E 33-20)\end{array}$ & $122.08-122.18$ & 0.14 \\
\hline $\mathrm{C}$ & $\begin{array}{c}120 \\
116-118\end{array}$ & $116-118$ & $\begin{array}{l}\text { 124.4 February } 1990 \\
\text { (299-E27-13) }\end{array}$ & $122.11-122.18$ & 0.11 \\
\hline \multicolumn{6}{|c|}{$\begin{array}{l}\text { (a) Kipp and Mudd (1974). } \\
\text { (b) Bergeron and Wurstner (2000). } \\
\text { (c) Hartman et al. (2006). } \\
\text { amsl = Above mean sea level. }\end{array}$} \\
\hline
\end{tabular}

All non-permitted discharges of liquid effluent to the ground were stopped in 1995. Since that time, continued changes have occurred in the water-table elevation. Table 3.5 also gives the average rate of water table decline in wells at each WMA during the past 5 years. The average rate of decline was obtained by averaging the rate of decline in each monitoring well in the RCRA monitoring network at each WMA between March 2000 and March 2005. (In some cases, February or July 2005 water levels were used if March data did not exist.) Wells drilled after 2001 were not used because they would bias the water level change toward low values. All data used are in the HydroDat database (see data files on CD included in Hartman et al. 2006). 
The data show that the water table beneath all 200 East Area single-shell tank WMAs is declining at a rate of about 0.11 to $0.14 \mathrm{~m} /$ year. At the current rate of decline, the water table will take between 30 and 50 years to reach the estimated post-Hanford water-table elevation (Bergeron and Wurstner 2000).

Comparing the approximate rate of water-table decline in the 200 East Area (Table 3.5) with that in the 200 West Area (Table 2.10) shows that the rate of decline is about three times faster in the 200 West Area. This is because the larger diffusivities (hydraulic transmissivity/storativity) of the 200 East Area sediments, compared to the 200 West Area sediments, result in slower and smaller rises of the water table when effluents are added to the soil column and faster and greater declines of the water table when effluent quantities are decreased.

Accompanying the changes in water level were changes in groundwater flow direction. Pre-Hanford Site groundwater flow direction was generally toward the east or southeast (Kipp and Mudd 1974). Since 1944, liquid disposal to the B Pond, Gable Mountain Pond, and other disposal facilities has changed the flow direction several times during Hanford Site operations. Tables 3.6 through 3.8 give historical groundwater flow directions and water-table gradients near each of the 200 East Area single-shell tank WMAs. The flow directions and gradients were calculated using the three-point analysis method and water level measurements in the HydroDat database (see data files on CD included in Hartman et al. 2006) as described earlier for similar 200 West Area analyses. A discussion of the reasoning for choosing wells and the uncertainties in the data are given in Section 2.2, where similar analyses were done for the 200 West Area.

An analysis of groundwater flow data in Appendix C of Field Investigation Report for Waste Management Area B-BX-BY (Knepp 2002b) summarized the changes in flow direction and flow rate in the vicinity of WMA B-BX-BY. One of the wells used in that analysis, well 699-50-53A, was drilled into basalt in an area that was above the water table until early to mid 1959. Consequently, the analysis in Knepp (2002b) was redone omitting the early data from well 699-50-53A. The results are shown in Table 3.6 and give the historical groundwater flow directions and gradients in the WMA B-BX-BY area.

The groundwater flow was in a southerly direction during the late 1950s (Figure $3.8 \mathrm{~A}$ ) when influences from Gable Mountain pond had a strong influence on groundwater flow. Prior to this time, groundwater flow may have been northerly due to influences from B Pond, but there are no appropriate water-level data in the area to confirm this. The southerly flow lasted until 1974. Groundwater flow direction between the late 1950s and about 1972 was south to southeast followed by a swing to the southwest during 1973 and 1974 (Appendix C of Knepp 2002b). After 1974, the flow direction shifted again and was toward the north (Figure $3.8 \mathrm{~B}$ ) as the influence of B Pond increased relative to the influence of Gable Pond. The northerly flow lasted until the late 1990s when the flow direction once again changed and was toward the southwest (Figure 3.8 C). The latest change reflects waning influences from the B Pond system and a drop in the water table to near (or below) the top of basalt in some areas.

Although Figure 3.8 C shows a relatively constant groundwater flow direction toward the southwest since late 1999, groundwater flow directions in the northern part of the 200 East Area are probably more variable than the figure indicates. A trend surface analysis performed on FY 2003 through FY 2005 water level data indicated highly variable flow direction beneath low-level burial ground WMA 1, located west of WMA B-BX-BY (Thornton et al. 2006). Thornton et al. (2006) interpreted the groundwater flow direction beneath low-level burial ground WMA 2, located east of WMA B-BX-BY, to be toward the west or southwest. Narbutovskih et al. (2002) used in situ flow measurements to show highly variable but 
Table 3.6. Historical Water Levels, Groundwater Flow Directions, and Water-Table Gradients in the Area of Waste Management Area B-BX-BY (from Reidel et al. 2006)

\begin{tabular}{|c|c|c|c|c|c|c|c|}
\hline \multirow{2}{*}{$\begin{array}{l}\text { Duration }^{(a)} \\
\quad \text { (day) }\end{array}$} & \multirow[b]{2}{*}{ Start Date } & \multirow[b]{2}{*}{ End Date } & \multicolumn{3}{|c|}{ Water Levels (m amsl) } & \multirow{2}{*}{$\begin{array}{c}\text { Groundwater } \\
\text { Flow Direction }\end{array}$} & \multirow{2}{*}{$\begin{array}{c}\text { Water-Table } \\
\text { Gradient }\end{array}$} \\
\hline & & & 299-E33-14 & $699-49-57 \mathrm{~A}$ & $699-50-53 \mathrm{~A}$ & & \\
\hline 6 & $12 / 23 / 59$ & $12 / 28 / 59$ & 123.42 & 123.49 & 123.46 & 132.193 & 0.000044 \\
\hline 5 & $09 / 23 / 60$ & $09 / 27 / 60$ & 123.65 & 123.75 & 123.62 & 59.015 & 0.000114 \\
\hline 7 & $12 / 08 / 60$ & $12 / 14 / 60$ & 123.72 & 123.81 & 123.74 & 92.516 & 0.000065 \\
\hline 2 & $03 / 23 / 61$ & $03 / 24 / 61$ & 123.69 & 123.72 & 123.75 & 188.363 & 0.000055 \\
\hline 6 & $06 / 23 / 61$ & $06 / 28 / 61$ & 123.73 & 123.82 & 123.76 & 105.079 & 0.000052 \\
\hline 4 & $12 / 11 / 61$ & $12 / 14 / 61$ & 123.93 & 124.04 & 124.01 & 147.529 & 0.000070 \\
\hline 10 & $07 / 10 / 62$ & $07 / 19 / 62$ & 124.03 & 124.12 & 124.10 & 149.767 & 0.000061 \\
\hline 9 & $01 / 09 / 63$ & $01 / 17 / 63$ & 124.09 & 124.15 & 124.17 & 179.259 & 0.000075 \\
\hline 7 & $12 / 17 / 63$ & $12 / 23 / 63$ & 124.23 & 124.24 & 124.26 & 197.078 & 0.000030 \\
\hline 9 & $01 / 11 / 65$ & $01 / 19 / 65$ & 124.33 & 124.57 & 124.40 & 95.154 & 0.000159 \\
\hline 8 & $05 / 11 / 70$ & $05 / 18 / 70$ & 124.51 & 124.58 & 124.60 & 180.031 & 0.000082 \\
\hline 1 & $09 / 14 / 71$ & $09 / 14 / 71$ & 124.46 & 124.59 & 124.56 & 146.842 & 0.000087 \\
\hline 4 & $10 / 02 / 72$ & $10 / 05 / 72$ & 124.25 & 124.55 & 124.65 & 179.606 & 0.000365 \\
\hline 4 & $01 / 05 / 73$ & $01 / 08 / 73$ & 124.29 & 124.39 & 124.51 & 194.000 & 0.000229 \\
\hline 11 & $07 / 10 / 73$ & $07 / 20 / 73$ & 124.36 & 124.18 & 124.31 & 272.979 & 0.000122 \\
\hline 3 & $08 / 13 / 73$ & $08 / 15 / 73$ & 124.19 & 124.13 & 124.26 & 227.109 & 0.000131 \\
\hline 2 & $09 / 10 / 73$ & $09 / 11 / 73$ & 124.20 & 124.12 & 124.24 & 234.016 & 0.000117 \\
\hline 6 & $10 / 03 / 73$ & $10 / 08 / 73$ & 124.15 & 124.09 & 124.20 & 230.916 & 0.000108 \\
\hline 8 & $04 / 11 / 74$ & $04 / 18 / 74$ & 123.99 & 123.94 & 124.08 & 222.004 & 0.000141 \\
\hline 5 & $07 / 12 / 74$ & $07 / 16 / 74$ & 123.98 & 123.93 & 123.92 & 2.441 & 0.000058 \\
\hline 9 & $07 / 07 / 75$ & $07 / 15 / 75$ & 123.86 & 123.81 & 123.80 & 355.688 & 0.000051 \\
\hline 1 & $12 / 03 / 75$ & $12 / 03 / 75$ & 123.89 & 123.83 & 123.80 & 5.178 & 0.000084 \\
\hline 1 & $07 / 01 / 77$ & $07 / 01 / 77$ & 123.85 & 123.87 & 123.85 & 61.977 & 0.000023 \\
\hline 1 & $12 / 07 / 77$ & $12 / 07 / 77$ & 123.96 & 123.91 & 123.89 & 1.288 & 0.000062 \\
\hline 1 & $06 / 01 / 78$ & $06 / 01 / 78$ & 123.86 & 123.82 & 123.85 & 282.185 & 0.000020 \\
\hline 1 & $12 / 01 / 79$ & $12 / 01 / 79$ & 123.83 & 123.74 & 123.75 & 339.206 & 0.000070 \\
\hline 1 & $06 / 01 / 80$ & $06 / 01 / 80$ & 123.74 & 123.71 & 123.69 & 2.459 & 0.000049 \\
\hline 1 & $12 / 01 / 80$ & $12 / 01 / 80$ & 123.79 & 123.72 & 123.73 & 338.012 & 0.000052 \\
\hline 1 & $06 / 01 / 81$ & $06 / 01 / 81$ & 123.73 & 123.71 & 123.68 & 10.714 & 0.000052 \\
\hline 1 & $06 / 01 / 82$ & $06 / 01 / 82$ & 123.70 & 123.68 & 123.64 & 15.267 & 0.000060 \\
\hline 1 & $12 / 01 / 82$ & $12 / 01 / 82$ & 124.37 & 123.95 & 123.74 & 4.144 & 0.000588 \\
\hline 1 & $06 / 01 / 83$ & $06 / 01 / 83$ & 124.46 & 123.85 & 123.82 & 348.515 & 0.000558 \\
\hline 1 & $12 / 01 / 83$ & $12 / 01 / 83$ & 124.13 & 123.98 & 123.93 & 359.538 & 0.000180 \\
\hline 1 & $06 / 01 / 84$ & $06 / 01 / 84$ & 124.32 & 124.22 & 124.17 & 4.609 & 0.000144 \\
\hline 1 & $12 / 01 / 84$ & $12 / 01 / 84$ & 124.40 & 124.28 & 124.26 & 354.204 & 0.000131 \\
\hline 2 & $06 / 26 / 85$ & $06 / 27 / 85$ & 124.37 & 124.34 & 124.35 & 326.061 & 0.000021 \\
\hline 14 & $12 / 17 / 85$ & $12 / 30 / 85$ & 124.62 & 124.51 & 124.45 & 6.611 & 0.000160 \\
\hline 21 & $12 / 09 / 86$ & $12 / 29 / 86$ & 124.61 & 124.54 & 124.55 & 340.809 & 0.000051 \\
\hline 13 & $06 / 08 / 89$ & $06 / 20 / 89$ & 124.50 & 124.45 & 124.44 & 352.875 & 0.000049 \\
\hline 2 & $12 / 12 / 89$ & $12 / 13 / 89$ & 124.40 & 124.31 & 124.30 & 351.193 & 0.000092 \\
\hline 2 & $06 / 18 / 90$ & $06 / 19 / 90$ & 124.25 & 124.18 & 124.17 & 351.090 & 0.000066 \\
\hline 3 & $12 / 10 / 90$ & $12 / 12 / 90$ & 124.14 & 124.09 & 124.06 & 7.479 & 0.000073 \\
\hline 1 & $03 / 19 / 91$ & $03 / 19 / 91$ & 124.07 & 124.02 & 124.01 & 355.860 & 0.000050 \\
\hline 5 & $05 / 16 / 91$ & $05 / 20 / 91$ & 124.01 & 123.96 & 123.93 & 6.749 & 0.000076 \\
\hline
\end{tabular}


Table 3.6. (contd)

\begin{tabular}{|c|c|c|c|c|c|c|c|}
\hline \multirow{2}{*}{$\begin{array}{l}\text { Duration }^{(a)} \\
\quad \text { (day) }\end{array}$} & \multirow[b]{2}{*}{ Start Date } & \multirow[b]{2}{*}{ End Date } & \multicolumn{3}{|c|}{ Water Levels (m amsl) } & \multirow{2}{*}{$\begin{array}{c}\text { Groundwater } \\
\text { Flow Direction }\end{array}$} & \multirow{2}{*}{$\begin{array}{c}\text { Water-Table } \\
\text { Gradient }\end{array}$} \\
\hline & & & 299-E33-14 & $699-49-57 \mathrm{~A}$ & $699-50-53 \mathrm{~A}$ & & \\
\hline 2 & $06 / 18 / 91$ & $06 / 19 / 91$ & 124.04 & 123.96 & 123.95 & 355.931 & 0.000079 \\
\hline 2 & $07 / 29 / 91$ & $07 / 30 / 91$ & 124.00 & 123.96 & 123.93 & 9.095 & 0.000069 \\
\hline 2 & $09 / 23 / 91$ & $09 / 24 / 91$ & 124.02 & 124.00 & 123.97 & 13.232 & 0.000053 \\
\hline 1 & $11 / 22 / 91$ & $11 / 22 / 91$ & 123.96 & 123.93 & 123.86 & 21.039 & 0.000100 \\
\hline 2 & $01 / 22 / 92$ & $01 / 23 / 92$ & 123.91 & 123.85 & 123.84 & 350.456 & 0.000064 \\
\hline 6 & $02 / 20 / 92$ & $02 / 25 / 92$ & 123.85 & 123.73 & 123.82 & 273.501 & 0.000082 \\
\hline 2 & $03 / 19 / 92$ & $03 / 20 / 92$ & 123.86 & 123.78 & 123.79 & 339.855 & 0.000069 \\
\hline 1 & $06 / 17 / 92$ & $06 / 17 / 92$ & 123.80 & 123.79 & 123.71 & 26.658 & 0.000114 \\
\hline 2 & $07 / 21 / 92$ & $07 / 22 / 92$ & 123.79 & 123.68 & 123.70 & 328.376 & 0.000074 \\
\hline 2 & $08 / 19 / 92$ & $08 / 20 / 92$ & 123.75 & 123.67 & 123.68 & 337.796 & 0.000064 \\
\hline 2 & $09 / 17 / 92$ & $09 / 18 / 92$ & 123.69 & 123.61 & 123.64 & 317.947 & 0.000053 \\
\hline 2 & $12 / 09 / 92$ & $12 / 10 / 92$ & 123.64 & 123.59 & 123.61 & 312.087 & 0.000036 \\
\hline 1 & $03 / 12 / 93$ & $03 / 12 / 93$ & 123.67 & 123.54 & 123.55 & 342.318 & 0.000103 \\
\hline 1 & $09 / 01 / 93$ & $09 / 01 / 93$ & 123.56 & 123.46 & 123.48 & 331.220 & 0.000070 \\
\hline 1 & $12 / 14 / 93$ & $12 / 14 / 93$ & 123.47 & 123.38 & 123.41 & 318.375 & 0.000061 \\
\hline 1 & $03 / 28 / 94$ & $03 / 28 / 94$ & 123.43 & 123.35 & 123.36 & 335.010 & 0.000061 \\
\hline 1 & $06 / 21 / 94$ & $06 / 21 / 94$ & 123.49 & 123.39 & 123.37 & 356.166 & 0.000111 \\
\hline 9 & $06 / 06 / 96$ & $06 / 14 / 96$ & 123.37 & 123.31 & 123.29 & 2.057 & 0.000078 \\
\hline 4 & $12 / 13 / 99$ & $12 / 16 / 99$ & 122.76 & 122.73 & 122.77 & 247.587 & 0.000036 \\
\hline 1 & $03 / 21 / 00$ & $03 / 21 / 00$ & 122.73 & 122.73 & 122.76 & 210.655 & 0.000036 \\
\hline 1 & $06 / 21 / 00$ & $06 / 21 / 00$ & 122.73 & 122.72 & 122.74 & 219.236 & 0.000022 \\
\hline 1 & $09 / 21 / 00$ & $09 / 21 / 00$ & 122.68 & 122.66 & 122.71 & 227.285 & 0.000042 \\
\hline 2 & $12 / 14 / 00$ & $12 / 15 / 00$ & 122.61 & 122.62 & 122.66 & 202.432 & 0.000057 \\
\hline 1 & $03 / 12 / 01$ & $03 / 12 / 01$ & 122.60 & 122.58 & 122.64 & 220.481 & 0.000068 \\
\hline 1 & $06 / 21 / 01$ & $06 / 21 / 01$ & 122.58 & 122.53 & 122.59 & 245.723 & 0.000054 \\
\hline $\begin{array}{l}\text { (a) Duration } \\
\text { (b) Groundv }\end{array}$ & the length of & e between $t$ & $\mathrm{rt}$ and end & s. & & & \\
\hline
\end{tabular}

generally southwest to southeast groundwater flow beneath WMA B-BX-BY. Further analysis of water elevations in Thornton et al. (2007) and local plume movement show the flow direction to be to the south across the WMA. These interpreted flow directions are local to the respective WMAs and represent flow directions on a relatively small scale. The water levels used to make Figure 3.8 are from wells more regional to WMA B-BX-BY and represent general flow directions on a larger scale.

The apparent variations in flow directions in the northern part of the 200 East Area may, in part, be due to the very thin unconfined aquifer that is being influenced by the top of the basalt. The top of the basalt, which forms the base of the unconfined aquifer in the area, is above the water table in the northeast corner of the 200 East Area and dips south to southwest. This surface is expected to influence flow directions especially near areas where the aquifer pinches out against the basalt. Also, the top of the basalt is an erosional surface with up to about $3.5 \mathrm{~m}$ of relief (Hartman et al. 2001). Thus, local flow directions may differ greatly as water moves between high areas on the top of basalt. 
Table 3.7. Water Levels, Groundwater Flow Directions, and Water-Table Gradients in the Area of Waste Management Area C from 1958 to 2003 (from Reidel et al. 2006)

\begin{tabular}{|c|c|c|c|c|c|c|c|}
\hline \multirow{2}{*}{$\begin{array}{l}\text { Duration }^{(a)} \\
\text { (day) }\end{array}$} & \multirow[b]{2}{*}{ Start Date } & \multirow[b]{2}{*}{ End Date } & \multicolumn{3}{|c|}{ Water Levels (m amsl) } & \multirow{2}{*}{$\begin{array}{c}\text { Groundwater } \\
\text { Flow Direction } \\
\end{array}$} & \multirow{2}{*}{$\begin{array}{c}\text { Water-Table } \\
\text { Gradient }\end{array}$} \\
\hline & & & 299-E26-1 & 299-E26-4 & 299-E27-1 & & \\
\hline 4 & $12 / 09 / 58$ & $12 / 12 / 58$ & 123.343 & 123.194 & 122.973 & 212.673 & 0.000433 \\
\hline 1 & $08 / 18 / 65$ & $08 / 18 / 65$ & 124.48 & 124.660 & 124.500 & 328.459 & 0.000203 \\
\hline 1 & $10 / 20 / 65$ & $10 / 20 / 65$ & 124.492 & 124.495 & 124.485 & 258.557 & 0.000009 \\
\hline 4 & $01 / 03 / 66$ & $01 / 06 / 66$ & 124.559 & 124.486 & 124.485 & 188.628 & 0.000113 \\
\hline 11 & $04 / 04 / 66$ & $04 / 14 / 66$ & 124.498 & 124.474 & 124.488 & 164.863 & 0.000029 \\
\hline 1 & $05 / 20 / 66$ & $05 / 20 / 66$ & 124.498 & 124.474 & 124.463 & 199.422 & 0.000046 \\
\hline 2 & $11 / 02 / 66$ & $11 / 03 / 66$ & 124.514 & 124.510 & 124.463 & 230.877 & 0.000056 \\
\hline 11 & $03 / 28 / 67$ & $04 / 07 / 67$ & 124.462 & 124.568 & 124.436 & 308.904 & 0.000125 \\
\hline 5 & $10 / 19 / 67$ & $10 / 23 / 67$ & 124.553 & 124.556 & 124.512 & 239.716 & 0.000046 \\
\hline 1 & $05 / 18 / 70$ & $05 / 18 / 70$ & 124.675 & 124.678 & 124.631 & 239.428 & 0.000049 \\
\hline 1 & $09 / 14 / 71$ & $09 / 14 / 71$ & 124.608 & 124.641 & 124.573 & 277.811 & 0.000055 \\
\hline 6 & $03 / 15 / 72$ & $03 / 20 / 72$ & 124.824 & 124.538 & 124.771 & 152.595 & 0.000325 \\
\hline 1 & $07 / 11 / 72$ & $07 / 11 / 72$ & 124.526 & 124.541 & 124.463 & 248.930 & 0.000073 \\
\hline 5 & $10 / 03 / 72$ & $10 / 07 / 72$ & 124.59 & 124.635 & 124.518 & 267.052 & 0.000097 \\
\hline 1 & $01 / 08 / 73$ & $01 / 08 / 73$ & 124.642 & 124.855 & 124.448 & 281.927 & 0.000331 \\
\hline 1 & $08 / 13 / 73$ & $08 / 13 / 73$ & 124.279 & 124.352 & 124.210 & 280.928 & 0.000115 \\
\hline 1 & $09 / 10 / 73$ & 09/10/73 & 124.291 & 124.309 & 124.226 & 250.994 & 0.000076 \\
\hline 1 & $04 / 11 / 74$ & $04 / 11 / 74$ & 124.078 & 124.328 & 124.037 & 313.189 & 0.000288 \\
\hline 1 & $10 / 18 / 74$ & $10 / 18 / 74$ & 124.111 & 124.096 & 124.030 & 224.666 & 0.000090 \\
\hline 1 & $01 / 08 / 75$ & $01 / 08 / 75$ & 124.038 & 124.026 & 123.988 & 221.536 & 0.000056 \\
\hline 1 & $04 / 14 / 75$ & $04 / 14 / 75$ & 123.962 & 123.943 & 123.909 & 215.007 & 0.000061 \\
\hline 1 & $07 / 07 / 75$ & $07 / 07 / 75$ & 123.965 & 123.950 & 123.884 & 224.666 & 0.000090 \\
\hline 1 & $12 / 03 / 75$ & $12 / 03 / 75$ & 123.944 & 123.947 & 123.857 & 237.477 & 0.000096 \\
\hline 1 & $06 / 15 / 76$ & $06 / 15 / 76$ & 123.904 & 123.870 & 123.814 & 213.979 & 0.000105 \\
\hline 1 & $12 / 08 / 76$ & $12 / 08 / 76$ & 123.907 & 123.873 & 123.793 & 218.279 & 0.000130 \\
\hline 1 & $07 / 01 / 77$ & $07 / 01 / 77$ & 123.916 & 123.876 & 123.878 & 186.664 & 0.000060 \\
\hline 1 & $12 / 07 / 77$ & $12 / 07 / 77$ & 123.995 & 123.931 & 123.966 & 166.661 & 0.000077 \\
\hline 1 & $06 / 01 / 78$ & $06 / 01 / 78$ & 123.91 & 123.886 & 123.869 & 203.768 & 0.000051 \\
\hline 1 & $12 / 01 / 78$ & $12 / 01 / 78$ & 123.904 & 123.806 & 123.802 & 189.428 & 0.000153 \\
\hline 1 & $12 / 01 / 79$ & $12 / 01 / 79$ & 123.928 & 123.931 & 123.857 & 237.928 & 0.000079 \\
\hline 1 & $06 / 01 / 80$ & $06 / 01 / 80$ & 123.828 & 123.825 & 123.774 & 232.217 & 0.000060 \\
\hline 1 & $12 / 01 / 80$ & $12 / 01 / 80$ & 123.852 & 123.907 & 123.826 & 297.966 & 0.000070 \\
\hline 1 & \begin{tabular}{|l|}
$06 / 01 / 81$ \\
\end{tabular} & $06 / 01 / 81$ & 123.809 & 123.745 & 123.762 & 179.040 & 0.000087 \\
\hline 1 & $12 / 01 / 81$ & $12 / 01 / 81$ & 123.819 & 123.800 & 123.762 & 216.359 & 0.000065 \\
\hline 1 & $06 / 01 / 82$ & $06 / 01 / 82$ & 123.749 & 123.386 & 123.720 & 146.706 & 0.000409 \\
\hline 1 & $12 / 01 / 82$ & $12 / 01 / 82$ & 123.944 & 123.904 & 123.845 & 212.603 & 0.000116 \\
\hline 1 & $06 / 01 / 84$ & $06 / 01 / 84$ & 124.562 & 124.562 & 124.314 & 235.468 & 0.000274 \\
\hline 1 & $12 / 01 / 84$ & $12 / 01 / 84$ & 124.709 & 124.788 & 124.515 & 257.542 & 0.000237 \\
\hline 9 & $06 / 12 / 85$ & $06 / 20 / 85$ & 124.588 & 124.565 & 124.549 & 203.569 & 0.000049 \\
\hline 2 & $12 / 17 / 85$ & $12 / 18 / 85$ & 124.924 & 124.723 & 124.695 & 192.163 & 0.000330 \\
\hline 4 & $12 / 08 / 87$ & $12 / 11 / 87$ & 124.771 & 124.711 & 124.671 & 203.112 & 0.000126 \\
\hline 2 & $12 / 03 / 92$ & $12 / 04 / 92$ & 123.793 & 123.845 & 123.650 & 255.420 & 0.000172 \\
\hline 2 & $06 / 09 / 93$ & $06 / 10 / 93$ & 123.729 & 123.760 & 123.607 & 249.787 & 0.000141 \\
\hline
\end{tabular}


Table 3.7. (contd)

\begin{tabular}{|c|c|c|c|c|c|c|c|}
\hline \multirow{2}{*}{$\begin{array}{l}\text { Duration }^{(a)} \\
\quad \text { (day) }\end{array}$} & \multirow[b]{2}{*}{ Start Date } & \multirow[b]{2}{*}{ End Date } & \multicolumn{3}{|c|}{ Water Levels (m amsl) } & \multirow{2}{*}{$\begin{array}{c}\text { Groundwater } \\
\text { Flow Direction }^{(b)}\end{array}$} & \multirow{2}{*}{$\begin{array}{c}\text { Water-Table } \\
\text { Gradient }\end{array}$} \\
\hline & & & 299-E26-1 & 299-E26-4 & 299-E27-1 & & \\
\hline 2 & $12 / 01 / 93$ & $12 / 02 / 93$ & 123.619 & 123.613 & 123.427 & 233.640 & 0.000212 \\
\hline 1 & $06 / 03 / 94$ & $06 / 03 / 94$ & 123.653 & 123.735 & 123.558 & 275.430 & 0.000144 \\
\hline & & & 299-E27-12 & 299-E27-14 & 299-E27-7 & & \\
\hline 1 & $06 / 28 / 90$ & $06 / 28 / 90$ & 124.297 & 124.312 & 124.331 & 228.635 & 0.000229 \\
\hline 1 & $12 / 17 / 90$ & $12 / 17 / 90$ & 124.187 & 124.224 & 124.240 & 247.203 & 0.000316 \\
\hline 1 & 06/17/91 & 06/17/91 & 124.056 & 124.117 & 124.097 & 301.756 & 0.000332 \\
\hline 2 & $08 / 19 / 91$ & $08 / 19 / 91$ & 124.132 & 124.148 & 124.167 & 229.649 & 0.000233 \\
\hline 2 & $03 / 04 / 92$ & $03 / 05 / 92$ & 123.76 & 123.953 & 123.990 & 258.790 & 0.001348 \\
\hline 2 & $06 / 17 / 92$ & $06 / 18 / 92$ & 123.839 & 123.846 & 123.886 & 213.439 & 0.000388 \\
\hline 1 & $12 / 16 / 92$ & $12 / 16 / 92$ & 123.733 & 123.749 & 123.777 & 223.989 & 0.000312 \\
\hline 1 & $03 / 25 / 93$ & $03 / 25 / 93$ & 123.675 & 123.718 & 123.743 & 242.040 & 0.000415 \\
\hline 1 & $12 / 15 / 93$ & $12 / 15 / 93$ & 123.516 & 123.532 & 123.551 & 229.649 & 0.000233 \\
\hline 1 & $05 / 11 / 94$ & $05 / 11 / 94$ & 123.516 & 123.544 & 123.566 & 236.657 & 0.000315 \\
\hline 1 & $12 / 09 / 94$ & $12 / 09 / 94$ & 123.498 & 123.523 & 123.545 & 234.665 & 0.000300 \\
\hline 1 & $06 / 23 / 95$ & $06 / 23 / 95$ & 123.385 & 123.392 & 123.429 & 213.868 & 0.000360 \\
\hline 2 & $10 / 30 / 95$ & $10 / 30 / 95$ & 123.398 & 123.395 & 123.432 & 205.009 & 0.000332 \\
\hline 1 & $01 / 16 / 97$ & $01 / 16 / 97$ & 123.23 & 123.212 & 123.255 & 192.115 & 0.000361 \\
\hline 1 & 06/10/97 & 06/10/97 & 123.199 & 123.249 & 123.225 & 315.891 & 0.000285 \\
\hline 1 & $12 / 04 / 97$ & $12 / 04 / 97$ & 123.12 & 123.163 & 123.167 & 265.054 & 0.000277 \\
\hline 1 & $06 / 08 / 98$ & $06 / 08 / 98$ & 123.065 & 123.020 & 123.033 & 117.982 & 0.000244 \\
\hline 2 & $12 / 07 / 98$ & $12 / 08 / 98$ & 122.953 & 122.898 & 122.914 & 118.178 & 0.000298 \\
\hline 1 & 06/03/99 & 06/03/99 & 122.843 & 122.831 & 123.728 & 207.362 & 0.008207 \\
\hline 1 & $12 / 18 / 00$ & $12 / 18 / 00$ & 122.629 & 122.621 & 122.627 & 155.890 & 0.000055 \\
\hline 1 & $06 / 20 / 01$ & $06 / 20 / 01$ & 122.571 & 122.574 & 122.574 & 271.893 & 0.000018 \\
\hline 1 & 03/14/02 & $03 / 14 / 02$ & 122.388 & 122.391 & 122.389 & 330.530 & 0.000019 \\
\hline 1 & $12 / 16 / 02$ & $12 / 16 / 02$ & 122.442 & 122.410 & 122.520 & 197.195 & 0.000942 \\
\hline 3 & $06 / 02 / 03$ & $06 / 04 / 03$ & 122.309 & 122.328 & 126.511 & 207.970 & 0.038467 \\
\hline \multicolumn{7}{|c|}{ Duration is the length of time between the start and end dates. } & \\
\hline
\end{tabular}

Farther south, in the vicinity of WMA C, groundwater flow directions appear to have been less variable than in the WMA B-BX-BY area. Table 3.7 gives historical groundwater flow directions in the area of WMA C between 1958 and 1994 and, separately, more recent flow direction between 1990 and 2003. The earlier historical flow directions are determined from relatively far-field wells whereas the more recent directions are determined from wells in the RCRA monitoring network for the WMA. The data are shown graphically in Figure 3.9. The figure shows that the groundwater flow directions in the area of WMA C have been fairly constant and to the southwest between 1958 and the present.

No appropriately placed wells were identified in the WMA A-AX area to give historical groundwater flow directions prior to 1990. Table 3.8 gives water-level data, groundwater flow directions, and watertable gradient since 1990. The water levels in the table were obtained from wells in the RCRA monitoring network for WMA A-AX. Figure 3.10 is a plot of the groundwater flow directions tabulated in Table 3.8. Figure 3.10 shows that the groundwater flow direction at WMA A-AX has been constant and toward the south or slightly southwest from 1992 to the present. 
Table 3.8. Water Levels, Groundwater Flow Directions, and Water-Table Gradients in the Area of Waste Management Area A-AX from 1992 to 2003 (from Reidel et al. 2006)

\begin{tabular}{|c|c|c|c|c|c|c|c|}
\hline \multirow{2}{*}{$\begin{array}{l}\text { Duration }^{(a)} \\
\quad \text { (day) }\end{array}$} & \multirow[b]{2}{*}{ End Date } & \multirow[b]{2}{*}{ Start Date } & \multicolumn{3}{|c|}{ Water Level (m amsl) } & \multirow{2}{*}{$\begin{array}{c}\text { Groundwater } \\
\text { Flow Direction }\end{array}$} & \multirow{2}{*}{$\begin{array}{c}\text { Water-Table } \\
\text { Gradient }\end{array}$} \\
\hline & & & 299-E24-20 & 299-E25-2 & 299-E25-46 & & \\
\hline 1 & $10 / 20 / 1992$ & $10 / 20 / 1992$ & 123.807 & 123.789 & 123.772 & 164.68 & $3.14 \mathrm{E}-04$ \\
\hline 1 & $4 / 22 / 1993$ & $4 / 22 / 1993$ & 123.701 & 123.670 & 123.671 & 146.06 & $2.27 \mathrm{E}-04$ \\
\hline 1 & $7 / 20 / 1993$ & $7 / 20 / 1993$ & 123.652 & 123.634 & 123.623 & 161.38 & $2.50 \mathrm{E}-04$ \\
\hline 1 & $10 / 27 / 1993$ & $10 / 27 / 1993$ & 123.612 & 123.585 & 123.556 & 165.63 & $5.08 \mathrm{E}-04$ \\
\hline 1 & $1 / 25 / 1994$ & $1 / 25 / 1994$ & 123.515 & 123.509 & 123.504 & 163.74 & $9.74 \mathrm{E}-05$ \\
\hline 1 & $4 / 12 / 1994$ & $4 / 12 / 1994$ & 123.512 & 123.494 & 123.473 & 166.22 & $3.57 \mathrm{E}-04$ \\
\hline 1 & $7 / 26 / 1994$ & $7 / 26 / 1994$ & 123.539 & 123.536 & 123.516 & 174.56 & $2.40 \mathrm{E}-04$ \\
\hline 1 & $10 / 12 / 1994$ & $10 / 12 / 1994$ & 123.536 & 123.527 & 123.504 & 171.03 & $3.14 \mathrm{E}-04$ \\
\hline 1 & $1 / 30 / 1995$ & $1 / 30 / 1995$ & 123.515 & 123.512 & 123.479 & 175.57 & $3.83 \mathrm{E}-04$ \\
\hline 1 & $4 / 21 / 1995$ & $4 / 21 / 1995$ & 123.390 & 123.390 & 123.370 & 177.28 & $2.20 \mathrm{E}-04$ \\
\hline 1 & $7 / 25 / 1995$ & $7 / 25 / 1995$ & 123.506 & 123.494 & 123.461 & 171.39 & $4.45 \mathrm{E}-04$ \\
\hline 1 & $10 / 30 / 1995$ & $10 / 30 / 1995$ & 123.448 & 123.430 & 123.403 & 167.94 & 4.22E-04 \\
\hline 1 & $12 / 18 / 1995$ & $12 / 18 / 1995$ & 123.487 & 123.366 & 123.354 & 151.05 & $1.04 \mathrm{E}-03$ \\
\hline 1 & $1 / 20 / 1997$ & $1 / 20 / 1997$ & 123.301 & 123.277 & 123.257 & 163.74 & $3.90 \mathrm{E}-04$ \\
\hline 1 & $6 / 11 / 1997$ & $6 / 11 / 1997$ & 123.240 & 123.210 & 123.202 & 155.59 & $3.09 \mathrm{E}-04$ \\
\hline 1 & $12 / 5 / 1997$ & $12 / 5 / 1997$ & 123.201 & 123.137 & 123.114 & 157.51 & 7.19E-04 \\
\hline 1 & $6 / 8 / 1998$ & $6 / 8 / 1998$ & 123.085 & 123.049 & 123.047 & 149.57 & $2.94 \mathrm{E}-04$ \\
\hline 1 & $12 / 7 / 1998$ & $12 / 7 / 1998$ & 122.930 & 122.899 & 122.888 & 157.42 & $3.47 \mathrm{E}-04$ \\
\hline 1 & $3 / 9 / 1999$ & $3 / 9 / 1999$ & 122.856 & 122.832 & 122.809 & 164.79 & 4.22E-04 \\
\hline 1 & $6 / 15 / 1999$ & $6 / 15 / 1999$ & 122.799 & 122.823 & 122.733 & 183.55 & 8.35E-04 \\
\hline 1 & $9 / 28 / 1999$ & 9/28/1999 & 122.805 & 122.768 & 122.772 & 142.32 & $2.46 \mathrm{E}-04$ \\
\hline 1 & $12 / 16 / 1999$ & $12 / 16 / 1999$ & 122.795 & 122.759 & 122.757 & 149.57 & $2.94 \mathrm{E}-04$ \\
\hline 1 & $3 / 23 / 2000$ & $3 / 23 / 2000$ & 122.731 & 122.686 & 122.699 & 129.51 & $2.31 \mathrm{E}-04$ \\
\hline 1 & $6 / 21 / 2000$ & $6 / 21 / 2000$ & 122.766 & 122.739 & 122.719 & 162.85 & 4.12E-04 \\
\hline 1 & $12 / 18 / 2000$ & $12 / 18 / 2000$ & 122.642 & 122.617 & 122.607 & 158.25 & 2.92E-04 \\
\hline 1 & $3 / 14 / 2001$ & $3 / 14 / 2001$ & 122.612 & 122.550 & 122.557 & 142.06 & 4.09E-04 \\
\hline 1 & $6 / 19 / 2001$ & $6 / 19 / 2001$ & 122.597 & 122.552 & 122.578 & 91.43 & $1.72 \mathrm{E}-04$ \\
\hline 1 & $12 / 26 / 2001$ & $12 / 26 / 2001$ & 122.476 & 122.433 & 122.431 & 149.24 & 3.48E-04 \\
\hline 1 & $3 / 14 / 2002$ & $3 / 14 / 2002$ & 122.423 & 122.398 & 122.383 & 161.24 & $3.44 \mathrm{E}-04$ \\
\hline 1 & $6 / 25 / 2002$ & $6 / 25 / 2002$ & 122.378 & 122.345 & 122.340 & 152.65 & 3.01E-04 \\
\hline 1 & $12 / 16 / 2002$ & $12 / 16 / 2002$ & 122.414 & 122.692 & 122.407 & 216.60 & $1.67 \mathrm{E}-03$ \\
\hline 1 & $2 / 25 / 2003$ & $2 / 25 / 2003$ & 122.409 & 122.370 & 122.365 & 151.96 & $3.47 \mathrm{E}-04$ \\
\hline 1 & $3 / 20 / 2003$ & $3 / 20 / 2003$ & 122.397 & 122.360 & 122.362 & 145.06 & $2.64 \mathrm{E}-04$ \\
\hline 1 & $5 / 29 / 2003$ & $5 / 29 / 2003$ & 122.358 & 122.323 & 122.319 & 151.53 & $3.06 \mathrm{E}-04$ \\
\hline 1 & $6 / 3 / 2003$ & $6 / 3 / 2003$ & 122.338 & 122.305 & 122.321 & 106.12 & $1.33 \mathrm{E}-04$ \\
\hline 1 & $7 / 16 / 2003$ & $7 / 16 / 2003$ & 122.376 & 122.338 & 122.340 & 145.13 & $2.72 \mathrm{E}-04$ \\
\hline \multicolumn{8}{|c|}{ (a) Duration is the length of time between the start and end dates. } \\
\hline
\end{tabular}


A

\section{$1959-1974$}

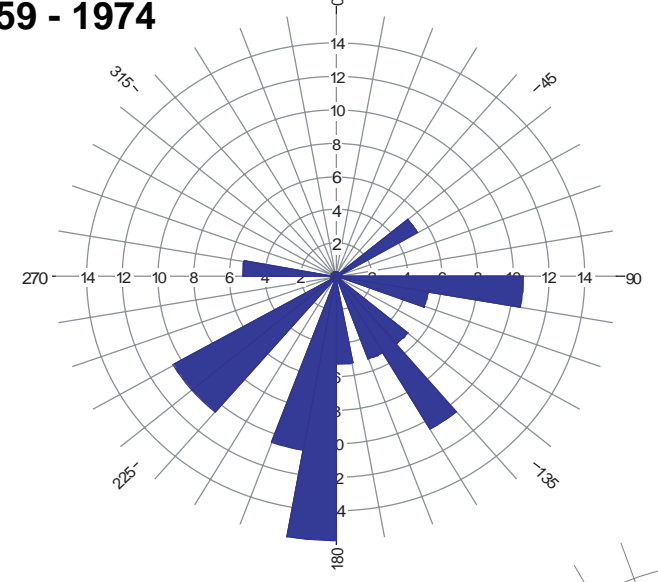

B

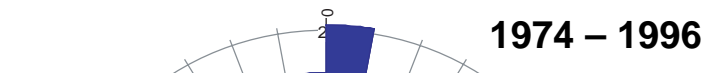

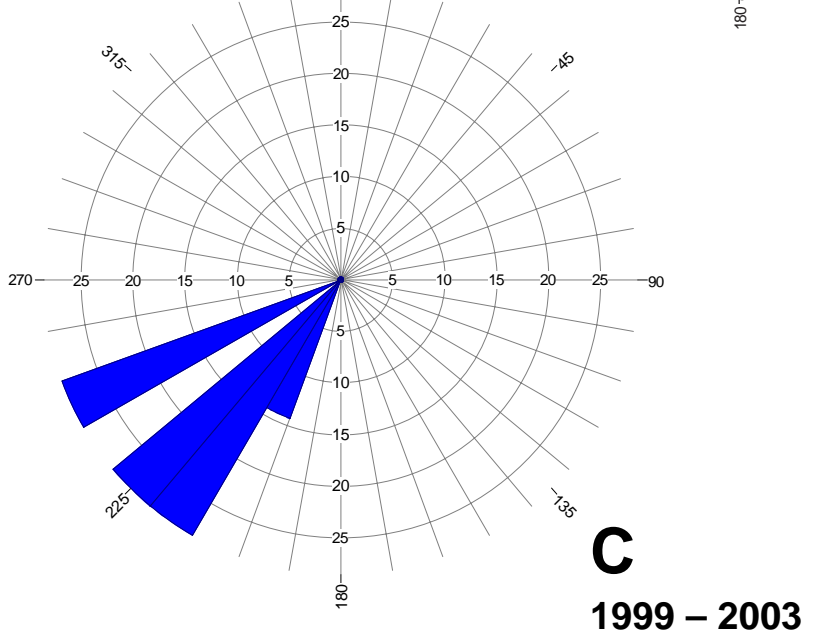

Figure 3.8. Groundwater Flow Directions in the Northern Part of the 200 East Area Near the B, BX, and BY Tank Farms. (A. 1959 to 1974, 19 measurements; B. 1974 to 1996, 43 measurements; and C. 1999 to 2003, 7 measurements. All water-level measurements were from wells 299-E33-14, 600-49-57A, and 699-50-53A. Well 699-E33-14 is about $250 \mathrm{~m}$ east of the BY Tank Farm; well 699-49-57A is about 850 m north of the northwest corner of 200 East Area; well 699-50-53A is about 1,500 m north of the BY Tank Farm. From Reidel et al. 2006.) 

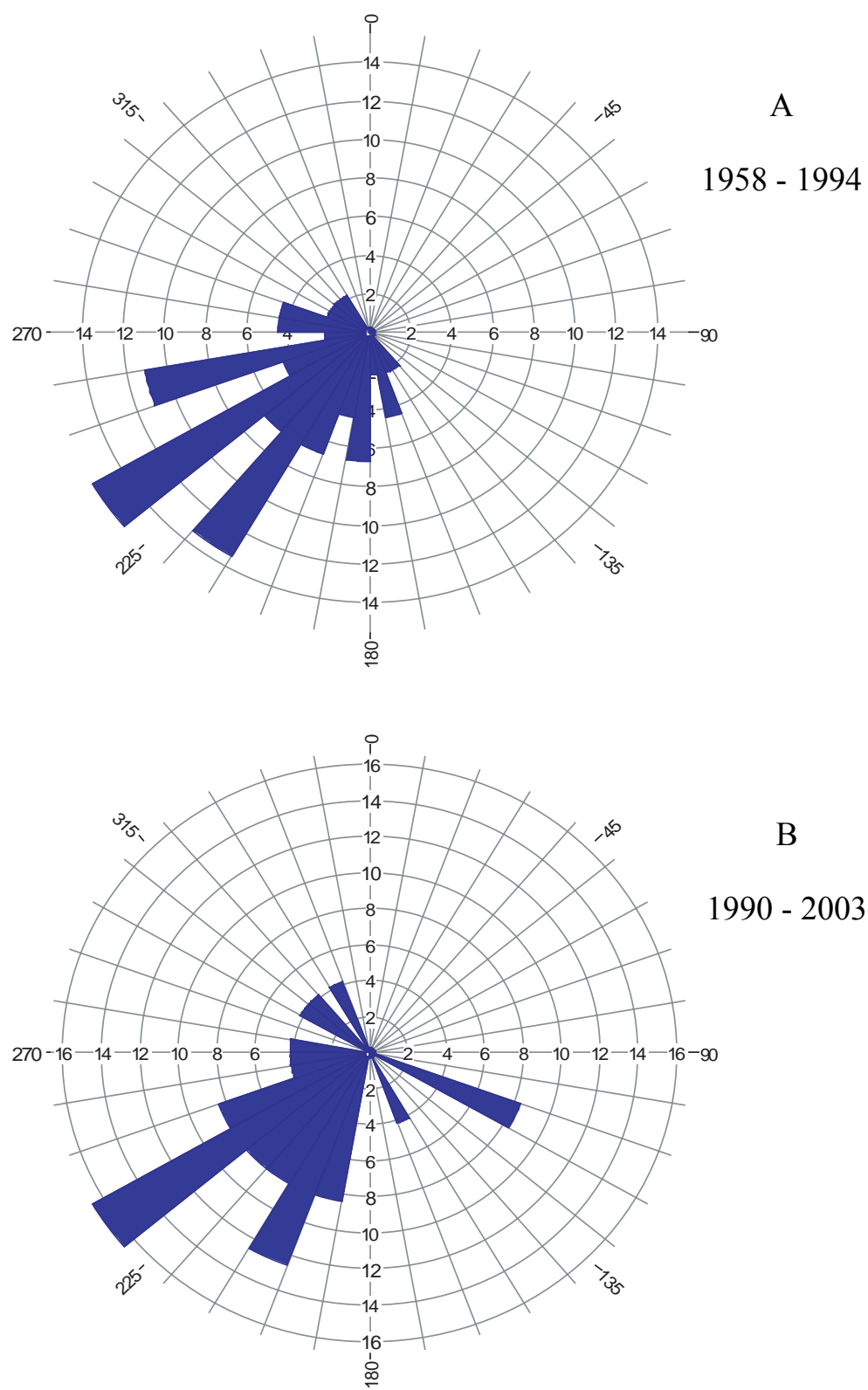

Figure 3.9. Groundwater Flow Directions in the Vicinity of the C Tank Farm. (A. 1958 to 1994, wells 299-E26-1, 299-E26-4, and 299-E27-1, 45 measurements; B. 1990 to 2003, wells 299-E27-12, 299-E27-14, and 299-E27-7, 24 measurements. Well 299-E26-1 is located about 450 m north of Waste Management Area C; well 299-E26-6 is about 500 m southeast of Waste Management Area C; well 299-E27-1 is about 550 m west of Waste Management Area $\mathrm{C}$; the locations of all other wells are on Figure 3.3. From Reidel et al. 2006.) 


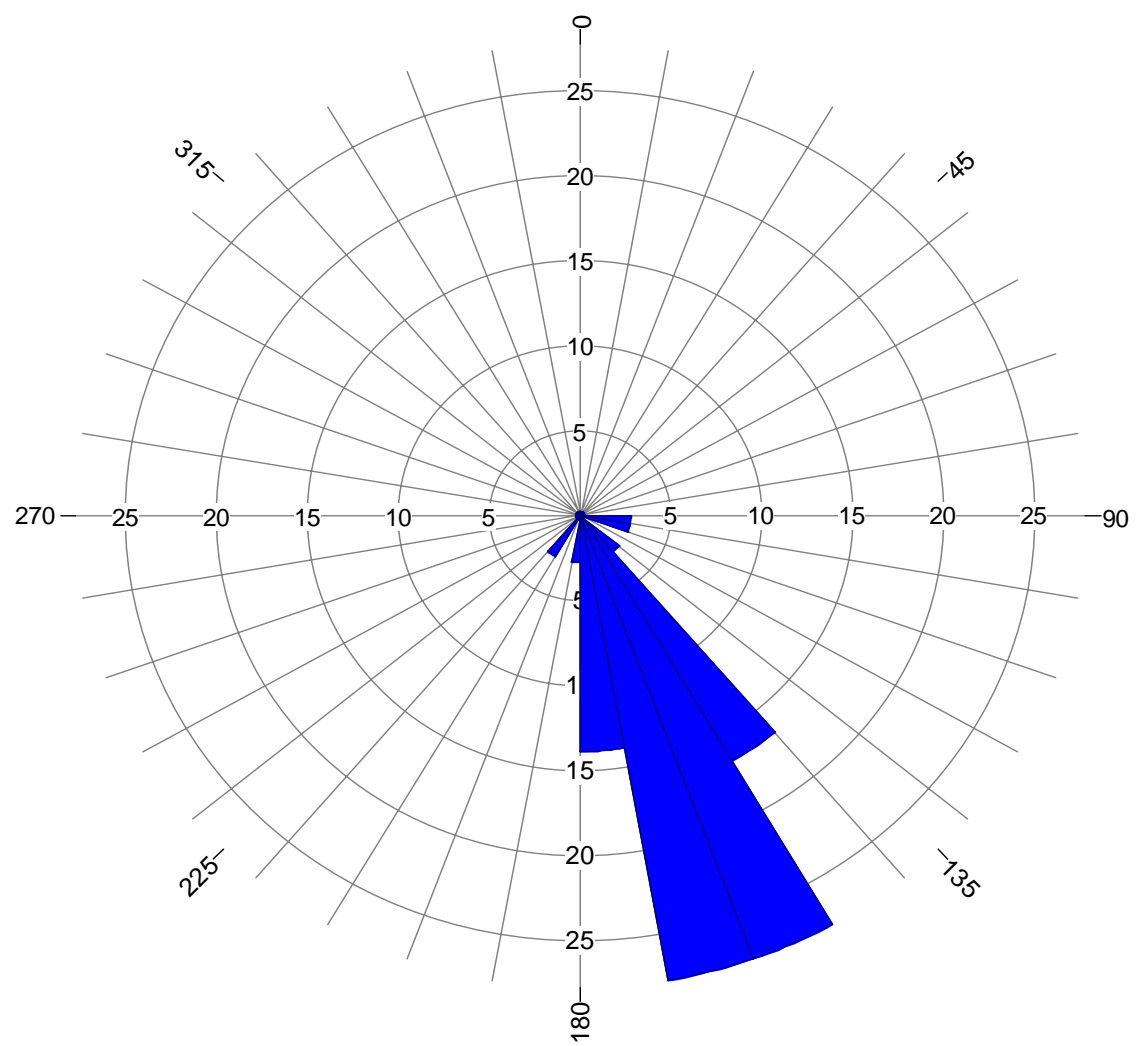

Figure 3.10. Groundwater Flow Directions at the A and AX Tank Farms from 1990 to 2003. (All data are from wells 299-E24-20, 299-E25-2, and 299-E25-46; 36 measurements. From Reidel et al. 2006.) 


\subsection{Groundwater Geochemistry Beneath Single-Shell Waste Management Areas}

The purpose of this section is to describe the groundwater geochemistry beneath each of the singleshell tank WMAs. General background for the Hanford Site is given first. This is followed by discussions of background specific to each individual single-shell tank WMA, a description of contaminant plumes associated with each WMA, and an account of the historical contamination at each WMA.

\subsection{Hanford Site Groundwater Background}

This section presents the background groundwater chemical composition for the Hanford Site. Two "backgrounds" are presented. Natural background for the Hanford Site is given from the work in DOE (1997). Hanford Site background is also described in terms of the water chemistry from samples of two upgradient wells used to monitor Hanford Site background. Local background for each WMA is given in subsequent sections using existing upgradient monitoring wells. Most of the information in this section is from Reidel et al. (2006).

\subsubsection{Hanford Site Background}

DOE published a study of Hanford Site groundwater background in 1997 (DOE 1997). The study included historical groundwater monitoring data collected between 1989 and 1993 and new data collected specifically for the purpose of evaluating groundwater background.

An initial screening of the historical data eliminated all data from wells that (1) did not sample the unconfined aquifer, (2) were located within or proximal to known contaminated sites or contaminant plumes, and (3) contained halogenated hydrocarbons. Data from each well were then screened against a list of target analytes most likely to reflect concentration variations in response to contamination events. Wells were eliminated if they yielded samples with concentrations greater than a threshold concentration for the target analytes. The threshold values were obtained from a preliminary background determination in 1992 (DOE 1992b). The remaining data were then put through a final screening by eliminating outliers (i.e., data that did not conform to the pattern established by other observations) (DOE 1997).

New groundwater data were collected from 45 wells located mostly in gaps in the geographic coverage of the historical data. There are several important differences between the historical data and the new data.

- The historical data were collected to monitor groundwater whereas the new data were collected specifically to determine background. Therefore, the historical data lack analytes important in considerations of background composition.

- The historical data have a temporal coverage that is lacking from the new data.

- The detection limits are substantially different for the two data sets. The detection limits for metals and radionuclides are significantly lower for the new data. 
- The new data represent an internally consistent data set resulting from using the same laboratories and methods for all samples. This is not necessarily true for the older data.

The resulting Hanford Site groundwater background concentrations are given in Table 4.1. Data reported as equal to or less than the detection limit were assigned a value of one-half the detection limit for purposes of calculating the mean. In general, filtered samples were used for analyses of metals and radionuclides and unfiltered samples were used for anions.

Several variables affect the chemical composition of groundwater used for the Hanford Site groundwater background study. These variables are discussed in detail in DOE (1992b) and include well construction, lithology of the sediment in the screened (or perforated) interval, the length of the screened or perforated interval, and recharge.

The concentrations of major cations and anions in groundwater samples give a good indication of the quality of the groundwater and offer a useful tool for comparing groundwater samples. One useful way to depict major ion concentrations in groundwater is with Stiff diagrams. (Stiff diagrams are a graphical means of representing the chemical analysis of major cations and anions in water samples [Stiff 1983]). Figure 4.1 shows the mean composition of the major cations and anions, as determined in the Hanford Site groundwater background study (DOE 1997), as a modified Stiff diagram. Nitrate has been added to the conventional Stiff diagram because nitrate is a major anion in much of the Hanford Site's contaminated groundwater. Although average groundwater compositions do not represent actual groundwater compositions, the charge balance for the average composition depicted in Figure 4.1 is $+3.3 \%$, which suggests that the representation in the figure describes Hanford Site background groundwater composition. Figure 4.1 shows that the Hanford Site's background groundwater is a calcium-bicarbonate dominated groundwater.

\subsubsection{Hanford Site Background as Determined from Wells 699-19-88 and 699-49-100C}

Wells 699-19-88 and 699-49-100C were chosen because they are upgradient of all operating facilities at the Hanford Site and they are believed to be free of any Hanford Site contamination. As such, they are monitored as part of the Hanford Site Groundwater Performance Assessment Project and represent background conditions for Hanford Site groundwater.

Well 699-49-100C is located at the Yakima barricade. The well was drilled $2.4 \mathrm{~m}$ into basalt (total depth was $124.3 \mathrm{~m}$ below ground surface [bgs]), completed with carbon steel casing in 1976, and perforated from 91.4 to $124.3 \mathrm{~m}$ bgs. The only records available for this well are an as-built diagram with driller's log that suggest that the water sampled from this well is from silty sandy gravels and sandy gravels of the Ringold Formation, member of Wooded Island of Lindsey (1995) or hydrogeologic units 5, 8 , and 9 of Thorne et al. (1993).

Well 699-19-88 is located in the Dry Creek Valley, southwest of Highway 240. The well was drilled $8.5 \mathrm{~m}$ into basalt (total depth was $118.3 \mathrm{~m}$ bgs), completed with carbon steel casing in 1957, and perforated from 21.3 to $51.8 \mathrm{~m}$ bgs. The aquifer sampled is the Hanford formation and consists of unconsolidated gravel from 21.3 to $30.5 \mathrm{~m}$ bgs, very hard cemented gravel from 30.5 to $39.6 \mathrm{~m}$ bgs, and sand, silt and gravel from 39.6 to $51.8 \mathrm{~m}$ bgs. 
Table 4.1. Hanford Site Groundwater Background Concentrations ${ }^{(a)}$ (from DOE 1997)

\begin{tabular}{|c|c|c|c|c|c|c|c|c|}
\hline Analyte $^{(b)}$ & Data Set & $\begin{array}{c}\text { Reason } \\
\text { for } \\
\text { Selection }\end{array}$ & Units & $\begin{array}{c}\text { Geometric } \\
\text { Mean }\end{array}$ & $\begin{array}{c}\text { Geometric } \\
\text { Standard } \\
\text { Deviation }\end{array}$ & $\begin{array}{c}\text { Number } \\
\text { of } \\
\text { Samples }\end{array}$ & Minimum & Maximum \\
\hline $\begin{array}{l}\text { Alkalinity as } \\
\mathrm{CaCO}_{3}\end{array}$ & New & More data & $\mu \mathrm{g} / \mathrm{L}$ & 118,650 & 1,183 & 30 & 80,000 & 170,000 \\
\hline Aluminum & New & Lower DL & $\mu g / L$ & 1.23 & 3.92 & 32 & 0.5 & 187 \\
\hline $\begin{array}{l}\text { Americium- } \\
241\end{array}$ & New & Lower DL & $f C i / L$ & 0.732 & 2.11 & 16 & 0.05 & 1 \\
\hline Ammonia & New & Lower DL & $\mu g / L$ & 26.2 & 3,120 & 32 & 5 & 882 \\
\hline Antimony & Historical & No new & $\mu g / L$ & 23.8 & 1.92 & 15 & 9.47 & 53.9 \\
\hline Antimony-125 & New & Lower DL & $f C i / L$ & 3.77 & 1.61 & 17 & 1.73 & 8.97 \\
\hline Arsenic & New & Lower DL & $\mu \mathrm{g} / \mathrm{L}$ & 1.83 & 3.11 & 29 & 0.5 & 8.81 \\
\hline Barium & New & Lower DL & $\mu \mathrm{g} / \mathrm{L}$ & 31.2 & 2.58 & 32 & 0.5 & 94.1 \\
\hline Beryllium & Historical & Lower DL & $\mu g / L$ & 0.583 & 2.91 & 17 & 0.2 & 2.5 \\
\hline Beryllium-7 & Historical & No new & $p C i / L$ & 6.42 & 1.26 & 4 & 5.25 & 8.3 \\
\hline Boron & Historical & No new & $\mu \mathrm{g} / \mathrm{L}$ & 20.3 & 1.56 & 7 & 12.6 & 45 \\
\hline Bromide & New & Lower DL & $\mu \mathrm{g} / \mathrm{L}$ & 61.9 & 1,721 & 32 & 15 & 235 \\
\hline Cadmium & New & Lower DL & $\mu g / L$ & 0.274 & 2.57 & 32 & 0.05 & 0.5 \\
\hline Calcium & Historical & More data & $\mu \mathrm{g} / \mathrm{L}$ & 36,518 & 1.33 & 25 & 19,200 & 79,683 \\
\hline Cesium-134 & Historical & No new & $p C i / L$ & 0.747 & 1.39 & 4 & 0.496 & 1.06 \\
\hline Cesium-137 & New & Lower DL & $f C i / L$ & 2.26 & 2.79 & 17 & 0.643 & 29.5 \\
\hline Chloride & Historical & More data & $\mathrm{mg} / \mathrm{L}$ & 7.05 & 0.0019 & 27 & 1.14 & 21.95 \\
\hline Chromium & New & Lower DL & $\mu g / L$ & 0.893 & 2.16 & 27 & 0.5 & 4.41 \\
\hline Cobalt & New & Lower DL & $\mu g / L$ & 0.274 & 2.57 & 32 & 0.05 & 0.5 \\
\hline Cobalt-60 & New & Lower DL & $f C i / L$ & 1.09 & 2.43 & 17 & 0.404 & 23 \\
\hline Conductivity & Historical & More data & $\mu \mathrm{S} / \mathrm{cm}$ & 348,000 & 1,410 & 35 & 150,000 & $1,361,000$ \\
\hline Copper & New & Lower DL & $\mu g / L$ & 0.332 & 2.01 & 32 & 0.05 & 0.5 \\
\hline Cyanide & New & $\begin{array}{l}\text { No } \\
\text { Historical }\end{array}$ & $\mu g / L$ & 5.43 & 1,407 & 25 & 5 & 26.7 \\
\hline $\begin{array}{l}\text { Dissolved } \\
\text { oxygen }\end{array}$ & New & $\begin{array}{l}\text { No } \\
\text { Historical }\end{array}$ & $\mu \mathrm{g} / \mathrm{L}$ & 5,306 & 2,117 & 31 & 380 & 9,440 \\
\hline Eh & New & $\begin{array}{l}\text { No } \\
\text { Historical }\end{array}$ & $\mathrm{mv}$ & 315 & 1.38 & 31 & 91 & 510 \\
\hline Europium-152 & New & Lower DL & $f C i / L$ & 12.9 & 1.51 & 17 & 5.39 & 24.1 \\
\hline Europium-154 & New & Lower DL & $f C i / L$ & 8 & 1.52 & 17 & 3.43 & 18.3 \\
\hline Europium-155 & New & Lower DL & $f C i / L$ & 2.33 & 1.87 & 17 & 0.969 & 11.7 \\
\hline Fluoride & Historical & More data & $\mathrm{mg} / \mathrm{L}$ & 0.491 & 0.0018 & 28 & 0.267 & 5.85 \\
\hline Gross alpha & New & More data & $\mathrm{pCi} / \mathrm{L}$ & 1.09 & 2.03 & 19 & 0.25 & 3.02 \\
\hline Gross beta & New & More data & $\mathrm{pCi} / \mathrm{L}$ & 5.5 & 1.33 & 19 & 3.39 & 9.45 \\
\hline Iodine & New & $\begin{array}{l}\text { No } \\
\text { Historical }\end{array}$ & $\mu g / L$ & 250 & 1,000 & 25 & 250 & 250 \\
\hline Iodine-129 & New & Lower DL & $\mathrm{aCi} / \mathrm{L}$ & 28.8 & 2.51 & 9 & 6.3 & 96.1 \\
\hline Iron & Historical & More data & $\mu \mathrm{g} / \mathrm{L}$ & 55.3 & 6.17 & 22 & 6 & 7,225 \\
\hline Lead & New & Lower DL & $\mu g / L$ & 0.271 & 2.59 & 31 & 0.05 & 0.5 \\
\hline
\end{tabular}


Table 4.1. (contd)

\begin{tabular}{|c|c|c|c|c|c|c|c|c|}
\hline Analyte & Data Set & $\begin{array}{l}\text { Reason } \\
\text { for } \\
\text { Selection }\end{array}$ & Units & $\begin{array}{c}\text { Geometric } \\
\text { Mean }\end{array}$ & $\begin{array}{l}\text { Geometric } \\
\text { Standard } \\
\text { Deviation }\end{array}$ & $\begin{array}{c}\text { Number } \\
\text { of } \\
\text { Samples }\end{array}$ & Minimum & Maximum \\
\hline Lithium & New & More data & $\mu \mathrm{g} / \mathrm{L}$ & 5,729 & 1,701 & 30 & 2,380 & 19,000 \\
\hline Magnesium & New & More data & $\mu \mathrm{g} / \mathrm{L}$ & 11,245 & 1.85 & 25 & 825 & 39,600 \\
\hline Manganese & New & More data & $\mu \mathrm{g} / \mathrm{L}$ & 2.22 & 9.25 & 32 & 0.05 & 94.4 \\
\hline Mercury & New & Lower DL & $\mu \mathrm{g} / \mathrm{L}$ & 0 & 5.34 & 27 & 0 & 0.012 \\
\hline Molybdenum & New & Lower DL & $\mu g / L$ & 0.862 & 2.79 & 25 & 0.5 & 11.6 \\
\hline Nickel & New & Lower DL & $\mu \mathrm{g} / \mathrm{L}$ & 0.686 & 1.9 & 31 & 0.27 & 2.56 \\
\hline Nitrate & New & More data & $\mathrm{mg} / \mathrm{L}$ & 5.68 & 3.36 & 26 & 0.085 & 28.063 \\
\hline Nitrite & New & More data & $m g / L$ & 0.03 & 2.48 & 32 & 0.01 & 0.63 \\
\hline Oxalate & New & $\begin{array}{l}\text { No } \\
\text { Historical }\end{array}$ & $\mu g / L$ & 161 & 1,566 & 32 & 95 & 280 \\
\hline $\mathrm{pH}$ & Historical & More data & $\begin{array}{c}\mathrm{pH} \\
\text { units }\end{array}$ & 7.78 & 1.04 & 35 & 6.94 & 8.79 \\
\hline Phosphate & New & Lower DL & $\mu g / L$ & 102 & 1,432 & 32 & 65 & 293 \\
\hline Plutonium & New & $\begin{array}{l}\text { No } \\
\text { Historical }\end{array}$ & $\mu g / L$ & 0.0038 & 2.15 & 25 & 0.001 & 0.005 \\
\hline Plutonium-238 & New & Lower DL & $f C i / L$ & 0.064 & 2.64 & 16 & 0.015 & 0.485 \\
\hline $\begin{array}{l}\text { Plutonium- } \\
239 / 240\end{array}$ & New & Lower DL & $\mathrm{fCi} / \mathrm{L}$ & 0.398 & 1.97 & 16 & 0.04 & 0.762 \\
\hline Potassium & Historical & No new & $\mu \mathrm{g} / \mathrm{L}$ & 4,578 & 1.71 & 25 & 768 & 10,000 \\
\hline Potassium-40 & Historical & No new & $\mathrm{pCi} / \mathrm{L}$ & 77.3 & 2.12 & 10 & 12 & 188 \\
\hline Radium-226 & New & Lower DL & $\mathrm{fCi} / \mathrm{L}$ & 18.2 & 1.6 & 17 & 7 & 41.5 \\
\hline Radium-228 & New & Lower DL & $\mathrm{fCi} / \mathrm{L}$ & 32.3 & 1.72 & 17 & 12.8 & 75.6 \\
\hline $\begin{array}{l}\text { Ruthenium- } \\
106\end{array}$ & New & Lower DL & $f C i / L$ & 1.63 & 1.89 & 17 & 0.607 & 5.92 \\
\hline Selenium & New & Lower DL & $\mu \mathrm{g} / \mathrm{L}$ & 0.96 & 6.47 & 32 & 0.5 & 11.6 \\
\hline Silicon & Historical & No new & $\mu \mathrm{g} / \mathrm{L}$ & 13,691 & 2.03 & 7 & 2,966 & 23,900 \\
\hline Silver & Historical & No new & $\mu g / L$ & 3.42 & 1.41 & 15 & 1.93 & 5 \\
\hline Sodium & Historical & More data & $\mu \mathrm{g} / \mathrm{L}$ & 13,402 & 1.73 & 25 & 2,360 & 32,000 \\
\hline $\begin{array}{l}\text { Strontium } \\
\text { (elemental) }\end{array}$ & New & More data & $\mu \mathrm{g} / \mathrm{L}$ & 158 & 1.75 & 32 & 13.1 & 402 \\
\hline Strontium-90 & New & Lower DL & $\mathrm{fCi} / \mathrm{L}$ & 4.78 & 2.39 & 14 & 0.641 & 15.6 \\
\hline Sulfate & New & More data & $\mathrm{mg} / \mathrm{L}$ & 27.1 & 1.54 & 28 & 11.19 & 71.21 \\
\hline Sulfide & New & More data & $\mu g / L$ & 1.71 & 1.21 & 32 & 1.6 & 3.21 \\
\hline Technetium-99 & Historical & No new & $p C i / L$ & 0.447 & 1.62 & 5 & 0.271 & 0.752 \\
\hline Thallium & Historical & No new & $\mu g / L$ & 1.14 & 1.35 & 4 & 0.883 & 1.73 \\
\hline Thorium & New & $\begin{array}{l}\text { No } \\
\text { Historical } \\
\end{array}$ & $\mu g / L$ & 0.5 & 1 & 25 & 0.5 & 0.5 \\
\hline Tin & Historical & No new & $\mu g / L$ & 15.9 & 1.27 & 12 & 11.8 & 31.3 \\
\hline Titanium & Historical & No new & $\mu g / L$ & 30 & 1 & 7 & 30 & 30 \\
\hline Total carbon & New & $\begin{array}{l}\text { No } \\
\text { Historical }\end{array}$ & $\mu \mathrm{g} / \mathrm{L}$ & 30,325 & 1,174 & 32 & 20,990 & 43,175 \\
\hline
\end{tabular}


Table 4.1. (contd)

\begin{tabular}{|c|c|c|c|c|c|c|c|c|}
\hline Analyte & Data Set & $\begin{array}{l}\text { Reason } \\
\text { for } \\
\text { Selection }\end{array}$ & Units & $\begin{array}{l}\text { Geometric } \\
\text { Mean }\end{array}$ & $\begin{array}{l}\text { Geometric } \\
\text { Standard } \\
\text { Deviation }\end{array}$ & $\begin{array}{l}\text { Number } \\
\text { of } \\
\text { Samples }\end{array}$ & Minimum & Maximum \\
\hline $\begin{array}{l}\text { Total dissolved } \\
\text { solids }\end{array}$ & New & $\begin{array}{l}\text { No } \\
\text { Historical }\end{array}$ & $\mu \mathrm{g} / \mathrm{L}$ & 200,919 & 1.22 & 30 & 140,000 & 295,000 \\
\hline $\begin{array}{l}\text { Total inorganic } \\
\text { carbon }\end{array}$ & New & More data & $\mu \mathrm{g} / \mathrm{L}$ & 28,722 & 1,166 & 32 & 19,550 & 39,020 \\
\hline $\begin{array}{l}\text { Total organic } \\
\text { carbon }\end{array}$ & New & $\begin{array}{l}\text { No } \\
\text { Historical }\end{array}$ & $\mu \mathrm{g} / \mathrm{L}$ & 1,293 & 1,779 & 32 & 560 & 6,720 \\
\hline Tritium & Historical & More data & $p C i / L$ & 63.9 & 1.63 & 15 & 27.8 & 131 \\
\hline Uranium & New & More data & $\mu \mathrm{g} / \mathrm{L}$ & 2.57 & 2.85 & 25 & 0.5 & 12.8 \\
\hline Uranium-234 & Historical & No new & $\mathrm{pCi} / \mathrm{L}$ & 0.75 & 1.1 & 2 & 0.7 & 0.803 \\
\hline Uranium-235 & New & Lower DL & $\mathrm{fCi} / \mathrm{L}$ & 23.1 & 3.34 & 17 & 1.55 & 114 \\
\hline Uranium-238 & New & Lower DL & $\mathrm{fCi} / \mathrm{L}$ & 721 & 1.89 & 17 & 150 & 2,440 \\
\hline Vanadium & New & Lower DL & $\mu g / L$ & 1.83 & 4.19 & 32 & 0.5 & 16.7 \\
\hline Zinc & New & Lower DL & $\mu g / L$ & 1.27 & 9.22 & 32 & 0.05 & 1,270 \\
\hline Zirconium & Historical & No new & $\mu g / L$ & 25 & 1 & 7 & 25 & 25 \\
\hline \multicolumn{9}{|c|}{$\begin{array}{l}\text { (a) Data rows entered in italics signify that }>50 \% \text { of the data were below the detection limit. } \\
\text { (b) Radionuclides with half-lives less than } 1,000 \text { years are decayed to June } 1,1997 \text {. } \\
\text { DL = detection limit. }\end{array}$} \\
\hline
\end{tabular}

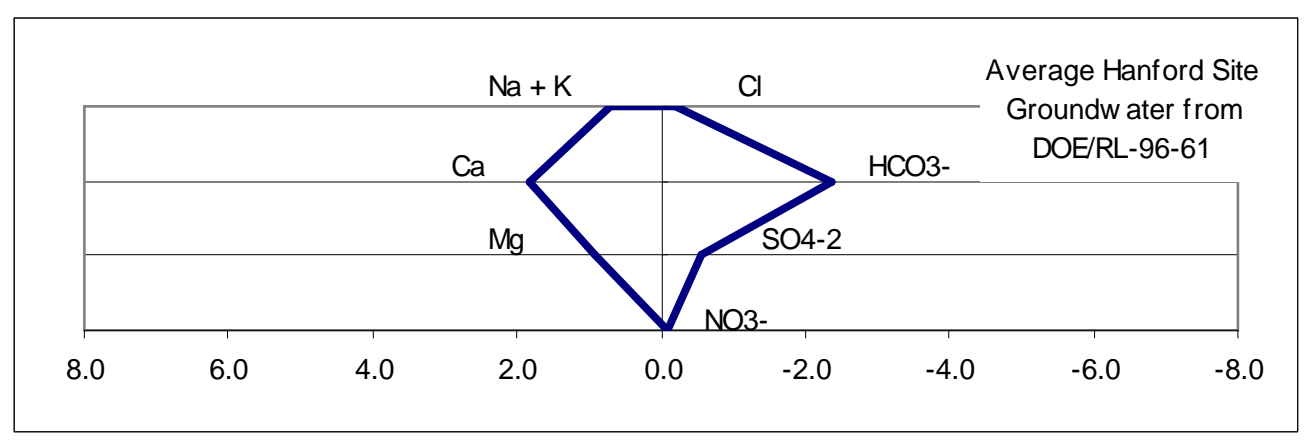

Figure 4.1. Modified Stiff Diagram Depicting Major Cation and Anion Compositions for Background Groundwater, Top of the Aquifer in the Hanford Site's Unconfined Aquifer. Units for the $\mathrm{x}$-axis are milliequivalents/liter with cations on the left and anions on the right.

Neither of these wells samples the same formation as upgradient wells at the single-shell tank WMAs. However, monitoring wells in 200 East Area are screened in similar Hanford formation gravels. Also, both wells are located west of the 200 Areas and closer to the natural recharge area for the unconfined aquifer. The groundwater in that part of the aquifer is younger than the natural groundwater beneath the single-shell tank WMAs and is less altered by reaction with aquifer sediments. Upgradient groundwater at most single-shell tank farms has been impacted by liquid disposal to cribs, ditches, and trenches. However, a few upgradient wells at some tank farms are only slightly impacted and the general water composition from those wells resembles the groundwater composition of the background wells 699-49-100C and 699-19-88. Regardless of impacts from past-practice disposal facilities, groundwater 
from upgradient wells at each single-shell tank farm is used as background for the tank farms when making upgradient-downgradient comparisons.

The average FY 2005 groundwater composition from the two upgradient wells is given in Table 4.2 and a depiction of the major cations and anions is shown in Figure 4.2. The charge balances for the two analyses in Figure 4.2 are $+3.5 \%$ for the $699-19-88$ analysis and $+1.9 \%$ for the well $699-49-100 \mathrm{C}$ analysis. Just as for the site-wide background groundwater, the upgradient well groundwaters are a calcium-bicarbonate dominated water type. Also, the groundwater from well 699-49-100C contains $12 \mathrm{mg} / \mathrm{L}$ nitrate suggesting that the groundwater at this location contains some nitrate contamination from upgradient, probably agricultural, sources.

\subsection{Groundwater Geochemistry Beneath Single-Shell Tank Waste Management Areas in 200 West Area}

This section describes the geochemical characteristics of groundwater beneath each of the single-shell tank WMAs in the 200 West Area. The current background groundwater composition, local to each WMA, is described by data from each upgradient well. It should be noted that, although the upgradient groundwater composition is background for the WMA, it may not represent background composition for the Hanford Site because groundwater upgradient of most single-shell tank WMAs has been impacted by contamination from nearby past-practice liquid disposal facilities.

The descriptions of current background groundwater compositions is followed by descriptions of current and historic trends in contamination at each WMA and, finally, by a comparison of the groundwater composition with contaminated pore water from the vadose zone at the WMA (where available) and/or estimates of the composition of fluids associated with tank leaks and overfills, and tank infrastructure spills at the corresponding WMA.

\subsubsection{Background Groundwater Composition Beneath Waste Management Area S-SX}

Upgradient groundwater compositions for the single-shell tank WMA S-SX is shown in Table 4.3 and Figure 4.3. The data in the table are the average FY 2005 concentrations in each upgradient well at the WMA. The charge balances for the two analyses in Figure 4.3 are $+3.9 \%$ for well $299-$ W23-20 and $+1.2 \%$ for well 299-W23-21. All data are from the Hanford Environmental Information System (HEIS 1994) database and are available on the CD included in Hartman et al. (2006). Data for the metals are from filtered samples; all other data are from unfiltered samples. Data flagged as suspect in the HEIS database have been excluded from the calculated averages.

Upgradient groundwater at WMA S-SX is more dilute than Hanford Site background groundwater (Tables 4.1 and 4.2) with lower concentrations of all major cations and anions except sodium and, in well 299-W23-21, nitrate. Alkalinity and specific conductance in WMA S-SX upgradient groundwater also are at or lower than those in Hanford Site background groundwater (compare with Table 4.1). The elevated sodium and nitrate are from disposal of effluent to facilities upgradient of the WMA. The groundwater in well 299-W23-20 is a sodium-bicarbonate water and that in well 299-W23-21 is a calcium-sodium-bicarbonate-nitrate water. The technetium-99 and tritium, present in the groundwater from well 299-W23-21, are indicative of past-practice liquid disposal upgradient of the WMA. 
Table 4.2. Average FY 2005 Composition of Groundwater from Wells 699-49-100C and 699-19-88 (data from CD included in Hartman et al. 2006)

\begin{tabular}{|c|c|c|}
\hline Constituent (units) & $699-49-100 \mathrm{C}$ & 699-19-88 \\
\hline Alkalinity as $\mathrm{CaCO}_{3}(\mu \mathrm{g} / \mathrm{L})$ & 180,000 & 119,000 \\
\hline Antimony $(\mu \mathrm{g} / \mathrm{L})$ & Not Detected & Not detected \\
\hline Arsenic $(\mu \mathrm{g} / \mathrm{L})$ & Not Analyzed & Not analyzed \\
\hline Cadmium $(\mu \mathrm{g} / \mathrm{L})$ & Not Detected & Not detected \\
\hline Calcium $(\mu \mathrm{g} / \mathrm{L})$ & 58,700 & 28,100 \\
\hline Carbon Tetrachloride $(\mu \mathrm{g} / \mathrm{L})$ & Not Detected & Not detected \\
\hline Cesium-137 (pCi/L) & Not Detected & Not analyzed \\
\hline Chloride $(\mathrm{mg} / \mathrm{L})$ & 18.1 & 3.8 \\
\hline Chloroform $(\mu \mathrm{g} / \mathrm{L})$ & Not Detected & Not detected \\
\hline cis-1,2-Dichloroethene $(\mu \mathrm{g} / \mathrm{L})$ & Not Detected & Not detected \\
\hline Chromium $(\mu \mathrm{g} / \mathrm{L})$ & Not Detected & Not detected \\
\hline Cobalt-60 (pCi/L) & Not Detected & Not analyzed \\
\hline Cyanide $(\mu \mathrm{g} / \mathrm{L})$ & Not Analyzed & Not detected \\
\hline Fluoride $(\mathrm{mg} / \mathrm{L})$ & 0.31 & 0.24 \\
\hline Gross Alpha (pCi/L) & 2.56 & Not detected \\
\hline Gross Beta $(\mathrm{pCi} / \mathrm{L})$ & 8.09 & 5.95 \\
\hline Iodine-129 (pCi/L) & Not Detected & Not analyzed \\
\hline Iron $(\mu \mathrm{g} / \mathrm{L})$ & Not Detected & Not detected \\
\hline Magnesium $(\mu \mathrm{g} / \mathrm{L})$ & 21,300 & 11,200 \\
\hline Nickel $(\mu \mathrm{g} / \mathrm{L})$ & Not Detected & Not detected \\
\hline Nitrate $(\mathrm{mg} / \mathrm{L})$ & 12.0 & 1.75 \\
\hline Nitrite $(\mathrm{mg} / \mathrm{L})$ & Not Detected & Not detected \\
\hline $\mathrm{pH}$ (pH units) & 7.78 & 7.78 \\
\hline Potassium $(\mu \mathrm{g} / \mathrm{L})$ & 7,990 & 3,360 \\
\hline Sodium $(\mu \mathrm{g} / \mathrm{L})$ & 24,500 & 13,300 \\
\hline Specific Conductance $(\mu \mathrm{S} / \mathrm{cm})$ & 566 & 272 \\
\hline Sulfate $(\mathrm{mg} / \mathrm{L})$ & 68.5 & 12.9 \\
\hline Technetium-99 (pCi/L) & Not Detected & Not analyzed \\
\hline Total Organic Carbon $(\mu \mathrm{g} / \mathrm{L})$ & 690 & 575 \\
\hline Total Organic Halogens $(\mu \mathrm{g} / \mathrm{L})$ & Not Analyzed & Not analyzed \\
\hline Trichloroethene $(\mu \mathrm{g} / \mathrm{L})$ & Not Detected & Not detected \\
\hline Tritium $(\mathrm{pCi} / \mathrm{L})$ & Not Detected & Not detected \\
\hline Uranium $(\mu \mathrm{g} / \mathrm{L})$ & 1.93 & 0.66 \\
\hline
\end{tabular}



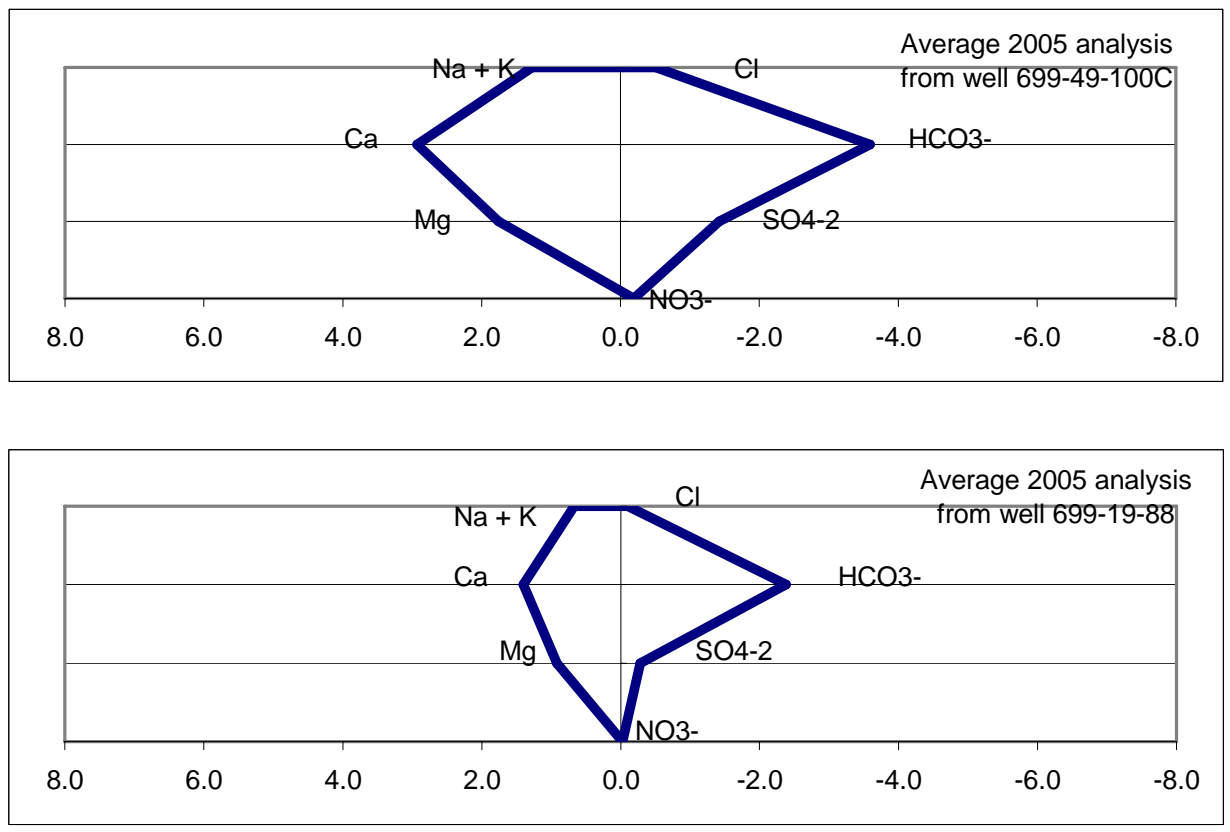

Figure 4.2. Modified Stiff Diagrams Depicting Major Cation and Anion Compositions for Groundwater from the Groundwater Performance Assessment Project's Quality Control Wells. Units on the $\mathrm{x}$-axis are milliequivalents/liter with cations to the left and anions to the right.

\subsubsection{Groundwater Contamination Beneath Waste Management Area S-SX}

This section discusses the current and historical groundwater contamination at WMA S-SX. The evaluation of contamination includes descriptions of the types and concentrations of contaminants in the groundwater and the extent of contamination in the area. Most of the information in this section is taken from McDonald et al. (2006).

Groundwater at WMA S-SX is routinely monitored for RCRA and Atomic Energy Act purposes. The objective of RCRA groundwater monitoring at WMA S-SX is to assess the nature and extent of groundwater contamination with hazardous constituents and determine their rate of movement in the aquifer. Groundwater monitoring under the Atomic Energy Act tracks radionuclides beneath the WMA and surrounding vicinity.

\subsubsection{Extent of Contamination at Waste Management Area S-SX - Depth Distribution}

There are two sources of information that provide indications of the current depth distribution of contaminants at WMA S-SX: depth-discrete sampling in the aquifer during drilling of well 299-W22-47 during 2004 and specific conductance measurements in well 299-W23-19. Depth-discrete sampling also was done earlier in 1999 during drilling of well 299-W22-50. 
Table 4.3. Average FY 2005 Groundwater Composition in Upgradient Wells at Waste Management Area S-SX (data from CD included in Hartman et al. 2006)

\begin{tabular}{||l|c|c||}
\hline \multirow{2}{*}{\multicolumn{1}{|c|}{ Constituent }} & \multicolumn{2}{|c||}{ Concentration } \\
\cline { 2 - 3 } & Well 299-W23-20 & Well 299-W23-21 \\
\hline \hline Alkalinity as CaCO $(\mu \mathrm{g} / \mathrm{L})$ & 90,250 & 85,500 \\
\hline Calcium $(\mu \mathrm{g} / \mathrm{L})$ & 18,300 & 33,250 \\
\hline Carbon tetrachloride $(\mu \mathrm{g} / \mathrm{L})$ & Not analyzed & Not detected \\
\hline Cesium-137 $(\mathrm{pCi} / \mathrm{L})$ & Not analyzed & 7.68 \\
\hline Chloride $(\mathrm{mg} / \mathrm{L})$ & 4.28 & 3.78 \\
\hline Chloroform $(\mu \mathrm{g} / \mathrm{L})$ & Not analyzed & 2.25 \\
\hline Chromium $(\mu \mathrm{g} / \mathrm{L})$ & 3.35 & Not detected \\
\hline Cobalt-60 & Not analyzed & 0.30 \\
\hline Fluoride $(\mathrm{mg} / \mathrm{L})$ & 0.33 & 5.68 \\
\hline Gross alpha $(\mathrm{pCi} / \mathrm{L})$ & Not analyzed & Not detected \\
\hline Iodine- 129 & Not analyzed & 21.8 \\
\hline Iron $(\mu \mathrm{g} / \mathrm{L})$ & 30.3 & 10,172 \\
\hline Magnesium $(\mu \mathrm{g} / \mathrm{L})$ & 6,070 & 86.2 \\
\hline Nitrate $(\mathrm{mg} / \mathrm{L})$ & 6.97 & 7.8 \\
\hline pH Measurement $(\mathrm{pH}$ units $)$ & 8.0 & 4,875 \\
\hline Potassium $(\mu \mathrm{g} / \mathrm{L})$ & 4,328 & 27,825 \\
\hline Sodium $(\mu \mathrm{g} / \mathrm{L})$ & 24,275 & 389 \\
\hline Specific $\mathrm{Conductance}(\mu \mathrm{S} / \mathrm{cm})$ & 235 & 0.67 \\
\hline Strontium-90 & Not analyzed & 16.82 \\
\hline Sulfate $(\mathrm{mg} / \mathrm{L})$ & 14.38 & 98.8 \\
\hline Technetium-99 $(\mathrm{pCi} / \mathrm{L})$ & Not detected & 0.52 \\
\hline Trichloroethene $(\mu \mathrm{g} / \mathrm{L})$ & Not analyzed & 11.12 \\
\hline Tritium $(\mathrm{pCi} / \mathrm{L})$ & Not analyzed & \\
\hline Uranium $(\mu \mathrm{g} / \mathrm{L})$ & 4.57 & \\
\hline & & \\
\hline
\end{tabular}

Sampling During Drilling. Well 299-W22-47 is located southeast of the southeast corner of WMA S-SX in the center of the technetium-99, nitrate, and chromium plume emanating from the SX Tank Farm. The well was drilled to a depth of $36.6 \mathrm{~m}$ below the water table. Groundwater samples were collected during drilling of the well at 1.5-m-depth intervals using air-lift techniques and at 6.1-m-depth intervals by purge-and-pump methods. The groundwater samples were analyzed for anions, technetium-99, chromium (filtered), and carbon tetrachloride. Analytical results are shown on Figure 4.4 as a function of depth.

Only the pumped groundwater samples are included for chromium in Figure 4.4. The groundwater associated with the air lifted samples was in contact with the drill cuttings for up to several days before a filtered sample was collected. During this time, the chromium in solution is believed to have been reduced by freshly exposed sediment surfaces (ground up basalt particles) and precipitated from solution, resulting in artificially low chromium concentrations. A similar situation was seen in samples collected from WMAs T and TX-TY. 

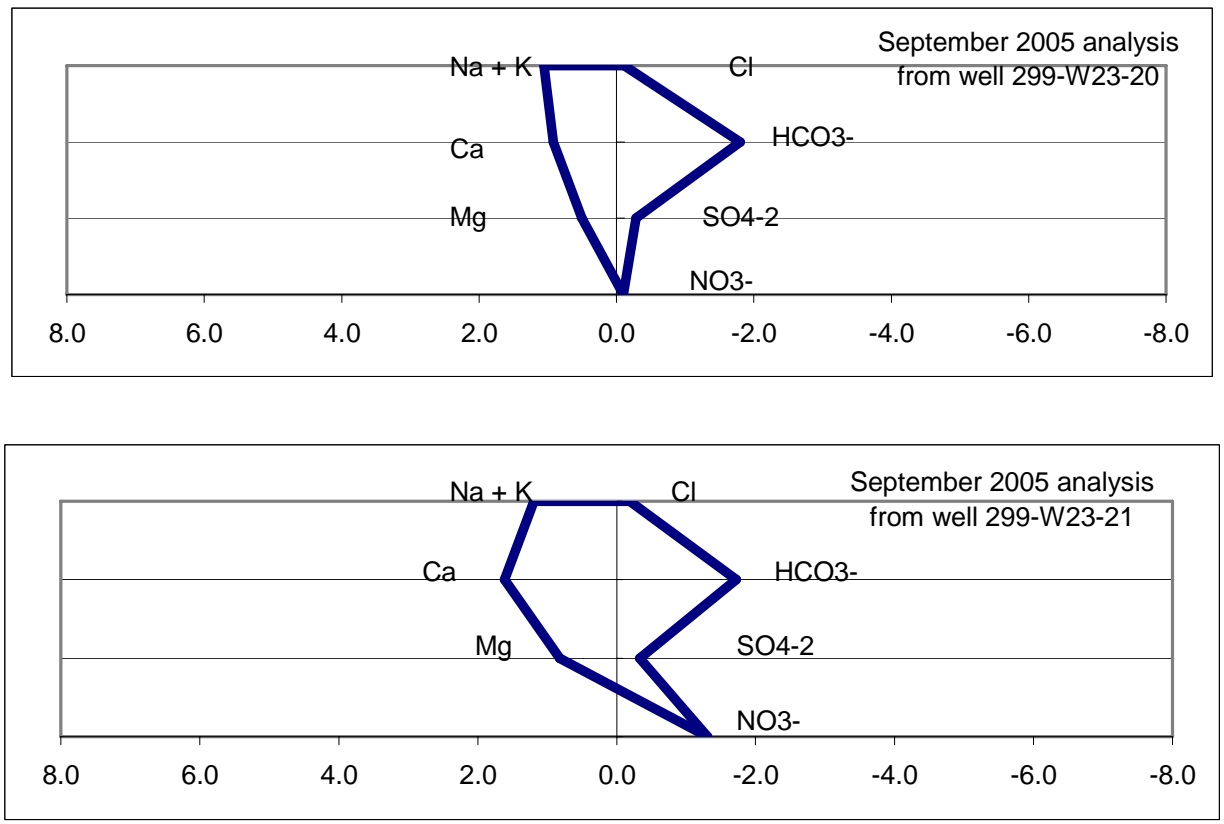

Figure 4.3. Major Cation and Anion Composition of Groundwater from Upgradient Wells at WMA S-SX. Units for the $\mathrm{x}$-axis are milliequivalents/liter with cations on the left and anions on the right.

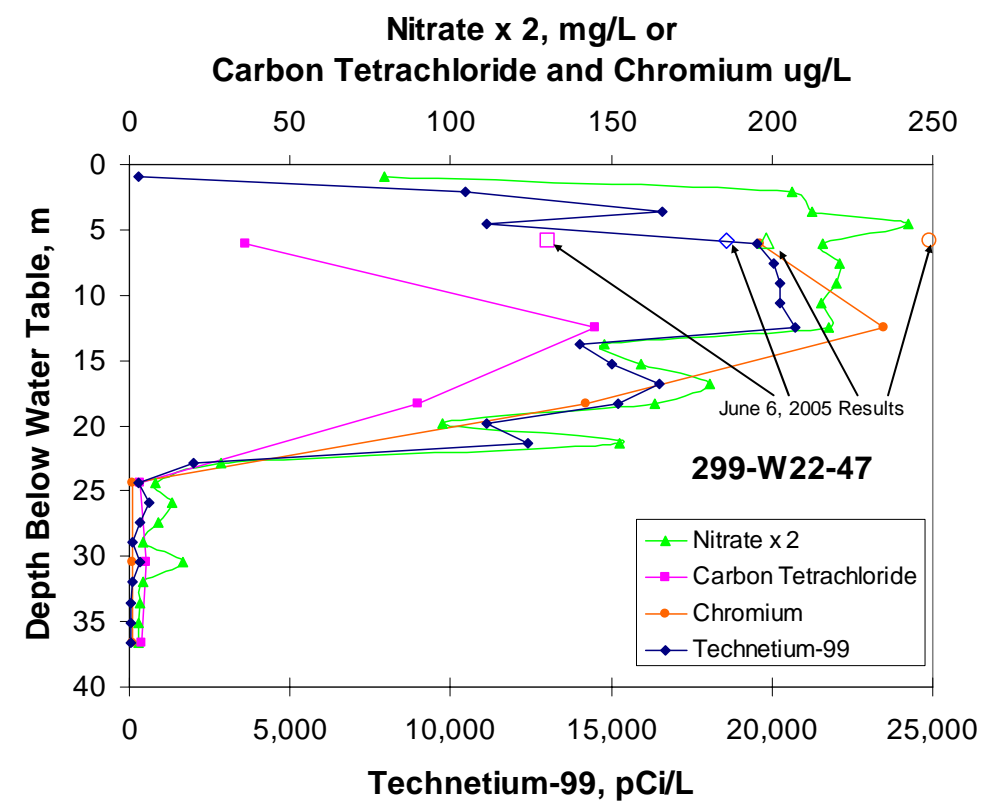

Figure 4.4. Carbon Tetrachloride, Nitrate, Technetium-99, and Chromium Concentrations versus Depth in the Aquifer in Well 299-W22-47 at Waste Management Area S-SX (modified from McDonald et al. 2005) 
Based on the data shown in Figure 4.4, the chromium, nitrate, and technetium-99 plume is present throughout almost the entire upper $23 \mathrm{~m}$ of the aquifer at well 299-W22-47. Subsequent routine, quarterly samples collected from the well in 2005 yielded concentrations at the same levels as reported in Figure 4.4.

Johnson and Chou (2001) present results from depth-discrete sampling during drilling of well 299W22-50, located approximately $60 \mathrm{~m}$ north of well 299-W22-47. Their results are tabulated in Table 4.4. The samples were collected at predetermined depths with a pump-and-packer assembly. One sample was collected just above and one sample from just below the Ringold Formation lower mud unit. (The lower mud unit is between 72.5 and $84.4 \mathrm{~m}$ below the water table in well 299-W22-50.) The drilling and sampling details are found in Johnson and Chou (2001) and Horton and Johnson (2000).

Table 4.4. Depth Distribution of Selected Contaminants during Drilling of Well 299-W22-50 (from Johnson and Chou 2001)

\begin{tabular}{|c|c|c|c|c|c|c|c|}
\hline $\begin{array}{c}\text { Sample } \\
\text { Depth (m) }\end{array}$ & $\begin{array}{l}\text { Sample } \\
\text { Mode }\end{array}$ & $\begin{array}{c}\text { Technetium-99 } \\
(\mathrm{pCi} / \mathrm{L})\end{array}$ & $\begin{array}{l}\text { Nitrate } \\
(\mathrm{mg} / \mathrm{L})\end{array}$ & $\begin{array}{c}\text { Chromium } \\
(\mu \mathrm{g} / \mathrm{L})\end{array}$ & $\begin{array}{l}\text { Tritium } \\
(\mathrm{pCi} / \mathrm{L})\end{array}$ & $\begin{array}{c}\text { Uranium } \\
(\mu \mathrm{g} / \mathrm{L})\end{array}$ & $\begin{array}{c}\text { Carbon } \\
\text { Tetrachloride } \\
(\mu \mathrm{g} / \mathrm{L})\end{array}$ \\
\hline 0.2 & B & 4,240 & 57 & $3.0 \mathrm{U}$ & 31,400 & 0.78 & 13 \\
\hline 2.3 & $\mathrm{~S}$ & 3,230 & 30 & 10.4 & 24,200 & 4.29 & 11 \\
\hline 6.7 & $\mathrm{P}$ & 812 & 12 & $3.0 \mathrm{U}$ & 19,900 & 3.34 & 5.6 \\
\hline 11.9 & $\mathrm{P}$ & $7.03 \mathrm{U}$ & 2 & $3.0 \mathrm{U}$ & 969 & 1.09 & 0.94 \\
\hline 28.7 & $\mathrm{P}$ & OU & 1 & $3.0 \mathrm{U}$ & 304 & 0.58 & 1.5 \\
\hline 53.0 & $\mathrm{P}$ & $0 \mathrm{U}$ & 3 & $3.0 \mathrm{U}$ & $185 \mathrm{U}$ & 0.79 & 5.6 \\
\hline 67.7 & $\mathrm{P}$ & $0.577 \mathrm{U}$ & 12 & $3.0 \mathrm{U}$ & OU & 0.43 & 0.89 \\
\hline 99.4 & $\mathrm{P}$ & $0 \mathrm{U}$ & 4 & $3.0 \mathrm{U}$ & $0 \mathrm{U}$ & 30.90 & 0.23 \\
\hline \multicolumn{8}{|c|}{$\begin{array}{l}\text { Note: } \mathrm{U} \text { denotes analytical result is non-detect. } \\
\mathrm{S}=\text { Sample collected by pumping from } 4.5-\mathrm{m} \text { screened interval. } \\
\mathrm{P}=\text { Sampled during drilling using temporary pump/screen and packer assembly. } \\
\mathrm{B}=\text { Bailed during drilling. }\end{array}$} \\
\hline
\end{tabular}

The data from well 299-W22-50 (Table 4.4), located near the northern edge of the technetium-99 and nitrate plume, show that the concentrations of technetium-99 and nitrate decrease fairly rapidly from the water table to about $7 \mathrm{~m}$ depth in the aquifer. This is in contrast to the broader, and deeper, plume found in well 299-W22-47 located near the axis of the plume (Figure 4.4). Also, the magnitudes of the concentrations are smaller in well 299-W22-50 than they are in well 299-W22-47. (The technetium-99 plume is shown later in this section.)

The distribution of nitrate concentrations with depth in well 299-W22-50 shows a second maximum between about 60 and $80 \mathrm{~m}$ below the water table. The second, deeper maximum is corroborated by several field measurements of nitrate collected from air lifted samples during drilling and is associated with a second, deeper concentration maximum for carbon tetrachloride (Johnson and Chou 2001). Johnson and Chou (2001) attribute the concentration profiles found in well 299-W22-50 to be due to two different plumes intercepted by the well. These include a shallow-depth plume consisting of tank waste constituents of technetium-99, tritium, and nitrate, and a deeper plume containing carbon tetrachloride 
and nitrate that were probably from past-practice wastewater discharges from the Plutonium Finishing Plant routed to U Pond. (See Figure 1.1 for location of U Pond with respect to WMA S-SX.)

Specific Conductance Measurements in Well 299-W23-19. Well 299-W23-19 was drilled in 1999 adjacent to tank SX-115. The well was originally drilled as a characterization borehole next to a tank that is suspected to have leaked about 189,270 L in 1965 (Field and Jones 2005). Groundwater, sampled from the well in October 1999, showed the highest technetium-99 concentrations yet observed in Hanford Site groundwater (Johnson and Chou 2001). For that reason, the borehole was completed as a monitoring well. Well 299-W23-19 was reconfigured in early 2003 so samples could be obtained without entering the SX Tank Farm. A permanent sampling pump and four specific conductance probes were installed in the well at that time.

Specific conductance measurements were recorded at intervals no longer than 30 minutes from March through September 2003. Those data are shown in Figure 4.5. The sharp discontinuities in Figure 4.5 represent pumping and sampling events. McDonald et al. (2004) reasoned that, during pumping for sampling purposes, the water passing Probes \#1, \#2, and \#3 is a blend of water entering the well above their respective depths because the pump intake is lower than Probe \#3. Using a simple mixing model, they calculated the average concentration of water entering the well within the specific interval of each probe. (Probe 4 was not considered because it malfunctioned.) For example, Probe \#1 reflects the composition of water entering the uppermost $1.2 \mathrm{~m}$ of the aquifer with specific conductance of about $2,100 \mu \mathrm{S} / \mathrm{cm}$ (Table 4.5). Probe \#2 represents a blend of water from the upper $3.1 \mathrm{~m}$ of the aquifer, but the concentration of the water entering the aquifer between the two probes is greater than that entering above Probe \#1. Thus, to achieve the composition of water measured by Probe \#2 $(2,600 \mu \mathrm{S} / \mathrm{cm})$, water with specific conductance of $2,915 \mu \mathrm{S} / \mathrm{cm}$ must be mixing with water passing Probe \#1. Table 4.5 shows the results of applying this same logic to all probes and depth intervals. The results suggest that the plume at well 299-W23-19, as indicated by elevated specific conductance, is located in mainly the upper 3 to $4 \mathrm{~m}$ of the aquifer. The lower plume boundary is reasonably sharp with the groundwater composition falling significantly over, at most, a 2-m interval (McDonald et al. 2004).

\subsubsection{Extent of Contamination at Waste Management Area S-SX - Geographic Distribution}

This section summarizes the spatial distribution of contaminants in groundwater at WMA S-SX. The contaminants of concern are technetium-99, nitrate, tritium, carbon tetrachloride, and chromium. Most of the information in this section is from McDonald et al. (2006).

Groundwater beneath WMA S-SX is contaminated with nitrate, chromium, technetium-99, tritium, and carbon tetrachloride. Tritium occurs above the drinking water standard in several wells downgradient of the 216-S-25 crib, located just west (upgradient) of WMA S-SX. The tritium plume passes underneath the WMA (Figure 4.6). Johnson and Chou $(1998,2001)$ used tritium concentrations, plume distribution, and tritium/technetium-99 ratios to infer that the source of most of the tritium beneath the WMA is probably the upgradient $216-\mathrm{S}-25 \mathrm{crib}$. The areal extent of the tritium plume is growing as evidenced by increasing concentrations in the furthest downgradient wells in the WMA S-SX monitoring network.

A carbon tetrachloride plume extends under most of the 200 West Area (Figure 4.7). The largest concentrations of carbon tetrachloride are north of the WMA S-SX near the Plutonium Finishing Plant and WMA TX-TY. Cribs associated with the Plutonium Finishing Plant are the source of the carbon tetrachloride. 


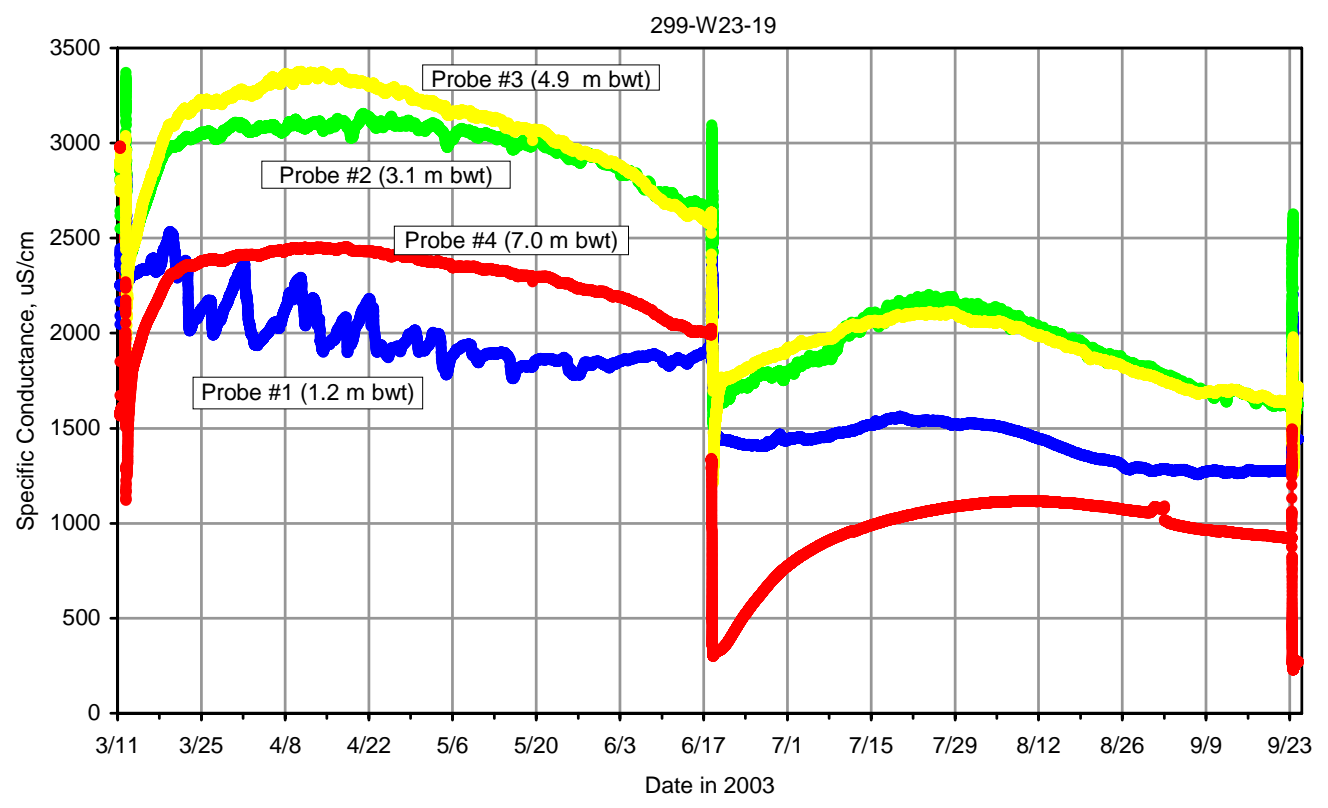

Figure 4.5. Wellbore-Fluid Specific Conductance Measurements Collected in Well 299-W23-19 at Waste Management Area S-SX (from McDonald et al. 2004; bwt = below water table)

Table 4.5. Vertical Variation of Groundwater Composition Measured in Well 299-W23-19 and Estimated for the Adjacent Aquifer on September 23, 2003 (from McDonald et al. 2004)

\begin{tabular}{||l|c|c|c|c||}
\hline $\begin{array}{c}\text { Measurement } \\
\text { Point }{ }^{(\mathrm{a})}\end{array}$ & $\begin{array}{c}\text { Depth Below } \\
\text { Water Table }(\mathrm{m})\end{array}$ & $\begin{array}{c}\text { Interval } \\
\text { Length }^{(\mathrm{a})}(\mathrm{m})\end{array}$ & $\begin{array}{c}\text { Measured In-Well } \\
\text { Specific Conductance } \\
(\mu \mathrm{S} / \mathrm{cm})\end{array}$ & $\begin{array}{c}\text { Estimated Aquifer } \\
\text { Specific Conductance } \\
\text { Over the Interval }^{(\mathrm{b})}(\mu \mathrm{S} / \mathrm{cm})\end{array}$ \\
\hline \hline Probe \#1 & 1.2 & 1.2 & 2,100 & 2,100 \\
\hline Probe \#2 & 3.1 & 1.9 & 2,600 & 2,915 \\
\hline Probe \#3 & 4.9 & 1.8 & 1,900 & 694 \\
\hline Pump Intake & 5.8 & 0.9 & 1,450 & 663 \\
\hline Well Bottom & 7.7 & 1.9 & Not measured & \\
\hline $\begin{array}{l}\text { (a) The interval length is the distance between Probe \#1 and the water table, between Probe \#2 and \#1, between } \\
\text { Probe \#3 and \#2, between Probe \#3 and the pump intake, and between the pump intake and the well bottom. }\end{array}$ \\
(b) It is assumed that the aquifer is homogeneous and isotropic, i.e. water enters the well uniformly across the entire \\
saturated portion of the screen during pumping. Therefore, the specific conductance in the aquifer for an \\
interval was computed assuming that the quantity of water entering the well across that interval is only a \\
function of the interval length.
\end{tabular}

Nitrate, chromium, and technetium-99 plumes beneath WMA S-SX are attributed to two general source areas within the WMA. One source area is in the S Tank Farm and the other is located to the south in the SX Tank Farm. Figures 4.8, 4.9, and 4.10 show the nitrate, chromium, and technetium-99 plumes, respectively, at the top of the aquifer beneath the WMA in 2005. 


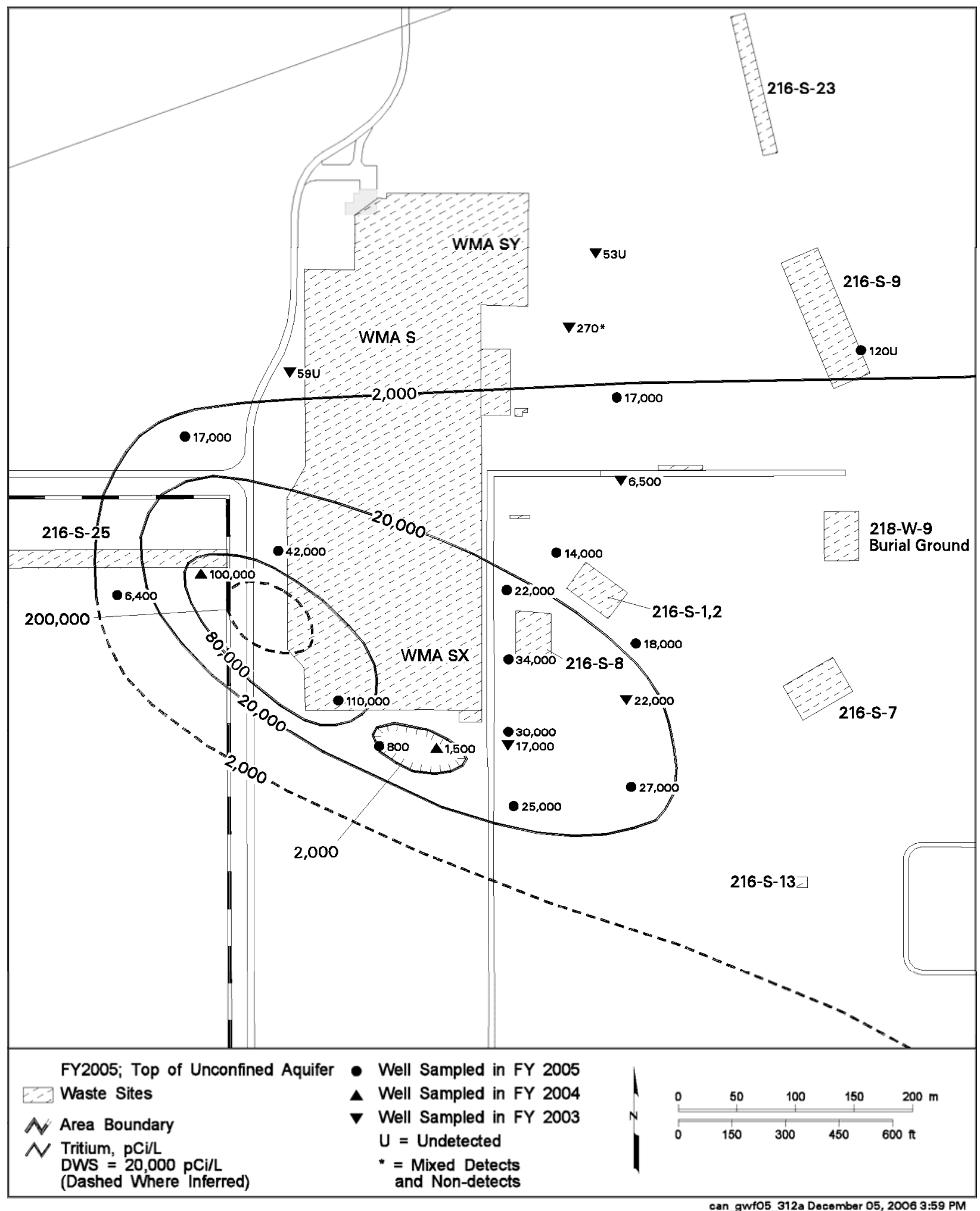

Figure 4.6. Average FY 2005 Tritium Concentrations in the 200-UP-1 Operable Unit, Top of the Aquifer (from Hartman et al. 2006) 


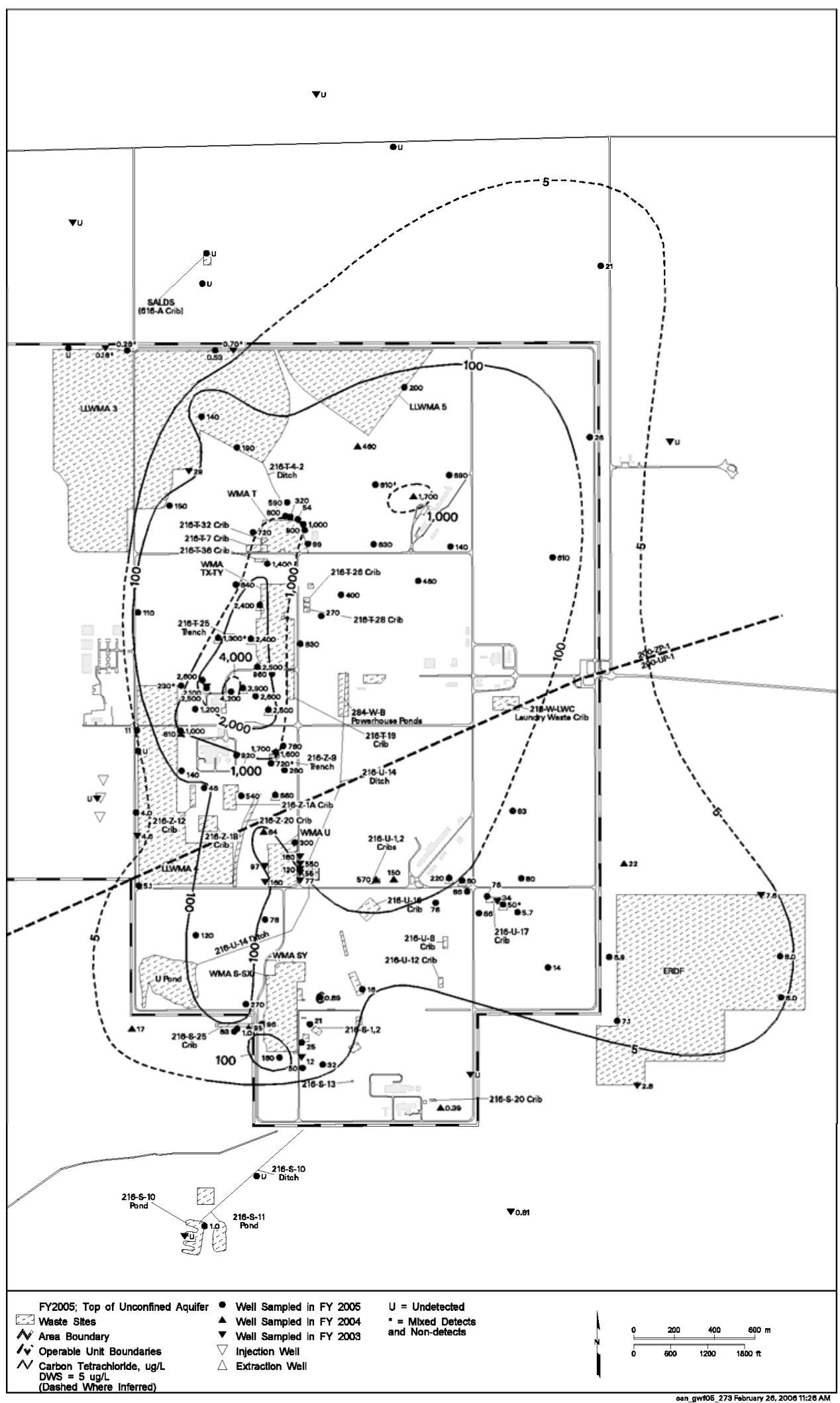

Figure 4.7. Average FY 2005 Carbon Tetrachloride Concentrations in Groundwater Beneath 200 West Area, Top of the Aquifer (from Hartman et al. 2006) 


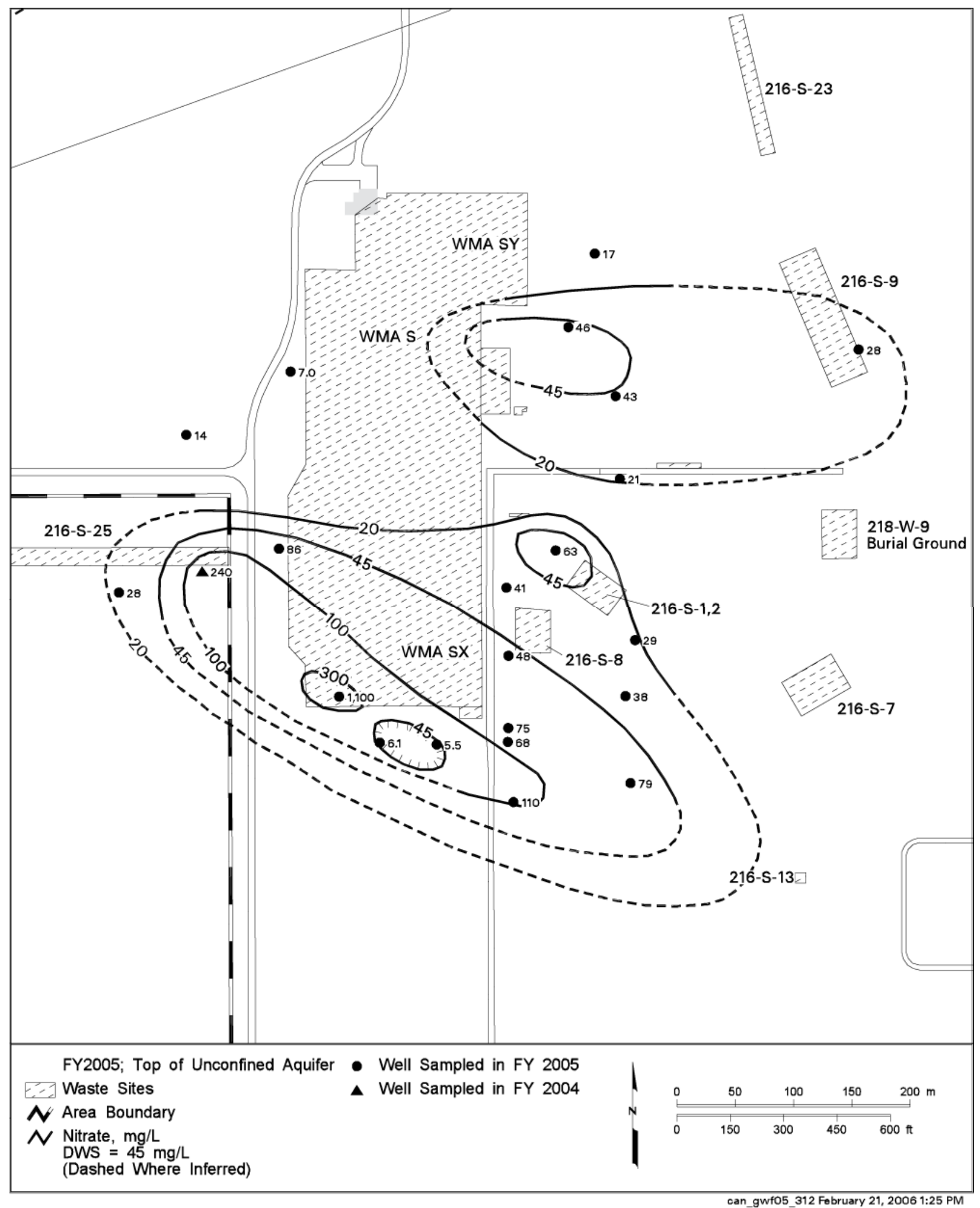

Figure 4.8. Average FY 2005 Nitrate Concentrations at Waste Management Area S-SX, Top of the Aquifer (from Hartman et al. 2006) 


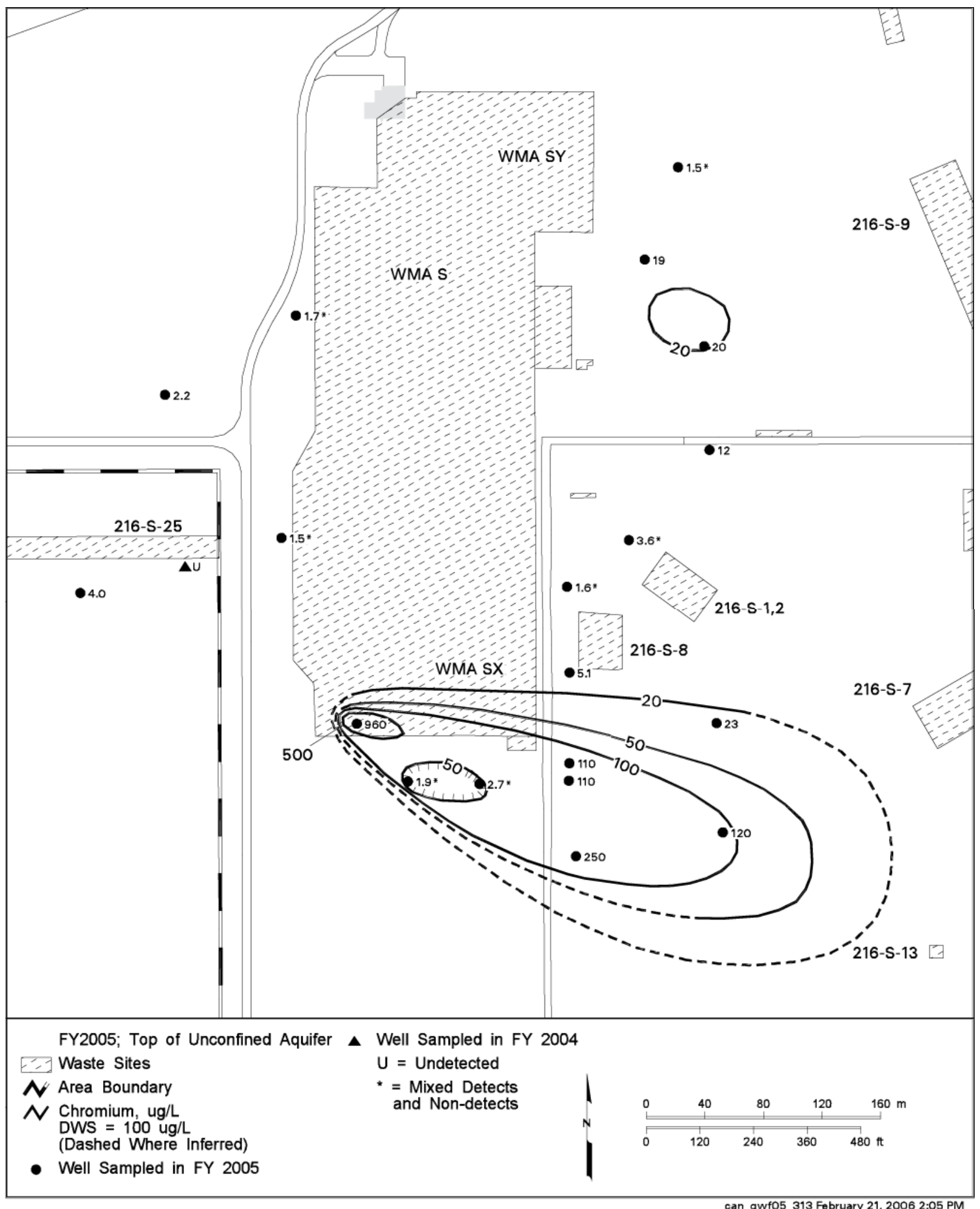

Figure 4.9. Average FY 2005 Chromium Concentrations at Waste Management Area S-SX, Top of the Aquifer (from Hartman et al. 2006) 


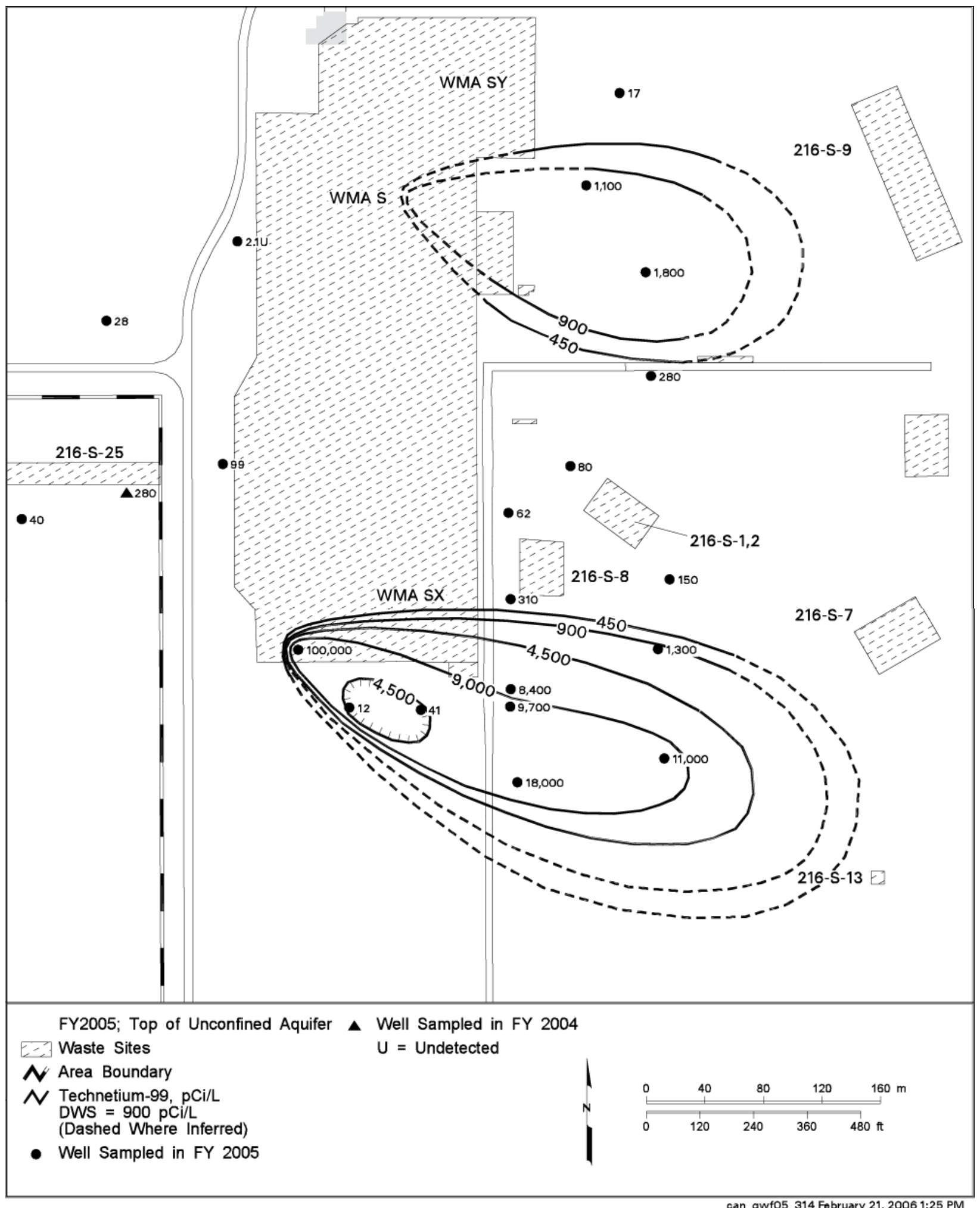

Figure 4.10. Average FY 2005 Technetium-99 Concentration at Waste Management Area S-SX, Top of the Aquifer (from Hartman et al. 2006) 
The northern technetium-99/nitrate plume, with a source in the S Tank Farm, has migrated eastward toward and beyond well 299-W22-48. Trend plots (Figure 4.11) indicate that the center of mass of the plume passed well 299-W22-48 in the 2002 to 2003 time frame. Well 299-W22-26, located approximately 250 m east (downgradient) of well 299-W22-48, was sampled and analyzed for technetium-99 recently for the first time in a number of years. The results indicate that technetium-99 is at a concentration just above the drinking water standard, indicating that the plume may have migrated to at least this distance from S Tank Farm. Also, three new wells (299-W22-69, 299-W22-72, and 299-W22-86) were recently drilled as part of the 200-UP-1 Operable Unit. These wells are located about $250 \mathrm{~m}$ downgradient of the pre-existing downgradient wells in the RCRA monitoring network. Preliminary results from the new wells indicate that the north plume has migrated at least $250 \mathrm{~m}$ beyond well 299-W22-48. Migration of $250 \mathrm{~m}$ downgradient from well 299-W22-48 between March 30, 2000 when technetium-99 exceeded $900 \mathrm{pCi} / \mathrm{L}$ to January 30, 2006, when the first sample was collected from well 299-W22-69 requires a groundwater flow rate of about $0.12 \mathrm{~m} /$ day which is consistent with the range of groundwater flow velocities in Table 2.6.

The northern extent of the S Tank Farm plume is at least as far north as well 299-W22-44, located about 70 to $80 \mathrm{~m}$ northwest of well 299-W22-48. Concentrations in the northern well are not as great as in the southern well suggesting that the main part of the plume is south of well 299-W22-44. Johnson and Chou (2001) noted that technetium-99/nitrate ratios in groundwater samples from wells downgradient of the S Tank Farm were much higher than upgradient ratios but lower than ratios estimated for the wastes in the tanks at S Tank Farm. The S-104 tank, the only tank in S Tank Farm identified as having leaked, has the lowest ratio of all of the tanks in the farm. One possibility is that nitrate from upgradient sources has co-mingled with tank waste from S Tank Farm, thereby lowering the technetium-99/nitrate ratio in the downgradient wells (Johnson and Chou 2001). (Use of technetium-99/nitrate ratios to relate groundwater and tank leak chemical compositions is further considered in Section 4.2.3.) Whereas the nitrate and technetium-99 concentrations track each other in well 299-W22-48 (located presumably near the axis of the plume), they do not track in well 299-W22-44 north of the plume axis (Figure 4.11). The concentration trends support the idea that an upgradient nitrate plume encroached on well 299-W22-44 before the technetium-99 from the tank farm reached the well.

The southern extent of the plume east of the S Tank Farm is not known, but neither technetium-99 or nitrate in well 299-W22-81, located south of well 299-W22-48, has ever exceeded the drinking water standard since the well was drilled in May 2001.

The contaminant plume located in the south portion of WMA S-SX, having a source in the SX Tank Farm, is comprised of nitrate, chromium, and technetium-99. This plume is presumed to have a source near tank SX-115 and entry into the aquifer near well 299-W23-19. A groundwater sample from this well yielded the largest technetium-99 concentration ever measured $(188,000 \mathrm{pCi} / \mathrm{L})$ in groundwater at the Hanford Site in January 2003 (Figure 4.12). The maximum in technetium-99 and nitrate passed the well between 2002 and mid-2003. Beginning in about mid 2004, the concentrations began to increase a second time in the well. Also, chromium began tracking with technetium-99 and nitrate at that time (Figure 4.12). This second increase indicates that another significant pulse of contamination has recently reached the well (McDonald et al. 2006). 

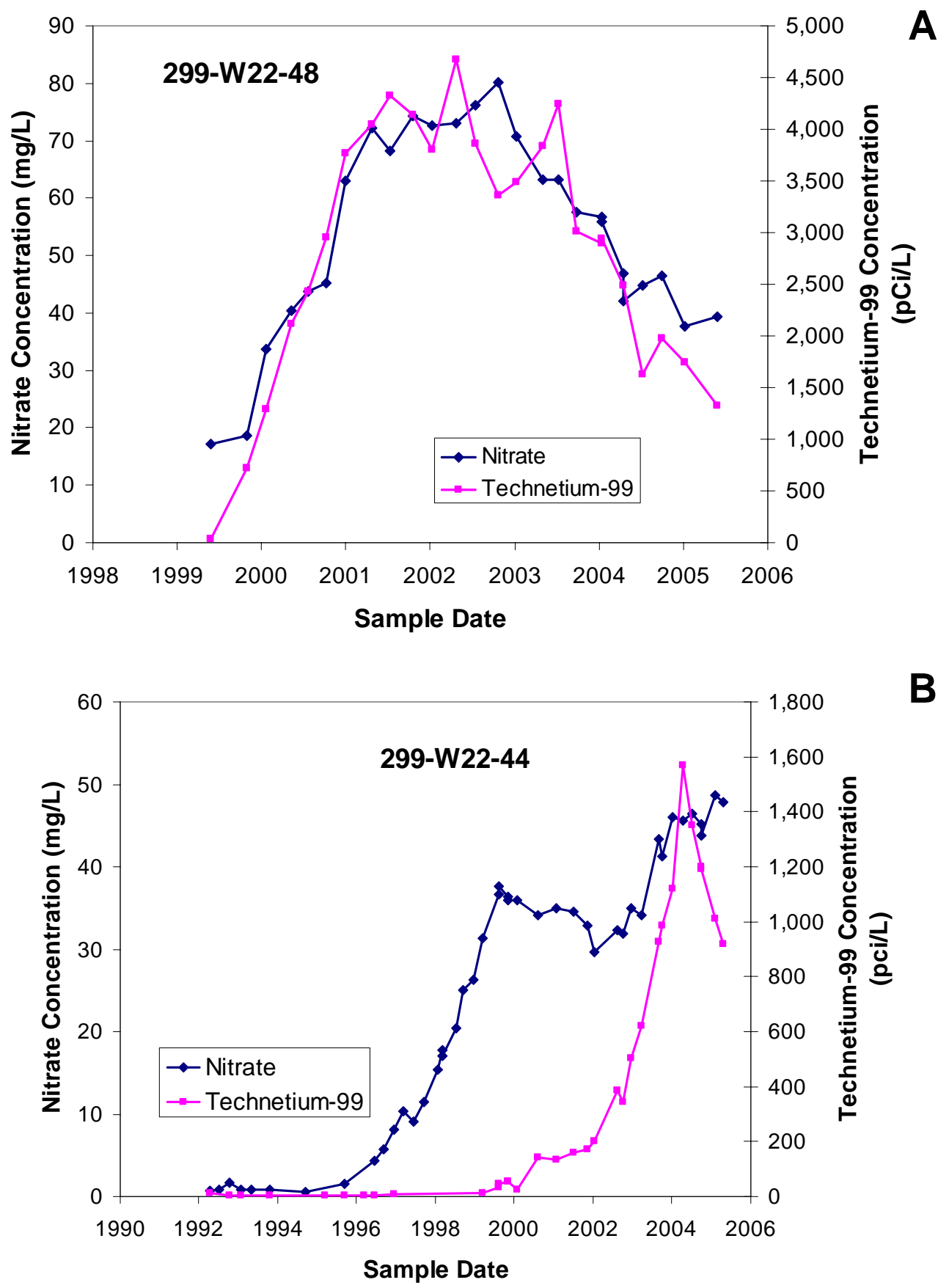

Figure 4.11. Nitrate and Technetium-99 Concentrations versus Time in Wells 299-W22-48 (A) and 299-W22-44 (B) East of the S Tank Farm 

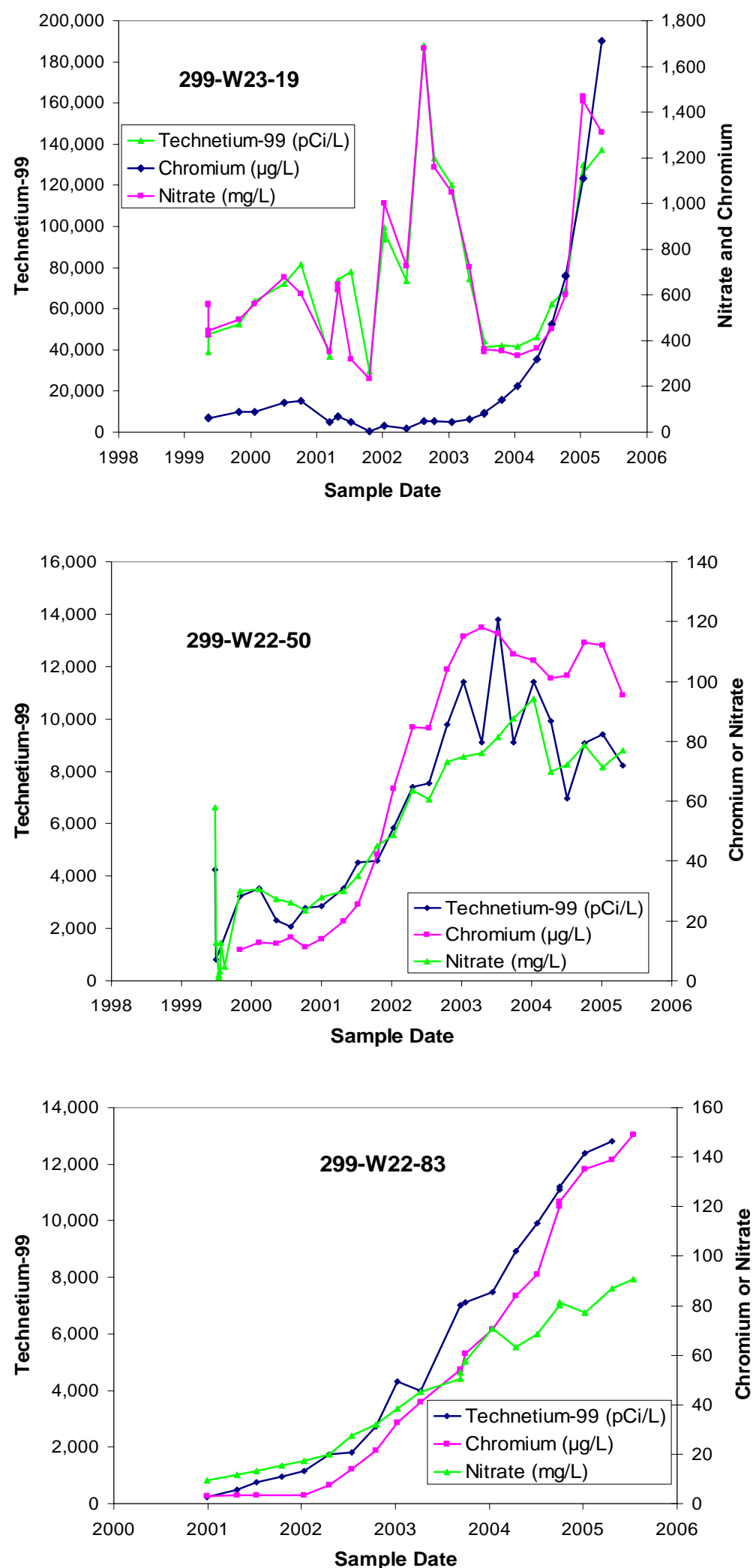

Figure 4.12. Nitrate, Technetium-99, and Chromium Concentrations versus Time in Wells at the Plume South of the SX Tank Farm 
Well 299-W22-50 is located downgradient and southeast of well 299-W23-19 near the middle, although possibly on the northern limb, of the southern plume. Concentrations of technetium-99, nitrate, and chromium (Figure 4.12 middle) began to increase during early 2001 in this well, reached a maximum in 2003, and began to decrease slightly after that. The maximum technetium-99 concentration was $13,800 \mathrm{pCi} / \mathrm{L}$ in December 2003. The leading edge of the southern plume has passed well 299-W22-83, although the center of mass appears to still remain upgradient of the well (Figure 4.12 and the plume maps in Figure 4.8, 4.9, and 4.10). Note that the concentrations in well 299-W22-83 (Figure 4.12 lower) are greater than those in well 299-W22-50 (Figure 299-W22-50 middle) in mid 2005. This may be due to well 299-W22-83 being nearer the center axis of the plume. One of the new wells (well 299-W22-86) drilled for the 200-UP-1 Operable Unit described previously, is located approximately $200 \mathrm{~m}$ farther downgradient of well 299-W22-83 and preliminary results from samples from that well collected during drilling indicate that the technetium-99 plume has migrated at least that far at concentrations $(1,990 \mathrm{pCi} / \mathrm{L})$ above the drinking water standard.

A low concentration island has been drawn in the plume maps at wells 299-W22-80 and 299-W23-15 to indicate that constituent concentrations in these wells are artificially low (Figures 4.8, 4.9, and 4.10).

The evidence for this is (1) aquifer tests that indicate a natural upward flow in the screened section of well 299-W22-80, (2) time series sampling during extensive pumping that indicates water near well 299-W2280 is much less contaminated than water farther from the well, and (3) a borehole flowmeter test in well 299-W22-80 that indicated an upward flow of about $0.3 \mathrm{~L} /$ minute exists during static (i.e., non-pumping) conditions (McDonald et al. 2005, 2006). Thus, relatively uncontaminated water near the bottom of the well is flowing up through the well and diluting the plume in the upper part of the aquifer at a rate of $430 \mathrm{~L} /$ day, or $\sim 40,000 \mathrm{~L}$ between quarterly samples. Because of this, the plume was reinterpreted as being farther south than previously thought (McDonald et al 2005, 2006). This is supported by elevated technetium-99 and chromium concentrations at new well 299-W22-47 installed about $50 \mathrm{~m}$ south of well 299-W22-46.

\subsubsection{Comparison of Groundwater, Vadose Zone Pore Water, and Tank Leak Chemical Compositions at Waste Management Area S-SX}

Nitrate and technetium-99 are commonly used to compare groundwater chemical composition with vadose zone pore water composition and estimated tank and crib waste chemical compositions (Johnson and Chou 2001, Serne et al. 2004a, 2004b) because these data are readily available for groundwater samples. Nitrate and technetium-99 also have very low distribution coefficients (Cantrell et al. 2002) and little, if any, fractionation of the two is expected in the vadose zone and aquifer.

One caveat to be considered when using concentration ratios to compare groundwater with potential contaminant sources is mixing of mobile contaminants from different sources in the groundwater. Nitrate is a common contaminant in almost all waste streams. Consequently, a concentration ratio with nitrate as one component representing a given source can be substantially changed in groundwater in areas with a second high nitrate source. Thus, some care is needed when interpreting concentration ratios as indicators of contaminant sources.

Johnson and Chou (2001) used technetium-99/nitrate concentration ratios to show that samples from downgradient wells with elevated technetium-99 had much higher ratios than upgradient wells and, in some cases, the ratios approached those estimated for waste in individual tanks. They obtained the tank composition estimates from Agnew et al. (1997). Recently, the composition of the drainable liquid in the 
tanks at the time of the leaks were estimated. These latter estimates are documented in the Hanford Soil Inventory Model, Rev. 1 (Corbin et al. 2005). The analysis by Johnson and Chou (2001) was updated using the tank leak estimates from the Hanford Soil Inventory Model, Rev. 1 (Corbin et al. 2005) and recent groundwater data. The results are shown in Table 4.6. The tank composition estimates from Agnew et al. (1997) and used by Johnson and Chou (2001) also are given in the table for comparison.

Table 4.6. Technetium-99/Nitrate Concentration Ratios $(\mu \mathrm{Ci} / \mu \mathrm{g})$ Estimated for Tank Leaks and Measured in Groundwater from Waste Management Area S-SX Wells

\begin{tabular}{|c|c|c|}
\hline Tank & $\begin{array}{c}\text { Updated Estimate of } \\
\text { Technetium-99/Nitrate in Tanks }{ }^{(a)} \\
(\mu \mathrm{Ci} / \mu \mathrm{g})\end{array}$ & $\begin{array}{c}\text { Original Estimate of } \\
\text { Technetium-99/Nitrate in Tanks }{ }^{(b)} \\
(\mu \mathrm{Ci} / \mu \mathrm{g})\end{array}$ \\
\hline S-104 & 0.008 & 0.14 \\
\hline SX-104 & 0.970 & 0.47 \\
\hline SX-107 & 0.488 & 0.10 \\
\hline SX-108 & 0.488 & 0.07 \\
\hline SX-109 & 0.488 & 0.18 \\
\hline SX-110 & 1.169 & 0.26 \\
\hline SX-111 & 1.584 & 0.16 \\
\hline SX-113 & 0.190 & 0.04 \\
\hline SX-115 & 0.318 & 0.12 \\
\hline \multicolumn{3}{|c|}{ Wells Downgradient of Tank S-104 ${ }^{(\mathrm{c})}$} \\
\hline 299-W22-44 & 0.026 & \\
\hline 299-W22-48 & 0.042 & \\
\hline \multicolumn{3}{|c|}{ Wells Downgradient of Tank SX-115 } \\
\hline 299-W22-46 & 0.146 & \\
\hline 299-W22-47 & 0.183 & \\
\hline 299-W22-50 & 0.121 & \\
\hline 299-W22-83 & 0.180 & \\
\hline 299-W23-19 & 0.117 & \\
\hline \multicolumn{3}{|c|}{ Other Wells in Waste Management Area S-SX } \\
\hline 299-W22-45 & 0.001 & \\
\hline 299-W22-49 & 0.006 & \\
\hline 299-W22-80 & 0.007 & \\
\hline 299-W22-81 & 0.015 & \\
\hline 299-W22-82 & 0.034 & \\
\hline 299-W22-84 & 0.001 & \\
\hline 299-W22-85 & 0.002 & \\
\hline 299-W23-15 & 0.003 & \\
\hline 299-W23-21 & 0.001 & \\
\hline \multicolumn{3}{|c|}{$\begin{array}{l}\text { (a) Tank leak composition estimates are from Corbin et al. } 2005 . \\
\text { (b) Data from Agnew et al. (1977) as reported in Johnson and Chou (2001). } \\
\text { (c) Groundwater ratios are calculated from the average of FY } 2005 \text { analyses. }\end{array}$} \\
\hline
\end{tabular}


Wells 299-W22-44 and 299-W22-48 are downgradient of tank S-104, which leaked 90,850 L of waste in 1965 (Field and Jones 2005). The data in Table 4.6 show that the technetium-99/nitrate ratios in these two wells are larger than the ratio estimated by Corbin et al. (2005) for tank S-104. The groundwater ratios are closer to, but smaller than, the ratios previously estimated by Agnew et al. (1997).

Wells 299-W22-47, 299-W22-50, and 299-W22-83 are downgradient of tank SX-115 and well 299-W23-19 is adjacent to tank SX-115. Tank SX-115 leaked 189,270 L of waste in 1965 (Field and Jones 2005). The technetium-99/nitrate ratios in all four wells are the same order of magnitude but still a factor of 2 to 3 less than the Corbin et al. (2005) estimated ratio for tank SX-115.

A better comparison is to contrast the groundwater ratios with ratios measured from the actual leaked fluids. Table 4.7 compares the technetium-99/nitrate ratios from the vadose zone pore water in samples from well 299-W23-19 with ratios from groundwater samples. Well 299-W23-19 was drilled as a characterization borehole through the suspected tank SX-115 leak in 1999. Sediments were collected throughout the vadose zone. One-to-one sediment:water extracts were analyzed for an array of chemicals and radionuclides (Serne et al. 2002a). The results were corrected back to the field moisture content so that the final results represent the concentrations in the pore fluid which presumably are samples of the fluid leaked from the tank mixed with recharge which would dilute the leaked fluids but not change concentration ratios. Wells in bold text in the table are downgradient of tank SX-115. (Wells 299-W2315 and 299-W22-80 are also downgradient of tank SX-115 but are located in an area of upwelling. See discussion in Section 4.2.2.2.) The technetium-99/nitrate ratios from wells that are downgradient of tank SX-115 are very similar to the ratios from pore water that represent the leaked fluids, especially between about 37 and $47 \mathrm{~m}$ bgs where technetium-99 was very elevated in 299-W23-19 sediment pore waters (Serne et al. 2002b). This supports the interpretation that leaks from tank SX-115 have impacted groundwater (McDonald et al. 2006).

\subsubsection{Background Groundwater Composition Beneath Waste Management Area T}

The composition of upgradient groundwater for the single-shell tank WMA T is shown in Table 4.8 and Figure 4.13. The data in the table are the average FY 2005 concentrations in each upgradient well at the WMA. All data are from the HEIS (1994) database and are available on the CD included in Hartman et al. (2006). Data for the metals are from filtered samples; all other data are from unfiltered samples. Data flagged as suspect in the HEIS database have been excluded from the calculated averages.

Upgradient water at single-shell tank WMA T has been severely affected by past-practice disposal of contaminants to the ground. Groundwater in this area had the highest average nitrate concentration on the Hanford Site in FY 2005. All major cations and anions are elevated in the upgradient wells, particularly wells 299-W10-28 and 299-W10-4. The groundwater from the May 2005 analysis from well 299-W10-4 (Figure 4.4) has a salinity of $4.4 \%$. Note that the charge balance for the analyses from wells 299-W10-28 and 299-W10-4 are slightly outside of the normally accepted range of $\pm 5 \%$, probably because of the highly saline nature of the groundwater in which some ionic species have not been accounted for in the Stiff diagram. Groundwater from well 299-W10-1 is a calcium-bicarbonate-nitrate groundwater; groundwater from the other two wells is a sodium-calcium-magnesium-nitrate water. Note scale change among the three diagrams in Figure 4.4. Charge balances are: $+2.0 \%$ for well 299-W10-1, $-5.5 \%$ for well $299-\mathrm{W} 10-28$, and $-7.5 \%$ for well $299-\mathrm{W} 10-4$. Nitrate is $-26.8 \mathrm{meq} / \mathrm{L}$ for well $299-\mathrm{W} 10-28$ and $-49.8 \mathrm{meq} / \mathrm{L}$ for well $299-\mathrm{W} 10-4$ where the negative sign denotes anion charge. 
Table 4.7. Technetium-99/Nitrate Concentration Ratios $(\mu \mathrm{Ci} / \mu \mathrm{g})$ from Pore Water Samples of Well 299-W23-19 and Groundwater from Waste Management Area S-SX Wells

\begin{tabular}{|c|c|c|c|}
\hline \multicolumn{2}{|c|}{ 299-W23-19 Pore Water ${ }^{(a)}$} & \multicolumn{2}{|c|}{ Groundwater } \\
\hline $\begin{array}{l}\text { Depth } \\
\text { (m bgs) }\end{array}$ & $\begin{array}{c}\text { Technetium-99/Nitrate } \\
(\mu \mathrm{Ci} / \mu \mathrm{g})\end{array}$ & Well Name & $\begin{array}{c}\text { Technetium-99/Nitrate }^{(\mathrm{b})} \\
(\mu \mathrm{Ci} / \mu \mathrm{g})\end{array}$ \\
\hline 22.33 & 0.094 & 299-W22-44 & 0.026 \\
\hline 24.16 & 0.105 & 299-W22-45 & 0.001 \\
\hline 24.31 & 0.092 & 299-W22-46 & 0.146 \\
\hline 24.46 & 0.089 & 299-W22-47 & 0.183 \\
\hline 26.85 & 0.106 & 299-W22-48 & 0.042 \\
\hline 28.96 & 0.090 & 299-W22-49 & 0.006 \\
\hline 30.19 & 0.054 & 299-W22-50 & 0.121 \\
\hline 31.38 & 0.082 & 299-W22-80 & 0.007 \\
\hline 31.99 & 0.169 & 299-W22-81 & 0.015 \\
\hline 32.63 & 0.106 & 299-W22-82 & 0.034 \\
\hline 35.46 & 0.079 & 299-W22-83 & 0.180 \\
\hline 37.74 & 0.096 & 299-W22-84 & 0.001 \\
\hline 38.51 & 0.106 & 299-W22-85 & 0.002 \\
\hline 38.51 & 0.113 & 299-W23-15 & 0.003 \\
\hline 41.39 & 0.131 & 299-W23-19 & 0.117 \\
\hline 41.96 & 0.127 & 299-W23-21 & 0.001 \\
\hline 42.72 & 0.120 & & \\
\hline 42.99 & 0.097 & & \\
\hline 43.24 & 0.119 & & \\
\hline 43.69 & 0.117 & & \\
\hline 44.15 & 0.151 & & \\
\hline 44.46 & 0.138 & & \\
\hline 44.94 & 0.087 & & \\
\hline 46.66 & 0.089 & & \\
\hline 46.66 & 0.093 & & \\
\hline 47.50 & 0.120 & & \\
\hline 47.50 & 0.124 & & \\
\hline 48.08 & 0.319 & & \\
\hline 48.69 & 0.080 & & \\
\hline 49.07 & 0.070 & & \\
\hline 49.07 & 0.093 & & \\
\hline 50.75 & 0.092 & & \\
\hline 50.75 & 0.081 & & \\
\hline 53.64 & 0.099 & & \\
\hline 56.22 & 0.079 & & \\
\hline 56.39 & 0.070 & & \\
\hline 56.39 & 0.239 & & \\
\hline 57.76 & 0.098 & & \\
\hline 59.30 & 0.295 & & \\
\hline 62.33 & 0.041 & & \\
\hline 62.53 & 0.168 & & \\
\hline
\end{tabular}

(a) Data from Serne et al. (2002a).

(b) Average ratio from FY 2005 analyses. Wells in bold text are downgradient of tank SX-115. 
Table 4.8. Average FY 2005 Groundwater Composition in Upgradient Wells at Waste Management Area $T$

\begin{tabular}{||l|c|c|c||}
\hline \multirow{2}{*}{\multicolumn{1}{|c|}{ Constituent }} & \multicolumn{3}{|c||}{ Concentration } \\
\cline { 2 - 4 } & Well 299-W10-1 & Well 299-W10-4 & Well 299-W10-28 \\
\hline \hline Alkalinity as CaCO $(\mu \mathrm{g} / \mathrm{L})$ & 100,000 & 190,000 & 159,500 \\
\hline Calcium $(\mu \mathrm{g} / \mathrm{L})$ & 62,375 & 345,750 & 253,000 \\
\hline Carbon tetrachloride $(\mu \mathrm{g} / \mathrm{L})$ & 715 & 1,383 & Not analyzed \\
\hline Cesium-137 & Not analyzed & Not detected & Not analyzed \\
\hline Chloride $(\mathrm{mg} / \mathrm{L})$ & 15.6 & 43.35 & 32.4 \\
\hline Chloroform $(\mu \mathrm{g} / \mathrm{L})$ & 7.8 & 11.6 & Not analyzed \\
\hline Chromium $(\mu \mathrm{g} / \mathrm{L})$ & 22.35 & 666.5 & 265 \\
\hline Cobalt-60 $(\mathrm{pCi} / \mathrm{L})$ & Not analyzed & Not detected & Not analyzed \\
\hline Fluoride $(\mathrm{mg} / \mathrm{L})$ & 0.22 & 3.33 & 1.85 \\
\hline Gross alpha $(\mathrm{pCi} / \mathrm{L})$ & Not detected & Not detected & Not detected \\
\hline Gross beta $(\mathrm{pCi} / \mathrm{L})$ & 21.1 & 217 & 86.2 \\
\hline Iodine-129 $(\mathrm{pCi} / \mathrm{L})$ & Not detected & Not detected & Not detected \\
\hline Iron $(\mu \mathrm{g} / \mathrm{L})$ & 24.6 & 45.6 & 55.6 \\
\hline Magnesium $(\mu \mathrm{g} / \mathrm{L})$ & 20,400 & 131,250 & 84,250 \\
\hline Nitrate $(\mathrm{mg} / \mathrm{L})$ & 128 & 2,420 & 1,625 \\
\hline pH Measurement $(\mathrm{pH}$ units) & 7.8 & 7.4 & 7.6 \\
\hline Potassium $(\mu \mathrm{g} / \mathrm{L})$ & 5,472 & 13,667 & 10,275 \\
\hline Sodium $(\mu \mathrm{g} / \mathrm{L})$ & 13,850 & 463,667 & 225,750 \\
\hline Specific Conductance $(\mu \mathrm{SS} / \mathrm{cm})$ & 550 & 4,858 & 3,173 \\
\hline Strontium-90 $(\mathrm{pCi} / \mathrm{L})$ & Not analyzed & Not analyzed & Not analyzed \\
\hline Sulfate $(\mathrm{mg} / \mathrm{L})$ & 37.42 & 97.07 & 54.92 \\
\hline Technetium-99 $(\mathrm{pCi} / \mathrm{L})$ & 74.3 & 827 & 288.5 \\
\hline Trichloroethene $(\mu \mathrm{g} / \mathrm{L})$ & 5.55 & 6.03 & Not analyzed \\
\hline Tritium $(\mathrm{pCi} / \mathrm{L})$ & 1,525 & 4,205 & 3,500 \\
\hline \hline
\end{tabular}

\subsubsection{Groundwater Contamination Beneath Waste Management Area T}

This section discusses the current and historical groundwater contamination at WMA T. The evaluation of contamination includes descriptions of the types and concentrations of contaminants in the groundwater and the extent of contamination in the area. Most of the information in this section is taken from Dresel et al (2006), Serne et al. (2004b), and Horton (2006).

Groundwater in the WMA T area is routinely monitored for RCRA and Atomic Energy Act purposes. The objective of RCRA monitoring at WMA T is to assess the nature and extent of groundwater contaminated with hazardous constituents and to determine their rate of movement in the aquifer. Groundwater monitoring under the Atomic Energy Act tracks radionuclides in the WMA and surrounding vicinity.

\subsubsection{Extent of Contamination at Waste Management Area T - Depth Distribution}

The most recent source of information that gives indications of the current depth distribution of contaminants at WMA T is depth-discrete sampling in the aquifer during drilling of wells 299-W11-25B 
and 299-W11-45. Previous indications of vertical concentration gradients in the aquifer include depthdiscrete sampling of well 299-W10-24 when it was drilled in 1998 (Horton et al. 2002); comparisons of groundwater chemistry in older wells with their adjacent, replacement wells (Horton et al. 2002); and depth profiles of specific conductance in the screened interval of existing wells (Dresel et al. 2004).
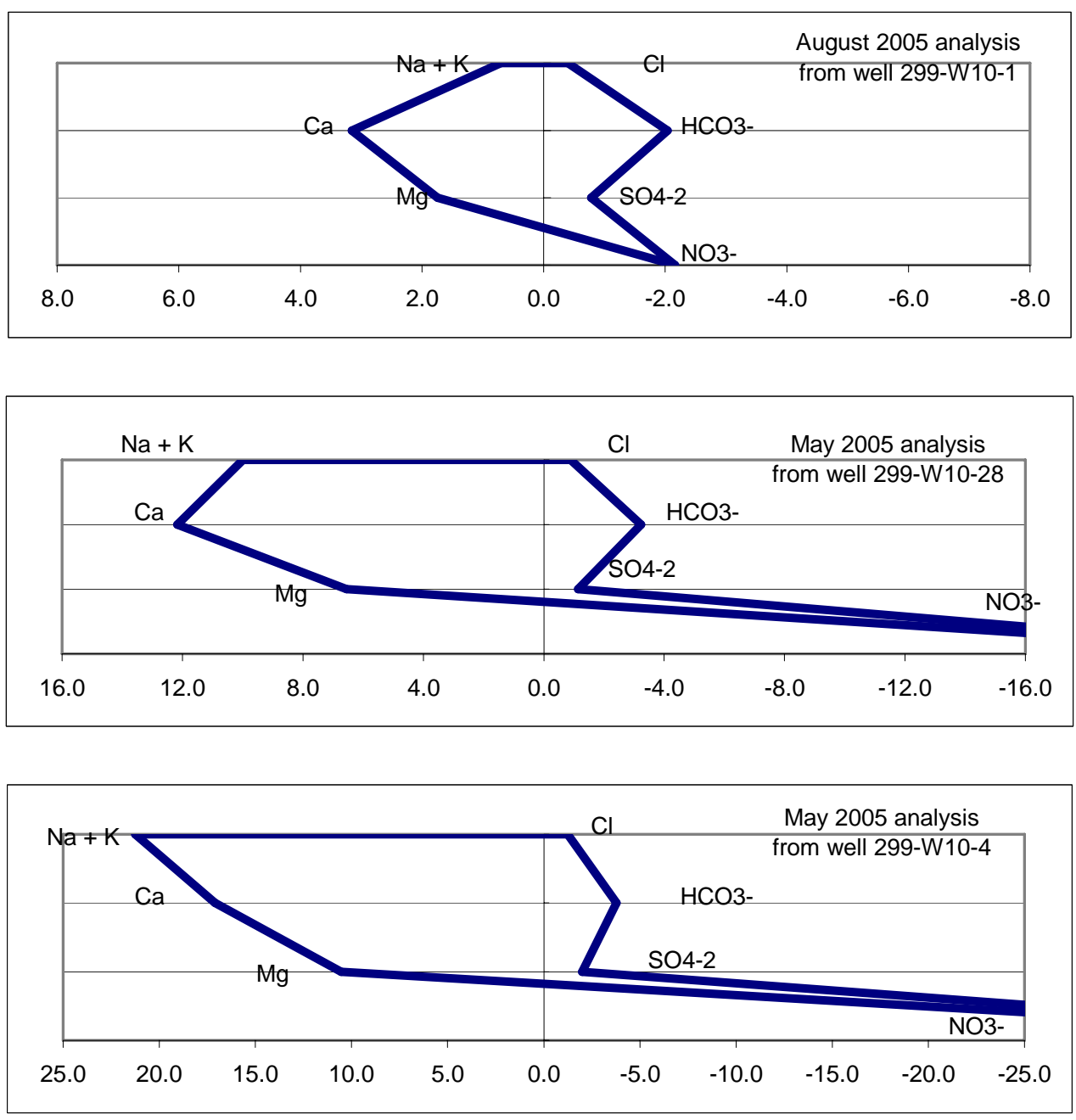

Figure 4.13. Major Cation and Anion Composition of Groundwater from Upgradient Wells at Waste Management Area T. Units for the x-axis are milliequavlents/liter with cations on the left and anions on the right.

Specific Conductance Profiling. In September 2002, specific conductance measurements were taken at 0.5 to $1 \mathrm{~m}$ intervals throughout the screened intervals of four groundwater monitoring wells at WMA T (Hartman et al. 2004). Significant differences in specific conductance with depth were found in three of these wells. The remaining well (299-W10-24) showed no variation of specific conductance with depth.

Figure 4.14 shows a plot of specific conductance versus depth in well 299-W10-28, an upgradient well at WMA T. There is a marked increase in specific conductance with increasing depth through the upper $4 \mathrm{~m}$ of the screened interval below which specific conductance remains unchanged. In general, specific conductance reflects nitrate (and sodium and calcium) concentrations in the WMA T area. At 
well 299-W10-28, the data suggest that the nitrate concentration increases from the water table to about 4-m depth within the aquifer. Also shown on the figure are the values of specific conductance measured after purging the well for the four routine quarterly groundwater samples taken prior to the specific conductance profile. The red triangles to the left of the curve, representing the pumped values, are at the depth of the pump intake; the screened interval is from the water table to $10.5 \mathrm{~m}$ below the water table. The pumped values appear to be a mixture of the low conductance water at the water-table surface and the relatively high conductance water deeper in the screened interval as might be expected.

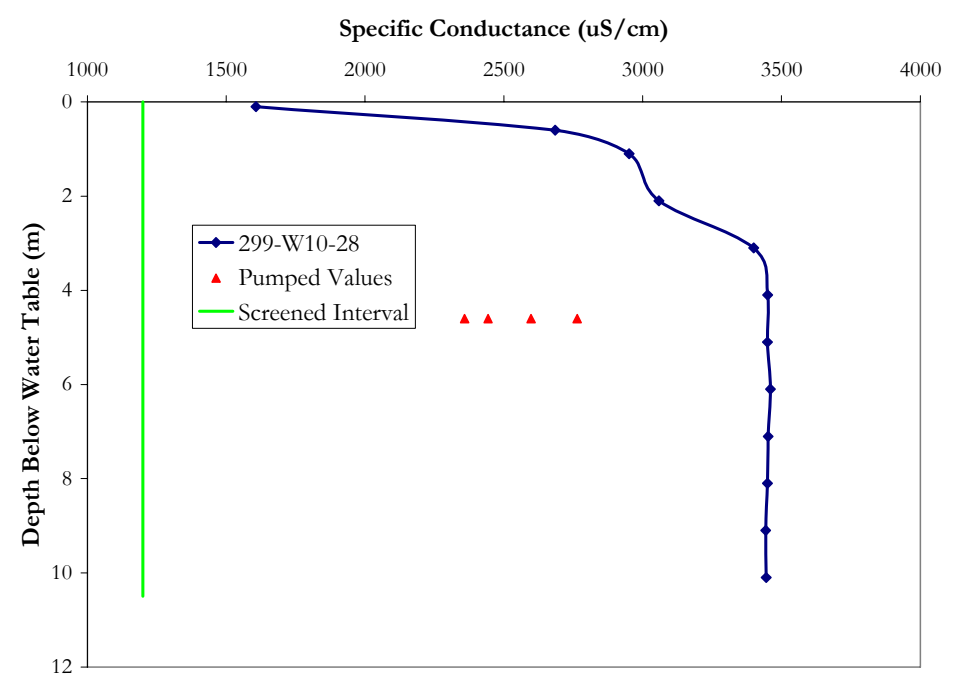

Figure 4.14. Specific Conductance versus Depth below the Water Table in Well 299-W10-28 (modified from Serne et al. 2004b)

A specific conductance profile measured in well 299-W11-39 (graph not shown), a downgradient well at WMA T, has a shape very similar to that of well 299-W10-28, although the absolute values of the specific conductance are much smaller (maximum value of $551 \mu \mathrm{S} / \mathrm{cm}$ ) and the magnitude of the change is much less than in well 299-W10-28.

A specific conductance profile measured in well 299-W11-42 (Figure 4.15), another downgradient well at WMA T, also shows an increase in specific conductance with depth. However, the specific conductance increase in well 299-W11-42 occurs between 6 and 9 m below the water table instead of very near the water table as in well 299-W10-28 and, again, the magnitude of the change is much less than that shown in well 299-W10-28. Specific conductance continues to increase in the deepest measurement allowing for a continued increase below the screened interval. The specific conductance values from the samples pumped during the four quarters before the profile was made increase from about $1,470 \mu \mathrm{S} / \mathrm{cm}$ to about $1,515 \mu \mathrm{S} / \mathrm{cm}$ with time (Figure 4.15 ). The last pumped value obtained (farther to the right on Figure 4.15) was measured in August 2002 and is a reasonable mean of the values measured in the screened interval when the depth profile was made in September 2002. The previous pumped values suggest that the profile did not look the same throughout the entire previous year.

If the specific conductance reflects the nitrate concentration, these data can be interpreted to reflect the relatively deep, regional nitrate plume found beneath WMA T and suggest that the main part of the plume may be located at some depth below the bottom of the screen. Data obtained during drilling of new wells, discussed below, support this conclusion. 


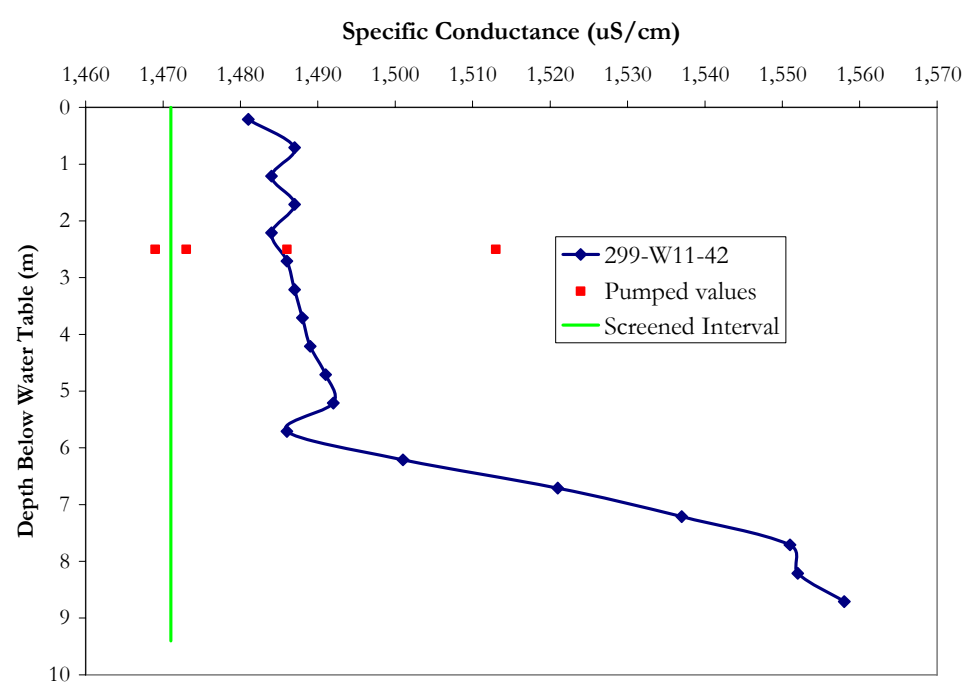

Figure 4.15. Specific Conductance versus Depth below the Water Table in Well 299-W11-42 (modified from Serne et al. 2004b)

Comparison of Chemical Data from Old and New Wells. Replacement wells, when located immediately adjacent to the older wells, offer an opportunity to look for vertical variation within the upper part of the aquifer. Three well pairs at WMA T show vertical stratification of contaminants in the upper part of the aquifer.

In each case, the old well and its replacement well are separated by only a few meters. In addition, in each case, the older well was last sampled when there was a fraction of a meter of water within the screened interval, and the replacement well was sampled with a pump placed at least $3 \mathrm{~m}$ below the water table within a 10.7-m screened interval. Thus, the last samples from the old well represent the top of the aquifer, and the samples from the replacement well represent a composite of water pumped from the length of the screened interval.

Figure 4.16 shows the concentration of nitrate versus time for two well pairs at WMA T. Wells 299-W11-27 and 299-W10-24 are about $3 \mathrm{~m}$ apart and are located near the northeastern corner of WMA T. Well 299-W10-24 is the replacement well for well 299-W11-27 that went dry in early 1999. The last sampling of well 299-W11-27 took place in March 1999 and sampling of replacement well 299-W10-24 started in December 1998, allowing a sampling overlap between the two adjacent wells. The last samples collected from well 299-W11-27 represent the top of the aquifer. The samples collected from well 299-W10-24 represent water throughout the screened interval, which extends from the water table to $10 \mathrm{~m}$ below the water table.

Well 299-W11-27 reached a peak nitrate concentration of $231 \mathrm{mg} / \mathrm{L}$ in November 1996 and dropped to $72 \mathrm{mg} / \mathrm{L}$ for the last sampling in March 1999 before going dry. This sample represented the nitrate concentration at the top of the aquifer. The nitrate concentration in adjacent well 299-W10-24 during March 1999 was $474 \mathrm{mg} / \mathrm{L}$ (Figure 4.16). The sample from well 299-W10-24 represented the nitrate concentration throughout the upper $10 \mathrm{~m}$ of the aquifer after ambient water was purged from the well. The interpretation is that, in early 1999 , the nitrate concentration at the water table at the northeast corner of WMA T was about $72 \mathrm{mg} / \mathrm{L}$ and the concentration increased with depth in the aquifer. 


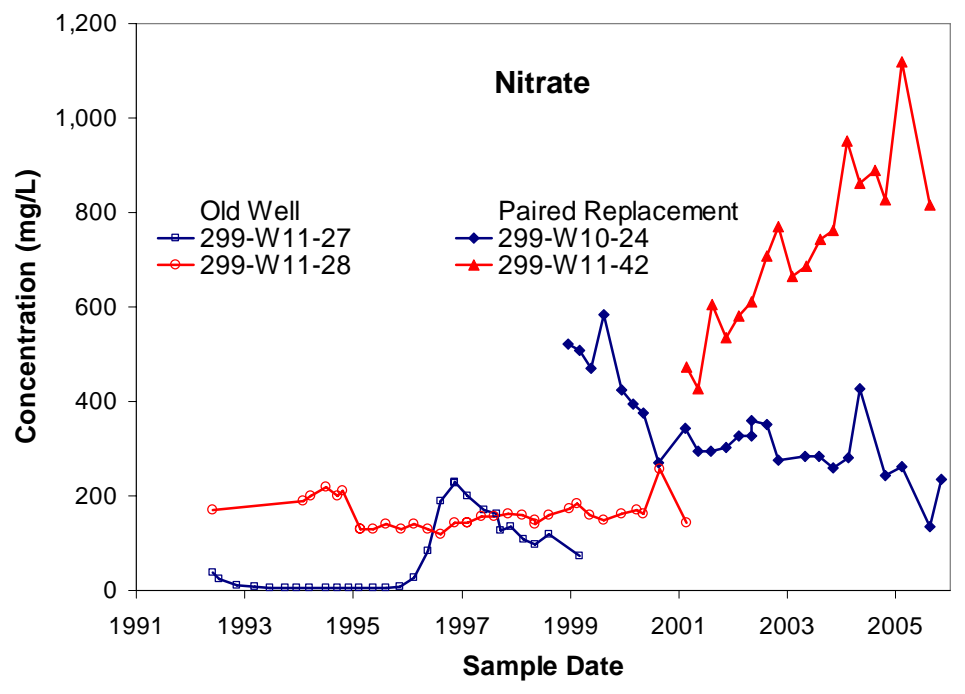

Figure 4.16. Nitrate Concentration in Well Pair 299-W10-24 and 299-W11-27 and Well Pair 299-W11-42 and 299-W11-28 Downgradient of Waste Management Area T

Figure 4.16 also shows the concentration of nitrate versus time for the well pair 299-W11-28 and 299-W11-42, located near the center of the downgradient side of WMA T. Well 299-W11-42 is the replacement well for now dry well 299-W11-28. The data from this well pair show a similar situation as seen in the previous well pair. That is, the nitrate concentration was higher in the screened interval of the new well (474 mg/L in well 299-W11-42) than it was at the water table in the older well $(144 \mathrm{mg} / \mathrm{L}$ in well 299-W11-28). These data are consistent with the specific conductance profiles and suggest that nitrate concentration in groundwater beneath WMA T is relatively low at the water table and increases with depth in the aquifer.

Well 299-W11-27 reached a peak technetium-99 concentration of 21,700 pCi/L in February 1997 and dropped to 6,000 pCi/L for the last sampling in March 1999 before going dry (Figure 4.17). The last sample represented the technetium-99 concentration at the top of the aquifer. The first analysis of technetium-99, from the December 1998 sampling of replacement well 299-W10-24, contained $2,090 \mathrm{pCi} / \mathrm{L}$ technetium-99, about 4,000 pCi/L less than the older, dry well (Figure 4.17). Using the same argument as used above for nitrate, the sample from well 299-W11-27 represented the technetium-99 concentration at the water table and the sample from well 299-W10-24 represented the technetium-99 concentration throughout the upper $10 \mathrm{~m}$ of the aquifer. The interpretation is that, in early 1999, the technetium concentration at the water table at the northeast corner of WMA T was $6,000 \mathrm{pCi} / \mathrm{L}$ and the concentration decreased with depth in the aquifer. As will be shown below, this interpretation is contradicted by new evidence obtained during drilling of two new wells in the area.

Well 299-W11-39 is the replacement well for now dry well 299-W11-23; both are located near the northeast corner of WMA T. Comparison of the technetium-99 concentration in the two wells indicates essentially no difference between the last samples from well 299-W11-23 and the first samples from 299-W11-39 (Figure 4.17). The situation here, however, is complicated by the downward in-well flow in well 299-W11-39 (Spane et al. 2002) which may cause mixing of water near the water table with water deeper in the screened interval. 


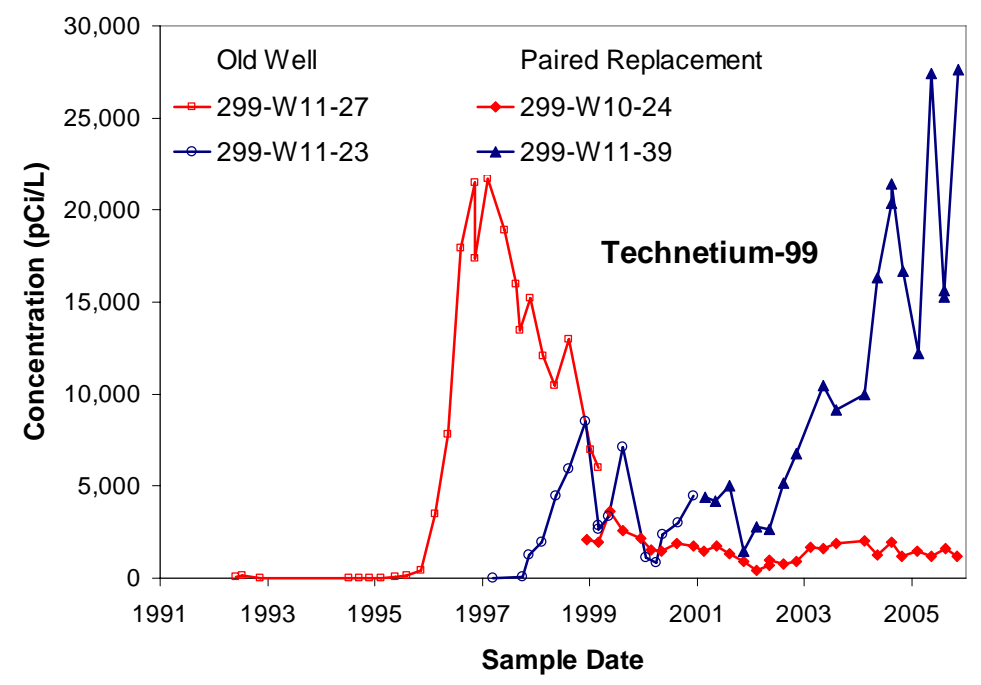

Figure 4.17. Technetium-99 Concentrations in Well Pair 299-W10-24 and 299-W11-27 and Well Pair 299-W11-23 and 299-W11-39 at the Northeast Corner of T Tank Farm

Sampling During Drilling. In 1998, well 299-W10-24 was drilled at the northeast corner of WMA T and through the lower mud unit of the Ringold Formation (hydrogeologic unit 8) prior to being completed as a top-of-the-aquifer monitoring well. The well was sampled with a pump-and-packer assembly at five depths in the aquifer (Horton et al. 2002).

The results from the pump-and-packer samples are shown in Figure 4.18. The profiles in Figure 4.18 are composed of the five pumped samples collected during drilling (the deepest five points) plus a sample bailed from the adjacent and now dry well 299-W11-27 (the shallowest point) and the first routine quarterly RCRA sample pumped from the screened interval after the well was constructed (the second most shallow point for tritium, nitrate, and technetium-99).

The profiles from well 299-W10-24 show that the concentration of tritium, nitrate, and carbon tetrachloride increase to a maximum somewhere near $20 \mathrm{~m}$ (about $35 \mathrm{~m}$ for carbon tetrachloride) below the water table. For nitrate this supports the conclusion from the specific conductance profiles and the comparisons from well pairs described above that nitrate concentration is greater at some depth in the aquifer than it is at the water table.

For technetium-99, the bailed (shallowest) sample in the profile shown in Figure 4.18 is the last sample taken from the well discussed in the section Comparison of Chemical Data from Old and New Wells; the pumped sample (second shallowest sample) is the same as the first pumped sample discussed in the same section; and the deepest five samples were collected when the well was drilled. When all the samples are taken together, the results indicate that technetium-99 concentration is highest at the water table and decreases rapidly with depth at this location. This suggested a nearby source for the contamination because the contamination had not traveled far enough to disperse vertically in the aquifer (Hodges 1998). This was the conceptual model in 2005 when well 299-W11-25B was drilled. 

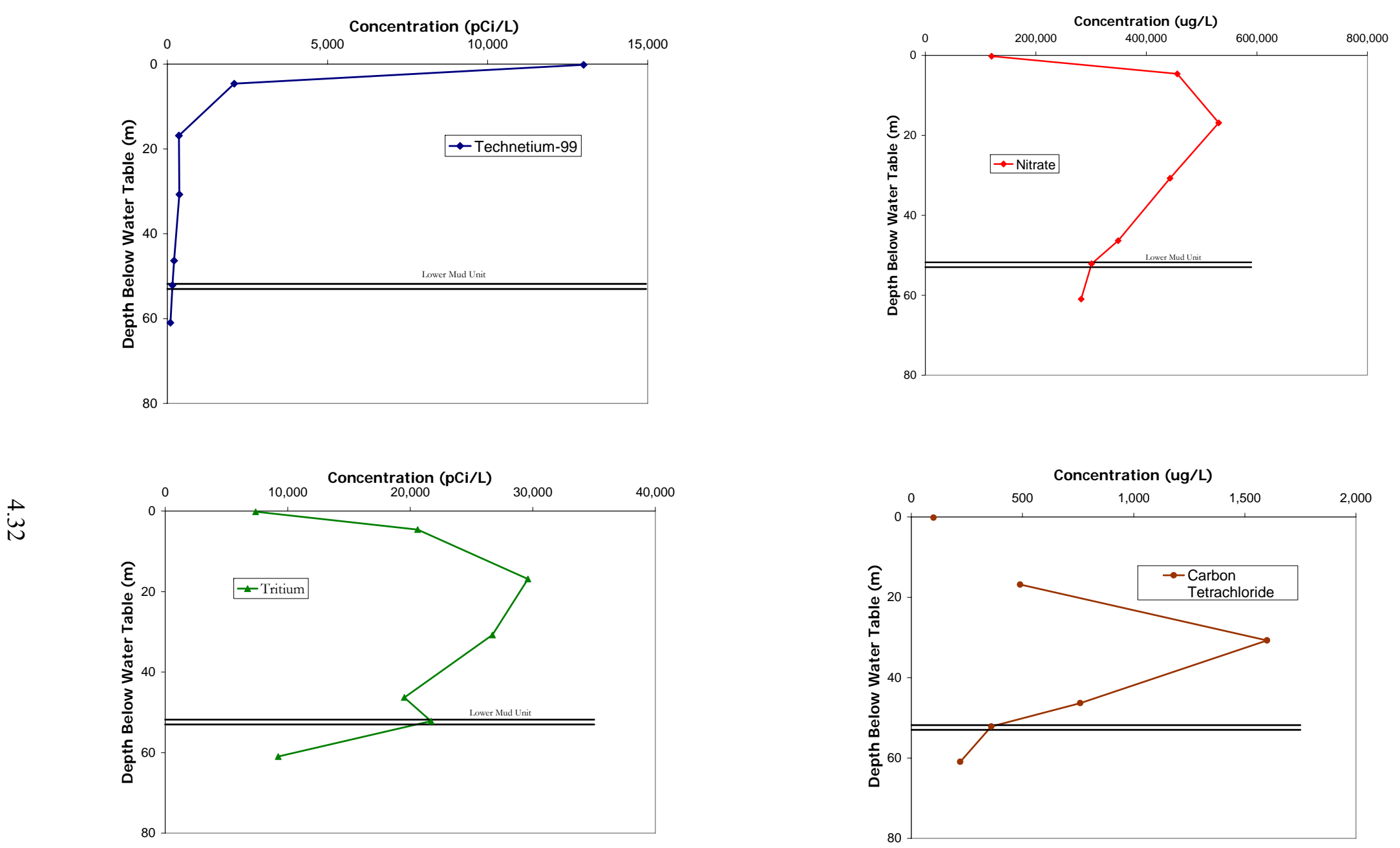

Figure 4.18. Depth Distribution of Key Contaminants in Well 299-W10-24 (modified from Horton et al. 2002) 
For technetium-99, the bailed (shallowest) sample in the profile shown in Figure 4.18 is the last sample taken from the well discussed in the section Comparison of Chemical Data from Old and New Wells; the pumped sample (second shallowest sample) is the same as the first pumped sample discussed in the same section; and the deepest five samples were collected when the well was drilled. When all the samples are taken together, the results indicate that technetium-99 concentration is highest at the water table and decreases rapidly with depth at this location. This suggested a nearby source for the contamination because the contamination had not traveled far enough to disperse vertically in the aquifer (Hodges 1998). This was the conceptual model in 2005 when well 299-W11-25B was drilled.

Figure 4.19 shows the concentrations of technetium-99 and nitrate with depth in well 299-W11-25B. Well 299-W11-25B was drilled about $4 \mathrm{~m}$ from well 299-W11-39 in February 2005. The well was drilled to the top of the Ringold Formation lower mud unit, about $50 \mathrm{~m}$ below the water table. The purpose of the well was to characterize the vertical distribution of contaminants downgradient of WMA T. Groundwater samples were collected at $1.5-\mathrm{m}$ intervals throughout the drilled part of the aquifer. Samples were analyzed for technetium-99, chromium, and nitrate. Unexpected high levels of all three contaminants were found. The maximum technetium-99 concentration was $181,900 \mathrm{pCi} / \mathrm{L}$ at $10 \mathrm{~m}$ below the water table. The technetium-99 concentration decreased abruptly between 12 and $14 \mathrm{~m}$ below the water table and then gradually decreased to the bottom of the well. However, concentrations at the bottom of the well remained quite high, in the 20,000 to $30,000 \mathrm{pCi} / \mathrm{L}$ range. The maximum nitrate concentration was about $664 \mathrm{mg} / \mathrm{L}$ and coincided with the maximum technetium-99 concentration at $10 \mathrm{~m}$ below the water table. The concentrations of both technetium-99 and nitrate track each other throughout the aquifer, although the technetium-99/nitrate concentration ratio varies by about a factor of five possibly due to mixing of a local plume east of WMA T with the more regional nitrate plume in the area.

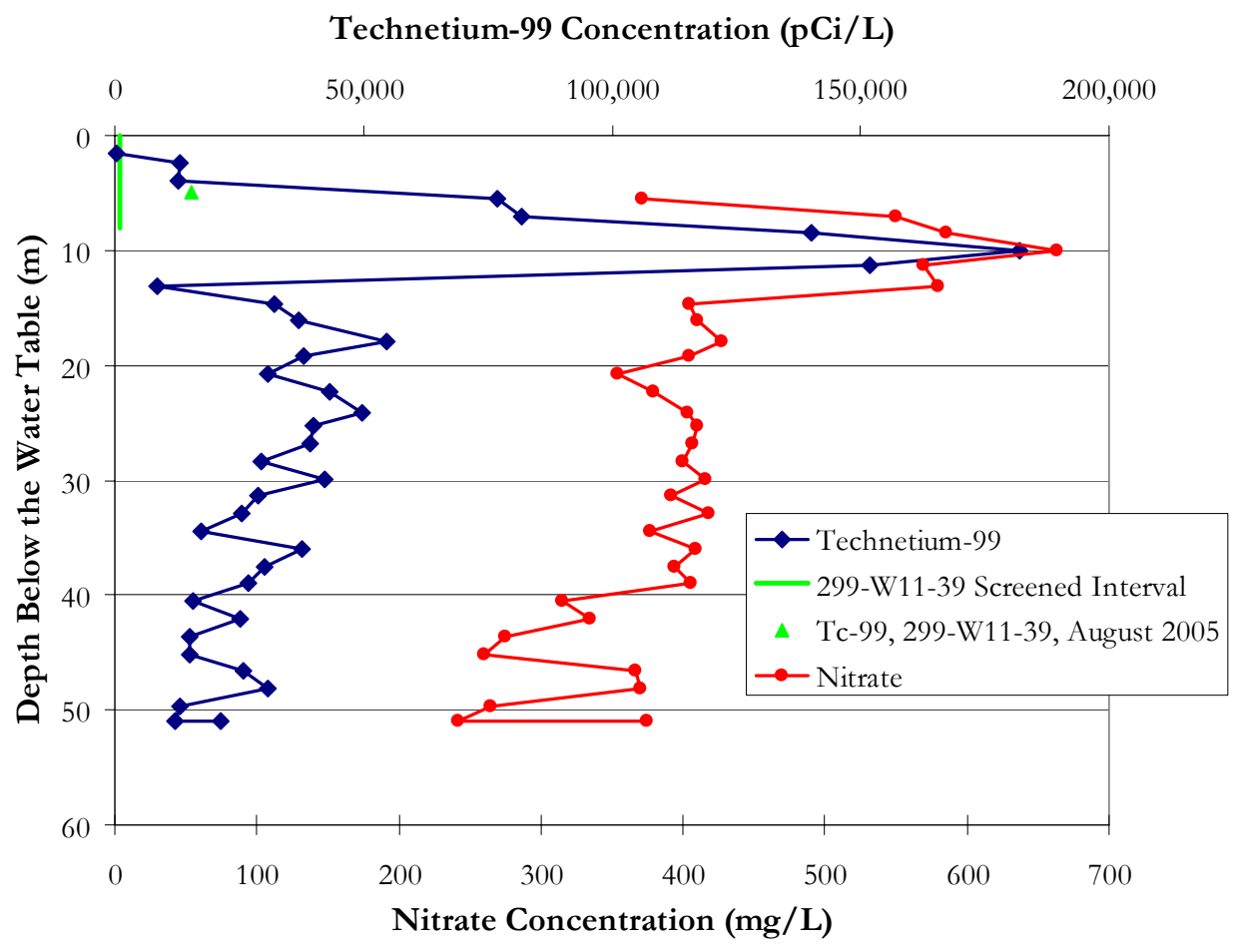

Figure 4.19. Technetium-99 and Nitrate Concentrations in Well 299-W11-25B (modified from Dresel et al. 2006) 
The extremely high levels of technetium-99 were unexpected because past monitoring at WMA T gave no indication that such concentrations existed. Also unexpected was that the maximum concentration was $10 \mathrm{~m}$ below the water table. Previous sampling at well 299-W10-24 suggested that the maximum concentration would be very near the water table. If the profile in Figure 4.18 represents the actual technetium-99 concentration gradient in the well, then concentration gradients can change greatly in the aquifer over distances of about $35 \mathrm{~m}$.

Figure 4.19 also shows the technetium-99 concentration from the routine quarterly sample from well 299-W11-39, located about $9 \mathrm{~m}$ from well 299-W11-25B. The concentration is $15,600 \mathrm{pCi} / \mathrm{L}$ and is a reasonable mix of concentrations in adjacent well 299-W11-25B over the interval of the aquifer screened in well 299-W11-39 especially considering that the lower $\sim 3 \mathrm{~m}$ of the screened part of the aquifer in well 299-W11-39 is not very permeable (Spane et al. 2002).

Well 299-W11-45 was drilled about $80 \mathrm{~m}$ downgradient of well 299-W11-25B. The purpose of the well was to define the horizontal extent of the very high technetium-99 concentrations found in well 299-W11-25B. Groundwater from well 299-W11-45 was sampled every $1.5 \mathrm{~m}$ throughout the upper $56 \mathrm{~m}$ of the aquifer. Figure 4.20 shows the depth distribution of technetium-99 and nitrate in well 299-W11-45. The maximum technetium-99 concentrations found during drilling of well 299-W11-45 was $15,646 \mathrm{pCi} / \mathrm{L}$ at $9.1 \mathrm{~m}$ below the water table. The depths of the maximum concentrations are similar in wells 299-W11-25B and 299-W11-45. Although the technetium-99 concentration is very high in well $299-\mathrm{W} 11-45$, it is much less than the $181,000 \mathrm{pCi} / \mathrm{L}$ found in well 299-W11-25B. This suggests that if the technetium-99 found in the two wells is from the same plume, the front edge of the plume is probably a short distance east of well 299-W11-45.

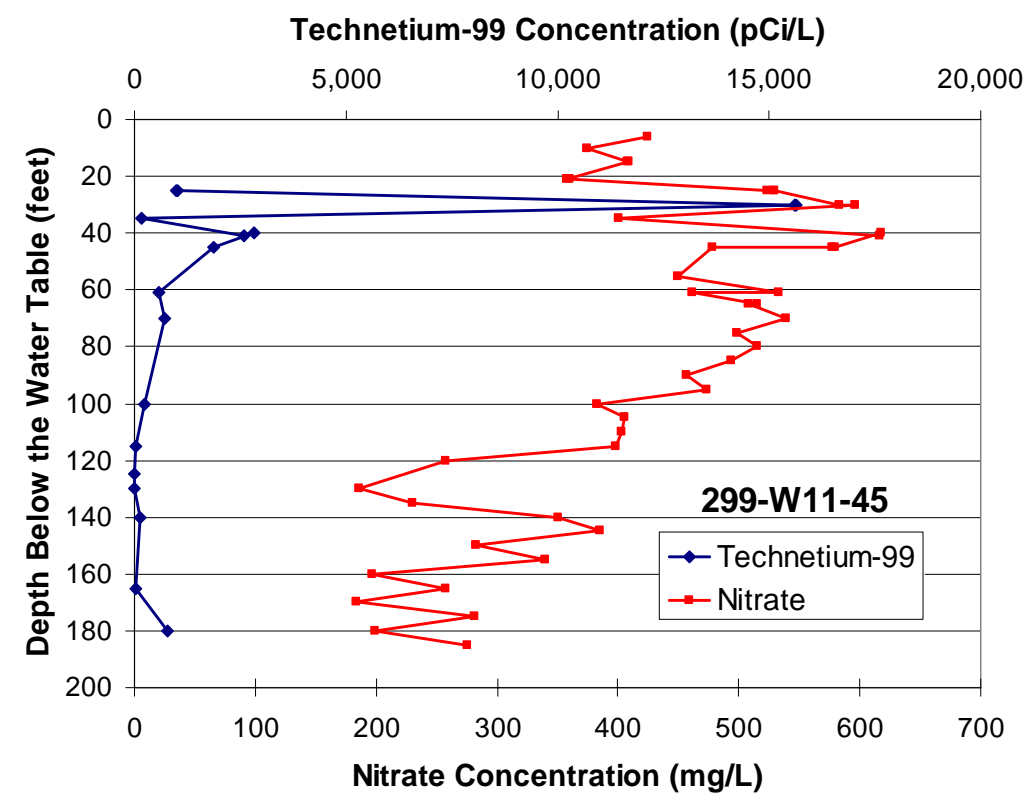

Figure 4.20. Technetium-99 and Nitrate Concentrations in Well 299-W11-45 (modified from Dresel et al. 2006) 
The nitrate and technetium-99 concentrations tracked each other in well 299-W11-25B. This does not seem to be the case in well 299-W11-45 (Figure 4.20). The maximum nitrate concentration (590 mg/L) roughly coincides with the maximum technetium-99 concentration, but the nitrate has a much broader high concentration interval before gradually decreasing. Both wells are located in the regional nitrate plume and, perhaps, the regional nitrate masks the nitrate associated with the technetium- 99 at lower technetium-99 concentrations (and presumably lower associated nitrate concentrations). Alternatively, if the technetium-99 plume in well 299-W11-45 is the same as that in well 299-W11-25B, some of the technetium-99 may be sorbed on the aquifer sediments as the plume traveled from well 299-W11-25B to well 299-W11-45.

\subsubsection{Extent of Contamination at Waste Management Area T - Geographic Distribution}

This section summarizes the spatial distribution of contaminants in groundwater at WMA T. The contaminants of concern are technetium-99, nitrate, tritium, fluoride, carbon tetrachloride, and chromium. Most of the information in this section is from Dresel et al (2006).

Spatial distribution of contaminant concentrations may provide some clues about source areas. Because concentrations change over time, a time-period must be chosen to examine spatial distribution patterns. For this purpose, the most recent data (average of FY 2005 sampling events) were chosen. The data from wells near WMA T are tabulated in Table 4.9. Data were then plotted and inspected for distribution patterns or groupings. Contour maps of contaminant concentrations were drawn to identify spatial patterns that might be indicative of source areas. Those maps are shown in this section. Regional data from Dresel et al. (2006), in addition to the data in Table 4.9, were used to construct the plume maps.

Table 4.9. Average Concentration of Mobile Contaminants in Groundwater in the Vicinity of Waste Management Areas T for FY 2005 (from Dresel et al. 2006)

\begin{tabular}{|c|c|c|c|c|c|c|c|}
\hline Wells $^{(a)}$ & $\begin{array}{c}\mathrm{NO}_{3} \\
(\mathrm{mg} / \mathrm{L})\end{array}$ & $\begin{array}{c}\mathrm{F} \\
(\mathrm{mg} / \mathrm{L})\end{array}$ & $\begin{array}{c}\mathrm{Cr} \\
(\mu \mathrm{g} / \mathrm{L})\end{array}$ & $\begin{array}{c}\mathrm{CCl}_{4} \\
(\mu \mathrm{g} / \mathrm{L})\end{array}$ & $\begin{array}{l}\text { Trichloroethene } \\
(\mu \mathrm{g} / \mathrm{L})\end{array}$ & $\begin{array}{c}\text { Tc-99 } \\
\text { (pCi/L) }\end{array}$ & $\begin{array}{l}\text { Tritium } \\
(\mathrm{pCi} / \mathrm{L})\end{array}$ \\
\hline 299-W10-1 & 130 & 0.22 & 22 & 720 & 5.6 & 74 & 1,500 \\
\hline 299-W10-4 & 3,000 & 3.30 & 670 & 1,400 & 6.0 & 830 & 4,200 \\
\hline 299-W10-8 & 160 & 3.40 & 42 & 320 & 2.4 & 68 & 4,800 \\
\hline 299-W10-22 & 250 & 0.73 & 59 & 590 & 6.0 & 140 & 7,700 \\
\hline 299-W10-23 & 220 & 4.20 & 67 & 800 & 4.8 & 140 & 8,400 \\
\hline 299-W10-24 & 120 & 2.60 & 57 & 54 & ND & 1,400 & 3,500 \\
\hline 299-W10-28 & 1,700 & 1.80 & 280 & NA & NA & 290 & 3,500 \\
\hline 299-W11-12 & 110 & 0.41 & 36 & NA & NA & 190 & 44,000 \\
\hline 299-W11-39 & 120 & 1.10 & 85 & NA & NA & 17,000 & 3,000 \\
\hline 299-W11-40 & 310 & 2.50 & 57 & NA & NA & 1,800 & 12,000 \\
\hline 299-W11-41 & 700 & 2.30 & 160 & 99 & ND & 3,500 & 14,000 \\
\hline 299-W11-42 & 500 & 2.80 & 180 & 900 & 3.8 & 1,900 & 5,300 \\
\hline \multicolumn{8}{|c|}{$\begin{array}{l}\text { (a) All wells screened at the water table. } \\
\text { NA = Not analyzed. } \\
\text { ND }=\text { Not detected }\end{array}$} \\
\hline
\end{tabular}


Carbon tetrachloride is present in the unconfined aquifer beneath most of the 200 West Area (Figure 4.7). The highest average carbon tetrachloride concentration near WMA T in FY 2005 was $1,400 \mu \mathrm{g} / \mathrm{L}$ in well 299-W10-4, south of the WMA. High concentrations were also found north (well 299-W10-23) and east (well 299-W11-42) of the WMA. The carbon tetrachloride and associated trichloroethene are believed to be from pre-1973 waste from the Plutonium Finishing Plant operations and not from WMA T based on plant history.

A tritium plume lies beneath much of the northern half of the 200 West Area (Figure 4.21). The plume geometry suggests that the major tritium source is near the 242-T evaporator, the TY Tank Farm, and nearby cribs (Hartman et al. 2006). Other contributing sources are likely present in the vicinity of the $\mathrm{T}$ Tank Farm and include nearby cribs and trenches and tank leaks.

The highest average tritium concentration near WMA T in 2005 was $44,000 \mathrm{pCi} / \mathrm{L}$ in well 299-W11-12, located at the southeast corner of the WMA. The tritium concentration has generally been decreasing in this area since late 1998. WMA T is not thought to be a major contributor of tritium to groundwater in the area (Dresel et al. 2006).

A regional nitrate plume underlies WMA T and much of the northern part of the $200 \mathrm{West}$ Area and all monitoring wells in the WMA T monitoring network have nitrate concentrations in excess of the $45 \mathrm{mg} / \mathrm{L}$ maximum contaminant level. However, a local nitrate plume sits within the regional nitrate plume and beneath WMA T (Figure 4.22). The highest FY 2005 average nitrate concentrations are at two wells located west and southwest of the WMA: 3,000 mg/L in well 299-W10-4 and 1,700 mg/L in well 299-W10-28. The nitrate concentration began to increase in well 299-W10-4 in about 1997 when the groundwater flow direction changed from northerly to easterly (Figure 4.23). The rate of increase surged in 2001 to a maximum of $3,540 \mathrm{mg} / \mathrm{L}$ in August 2005. The recent surge in nitrate concentration was accompanied by similar concentration increases for most major cations, major anions, and chromium. The most likely source for the nitrate in this area is one or more of the past-practice liquid disposal facilities upgradient of the T Tank Farm such as the 216-T-7 crib and tile field at the west boundary of the T Tank Farm.

A plume map depicting the FY 2005 average chromium concentration in wells near WMA T is shown in Figure 4.24. The highest average chromium concentrations are in wells 299-W10-28 and 299-W10-4 where chromium reached 280 and $670 \mu \mathrm{g} / \mathrm{L}$ respectively. Figure 4.25 shows trend plots for chromium in those wells. Prior to about 1997 when groundwater flow direction was toward the north, several wells on the north side (then downgradient) side of the WMA had relatively high chromium concentrations. Also, prior to 1997, chromium concentrations exceeded $200 \mu \mathrm{g} / \mathrm{L}$ in well 299-W10-1, which was lateral to the tank farm with respect to groundwater flow direction but downgradient of the 216-T-5 trench, the 216-T-7 crib and tile field, and the 216-T-32 crib. After the flow direction changed toward the east in about 1997, chromium concentrations dropped to $<40 \mu \mathrm{g} / \mathrm{L}$ in well 299-W10-1 and decreased in all of the northern wells (Figure 4.26). This suggests that the most likely source for the chromium west and north of WMA $\mathrm{T}$ is one or more of the disposal facilities upgradient of the WMA.

Finally, chromium has exceeded the maximum contaminant level in two downgradient wells, 299-W11-41 (average for FY 2005, $160 \mu \mathrm{g} / \mathrm{L}$ ) and 299-W11-42 (average for FY 2005, $180 \mu \mathrm{g} / \mathrm{L}$ ) since they were drilled in December 2000. These wells are located downgradient of the disposal facilities west of WMA T but appear to be too far away for chromium to have migrated from west of the WMA to the wells since the 1996 change in groundwater flow direction, given a flow rate of $0.025 \mathrm{~m} /$ day. The chromium seen in these wells may be from WMA T. 


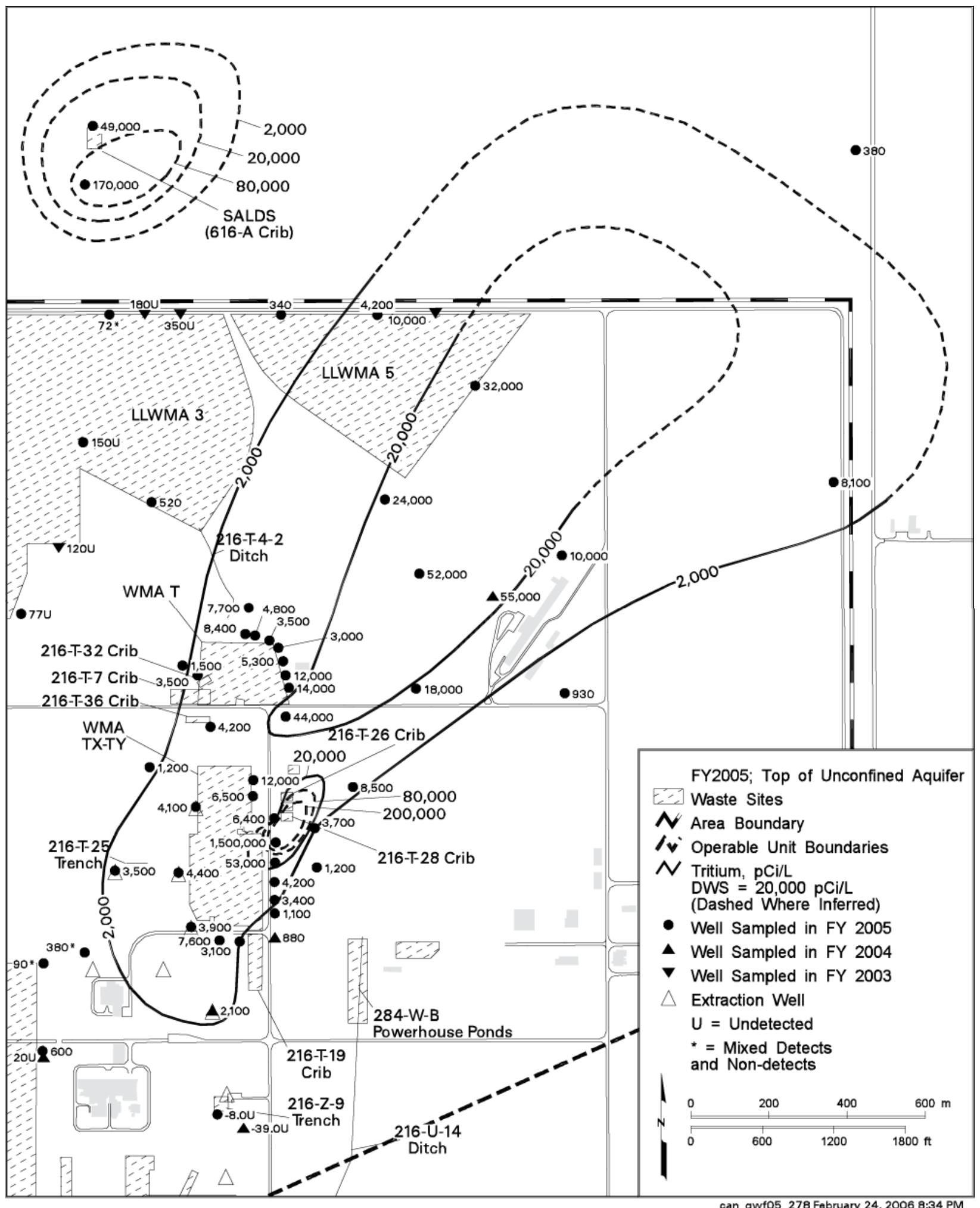

Figure 4.21. Average FY 2005 Concentrations of Tritium in the Northern Part of 200 West Area, Top of the Unconfined Aquifer (from Hartman et al. 2006) 


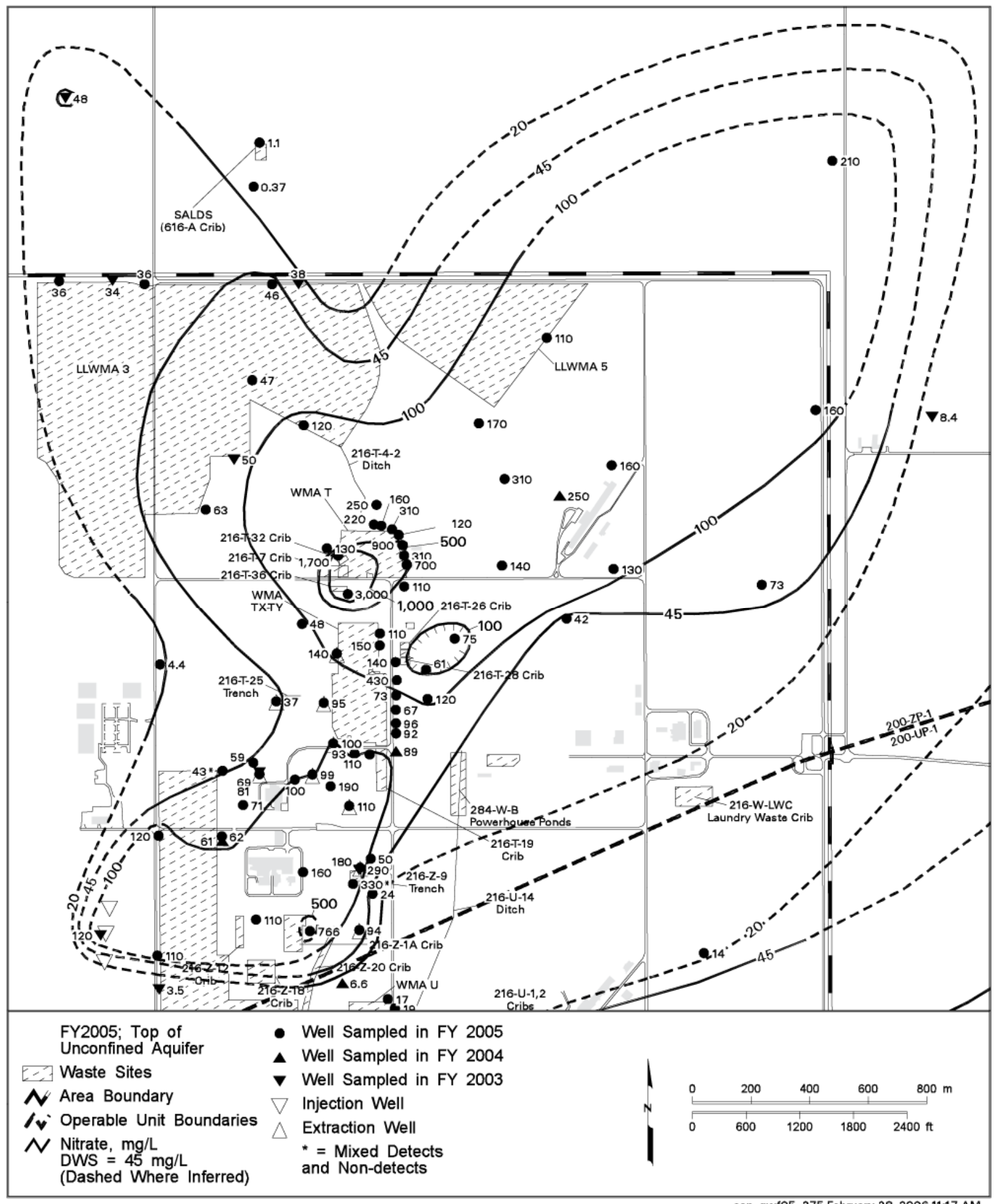

can gwf05 275 February 28, 2006 11:17 AM

Figure 4.22. Average FY 2005 Concentrations of Nitrate in the Northern Part of 200 West Area, Top of the Unconfined Aquifer (from Hartman et al. 2006) 


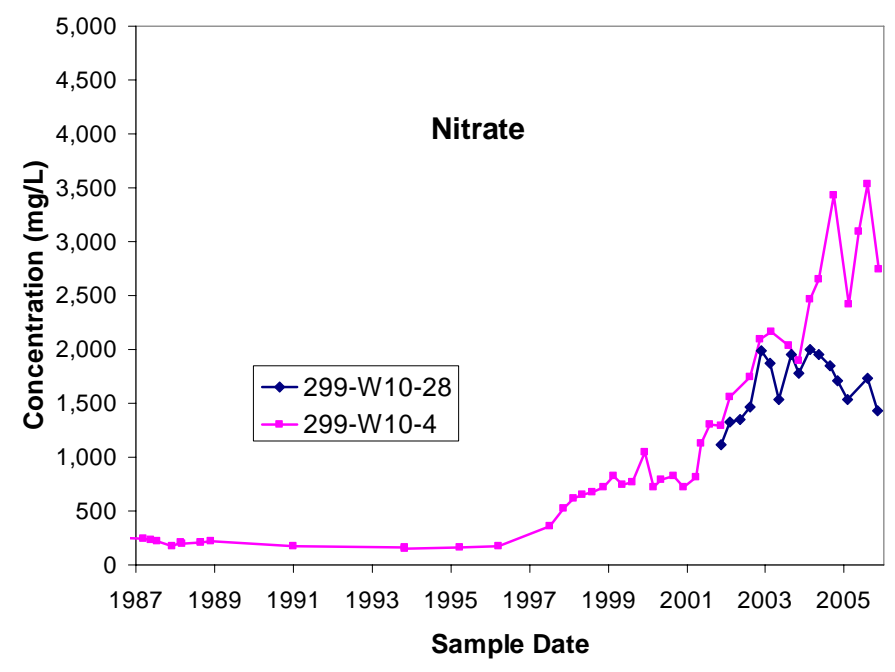

Figure 4.23. Nitrate Concentration versus Time in Wells West and Southwest of Waste Management Area T

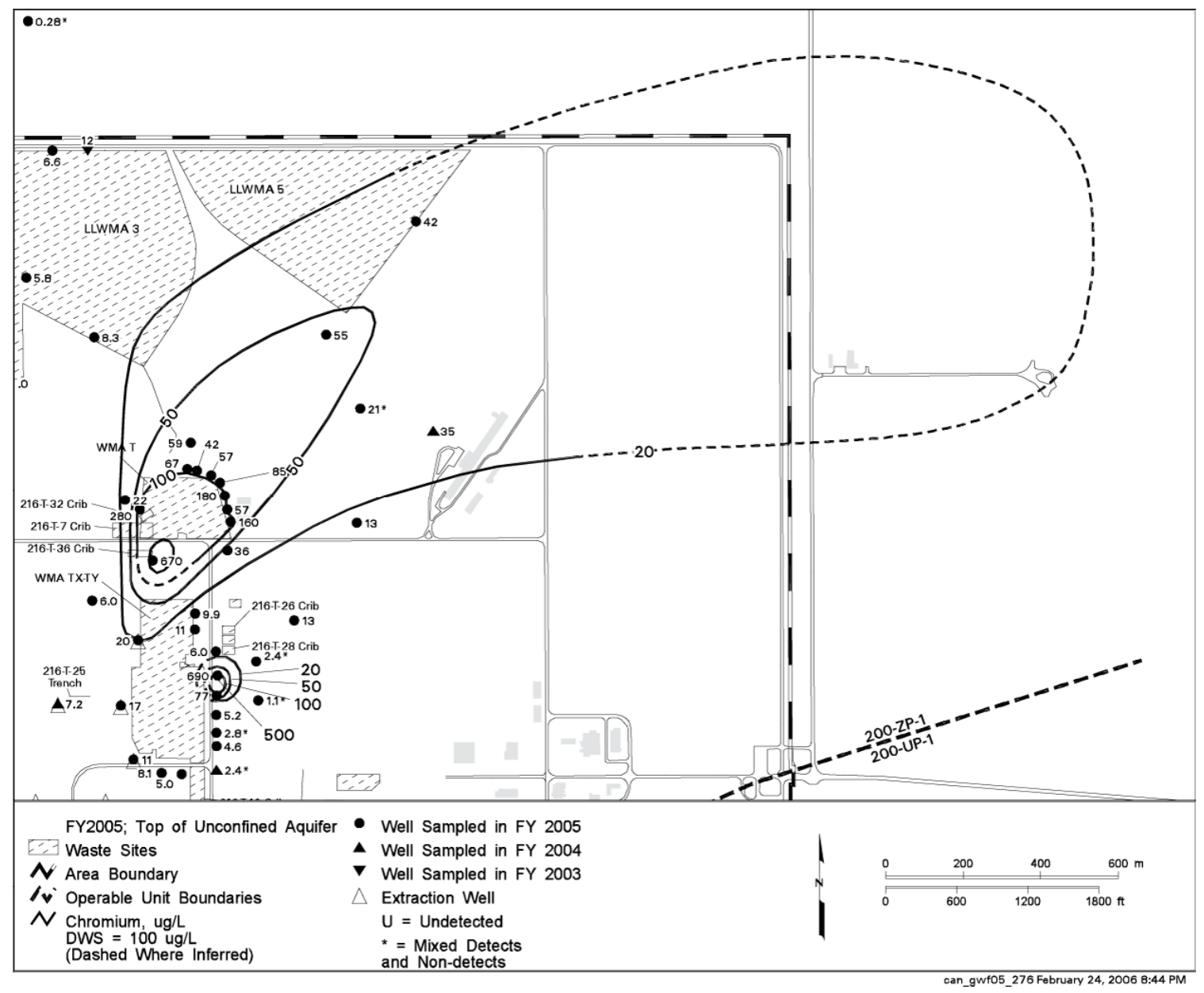

Figure 4.24. Average FY 2005 Chromium Concentrations near Waste Management Areas T and TX-TY, Top of the Unconfined Aquifer (from Hartman et al. 2006) 


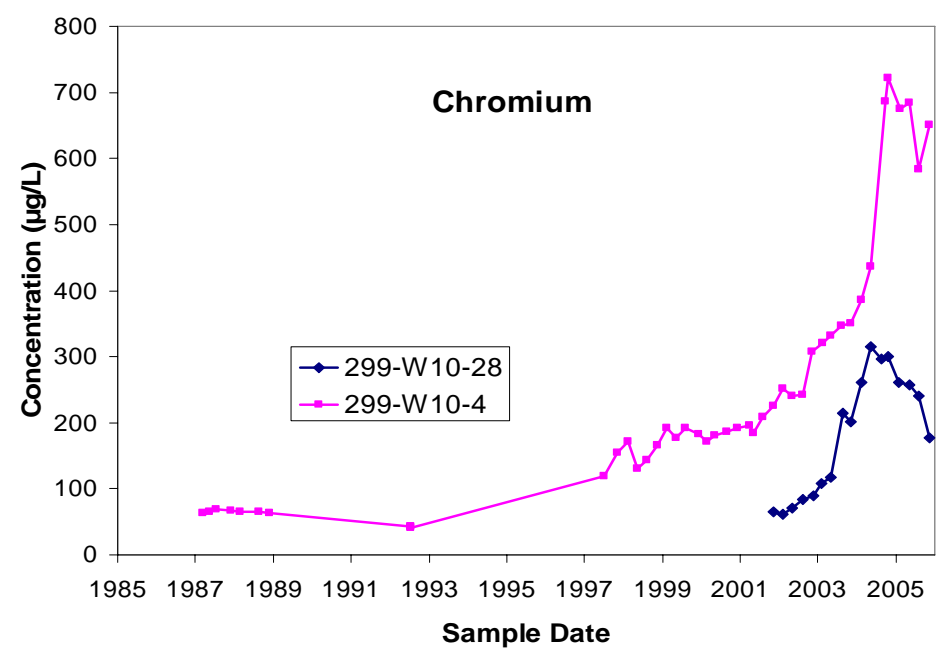

Figure 4.25. Chromium Concentration versus Time for Selected Wells West and Southwest of Waste Management Area T

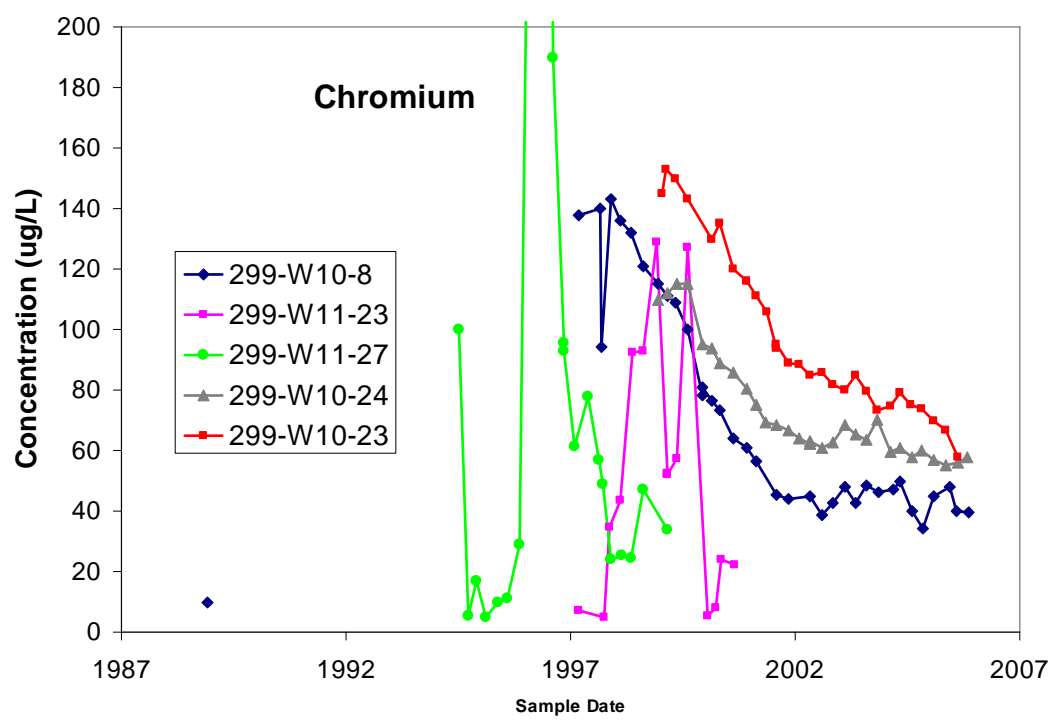

Figure 4.26. Chromium Concentration versus Time for Selected Wells North of Waste Management Area T

A fluoride plume, exceeding the secondary drinking water standard of $2 \mathrm{mg} / \mathrm{L}$, extends from the southwest to the north and east of WMA. The extent of the plume in 2005 remained almost unchanged from previous years. However, the average FY 2005 fluoride concentration exceeded the primary drinking water standard of $4 \mathrm{mg} / \mathrm{L}$ in well 299-W10-23 (average concentration of $4.2 \mathrm{mg} / \mathrm{L}$ ), north of the WMA, whereas no well exceeded the primary drinking water standard during the previous year.

There is a technetium-99 plume located along the east (downgradient) side of WMA T (Figure 4.27). The highest technetium-99 concentrations near the top of the aquifer are along the northeast side of the WMA where the average technetium-99 concentration was $17,440 \mathrm{pCi} / \mathrm{L}$ in FY 2005. This is up somewhat from an average concentration of $16,480 \mathrm{pCi} / \mathrm{L}$ during the previous year. Prior to FY 2005 , the 
technetium-99 concentrations had been increasing regularly in the south three downgradient wells, but concentrations began to drop during 2005 before increasing again during the last part of the year. The most probable source for the technetium-99 is the WMA T.

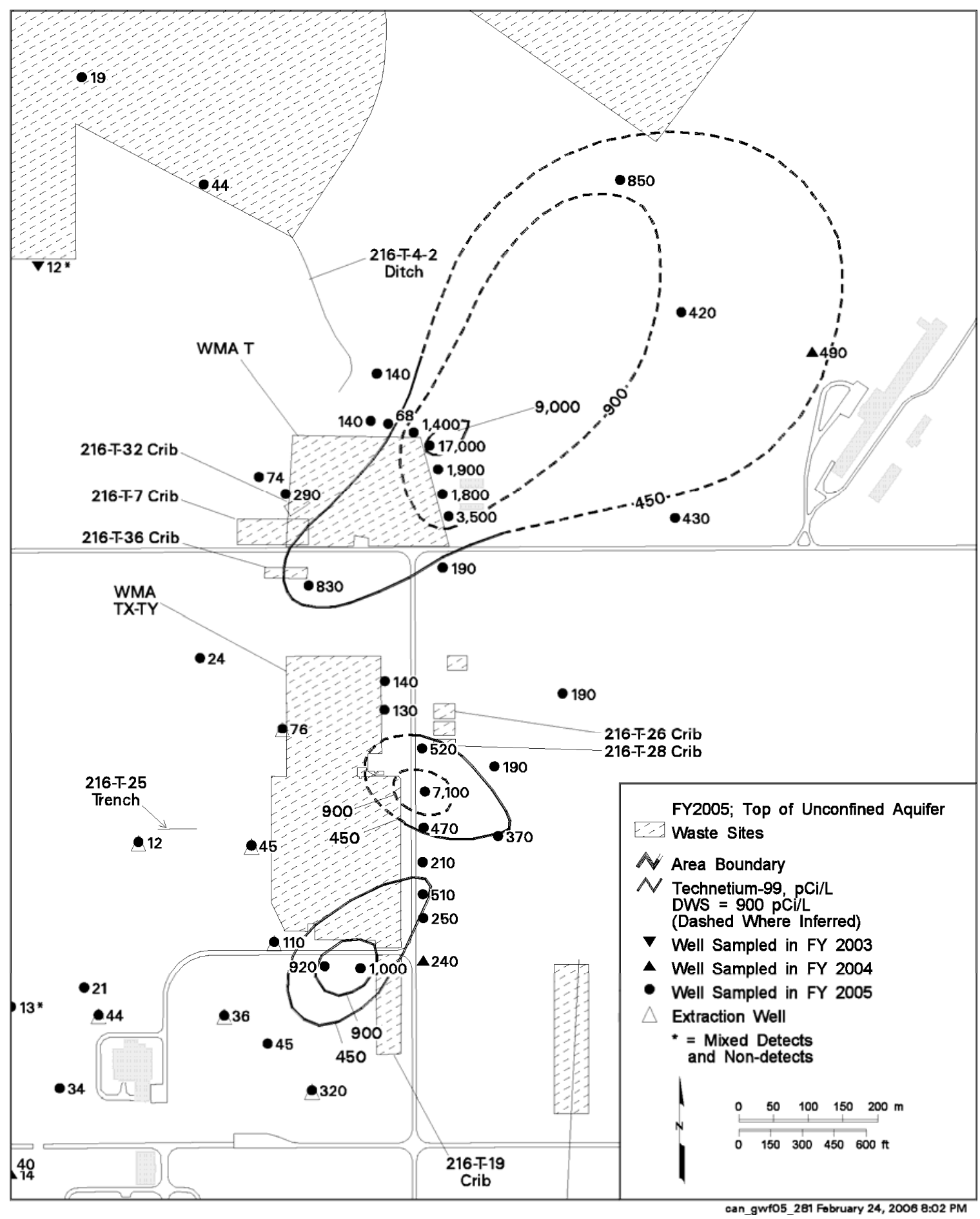

Figure 4.27. Average FY 2005 Technetium-99 Concentrations near Waste Management Areas T and TX-TY, Top of the Unconfined Aquifer (from Hartman et al. 2006) 
The first indication of technetium-99 contamination in groundwater at WMA T was in well 299-W11-27, located at the northeast corner of the T Tank Farm, in late 1995 coincident with the cessation of surface water disposal in the 200 West Area. Concentrations reached a maximum of 21,700 pCi/L in February 1997 (see Figure 4.17) then decreased to 6,000 pCi/L in March 1999. Hodges (1998) suggested that technetium-99 had arrived at well 299-W11-27 by the early 1990s, but was masked by dilution with water from a leaking water line located immediately adjacent to the well. (This is supported by marked increases in specific conductance and in most major cations and anions in late 1995.) The water line carried cooling and ventilation steam condensate, process cooling water, and evaporator condensate (relatively uncontaminated water) until 1995 (DOE 1992a). The increase in technetium-99 began in November 1995, shortly after the water line was taken out of service. The subsequent decrease in technetium-99 in well 299-W11-27 since 1997 may have been a result of changing groundwater flow direction.

Technetium-99 began to increase in well 299-W11-23, located east of well 299-W11-27, in November 1997 coincident with the change in groundwater flow to a more easterly direction. It increased to a high of 8,540 pCi/L in November 1998 (see Figure 4.17). Subsequently, technetium-99 values fluctuated between 7,110 and $840 \mathrm{pCi} / \mathrm{L}$. The last sample from this well, taken in December 2000, indicated a technetium- 99 concentration of $4,470 \mathrm{pCi} / \mathrm{L}$. The most plausible explanation for the 1997 arrival of the contaminant plume at well 299-W11-23 is easterly groundwater flow that brought contamination from well 299-W11-27 to well 299-W11-23.

In early 2002, technetium-99 concentrations began to increase in well 299-W11-42, south of well 299-W11-39, and in well 299-11-41, south of 299-W11-42. Apparently, the technetium-99 contamination that was detected in the northeast corner of WMA T is spreading southward along the east and downgradient side of the WMA. Alternatively, a second technetium-99 source may be responsible for the increasing technetium-99 in the wells along the southern part of the east WMA boundary.

\subsubsection{Comparison of Groundwater, Vadose Zone Pore Water, and Tank Leak Chemical Compositions at Waste Management Area T}

This section compares the chemical composition of groundwater with the composition of the vadose zone pore water and with the composition of tank fluids and discharges to nearby cribs in an attempt to more accurately pinpoint specific sources for the contamination in the groundwater at WMA T.

The earliest evidence of groundwater contamination around WMA T as found in the HEIS database is high levels of gross beta in wells located at the cribs and trenches west of WMA T (Figure 4.28). By 1955 and 1956, levels of gross beta had reached values in excess of 1,000,000 pCi/L in well 299-W10-2, located about $20 \mathrm{~m}$ south of the 216-T-7 tile field. The gross beta contamination was accompanied by nitrate levels in excess of $3,000 \mathrm{mg} / \mathrm{L}$ in the general area and up to $6,900 \mathrm{mg} / \mathrm{L}$ in well $299-\mathrm{W} 10-2$. It is possible that gross beta and nitrate groundwater contamination pre-date 1955, but there are no available analyses.

The oldest available analysis for cobalt-60 in groundwater in the area is from well 299-W10-4 in 1957; it showed that the cobalt-60 concentration was $2000 \mathrm{pCi} / \mathrm{L}$ at that time. Cobalt- 60 was later found in well 299-W10-2 in 1969 at a concentration of $680 \mathrm{pCi} / \mathrm{L}$. Finally, ruthenium-106 was first noted in groundwater in 1972 at wells 299-W10-2 and 299-W10-4 at concentrations of $140 \mathrm{pCi} / \mathrm{L}$ and $400 \mathrm{pCi} / \mathrm{L}$, respectively. 


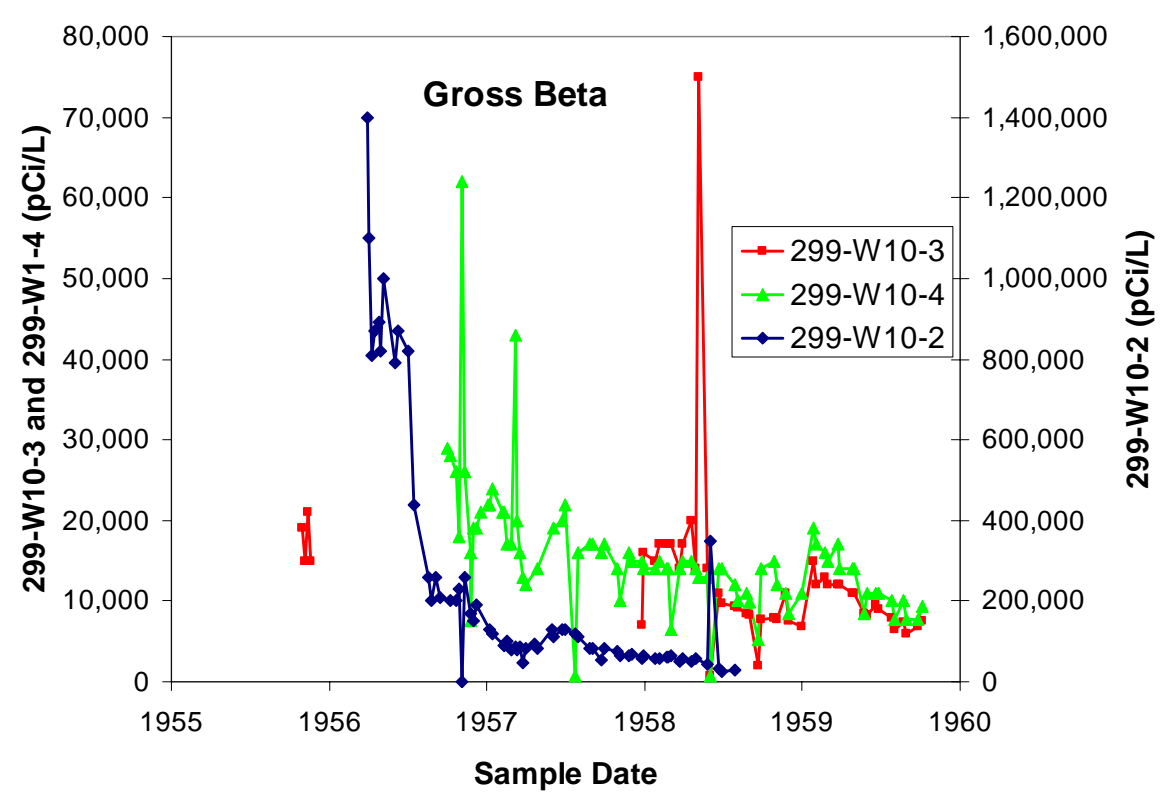

Figure 4.28. Gross Beta Contamination in Wells West and Southwest of Waste Management Area T. Note the large difference in concentration scale for well 299-W10-2. (Well 299-W10-3 was located inside the tank farm fence and west of tanks 109 and 112 until it was decommissioned in 2002).

Two things should be remembered about these early analyses. First, they are the oldest available analyses and do not represent the first arrival of contamination in groundwater in the area. Second, the concentrations should be considered approximate since detection limits and analytical accuracies have improved through the years.

This early groundwater contamination pre-dates any reported tank leak from the T Tank Farm. The most likely source for this contamination is either the 216-T-7 crib and tile field, which operated between 1947 and 1955 and received 110,000,000 L of effluent, or the 216-T-32 crib, which operated between 1946 and 1952 and received 29,000,000 L of waste. Groundwater at that time was flowing toward the south from the disposal facilities toward the contaminated wells.

Groundwater contamination was first noted north of WMA T in well 299-W10-8 in October 1973, when ruthenium-106 was found at a concentration of $430 \mathrm{pCi} / \mathrm{L}$ and quickly increased to $1,100 \mathrm{pCi} / \mathrm{L}$ in March 1974. Cobalt-60 was first noted in the well in early 1974 at $20 \mathrm{pCi} / \mathrm{L}$. Groundwater had shifted flow direction from southerly to northeasterly in about 1957. This placed well 299-W10-8 downgradient of the 216-T-7 tile field and 216-T-32 crib. Well 299-W10-8 is about 150 m northeast of 216-T-32 crib and $170 \mathrm{~m}$ northeast of the 216-T-7 tile field. Given a typical groundwater flow rate of $0.02 \mathrm{~m} / \mathrm{day}$, contamination could have traveled about $130 \mathrm{~m}$ from the disposal facilities to the contaminated well between January 1956 and October 1973. It is possible that the groundwater flow rate was greater than $0.02 \mathrm{~m} /$ day in the $1960 \mathrm{~s}$ driven by the groundwater mound under U Pond. A groundwater velocity of $0.03 \mathrm{~m} /$ day would allow for transport of contaminants from the 216-T-7 tile field well beyond well 299-W10-8 by late 1973 (assuming no contaminant retardation). Clearly, however, a groundwater flow rate of $0.03 \mathrm{~m} /$ day is not sufficient to drive contaminants from the vicinity of tank T-106 to well 
299-W10-8, a distance of about $105 \mathrm{~m}$, in the 4 month time period between the reported tank leak in June 1973 and the first detection of ruthenium-106 at the well.

To determine whether tank leak T-106 has affected groundwater quality, one or more components of the leak need to be detected in groundwater. Estimates of the leak composition are available (Corbin et al. 2005) but, unfortunately, most major, mobile components in the tank leak for which we have groundwater data, are also major mobile components in effluents disposed to the nearby cribs and trenches.

In 2004, the technetium-99/nitrate concentration ratios in groundwater were compared to the estimated concentration ratios of single-shell tank leaks from tanks T-101 and T-106 and to the concentration ratios of some cribs and trenches in the area of WMA T (Hartman et al. 2005; Serne et al. 2004b). Figure 4.29 shows the results of that comparison for selected wells. The figure suggests that, after about 1995, groundwater in the northeast part of the WMA (Figure 4.29C) was impacted by tank waste. However, groundwater in the southwest, west, north, and east parts of the WMA (Figures 4.29A, $\mathrm{B}$, and D) does not appear to have been influenced to any great extent by tank waste. Recent high resolution resistivity surveys (Rucker et al. 2006a) suggest that the specific retention trenches 216-T-14 through 216-T-17 have not impacted groundwater and this was supported by analysis of vadose zone samples from well 299-W11-45. Therefore, the apparent agreement between the groundwater ratios and the estimated trench ratios on Figure 4.29 is likely coincidental.

Figure 4.30A shows the technetium-99/nitrate composition ratios estimated for the two tank leaks with ratios measured from vadose zone pore water associated with the tank T-106 leak (Serne et al. 2004b). Figure 4.30B compares the technetium-99/nitrate ratios estimated for two tank leaks with the compositions of groundwater samples from wells 299-W11-25B and 299-W11-45. For well 299-W11-25B, the well with very high technetium-99 concentration located just east of the WMA, the technetium-99/nitrate concentrations ratios are within the same order of magnitude range as are the estimated tank leak ratios and, more importantly, the sampled pore water. The technetium-99/nitrate ratios for well 299-W11-45, located about 80 m downgradient of well 299-W11-25B, are several orders of magnitude less than the estimated tank leaks. This may be the result of high nitrate from wastes disposed to cribs upgradient of the WMA mixing with the groundwater found in well 299-W11-25B.

\subsubsection{Background Groundwater Composition Beneath Waste Management Area TX-TY}

The composition of the upgradient groundwater for the single-shell tank WMA TX-TY is shown in Table 4.10 and Figure 4.31. The data in the table are the average FY 2005 concentrations in each upgradient well at the WMA. All data are available on the CD available with Hartman et al. (2006). Data for the metals are from filtered samples; all other data are from unfiltered samples. Data flagged as suspect in the Hanford Environmental Information System database have been excluded from the calculated averages. The upgradient wells at WMA TX-TY were converted to extraction wells for the 200-ZP-1 pump-and-treat system in July 2005. This is expected to change the direction of groundwater flow beneath the WMA in the future and change the groundwater chemistry in samples collected from the wells. Indeed, the technetium-99 concentration in well 299-W15-765 began increasing at the end of FY 2005. 

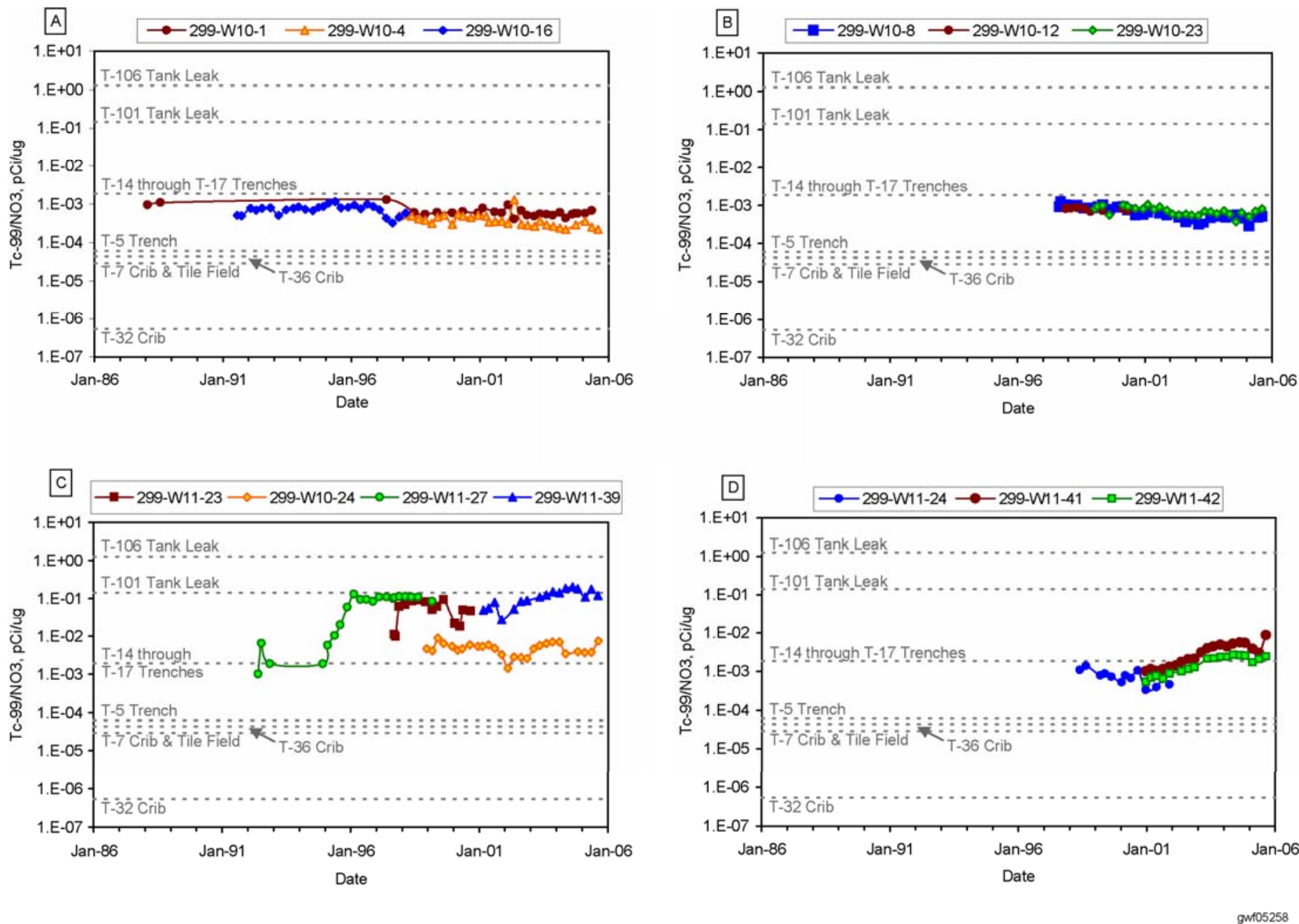

Figure 4.29. Technetium-99/Nitrate Composition Ratios for Groundwater and Estimated Tank Leaks at Waste Management Area T. (A) Wells west and southwest of the waste management area; (B) Northern wells; (C) Northeastern wells; and (D) Eastern wells (modified from Dresel et al. 2006). Note that the units on the ordinate are $\mathrm{pCi} / \mu \mathrm{g}$. 

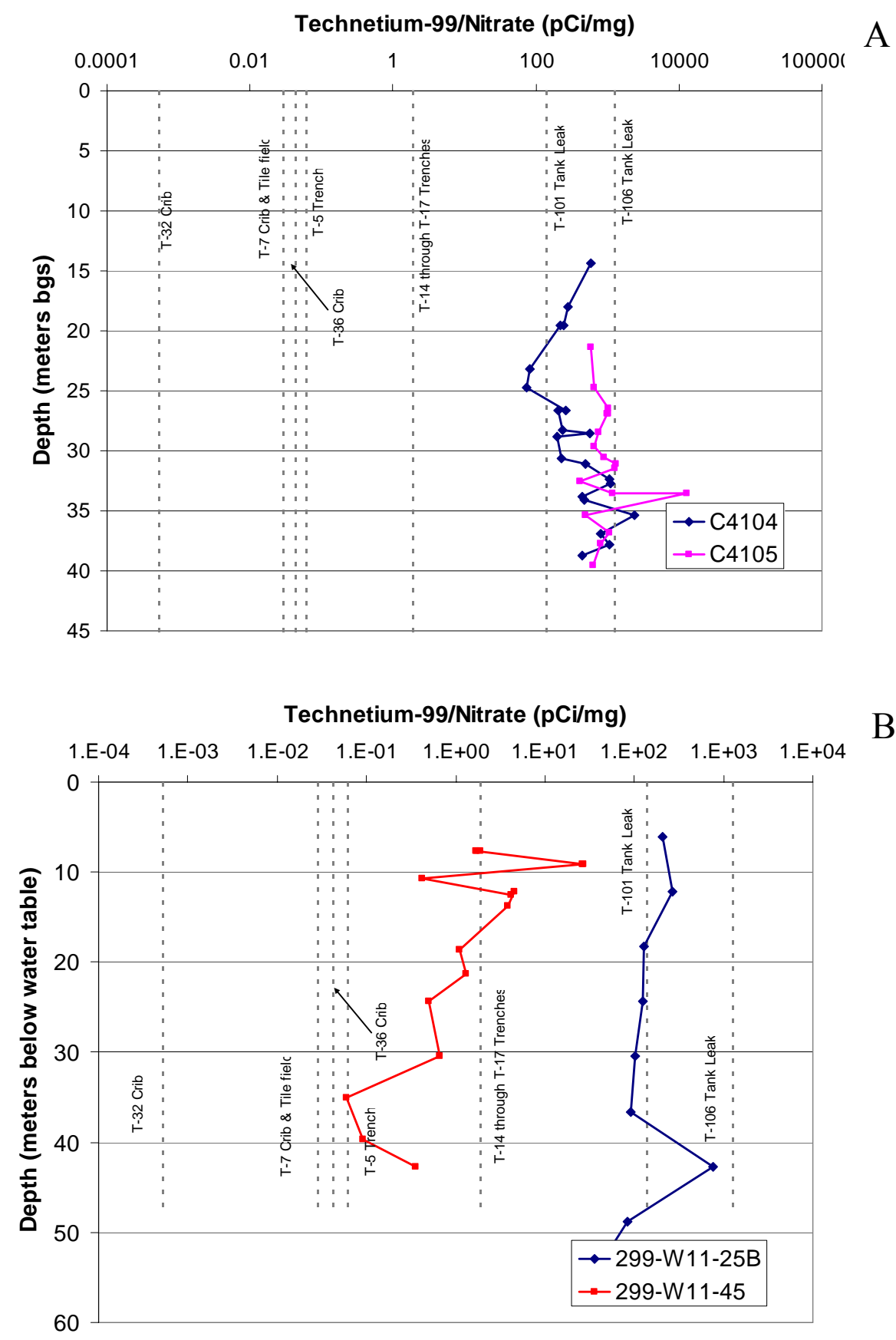

Figure 4.30. Technetium-99/Nitrate Composition Ratios for (A) Pore Water at the Tank T-106 Leak and (B) Pumped Samples from Two New Monitoring Wells at Waste Management Area T (modified from Horton 2006) 
Table 4.10. Average FY 2005 Groundwater Composition in Waste Management Area TX-TY Upgradient Wells

\begin{tabular}{||l|c|c||}
\hline \multirow{2}{*}{\multicolumn{1}{|c|}{ Constituent (units) }} & \multicolumn{2}{|c||}{ Concentration } \\
\cline { 2 - 3 } & Well 299-W15-40 & Well 299-W15-765 \\
\hline \hline Alkalinity $(\mu \mathrm{g} / \mathrm{L})$ & 115,000 & 112,800 \\
\hline Calcium $(\mu \mathrm{g} / \mathrm{L})$ & 59,500 & 68,280 \\
\hline Carbon tetrachloride $(\mu \mathrm{g} / \mathrm{L})$ & 2,291 & Not analyzed \\
\hline Cesium-137 $(\mathrm{pCi} / \mathrm{L})$ & Not analyzed & 18.5 \\
\hline Chloride $(\mathrm{mg} / \mathrm{L})$ & 20.96 & 24 \\
\hline Chloroform $(\mu \mathrm{g} / \mathrm{L})$ & 15.1 & 20.32 \\
\hline Chromium $(\mu \mathrm{g} / \mathrm{L})$ & 17.44 & Not analyzed \\
\hline Cobalt-60 $(\mathrm{pCi} / \mathrm{L})$ & Not analyzed & 0.29 \\
\hline Fluoride $(\mathrm{mg} / \mathrm{L})$ & 0.24 & 2.12 \\
\hline Gross alpha $(\mathrm{pCi} / \mathrm{L})$ & 1.87 & 16.5 \\
\hline Gross beta $(\mathrm{pCi} / \mathrm{L})$ & 30.4 & Not detected \\
\hline Iodine-129 $(\mathrm{pCi} / \mathrm{L})$ & Not analyzed & 23.2 \\
\hline Iron $(\mu \mathrm{g} / \mathrm{L})$ & 31.3 & 136.2 \\
\hline Magnesium $(\mu \mathrm{g} / \mathrm{L})$ & 19,320 & 7.7 \\
\hline Nitrate $(\mathrm{mg} / \mathrm{L})$ & 94.6 & 18,460 \\
\hline pH Measurement $(\mathrm{pH}$ units $)$ & 7.6 & 631 \\
\hline Sodium $(\mu \mathrm{g} / \mathrm{L})$ & 16,120 & Not analyzed \\
\hline Specific Conductance $(\mu \mathrm{S} / \mathrm{cm})$ & 550 & 43.14 \\
\hline Strontium-90 $(\mathrm{pCi} / \mathrm{L})$ & Not analyzed & 75.74 \\
\hline Sulfate $(\mathrm{mg} / \mathrm{L})$ & 43.4 & 13 \\
\hline Technetium-99 $(\mathrm{pCi} / \mathrm{L})$ & 44.96 & 4,116 \\
\hline Trichloroethene $(\mu \mathrm{g} / \mathrm{L})$ & 10.0 & \\
\hline Tritium $(\mathrm{pCi} / \mathrm{L})$ & 4,410 & \\
\hline \hline
\end{tabular}

Upgradient groundwater at single-shell tank WMA TX-TY is similar to Hanford Site background and the Hanford Site Groundwater Performance Assessment Project's quality control wells (Figures 4.1 and 4.2) except for higher calcium, magnesium, and nitrate concentrations. Upgradient groundwater at this WMA is a calcium-magnesium-bicarbonate-nitrate water. The upgradient groundwater also contains elevated carbon tetrachloride, chloroform, trichloroethene, technetium-99, and tritium. Charge balances for the wells shown in Figure 4.31 are: $-1.1 \%$ for well 299-W15-40 and $+4.6 \%$ for well 299-W15-765.

\subsubsection{Groundwater Contamination Beneath Waste Management Area TX-TY}

This section discusses the current and historical groundwater contamination at WMA TX-TY. The evaluation of contamination includes descriptions of the types and concentrations of contaminants in the groundwater and the extent of contamination in the area. Most of the information in this section is taken from Dresel et al. (2006) and Serne et al. (2004a).

Groundwater in the WMA TX-TY area is routinely monitored for RCRA and Atomic Energy Act purposes. The objective of RCRA monitoring at WMA TX-TY is to assess the nature and extent of groundwater contamination with hazardous constituents and determine their rate of movement in the aquifer. Groundwater monitoring under the Atomic Energy Act tracks radionuclides at the WMA and surrounding vicinity. 

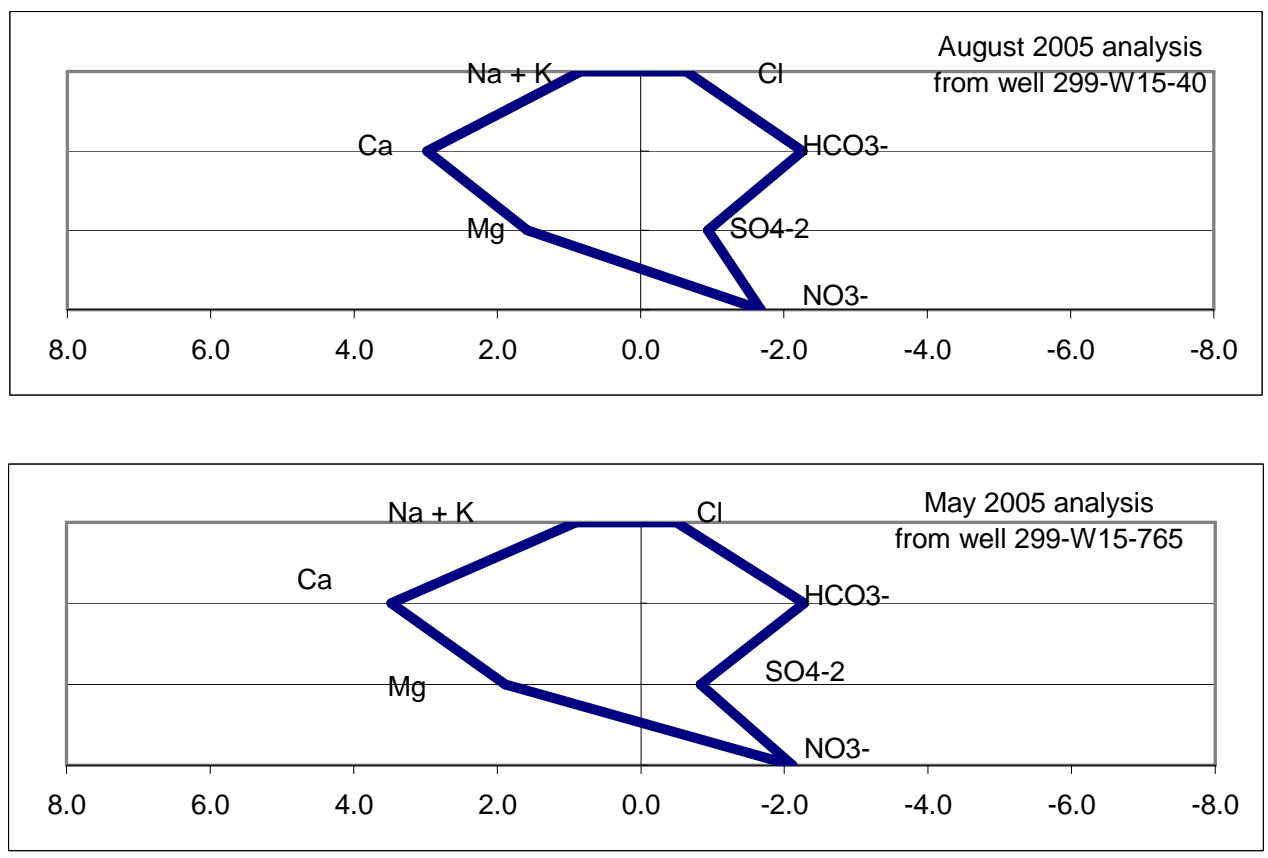

Figure 4.31. Major Cation and Anion Composition of Groundwater from Upgradient Wells at WMA TX-TY. Units for the X-axis are milliequivalents/liter with cations on the left and anions on the right.

Groundwater at the TX and TY Tank Farms contains elevated concentrations of carbon tetrachloride, chromium, iodine-129, nitrate, technetium-99, and tritium. This contamination is a result of mixing of wastes from a number of past waste-disposal activities, including the disposal of tank waste process water, and steam condensate at nearby cribs and trenches, disposal of plutonium processing waste at cribs and trenches associated with the Plutonium Finishing Plant, and possibly leaks from single-shell tanks and transfer lines within the TX and TY Tank Farms.

\subsubsection{Extent of Contamination at Waste Management Area TX-TY - Depth Distribution}

The most recent source of information giving indications of contaminant depth distribution at WMA TX-TY is depth-discrete sampling in the aquifer during drilling of well 299-W14-11. Previous indications of vertical concentration gradients include depth-discrete sampling of wells 299-W14-14 (Horton and Hodges 1999), 299-W14-19, and 299-W15-44 (Horton 2003), comparisons of groundwater chemistry in older wells with their adjacent replacement wells (Horton 2002), and depth profiles of specific conductance in the screened interval of existing wells (Serne et al. 2004a). These recent studies provided new insights into the occurrence and nature of groundwater contamination in the WMA TX-TY area.

Specific Conductance Profiling. Specific conductance measurements were taken at 0.5- to 1-m intervals throughout the screened intervals of three groundwater monitoring wells around the TX and TY Tank Farms in 2002. Significant differences in specific conductance with depth were found in one of these wells (299-W14-13). The other two wells (299-W15-41, and 299-W15-763) showed no variation of specific conductance with depth. 
Specific conductance versus depth measured in the screened interval of well 299-W14-13, a downgradient well at WMA TX-TY, is shown in Figure 4.32. Specific conductance in this well has a maximum at about 1 to $1.5 \mathrm{~m}$ below the water table, decreases rapidly between 1.5 and $4 \mathrm{~m}$, and then decreases only slightly with increasing depth to the bottom of the screened interval.

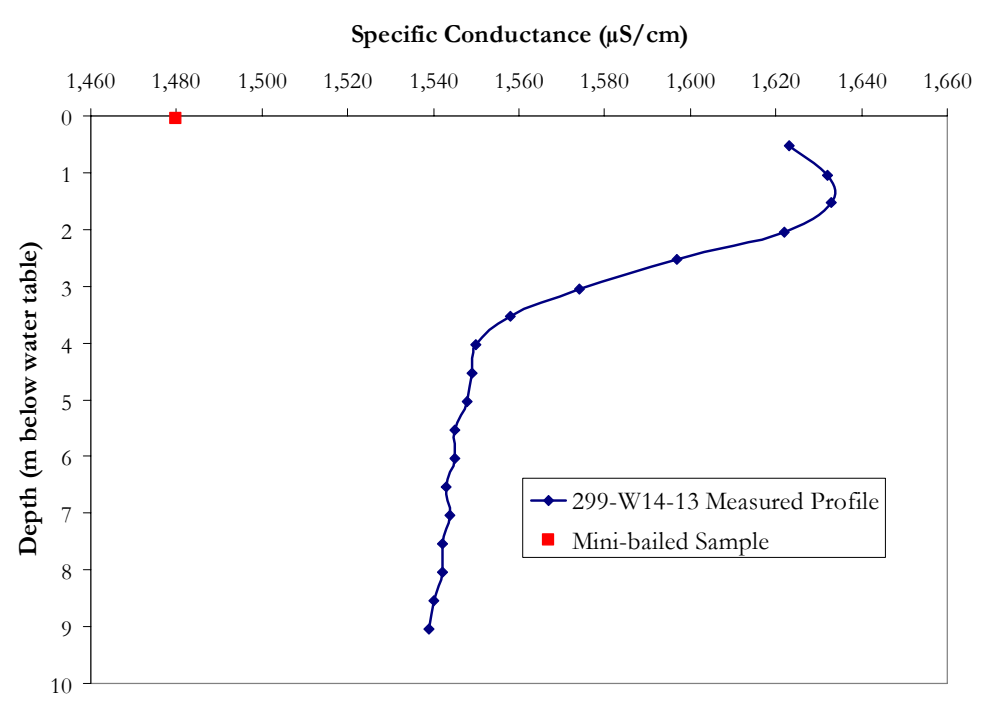

Figure 4.32. Specific Conductance versus Depth in Well 299-W14-13 (from Serne et al. 2004a)

Interpreting the contaminant distribution in well 299-W14-13 is very difficult because groundwater at the well contains high concentrations of several contaminants that show different vertical concentration profiles and probably come from several sources in the area. These variations are discussed later in this section. For now, the specific conductance indicates that there are concentration gradients in the screened interval of well 299-W14-13 and that the highest conductance, which probably reflects the highest nitrate concentration, occurs between 0.5 and $2 \mathrm{~m}$ beneath the water table.

Comparison of Chemical Data from Old and New Wells. Replacement wells, when located immediately adjacent to older wells, offer an opportunity to look for vertical variation within the upper part of the aquifer. Data from three well pairs at WMA TX-TY suggest vertical stratification of contaminants in the upper part of the aquifer. In each case, the old well and its replacement well are separated by only a few meters. In addition, in each case, the older well was last sampled when there was a fraction of a meter of water within the screened interval and the replacement well was sampled with a pump placed at least $3 \mathrm{~m}$ below the water table within a $10.7-\mathrm{m}$ screened interval. Thus, the last samples from the old wells represent the top of the aquifer and the samples from the replacement wells represent a composite of water pumped from the length of the screened interval that includes both water from near the water table and water from $10.7 \mathrm{~m}$ below the water table.

Well 299-W14-13 is at the northeast corner of the TX Tank Farm on the downgradient side of WMA TX-TY (Figure 2.3). This well currently has the highest concentration of technetium-99, tritium, iodine-129, fluoride, nitrate, and chromium of any well in WMA TX-TY monitoring network. Well 299-W14-13 is the replacement well for well 299-W14-12 that went dry in early 1999. The two wells are located $\sim 3$ m apart. The last sampling of well 299-W14-12 took place in January 1999 and sampling of replacement well 299-W14-13 started in December 1998, allowing a sampling overlap between the two 
adjacent wells. The last samples collected from well 299-W14-12 represent the top of the aquifer. The samples collected from well 299-W14-13 represent water throughout the screened interval, which extends from the water table to $10 \mathrm{~m}$ below the water table. The pump intake is at $4.8 \mathrm{~m}$ below the water table.

Trend plots for several key constituents are shown in the series of Figures 4.33 to 4.35. The results for technetium-99 are particularly interesting (Figure 4.33). The concentration of technetium-99 in the last sample from well $299-\mathrm{W} 14-12$ was $\sim 6,000 \mathrm{pCi} / \mathrm{L}$. This represented the concentration of technetium-99 at the top of the aquifer in January 1999. The sample from replacement well 299-W14-13, taken about the same time, contained $\sim 2,500 \mathrm{pCi} / \mathrm{L}$ technetium- 99 . That sample represented the technetium- 99 concentration throughout the upper $10 \mathrm{~m}$ of the aquifer. The conclusion is that technetium- 99 existed at the top of the aquifer at about $6,000 \mathrm{pCi} / \mathrm{L}$ and the concentration decreased deeper in the aquifer. The $2,500 \mathrm{pCi} / \mathrm{L}$ technetium-99 value from well $299-\mathrm{W} 14-13$ is a mixture of the relatively concentrated technetium-99 near the water table with more dilute groundwater from deeper in the screened interval.

Technetium-99 in the area of well 299-W14-12 began decreasing from a maximum of $\sim 13,500 \mathrm{pCi} / \mathrm{L}$ in 1993 and continued to decrease until about January 1997. At that time, technetium-99 began to increase and reached 6,000 pCi/L in January 1999 when the well went dry. The increasing technetium-99 trend was continued in the replacement well (although offset to lower concentrations) until early 2000 when technetium- 99 concentrations climbed to $\sim 8,000 \mathrm{pCi} / \mathrm{L}$. In early 2000 , technetium-99 began to decrease and dropped to about $3,300 \mathrm{pCi} / \mathrm{L}$ in early 2001 at which time the concentration began to increase again. The latest increase continued until late 2004 and reached 9,080 pCi/L.

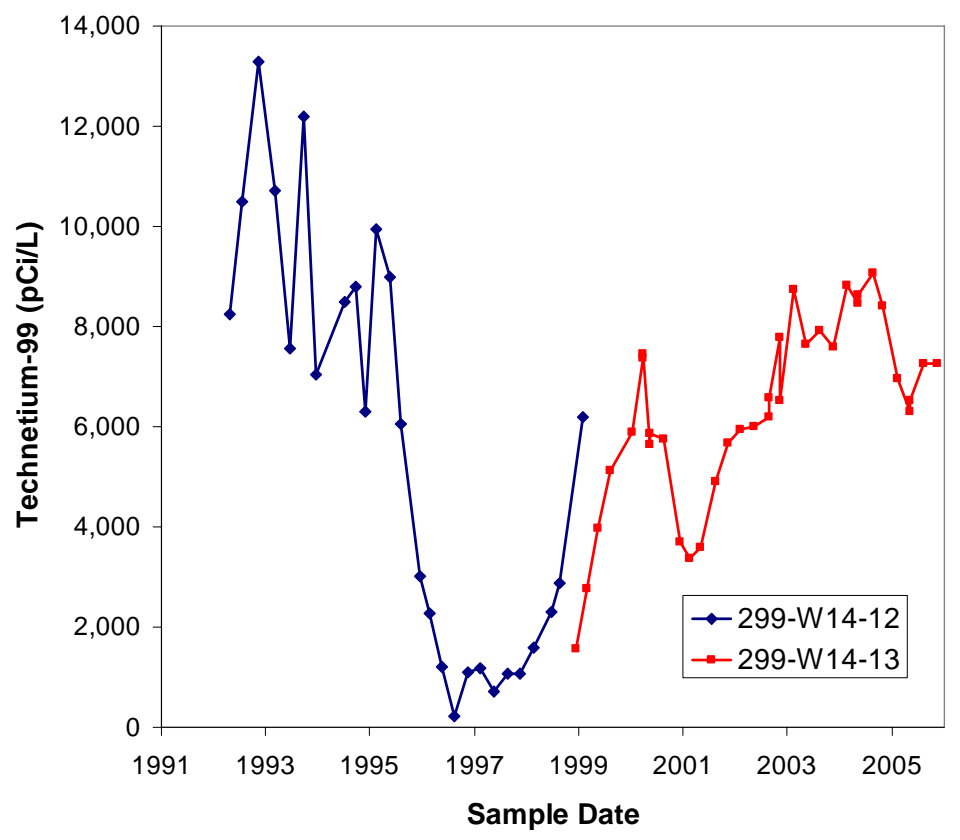

Figure 4.33. Technetium-99 Concentration in Wells 299-W14-12 and 299-W14-13 in Waste Management Area TX-TY 


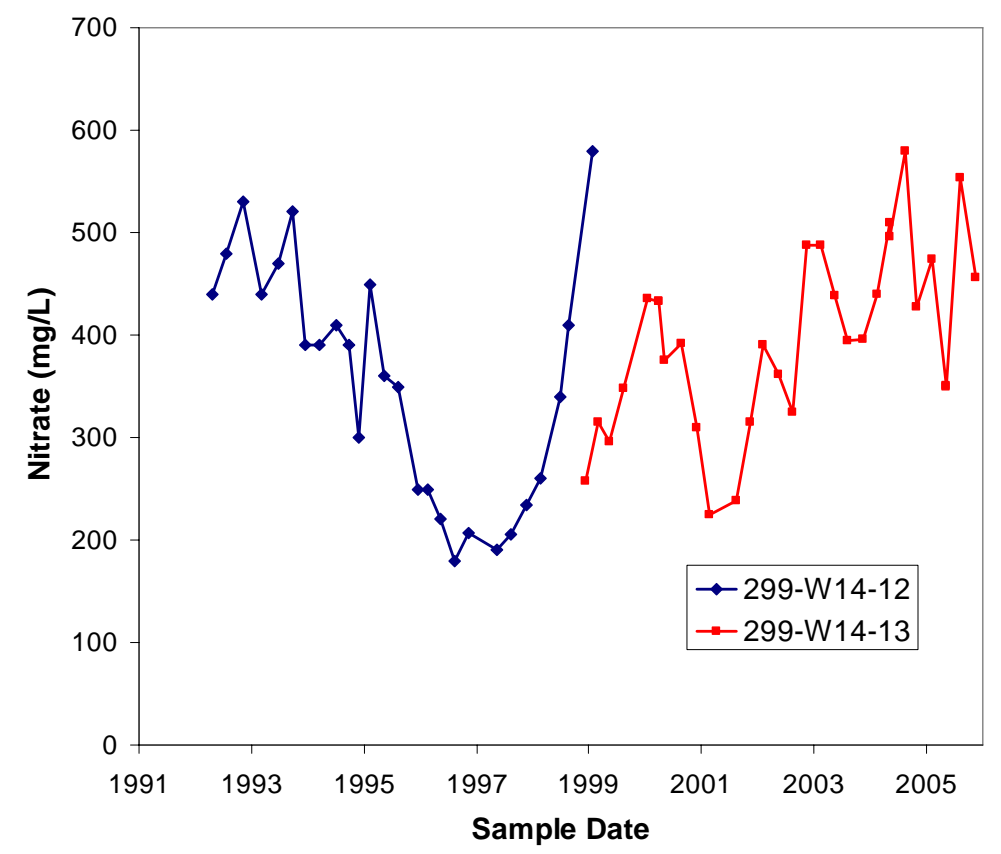

Figure 4.34. Nitrate Concentrations in Wells 299-W14-12 and 299-W14-13 at Waste Management Area TX-TY

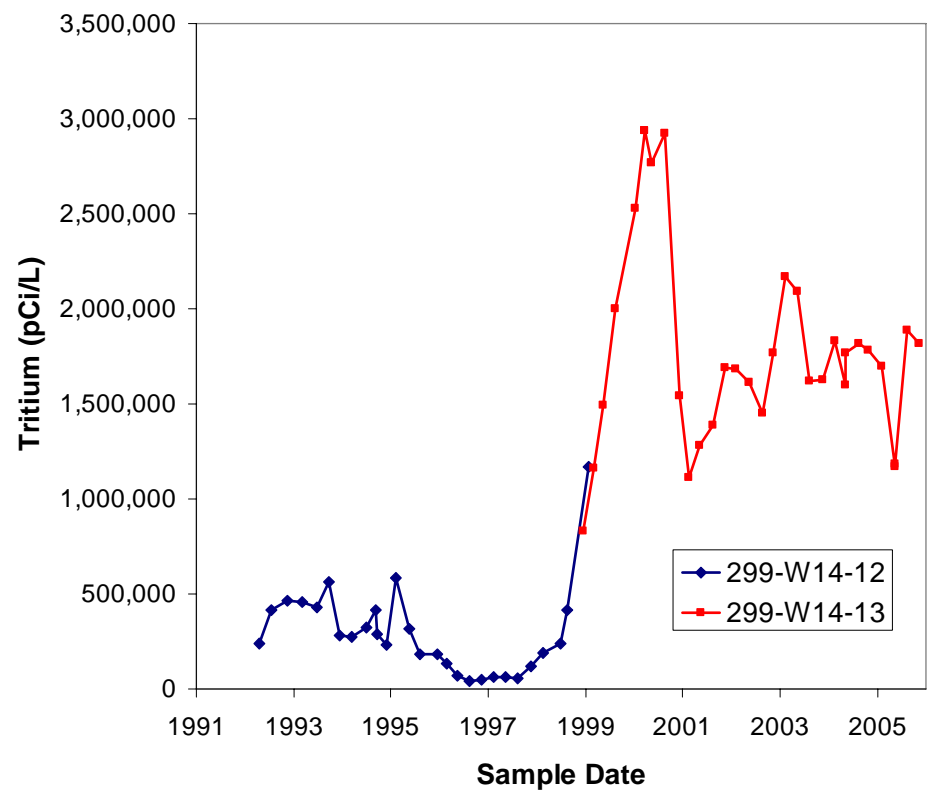

Figure 4.35. Tritium Concentrations in Wells 299-W14-12 and 299-W14-13 at Waste Management Area TX-TY

The results for nitrate in wells 299-W14-12 and 299-W14-13 (Figure 4.34) show a trend similar to that seen for technetium-99. The concentration of nitrate in the last sample from well 299-W14-12 was about $600 \mathrm{mg} / \mathrm{L}$, and this represented the concentration of nitrate at the top of the aquifer. The sample from well 299-W14-13, taken at about the same time, contained about $315 \mathrm{mg} / \mathrm{L}$ of nitrate. Just as for technetium-99, the conclusion is that nitrate existed at the water table at about $600 \mathrm{mg} / \mathrm{L}$ in January 1999, 
and the concentration decreased with depth in the aquifer. The $315 \mathrm{mg} / \mathrm{L}$ nitrate value from well 299-W14-13 is a mixture of the high nitrate-bearing water at the top of the aquifer with lower nitratebearing water deeper in the screened interval. The proposed distribution of nitrate in the screened interval is supported by the trend in specific conductance discussed above (Figure 4.34).

The nitrate concentration trends through time are similar to those seen for technetium-99 (compare Figures 4.33 and 4.34). Nitrate began to decrease from a maximum of about $540 \mathrm{mg} / \mathrm{L}$ in 1993 to about $200 \mathrm{mg} / \mathrm{L}$ in early 1997. Nitrate then began to increase, reaching $580 \mathrm{mg} / \mathrm{L}$ in January 1999. The increasing nitrate trend continued in the replacement well until early 2000 when concentrations reached $\sim 440 \mathrm{mg} / \mathrm{L}$. Nitrate then began to decrease a second time until early 2001, at which time it began a second generally increasing trend that lasted through mid 2004. Since that time, nitrate concentration has decreased somewhat.

The analytical results for tritium in wells 299-W14-12 and 299-W14-13 (Figure 4.35) show a different trend than that seen for technetium-99 and nitrate. The concentration of tritium in the last sample from well 299-W14-12 was 1,170,000 pCi/L. The sample from well 299-W14-13, obtained about one month later, contained 1,160,000 pCi/L tritium. Following the same logic as used for technetium-99 and nitrate, the sample from well 299-W14-12 represents the tritium concentration at the top of the aquifer, whereas the sample from well 299-W14-13 represents the upper $10 \mathrm{~m}$ of the aquifer. Both results are the same, indicating little, if any, vertical concentration differences for tritium. Thus, unlike nitrate and technetium-99, the upper part of the aquifer at this location appears to be fairly homogeneous with respect to tritium concentration.

However, tritium concentrations in the groundwater show the same general trend with time as shown by nitrate and technetium-99. Tritium began to decrease in concentration in 1993 and began to increase in early 1997 to a maximum of 2,940,000 pCi/L in early 2000. At that time, tritium began to decrease until early 2001 when tritium concentrations began to increase again. The latest increase reached $2,170,000 \mathrm{pCi} / \mathrm{L}$ in February 2003. Since that time, concentrations have been fairly steady at around $1,800,000 \mathrm{pCi} / \mathrm{L}$.

Two other well pairs were examined at the TY Tank Farm. No concentration differences versus depth in the aquifer were noted for technetium-99, tritium, or nitrate in well pair 299-W10-18 and 299-W10-26, located downgradient (east) of TY Tank Farm. Data from well pair 299-W15-12 and 299-W15-765, located upgradient of the TY Tank Farm and not in a high contamination area, suggest that technetium-99 concentrations are somewhat greater at the water table than at depth in the screened interval.

Sampling During Drilling. Well 299-14-11 was drilled to $36 \mathrm{~m}$ below the water table in April 2005 to delineate the vertical extent of contamination along the downgradient side of WMA TX-TY. The well is located about $4 \mathrm{~m}$ from existing well 299-W14-13. Groundwater samples were air lifted every $1.5 \mathrm{~m}$ during drilling and pumped samples were collected every $6 \mathrm{~m}$. The samples were analyzed for technetium-99, chromium, anions, tritium, and iodine-129.

Figure 4.36 shows the distribution of technetium-99 in the upper part of the aquifer at well 299-W14-11. Technetium-99 has a maximum concentration of 7,532 $\mathrm{pCi} / \mathrm{L}$ at about $4.5 \mathrm{~m}$ below the water table and generally decreases with increasing depth. The adjacent well (299-W14-13) is screened 
from the water table to $8.2 \mathrm{~m}$ below the water table and the latest (August 2005) technetium-99 concentration from that well is $7,270 \mathrm{pCi} / \mathrm{L}$, comparable to the maximum result from the new well.

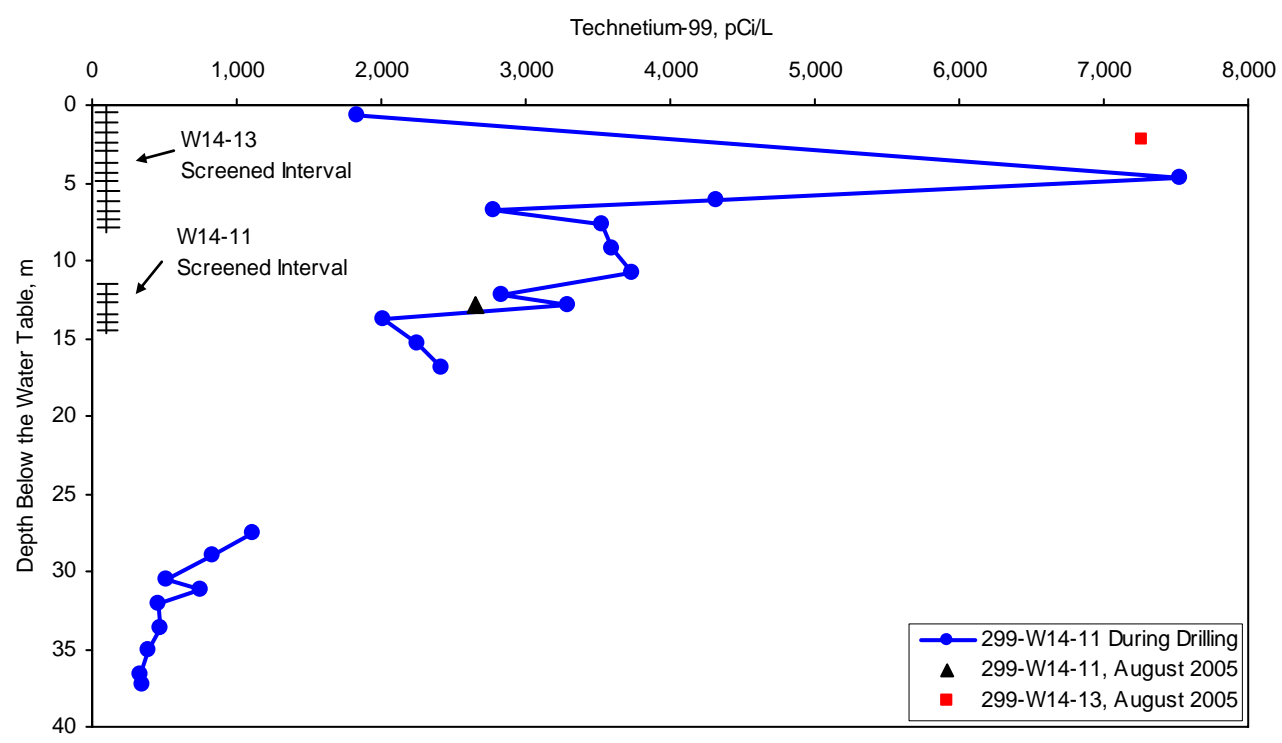

Figure 4.36. Distribution of Technetium-99 in the Aquifer at Well 299-W14-11, Waste Management Area TX-TY (from Dresel et al. 2006)

Figure 4.37 shows the distribution of nitrate in the aquifer at well 299-W14-11. The maximum nitrate concentration is $603 \mathrm{mg} / \mathrm{L}$ at about $0.7 \mathrm{~m}$ below the water table and decreases with increasing depth until about $18 \mathrm{~m}$ depth at which depth the nitrate concentration begins to increase slightly. The nitrate concentrations measured in the August quarterly samples from both wells 299-W14-11 and 299-W14-13 correspond well with the nitrate concentration versus depth curve. A similar relationship exists for tritium (not shown).

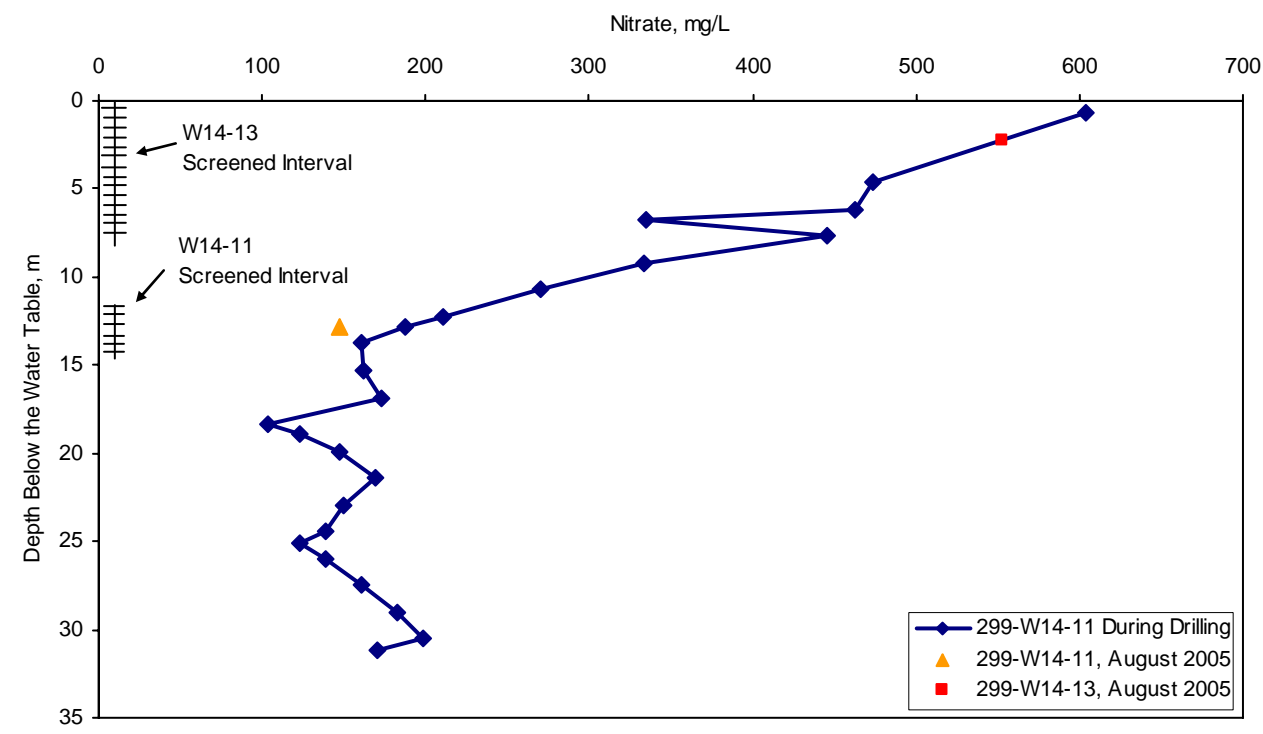

Figure 4.37. Distribution of Nitrate in the Aquifer at Well 299-W14-11, Waste Management Area TX-TY (from Dresel et al. 2006) 
Figure 4.38 shows the iodine-129 concentration versus depth below the water table in samples from 299-W14-11. All analyses from 25 to $37 \mathrm{~m}$ below the water table yielded undetectable concentrations and have been omitted from the figure. Clearly, the concentration of iodine-129 decreases with increasing depth. The highest concentration of iodine- 129 was $72 \mathrm{pCi} / \mathrm{L}$ at $0.7 \mathrm{~m}$ below the water table. This is the highest iodine-129 concentration measured on the Hanford Site in FY 2005. The August quarterly sample from well 299-W14-11 yielded undetectable iodine-129. The August quarterly sample from well 299-W14-13 yielded $22.1 \mathrm{pCi} / \mathrm{L}$ iodine-129 (Figure 4.38), a reasonable mean of the concentrations over the upper $8 \mathrm{~m}$ of the aquifer (the screened interval) as determined by the drilling samples.

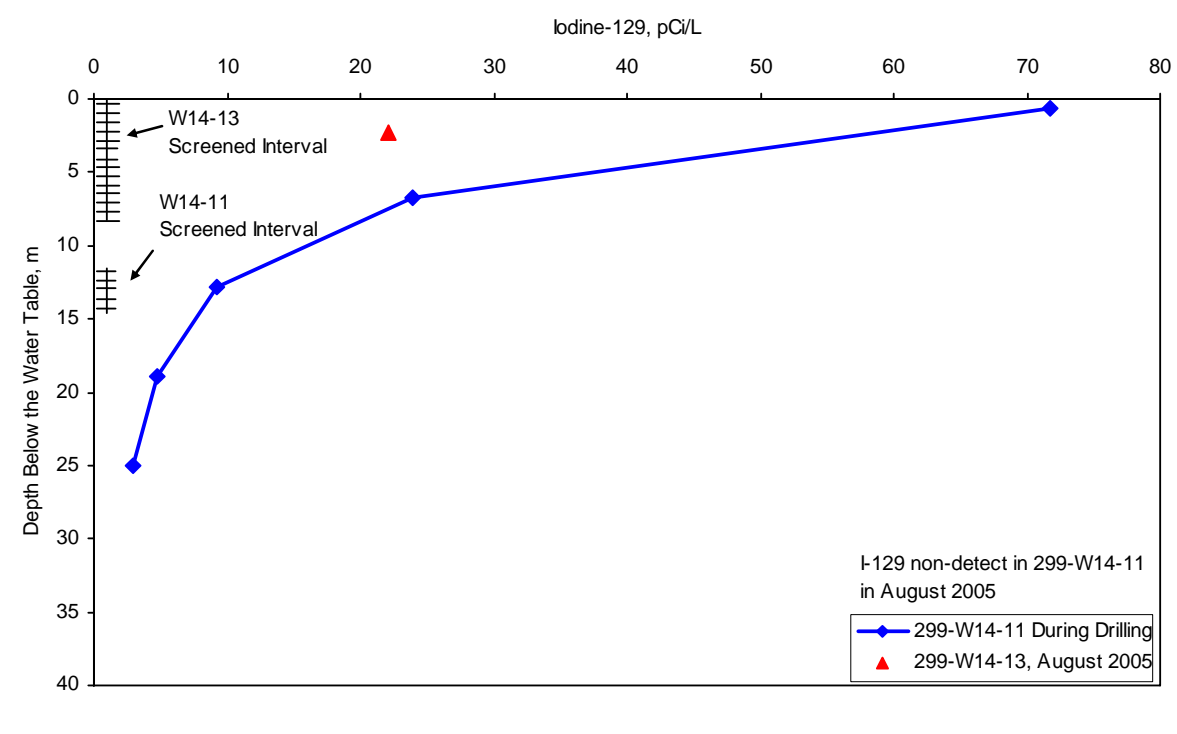

Figure 4.38. Distribution of Iodine-129 in the Aquifer at Well 299-W14-11, Waste Management Area TX-TY (from Dresel et al. 2006)

Previously, in 1999, groundwater samples were collected by pumping during drilling of well 299-W14-14 east of TX Tank Farm (Horton and Hodges 1999). Each sample interval was isolated by packers before sampling. Figure 4.39 shows the results of analysis of those samples for technetium-99, nitrate, tritium, and carbon tetrachloride. The uppermost sample on Figure 4.39 was collected by pumping from the screened interval (extending from the water table to $10.5 \mathrm{~m}$ below the water table) after the well was completed. Note that the sampling interval was fairly large, between 10 and $16 \mathrm{~m}$, so that the concentration profiles are not well defined.

The Ringold Formation lower mud unit (hydrogeologic unit 8) (indicated by horizontal solid lines on Figure 4.39) occurs between 56 and $67 \mathrm{~m}$ below the water table in well 299-W14-14. The largest concentrations of carbon tetrachloride $(920 \mu \mathrm{g} / \mathrm{L})$ and tritium $(9,010 \mathrm{pCi} / \mathrm{L})$ occur above this unit at $46 \mathrm{~m}$ below the water table. Concentrations of both constituents decrease near the top of, but within, the lower mud unit at $58 \mathrm{~m}$ depth and increase again near the bottom contact of the lower mud unit with the underlying Ringold Formation unit A (hydrogeologic unit 9). Concentrations of both constituents show increases in the deepest sample indicating that the deepest occurrence of these constituents may not have been encountered in the well and that significant concentrations may exist in the confined Ringold Formation aquifer. 

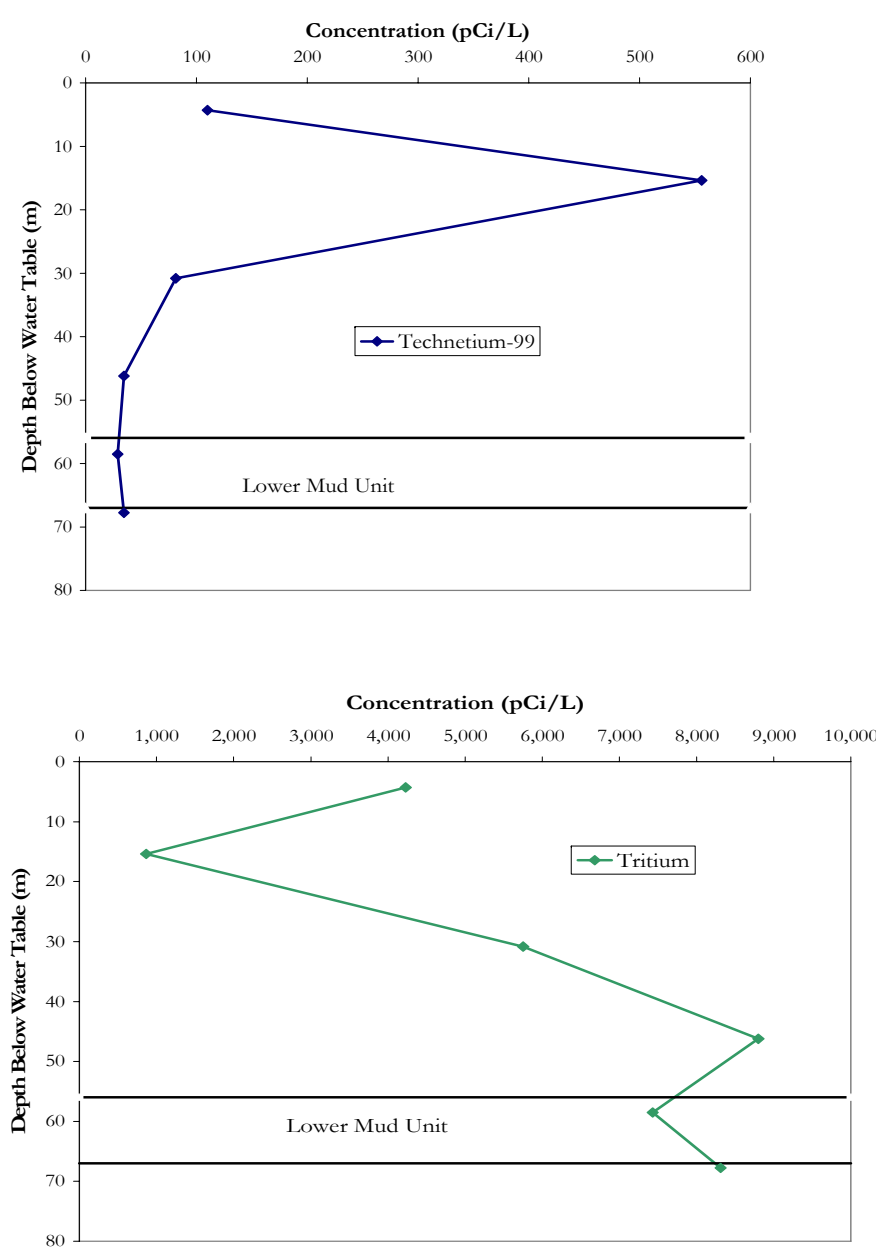
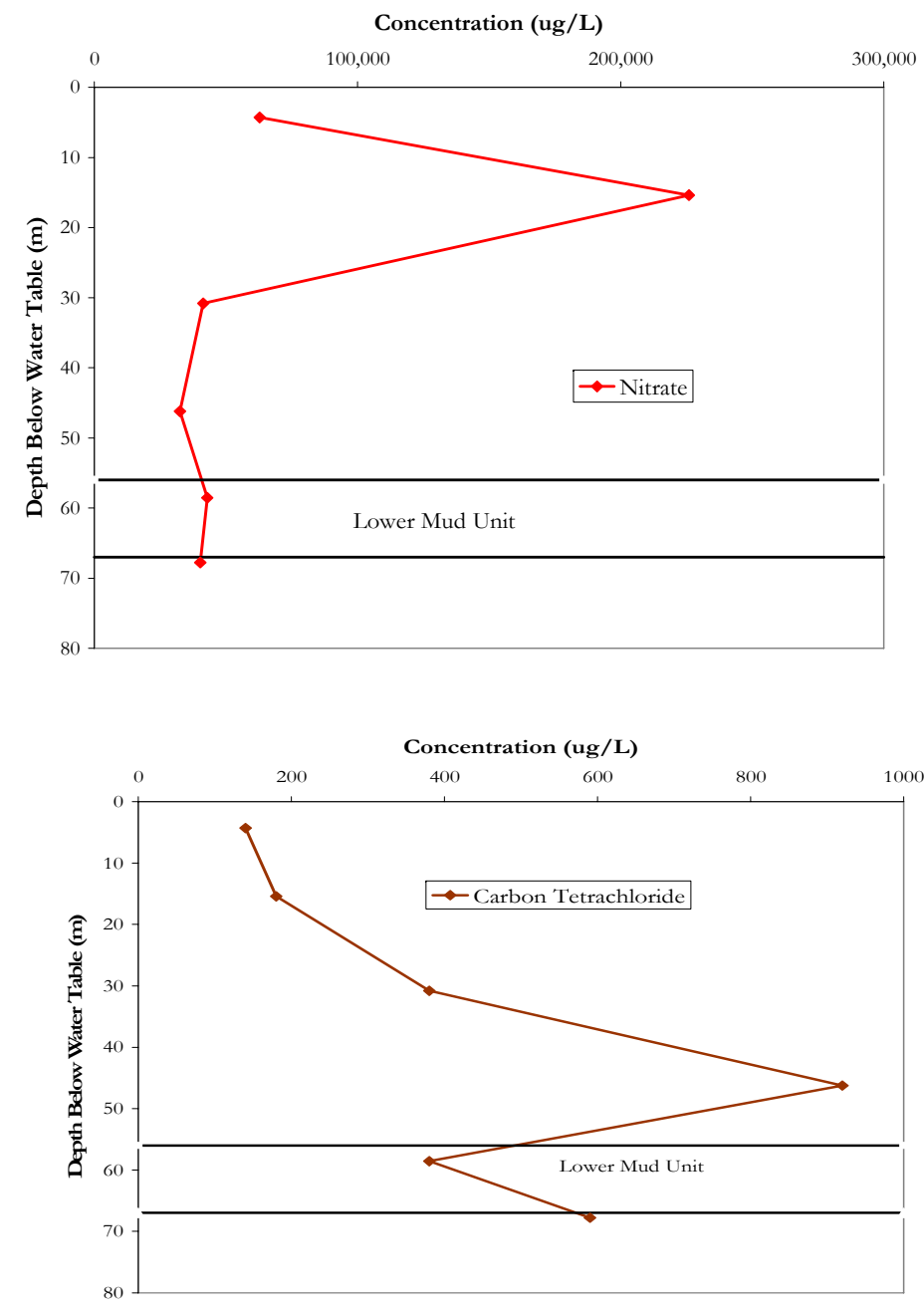

Figure 4.39. Contaminant Distributions in Samples Collected During Drilling of Well 299-W14-14 (modified from Horton 2002) 
The maximum concentrations of technetium-99 $(556 \mathrm{pCi} / \mathrm{L})$ and nitrate $(226 \mathrm{mg} / \mathrm{L})$ occurred at $15.4 \mathrm{~m}$ below the water table. Concentrations decreased immediately below $15.4 \mathrm{~m}$ and remained constant throughout the remainder of the drilled depth. No concentration changes were noted across the lower mud unit.

Two other wells have been sampled during drilling at WMA TX-TY. Air lifted samples of groundwater and sediment cuttings were collected from wells 299-W14-19 and 299-W15-44 during drilling in 2002. The samples were collected at 6-m intervals down to $36 \mathrm{~m}$ below the water table and analyzed for metals, anions, tritium, and technetium-99 (Horton 2003). No significant levels of contamination were encountered. Several metals and anions, however, showed concentration variations with depth in the aquifer. The results from well 299-W14-19 are similar to those from well 299-W15-44.

Additional groundwater samples were collected from drilling slurries at well 299-W15-44 for analysis of nitrate in the field. The nitrate data from well 299-W15-44 are shown in Figure 4.40. The nitrate concentration in well 299-W15-44 is relatively high at the water table and decreases with depth down to about $20 \mathrm{~m}$ below the water table. This is followed by an increase in concentration at about $60 \mathrm{~m}$ below the water table, below which the nitrate concentration remains constant to the bottom of the borehole.

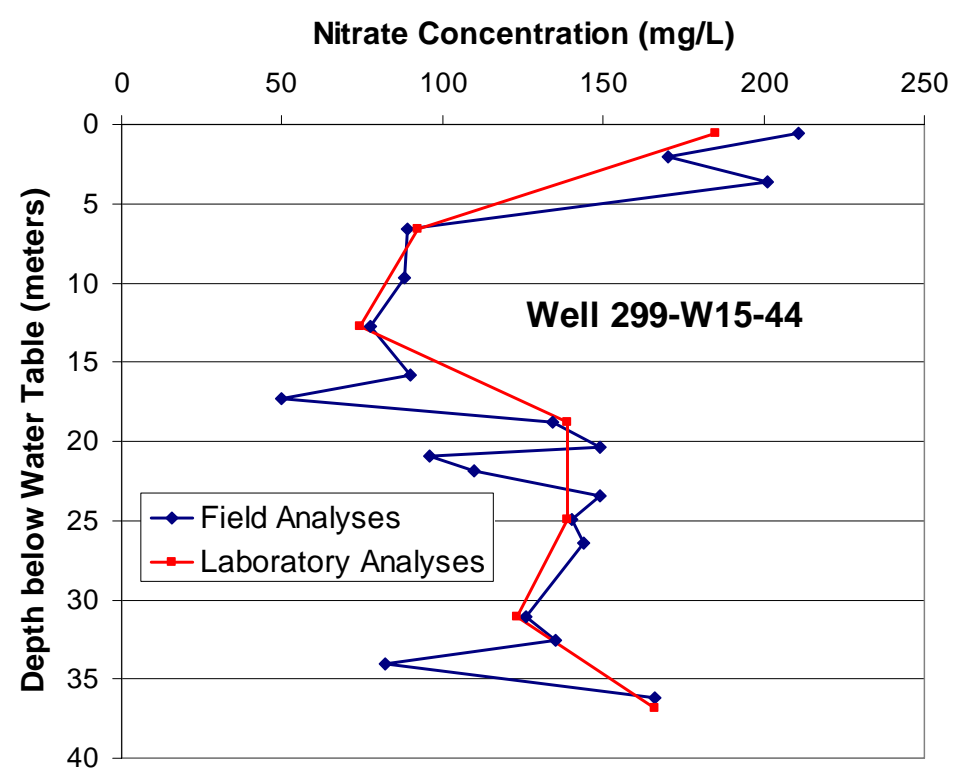

Figure 4.40. Nitrate Concentration in Groundwater versus Depth in Well 299-W15-44 (from Serne et al. 2004a)

The high nitrate concentrations near the water table in well 299-W15-44 are interpreted to be from a nearby source such that the nitrate has not traveled far enough in the aquifer to become more highly dispersed. The nearby source for the nitrate is not known for certain but may be the WMA. The deeper, relatively high nitrate concentrations in well 299-W15-44, and in other wells at WMA TX-TY, have been interpreted elsewhere to represent past-practice discharges, probably from the Plutonium Finishing Plant, that were disposed to U Pond (Hodges and Chou 2001; Johnson and Chou 2001). Thus, the deeper nitrate concentrations probably represent the widespread, regional plume. Alternatively, the 216-T-19 crib and tile field, located about 140 m east of well 299-W15-44 may be the source of some of the deeper nitrate in the well. 
Multi-Level Dialysis Sampling in Well 299-W14-13. Well 299-W14-13 is located on the east (downgradient) side of WMA TX-TY in an area of high chromium, nitrate, technetium-99, iodine-129, and tritium groundwater contamination. Multi-level, depth-discrete sampling was done in the screened interval of well 299-W14-13 to help determine the source or sources of chromium and technetium-99 and to refine the chromium distribution in the upper part of the aquifer. The description of the sampling results given here is from Dresel et al. (2004).

The multi-level, dialysis sampling device was deployed in the well September 2002. The sampling device was left in the well for about one month to allow equilibration of the water in the dialysis tubes with the groundwater. Samples were obtained every $1.5 \mathrm{~m}$ from about $1 \mathrm{~m}$ below the top of the aquifer to the bottom of the well screen at about $9 \mathrm{~m}$ below the water table. Samples were analyzed for major cations, anions, tritium, chromium, and technetium-99.

In addition, one sample was collected from about $4 \mathrm{~cm}$ below the water table using a mini-bailer. The bailed sample was analyzed for chromium and nitrate in the field and chromium and technetium-99 in the laboratory.

The analytical results from both the multi-level dialysis and the bailed samples are shown in Figure 4.41. The results show that, except for a zone at about $2.5 \mathrm{~m}$ below the water table, the concentrations of most cations and anions are fairly constant throughout the screened interval of the aquifer (the upper $\sim 9 \mathrm{~m}$ of the aquifer). Neither the geology, the geophysical logs, nor aquifer testing results show any evidence of changes in the formation at $2.5 \mathrm{~m}$ below the water table, so the reason for the increased concentrations at this depth is unknown.

In contrast, nitrate and technetium-99 show decreasing concentrations with depth from the shallowest dialysis sample at $1 \mathrm{~m}$ below the water table to about 4 to $5 \mathrm{~m}$ below the water table. For nitrate, there is an extremely large increase in concentration between the shallowest dialysis sample and the bailed sample near the water table. For technetium-99, the mini-bailed sample has lower technetium-99 concentration than any of the dialysis samples.

The solid squares on Figure 4.41 represent the concentrations of the various constituents in pumped samples collected the quarter before and the quarter after the dialysis samples were collected. The data show that for some cations and anions, the concentrations in the pumped samples are similar to the dialysis concentrations throughout the screened interval. Exceptions are calcium, chromium, nitrate, and technetium-99. The pumped concentrations of calcium, chromium, and technetium-99 are substantially less than the ambient concentrations measured from the dialysis samples. For nitrate, the opposite is true.

All of the vertical profile data suggest that vertical concentration gradients are not unusual at WMA TX-TY; however, there are differences from well to well that may reflect actual differences in the aquifer. However, the different vertical profile data were collected by different means (pumped during drilling, dialysis, comparing old and new wells) and at different times over the past 6 years during which time contaminant plumes have moved in the aquifer. 

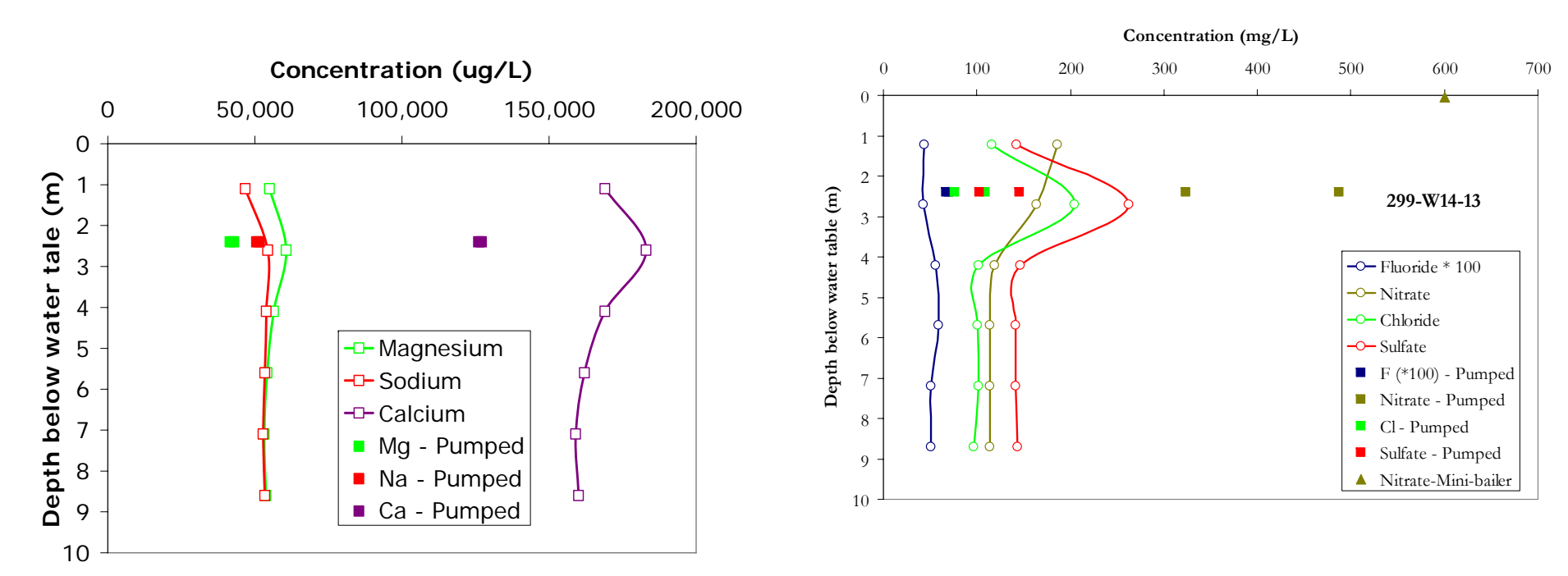

$\underset{i}{\dot{m}}$

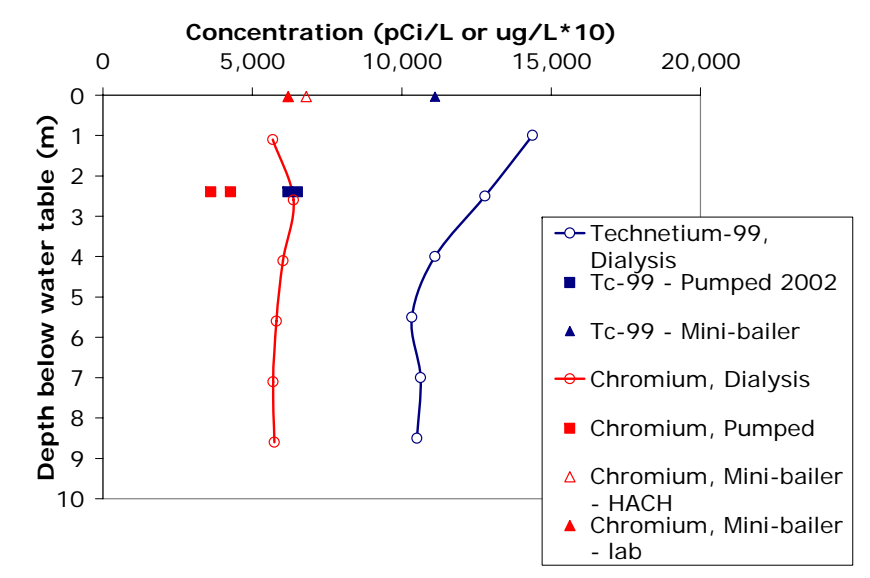

Figure 4.41. Results of Multi-Depth Sampling of Well 299-W14-13 (modified from Serne et al. 2004a) 
In the area where the highest contamination occurs at the WMA, near well 299-W14-13, most data indicate that concentrations of technetium-99, nitrate, iodine-129, and possibly chromium are highest within the upper meter or so of the aquifer and decrease with increasing depth below the water table. The higher concentrations near the water table and fairly rapid decrease with depth suggests that the source(s) for the contamination is nearby because the contaminants have not traveled far enough in the aquifer to become highly dispersed. If this is the case, the closest facilities with possible contaminant sources are the 216-T-26 through 216-T-28 cribs. Another potential source is the WMA TX-TY.

\subsubsection{Extent of Contamination at Waste Management Area TX-TY - Geographic Distribution}

This section summarizes the aerial distribution of contaminants in groundwater at WMA TX-TY. Spatial variation in contaminant concentrations may provide some clues about source areas. Because concentrations change over time, a time period must be chosen to examine spatial distribution patterns. For this purpose, the most recent data (FY 2005 quarterly samples) were chosen. All data can be found on the CD in Hartman et al. (2006). Data were first grouped by geographic location and tabulated as shown in Table 4.11. Data were then plotted and inspected for distribution patterns or groupings. Contour maps of contaminant concentrations were drawn to identify spatial patterns that might be indicative of source areas.

Contamination in two areas near the WMA warrants consideration: east and downgradient of the TX and TY Tank Farms, and south of the TX Tank Farm. The contaminants of interest east of WMA TX-TY are technetium-99, iodine-129, nitrate, tritium, and chromium. The contaminant of interest south of TX Tank Farm is technetium-99.

Carbon tetrachloride $\left(\mathrm{CCl}_{4}\right)$ is a contaminant both east and south of WMA TX-TY (Figure 4.7). The maximum carbon tetrachloride found in the area in 2005 was $2,951 \mu \mathrm{g} / \mathrm{L}$ (average of FY 2005 samples) in well 299-W15-765, west of the TY Tank Farm. This well was converted from an upgradient monitoring well for RCRA purposes to an extraction well for the 200-ZP-1 carbon tetrachloride pump-and-treat system in July of 2005. The carbon tetrachloride in the area of WMA TX-TY is believed to be from pre1973 waste from the Plutonium Finishing Plant. The major identified sources are the 216-Z-9 trench, the 216-Z-1A tile field, and the 216-Z-18 crib.

Contamination East of WMA TX-TY. A small local chromium, technetium, nitrate, tritium, iodine-129 plume exists east of WMA TX-TY at well 299-W14-13. The average chromium concentration in the well was $684 \mu \mathrm{g} / \mathrm{L}$ in FY 2005. The chromium concentration in the nearest wells north, south, and east (downgradient) of well 299-W14-13 has never exceeded the $100-\mu \mathrm{g} / \mathrm{L}$ drinking water standard.

Figure 4.27 shows a plume map for technetium-99 in the WMA TX-TY Area. Elevated technetium-99 is centered on well 299-W14-13 where the average 2005 concentration was 7,094 pCi/L. An iodine-129 plume map is shown in Figure 4.42. Like chromium and technetium-99, the iodine-129 plume is restricted to the area of well 299-W14-13. The average FY 2005 iodine-129 concentration in the well was $18.5 \mathrm{pCi} / \mathrm{L}$. 
Table 4.11. Average Concentration of Mobile Contaminants in Groundwater in the Vicinity of Waste Management Area TX-TY for FY 2005

\begin{tabular}{|c|c|c|c|c|c|c|c|}
\hline Wells & $\begin{array}{c}\mathrm{NO}_{3} \\
(\mathrm{mg} / \mathrm{L})\end{array}$ & $\begin{array}{c}\mathrm{F} \\
(\mathrm{mg} / \mathrm{L})\end{array}$ & $\begin{array}{c}\mathrm{Cr}^{(\mathrm{a})} \\
(\mu \mathrm{g} / \mathrm{L})\end{array}$ & $\begin{array}{c}\mathrm{CCl}_{4} \\
(\mu \mathrm{g} / \mathrm{L})\end{array}$ & $\begin{array}{c}\text { Tc-99 } \\
(\mathrm{pCi} / \mathrm{L})\end{array}$ & $\begin{array}{l}\text { Tritium } \\
(\mathrm{pCi} / \mathrm{L})\end{array}$ & $\begin{array}{c}\mathrm{I}-129 \\
(\mathrm{pCi} / \mathrm{L})\end{array}$ \\
\hline \multicolumn{8}{|c|}{ West (Upgradient) Side of Waste Management Area TX-TY } \\
\hline 299-W15-40 & $\begin{array}{l}94.58 \\
(5)^{(\mathrm{b})}\end{array}$ & $0.270(4)$ & $17(5)$ & $2291(11)$ & $45(5)$ & $4,410(5)$ & $\begin{array}{c}\text { Not } \\
\text { analyzed }\end{array}$ \\
\hline 299-W15-765 & $123.75(4)$ & $0.286(5)$ & $20(5)$ & $2951(11)$ & $76(5)$ & $4,116(5)$ & Not detected \\
\hline \multicolumn{8}{|c|}{ East (Downgradient) Side of Waste Management Area TX-TY } \\
\hline 299-W10-26 & $147.00(4)$ & $1.250(4)$ & $10(4)$ & $\begin{array}{c}\text { Not } \\
\text { analyzed }\end{array}$ & $129(4)$ & $6,545(4)$ & $\begin{array}{c}\text { Not } \\
\text { analyzed }\end{array}$ \\
\hline 299-W10-27 & $108.02(5)$ & $0.770(4)$ & $10(5)$ & $\begin{array}{c}\text { Not } \\
\text { analyzed }\end{array}$ & $135(5)$ & $11,654(5)$ & $\begin{array}{c}\text { Not } \\
\text { analyzed }\end{array}$ \\
\hline 299-W14-6 & $92.30(4)$ & $0.962(4)$ & $5(4)$ & $132(2)$ & $248(4)$ & $1,140(4)$ & $\begin{array}{c}\text { Not } \\
\text { analyzed }\end{array}$ \\
\hline 299-W14-13 & $431.00(5)$ & $0.880(2)$ & $684(5)$ & $\begin{array}{c}\text { Not } \\
\text { analyzed }\end{array}$ & $7,094(5)$ & $1,544,000(5)$ & $18.5(5)$ \\
\hline 299-W14-14 & $67.18(4)$ & $0.838(4)$ & $5(4)$ & 409 (4) & $211(4)$ & $4,162(4)$ & Not detected \\
\hline 299-W14-15 & $72.90(3)$ & $1.150(2)$ & $73(3)$ & $\begin{array}{c}\text { Not } \\
\text { analyzed }\end{array}$ & 469 (3) & $52,700(3)$ & $2(1)$ \\
\hline 299-W14-16 & $60.78(3)$ & $0.417(3)$ & $3(3)$ & $270(1)$ & $190(4)$ & $3685(4)$ & Not detected \\
\hline 299-W14-17 & $122.00(5)$ & $0.385(4)$ & $3(2)$ & $\begin{array}{c}\text { Not } \\
\text { analyzed }\end{array}$ & $366(5)$ & $1,244(5)$ & Not detected \\
\hline 299-W14-18 & $138.75(4)$ & $0.183(3)$ & $6(4)$ & $\begin{array}{c}\text { Not } \\
\text { analyzed }\end{array}$ & $523(4)$ & $6,432(4)$ & Not detected \\
\hline 299-W14-19 & $96.25(4)$ & $0.978(4)$ & $4(3)$ & $\begin{array}{c}\text { Not } \\
\text { analyzed }\end{array}$ & $512(4)$ & $3,368(4)$ & $\begin{array}{c}\text { Not } \\
\text { analyzed }\end{array}$ \\
\hline \multicolumn{8}{|c|}{ South of Waste Management Area TX-TY } \\
\hline 299-W15-41 & $95.82(4)$ & $0.420(4)$ & $8(4)$ & $1,530(2)$ & $1,002(4)$ & $7,738(4)$ & Not detected \\
\hline 299-W15-44 & $89.00(3)$ & $0.295(4)$ & $10(4)$ & $2,640(8)$ & $107(4)$ & $3,902(4)$ & Not detected \\
\hline 299-W15-763 & $105.60(4)$ & $0.507(3)$ & $5(4)$ & $\begin{array}{c}\text { Not } \\
\text { analyzed }\end{array}$ & $1,010(4)$ & $3,100(4)$ & $\begin{array}{c}\text { Not } \\
\text { analyzed }\end{array}$ \\
\hline $\begin{array}{l}\text { (a) Filtered s } \\
\text { (b) Numbers }\end{array}$ & . & c 1 & & & & & \\
\hline
\end{tabular}

A nitrate plume map for the northern part of 200 West Area is shown in Figure 4.22. Almost all wells in the groundwater monitoring network at WMA TX-TY, including upgradient wells, have had nitrate concentrations greater than the drinking water standard of $45 \mathrm{mg} / \mathrm{L}$ throughout most of their sampling life. The highest nitrate concentration coincides with elevated concentrations of technetium-99, chromium, and iodine-129 in well 299-W14-13. The average FY 2005 nitrate concentration in that well was $431 \mathrm{mg} / \mathrm{L}$. This well has had nitrate concentrations greater than those in the regional plume since it was drilled in 1998. Before that time, nitrate concentration in well 299-W14-12 (now dry, but adjacent to well 299-W14-13) was between 440 and $530 \mathrm{mg} / \mathrm{L}$ when it was drilled in 1992. Subsequently, nitrate in well 299-W14-12 decreased to about $190 \mathrm{mg} / \mathrm{L}$ in 1997 before increasing to about $580 \mathrm{mg} / \mathrm{L}$ when it went dry in late 1998 (see Figure 4.34).

Finally, a local tritium plume at well 299-W14-13 is superimposed on the regional tritium plume east of the WMA (Figure 4.21). The average FY 2005 tritium concentration was 1,544,000 pCi/L. 


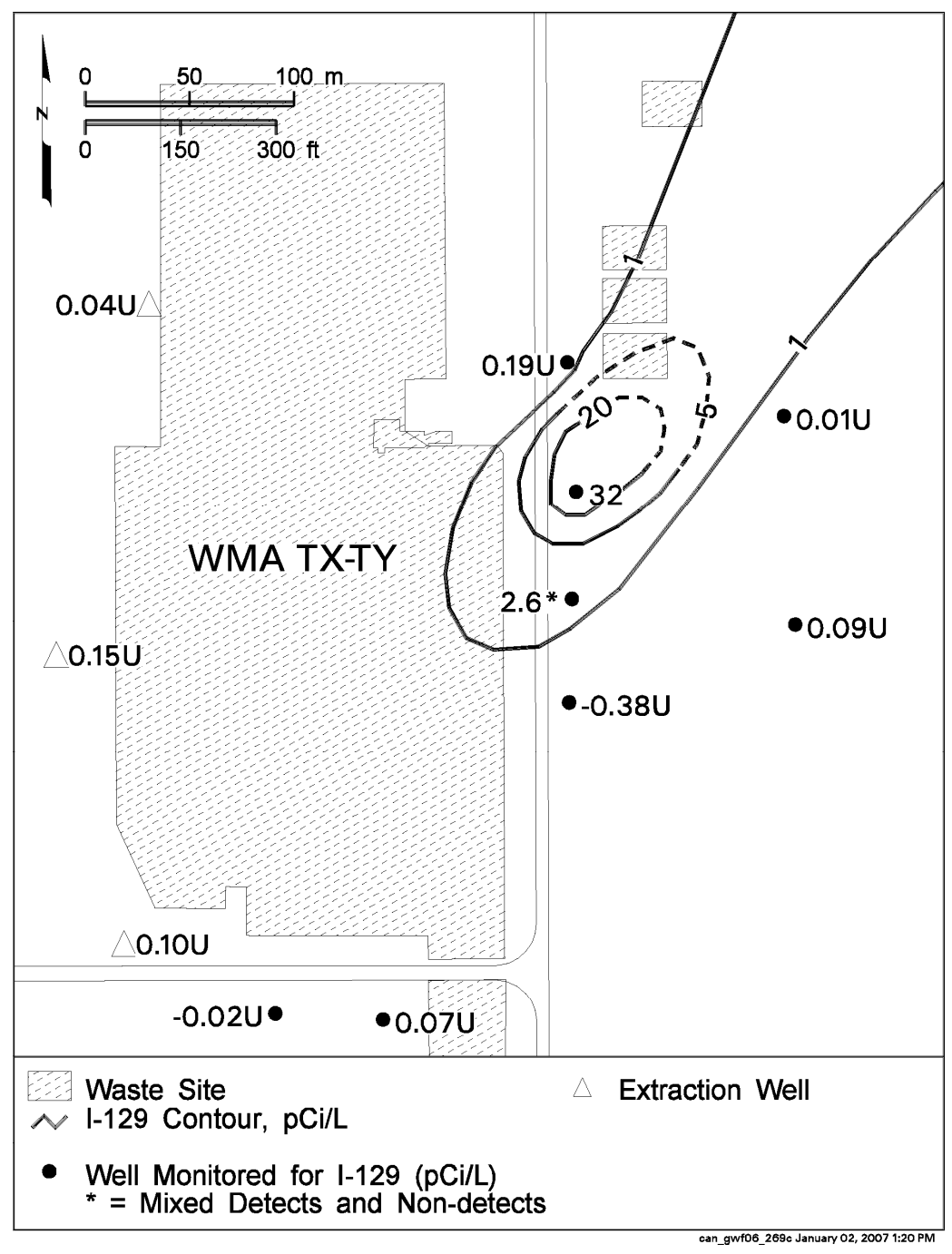

Figure 4.42. Average FY 2006 Iodine-129 Concentrations in the Vicinity of Waste Management Area TX-TY, Top of the Aquifer (from Hartman et al. 2006)

Cobalt-60 was found in several wells along the eastern and southern edges of the WMA prior to 1982. Cobalt-60 concentrations were highly variable in the wells and reached a maximum concentration of $75 \mathrm{pCi} / \mathrm{L}$ in 1971 in well 299-W14-2, located at the 216-T-28 crib. Since that time, cobalt-60 concentrations in the well decreased to between 10 and $25 \mathrm{pCi} / \mathrm{L}$ (between 1976 and 1981) and has been undetectable since 1986. (The well went dry in 2000.)

Cobalt-60 was found in well 299-W14-12 during the entire life of the well, between 1992 and 1999. The cobalt-60 concentration was $28 \mathrm{pCi} / \mathrm{L}$ in late 1992 and decreased to about $4 \mathrm{pCi} / \mathrm{L}$ in early 1996. Cobalt-60 concentration increased to $16 \mathrm{pCi} / \mathrm{L}$ in 1999 when the well was last sampled before it went dry. Cobalt-60 has not been found in replacement well 299-W14-13.

There are several potential sources for the contamination found in well 299-W14-13 including the 216-TY cribs, the 216-T-19 crib and tile field, and the WMA TX-TY. 
The 216-TY cribs, located just north of well 299-W14-13 received about 8,414 kg of chromium, $306,477 \mathrm{~kg}$ of nitrate, $1.80 \mathrm{Ci}$ of technetium-99, and 2.96 Ci of tritium (Corbin et al. 2005). Although these cribs have not been upgradient from well 299-W14-13 since about the mid 1950s, lateral spreading through the vadose zone may have brought contamination toward the south. The general dip of strata beneath the cribs is toward the west or southwest so it is possible that contamination from the cribs migrated through the vadose zone toward well 299-W14-13. Water from a tanker truck filling station, located about $140 \mathrm{~m}$ up dip of the 216-TY cribs, was seen leaking onto the ground from the fill spout in about 2000. Water was seen to pool on the ground and run about $100 \mathrm{~m}$ down slope (toward WMA TX-TY) in a ditch along the side of the gravel road. It is not known how long the fill spout leaked. Infiltration of this water, and similar leaks in the past, could have mobilized contamination in the vadose zone beneath the 216-TY cribs and moved the contamination down dip toward the vicinity of well 299-W14-13.

Also, Fecht et al. (1977) state that gross gamma logs obtained prior to 1977 showed that contamination at the 216-T-28 crib extended from near the surface to the water table and that breakthrough to groundwater could have occurred at the site. (The 216-T-28 crib received 42.3 million L of effluent [DOE/RL 1992a].) They also state that waste from the crib was noted in well 299-W14-1, located $38 \mathrm{~m}$ south of the crib so that considerable lateral spreading had occurred in the vadose zone beneath the 216-TY cribs. Thus, the 216-TY cribs are a potential source for at least some of the contamination noted in well 299-W14-13.

The 216-T-19 crib and tile field is located about 240 m south of well 299-W14-13 and is another potential source for some of the contamination east of WMA TX-TY. The facility received 455 billion L of primarily steam condensate from the 242-T evaporator (DOE 1992a), which contained considerable amounts of tritium. However, none of the wells between the crib and tile field and well 299-W14-13 are highly contaminated which would be expected if the tile field was a major source of contamination in well 299-W14-13.

The nearest tank in WMA TX-TY that is upgradient of well 299-W14-13 is TY-105. This tank is about 164 m northwest of the well. Given that well 299-W14-13 has been downgradient of tank TY-105 for about 9 years, a groundwater flow rate of $0.05 \mathrm{~m} /$ day is required to move contaminants from the tank to the well. A flow rate of $0.05 \mathrm{~m} /$ day is within the range of groundwater velocities measured by a variety of aquifer tests in wells in the area. It is, therefore, possible that the local plume of contaminants east of WMA TX-TY could be from WMA TX-TY. However, the contaminants still need a mechanism to move through the 52-m-thick vadose zone from the tank to groundwater.

Contamination South of WMA TX-TY. Phase 1 of the 200-ZP-1 pump-and-treat operation began in 1994 with one extraction well. The operation was expanded to three wells in 1996 (Phase 2) and then to six extraction wells in August 1997 (Phase 3). The first distinct effects of the pump-and-treat operation on groundwater flow direction beneath WMA TX-TY was observed on the June 1998 water-table map (Hartman 1999). Well 299-W15-22, located at the southwest corner of the WMA and originally drilled as an upgradient well, was the closest to the 200-ZP-1 pump-and-treat extraction wells before it went dry in 1998. Technetium-99 began to increase in this well in May 1997, exceeded the maximum contaminant level in August 1997, and reached a high of 3,680 pCi/L in May 1998 (Figure 4.43). The well was last sampled in August 1998. 


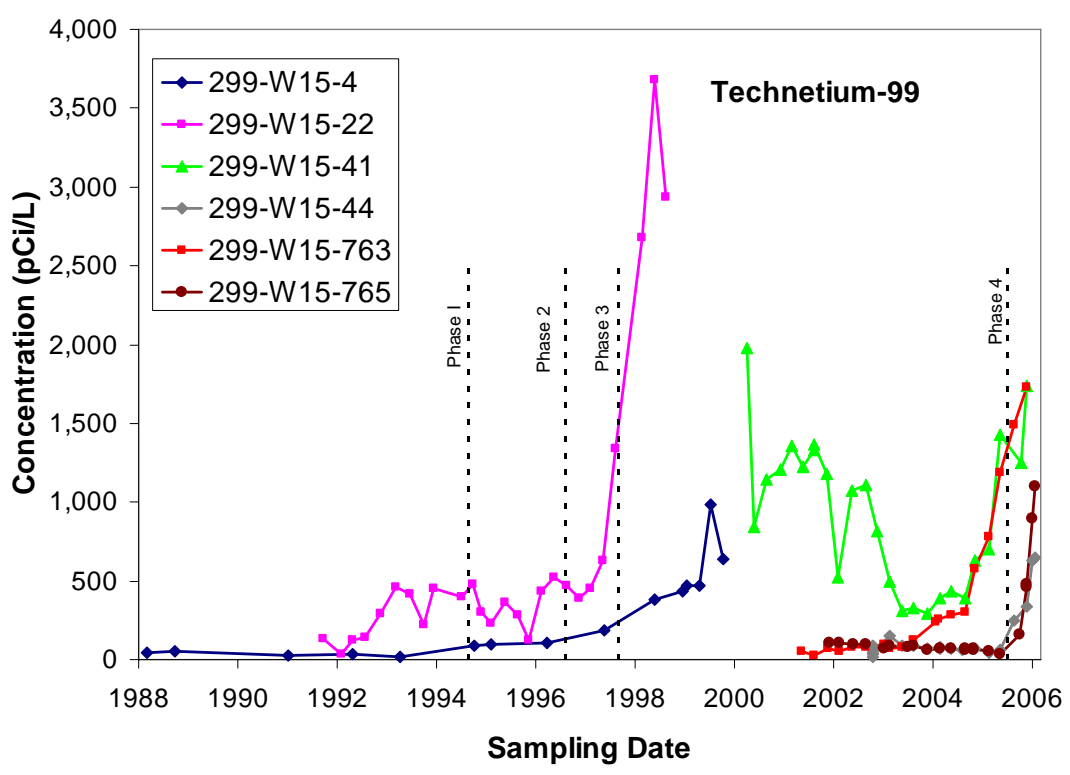

Figure 4.43. Technetium-99 Concentration in Selected Wells South and West of the Waste Management Area TX-TY. (The start dates for the 200-ZP-1 pump-and-treat phases are also indicated by vertical dotted lines. Well locations are shown on Figure 2.3.)

Well 299-W15-4 is an older pre-RCRA well originally drilled to monitor the 216-T-19 crib at the southeast corner of the WMA. Prior to May 1998, the well was sampled only on an annual basis; however, available data indicate that technetium-99 started to increase in this well in mid-1997 and reached a peak value of $980 \mathrm{pCi} / \mathrm{L}$ in July 1999. The last sampling in October 1999 yielded a value of $640 \mathrm{pCi} / \mathrm{L}$ technetium-99 (Figure 4.43).

Well 299-W15-763 was completed as a replacement well for 299-W15-4 in 2001. The first routine sample from this well, taken in May 2001, indicated a technetium-99 level of $57 \mathrm{pCi} / \mathrm{L}$. The most recent sample taken from this well contained $1,730 \mathrm{pCi} / \mathrm{L}$ technetium-99. Well 299-W15-41 was completed in January 2000 and was first sampled in March 2000. The initial sampling yielded a technetium-99 concentration of $1,980 \mathrm{pCi} / \mathrm{L}$. Concentrations of technetium- 99 decreased to about $295 \mathrm{pCi} / \mathrm{L}$ in November 2003 but have since increased to $1,740 \mathrm{pCi} / \mathrm{L}$ in November 2005 (Figure 4.43).

Although it is difficult to correlate technetium-99 concentrations with 200-ZP-1 pump-and-treat operations because extraction rates change and extraction wells are taken on and off line, technetium-99 in wells along the southern boundary of WMA TX-TY started to increase approximately one year after Phase 2 of the pump-and-treat operation began (Figure 4.43). (Phase 2, consisting of three extraction wells, began the use of the closest extraction wells to the WMA, wells 299-W15-34 and 299-W15-35.) Given the southerly groundwater flow direction imposed on the southern portion of the WMA by the pump-and-treat operation, the most reasonable explanation for the increasing technetium-99 is that groundwater contaminated with technetium-99 is being drawn from beneath the WMA into the pumpand-treat system. Alternatively, technetium- 99 may be originating from the $216-T-19$ crib and tile field (DOE 2002).

The most recent changes to the 200-ZP-1 pump-and-treat system were in July 2005 when upgradient wells 299-W15-765 and 299-W15-40 and downgradient well 299-W15-44 were converted from RCRA 
monitoring wells to extraction wells. Subsequently, the technetium-99 concentration in one of these wells (299-W15-765) has increased dramatically (Figure 4.43), probably as a direct result of drawing technetium-99 from beneath the tank farms to the wells.

\subsubsection{Comparison of Groundwater, Vadose Zone Pore Water, and Tank Leak Chemical Compositions at Waste Management Area TX-TY}

Three characterization boreholes were drilled in the TX Tank Farm in 2002. Borehole C3830 was drilled to investigate a known vadose zone contamination area near tank TX-105; borehole C3831 was drilled to investigate a contamination zone from the TX-107 leak (used for many intra-tank farm transfers); and borehole C3832 was drilled to investigate a known vadose zone contamination area near tank TX-104. All potential leaks were estimated to have occurred in the 1975 to 1977 time frame. The leak from tank TX-107 is presumed to be the largest leak and was probably about 30,300 L (Field and Jones 2005).

Vadose zone sediment samples were collected from boreholes C3830, C3831, and C3832. The moisture content was measured from each sample and the concentrations of major cations and anions, trace metals, gamma ray emitters, alkalinity, and carbon were determined from 1:1 sediment to water extracts (Serne et al. 2004a). The results of those analyses showed that the more mobile contaminants in the pore water from boreholes C3830 through C3832 are cobalt-60, technetium-99, nitrate, sulfate, and uranium, which is the least mobile of these contaminants. Therefore, it is these constituents that would be expected first in the groundwater if tank fluids have entered the groundwater.

A plume of cobalt-60, strontium-90, and nitrate passed well 299-W14-2 between 1971 and about 1980 (Figure 4.44). A cobalt-60, nitrate, and tritium plume also passed through the area of wells 299-W14-5 and 299-W15-4 during the early to mid-1970s. These latter two wells are to the east and south, respectively, of the TX Tank Farm and not downgradient of the TX-107 tank during the 1970s and 1980s. This early cobalt-60, nitrate, tritium (and strontium-90) plume appears to have begun passing through the area a few years before the reported tank TX-107 leak.

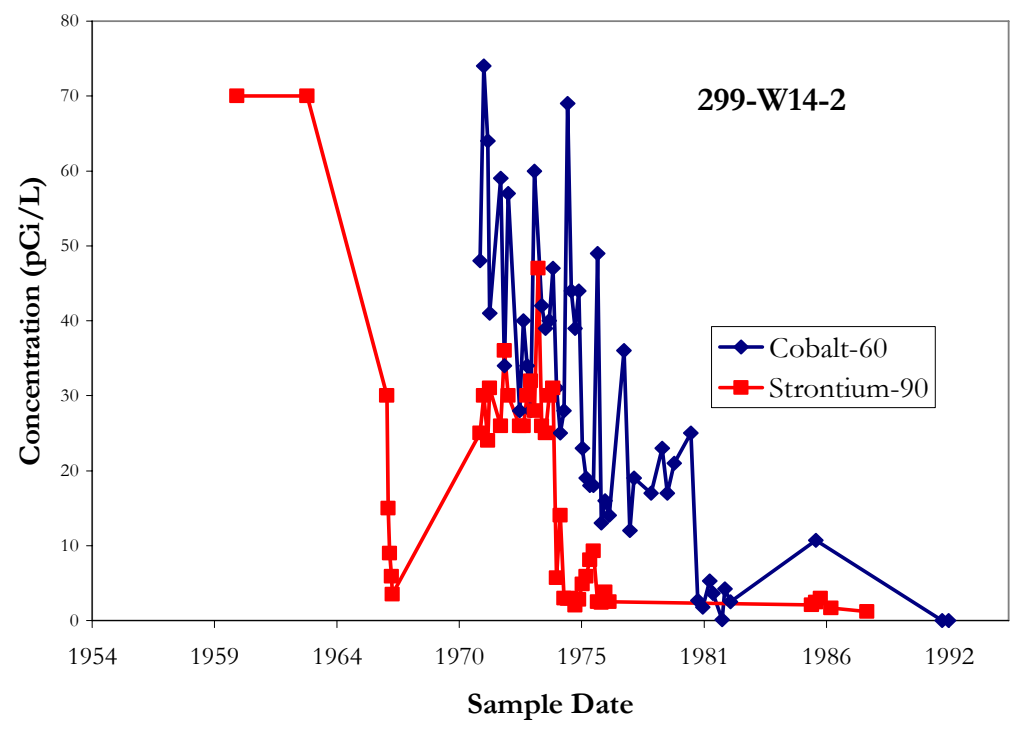

Figure 4.44. Cobalt-60 and Strontium-90 Concentrations in Well 299-W14-2 
A cobalt-60, chromium, nitrate, technetium-99, and tritium plume passed well 299-W14-12 in the early- to mid-1990s (Figures 4.33 through 4.37 and Figure 4.45). To test whether this plume (and the earlier 1970s plume) may have been fed by contaminants from the tank TX-107 leak, the concentrations of technetium-99, nitrate, and cobalt-60 from groundwater samples were compared to the moisture corrected 1:1 water extract samples from borehole C3831. Table 4.12 compares the technetium-99/nitrate concentration ratios ( $\mathrm{pCi} / \mathrm{mg}$ ) measured in groundwater, from the only two wells east of the WMA showing substantial contamination, with moisture-corrected, 1:1 sediment-to-water extracts from borehole C3831. There is an order of magnitude difference between the pore water (C3831) and groundwater (299-W14-12 and 299-W14-13) technetium-99/nitrate concentration ratios with the groundwater being lower than the pore water. One reason for the difference may be that nitrate from the regional groundwater plume has increased the nitrate concentration relative to the technetium-99 concentration in the groundwater, thereby lowering the ratios. Another reason may be that the leak from tank TX-107 has not reached groundwater.

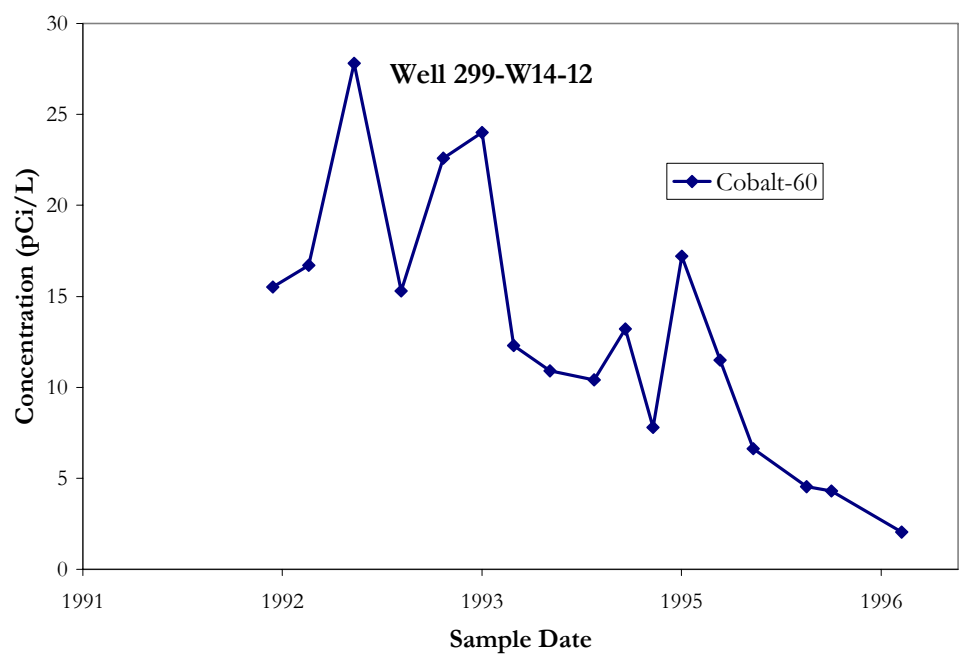

Figure 4.45. Cobalt-60 Concentrations in Well 299-W14-12

Other than major anions, major cations, and technetium-99, there are no constituents that are common to both the pore water and recent groundwater data sets. There are a few older cobalt-60 measurements in the groundwater database and an attempt was made to compare the technetium-99/cobalt-60 ratios in the groundwater and pore water. The comparison between the two was very poor (two orders of magnitude difference). The conclusion is the same as reached by Serne et al. (2004a) after they compared several other chemical ratios. There is no close similarity between the present or past groundwater composition and current pore water composition from the contaminated borehole sediments. Therefore, we cannot link the contaminants in the groundwater to the pore waters currently in the borehole sediments, which are thought to be derived from liquids that leaked from tank TX-107.

\subsubsection{Background Groundwater Composition Beneath Waste Management Area U}

Upgradient groundwater composition for the single-shell tank WMA U is shown in Table 4.13 and Figure 4.46. The data in the table are the average FY 2005 concentrations in each upgradient well at the WMA. All data are available on the CD included in Hartman et al. (2006). Data for the metals are from filtered samples; all other data are from unfiltered samples. Data flagged as suspect in the HEIS (1994) database have been excluded from the calculated averages. 
Table 4.12. Technetium-99/Nitrate Concentration Ratios for Contaminated Groundwater Downgradient of Waste Management Area TX-TY and Pore Water from Borehole C3831

\begin{tabular}{|c|c|c|c|c|c|}
\hline \multicolumn{2}{|c|}{ 299-W14-12 } & \multicolumn{2}{|c|}{ 299-W14-13 } & \multicolumn{2}{|c|}{$\mathrm{C} 3831^{\text {(a) }}$} \\
\hline Sample Date & $\begin{array}{l}\text { Tc-99/Nitrate } \\
\text { (pCi } / \mathrm{mg})\end{array}$ & Sample Date & $\begin{array}{c}\text { Tc-99/Nitrate } \\
(\mathrm{pCi} / \mathrm{mg})\end{array}$ & $\begin{array}{c}\text { Depth } \\
(\mathrm{m} \text { bgs })\end{array}$ & $\begin{array}{l}\text { Tc-99/Nitrate } \\
\text { (pCi/mg) }\end{array}$ \\
\hline $4 / 21 / 1992$ & 19 & $12 / 14 / 1998$ & 6 & 16.21 & 53 \\
\hline $7 / 20 / 1992$ & 22 & $3 / 2 / 1999$ & 9 & 18.27 & 120 \\
\hline 11/11/1992 & 25 & $5 / 19 / 1999$ & 13 & 18.64 & 245 \\
\hline $3 / 9 / 1993$ & 24 & $8 / 12 / 1999$ & 15 & 20.58 & 217 \\
\hline $6 / 23 / 1993$ & 16 & $1 / 13 / 2000$ & 14 & 20.58 & 206 \\
\hline 9/28/1993 & 23 & $3 / 27 / 2000$ & 17 & 20.79 & 92 \\
\hline $12 / 16 / 1993$ & 18 & $5 / 9 / 2000$ & 31 & 21.21 & 179 \\
\hline $7 / 6 / 1994$ & 21 & $8 / 21 / 2000$ & 15 & 22.86 & 157 \\
\hline $9 / 22 / 1994$ & 23 & $12 / 6 / 2000$ & 12 & 23.67 & 128 \\
\hline $11 / 30 / 1994$ & 21 & $2 / 20 / 2001$ & 15 & 23.99 & 141 \\
\hline $2 / 10 / 1995$ & 22 & $8 / 14 / 2001$ & 21 & 26.21 & 78 \\
\hline $5 / 17 / 1995$ & 25 & $11 / 14 / 2001$ & 18 & 27.25 & 172 \\
\hline $8 / 8 / 1995$ & 17 & $2 / 5 / 2002$ & 15 & 28.65 & 216 \\
\hline $12 / 20 / 1995$ & 12 & $5 / 13 / 2002$ & 17 & 29.89 & 142 \\
\hline $2 / 20 / 1996$ & 9 & $8 / 21 / 2002$ & 39 & 30.87 & 139 \\
\hline $5 / 16 / 1996$ & 5 & $11 / 14 / 2002$ & 29 & 31.29 & 145 \\
\hline $8 / 14 / 1996$ & 1 & $2 / 12 / 2003$ & 18 & 34.88 & 198 \\
\hline 11/13/1996 & 5 & $5 / 15 / 2003$ & 17 & 34.88 & 195 \\
\hline 5/14/1997 & 4 & $8 / 11 / 2003$ & 20 & 35.07 & 186 \\
\hline 11/17/1997 & 5 & $11 / 17 / 2003$ & 19 & & \\
\hline $2 / 17 / 1998$ & 6 & $2 / 18 / 2004$ & 20 & & \\
\hline $6 / 25 / 1998$ & 7 & $5 / 13 / 2004$ & 17 & & \\
\hline $8 / 20 / 1998$ & 7 & $8 / 18 / 2004$ & 16 & & \\
\hline $1 / 28 / 1999$ & 11 & $10 / 28 / 2004$ & 20 & & \\
\hline & & $2 / 8 / 2005$ & 15 & & \\
\hline & & $5 / 12 / 2005$ & 18 & & \\
\hline & & $8 / 12 / 2005$ & 13 & & \\
\hline & & $11 / 16 / 2005$ & 16 & & \\
\hline
\end{tabular}

The upgradient groundwater at WMA U is fairly dilute and resembles the Hanford Site background groundwater with the addition of a small amount of nitrate. The groundwater from both upgradient wells at this WMA is calcium-bicarbonate water (Figure 4.46). The water also contains minor technetium-99. Charge balances for the wells in Figure 4.46 are: $+3.3 \%$ for well $299-\mathrm{W} 18-31$ and $+5.0 \%$ for well 299-W18-40.

\subsubsection{Groundwater Contamination Beneath Waste Management Area U}

This section discusses the current and historical groundwater contamination at WMA U. The evaluation of contamination includes descriptions of the types and concentrations of contaminants in the 
groundwater and the extent of contamination in the area. Most of the information in this section is taken from McDonald et al. (2006) and Hodges and Chou (2000). Groundwater in the vicinity of WMA U is routinely monitored for RCRA and Atomic Energy Act purposes. The objective of RCRA monitoring is to assess the nature and extent of groundwater contamination with hazardous constituents and determine their rate of movement in the aquifer. Groundwater monitoring under the Atomic Energy Act tracks radionuclides in the vicinity of the WMA.

Groundwater beneath the U Tank Farm contains elevated concentrations of technetium-99, nitrate, carbon tetrachloride, and chloroform. The source for the carbon tetrachloride and chloroform is considered to be the cribs and trenches associated with the Plutonium Finishing Plant (Dresel et al. 2006).

Table 4.13. Average FY 2005 Groundwater Composition in Waste Management Area U Upgradient Wells

\begin{tabular}{||l|c|c||}
\hline \multirow{2}{*}{\multicolumn{1}{|c|}{ Constituent (units) }} & Well 299-W18-31 & Well 299-W18-40 \\
\cline { 2 - 3 } & 86,250 & 85,750 \\
\hline \hline Alkalinity as $\mathrm{CaCO}_{3}(\mu \mathrm{g} / \mathrm{L})$ & 28,325 & 26,675 \\
\hline Calcium $(\mu \mathrm{g} / \mathrm{L})$ & Not analyzed & Not analyzed \\
\hline Carbon tetrachloride $(\mu \mathrm{g} / \mathrm{L})$ & Not detected & 7.6 \\
\hline Cesium-137 $(\mathrm{pCi} / \mathrm{L})$ & 8.43 & 4.5 \\
\hline Chloride $(\mathrm{mg} / \mathrm{L})$ & 7.7 & Not detected \\
\hline Chromium $(\mu \mathrm{g} / \mathrm{L})$ & Not detected & 0.38 \\
\hline Cobalt-60 $(\mathrm{pCi} / \mathrm{L})$ & 0.37 & 2.02 \\
\hline Fluoride $(\mathrm{mg} / \mathrm{L})$ & 2.22 & 8.35 \\
\hline Gross alpha $(\mathrm{pCi} / \mathrm{L})$ & 9.41 & Not analyzed \\
\hline Gross beta $(\mathrm{pCi} / \mathrm{L})$ & Not analyzed & 21.95 \\
\hline Iodine- $129(\mathrm{pCi} / \mathrm{L})$ & 53.2 & 8,615 \\
\hline Iron $(\mu \mathrm{g} / \mathrm{L})$ & 9,085 & 24.07 \\
\hline Magnesium $(\mu \mathrm{g} / \mathrm{L})$ & 28.65 & 7.9 \\
\hline Nitrate $(\mathrm{mg} / \mathrm{L})$ & 8.1 & 3,448 \\
\hline pH Measurement $(\mathrm{pH}$ units $)$ & 4,275 & 17,025 \\
\hline Potassium $(\mu \mathrm{g} / \mathrm{L})$ & 16,550 & 288 \\
\hline Sodium $(\mu \mathrm{g} / \mathrm{L})$ & 293 & Not analyzed \\
\hline Specific $\mathrm{Conductance}(\mu \mathrm{S} / \mathrm{cm})$ & Not analyzed & 17.88 \\
\hline Strontium-90 $(\mathrm{pCi} / \mathrm{L})$ & 19.9 & Not analyzed \\
\hline Sulfate $(\mathrm{mg} / \mathrm{L})$ & 17.65 & \\
\hline Technetium-99 $(\mathrm{pCi} / \mathrm{L})$ & Not analyzed & \\
\hline Tritium $(\mathrm{pCi} / \mathrm{L})$ & & \multicolumn{2}{|c||}{} \\
\hline \hline
\end{tabular}



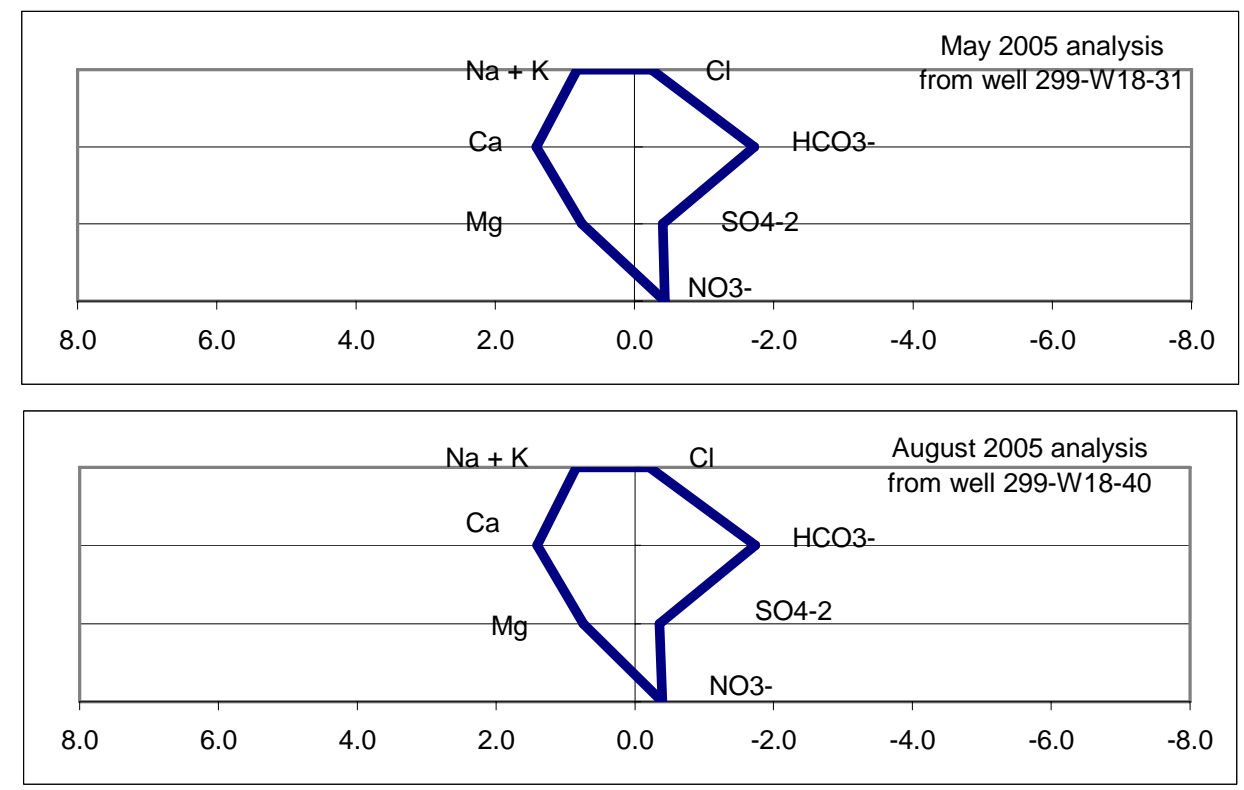

Figure 4.46. Major Cation and Anion Composition of Groundwater from Upgradient Wells at Waste Management Area U. Units for the X-axis are milliequivalents/liter with cations on the left and anions on the right.

\subsubsection{Extent of Contamination at Waste Management Area U - Depth Distribution}

Information for WMA $\mathrm{U}$ concerning vertical concentration gradients in the unconfined aquifer is limited to data from two well pairs (Hodges and Chou 2000). Each well pair consists of an older, now dry, well and its replacement.

Well 299-W19-31 was last sampled in December 1999 before it went dry. The replacement well, i.e., well 299-W19-42, was first sampled in December 1998. The last sample from well 299-W19-31 contained $47 \mathrm{pCi} / \mathrm{L}$ technetium- 99 and $9.3 \mathrm{mg} / \mathrm{L}$ nitrate. The first sample from well 299-W19-42 contained $302 \mathrm{pCi} / \mathrm{L}$ technetium-99 and $24.8 \mathrm{mg} / \mathrm{L}$ nitrate (Figure 4.47). Using the same arguments that were used to interpret data from well pairs at WMAs T and TX-TY, the last sample from the dry well represented the chemical composition of the aquifer very near the water table, whereas the first sample from the replacement well represented the chemical composition of the upper $10 \mathrm{~m}$ of the aquifer. If this is true, the concentrations of both technetium-99 and nitrate were lower at the water table than they were deeper in the screened interval.

A similar situation existed with well pair 299-W19-32 and 299-W19-41, located at the southeastern corner of the WMA (Figure 2.4). The magnitude of the technetium-99 and nitrate concentrations at WMA U is much less than at other WMAs in the 200 West Area, however.

\subsubsection{Extent of Contamination at Waste Management Area U - Geographic Distribution}

WMA U has been identified as the source for a small contaminant plume that is limited to the downgradient (east) side of the site (Hodges and Chou 2000; McDonald et al. 2006). Plume constituents of interest originally included chromium, nitrate, and technetium-99, but chromium concentrations have recently decreased to near the analytical detection limit of $3.1 \mu \mathrm{g} / \mathrm{L}$. 

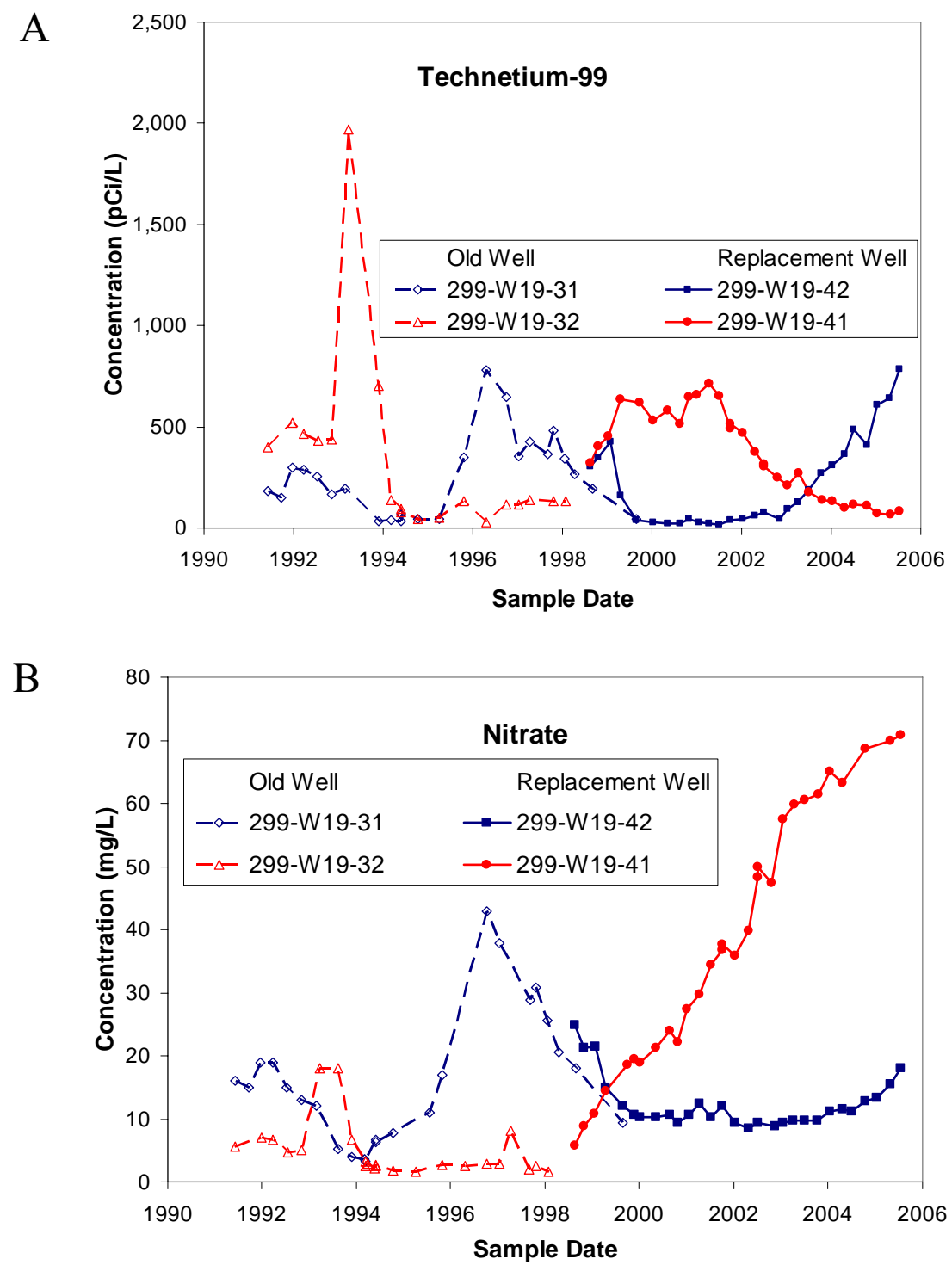

Figure 4.47. Concentrations versus Time for Technetium-99 (A) and Nitrate (B) at Two Well Pairs Downgradient of Waste Management Area U

Table 4.14 shows the average concentrations of selected contaminants in groundwater in the vicinity of WMA U during FY 2005. In FY 2005, measured technetium-99 concentrations exceeded the drinking water standard $(900 \mathrm{pCi} / \mathrm{L})$ for the first time at the WMA since $1993(1,230 \mathrm{pCi} / \mathrm{L}$ in well 299-W19-45 and $980 \mathrm{pCi} / \mathrm{L}$ in well 299-W19-47) (McDonald et al. 2006). Nitrate and technetium-99 appear to have different sources because they have different concentration distributions within the contaminated area. The distribution of the two contaminants is shown on Figure 4.48. Nitrate concentrations are highest in the southern part of the WMA and technetium-99 concentrations are highest in the northern part of the WMA. Also, note that both technetium-99 and nitrate are increasing in the northern part of the downgradient side of WMA U (well 299-W19-42), whereas nitrate currently is increasing and technetium-99 is decreasing in the southern part (well 299-W19-41; Figure 4.47). 
Table 4.14. Average Concentration of Selected Contaminants in Groundwater in the Vicinity of Waste Management Area U for FY $2005^{\text {(a) }}$

\begin{tabular}{|c|c|c|c|c|}
\hline Well & $\begin{array}{c}\text { Chromium } \\
(\mu \mathrm{g} / \mathrm{L})\end{array}$ & $\begin{array}{l}\text { Nitrate } \\
(\mathrm{mg} / \mathrm{L})\end{array}$ & $\begin{array}{c}\text { Specific } \\
\text { Conductance } \\
(\mu \mathrm{S} / \mathrm{cm})\end{array}$ & $\begin{array}{l}\text { Technetium-99 } \\
(\mathrm{pCi} / \mathrm{L})\end{array}$ \\
\hline 299-W18-30 & $6(4)$ & $17.13(3)$ & $269(4)$ & $273(4)$ \\
\hline $299-W 18-31^{(b)}$ & 8 (4) & $28.65(4)$ & $293(4)$ & $18(4)$ \\
\hline 299-W18-40 & $4(3)$ & $24.25(4)$ & $288(4)$ & 17 (4) \\
\hline 299-W19-12 & $4(4)$ & 40.7 (4) & $462(4)$ & $290(4)$ \\
\hline 299-W19-41 & $9(4)$ & $69.25(2)$ & $532(4)$ & $91(4)$ \\
\hline 299-W19-42 & $4(2)$ & 13.18 (4) & $264(4)$ & $537(4)$ \\
\hline 299-W19-44 & $4(5)$ & $59.5(5)$ & $501(4)$ & $165(5)$ \\
\hline 299-W19-45 & $4(4)$ & $29.2(4)$ & $338(4)$ & $1,142(4)$ \\
\hline 299-W19-47 & $2(2)$ & $19.12(4)$ & $274(4)$ & $818(4)$ \\
\hline
\end{tabular}

Groundwater monitoring at WMA U began in 1983 at well 299-W19-12 (Hodges and Chou 2000). The nitrate concentration at that time was $40.7 \mathrm{mg} / \mathrm{L}$ but dropped rapidly within a year to $2.5 \mathrm{mg} / \mathrm{L}$ (Figure 4.49). The nitrate concentration subsequently increased to about $16.7 \mathrm{mg} / \mathrm{L}$ in 1990 before decreasing again in 1994. The latter minimum corresponds to the reversal in groundwater flow during that time due to discharges to 216-U-14 ditch (Hodges and Chou 2000). Since 1995, the concentration of nitrate generally increased until recently.

Technetium-99 was first analyzed at WMA U in 1988. The second sample analyzed from well 299-W19-12, in September 1988, contained 2,350 pCi/L technetium-99. No subsequent samples were analyzed for technetium-99 until mid 1992 at which time the technetium-99 concentration had dropped to $302 \mathrm{pCi} / \mathrm{L}$ (Hodges and Chou 2000). There were also indications of small amounts of cobalt-60 $(<10 \mathrm{pCi} / \mathrm{L})$ in the aquifer during the early and mid 1980s (HEIS 1994). It is not possible to determine whether the early contamination was from the WMA or some other source because there were no upgradient wells at WMA U until 1990.

Upgradient wells were drilled at WMA U in 1990 and 1991. Since that time, upgradient and downgradient groundwater compositions have been determined and found to be different. Hodges and Chou (2000) contrasted groundwater composition in wells 299-W18-25, 299-W18-31 (upgradient wells) with the composition in downgradient wells. Figures 4.50 and 4.51 show the upgradient-downgradient comparison for technetium-99 and nitrate respectively. Downgradient concentrations are considerably higher than upgradient concentrations especially for technetium-99.

Two things should be noted from Figure 4.50. First, the concentration of technetium-99 in the upgradient wells is one to two orders of magnitude less than in the downgradient wells, indicating that the downgradient technetium-99 is from WMA U. (Technetium-99 was undetected in upgradient wells between about 1997 and 2002.) Second, throughout the 1990s and 2000s, technetium-99 concentration in 


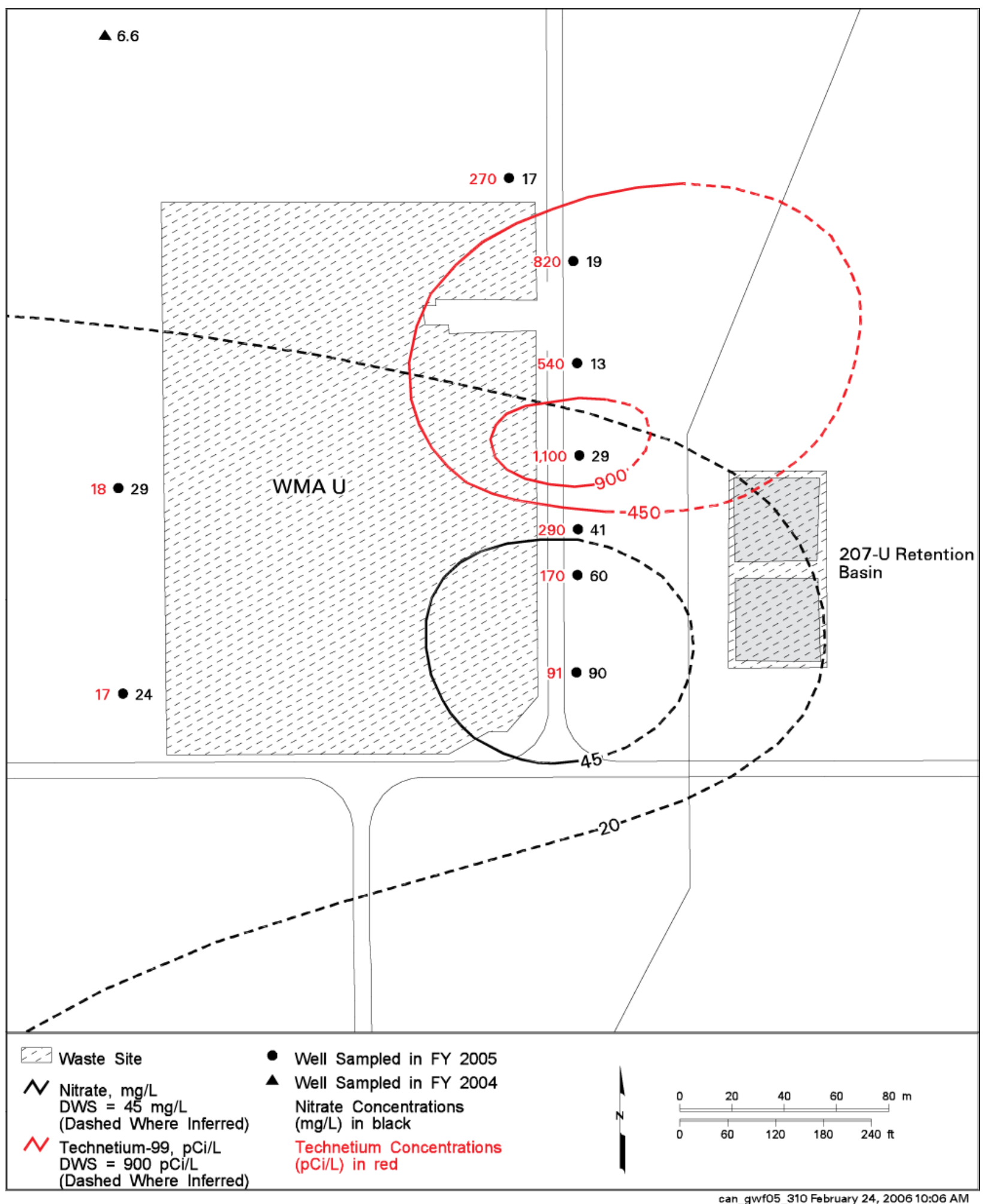

Figure 4.48. Average FY 2005 Nitrate and Technetium-99 Concentrations at Waste Management Area U, Top of the Aquifer (from Hartman et al. 2006) 


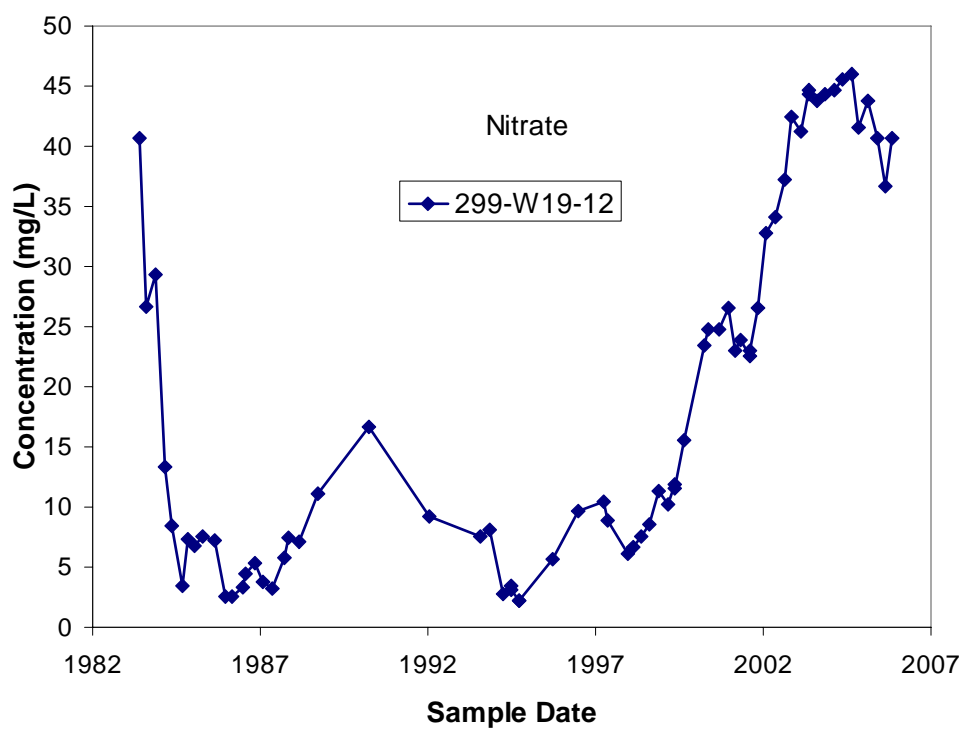

Figure 4.49. Nitrate Concentration in Downgradient Well 299-W19-12 at Waste Management Area U

wells 299-W19-12 and 299-W19-44, near the central part of the east (downgradient) side of the WMA has been in the 100 to $300 \mathrm{pCi} / \mathrm{L}$ range and fairly constant. The technetium- 99 concentration south of these wells along the downgradient side (well 299-W19-41) peaked in late 2001 and has been decreasing ever since. This is in contrast with the technetium-99 concentrations north of wells 299-W19-12 and 299-W19-44 (wells 299-W18-30, 299-W19-42, and 299-W19-45) where the concentration remained very low until after the start of 2002 and then increased dramatically. This suggests that the contamination found at the northern and southern corners of the WMA are different plumes and have different sources and neither plume has passed directly through the area of wells 299-W19-12 and 299-W19-44.

Figure 4.51 shows the concentrations of nitrate in selected monitoring wells at WMA U. The trends in nitrate concentration are much different than those of technetium-99. Nitrate concentrations were low and fairly constant in wells 299-W18-30 and 299-W19-42, located toward the northern part of the downgradient side of the WMA until mid 2004 when they began to rise very slightly (Figure 4.51). Further south along the downgradient side of the WMA, at wells 299-W19-12 and 299-W19-45, nitrate concentrations began to increase significantly in 1999 (well 299-W19-12) and are currently greater than they are in the north. Still further south, at well 299-W19-41, nitrate concentrations again began to increase in 1999 and are currently significantly higher than they are in the northern wells. Well 299-W19-44 is anomalous. This well is located very near well 299-W19-12 but has substantially more nitrate than well 299-W19-12.

The data in Figures 4.50 and 4.51 illustrate what McDonald et al. (2006) noted, i.e., the nitrate and technetium-99 appear to have two sources because they have different distribution patterns downgradient of WMA U.

\subsubsection{Comparisons of Groundwater, Vadose Zone Pore Water, and Tank Leak Chemical Composition at Waste Management Area U}

The best way to compare groundwater contamination with single-shell tank leaks is to compare the groundwater with pore water obtained from a portion of the vadose zone effected by a leak as was done 
for WMA B-BX-BY (Section 4.3.4.3), WMA C (Section 4.3.6.3), WMAs T and TX-TY (Sections 4.2.5.3 and 4.2.7.3) and WMA S-SX (Section 4.2.3). This is not possible at WMA U because no sediment samples have been obtained from an appropriate vadose zone location.
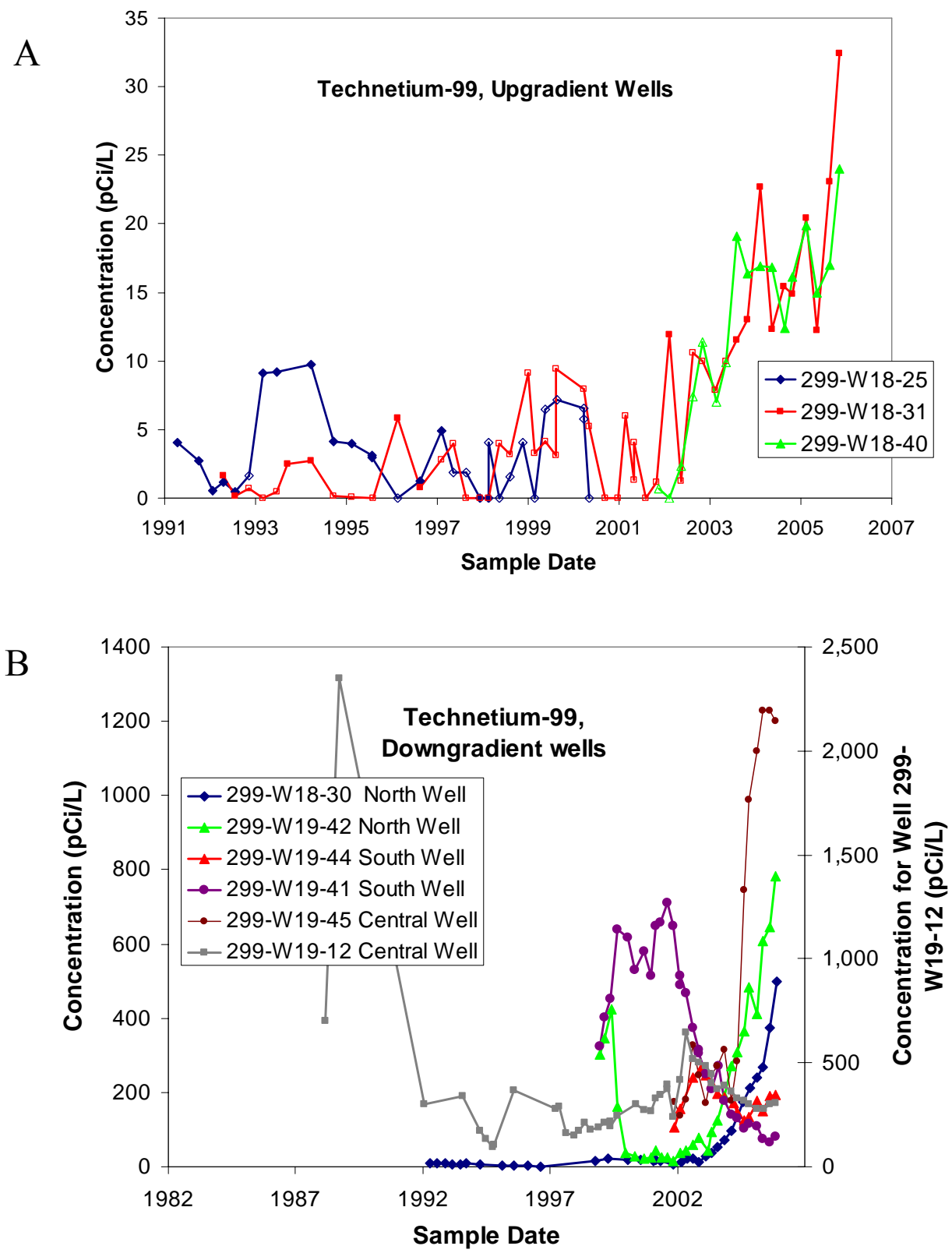

Figure 4.50. Technetium-99 Concentrations in Monitoring Wells at Waste Management Area U. (A) Concentrations in upgradient wells; (B) Concentrations in downgradient wells. (Open symbols represent non-detectable quantities.) 


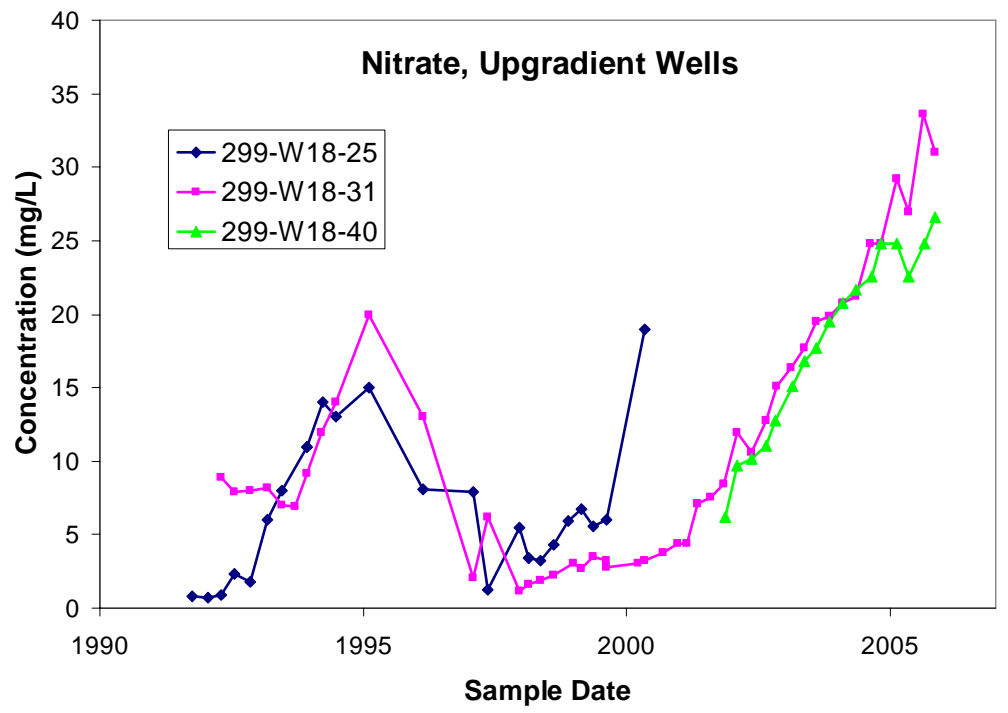

B

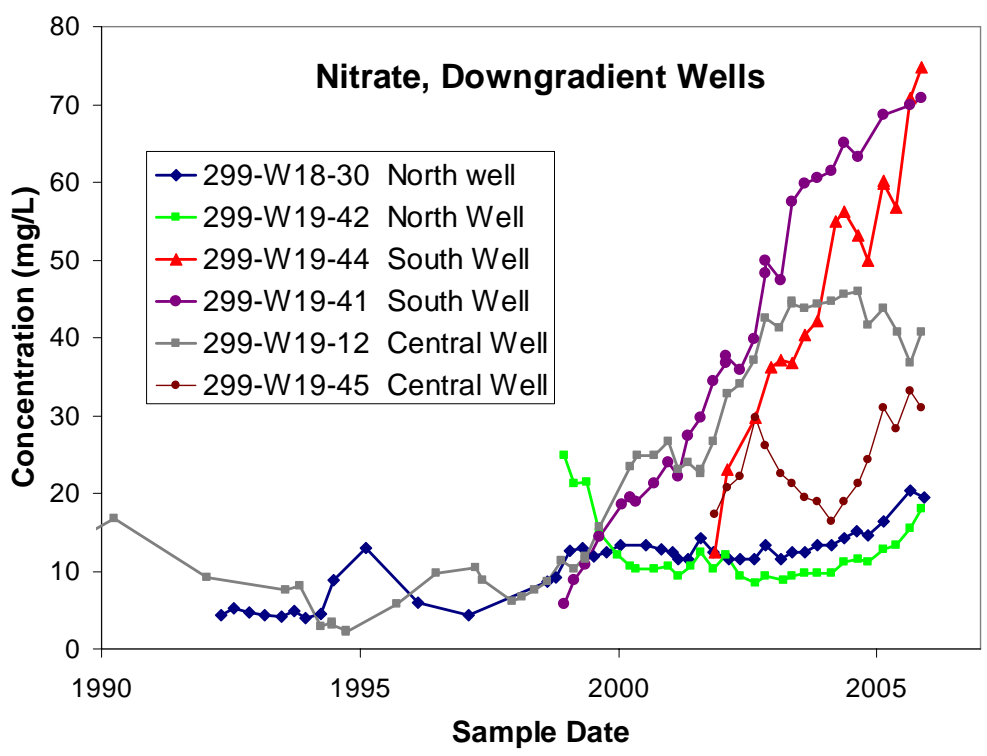

Figure 4.51. Nitrate Concentrations in Monitoring Wells at Waste Management Area U.

(A) Concentrations in Upgradient Wells; (B) Concentrations in Downgradient Wells. (Note change in concentration scale.)

As an alternative approach, groundwater compositions can be compared with those estimated for tank waste fluids. The unknowns and assumptions associated with tank leak estimates are large and caution is needed when making such comparisons. If the comparison is favorable, then either (1) the groundwater contamination was derived from the tank leak fluids, (2) the estimated leak fluid comparison is incorrect and the comparison is fortuitous, or (3) tank fluids and crib/trench fluids have similar concentrations and concentration ratios. If the comparison is unfavorable, either (1) the groundwater contamination is not from a tank leak, (2) the tank leak estimate is incorrect and the comparison has resulted in a false negative, or (3) tank waste has entered groundwater and mixed with past-practice discharges with dissimilar composition ratios. 
With these limitations in mind, McDonald et al. (2006) compared the nitrate/technetium-99 concentration ratios from groundwater samples taken from wells at WMA U with estimated ratios for tank leak fluids (Corbin et al. 2005) from the WMA. Figure 4.52 shows their results. Wells from WMA U fall into one of three distinct groups: upgradient wells with fairly constant ratios above 1,000; downgradient wells on the south half of the WMA with increasing ratios between about 300 to 1,000; and downgradient wells on the north half of the WMA with decreasing ratios between about 30 and 80. McDonald et al. (2006) interpreted these trends as follows. Upgradient wells show the influence of a nitrate plume that has migrated beneath the tank farm from some upgradient source to the west. Ratios on the downgradient side suggest mixing of tank farm waste with the upgradient plume, because the downgradient well ratios are between the ratios for the upgradient plume and the tank waste. The two downgradient plumes appear to have different sources, because ratios in the south wells are rising and approaching the levels in the upgradient wells, and ratios in the north wells are falling and approaching the ratios in the tank waste. It appears that the relative contribution to groundwater contamination from the tank farm is declining in the southern wells, but increasing in the northern wells. This suggests there are at least two separate locations where tank waste has entered groundwater (McDonald et al. 2006). However, the situation at WMA U is not straight forward because of changes in groundwater flow direction, the possibility of multiple sources within the WMA, and the encroaching, upgradient nitrate plume all of which can influence the technetium-99/nitrate ratios.

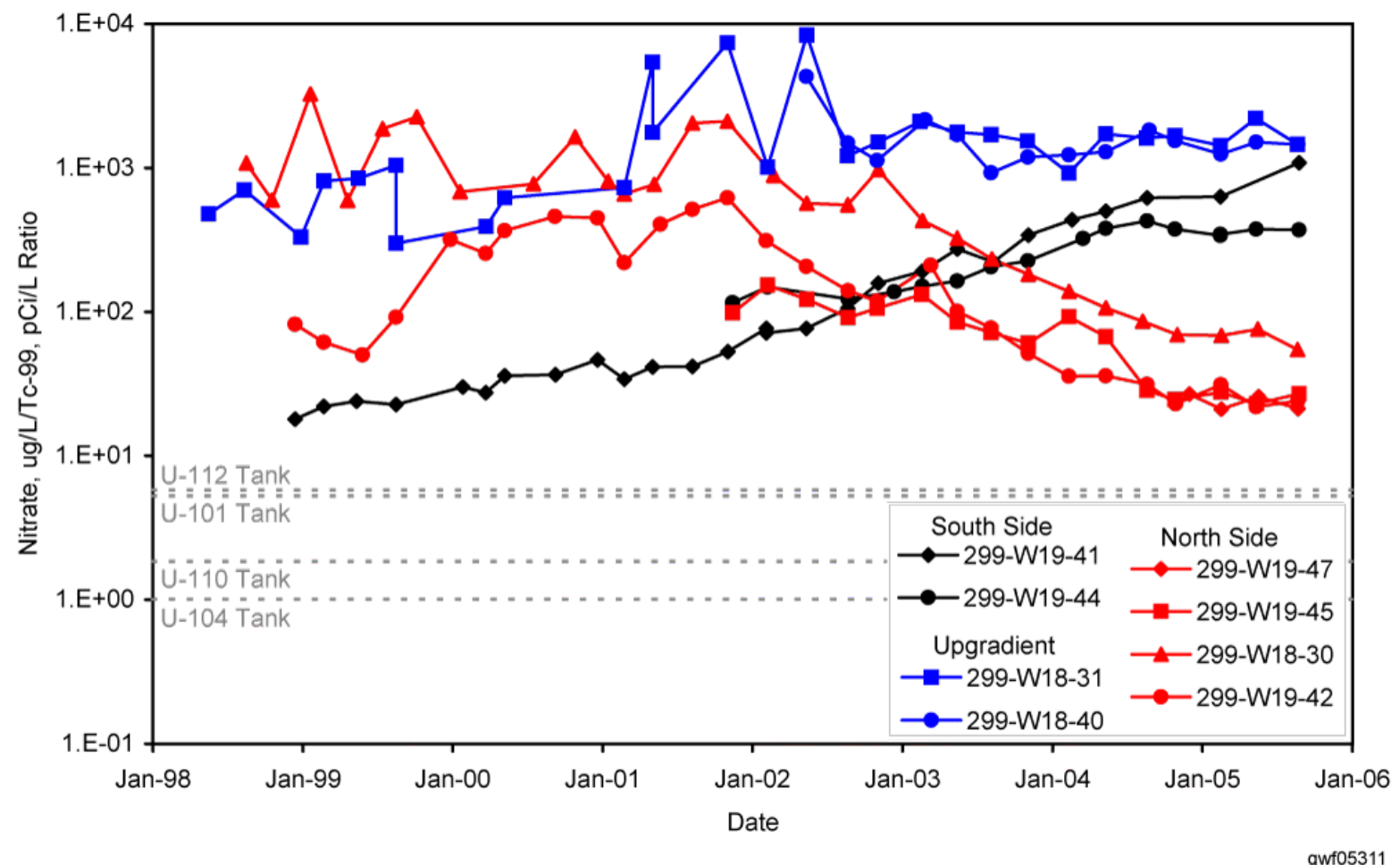

Figure 4.52. Technetium-99 Concentration Ratios at Waste Management Area U (from McDonald et al. 2006) 


\subsection{Groundwater Geochemistry Beneath Single-Shell Tank Waste Management Areas in 200 East Area}

This section describes the geochemical characteristics of groundwater beneath each of the single-shell tank WMAs in the 200 East Area. The background groundwater composition, for each WMA, is described by data from each upgradient well. This is followed by descriptions of current and historic trends in contamination at each WMA and, finally, by a comparison of the groundwater composition with contaminated pore water from the vadose zone at the WMA (where available) and/or estimates of the composition of tank leaks at the corresponding WMA.

\subsubsection{Background Groundwater Composition Beneath Waste Management Area A-AX}

Upgradient groundwater for the single-shell tank farm WMA A-AX is shown in Table 4.15. The data in the table are the average FY 2005 concentrations in each upgradient well at the WMA. All data are available on the CD included in Hartman et al. (2006). Data for the metals are from filtered samples; all other data are from unfiltered samples. Data flagged as suspect in the HEIS (1994) database have been excluded from the calculated averages.

Figure 4.53 shows modified Stiff diagrams for groundwater from each upgradient well at WMA A-AX. The composition of the groundwater from all three wells is similar. In general, the composition of groundwater from all three wells also is similar to the Hanford Site background groundwater and to groundwater from the Groundwater Performance Assessment Project's background wells (compare with Figures 4.1 and 4.2). The groundwater from WMA A-AX, however, has somewhat higher sulfate concentration relative to bicarbonate concentration when compared to the Hanford Site background and the Groundwater Project's background wells. The upgradient groundwater at WMA A-AX is a calciumbicarbonate-sulfate groundwater that has been slightly impacted by Hanford Site process waste discharge water with some nitrate contamination, particularly well 299-E24-20. Table 4.15 shows that upgradient groundwater at WMA A-AX also contains small concentrations of the contaminants iodine-129, technetium-99, and tritium. Charge balances for the analyses shown on Figure 4.53 are: $+1.5 \%$ for well $299-E 24-20,+1.5 \%$ for well 299-E24-22, and +3.2\% for well 299-E24-33.

\subsubsection{Groundwater Contamination Beneath Waste Management Area A-AX}

This section describes recent contamination associated with the single-shell tank WMA A-AX. Most of the information in this section is taken from Lindberg et al. (2006). Groundwater in the WMA A-AX vicinity is routinely monitored for RCRA and Atomic Energy Act purposes. Until recently, groundwater beneath this WMA was monitored under an interim status detection-level, indicator evaluation program. Sampling results in 2005 showed that the indicator parameter specific conductance exceeded the critical mean value for the WMA, thus changing the RCRA monitoring to groundwater quality assessment program. The assessment is in Phase 1 for which the goal is to determine whether the WMA is responsible for degrading groundwater quality. If it is found that no dangerous waste or dangerous waste constituents from WMA A-AX have entered the groundwater, then the WMA will be reinstated to an indicator evaluation program. If the Phase 1 investigation confirms that dangerous waste or dangerous waste constituents from the WMA have impacted the groundwater quality, further assessment investigations will be initiated to determine the rate, extent, and concentration of the migrating constituents (Narbutovskih and Chou 2006). 
Table 4.15. Average FY 2005 Groundwater Composition in Upgradient Wells at Waste Management Area A-AX

\begin{tabular}{|c|c|c|c|}
\hline \multirow[b]{2}{*}{ Constituent (units) } & \multicolumn{3}{|c|}{ Concentration } \\
\hline & Well 299-E24-20 & Well 299-E24-22 & Well 299-E24-33 \\
\hline Alkalinity as $\mathrm{CaCO}_{3}(\mu \mathrm{g} / \mathrm{L})$ & 94,500 & 94,000 & 94,500 \\
\hline Arsenic $(\mu \mathrm{g} / \mathrm{L})$ & 6.3 & 8.8 & 5.8 \\
\hline Calcium $(\mu \mathrm{g} / \mathrm{L})$ & 45,000 & 39,300 & 53,900 \\
\hline Cesium-137 (pCi/L) & Not detected & Not detected & Not analyzed \\
\hline Chloride $(\mathrm{mg} / \mathrm{L})$ & 8.1 & 8.75 & 11.3 \\
\hline Chromium $(\mu \mathrm{g} / \mathrm{L})$ & 4.1 & Not detected & Not detected \\
\hline Cobalt-60 (pCi/L) & Not detected & Not detected & Not analyzed \\
\hline $\begin{array}{l}\text { Coliform bacteria } \\
(\mathrm{Col} / 100 \mathrm{~mL})\end{array}$ & Not detected & Not detected & Not detected \\
\hline Fluoride $(\mathrm{mg} / \mathrm{L})$ & 0.22 & 0.24 & 0.20 \\
\hline Gross Alpha (pCi/L) & Not analyzed & Not analyzed & Not detected \\
\hline Gross beta $(\mathrm{pCi} / \mathrm{L})$ & 13.4 & 70.65 & 141.5 \\
\hline Iodine-129 (pCi/L) & 3.15 & Not detected & Not analyzed \\
\hline $\operatorname{Iron}(\mu \mathrm{g} / \mathrm{L})$ & 18.15 & 15.7 & 16.2 \\
\hline Magnesium $(\mu \mathrm{g} / \mathrm{L})$ & 13,150 & 11,150 & 15,050 \\
\hline Nitrate $(\mathrm{mg} / \mathrm{L})$ & 46.95 & 11,05 & 12.20 \\
\hline pH Measurement (pH units) & 8.1 & 8.0 & 7.8 \\
\hline Potassium $(\mu \mathrm{g} / \mathrm{L})$ & 5,765 & 5,485 & 6,480 \\
\hline Sodium $(\mu \mathrm{g} / \mathrm{L})$ & 18,400 & 19,500 & 18,850 \\
\hline Specific Conductance $(\mu \mathrm{S} / \mathrm{cm})$ & 433.75 & 386 & 467.5 \\
\hline Strontium-90 (pCi/L) & Not detected & Not detected & Not detected \\
\hline Sulfate $(\mathrm{mg} / \mathrm{L})$ & 64.3 & 67.9 & 68.1 \\
\hline Technetium-99 (pCi/L) & 32.15 & 134 & 574 \\
\hline Total organic carbon $(\mu \mathrm{g} / \mathrm{L})$ & 613 & 692 & 710 \\
\hline Total organic halides $(\mu \mathrm{g} / \mathrm{L})$ & 3.3 & 6.9 & 10.5 \\
\hline Tritium $(\mathrm{pCi} / \mathrm{L})$ & 9,840 & 3,800 & Not analyzed \\
\hline Uranium $(\mu \mathrm{g} / \mathrm{L})$ & 1.67 & 1.96 & Not analyzed \\
\hline
\end{tabular}

Groundwater monitoring under the Atomic Energy Act tracks radionuclides beneath the WMA and surrounding vicinity. The constituents of interest at WMA A-AX are sulfate, nitrate, technetium-99, and tritium. Iodine-129 is also found beneath the WMA but iodine-129 is associated with a regional plume emanating from the PUREX crib area.

\subsubsection{Extent of Contamination at Waste Management Area A-AX - Depth Distribution}

There are no data in the vicinity of WMA A-AX to evaluate vertical concentration gradients in the unconfined aquifer. Vertical concentration gradients have been documented at other single-shell tank WMAs (WMA B-BX-BY, Section 4.3.4.1; WMA T, Section 4.2.5.1, WMA TX-TY, Section 4.2.7.1, and WMA S-SX, Section 4.2.2.1) and such gradients may exist beneath WMA A-AX, but until appropriate data become available, this cannot be evaluated. 

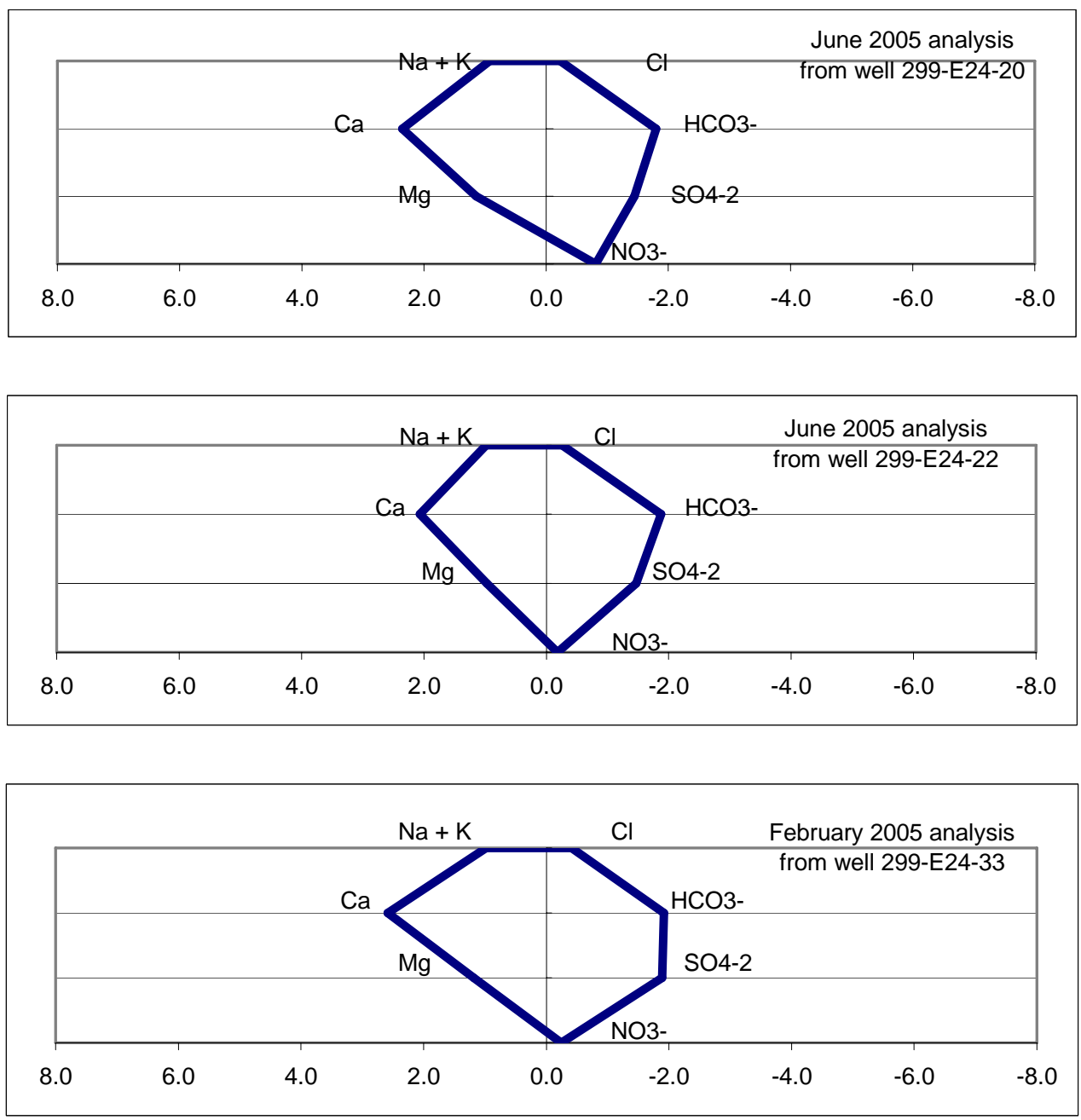

Figure 4.53. Major Cation and Anion Composition of Groundwater from Upgradient Wells at Waste Management Area A-AX. Units for the x-axis are milliequivalents/liter with cations on the left and anions on the right.

\subsubsection{Extent of Contamination Waste Management Area A-AX - Geographic Distribution}

This section summarizes the areal distribution of contaminants in groundwater at WMA A-AX. Because concentrations change over time, a time period must be chosen to examine spatial distribution patterns. For this purpose, the most recent data (FY 2005 quarterly samples) were chosen. All data are available on the CD included in Hartman et al. (2006). Data were first grouped by geographic location and tabulated as shown in Table 4.16. Data were then plotted and inspected for distribution patterns or groupings. Contour maps of contaminant concentrations were drawn to identify spatial patterns that might be indicative of source areas.

Sulfate is elevated in the vicinity of WMA A-AX when compared to Hanford Site background concentrations but does not exceed the secondary drinking water standard of $250 \mathrm{mg} / \mathrm{L}$. The highest concentrations are in downgradient wells with the highest average FY 2005 concentration being 
Table 4.16. Average FY 2005 Concentrations of Mobile Contaminants in Groundwater in the Vicinity of Waste Management Area A-AX ${ }^{(a)}$

\begin{tabular}{|c|c|c|c|c|c|c|c|c|c|}
\hline Well & $\begin{array}{l}\text { Chromium } \\
(\mu \mathrm{g} / \mathrm{L})\end{array}$ & $\begin{array}{l}\text { Fluoride } \\
(\mathrm{mg} / \mathrm{L})\end{array}$ & $\begin{array}{l}\text { Gross } \\
\text { Beta } \\
(\mathrm{pCi} / \mathrm{L})\end{array}$ & $\begin{array}{l}\text { Iodine-129 } \\
(\mathrm{pCi} / \mathrm{L})\end{array}$ & $\begin{array}{l}\text { Nitrate } \\
(\mathrm{mg} / \mathrm{L})\end{array}$ & $\begin{array}{c}\text { Specific } \\
\text { Conductance } \\
(\mu \mathrm{S} / \mathrm{cm})\end{array}$ & $\begin{array}{l}\text { Sulfate } \\
(\mathrm{mg} / \mathrm{L})\end{array}$ & $\begin{array}{l}\text { Technetium-99 } \\
\quad(\mathrm{pCi} / \mathrm{L})\end{array}$ & $\begin{array}{l}\text { Tritium } \\
(\mathrm{pCi} / \mathrm{L})\end{array}$ \\
\hline \multicolumn{10}{|c|}{ Upgradient Wells } \\
\hline 299-E24-22 & Not detected & $0.235(2)$ & $71(2)$ & Not detected & $11(2)$ & $386(8)$ & $67.9(2)$ & $134(2)$ & $3,800(1)$ \\
\hline 299-E24-33 & Not detected & $0.205(2)$ & $142(2)$ & Not analyzed & $12.20(2)$ & $468(8)$ & $68.1(2)$ & $574(2)$ & Not analyzed \\
\hline 299-E25-40 & $34(1)$ & $0.250(2)$ & $8(2)$ & $5.45(1)$ & $4.3(2)$ & $339(8)$ & $58.4(2)$ & $15(1)$ & $4,520(1)$ \\
\hline 299-E25-41 & $5.1(2)$ & $0.175(2)$ & $52(2)$ & $3.67(1)$ & $15.2(2)$ & $442(5)$ & $82.9(2)$ & $166(2)$ & $6,210(1)$ \\
\hline 299-E25-93 & $1(1)$ & $0.174(5)$ & $23(5)$ & $2.94(1)$ & $43.7(5)$ & $529(24)$ & $97.3(5)$ & $7.232(5)$ & $5,256(5)$ \\
\hline 299-E25-94 & Not detected & $0.220(4)$ & $115(3)$ & $3.01(1)$ & $38.1(4)$ & $481(13)$ & $81.7(4)$ & $377(4)$ & $3,900(4)$ \\
\hline
\end{tabular}


97.3 mg/L in well 299-E25-93 (Figure 4.54). Sulfate concentrations are also elevated in upgradient wells at WMA A-AX, consistent with the regional sulfate concentrations throughout the northern part of 200 East Area.

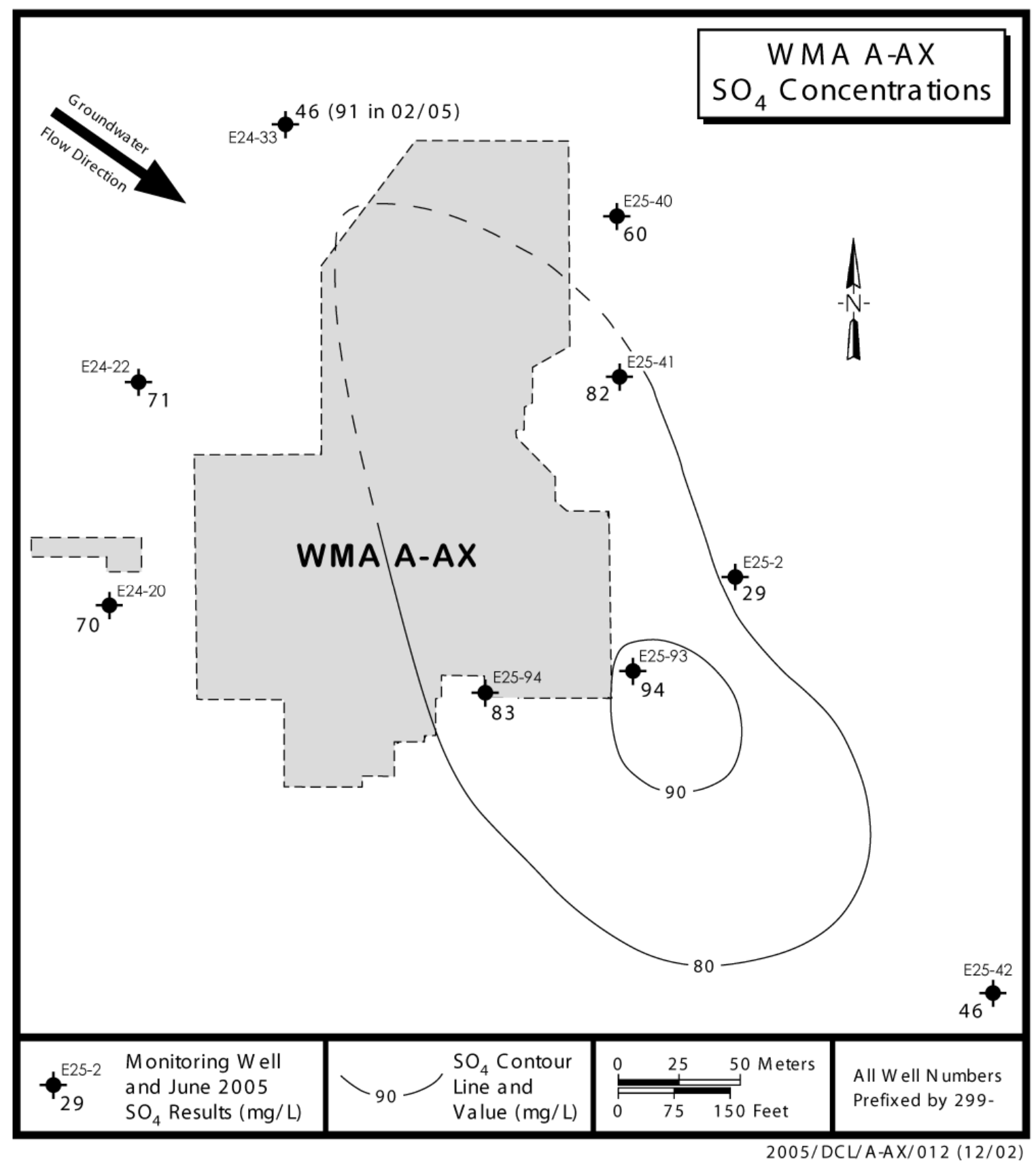

Figure 4.54. June 2005 Sulfate Concentrations in the Vicinity of Waste Management Area A-AX, Top of the Aquifer (from Hartman et al. 2006) 
Downgradient nitrate concentrations are elevated at the southern portion of WMA A-AX, creating a local area of high nitrate concentrations within the 200 East Area regional plume. The highest average 2005 nitrate concentration was $43.72 \mathrm{mg} / \mathrm{L}$ (just under the drinking water standard at $45 \mathrm{mg} / \mathrm{L}$ ) in well 299-W25-93 (Figure 4.55). Earlier, high nitrate concentrations were encountered in well 299-E24-20 in 1991 when the well was drilled. Concentrations decreased abruptly in 1993 and 1994 before increasing again to concentrations near those found in well 299-E25-93 today (Figure 4.56).

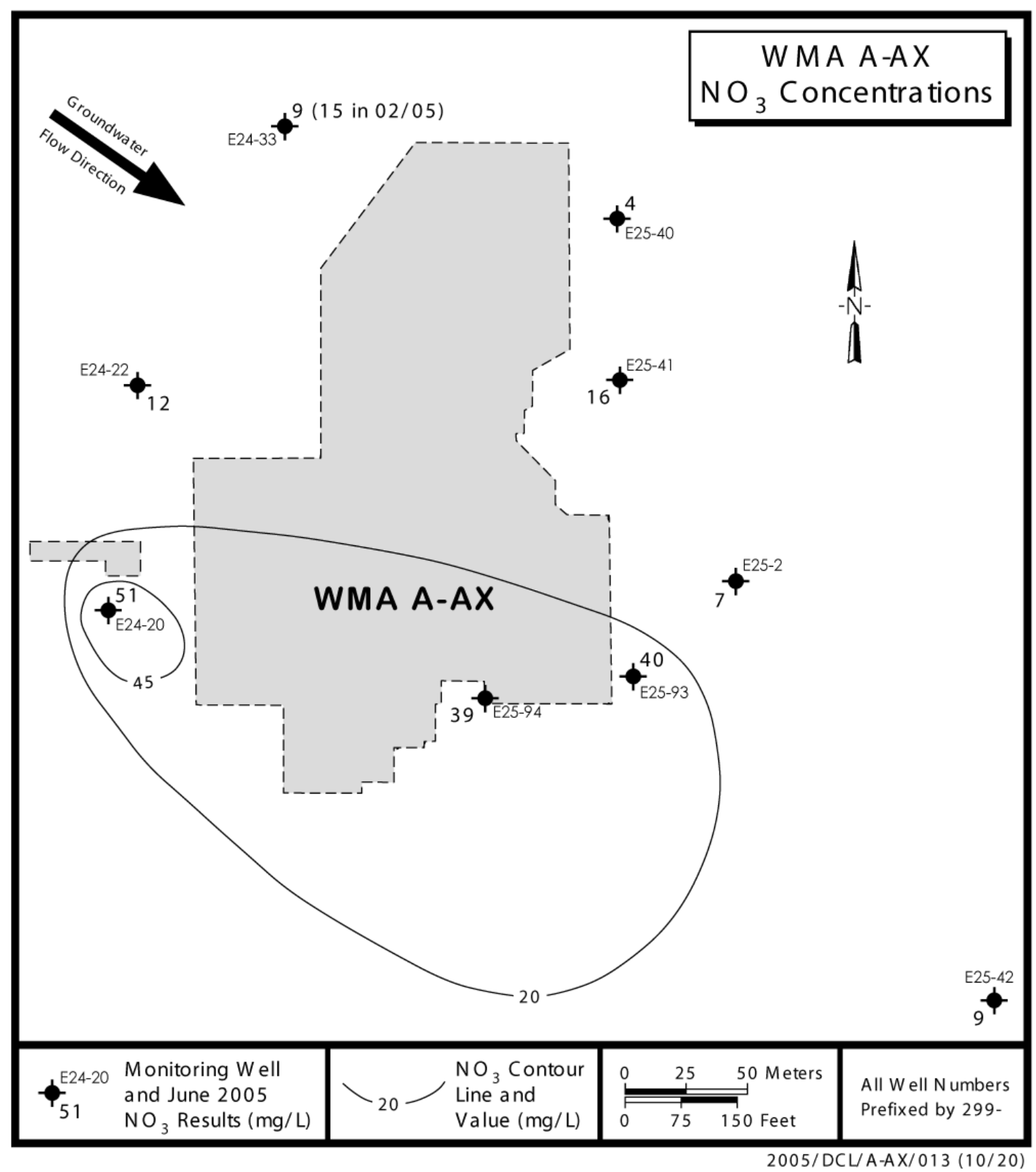

Figure 4.55. June 2005 Nitrate Concentrations in the Vicinity of Waste Management Area A-AX, Top of the Aquifer (from Hartman et al. 2006) 


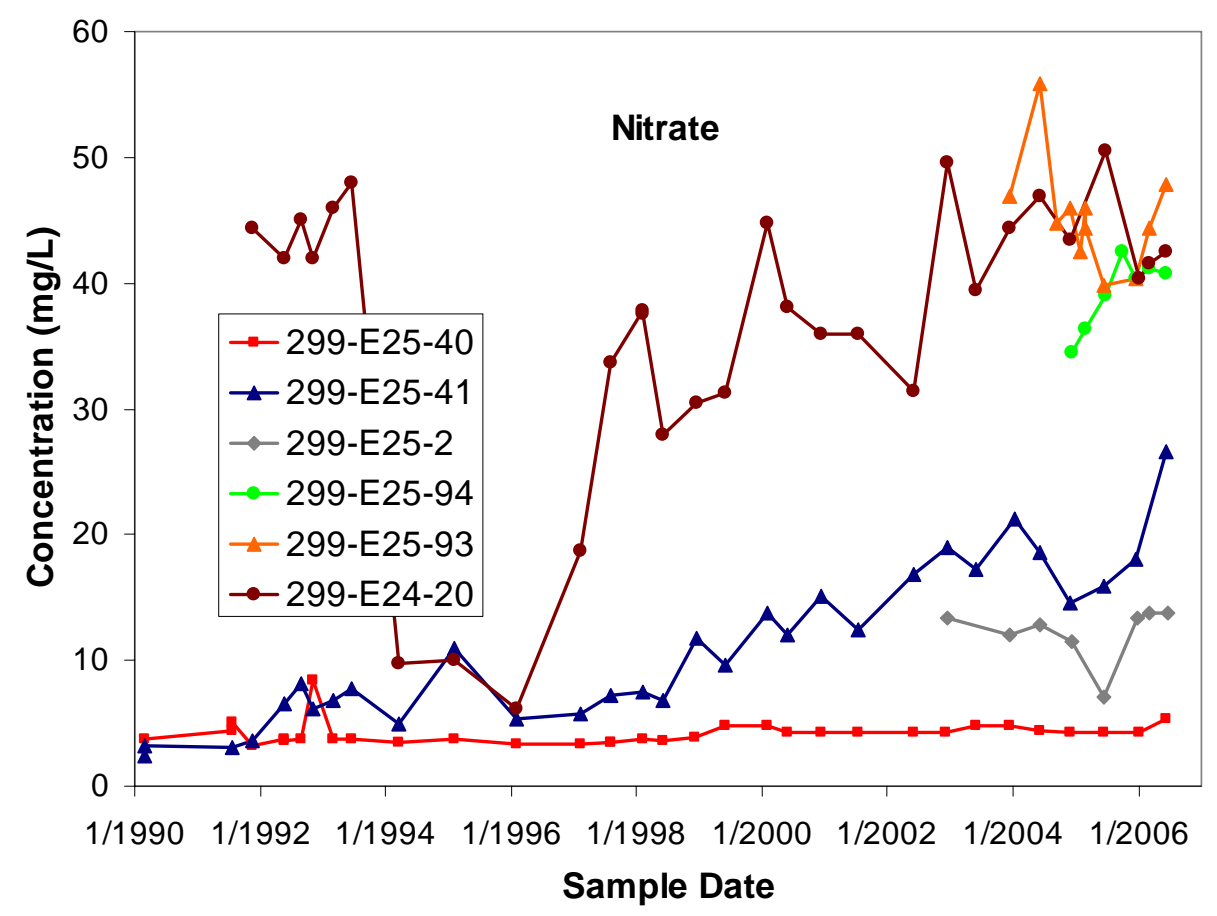

Figure 4.56. Nitrate Concentration versus Time in Selected Wells from Waste Management Area A-AX

A map of technetium-99 in groundwater in the vicinity of WMA A-AX is shown in Figure 4.57. The highest average 2005 technetium-99 concentration was at the southeast (downgradient) corner of WMA A-AX, coincident with the highest sulfate and nitrate concentrations, in well 299-W25-93. The technetium-99 concentration in the area was high when the well was drilled in mid-2003 and there was no other nearby wells to indicate when technetium-99 contamination first entered the area. Farther north along the downgradient side of the WMA, the technetium-99 concentration began to increase slightly in well 299-E25-41 in late 1998 and then more abruptly in 2002. Concentrations in the north, however, have not reached the magnitude of those in the south (Figure 4.58).

Iodine-129 beneath the WMA A-AX is part of a regional plume that exists across the 200 East Area and extends about 13 kilometers to the southeast. The primary source for the iodine-129 is PUREX process condensate previously discharged to the 216-A-10 and 216-A-45 cribs. Evaporator condensate discharged to the 216-A-31 crib also may have contributed to the widely dispersed plume that remains today (Lindberg 1997).

The earliest groundwater contamination in the area of the A and AX Tank Farms, as indicted by data in the HEIS database, was October 1951 when gross beta was 140,000 pCi/L in well 299-E25-1, located inside the A Tank Farm, and 160,000 pCi/L in downgradient well 299-E25-2 (Figure 4.59), located east of the A Tank Farm. Neither well was resampled for six years. In 1957, gross beta had reached $28,000,000 \mathrm{pCi} / \mathrm{L}$ in well 299-E25-1 and 210,000 pCi/L in well 299-E25-2. These high beta concentrations were accompanied by high concentrations of nitrate and cobalt-60 (Figure 4.59). Throughout most of the 1960s, groundwater sampling in these wells was sparse; by the time sampling resumed on a regular basis, the high concentration plumes had moved away from the wells, decayed away, or both. The source for the contamination in the WMA A-AX area in the early 1950s is not known but cannot be the WMA itself because the A and AX Tank Farms were not used until 1956 and 1965, respectively. 


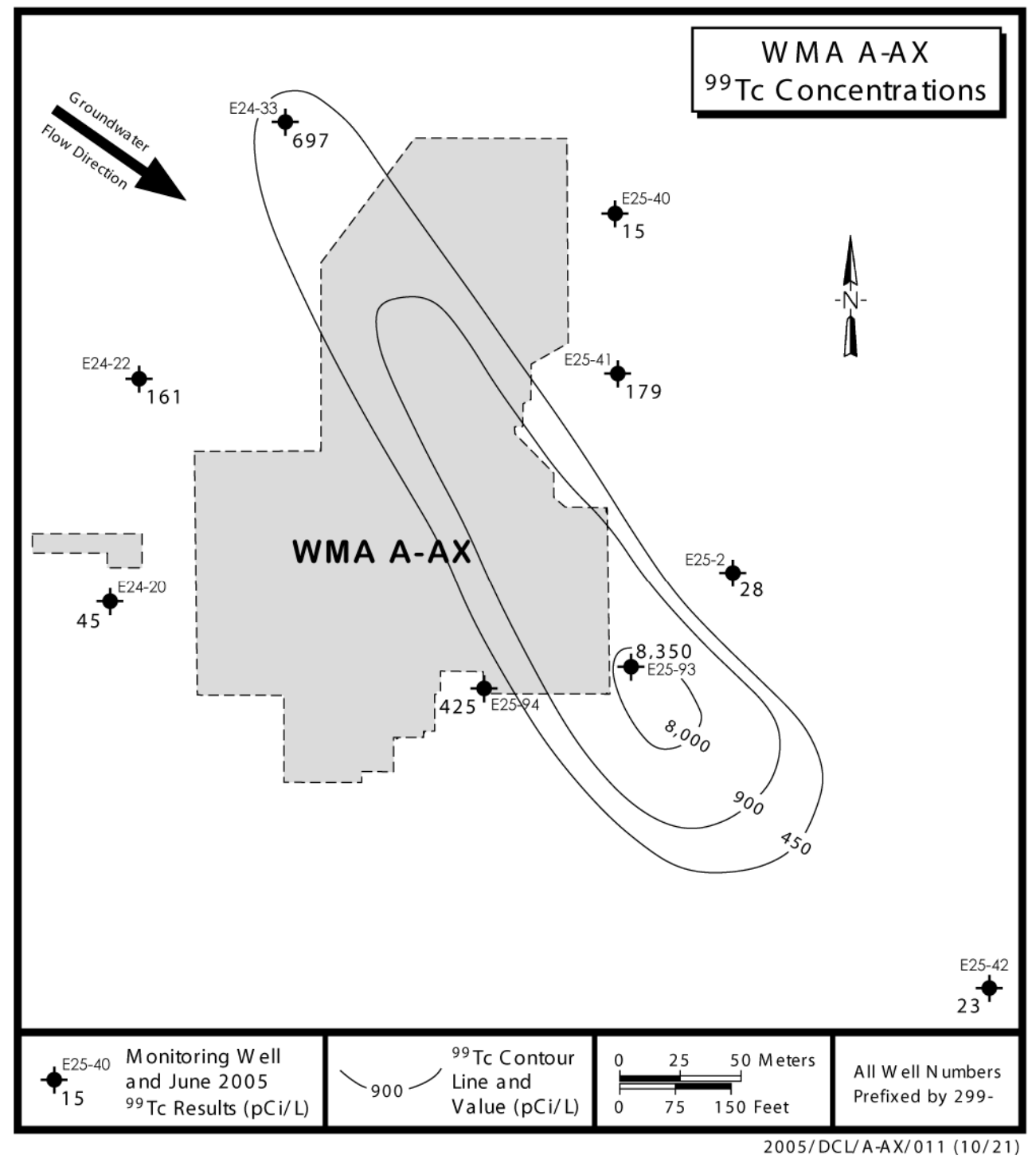

Figure 4.57. June 2005 Technetium-99 Concentrations in the Vicinity of Waste Management Area A-AX, Top of the Aquifer (from Hartman et al. 2006)

\subsubsection{Comparison of Groundwater and Estimated Tank Leak Chemical Compositions at Waste Management Area A-AX}

No contaminated vadose zone sediment has been sampled and analyzed in WMA A-AX. Therefore, the concentrations of contaminants in the groundwater cannot be compared with the contaminant composition of vadose zone pore water as can be done in other single-shell tank WMAs. As a substitute for measured pore water compositions, the estimated compositions of leaked tank fluids are compared with groundwater compositions in this section. The estimated tank leak compositions are taken from Corbin et al. (2005).

Nitrate and technetium-99 are chosen for the comparisons because these data are readily available for groundwater samples. Nitrate and technetium-99 also have very low distribution coefficients (Cantrell et al. 2002) and little, if any, fractionation of the two is expected in the vadose zone and aquifer. 


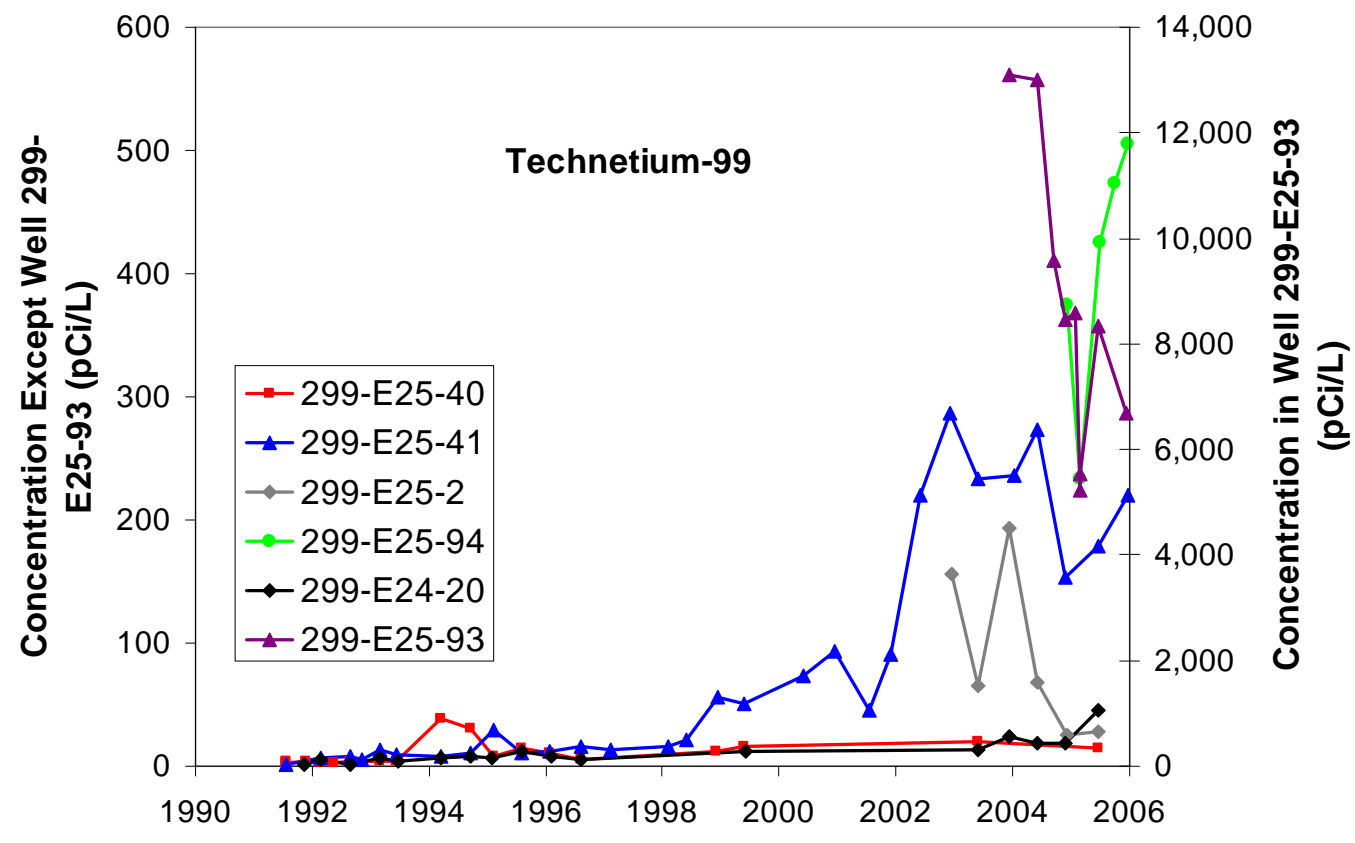

Sample Date

Figure 4.58. Technetium-99 Concentration versus Time in Selected Wells at Waste Management Area A-AX

Table 4.17 shows the technetium-99/nitrate concentration ratios $(\mathrm{pCi} / \mathrm{mg}$ ) for groundwater samples collected from WMA A-AX wells in FY 2005 and estimated technetium-99/nitrate concentration ratios of tank leaks in WMA A-AX. The data show that the composition of the groundwater, with respect to technetium-99 and nitrate, is not similar to the estimated composition of the tank waste. The ratios for well 299-E25-93, the well with relatively high contamination at the WMA, has significantly higher technetium-99/nitrate ratios than all other wells, but the ratios are still an order of magnitude less than the estimated tank composition ratios from Corbin et al. (2005).

Given the information and data available, little can be concluded from comparing the compositions of current groundwater at WMA A-AX and estimated tank waste from the WMA except that there is no readily apparent relationship.

\subsubsection{Background Groundwater Composition Beneath Waste Management Area B-BX-BY}

Upgradient groundwater for the single-shell tank farm WMA B-BX-BY is shown in Table 4.18 and Figure 4.60. The data in the table are the average FY 2005 concentrations in each upgradient well at the WMA. All data are included on the CD supplied with Hartman et al. (2006). Data for the metals are from filtered samples; all other data are from unfiltered samples. Data flagged as suspect in the Hanford Environmental Information System database have been excluded from the calculated averages. Charge balances for the analyses shown in Figure 4.60 are: $+3.4 \%$ for well $299-E 33-18,+4.5 \%$ for well 299-E33-38, $+2.2 \%$ for well 299-E33-39, and $+0.6 \%$ for well 299-E33-7. 

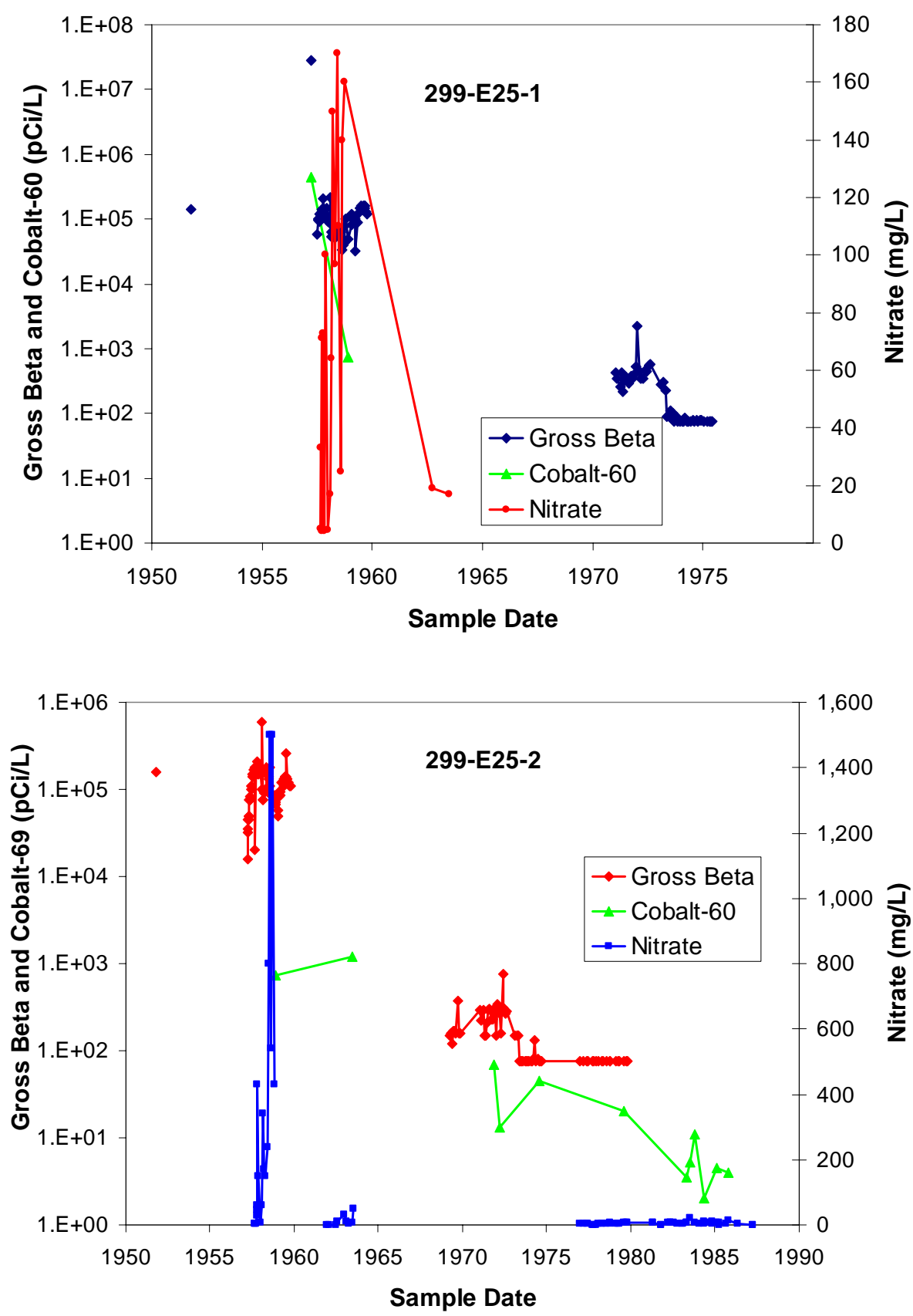

Figure 4.59. Concentration versus Time for Several Contaminants in Groundwater from Well 299-E25-1 (top) and 299-E25-2 (bottom) at Waste Management Area A-AX. (Note log scale used for concentrations.) 
Table 4.17. Comparison of Technetium-99/Nitrate Composition Ratios in Groundwater and Estimated Tank Leak Fluids

\begin{tabular}{|c|c|c|}
\hline Tank & Sample Date ${ }^{(a)}$ & $\begin{array}{c}\text { Technetium-99/Nitrate } \\
(\mathrm{pCi} / \mathrm{mg})^{(\mathrm{b})}\end{array}$ \\
\hline A-103 & & 1,132 \\
\hline A-104 & & 3,870 \\
\hline A-105 & & 15,270 \\
\hline AX-102 & & 4,125 \\
\hline \multicolumn{3}{|c|}{ Upgradient Wells } \\
\hline 299-E24-20 & June 2005 & 1 \\
\hline \multirow[t]{2}{*}{ 299-E24-22 } & December 2004 & 10 \\
\hline & June 2005 & 14 \\
\hline \multirow[t]{2}{*}{ 299-E24-33 } & February 2005 & 30 \\
\hline & June 2005 & 75 \\
\hline \multicolumn{3}{|c|}{ Downgradient Wells } \\
\hline \multirow[t]{2}{*}{ 299-E25-2 } & December 2004 & 2 \\
\hline & June 2005 & 4 \\
\hline 299-E25-40 & June 2005 & 4 \\
\hline \multirow[t]{2}{*}{ 299-E25-41 } & December 2004 & 11 \\
\hline & June 2005 & 11 \\
\hline \multirow[t]{4}{*}{ 299-E25-93 } & December 2004 & 184 \\
\hline & January 2005 & 202 \\
\hline & February 2005 & 119 \\
\hline & June 2005 & 210 \\
\hline \multirow[t]{4}{*}{ 299-E25-94 } & December 2004 & 11 \\
\hline & February 2005 & 6 \\
\hline & June 2005 & 11 \\
\hline & September 2005 & 11 \\
\hline \multicolumn{3}{|c|}{$\begin{array}{l}\text { (a) Sample dates are for groundwater samples. } \\
\text { (b) Tank estimates are from Corbin et al. (2005), groundwater data are from } \\
\text { HEIS. }\end{array}$} \\
\hline
\end{tabular}

The composition of upgradient groundwater at WMA B-BX-BY differs depending on the location of the wells. Well 299-E33-39 is located northeast of the WMA and is upgradient of most past-practice disposal facilities as well as the tank farms. Groundwater in that well is similar to the Hanford Site background groundwater but it has been impacted by liquid discharges and/or tank leaks. Sulfate and nitrate concentrations in groundwater from well 299-E33-39 are increased relative to Hanford Site background water. Groundwater in well 299-E33-39 is calcium-sulfate-bicarbonate water.

Groundwater in upgradient well 299-E33-18 is similar to that in well 299-E33-39 but has higher salt content particularly nitrate. Groundwater at this well also contains significant concentrations of the contaminants iodine-129, technetium-99, tritium, and uranium (Table 4.18) suggesting that it may be downgradient of past-practice discharge facilities. Groundwater in well 299-E33-18 is a calcium-nitratebicarbonate water. The latter well is upgradient to the B Tank Farm but may be downgradient to the BY Tank Farm. 
Table 4.18. Average FY 2005 Groundwater Composition in Waste Management Area B-BX-BY Upgradient Wells

\begin{tabular}{|c|c|c|c|c|}
\hline \multirow[b]{2}{*}{ Constituent (units) } & \multicolumn{4}{|c|}{ Concentration } \\
\hline & Well 299-E33-18 & Well 299-E33-38 & Well 299-E33-39 & Well 299-E33-7 \\
\hline Alkalinity as $\mathrm{CaCO}_{3}(\mu \mathrm{g} / \mathrm{L})$ & 104,250 & 106,600 & 102,000 & 94,080 \\
\hline Calcium $(\mu \mathrm{g} / \mathrm{L})$ & 70,400 & 130,000 & 54,780 & 150,000 \\
\hline Cesium-137 (pCi/L) & Not analyzed & Not detected & Not analyzed & Not detected \\
\hline Chloride (mg/L) & 15.78 & 30.42 & 20.64 & 25.54 \\
\hline Chromium $(\mu \mathrm{g} / \mathrm{L})$ & 36.38 & 21.46 & 11.72 & 34.26 \\
\hline Cobalt-60 (pCi/L) & Not analyzed & 39.18 & Not analyzed & 40.14 \\
\hline Cyanide $(\mu \mathrm{g} / \mathrm{L})$ & Not detected & 261 & Not detected & 397.6 \\
\hline Fluoride (mg/L) & 0.25 & 0.32 & 0.57 & 0.70 \\
\hline Gross alpha $(\mathrm{pCi} / \mathrm{L})$ & 208.75 & 177.75 & Not analyzed & Not detected \\
\hline Gross beta $(\mathrm{pCi} / \mathrm{L})$ & 921.25 & 4,232 & Not analyzed & 3,434 \\
\hline Iodine-129 (pCi/L) & 3.79 & Not detected & Not detected & 1.78 \\
\hline Iron $(\mu \mathrm{g} / \mathrm{L})$ & 23.68 & 180 & 20.68 & 241.2 \\
\hline Magnesium $(\mu \mathrm{g} / \mathrm{L})$ & 24,125 & 39,300 & 15,320 & 40,520 \\
\hline Nitrate $(\mathrm{mg} / \mathrm{L})$ & 155.50 & 521.25 & 47.02 & 804.00 \\
\hline $\mathrm{pH}$ (pH units) & 7.9 & 7.8 & 8.0 & 7.8 \\
\hline Potassium $(\mu \mathrm{g} / \mathrm{L})$ & 8,340 & 11,740 & 9,022 & 12,480 \\
\hline Sodium $(\mu \mathrm{g} / \mathrm{L})$ & 27,725 & 98,420 & 28,340 & 132,400 \\
\hline $\begin{array}{l}\text { Specific Conductance } \\
(\mu \mathrm{S} / \mathrm{cm})\end{array}$ & 722 & 1,448 & 536 & 1,678 \\
\hline Strontium-90 (pCi/L) & Not analyzed & Not detected & Not analyzed & Not analyzed \\
\hline Sulfate $(\mathrm{mg} / \mathrm{L})$ & 75.85 & 148 & 80.66 & 134.2 \\
\hline Technetium-99 (pCi/L) & 2,738 & 12,320 & 131 & 9,470 \\
\hline Tritium $(\mathrm{pCi} / \mathrm{L})$ & 4865 & 7,290 & 508 & 5,790 \\
\hline Uranium $(\mu \mathrm{g} / \mathrm{L})$ & 371 & 319 & 3.32 & 4.07 \\
\hline
\end{tabular}

Groundwater from the other two wells used as upgradient wells at WMA B-BX-BY, wells 299-E33-38 and 299-E33-7, is highly contaminated and does not resemble the Hanford Site background groundwater. These two wells are located in the area of the BY cribs and intercept contamination from those cribs. Groundwater in these two wells is classified as sodium-calcium-nitrate groundwater, although all major cations and anions are elevated above natural background concentrations. These wells also contain significant concentrations of the contaminants cyanide, cobalt- 60 , technetium-99, and, for well 299-E33-38, uranium.

\subsubsection{Groundwater Contamination Beneath Waste Management Area B-BX-BY}

This section describes recent and historical contamination associated with single-shell tank WMA B-BX-BY. Most of the information in this section is taken from Thornton et al. (2006). Groundwater at WMA B-BX-BY is routinely monitored for RCRA and Atomic Energy Act purposes. The objective of RCRA monitoring at WMA B-BX-BY is to assess the nature and extent of groundwater contamination with hazardous constituents; determine their rate of movement in the aquifer; and determine the source of the contamination. Groundwater monitoring under the Atomic Energy Act tracks radionuclides in the WMA and surrounding vicinity. 

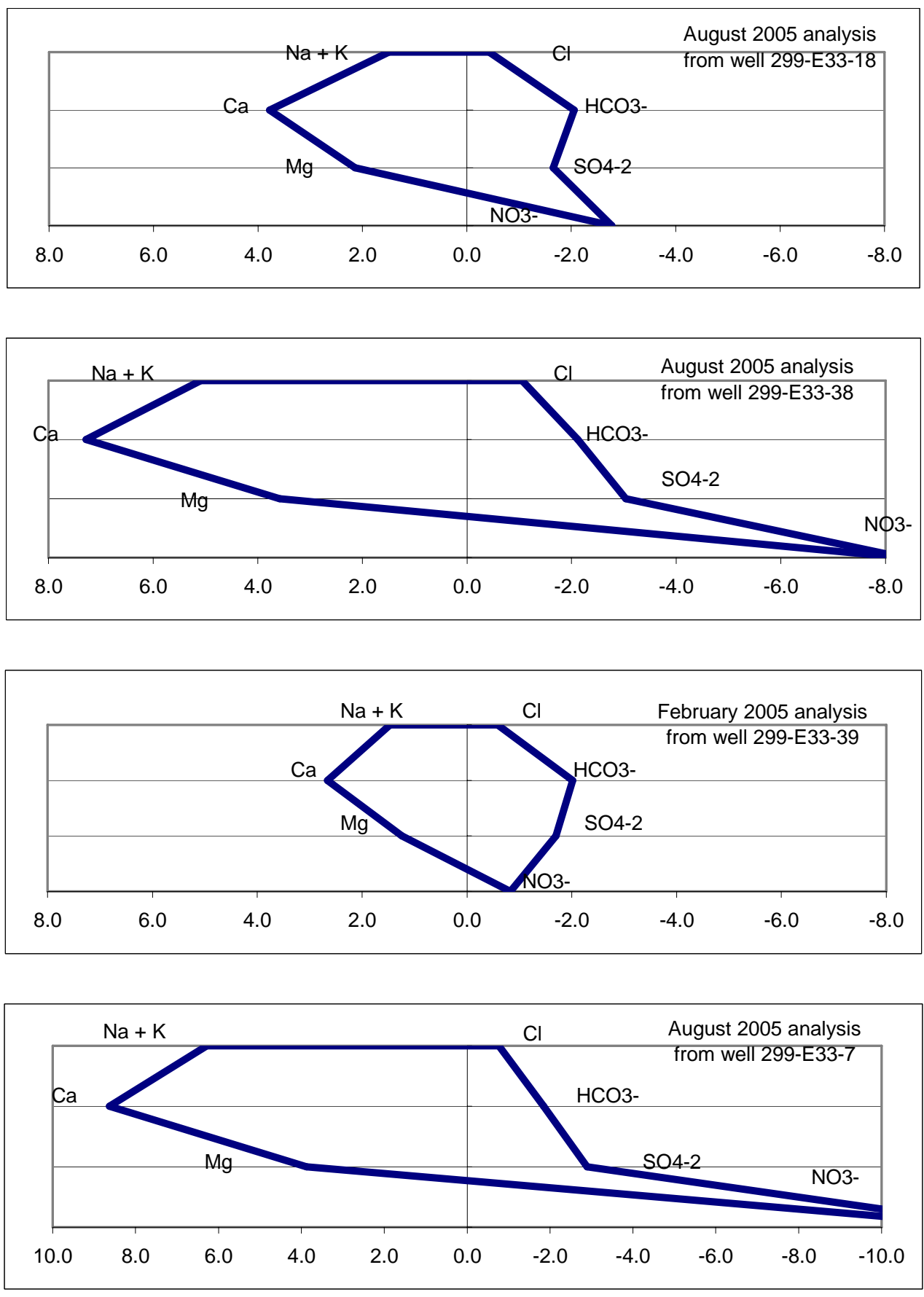

Figure 4.60. Major Cation and Anion Composition of Groundwater from Upgradient Wells at Waste Management Area B-BX-BY. Units for the $\mathrm{x}$-axis are milliequivalents/liter with cations on the left and anions on the right. (Note scale change for well 299-E33-7; nitrate for well 299-E33-7 is -13.06 meq.) 


\subsubsection{Extent of Contamination at Waste Management Area B-BX-BY - Depth Distribution}

Discrete-depth sampling for selected constituents was done in well 299-E33-334 in October 2002 and in well 299-E33-44 in April 2003 (Schalla and Narbutovskih 2006). Samples were collected at low flow rates with a device that allows sampling discrete depths within the aquifer. Sample collection procedures are described in Schalla and Narbutovskih (2006).

Figure 4.61 shows the depth distribution of tritium in well 299-E33-334. The well is located near the southwest corner of the WMA in an area of high tritium concentrations in the groundwater. Tritium in this area may be entering the aquifer from a known perched water horizon located about $4.6 \mathrm{~m}$ above the water table. The perched water contained up to about 79,800 pCi/L tritium in well 299-E33-45 (Serne et al. 2002a). Five groundwater samples were collected from well 299-E33-334 and analyzed for tritium. The results showed increasing concentration with increasing depth in the aquifer. However, the maximum tritium concentration at the bottom of the aquifer is much less than that in the perched water. Thus, the perched water may not be the source of the tritium in the groundwater south of WMA B-BX-BY. Schalla and Narbutovskih (2006) interpreted the results to indicate that well 299-E33-334 is not close enough to the point of tritium entry into the groundwater to allow delineation of a high-concentration layer at the top of the aquifer.

\section{Discrete Depth Tritium Concentrations}

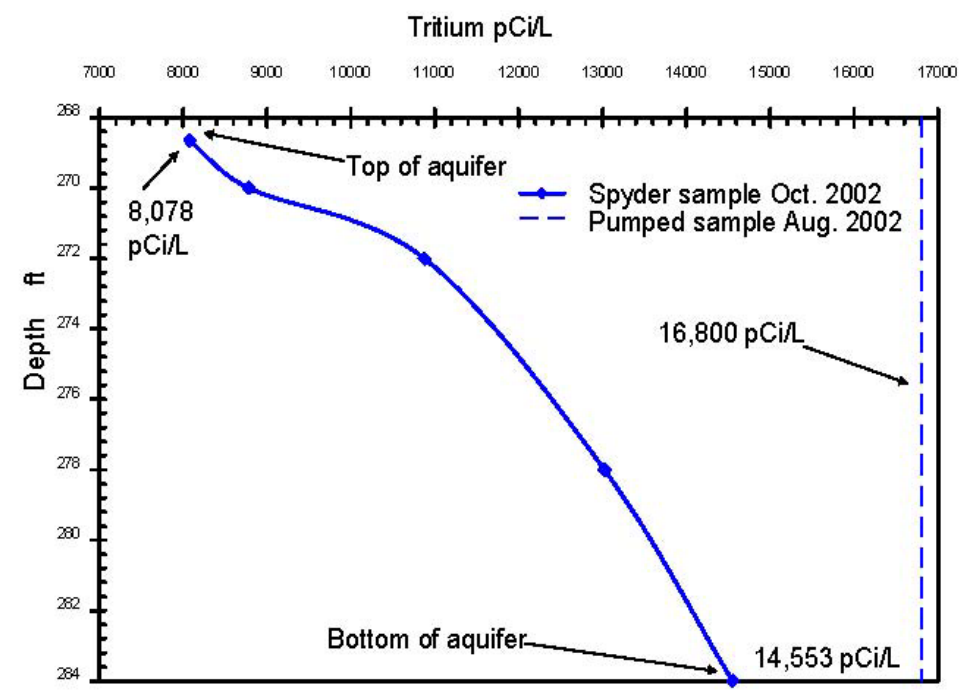

Figure 4.61. Depth Distribution of Tritium in Well 299-E33-334 (from Schalla and Narbutovskih 2006). Note that the depth scale is in feet; multiply by 0.3048 to convert feet to meters.

A routine, pumped groundwater sample collected two months before the depth-discrete samples had $16,800 \mathrm{pCi} / \mathrm{L}$ tritium. This concentration is higher than the depth-discrete sample. Although the cause of this discrepancy is not known, it may be related to the fairly large sampling intervals used for the depthdiscrete samples (Schalla and Narbutovskih 2006) or to plume movement during the two-month interval between collection of the routine pumped sample and the depth-discrete samples.

The second well at WMA B-BX-BY from which depth-discrete samples were collected is well 299-E33-44, located east of the BY Tank Farm. This well was sampled to test whether dense, salt-laden 
waste from either tank leaks or past-practice disposal operations had sunk to the bottom of the aquifer. The aquifer in this area is only $1.8-\mathrm{m}$ thick and the water table is declining at about $0.09 \mathrm{~m} / \mathrm{year}$. For this reason, well 299-E33-44 was drilled 1.5 meter into basalt to allow sampling to continue as the water table dropped. Twelve samples were collected in the aquifer and five samples were collected in the basalt. The samples were analyzed for technetium-99 and nitrate.

The results of the sampling effort for well 200-E33-44 are shown on Figure 4.62. Both technetium-99 and nitrate show a fairly steady and unchanging concentration distribution in the upper part of the aquifer and a distinct, high-concentration layer at the base of the aquifer. Concentrations continue to increase in the part of the well that extends into the basalt. (Reasons for the thin, relatively low concentration zone at the top of basalt [base of the aquifer] are not known and not explained by Schalla and Narbutovskih [2006].) The concentrations of both technetium-99 and nitrate track each other with depth in the well as expected, since both are co-contaminants in the area. Schalla and Narbutovskih (2006) believe that the data tend to support the idea of a high-density salt layer at the bottom of the aquifer, but that sampling in additional wells is needed to confirm this idea.

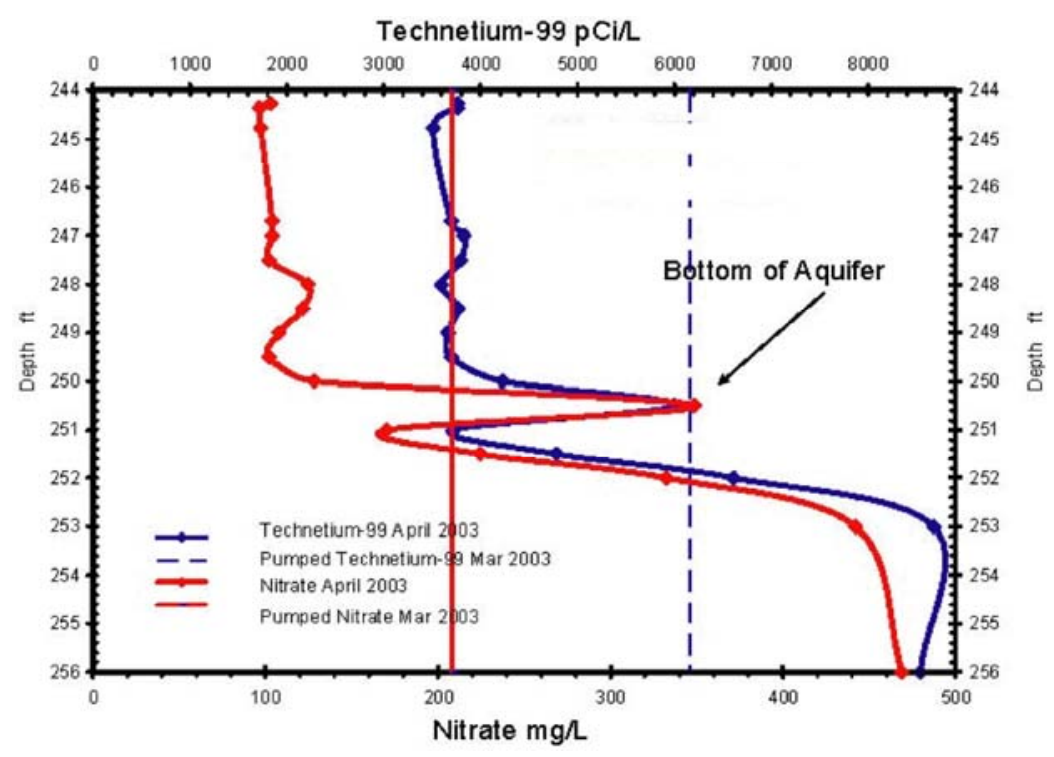

Figure 4.62. Depth Distribution of Technetium-99 and Nitrate in Well 299-E33-44 (from Schalla and Narbutovskih 2006). Top of basalt is at $\sim 250$ - $\mathrm{ft}$ depth. Note that the depth scale is in feet; multiply by 0.3048 to convert feet to meters.

\subsubsection{Extent of Contamination at Waste Management Area B-BX-BY - Geographic Distribution}

This section summarizes the spatial distribution of contaminants in groundwater at WMA B-BX-BY. The contaminants of concern are technetium-99, uranium, tritium, nitrate, sulfate, cyanide, and cobalt-60.

The average FY 2005 concentrations for selected constituents monitored at WMA B-BX-BY are tabulated in Table 4.19. The wells in the table are grouped according to geographic area around the WMA. 
Table 4.19. Average Concentration of Selected Mobile Contaminants in the Vicinity of Waste Management Area B-BX-BY for FY 2005 ${ }^{(\mathrm{a})}$

\begin{tabular}{|c|c|c|c|c|c|c|c|c|c|}
\hline Well Name $^{(b)}$ & $\begin{array}{c}\text { Chromium } \\
(\mu \mathrm{g} / \mathrm{L})\end{array}$ & $\begin{array}{c}\text { Cobalt-60 } \\
(\mathrm{pCi} / \mathrm{L})\end{array}$ & $\begin{array}{c}\text { Cyanide } \\
(\mu \mathrm{g} / \mathrm{L})\end{array}$ & $\begin{array}{c}\text { Gross Alpha } \\
(\mathrm{pCi} / \mathrm{L})\end{array}$ & $\begin{array}{l}\text { Nitrate } \\
(\mathrm{mg} / \mathrm{L})\end{array}$ & $\begin{array}{l}\text { Sulfate } \\
(\mathrm{mg} / \mathrm{L})\end{array}$ & $\begin{array}{c}\text { Technetium-99 } \\
(\mathrm{pCi} / \mathrm{L})\end{array}$ & $\begin{array}{l}\text { Tritium } \\
(\mathrm{pCi} / \mathrm{L})\end{array}$ & $\begin{array}{c}\text { Uranium } \\
(\mu \mathrm{g} / \mathrm{L})\end{array}$ \\
\hline 299-E33-32 & $4.7(3)^{(\mathrm{c})}$ & \begin{tabular}{|l|}
$\begin{array}{l}\text { Not detected } \\
(4)\end{array}$ \\
\end{tabular} & \begin{tabular}{|l|}
$\begin{array}{l}\text { Not detected } \\
(3)\end{array}$ \\
\end{tabular} & Not analyzed & $113.75(4)$ & $78.58(4)$ & $1,405(4)$ & $14,825(4)$ & $5.0(4)$ \\
\hline 299-E33-21 & $3.6(1)$ & Not analyzed & \begin{tabular}{|l|}
$\begin{array}{l}\text { Not detected } \\
(2)\end{array}$ \\
\end{tabular} & Not analyzed & $26.10(2)$ & $78.15(2)$ & $88(2)$ & $17,200(2)$ & $4.9(2)$ \\
\hline 299-E33-334 & $4.1(3)$ & Not analyzed & $\begin{array}{l}\text { Not detected } \\
(4)\end{array}$ & Not analyzed & $29.65(4)$ & $79.1(4)$ & $66(4)$ & $17,300(4)$ & $5.1(4)$ \\
\hline 299-E33-49 & $2.2(2)$ & Not analyzed & \begin{tabular}{|l} 
Not detected \\
$(4)$
\end{tabular} & Not analyzed & $24.68(4)$ & $75.8(4)$ & $51(3)$ & $14,900(4)$ & $5.0(4)$ \\
\hline 299-E33-339 & $3.1(2)$ & Not analyzed & $\begin{array}{l}\text { Not detected } \\
(4)\end{array}$ & Not analyzed & $26,65(4)$ & $79.05(4)$ & $125(3)$ & $13,175 \mathrm{n}(4)$ & $5.2(4)$ \\
\hline 299-E33-48 & $2.2(2)$ & Not analyzed & $\begin{array}{l}\text { Not detected } \\
(4)\end{array}$ & Not analyzed & $23.58(4)$ & $74.05(4)$ & $45(3)$ & $13,550(4)$ & $5.9(4)$ \\
\hline $399-E 33-9^{(\mathrm{d})}$ & $\begin{array}{l}\begin{array}{l}\text { Not } \\
\text { analyzed }\end{array} \\
\end{array}$ & Not analyzed & \begin{tabular}{|l|}
$\begin{array}{l}\text { Not } \\
\text { analyzed }\end{array}$ \\
\end{tabular} & Not analyzed & Not analyzed & Not analyzed & Not analyzed & Not analyzed & Not analyzed \\
\hline 299-E33-42 & $7.6(4)$ & $\begin{array}{l}\text { Not detected } \\
(4)\end{array}$ & $7(1)$ & $16(4)$ & $125.50(4)$ & $61.55(4)$ & $2,205(4)$ & $5,362(4)$ & $25.0(4)$ \\
\hline 299-E33-31 & $8.5(5)$ & $\begin{array}{l}\text { Not detected } \\
(5)\end{array}$ & \begin{tabular}{|l|} 
Not detected \\
$(5)$
\end{tabular} & $80(4)$ & $238.20(5)$ & $104.92(5)$ & $2,098(5)$ & $5,148(5)$ & $122.7(5)$ \\
\hline 299-E33-44 & $32.3(4)$ & $41(4)$ & $9.4(2)$ & $153(4)$ & $338.50(4)$ & $148.75(4)$ & $8,278(4)$ & $8,798(4)$ & $249(4)$ \\
\hline 299-E33-41 & $9.0(4)$ & $\begin{array}{l}\text { Not detected } \\
\text { (4) }\end{array}$ & \begin{tabular}{|l} 
Not detected \\
$(4)$
\end{tabular} & $11(4)$ & $49.73(3)$ & $55.65(4)$ & $473(4)$ & $4,408(4)$ & $18.0(4)$ \\
\hline
\end{tabular}


Table 4.19. (contd)

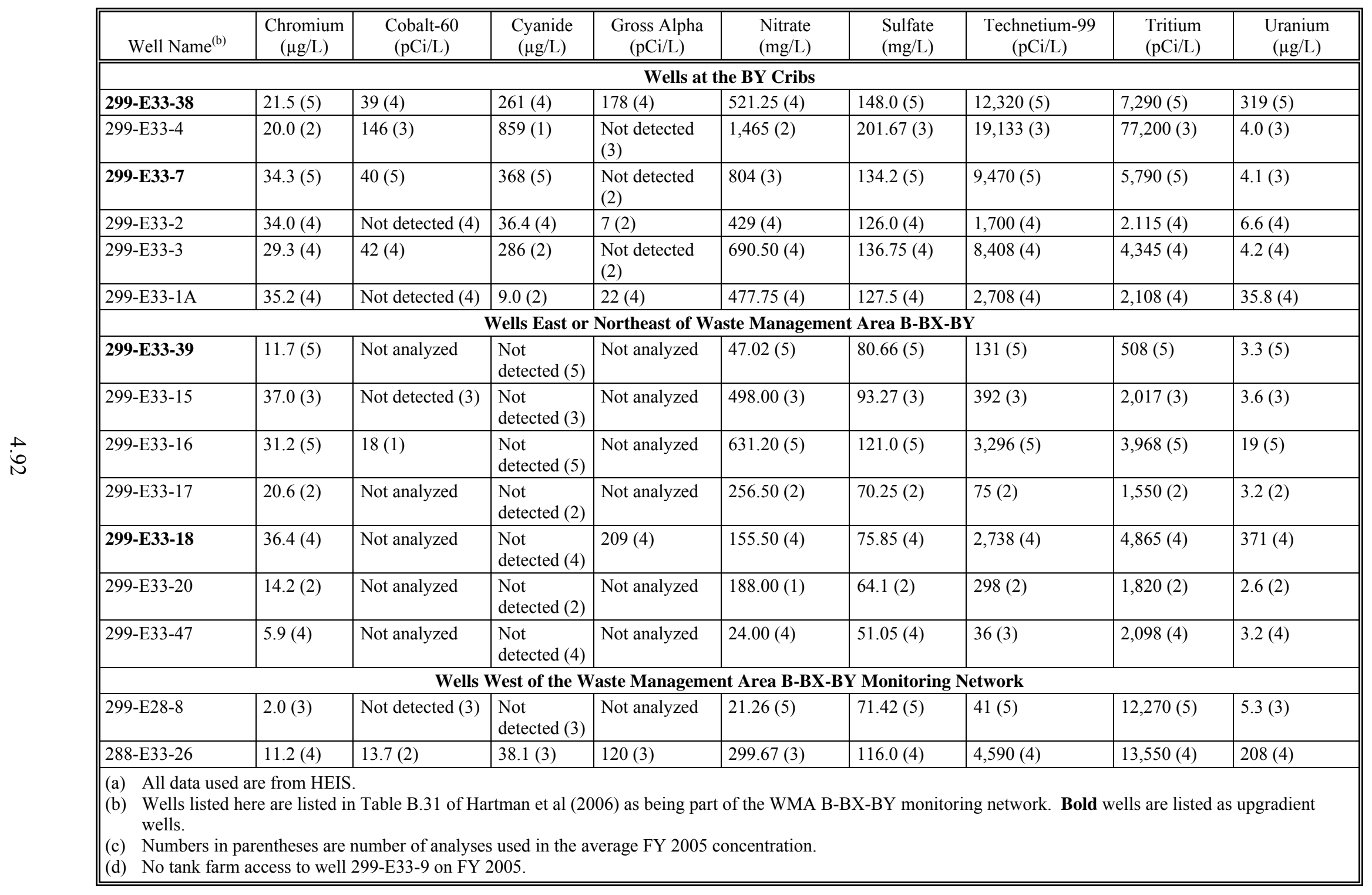


Groundwater monitoring has identified the following four distinct groups of contaminants at WMA B-BX-BY (Thornton et al. 2006).

- There is a technetium-99, nitrate, sulfate, uranium, and nitrite plume beneath and southeast of the BY Tank Farm. Past leaks of processing waste from the tank farms have contaminated the vadose zone under the farms and this contamination may, at least partly, be the source of the local groundwater contamination.

- There is a tritium plume beneath the southwest corner and southern boarder of the WMA B-BX-BY. The source of the tritium may be perched water located about $4.5 \mathrm{~m}$ above the water table beneath the BX Tank Farm.

- A technetium-99, nitrate, sulfate, cobalt-60, and cyanide plume is found beneath and around the BY cribs, north of the WMA. These contaminants are attributed to discharges of tank waste to the BY cribs in the 1950 s.

- A technetium-99 and nitrate plume is located beneath the 216-B-8 crib, east of the BY Tank Farm. Past discharges to the crib is the most likely source for this plume.

A regional nitrate plume extends across much of the 200 East Area. A local area of high nitrate concentrations, within the regional plume, occurs beneath the BY cribs (Figure 4.63). There appears to be a long-term increasing trend in nitrate concentration across the area beginning about 10 years ago (Thornton et al. 2006) (Figure 4.64). Nitrate concentrations range from 1,600 mg/L in the north beneath the BY cribs to less than $25 \mathrm{mg} / \mathrm{L}$ south of the WMA. A similar trend appears to be occurring in the area east and southeast of the BY Tank Farm over the years and current nitrate concentrations in that area range from 160 to $630 \mathrm{mg} / \mathrm{L}$.

Technetium-99 is a co-contaminant with nitrate, and a technetium-99 plume exists under WMA B-BX-BY and the BY cribs and may extend to the northwest of the WMA (Figure 4.65). The highest technetium-99 concentrations are found in wells at the BY cribs and the cribs are probably the source of much of the technetium-99 in groundwater beneath the WMA.

The technetium-99 concentrations were high at the BY cribs when monitoring for technetium-99 first began in the mid to late 1980s (wells 299-E33-7 and 299-E33-3 on Figure 4.66). Concentrations then decreased before increasing again in the mid to late 1990s. The latter increase was not just restricted to the area of the BY cribs. In the mid to late 1990s, technetium-99 concentrations also began increasing east of the WMA at the 216-B-7 cribs (well 299-E33-18 on Figure 4.66), along the west and southwest side of the WMA (wells 299-E33-31 and 299-E33-32), and about 250 m northwest of the WMA in well 299-E33-26 at the 216-B-61 crib (Lindberg et al. 2003). Lindberg et al. (2003) believe that the simultaneous increase in technetium-99 (and nitrate) across the entire WMA B-BX-BY area was primarily due to long-term, steady-state recharge from natural precipitation moving contaminants in the vadose zone to groundwater aided, perhaps, by local artificial discharges of water in places.

Lindberg et al. (2003) used nitrate/technetium-99 concentration ratios to delineate sources for groundwater contamination in the WMA B-BX-BY area. They interpret their results to indicate two possible contamination sources beneath the BY cribs, two possible sources west of the BX and BY Tank Farms, and a fifth source east of the BY Tank Farm extending to the 216-B-7 cribs. 


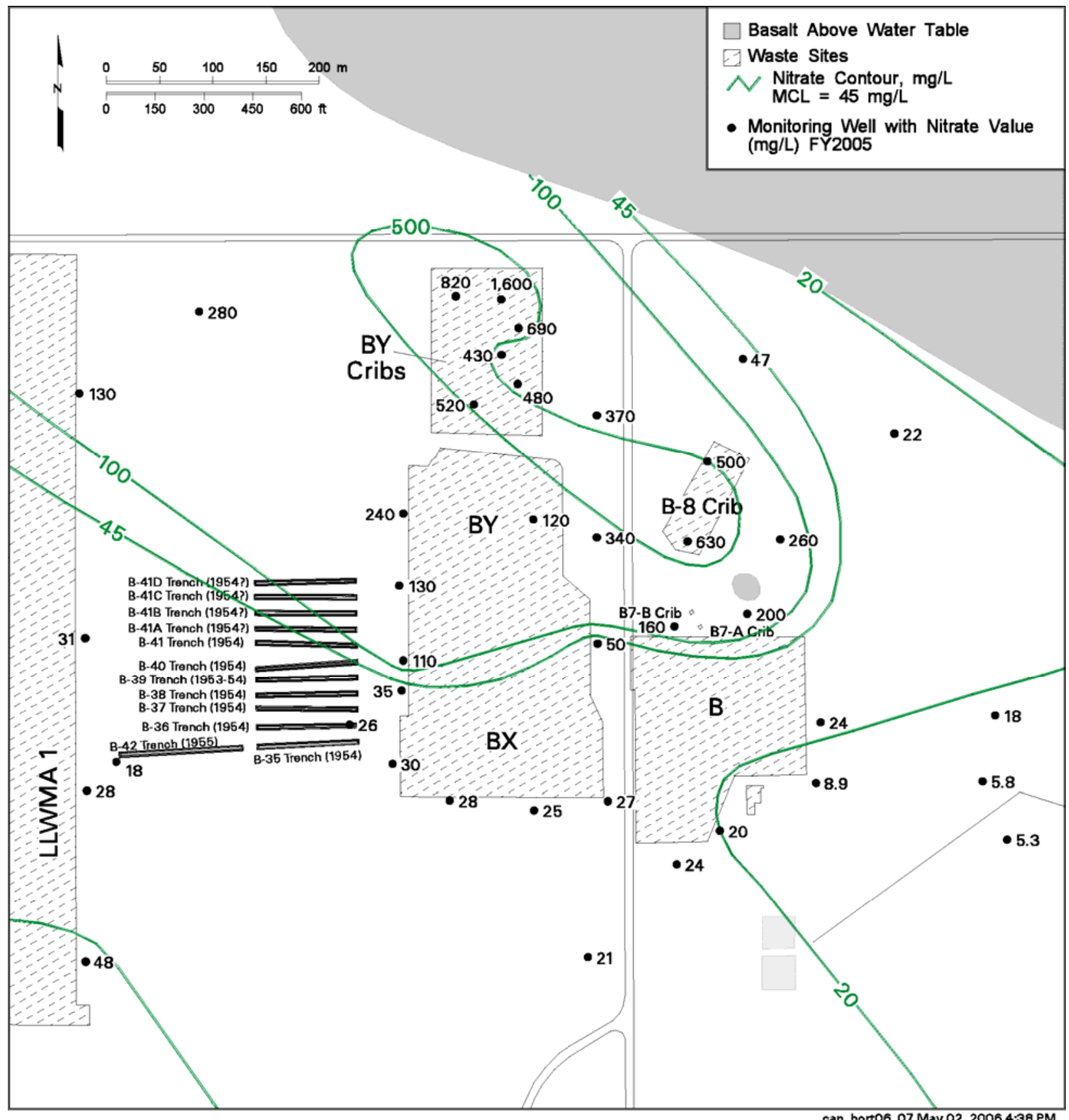

Figure 4.63. Average FY 2005 Nitrate Concentration in the Area of Waste Management Area B-BX-BY, Top of the Aquifer (modified from Hartman et al. 2006) 


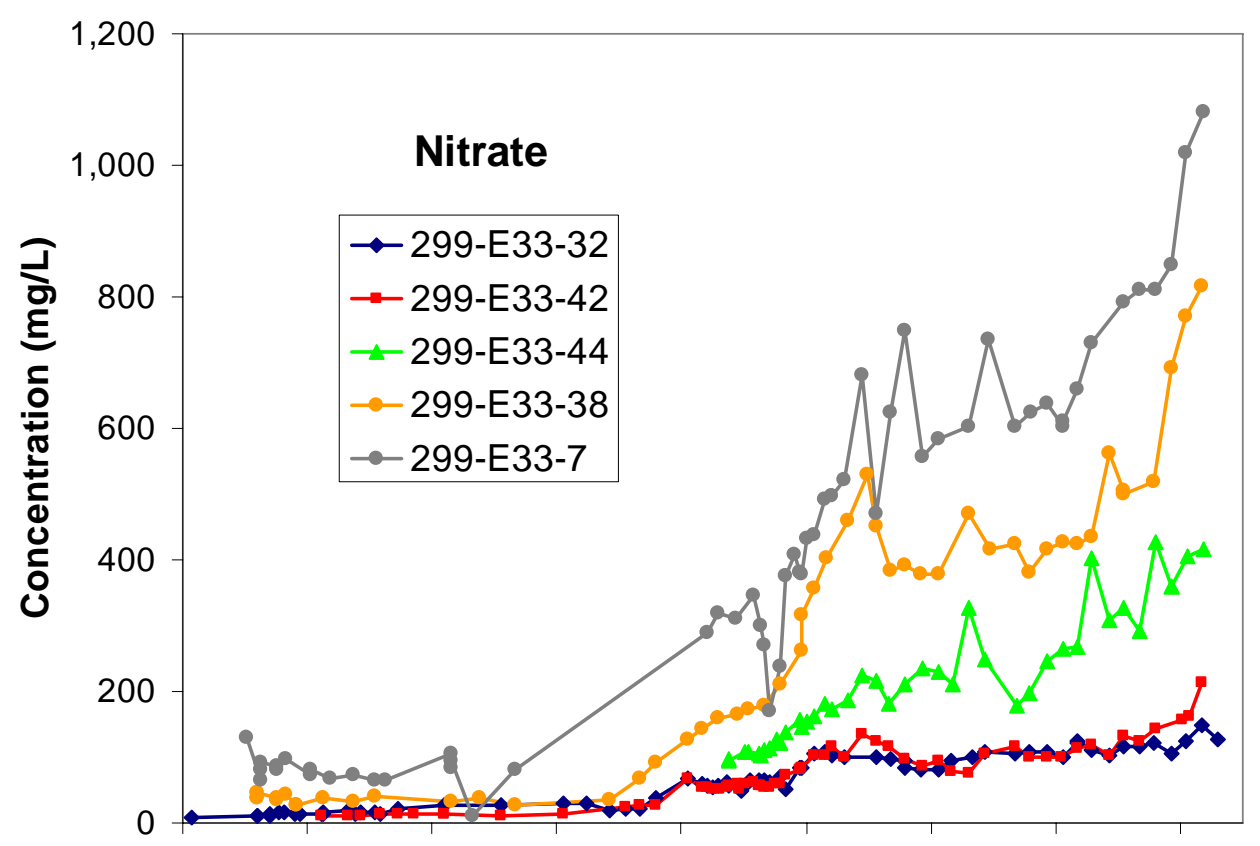

$\begin{array}{lllllll}1 / 1990 & 1 / 1992 & 1 / 1994 & 1 / 1996 & 1 / 1998 & 1 / 2000 & 1 / 2002\end{array}$

Sample Date

Figure 4.64. Nitrate Concentrations in Selected Wells at Waste Management Area B-BX-BY

A general trend of increasing technetium-99 was noted throughout FY 2005 (Thornton et al. 2006). The highest concentration was upgradient beneath the BY cribs and was 19,000 pCi/L in well 299-E33-4. A high technetium-99 concentration of $12,000 \mathrm{pCi} / \mathrm{L}$ was observed in the south part of the $\mathrm{BY}$ cribs.

Cobalt-60 and cyanide are associated with the technetium-99 contamination north of the WMA. The first available analyses for cobalt-60 are from the mid-to-late 1950s and cobalt-60 concentrations in groundwater beneath the BY cribs were high by that time (wells 299-E33-4 and 299-E33-7 on Figure 4.67). The highest concentrations, up to 1.6 million $\mathrm{pCi} / \mathrm{L}$, were found in well 299-E33-3 at the 216-B-45 crib (Figure 4.68). Also in the mid-to-late 1950s, cobalt-60 concentrations were high beneath the 216-B-8 crib (well 299-E33-16, Figure 4.67) and beneath the BY Tank Farm (well 299-E33-9). Concentrations beneath the BY cribs and BY Tank Farm decrease fairly rapidly and by the early 1960s were less than about 5,000 pCi/L in most wells. Monitoring for cobalt-60 stopped in most wells in the early to mid 1960s and did not resume for several years. There are probably multiple sources for the cobalt-60 in the groundwater beneath WMA B-BX-BY with the BY cribs being one of the major sources.

Figure 4.69 shows more recent cobalt-60 trends in groundwater near WMA B-BX-BY. The highest cobalt-60 concentrations are still beneath the BY cribs but concentrations are two to three orders of magnitude less than in the historic past due probably to both decay and dispersion. Concentrations are also fairly high in well 299-E33-44, located east of the BY Tank Farm and the cobalt-60 and associated cyanide at this well may be from the BY cribs. 


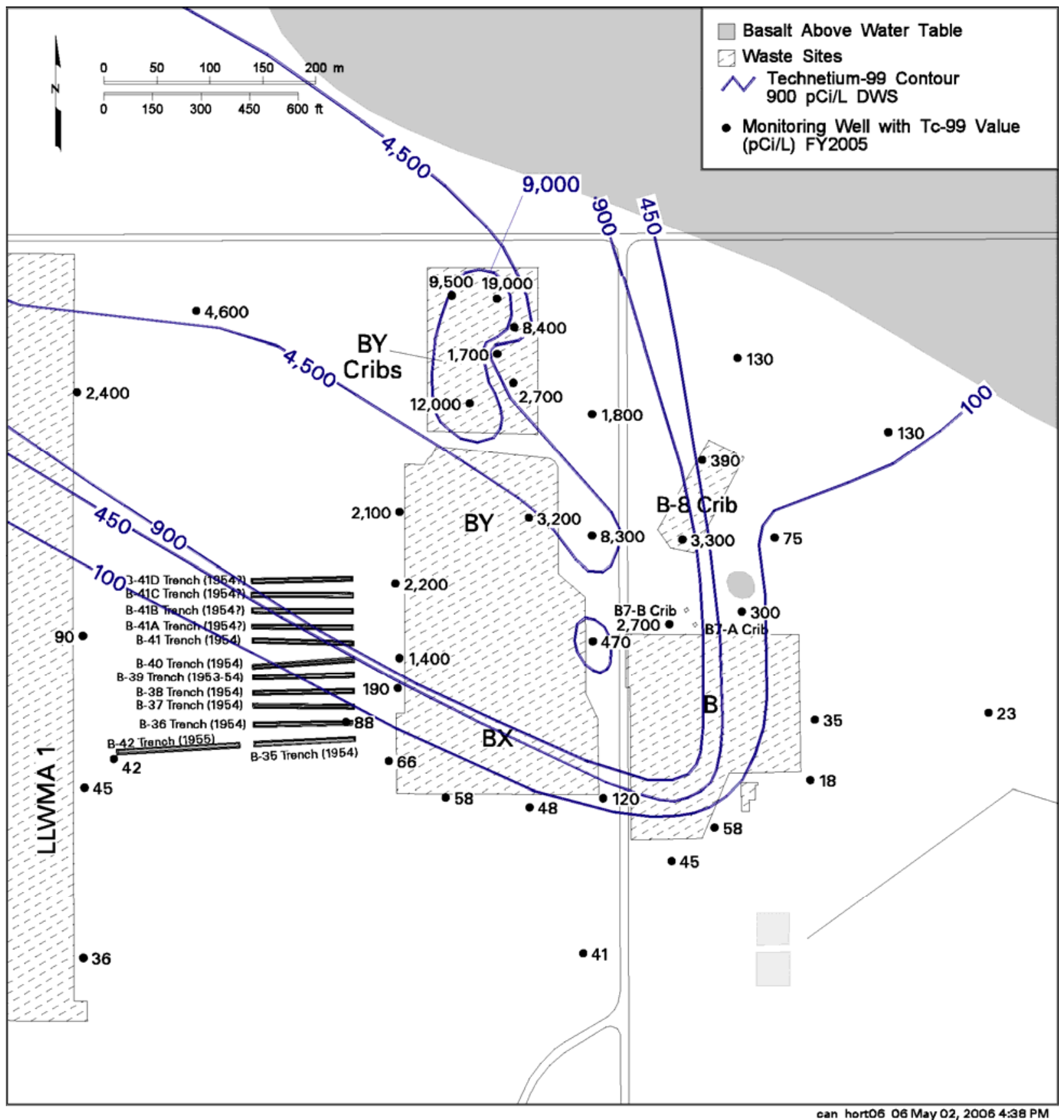

Figure 4.65. Average FY 2005 Technetium-99 Concentrations in the Area of Waste Management Area B-BX-BY, Top of the Aquifer (modified from Thornton et al. 2006) 


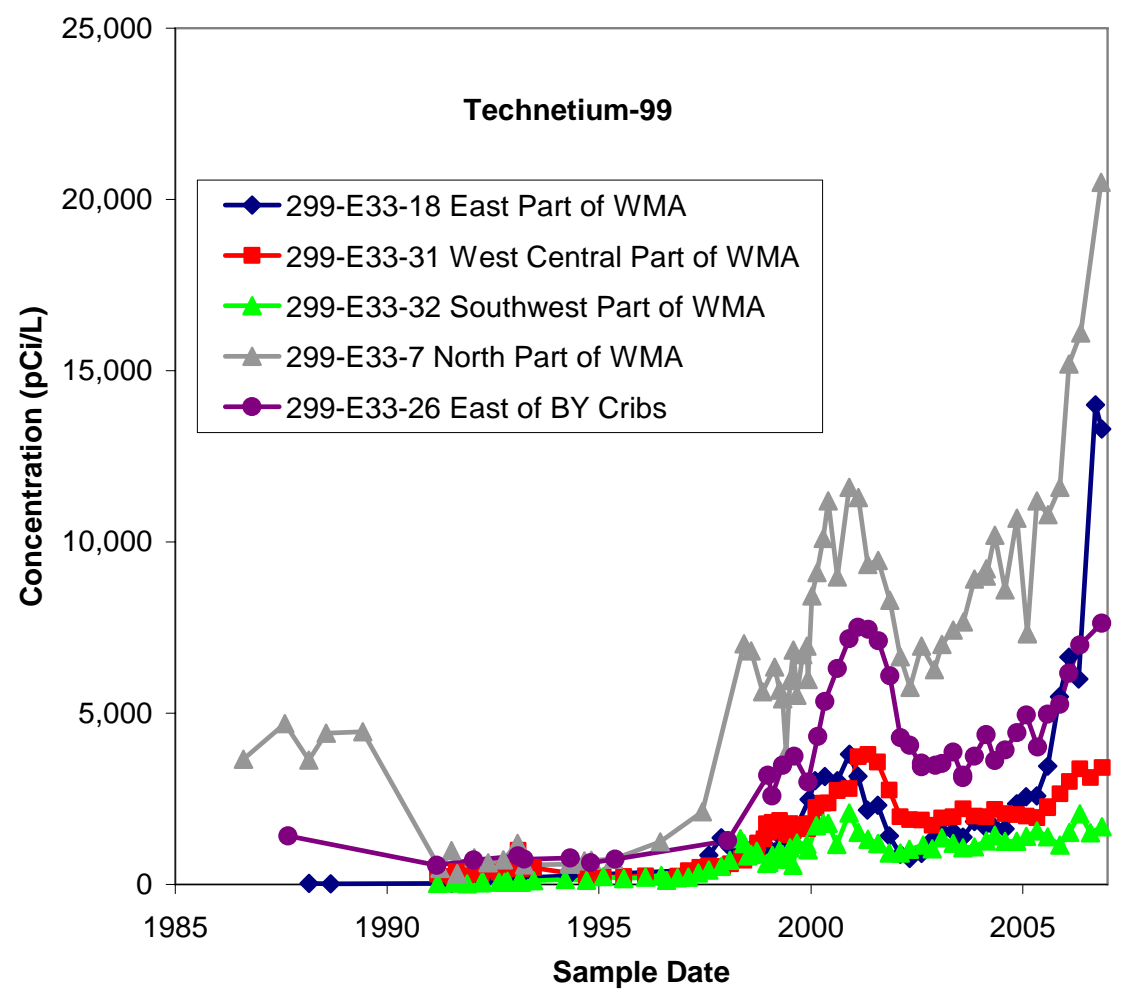

Figure 4.66. Technetium Concentrations in Selected Wells in the Vicinity of Waste Management Area B-BX-BY

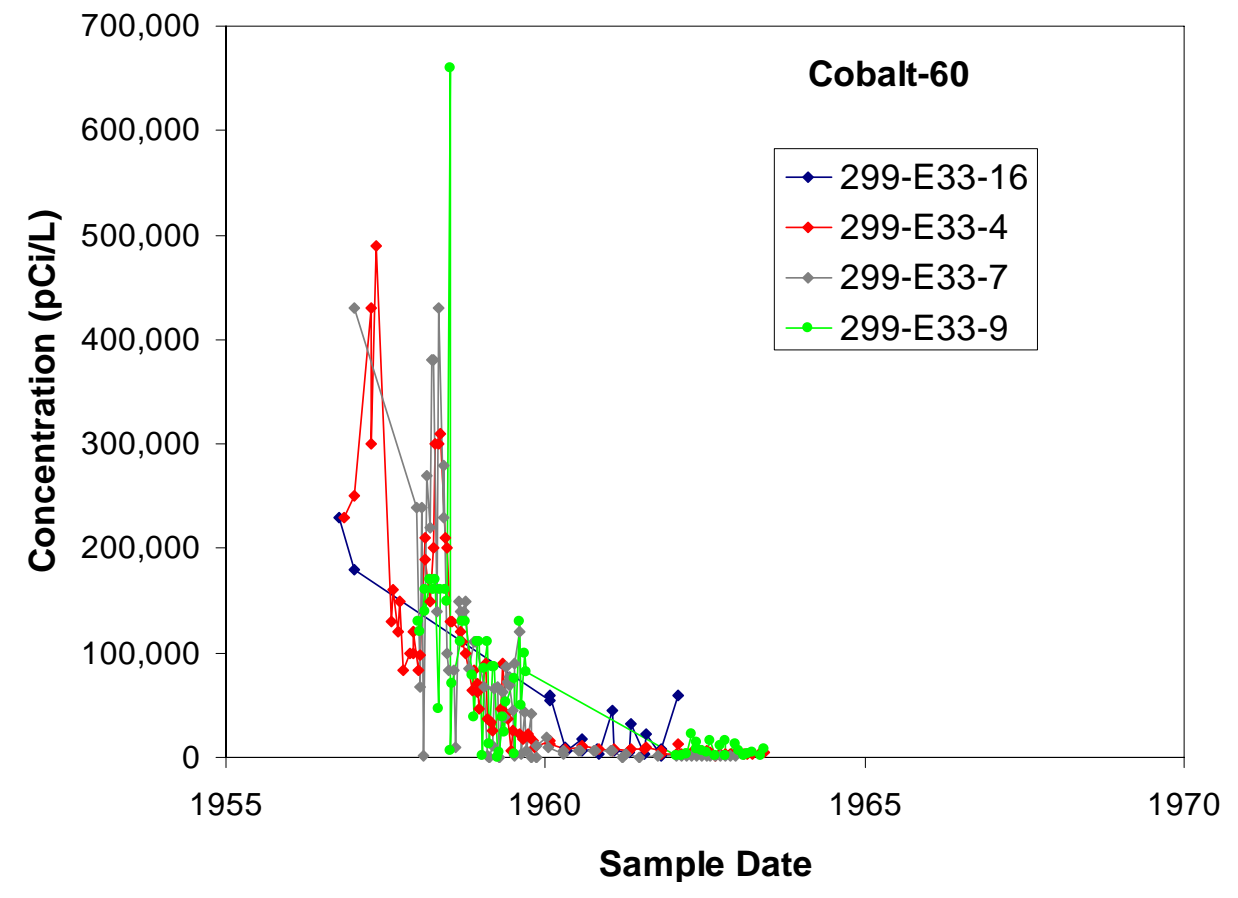

Figure 4.67. Historic Cobalt-60 Concentrations in Selected Wells in the Vicinity of Waste Management Area B-BX-BY 


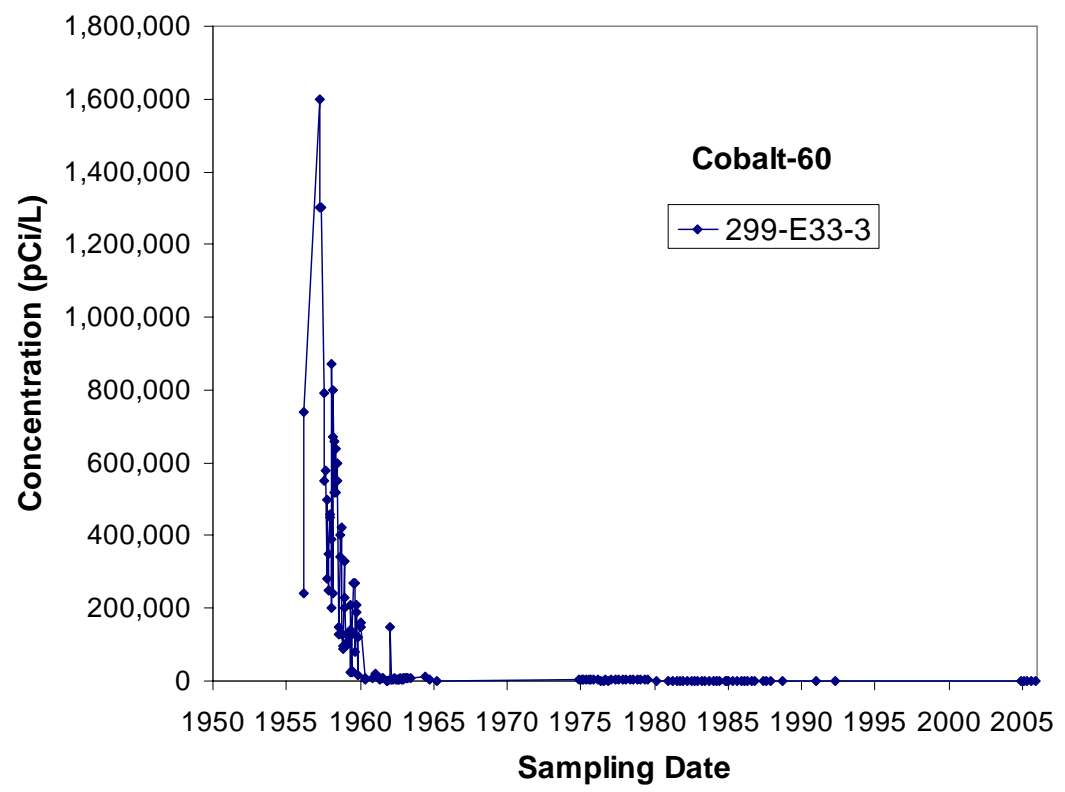

Figure 4.68. Cobalt-60 Concentrations at the 216-B-45 Crib near Waste Management Area B-BX-BY

The maximum cyanide concentration in the WMA B-BX-BY area during FY 2005 was $859 \mu \mathrm{g} / \mathrm{L}$ in well 299-E33-4, located in the northern part of the BY cribs. Well E33-38, located in the southern part of the BY cribs, had a maximum cyanide concentration of $341 \mu \mathrm{g} / \mathrm{L}$ in FY 2005 . The trends in cyanide concentrations in wells located at the BY cribs are similar to those of technetium-99, cobalt-60, and nitrate. The cyanide is probably related to past discharges of ferrocyanide waste to the cribs (Thornton et al. 2006).

The distribution of uranium in groundwater in the vicinity of WMA B-BX-BY is shown in Figure 4.70. The plume extends in a narrow band to the northwest from the area where the B, BX, and BY Tank Farms converge. Uranium first began to increase above the drinking water standard $(30 \mu \mathrm{g} / \mathrm{L})$ in the mid 1990s beneath the BY cribs (well 299-E33-38) and beneath the 216-B-7 cribs (well 299-E33-18). Uranium also began to increase in the mid 1990s at well 299-E33-34, located east of WMA B-BX-BY at the low-level burial ground WMA 1, but concentrations did not reach the $30-\mu \mathrm{g} / \mathrm{L}$ drinking water standard until mid 2001. Uranium concentration was already elevated to $253 \mu \mathrm{g} / \mathrm{L}$ between the BY cribs and the 216-B-7 cribs in 1998 when well 299-E33-44 was first sampled. Uranium concentrations continue to increase today beneath the BY cribs and the 216-B-7B crib (currently $353 \mu \mathrm{g} / \mathrm{L}$ in well 299-E33-38 and $844 \mu \mathrm{g} / \mathrm{L}$ in well 299-E33-18, respectively) and have stabilized at near $100 \mu \mathrm{g} / \mathrm{L}$ in well 299-E33-34 at the north part of low-level burial ground WMA 1, but appear to be decreasing at well 299-E33-44 (currently $266 \mu \mathrm{g} / \mathrm{L}$ ).

WMA B-BX-BY is within the $2,000 \mathrm{pCi} / \mathrm{L}$ contour of the regional 200 East Area tritium plume (Figure 4.72). There is an area along the south border of the WMA with tritium concentrations elevated above $10,000 \mathrm{pCi} / \mathrm{L}$. Tritium concentration began to increase above the regional concentrations in early 1999 (Figure 4.73). Tritium concentrations may be starting to decline but further monitoring is needed to confirm this. The tritium in groundwater in this area may be related to tritium-rich perched water encountered in borehole 299-E33-45. 

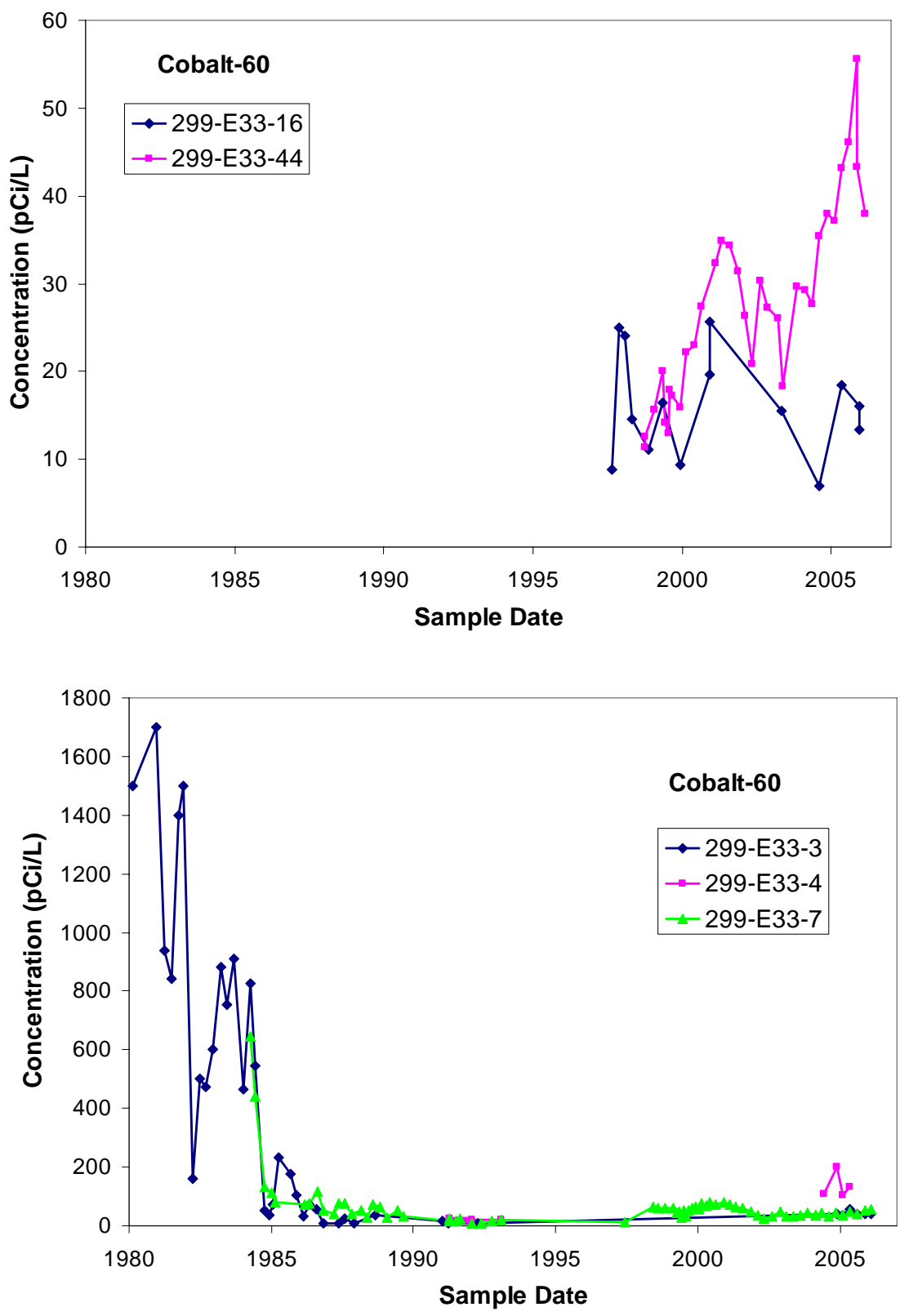

Figure 4.69. Cobalt-60 Concentrations in Selected Wells East of Waste Management Area B-BX-BY (top) and at the BY Cribs (Bottom). Note change in concentration scale (data from HEIS 1994).

\subsubsection{Comparison of Groundwater and Pore Water Compositions at Waste Management Area B-BX-BY}

Well 299-E33-45 was drilled in 2000 and 2001 about $21 \mathrm{~m}$ to the northeast of tank BX-102 to characterize the vadose zone in the area of a 1951 overfill event associated with the tank. Near continuous sediment samples were collected and analyzed for major cations and anions, contaminants, and physical properties. The results of the analyses were reported by Serne et al. (2002b). Borehole 299-E33-46 was drilled in 2001 near tank B-110 to characterize the vadose zone in the area of a pipe leak 


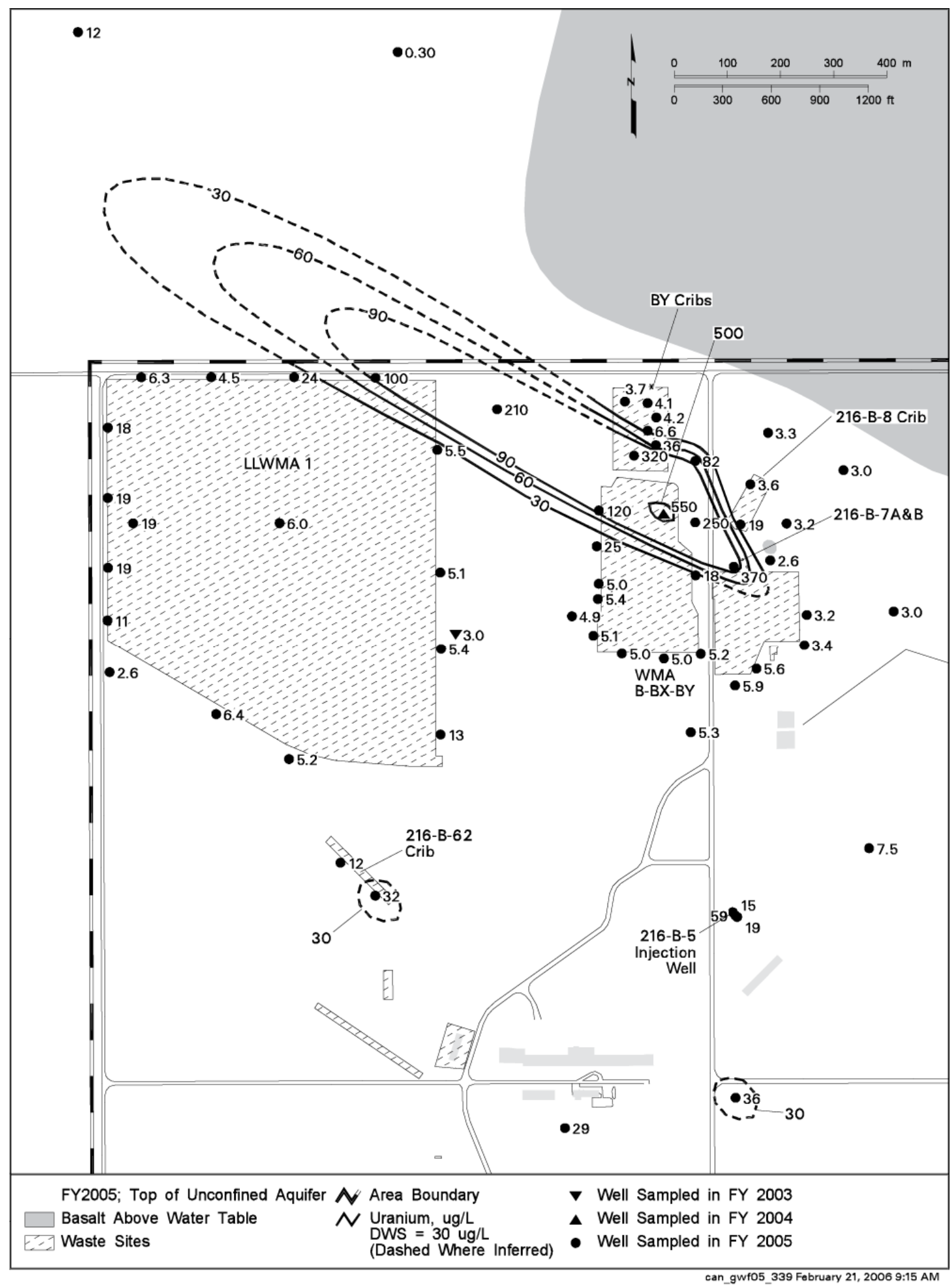

Figure 4.70. Average FY 2005 Uranium Concentrations in Groundwater in the Vicinity of Waste Management Area B-BX-BY, Top of the Aquifer (from Hartman et al. 2006) 


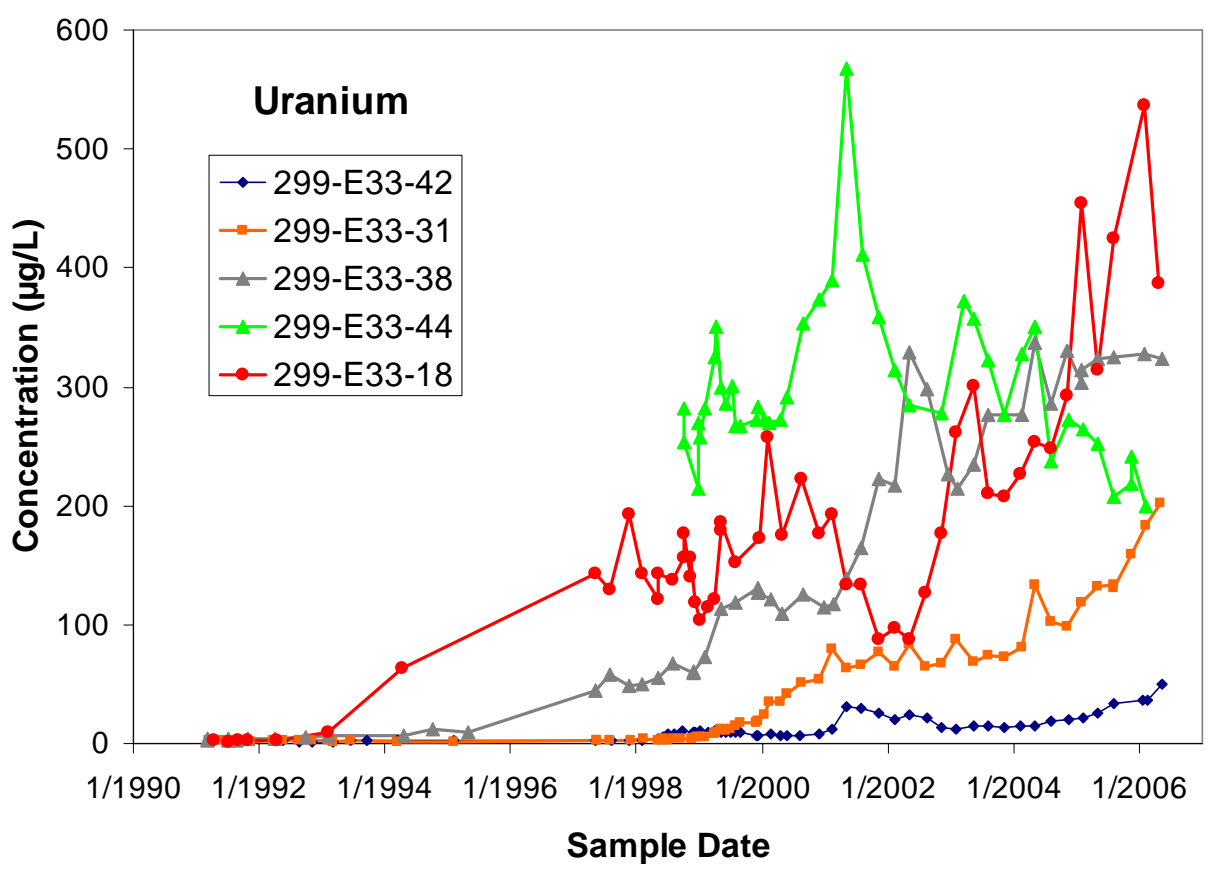

Figure 4.71. Uranium Concentrations in Selected Wells at Waste Management Area B-BX-BY

associated with that tank. Near continuous samples were collected and analyzed for the same suite of analytes as was done for samples from well 299-E33-45. The results from borehole 299-E33-46 were reported by Serne et al. (2002c).

Some of the samples analyzed by Serne et al. $(2002 \mathrm{~b}, \mathrm{c})$ were 1:1 sediment:water extracts. The results were dilution corrected and reported as concentrations in pore water. Samples of actual pore water were obtained from a few sediment samples by an ultracentrifuge. If the pore water was derived from the tank fluids, the composition of the pore water should represent the tank fluids. Serne et al. (2002b, c) compared the pore water from well 299-E33-45 with the estimated composition of the fluids leaked at tank BX-102 and the pore water from borehole 299-E33-46 with the estimated composition of fluids leaked at tank B-110. They found no consistent relationship between the analyzed pore water and the tank estimates.

This section attempts a similar analysis by comparing the groundwater at WMA B-BX-BY with the pore water from well 299-E33-45 and borehole 299-E33-46. Table 4.20 contains the chemical concentration ratios for groundwater in WMA B-BX-BY monitoring network wells, pore water from sediments at well 299-E33-45, perched water collected between 69 and $71 \mathrm{~m}$ bgs in well 299-E33-45, and two waste types that might be expected from reported past releases in the BX Tank Farm tanks BX-101 and BX-102. The groundwater data in the table are the range of concentration ratios obtained from FY 2005 RCRA sampling. The wells have been separated into those with greater than 5,000-pCi/L technetium, greater than $20-\mu \mathrm{g} / \mathrm{L}$ uranium, greater than $10,000-\mathrm{pCi} / \mathrm{L}$ tritium, or some combination of these.

The pore water ratios are from the ultracentrifuge samples reported in Serne et al. (2002a). The ultracentrifuge samples are used rather than the 1:1 water extracts because the ultracentrifuge samples are actual pore water samples. Only the pore water samples from depths that Serne et al. (2002a) noted as 


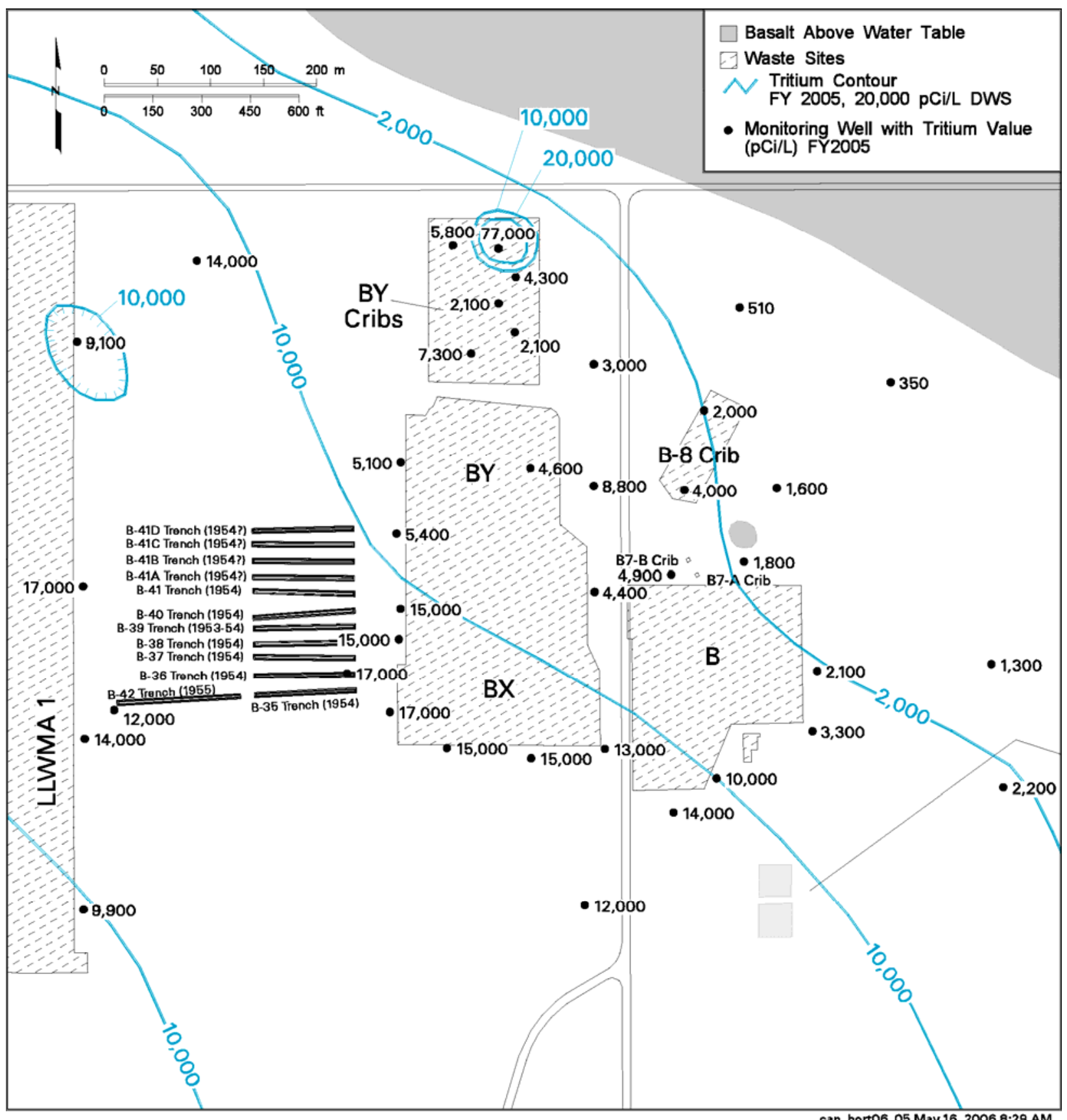

Figure 4.72. Average FY 2005 Tritium Concentrations South of Waste Management Area B-BX-BY, Top of the Aquifer (modified from Hartman et al. 2006) 


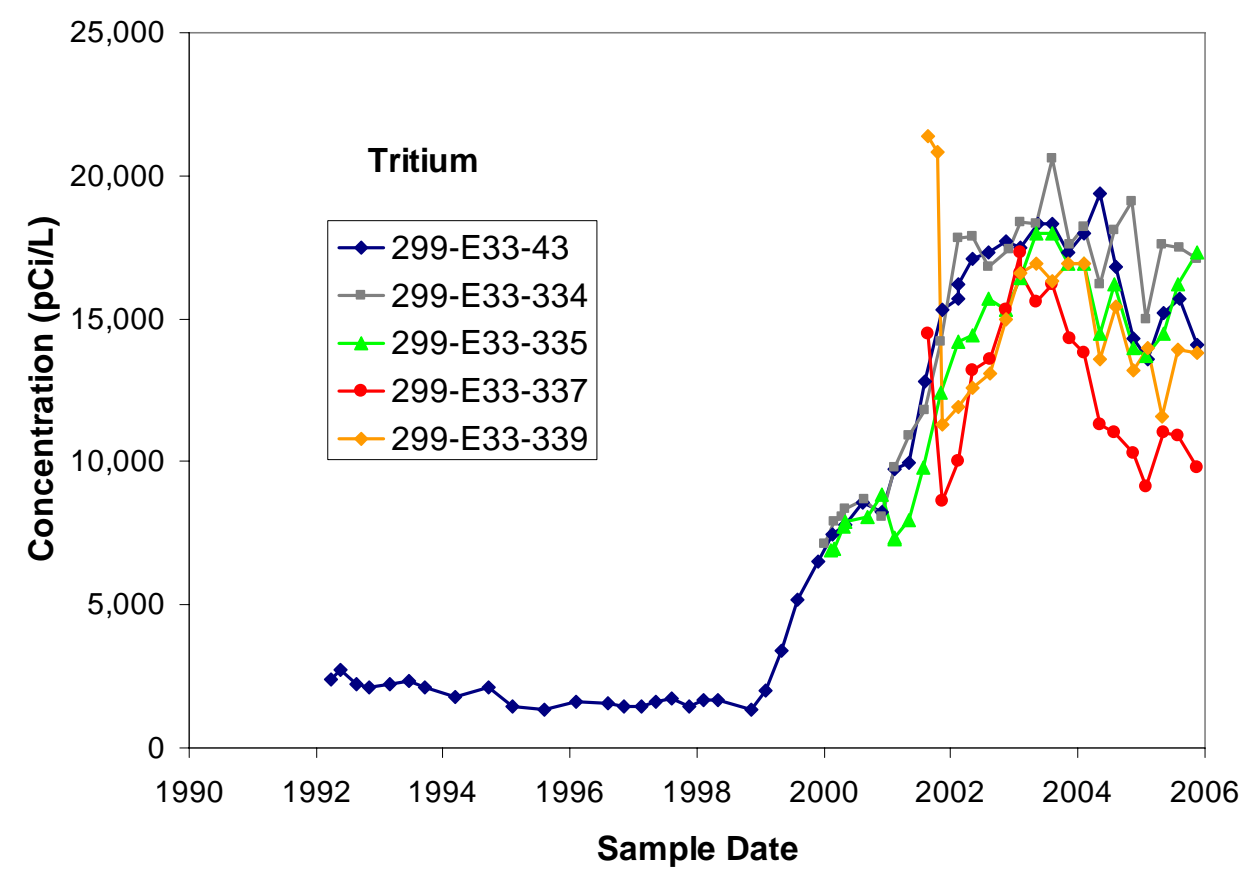

Figure 4.73. Tritium Concentration in Wells along the South Border of Waste Management Area B-BX-BY (modified from Thornton et al. 2006)

having obvious signs of tank overfill fluids are included in Table 4.20. The data for the perched water are also from Serne et al. (2002a). The composition of wastes associated with tanks BX-101 and BX-102 are from Corbin et al. (2005).

Table 4.20 shows that there is no good match between the groundwater composition and the pore water composition. All of the pore water ratios are larger, sometimes by orders of magnitude, than the groundwater ratios. All the groundwater ratios are consistent with too much nitrate and sulfate relative to the technetium-99 and uranium. This could be due to very little or no discharge of this pore water to the unconfined aquifer or the pore water mixing with the groundwater containing nitrate and sulfate from regional plumes that do not contain significant technetium-99 or uranium. Some retardation of uranium relative to the other constituents is expected based on distribution coefficients (Cantrell et al. 2002). This will tend to decrease the concentration ratios with uranium as a ratio component (numerator) in groundwater compared to pore water and estimated tank fluid.

Comparing the composition ratios of the perched water with the groundwater (Table 4.20) is favorable for some ratios but less so for others. For example, the technetium-99/nitrate, and the uranium/technetium-99 ratios for the perched water are of the same order of magnitude as most of the groundwater ratios but the other ratios are not. The lack of at least order of magnitude agreement across all ratios makes assigning relationships among the various contaminant sources (e.g., pore water, perched water, BX tank fluid compositions) with groundwater tentative at best.

Table 4.21 gives the chemical concentration ratios for groundwater in WMA B-BX-BY monitoring network wells, pore water from borehole 299-E33-46, and estimated B-110 waste. As for Table 4.20, the groundwater data are the range of concentration ratios from FY 2005 RCRA sampling. The pore water 
Table 4.20. Ratios of Tank Waste Mobile Contaminants in Groundwater, Pore Water, and Perched Water at Waste Management Area B-BX-BY

\begin{tabular}{|c|c|c|c|c|c|}
\hline \multicolumn{6}{|c|}{ Chemical Concentration Ratios $^{(\mathbf{a})}$} \\
\hline Well Name & $\begin{array}{l}\mathrm{Tc}-99 / \mathrm{NO}_{3} \\
(\mathrm{pCi} / \mathrm{mg})\end{array}$ & $\begin{array}{l}\mathrm{U} / \mathrm{NO}_{3} \\
(\mu \mathrm{g} / \mathrm{mg})\end{array}$ & $\begin{array}{l}\text { U/Tc-99 } \\
(\mu \mathrm{g} / \mathrm{pCi})\end{array}$ & $\begin{array}{c}\mathrm{U} / \mathrm{SO}_{4} \\
(\mu \mathrm{g} / \mathrm{mg})\end{array}$ & $\begin{array}{l}\mathrm{Tc}-99 / \mathrm{SO}_{4} \\
(\mathrm{pCi} / \mathrm{mg})\end{array}$ \\
\hline \multicolumn{6}{|c|}{ Wells with High Technetium-99 Concentration $(>5,000 \mathrm{pCi} / \mathrm{L})$} \\
\hline 299-E33-3 & $9-14$ & $0.005-0.008$ & $0.0005-0.001$ & $0.027-0.037$ & $51-68$ \\
\hline 299-E33-7 & $13-18$ & 0.005 & 0.0004 & 0.03 & $57-82$ \\
\hline \multicolumn{6}{|c|}{ Wells with High Uranium Concentration ( $>20 \mu \mathrm{g} / \mathrm{L}$ ) } \\
\hline 299-E33-18 & $16-20$ & $2.04-2.86$ & $0.121-0.177$ & $4.1-5.79$ & $32-43$ \\
\hline 299-E33-1A & $4-8$ & $0.065-0.090$ & $0.008-0.018$ & $0.239-0.331$ & $14-35$ \\
\hline 299-E33-31 & $7-10$ & $0.484-0.541$ & $0.048-0.068$ & $1.06-1.27$ & $16-22$ \\
\hline 299-E33-42 & $14-21$ & $0.163-0.235$ & $0.010-0.013$ & $0.330-0.535$ & $32-40$ \\
\hline \multicolumn{6}{|c|}{ Wells with High Technetium-99 $(>5,000 \mathrm{pCi} / \mathrm{L})$ and High Uranium $(>20 \mu \mathrm{g} / \mathrm{L})$} \\
\hline 299-E33-38 & $19-26$ & $0.59-0.63$ & $0.02-0.03$ & $2.04-2.24$ & $73-94$ \\
\hline 299-E33-44 & $20-27$ & $0.48-0.89$ & $0.024-0.033$ & $1.26-1.99$ & $50-61$ \\
\hline \multicolumn{6}{|c|}{ Wells with High Tritium Concentration $(>10,000 \mathrm{pCi} / \mathrm{L})$} \\
\hline 299-E28-8 & $1.8-2.0$ & $0.23-0.27$ & $0.118-0.152$ & $0.065-0.089$ & $0.51-0.66$ \\
\hline 299-E33-21 & $3.3-3.5$ & $0.18-0.2$ & $0.055-0.056$ & $0.061-0.062$ & 1.12 \\
\hline 299-E33-32 & $11-13$ & 0.04 & $0.003-0.004$ & $0.057-0.068$ & $16-20$ \\
\hline 299-E33-334 & $2.1-2.4$ & $0.16-0.19$ & $0.072-0.082$ & $0.056-0.068$ & $0.77-0.87$ \\
\hline 299-E33-335 & $1.9-2.4$ & $0.165-0.195$ & $0.076-0.099$ & $0.064-0.068$ & $0.74-0.84$ \\
\hline 299-E33-337 & $2.4-3.5$ & $0.23-0.32$ & $0.082-0.111$ & $0.085-0.088$ & $0.79-1.05$ \\
\hline 299-E33-339 & $2.4-7.1$ & $0.19-0.22$ & $0.026-0.080$ & $0.062-0.069$ & $0.68-2.6$ \\
\hline 299-E33-43 & $5.1-5.3$ & $0.13-0.16$ & $0.024-0.031$ & $0.065-0.074$ & $2.3-3.0$ \\
\hline 299-E33-48 & $1.8-2.0$ & $0.24-0.29$ & $0.123-0.149$ & $0.075-0.074$ & $0.56-0.63$ \\
\hline 299-E33-49 & $2.0-2.3$ & $0.17-0.23$ & $0.07-0.11$ & $0.052-0.076$ & $0.61-0.72$ \\
\hline \multicolumn{6}{|c|}{ Wells with High Tritium $(>10,000 \mathrm{pCi} / \mathrm{L})$ and High Uranium $(>20 \mu \mathrm{g} / \mathrm{L})$} \\
\hline 299-E33-26 & $13-18$ & $0.57-0.77$ & $0.041-0.054$ & $1.73-1.94$ & $36-43$ \\
\hline \multicolumn{6}{|c|}{ Wells with High Tritium $(>10,000 \mathrm{pCi} / \mathrm{L})$ and High Technetium-99 $(>5,000 \mathrm{pCi} / \mathrm{L})$} \\
\hline 299-E33-4 & $13-14$ & 0.003 & 0.0002 & 0.002 & $81-111$ \\
\hline \multicolumn{6}{|c|}{ 299-E33-45 Pore Water } \\
\hline \multicolumn{6}{|l|}{ Depth (m bgs) } \\
\hline 37 & 120 & 322 & 2.79 & 446 & 160 \\
\hline 39.8 & 120 & 1,250 & 10.8 & 1,750 & 160 \\
\hline 41.3 & 92 & 630 & $\mathrm{NA}^{(\mathrm{b})}$ & 761 & 110 \\
\hline 41.8 & 91 & 422 & $\mathrm{NA}^{(\mathrm{b})}$ & 567 & 120 \\
\hline $\begin{array}{l}\text { Perched Water at } \\
69 \mathrm{~m} \text { bgs }\end{array}$ & 1.75 & 0.03 & 0.016 & 560 & 3.47 \\
\hline BX-102 estimate & 0.599 & 2.65 & 4.42 & 1.8 & 0.41 \\
\hline BX-101 estimate & 0.342 & 0.0006 & 0.0018 & 0.0069 & 3.7589 \\
\hline \multicolumn{6}{|c|}{$\begin{array}{l}\text { (a) Data from well 299-E33-45 and perched water are taken from Serne et al. (2002b); groundwater data show the range of } \\
\text { values from FY } 2005 \text { sampling; data for tank BX-101 and BX-102 tanks are from Corbin et al. (2005). } \\
\text { (b) Not available - One constituent was not analyzed. }\end{array}$} \\
\hline
\end{tabular}


Table 4.21. Ratios of Selected Mobile Contaminants in Groundwater and Pore Water from Well 299-E33-46

\begin{tabular}{|c|c|c|c|c|}
\hline \multirow[b]{2}{*}{ Well Name } & \multicolumn{4}{|c|}{ Concentration Ratios } \\
\hline & $\begin{array}{c}\mathrm{Tc}-99 / \mathrm{NO}_{3} \\
(\mathrm{pCi} / \mathrm{mg})\end{array}$ & $\begin{array}{l}\mathrm{U} / \mathrm{NO}_{3} \\
(\mu \mathrm{g} / \mathrm{mg})\end{array}$ & $\begin{array}{c}\mathrm{U} / \mathrm{SO}_{4} \\
(\mu \mathrm{g} / \mathrm{mg})\end{array}$ & $\begin{array}{c}\mathrm{NO}_{3} / \mathrm{F} \\
(\mathrm{mg} / \mathrm{mg})\end{array}$ \\
\hline \multicolumn{5}{|c|}{ "Wells with High Technetium-99 Concentration (>5,000 pCi/L) } \\
\hline 299-E33-3 & $9-14$ & $0.005-0.008$ & $0.027-0.037$ & $751-1,092$ \\
\hline 299-E33-7 & $13-18$ & 0.005 & 0.03 & $550-1,209$ \\
\hline \multicolumn{5}{|c|}{ Wells with High Uranium Concentration $(>20 \mu \mathrm{g} / \mathrm{L})$} \\
\hline 299-E33-18 & $16-20$ & $2.04-2.86$ & $4.1-5.79$ & $550-782$ \\
\hline 299-E33-1A & $4-8$ & $0.065-0.090$ & $0.239-0.331$ & $625-898$ \\
\hline 299-E33-31 & $7-10$ & $0.484-0.541$ & $1.06-1.27$ & $804-1,092$ \\
\hline 299-E33-42 & $14-21$ & $0.163-0.235$ & $0.330-0.535$ & $416-592$ \\
\hline \multicolumn{5}{|c|}{ Wells with High Technetium-99 (>5,000 pCi/L) and High Uranium $(>20 \mu \mathrm{g} / \mathrm{L})$} \\
\hline 299-E33-38 & $19-26$ & $0.59-0.63$ & $2.04-2.24$ & $1,500-1,938$ \\
\hline 299-E33-44 & $20-27$ & $0.48-0.89$ & $1.26-1.99$ & $885-2,140$ \\
\hline \multicolumn{5}{|c|}{ Wells with High Tritium Concentration $(>10,000 \mathrm{pCi} / \mathrm{L})$} \\
\hline 299-E28-8 & $1.8-2.0$ & $0.23-0.27$ & $0.065-0.089$ & $62-85$ \\
\hline 299-E33-21 & $3.3-3.5$ & $0.18-0.2$ & $0.061-0.062$ & $93-96$ \\
\hline 299-E33-32 & $11-13$ & 0.04 & $0.057-0.068$ & $408-469$ \\
\hline 299-E33-334 & $2.1-2.4$ & $0.16-0.19$ & $0.056-0.068$ & $101-139$ \\
\hline 299-E33-335 & $1.9-2.4$ & $0.165-0.195$ & $0.064-0.068$ & $95-133$ \\
\hline 299-E33-337 & $2.4-3.5$ & $0.23-0.32$ & $0.085-0.088$ & $74-94$ \\
\hline 299-E33-339 & $2.4-7.1$ & $0.19-0.22$ & $0.062-0.069$ & $97-131$ \\
\hline 299-E33-43 & $5.1-5.3$ & $0.13-0.16$ & $0.065-0.074$ & $136-179$ \\
\hline 299-E33-48 & $1.8-2.0$ & $0.24-0.29$ & $0.075-0.074$ & $80-114$ \\
\hline 299-E33-49 & $2.0-2.3$ & $0.17-0.23$ & $0.052-0.076$ & $84-117$ \\
\hline \multicolumn{5}{|c|}{ Wells with High Tritium (>10,000 pCi/L) and High Uranium ( $>20 \mu g / L)$} \\
\hline 299-E33-26 & $13-18$ & $0.57-0.77$ & $1.73-1.94$ & $1,061-1,315$ \\
\hline \multicolumn{5}{|c|}{ Wells with High Tritium (>10,000 pCi/L) and High Technetium-99 (>5,000 pCi/L) } \\
\hline 299-E33-4 & $13-14$ & 0.003 & 0.002 & $1,440-1,691$ \\
\hline Depth (m bgs) & \multicolumn{4}{|c|}{$299-E 33-46^{(a)}$} \\
\hline 16.6 & & 5.22 & & 0.72 \\
\hline 17.3 & & 4.08 & & 0.75 \\
\hline 17.8 & & 1.15 & & 0.85 \\
\hline 18.2 & & 9.6 & & 0.54 \\
\hline 20.1 & & 20.7 & 9.08 & 0.69 \\
\hline 21.2 & & 39.2 & 42.54 & 1.51 \\
\hline 21.3 & & 138 & 44.96 & 0.37 \\
\hline 21.5 & & 135 & 46.65 & 0.39 \\
\hline 21.5-duplicate & & 165 & 49.15 & 0.31 \\
\hline 22.4 & & 33.2 & & 0.48 \\
\hline 23.6 & & 18.3 & & 0.69 \\
\hline 27.6 & & 0.8 & & 4.03 \\
\hline 29.5 & & 6.4 & & 2.27 \\
\hline 33.2 & & 0.21 & & \\
\hline 34 & & 0.7 & & \\
\hline 36.6 & & 0.58 & & \\
\hline 51.3 & 77.7 & & & \\
\hline 64 & 659 & & & \\
\hline 68.8 & 307 & & & \\
\hline \multicolumn{5}{|c|}{ Tank B-110 Waste } \\
\hline & 1.5929 & 0.0003 & 0.0033 & 158 \\
\hline $\begin{array}{l}\text { (a) Data from w } \\
\text { groundwater }\end{array}$ & $\begin{array}{l}-46 \text { are from } \\
\text { m FY } 2005 \mathrm{~F}\end{array}$ & $\begin{array}{l}\text { 1. (2002c); data } \\
\text { pling. }\end{array}$ & $\mathrm{B}-110$ are from & t al. (2005); \\
\hline
\end{tabular}


ratios are from Serne et al. (2002c) and the tank B-110 waste estimate is from Corbin et al. (2005). Only pore water ratios from depths that Serne et al. (2002c) note as zones of elevated concentration of contaminants are given on Table 4.21.

The conclusions from the data in Table 4.21 are the same as those from Table 4.20 data. That is, the concentrations of nitrate and sulfate in the groundwater, relative to technetium-99, uranium, and fluoride, is greater than in the pore water resulting in much smaller composition ratios in the groundwater than in the pore water (the opposite being true for nitrate/fluoride with nitrate in the numerator). This is probably due to any potential nitrate and sulfate from tank waste being superimposed on regional nitrate and sulfate groundwater plumes. The inconsistencies among groundwater data, perched water data, pore water data, and estimated tank fluids do not allow the source fluid for the groundwater contamination at WMA B-BX-BY to be assigned to fluids from the BX-102 and B-110 tank losses. No attempts were made to correlate ratios from other tanks or past-practice disposal facilities.

Although composition ratios do not allow assignment of groundwater contamination to specific sources in the WMA B-BX-BY area, they can be useful for comparing groundwater contamination among wells. Lindberg et al. (2003) compared nitrate/technetium-99 concentration ratios in an attempt to determine whether groundwater contamination at WMA B-BX-BY was due to one or more than one source. They found concentration differences suggesting up to five sources may contribute to the groundwater contamination in the area. They interpret the results to represent two sources beneath the BY cribs, two sources west of the BX and BY Tank Farms, and a fifth source east of the BY Tank Farm extending southeast to the 216-B-7 cribs.

One of the major problems in using concentration ratios involving uranium is that uranium is partly sorbed in the vadose zone and aquifer sediments. Hydrochemical studies of groundwater near WMA B-BX-BY were done recently using isotopic ratios instead of concentration ratios. Christensen et al. (2004) used uranium isotopic measurements and looked at the U-236/U-238, U-234/U-238, and U-238/U-235 ratios in contaminated pore water from wells 299-E33-45 and 299-E33-46 and in groundwater collected from wells in the vicinity of WMA B-BX-BY. Samples from the vadose zone contaminant plume at well 299-E33-45 had uranium isotopic values that clustered at a value believed to represent a single well-mixed source. Figure 4.74 is modified from Christensen et al. (2004).

The uranium concentrations from the contaminated sediments in well 299-E33-46 were much lower than the uranium concentrations in well 299-E33-45. Samples collected from the vadose zone plume in well 299-E33-46 showed a significant range in isotopic composition consistent with a mixture of contaminant uranium and natural uranium. The highest concentration samples had a lower U-236/U-238 ratio than those from well 299-E33-45 (Figure 4.74).

The uranium isotopic composition of nine groundwater samples from wells at WMA B-BX-BY covered a range in isotopic compositions that fall along a line between the well 299-E33-45 vadose zone water extract sediments' plume data and the natural isotopic U-238/U-235 ratio (Figure 4.74). One sample from well 299-E33-32, from the well farthest from the plume, falls off the line. When the $\mathrm{U}-236 / \mathrm{U}-238$ ratio is plotted against $\mathrm{U}-234 / \mathrm{U}-238$ ratio, the results indicate mixing of the contamination with characteristics like those seen in well 299-E33-45 water extracts containing contaminant uranium with natural groundwater, elevated in U-234/U-238 (due to alpha-recoil effect). The highest uranium concentration groundwater sample closely approached the isotopic composition of the water extracts from well 299-E33-45 vadose zone plume and the U-234/U-238 ratios from other groundwater samples fell 
along the line connecting the samples to natural uranium composition in order of decreasing concentration. Also, Christensen et al. (2004) eliminated the vadose zone plume in well 299-E33-46 as a source for the uranium in groundwater because the uranium isotopic ratios in the groundwater were not compatible with those in the 299-E33-46 plume.

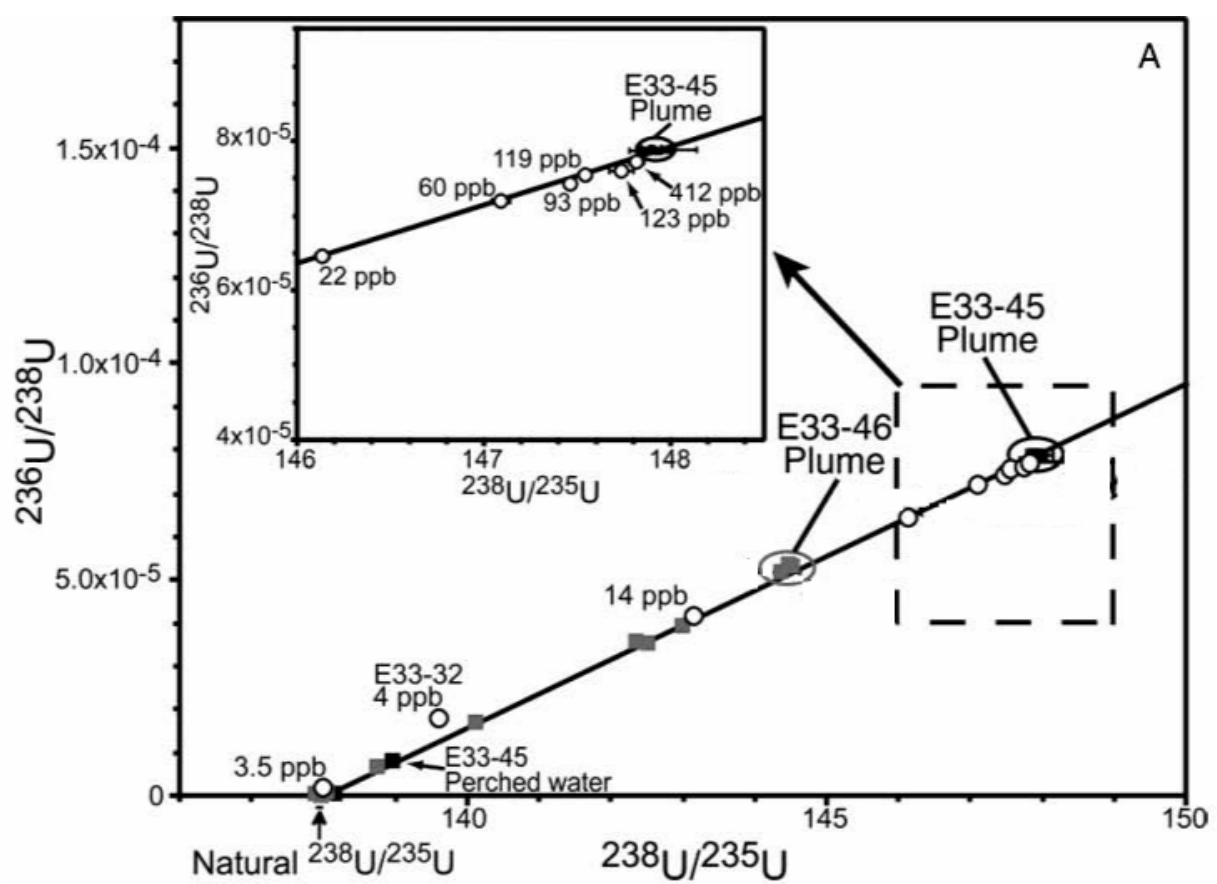

Figure 4.74. Uranium Isotopic Data for Vadose Zone Contamination in Well 299-E33-45 and 299-E33-46 and in Groundwater Samples from Wells in the Waste Management Area B-BX-BY Monitoring Network. (Black squares are data for water extractions from sediments from 299-E33-45 contaminated core; gray squares are data for water extractions from 299-E33-46 contaminated core; open circles are uranium isotopic data for groundwater samples.) (Figure is modified from Christensen et al. 2004.)

Also, Dresel et al. (2002) had provided model histories of the abundances of the uranium isotopes in the fuel rods that were processed at the Hanford Site. The average uranium isotopic abundances from the 299-E33-45 vadose zone plume are consistent with the composition of uranium fuel rods processed in a fairly narrow time period between 1950 and 1952. This supports the inference that the 1951 tank BX-102 overflow event is the source of the vadose zone contamination seen in core 299-E33-45.

Although the isotopic link between the groundwater and the well 299-E33-45 vadose zone plume (and by association, the 1951 overfill event at tank BX-102) is very good, several nearby past-practice liquid waste disposal facilities also operated during the late 1940s and early 1950s that discharged dissolved uranium. Christensen et al. (2004) concede that without vadose zone samples from those facilities, their study cannot entirely rule out the near-by past-practice disposal sites as possible sources of groundwater contamination at WMA B-BX-BY. Additional sampling of vadose zone sediments from nearby past-practice disposal facilities is necessary to unequivocally link uranium in the unconfined aquifer to a specific source. 


\subsubsection{Background Groundwater Composition Beneath Waste Management Area C}

Upgradient groundwater composition for the single-shell tank farm WMA C is shown in Table 4.22 and Figure 4.75. The data in the table are the average FY 2005 concentrations in each upgradient well at the WMA. All data are available on the CD included in Hartman et al. (2006). Data for the metals are from filtered samples; all other data are from unfiltered samples. Data flagged as suspect in the Hanford Environmental Information System database have been excluded from the calculated averages. Charge balances for the analyses shown in Figure 4.75 are: $+3.3 \%$ for well 299 -E27-22 and $+2.2 \%$ for well 299-E27-7.

The groundwater at WMA C is a calcium-sulfate water that is different than groundwater at any other single-shell tank WMA. Sulfate is also elevated in a few wells in the area of low-level burial ground WMA 2, north of WMA C, suggesting that the high sulfate found at WMA $\mathrm{C}$ is fairly regional in extent. The reason for the high sulfate is not known, but may be related to leaching of the vadose zone caused by increased water levels associated with disposal at B Pond. Calcium, chloride, magnesium, and nitrate are also elevated relative to Hanford Site background groundwater.

Table 4.22. Average FY 2005 Groundwater Composition in Upgradient Wells at Waste Management Area $\mathrm{C}$

\begin{tabular}{||l|c|c||}
\hline \multirow{2}{*}{\multicolumn{1}{|c|}{ Constituent (units) }} & \multicolumn{2}{c||}{ Concentration } \\
\cline { 2 - 3 } & Well 299-E27-22 & Well 299-E27-7 \\
\hline \hline Alkalinity as CaCO $(\mu \mathrm{g} / \mathrm{L})$ & 94,000 & 87,250 \\
\hline Calcium $(\mu \mathrm{g} / \mathrm{L})$ & 64,600 & 77,675 \\
\hline Cesium-137 $(\mathrm{pCi} / \mathrm{L})$ & Not detected & 31.3 \\
\hline Chloride $(\mathrm{mg} / \mathrm{L})$ & 23.92 & 12.5 \\
\hline Chromium $(\mu \mathrm{g} / \mathrm{L})$ & Not detected & Not detected \\
\hline Cobalt-60 $(\mathrm{pCi} / \mathrm{L})$ & Not detected & 31.03 \\
\hline Cyanide $(\mu \mathrm{g} / \mathrm{L})$ & Not detected & 0.15 \\
\hline Fluoride $(\mathrm{mg} / \mathrm{L})$ & 0.16 & Not analyzed \\
\hline Gross alpha $(\mathrm{pCi} / \mathrm{L})$ & Not analyzed & 38.05 \\
\hline Gross beta $(\mathrm{pCi} / \mathrm{L})$ & 19.18 & 3.81 \\
\hline Iodine-129 $(\mathrm{pCi} / \mathrm{L})$ & Not analyzed & 46.3 \\
\hline Iron $(\mu \mathrm{g} / \mathrm{L})$ & 20.6 & 22,025 \\
\hline Magnesium $(\mu \mathrm{g} / \mathrm{L})$ & 18,000 & 26.22 \\
\hline Nitrate $(\mathrm{mg} / \mathrm{L})$ & 20.15 & 8.0 \\
\hline pH Measurement $(\mathrm{pH}$ units $)$ & 8.3 & 7,915 \\
\hline Potassium $(\mu \mathrm{g} / \mathrm{L})$ & 8,285 & 15,450 \\
\hline Sodium $(\mu \mathrm{g} / \mathrm{L})$ & 14,025 & 649 \\
\hline Specific $\mathrm{Conductance}(\mu \mathrm{S} / \mathrm{cm})$ & 535 & 156.5 \\
\hline Sulfate $(\mathrm{mg} / \mathrm{L})$ & 113.85 & 81.4 \\
\hline Technetium-99 $(\mathrm{pCi} / \mathrm{L})$ & 38.2 & 840 \\
\hline Total organic carbon $(\mu \mathrm{g} / \mathrm{L})$ & 766 & 987 \\
\hline Tritium $(\mathrm{pCi} / \mathrm{L})$ & Not analyzed & 2.88 \\
\hline Uranium $(\mu \mathrm{g} / \mathrm{L})$ & 2.86 & \\
\hline \hline
\end{tabular}



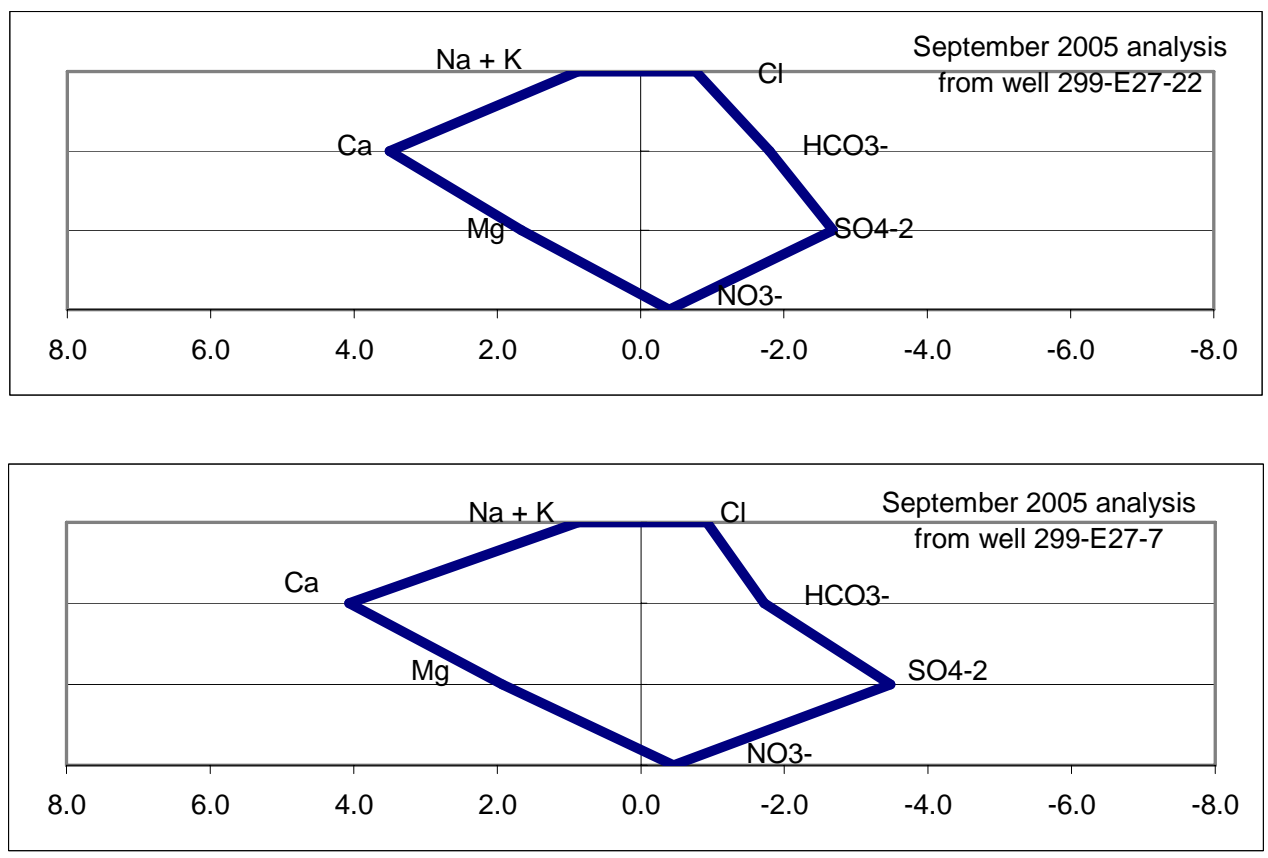

Figure 4.75. Major Cation and Anion Composition of Groundwater from Upgradient Wells at Waste Management Area C. Units for the x-axis are milliequivalents/liter with cations on the left and anions on the right.

\subsubsection{Groundwater Contamination Beneath Waste Management Area C}

This section discusses the current and historical groundwater contamination at WMA C. The evaluation of contamination includes descriptions of the types and concentrations of contaminants in the groundwater and the areal extent of contamination in the area. Much of the information in this section is taken from Thornton et al. (2006). Groundwater at WMA C is monitored to meet requirements of RCRA and the Atomic Energy Act. The objective of RCRA monitoring is to detect whether dangerous waste constituents associated with the facility have compromised groundwater quality. Monitoring continued under an interim status indicator evaluation program at the WMA in FY 2005. Groundwater monitoring under the Atomic Energy Act tracks radionuclides beneath the WMA and surrounding vicinity.

\subsubsection{Extent of Contamination at Waste Management Area C - Depth Distribution}

Very little information is available concerning the vertical extent of contaminants in the uppermost aquifer beneath WMA C. Well 299-E27-22 is the only well in the area that has been sampled at more than one depth in the aquifer. Air-lifted groundwater samples were collected during drilling of well 299-E27-22 from five intervals in the aquifer. Samples were analyzed in the field for specific conductivity, nitrate, technetium-99, and $\mathrm{pH}$ (Williams and Narbutovskih 2004). Table 4.23 and Figure 4.76 show the analytical results. The data show that specific conductance, nitrate, and technetium-99 all increase with increasing depth, although the magnitude of the increase is not great. All concentrations are greater than Hanford Site background. However, well 299-W27-22 is an upgradient well and the magnitudes of the concentrations are less than the concentrations found in some downgradient wells at the time well 299-E27-22 was drilled. The latest (September 2005) sampling of well 299-E27-22 yielded a 
nitrate concentration of $24.8 \mathrm{mg} / \mathrm{L}$ and technetium-99 concentration of $30.2 \mathrm{pCi} / \mathrm{L}$. These concentrations were obtained from the screened, upper $10 \mathrm{~m}$ of the aquifer and appear reasonable when compared with the depth discrete data in Figure 4.76.

Table 4.23. Depth-Discrete Water Sampling Results from Well 299-E27-22 (Williams and Narbutovskih 2004)

\begin{tabular}{|c|c|c|c|c|}
\hline $\begin{array}{c}\text { Sample Depth } \\
\text { (m below water table) }\end{array}$ & $\begin{array}{l}\text { Specific Conductivity } \\
(\mu \mathrm{S} / \mathrm{cm})\end{array}$ & $\mathrm{pH}$ & $\begin{array}{l}\text { Nitrate } \\
(\mathrm{mg} / \mathrm{L})\end{array}$ & $\begin{array}{c}\mathrm{Tc}-99 \\
(\mathrm{pCi} / \mathrm{L})\end{array}$ \\
\hline $2.8-3.7$ & 447 & Not analyzed & 14.2 & 10.9 \\
\hline $5.0-5.9$ & 412 & 8.11 & 16.2 & Not detected \\
\hline $6.6-7.2$ & 429 & 7.95 & 18.4 & 14 \\
\hline 9.0 & 439 & 7.98 & 20.1 & 38.5 \\
\hline 11.4 & 563 & 8.01 & 31.1 & 80.1 \\
\hline Hanford Site Background $^{(\mathrm{a})}$ & 348 & 7.78 & 5.68 & 0.447 \\
\hline
\end{tabular}

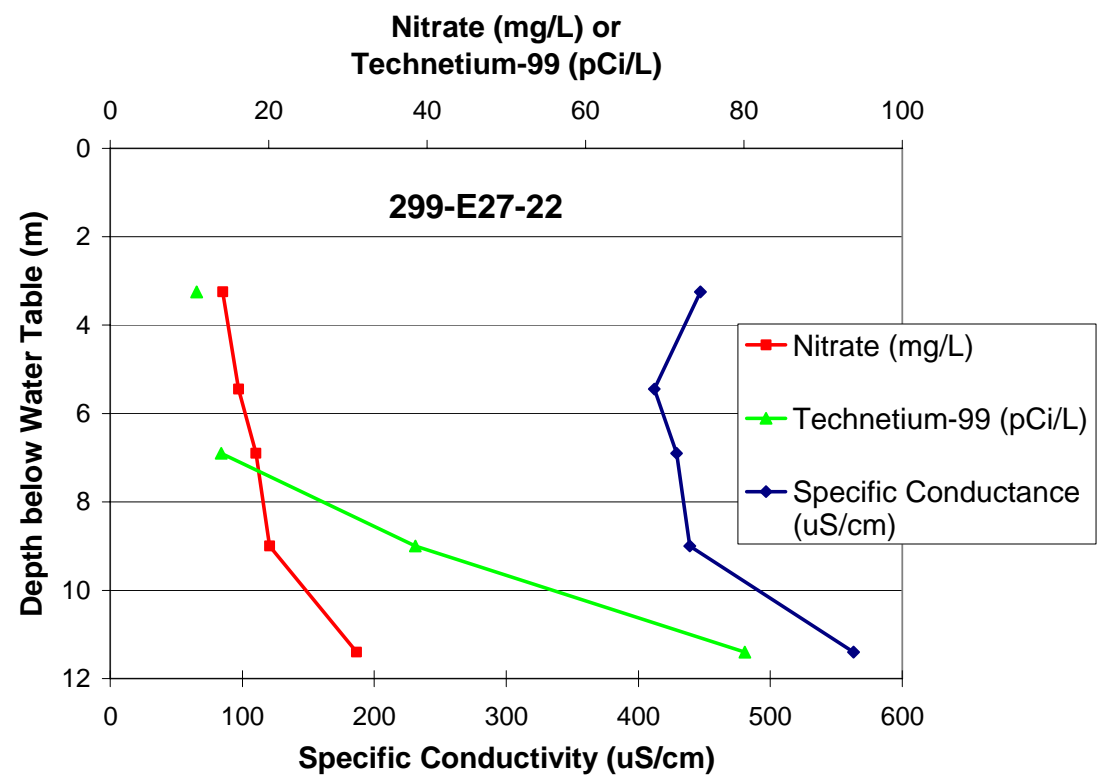

Figure 4.76. Specific Conductance and Concentrations of Nitrate and Technetium-99 versus Depth below the Water Table in Well 299-E27-22 (data from Williams and Narbutovskih 2004)

\subsubsection{Extent of Contamination at Waste Management Area C - Geographic Distribution}

This section summarizes the aerial distribution of contaminants in groundwater at WMA C. Most of the information in this section is from Thornton et al. (2006). Groundwater at WMA C contains elevated concentrations of calcium, chloride, cyanide, nitrate, sulfate, technetium-99, iodine-129, tritium and to lesser extents sodium and magnesium. Much of the tritium, nitrate, and iodine-129 at the WMA is 
attributed to regional plumes that extend across 200 East Area. However, there is a local area of high nitrate concentration beneath the WMA C and high iodine-129 in one well at the WMA.

Few data are available before the early 1990s when most of the monitoring wells were drilled at the tank farm. The oldest well, well 299-E27-7, was drilled in 1982 and the oldest groundwater monitoring data associated with the well are gross beta values beginning in 1984, and nitrate concentrations beginning in 1985. Between 1984 and about 1998, gross beta values in well 299-E27-7 were only slightly greater than the Hanford Site background of $5.6 \mathrm{pCi} / \mathrm{L}$ (DOE 1997). Nitrate concentrations were close to or less than Hanford Site background concentrations $(5.68 \mathrm{mg} / \mathrm{L})$ until about 1992 when an increase in nitrate concentrations occurred, accompanied by increases in concentrations of most major cations and anions. Nitrate decreased to near background concentrations in 1993 and remained low until 1998.

Cobalt-60 was also detected at low levels in five wells at WMA C between 1991 and 1994. The highest concentration was $10.4 \mathrm{pCi} / \mathrm{L}$ in mid 1992. Although analyses for cobalt- 60 have continued to the preset, no cobalt-60 has been detected in the groundwater at WMA C since November 1994. There are no available data to assess groundwater contamination beneath WMA C prior to the early 1990s.

Because concentrations change over time, a time period must be chosen to examine spatial distribution patterns. For this purpose, the most recent data (average of FY 2005 sampling events) were chosen and these data are tabulated in Table 4.24. Data were then plotted and inspected for distribution patterns or groupings. Contour maps of contaminant concentrations were drawn to identify spatial patterns that might be indicative of source areas. The maps are shown in the series of Figures 4.77 through 4.80 .

The data for iodine-129 in Table 4.24 are somewhat misleading because, in FY 2005, analyses for iodine-129 were made only on one sample from each of the two wells on the east side of the WMA. Prior to about early 2001, iodine-129 was detected routinely in wells 299-E27-12, 299-E27-13, and 299-E27-15, located along the western edge of the WMA, at concentrations comparable to those in wells along the eastern edge. No analyses were done in the western wells since that time. The situation is similar for tritium in that tritium analyses from all wells done in 2004 and earlier showed concentrations similar to the concentrations for the two wells in Table 4.24 and to the regional trends.

Tritium and iodine-129 are present in the unconfined aquifer beneath most of the 200 East Area (Figures 4.77 and 4.78, respectively) and both iodine-129 and tritium plumes have been mapped beneath the 200 East Area since at least the late 1970s (e.g., Eddy 1979). The iodine-129 and tritium in the groundwater beneath WMA C is believed to be part of the regional 200 East Area plume, and are attributed to liquid discharges associated with the cribs and trenches near the PUREX facility.

A nitrate plume underlies much of the 200 East Area (Figure 4.79) and much of this plume also is attributed to discharges to various cribs and ditches throughout the 200 East Area. However, a local plume of nitrate occurs in the area of WMA C (Figure 4.79) and some of this nitrate may be from the WMA. Prior to about 1998, the nitrate concentration at WMA C was less than or near background levels. Beginning in about 1998, the nitrate concentration started to increase in all wells at WMA C. The highest concentrations historically were in the upgradient wells 299-E27-7 and 299-E27-14 on the eastern side of the tank farm. These wells still had the largest nitrate concentrations in early 2005, but since about 2004, nitrate concentrations in some downgradient wells are similar to that in well 299-E27-7. 
Table 4.24. Average Concentration of Mobile Contaminants in Groundwater in the Vicinity of Waste Management Areas C for FY $2005^{\text {(a) }}$

\begin{tabular}{|c|c|c|c|c|c|c|c|c|c|c|}
\hline Wells & $\begin{array}{c}\mathrm{NO}_{3} \\
(\mathrm{mg} / \mathrm{L})\end{array}$ & $\begin{array}{c}\mathrm{CN} \\
(\mu \mathrm{g} / \mathrm{L})\end{array}$ & $\begin{array}{c}\mathrm{Ca} \\
(\mu \mathrm{g} / \mathrm{L})\end{array}$ & $\begin{array}{c}\mathrm{Na} \\
(\mu \mathrm{g} / \mathrm{L})\end{array}$ & $\begin{array}{c}\mathrm{Cl} \\
(\mathrm{mg} / \mathrm{L})\end{array}$ & $\begin{array}{c}\mathrm{SO}_{4} \\
(\mathrm{mg} / \mathrm{L})\end{array}$ & $\begin{array}{c}\mathrm{I}-129 \\
(\mathrm{pCi} / \mathrm{L})\end{array}$ & $\begin{array}{c}\text { Tc-99 } \\
\text { (pCi/L) }\end{array}$ & $\begin{array}{l}\text { Tritium } \\
(\mathrm{pCi} / \mathrm{L})\end{array}$ & $\begin{array}{c}\text { Specific } \\
\text { Conductance } \\
(\mu \mathrm{S} / \mathrm{cm})^{(\mathrm{b})}\end{array}$ \\
\hline 299-E27-4 & 18.18 & $\begin{array}{l}\text { Not } \\
\text { detected }\end{array}$ & $477,900^{(\mathrm{c})}$ & $1212,240^{(\mathrm{c})}$ & 10.55 & 70.42 & $\begin{array}{l}\text { Not } \\
\text { analyzed }\end{array}$ & (5,095 & $\begin{array}{l}\text { Not } \\
\text { analyzed }\end{array}$ & 388 \\
\hline 299-E27-7 & 26.22 & 31.03 & 77,675 & 15,450 & 31.30 & 156.5 & 3.81 & 81.4 & $987^{(\mathrm{d})}$ & $649^{(e)}$ \\
\hline 299-E27-12 & 9.19 & $\begin{array}{l}\text { Not } \\
\text { detected }\end{array}$ & 41,100 & 11,900 & 9.82 & 50.08 & $\begin{array}{l}\text { Not } \\
\text { analyzed }\end{array}$ & 60.3 & $\begin{array}{l}\text { Not } \\
\text { analyzed }\end{array}$ & 352 \\
\hline 299-E27-13 & $1 ., 20$ & $\begin{array}{l}\text { Not } \\
\text { detected }\end{array}$ & 40,825 & 11,650 & 8.75 & 58.1 & $\begin{array}{l}\text { Not } \\
\text { analyzed }\end{array}$ & 2,170 & $\begin{array}{l}\text { Not } \\
\text { analyzed }\end{array}$ & 355 \\
\hline 299-E27-14 & 46.70 & $\begin{array}{l}\text { Not } \\
\text { detected }\end{array}$ & 97,150 & 17,875 & 29.72 & 205.5 & 4.95 & 2,038 & $1,060^{(d)}$ & 771 \\
\hline 299-E27-15 & 17.92 & $5.6^{(\mathrm{d})}$ & 50,825 & 15,825 & 14.85 & 88.85 & $\begin{array}{l}\text { Not } \\
\text { analyzed }\end{array}$ & 208 & $\begin{array}{l}\text { Not } \\
\text { analyzed }\end{array}$ & 453 \\
\hline 299-E27-21 & 19.15 & $\begin{array}{l}\text { Not } \\
\text { detected }\end{array}$ & 42,500 & 13,700 & 8.52 & 63.2 & $\begin{array}{l}\text { Not } \\
\text { analyzed }\end{array}$ & 512 & $\begin{array}{l}\text { Not } \\
\text { analyzed }\end{array}$ & 369 \\
\hline 299-E27-22 & 20.15 & $\begin{array}{l}\text { Not } \\
\text { detected }\end{array}$ & 64,600 & 14,025 & 23.92 & 113.85 & $\begin{array}{l}\text { Not } \\
\text { analyzed }\end{array}$ & 38.2 & $\begin{array}{l}\text { Not } \\
\text { analyzed }\end{array}$ & 535 \\
\hline $299-\mathrm{E} 27-23^{(\mathrm{c})}$ & 25.56 & $\begin{array}{l}\text { Not } \\
\text { detected }\end{array}$ & 50,260 & 13,360 & 12.52 & 82.18 & $\begin{array}{l}\text { Not } \\
\text { analyzed }\end{array}$ & 1,904 & $\begin{array}{l}\text { Not } \\
\text { analyzed }\end{array}$ & 427 \\
\hline $\begin{array}{l}\text { Hanford Site } \\
\text { Background }^{(\mathrm{f})}\end{array}$ & 5.68 & 5.43 & 36,518 & 13,402 & 7.05 & 27.1 & $\begin{array}{l}2.88 \mathrm{x} \\
10^{-6}\end{array}$ & 0.447 & 63.9 & 348 \\
\hline \multicolumn{11}{|c|}{$\begin{array}{l}\text { (a) Average concentration of four, quarterly san } \\
\text { (b) Average of } 16 \text { analyses. } \\
\text { (c) Average of } 5 \text { analyses. } \\
\text { (d) One analysis. } \\
\text { (e) Average of } 13 \text { analyses. } \\
\text { (f) Background values are from DOE } 1997 . \\
\text { Bold indicates upgradient wells. }\end{array}$} \\
\hline
\end{tabular}

Figure 4.80 shows a plume map for technetium-99 in the top of the aquifer beneath WMA C in FY 2006. Elevated technetium- 99 was first noted in the area during the late part of 2000 when concentrations began to increase from less than $100 \mathrm{pCi} / \mathrm{L}$ to $2,730 \mathrm{pCi} / \mathrm{L}$ in early 2002 in upgradient well 299-E27-7 (Figure 4.81). Subsequently the technetium-99 concentration rapidly decreased to pre-2002 values of less than about $500 \mathrm{pCi} / \mathrm{L}$. The increase in technetium-99 was accompanied with an increase in sulfate and smaller increase in nitrate concentration (Figure 4.81). Both sulfate and nitrate concentrations continued to increase as the technetium-99 plume passed the well and both continue to increase today.

The relationships among nitrate, sulfate, and technetium-99 are not constant from well to well at WMA C. Figure 4.82 shows concentrations for these constituents for four downgradient wells. The concentrations of nitrate, sulfate, and technetium-99 began increasing simultaneously in well 299-E27-14 in 1998 to 1999 (Figure 4.82A). The sulfate and nitrate concentrations also began to increase in well 299-E27-13 in 1998. However, the technetium-99 concentration did not begin increasing in the latter well until about two years later in 2000 (Figure 4.82B). The other two downgradient wells with significant technetium-99, wells 299-E27-4 and 299-E27-23, were drilled after contamination arrived in the area such that the time of arrival of the contaminants is not recorded in the wells (Figure 4.82 C and D). 


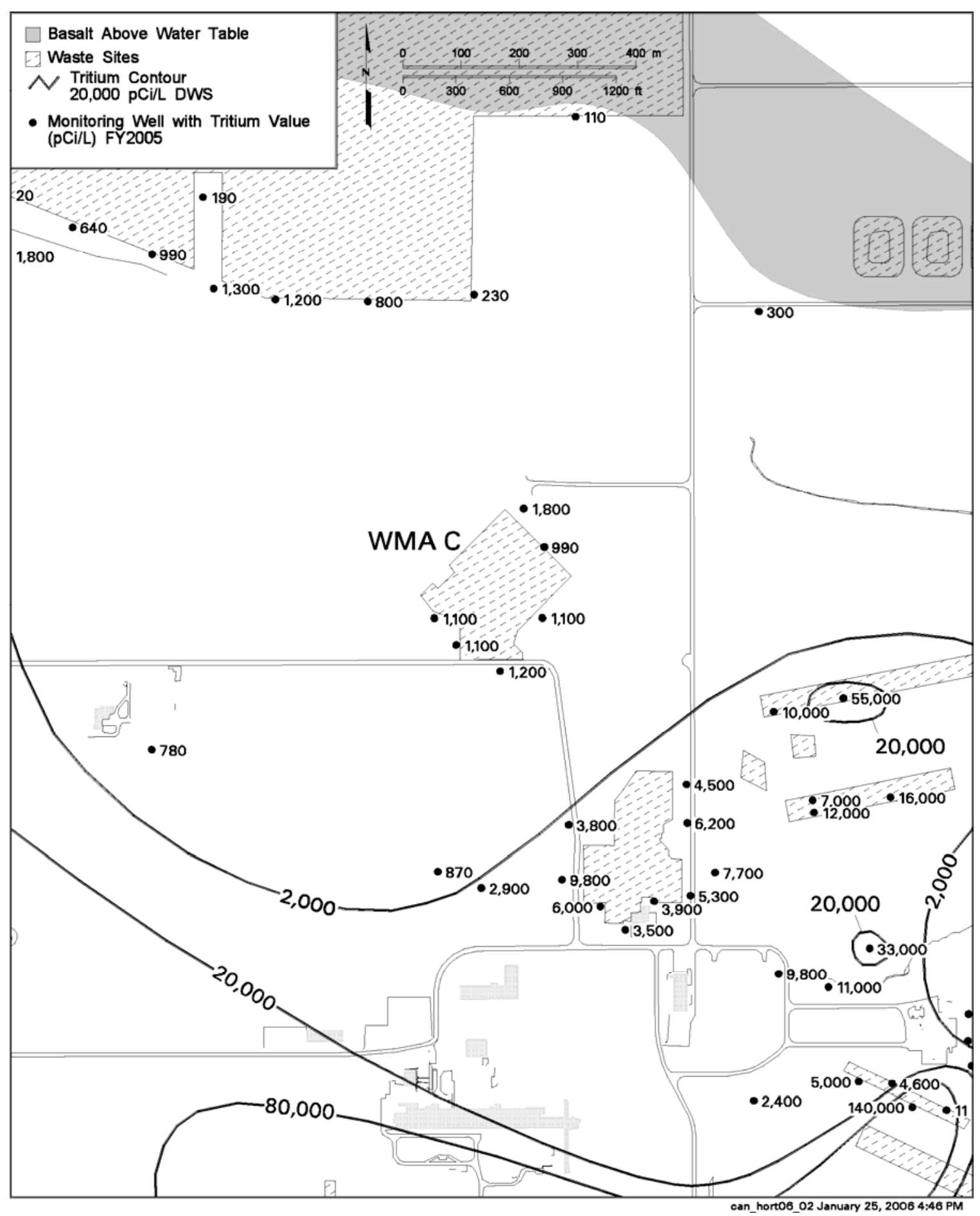

Figure 4.77. Average FY 2005 Tritium Concentration in the Area of Waste Management Area C, Top of the Aquifer (modified from Hartman et al. 2006) 


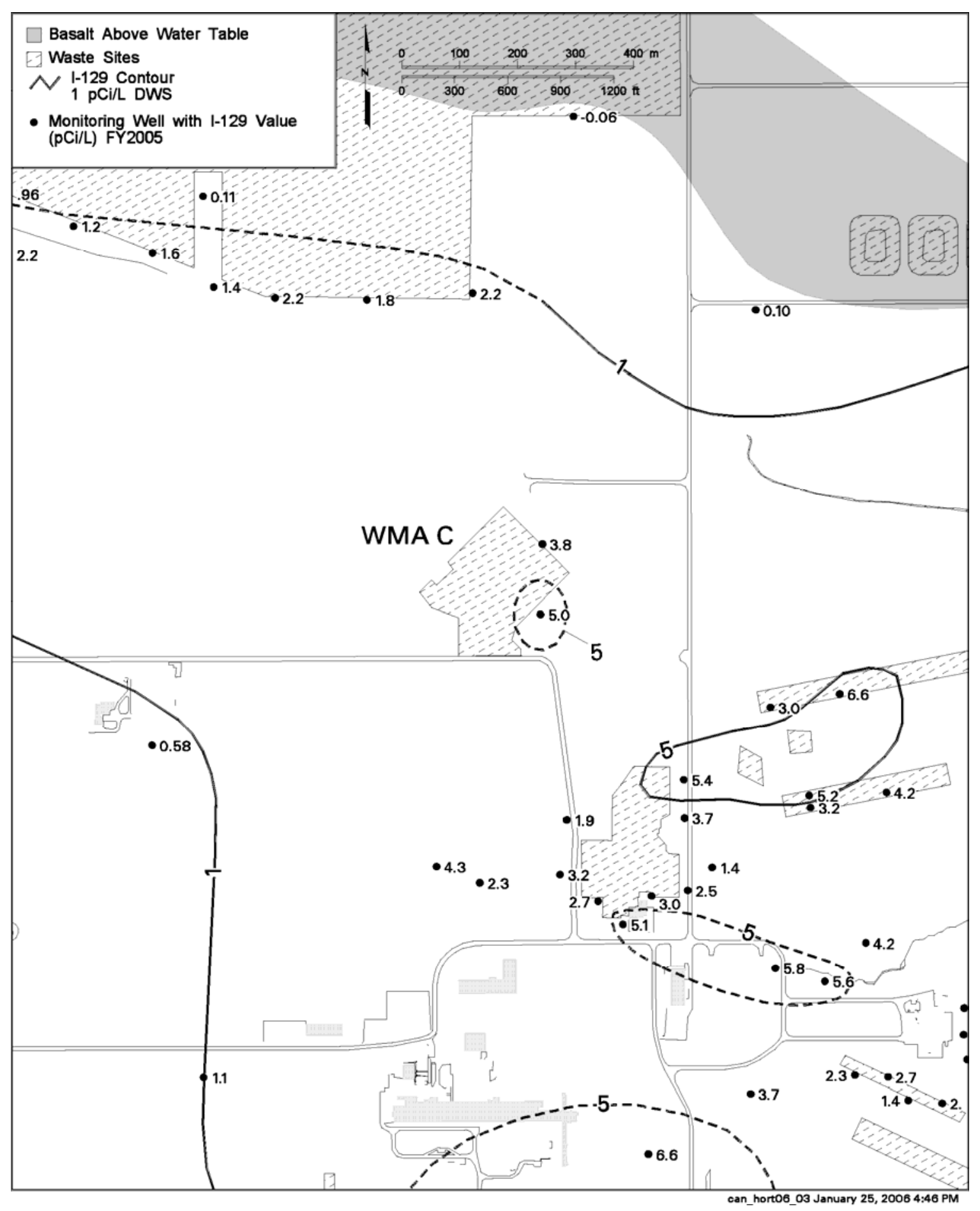

Figure 4.78. Average FY 2005 Iodine-129 Concentration in the Area of Waste Management Area C, Top of the Aquifer (modified from Hartman et al. 2006) 


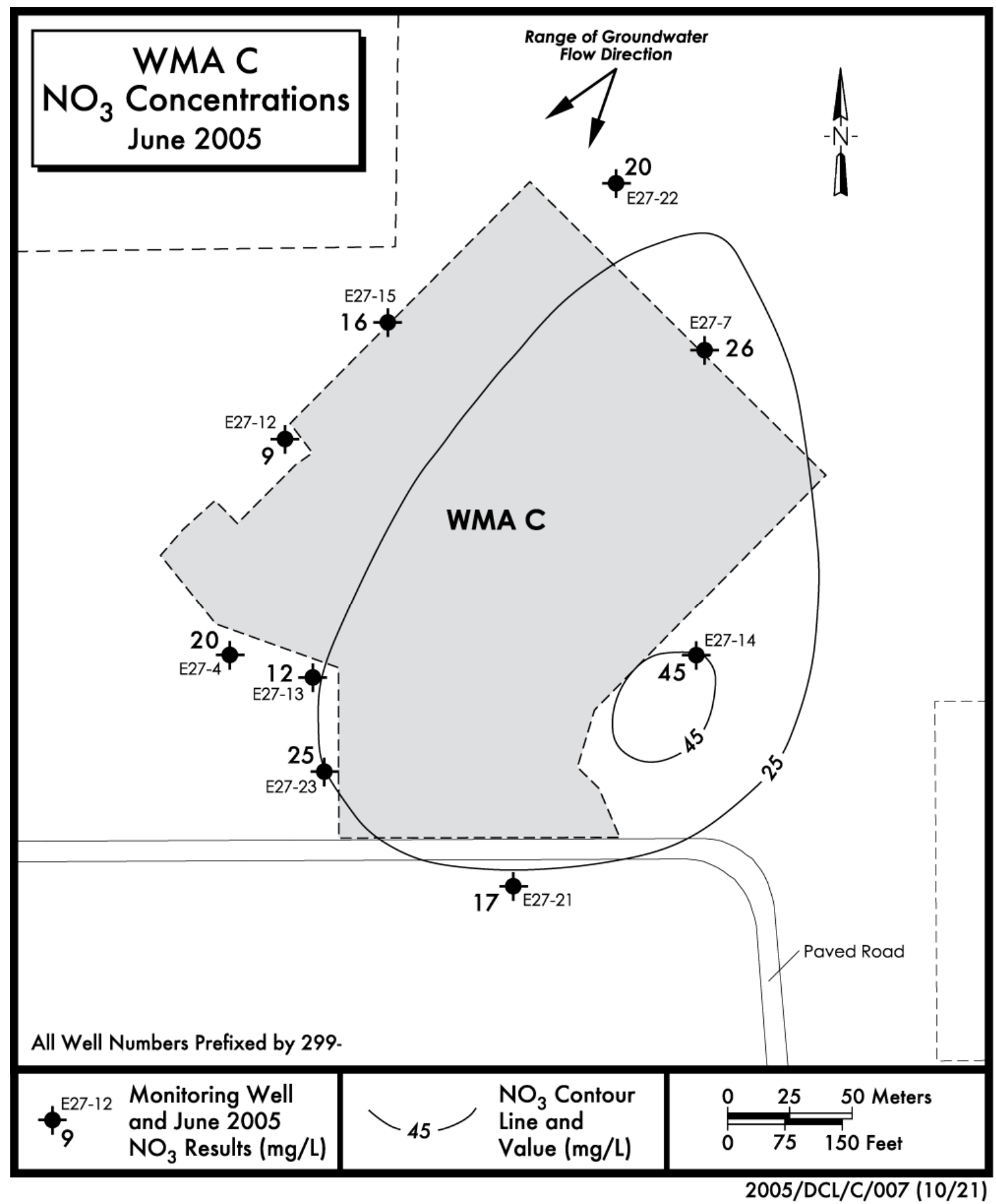

Figure 4.79. Average June 2005 Nitrate Concentrations in the Area of Waste Management Area C, Top of the Aquifer (from Hartman et al. 2006) 


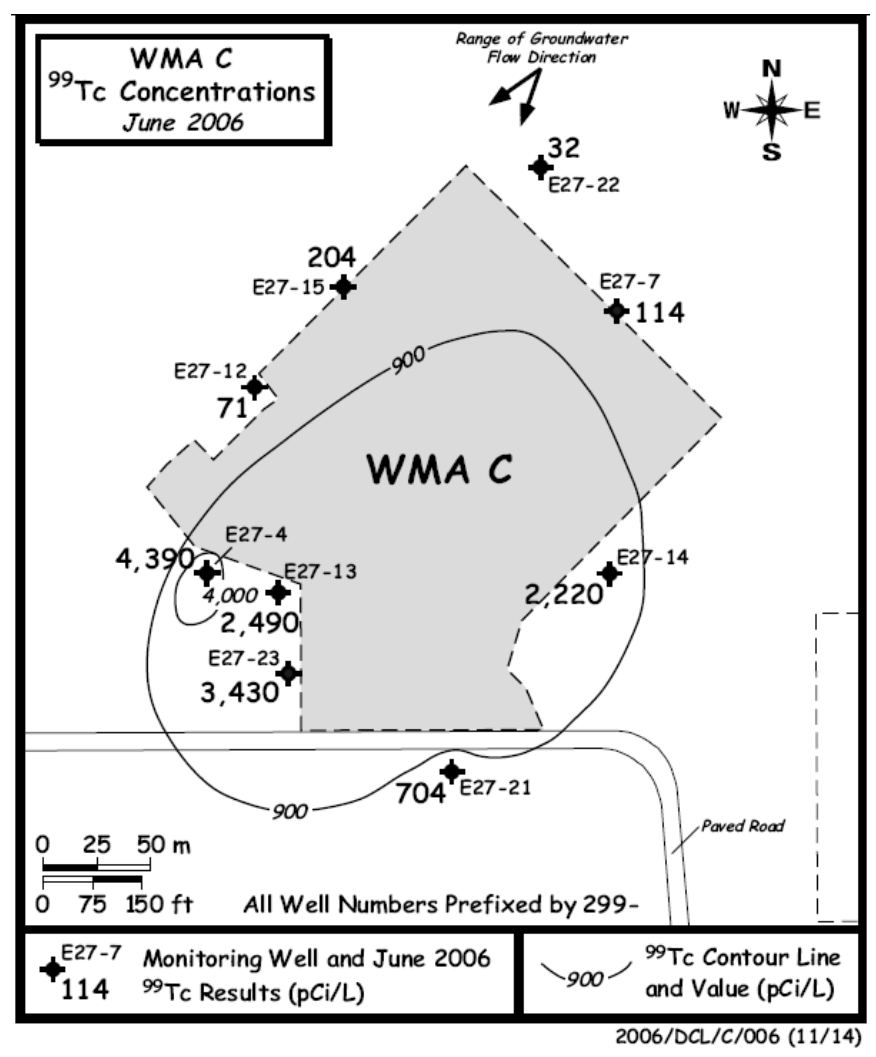

Figure 4.80. Average FY 2006 Technetium-99 Concentrations in the Area of Waste Management Area C, Top of the Aquifer

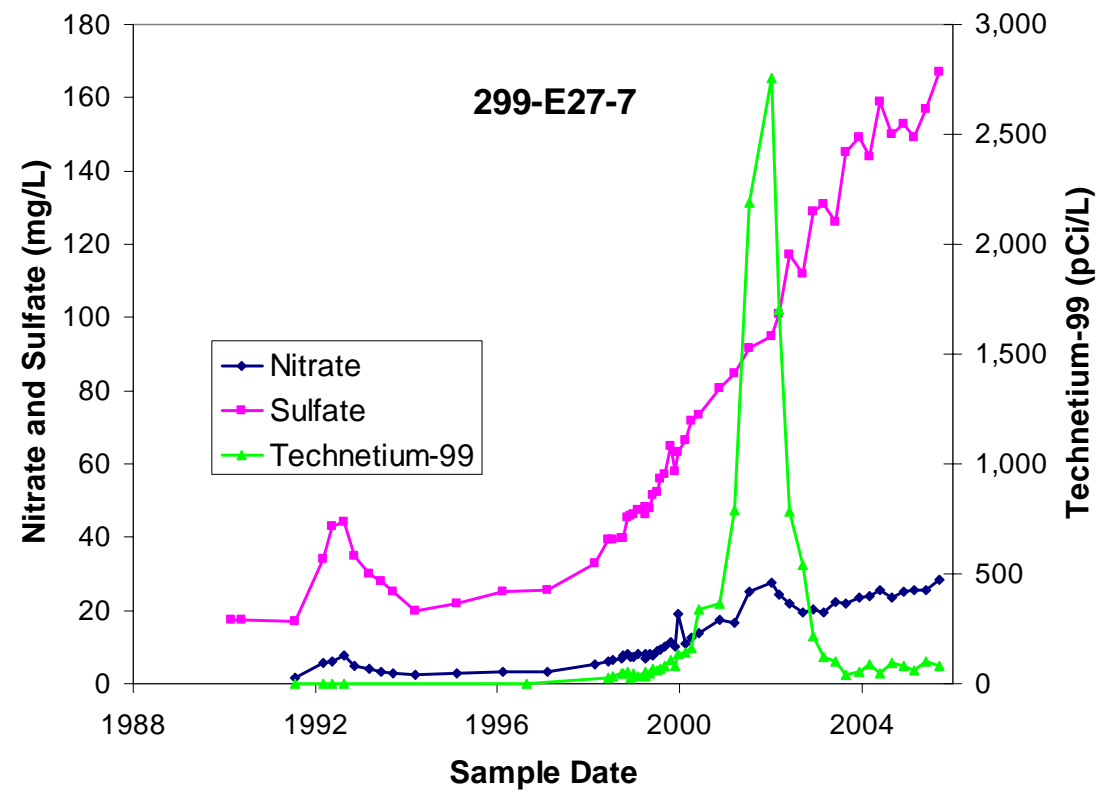

Figure 4.81. Nitrate, Sulfate, and Technetium-99 Concentrations in Upgradient Well 299-W27-7 at Waste Management Area C 

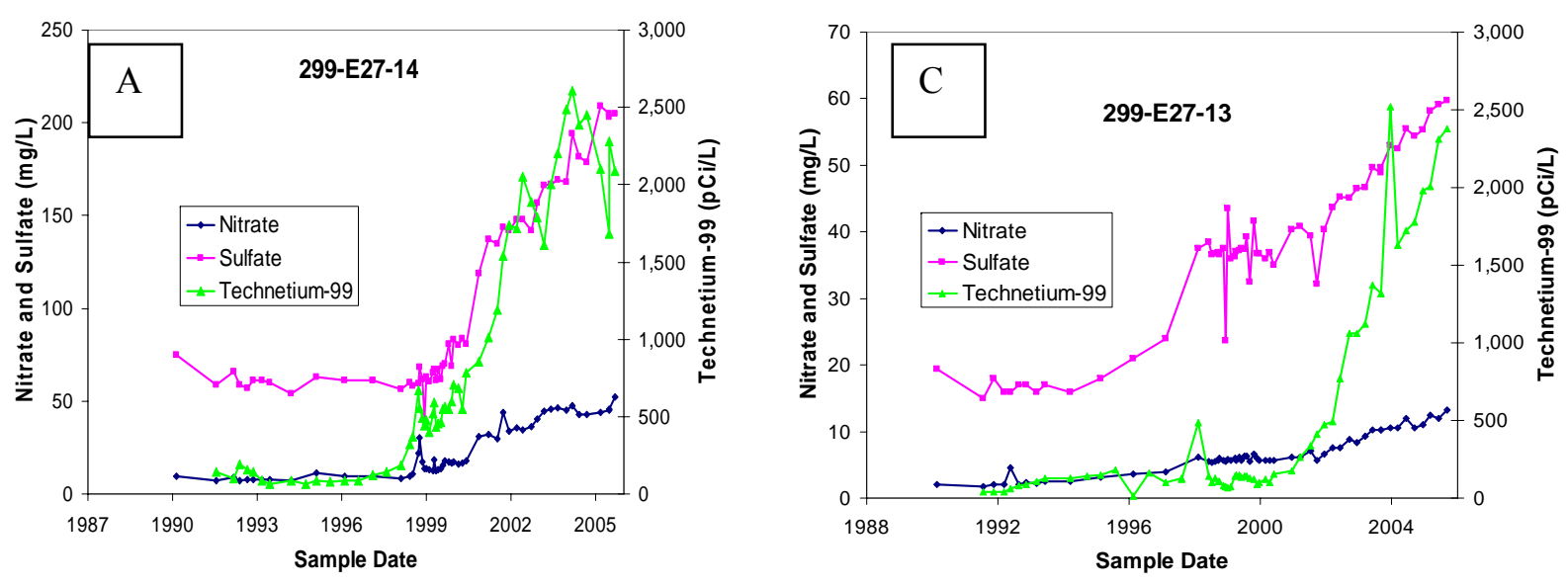

$\stackrel{\square}{\Xi}$
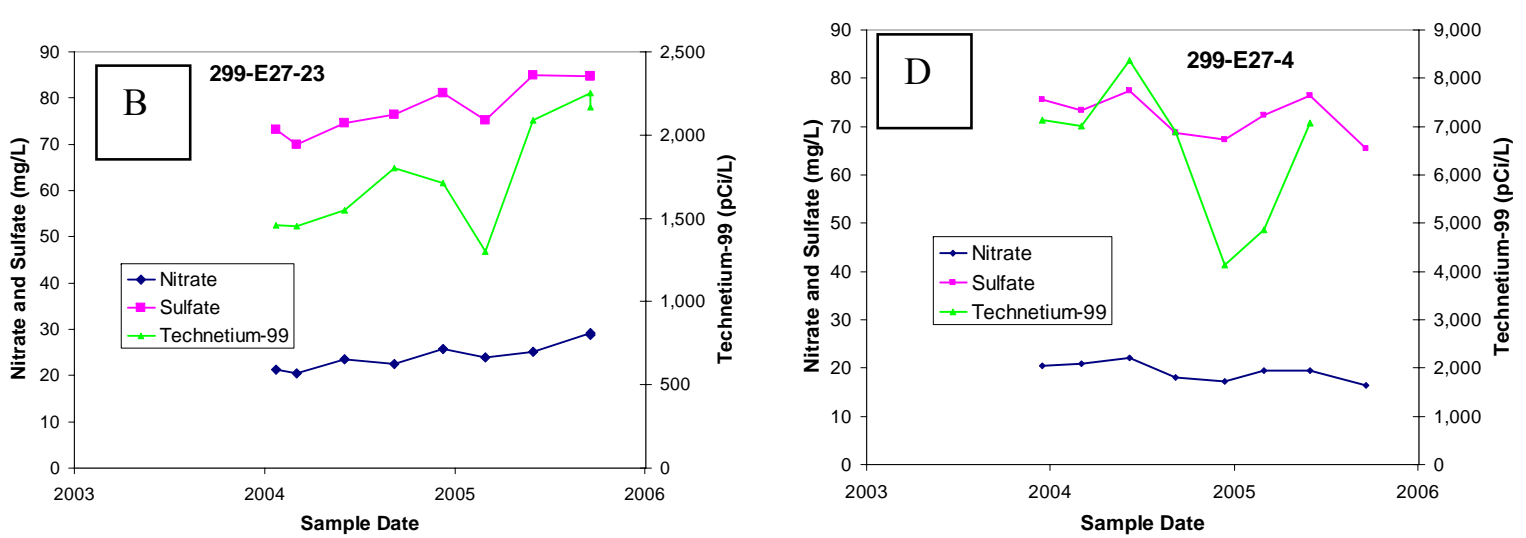

Figure 4.82. Sulfate, Nitrate, and Technetium-99 Concentrations in Selected Downgradient Wells at Waste Management Area C 
Figure 4.83 shows the technetium-99/nitrate and technetium-99/sulfate ratios (pCi/mg) in those wells at WMA C that have elevated technetium-99. The ratios in the figure show that only in well 299-E27-14 do the concentrations of technetium-99, nitrate, and sulfate track with each other. In all other wells the concentration of technetium-99 increases more rapidly than nitrate and sulfate, especially in wells 299-E27-13 and 299-E27-4. However, the presence of regional nitrate and sulfate plumes in the 200 East Area complicates the interpretation. These relationships show the difficulty in pinpointing a particular source for the contamination and it is likely that more than one source is involved.
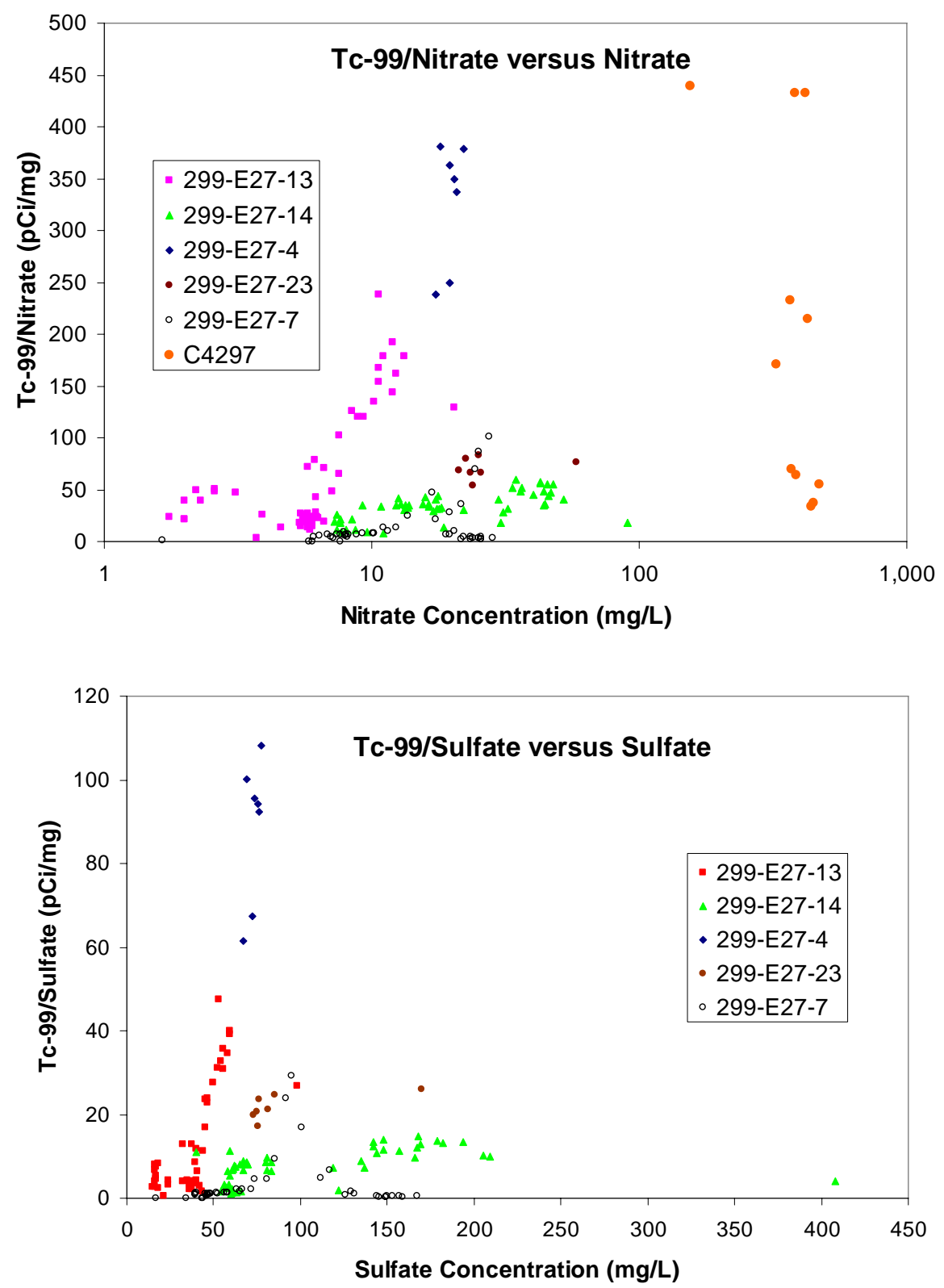

Figure 4.83. Technetium-99/Nitrate and Technetium-99/Sulfate Relationships for Selected Wells at Waste Management Area C (data for C4297 from Brown et al. 2006; all other data from HEIS 1994) 
Several wells at WMA C have had detectable cyanide concentrations in the past five to six years although the concentrations have been erratic in most wells. The earliest detected cyanide in the area was in wells 299-E27-14 and 299-E27-15, located on the west and east sides of the WMA respectively, in the early 1990s. Both wells had one detectable occurrence of cyanide at less that $6 \mu \mathrm{g} / \mathrm{L}$, but no subsequent analyses for cyanide were made until late in 2000 (Figure 4.84).

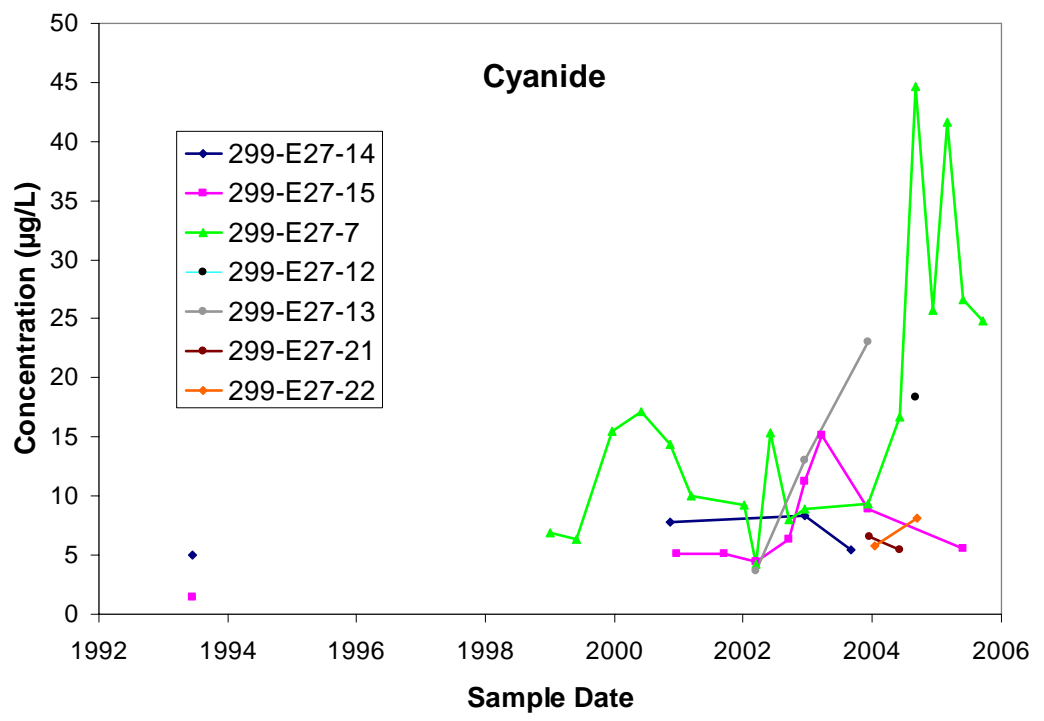

Figure 4.84. Cyanide Concentration in Wells at Waste Management Area C

Since 2000, most wells in the WMA C monitoring network have shown sporadic cyanide concentrations in the groundwater. The highest concentrations have been in upgradient well 299-E27-7. Although this is the well that showed the earliest technetium-99 plume in the area, the high cyanide post-dates the passing of the technetium- 99 plume by about 2 years. The fact that concentration increases and decreases of technetium-99, cyanide, sulfate, and nitrate do not all coincide suggests that there is more than one source for the contaminants at WMA C. The identity of the specific sources has not been determined.

\subsubsection{Comparison of Groundwater, Vadose Zone Pore Water, and Tank Leak Chemical Compositions}

Four of the 100 series tanks in WMA C are reported to have leaked in the past. Corbin et al. (2005) compiled an updated estimate of the chemical compositions of the single-shell tank leaks. Part of those estimates, in terms of technetium-99/nitrate and technetium-99/sulfate composition ratios, is given in Table 4.25. These particular ratios were chosen to compare with groundwater composition because technetium-99, nitrate and sulfate are routinely analyzed in groundwater. The technetium-99/nitrate and technetium-99/sulfate ratios from FY 2005 groundwater samples having elevated technetium-99 also are given in Table 4.25.

Comparison of the chemical ratios from the estimated tank fluids with those from groundwater analyses show that for some wells the tank fluids and groundwater ratios agree within an order of magnitude. For other wells, the ratios are not very similar. The best comparison is for wells 299-E27-4 and 299-E27-13, located near each other at the southwest edge of the WMA. Both the technetium-99/nitrate and the technetium-99/sulfate ratios from the groundwater samples are similar to the ratios estimated for 
tank fluids associated with C-110 and C-111. The technetium-99/nitrate ratio from well 299-E27-23 is also similar to the C-110 and C-111 tank leaks, but the technetium-99/sulfate ratios are lower in the groundwater than for the tank leaks.

Table 4.25. Concentration Ratios for Selected Constituents in Estimated Tank Leaks, Groundwater, and Pore Water from Waste Management Area $\mathrm{C}^{(\mathrm{a})}$

\begin{tabular}{|c|c|c|}
\hline Contaminant Source & Tc-99/Sulfate (pCi/mg) & Tc-99/Nitrate (pCi/mg) \\
\hline$C-101^{(a)}$ & 17,140 & 4,470 \\
\hline$C-105^{(a)}$ & 15,660 & 1,980 \\
\hline$C-110^{(a)}$ & 290 & 20 \\
\hline $\mathrm{C}-111^{(\mathrm{a})}$ & 670 & 50 \\
\hline \multicolumn{3}{|c|}{ Well 299-E27-13 } \\
\hline $12 / 8 / 2004$ & 178 & 36 \\
\hline $3 / 1 / 2005$ & 162 & 35 \\
\hline $6 / 1 / 2005$ & 193 & 39 \\
\hline $9 / 12 / 2005$ & 179 & 40 \\
\hline \multicolumn{3}{|c|}{ Well 299-E27-14 } \\
\hline $3 / 1 / 2005$ & 48 & 10 \\
\hline $6 / 27 / 2005$ & 19 & 4 \\
\hline $9 / 12 / 2005$ & 40 & 10 \\
\hline \multicolumn{3}{|c|}{ Well 299-E27-23 } \\
\hline $12 / 10 / 2004$ & 67 & 21 \\
\hline $2 / 28 / 2005$ & 54 & 17 \\
\hline $6 / 1 / 2005$ & 83 & 25 \\
\hline $9 / 19 / 2005$ & 76 & 26 \\
\hline \multicolumn{3}{|c|}{ Well 299-E27-4 } \\
\hline $12 / 13 / 2004$ & 239 & 61 \\
\hline $2 / 28 / 2005$ & 250 & 67 \\
\hline $6 / 1 / 2005$ & 363 & 92 \\
\hline \multicolumn{3}{|c|}{ Borehole C4297 (m bgs) } \\
\hline 40.8 & 69 & 439 \\
\hline 41.2 & 39 & 233 \\
\hline 41.7 & 88 & 433 \\
\hline 44.6 & 47 & 433 \\
\hline 46.2 & 17 & 171 \\
\hline 46.6 & 46 & 214 \\
\hline 47.1 & 11 & 55 \\
\hline 47.7 & 12 & 64 \\
\hline 47.7 Duplicate & 13 & 70 \\
\hline 48.5 & 7 & 37 \\
\hline 48.5 Duplicate & 7 & 34 \\
\hline \multicolumn{3}{|c|}{$\begin{array}{l}\text { Ratios for tank fluids are calculated using the mean mass values in Corbin et al. } 2005 \text { and } \\
\text { leak volumes from Field and Jones (2005). Ratios for pore water are from Brown et al. } \\
\text { (2006). Ratios for groundwater are from } 2005 \text { RCRA samples (HEIS 1994). }\end{array}$} \\
\hline
\end{tabular}


These comparisons allow for the possibility of tank waste from leaks associated with tanks C-110 and C-111 to have impacted groundwater. However, given the uncertainties in the tank fluid estimates and given the potential interferences in the groundwater ratios due to regional nitrate and sulfate plumes, a direct correlation is tenuous.

Borehole C4297 was drilled to investigate a possible leak from tank C-105 or a waste loss from a cascade line or inlet port associated with tank C-105. 1:1 sediment to water extracts from the borehole were analyzed for a wide suite of constituents and resulting pore water compositions were reported by Brown et al. (2006). The pore water compositions from depth noted by Brown et al. (2006) as having elevated technetium-99 and nitrate are included in Table 4.25. Comparisons of the borehole C4297 data with the estimates of the same constituent ratios for tank fluids show poor overall agreement between the two. The deepest three samples from borehole C4297 have technetium-99/nitrate ratios similar to two of the estimated tank leaks (but not C-105) and to the groundwater samples. Also the most of the technetium-99/sulfate ratios for C4297 pore water are similar to groundwater from well 299-E27-14 and 299-E27-23, but, except for the deepest three samples from C4297, the technetium-99/nitrate ratios are larger than groundwater samples.

Unfortunately, there are not many measured constituents common to both groundwater and borehole C4297 pore water. The available constituents are limited to technetium-99, some metals and most anions. Figure 4.85 shows several concentration ratios from groundwater analyses and pore water from borehole C4297. The data on the figure show no clear relationship between the compositions of the groundwater and pore water. Brown et al. (2006) showed two zones of technetium-99 contamination in borehole C4297: one zone is at about 12 to $18 \mathrm{~m}$ bgs and assumed to be associated with the bottom of tank C-105, and the other zone is between about 42.6 to $45.7 \mathrm{~m}$ bgs. The technetium-99/nitrate ratios of samples from the contaminated zones are generally greater than about $200 \mathrm{pCi} / \mathrm{mg}$. Such values are greater than the technetium-99/nitrate ratios in all groundwater wells except well 299-E27-4 (Figure 4.85). However, the agreement for the other ratios between groundwater from well 299-E27-4 and pore water from borehole C4297 is not good. This suggests (1) that there has been fractionation between technetium-99 and the other constituents, (2) that there has been mixing of tank waste with other groundwater contamination, or (3) that tank waste has not impacted groundwater in this area.

In summary, there is no clear chemical fingerprint that indicates similarities among estimated tank fluid compositions at the time of suspected leaks, groundwater contaminant compositions, or C4297 pore water composition at WMA C. 

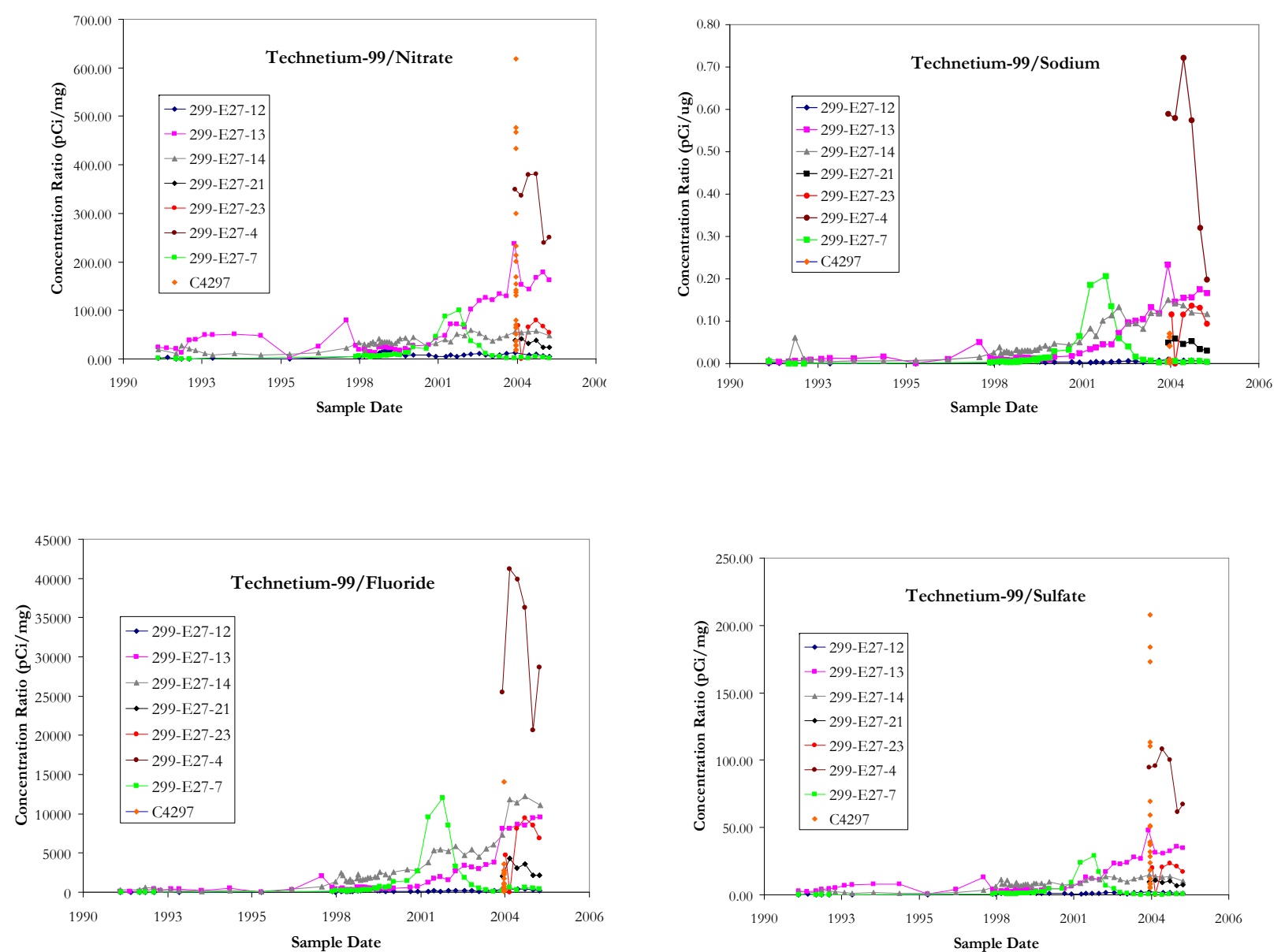

Figure 4.85. Selected Compositional Relationships between Groundwater Samples from Wells at Waste Management Area C and C4297 Pore Water (data from HEIS 1994 and Brown et al. 2006) 


\subsection{Conclusions and Summary}

Past Hanford Site operations caused large changes in the uppermost aquifer beneath the site in terms of both hydrologic properties and water quality. Disposal of large volumes of liquid waste formed groundwater mounds up to about $26 \mathrm{~m}$ above the pre-Hanford Site water table (Last et al. 1994). The groundwater mounds caused increases in flow velocity and large changes in flow direction that moved contamination throughout the unconfined aquifer in many localized places. Today, flow directions are generally toward the east below most of the 200 West Area except where flow directions are influenced by the 200-ZP-1 pump-and-treat operation. Flow directions are more variable in 200 East Area due to residual influences of B Pond. There is considerable uncertainty in the flow direction in the north part of 200 East Area because of thinning of the aquifer against basalt subcrops and an extremely low water-table gradient.

Aquifer testing has shown that vertical hydraulic gradients exist in some wells in the 200 West Area. Vertical flow is upward in some places and downward in other places. The reason for the vertical flow is not known for certain. Nevertheless, vertical flow has important implications pertaining to (1) the representativeness of groundwater samples collected from the wells and (2) the vertical distribution of contaminants in the aquifer.

Groundwater monitoring began around the single-shell tank farms in the late 1940s for operational and environmental protection purposes. Groundwater monitoring in support of the Atomic Energy Act was implemented primarily in the 1980s through various DOE Orders. Interim status detection monitoring at single-shell tank WMAs for RCRA purposes began in 1989. Since that time, all singleshell tank WMAs except WMA C have moved to interim status groundwater assessment monitoring because, for RCRA purposes, the WMAs are assumed to be the source for associated groundwater contamination until shown otherwise.

The major contaminants of concern to all single-shell tank WMAs in 200 West Area are carbon tetrachloride, technetium-99, and nitrate. Chromium and tritium are contaminants present at WMAs T, TX-TY, and S-SX; iodine-129 is of concern at WMA TX-TY; and fluoride is of concern at WMA T. Contaminants of concern to all single-shell tank WMAs in 200 East Area are nitrate and technetium-99. Sulfate, uranium, cobalt-60, tritium, and cyanide are also of concern at WMA B-BX-BY, and cyanide is of concern at WMA C. The presence of these contaminants of concern in groundwater beneath the tank farms does not necessarily mean that the tank farms are the source for all the contamination found.

Vertical contaminant concentration gradients are known to exist at several single-shell tank WMAs:

- Recent drilling and sampling show that the maximum technetium-99 concentrations at WMA T occur at about $10 \mathrm{~m}$ below the water table.

- The maximum concentrations of nitrate, technetium-99, and iodine-129 are within $1 \mathrm{~m}$ of the water table and their concentrations decrease with increasing depth in a small but high concentration plume east of WMA TX-TY. 
- Chromium, nitrate, and technetium-99 are present throughout the upper $23 \mathrm{~m}$ of the aquifer near the center of the plume south of WMA S-SX. Technetium-99 and nitrate decrease rapidly with depth in the aquifer at a well near the side edge of the plume.

- The concentration of tritium increases with increasing depth at one well at WMA B-BX-BY. The concentrations of technetium-99 and nitrate are high in a zone at the base of the aquifer in another well at WMA B-BX-BY.

- No information from WMA A-AX or WMA C is available concerning vertical concentration gradients at those waste management areas

The vertical concentration gradients are probably a function of several factors including distance from source area, salinity of waste fluids, and vertical hydraulic flow in some wells.

Attempts to relate chemical compositions of groundwater to specific estimated tank leaks and pastpractice liquid discharges generally have not been successful partly because of uncertainties in the tank leak and discharge composition estimates. Mixing of contaminants from different sources also complicates the situation.

A second approach recently taken is comparisons of concentrations of technetium-99 and nitrate in vadose zone pore water, which is thought to represent leaked tank waste, to their respective concentrations in groundwater. The technetium-99/nitrate concentration ratios in pore water and groundwater at WMAs T and S-SX are similar (within an order of magnitude) suggesting that tank waste may have influenced groundwater at WMAs T and S-SX. Similar comparisons at WMAs TX-TY and B-BX-BY do not show consistent similarities between groundwater and pore water so that no conclusions can be made using this approach at those WMAs. The lack of similarities may result, in part, from mixing of contaminants from more than one source.

A major difficulty in using constituent ratios to compare tank waste constituents in the vadose zone and groundwater is the possibility of one or more chemical components being retarded as they move through the vadose zone or aquifer. Recent studies at WMA B-BX-BY used ratios of uranium isotopes to avoid this difficulty. Using different isotopes of the same element eliminates problems related to differential retardation. The uranium isotopes suggested that the uranium in the groundwater had the same source as uranium in vadose zone pore water derived from an overflow event at tank BX-102. Recent studies involving uranium isotopes in pore water and groundwater and stable isotopes of oxygen and nitrogen in dissolved nitrate do not have the problem of differential retardation and show promise to be able to distinguish contaminant sources.

The bulk of groundwater related information comes from groundwater monitoring associated with ongoing RCRA and CERCLA activities at and near single-shell tank WMAs. Monitoring for RCRA purposes will continue well into the future allowing continuous tracking of contaminant plumes in the aquifer. Monitoring for support of CERCLA will continue at least until final cleanup decisions are made.

The large amount of existing groundwater monitoring and characterization data allow fairly detailed descriptions of current and historical contaminant plumes associated with single-shell tank WMAs in most cases. However, there still remain knowledge gaps in our understanding of groundwater flow 
directions in the north part of 200 East Area, the vertical (and in some cases lateral) distribution of contaminants in the aquifer in most areas, and the specific sources for the contaminants in groundwater beneath most single-shell tank WMAs.

Groundwater flow direction beneath 200 West Area is fairly well defined and generally toward the east except were influenced by the 200-ZP-1 pump-and-treat operation. Groundwater flow direction beneath 200 East Area is not as well defined especially beneath WMA B-BX-BY because of thinning of the aquifer, changes in the hydrologic system due to cessation of liquid disposal to ground, and influences of the top of basalt. Knowing the flow rate and flow direction is important in predicting future movement of contaminants. A special study was begun in fiscal year 2005 to collect continuous water-level measurements and continuous barometric pressure measurements in an attempt to better define groundwater flow characteristics in the area. Data continue to be collected but interpretation has not yet been made.

Most recently, unexpectedly high technetium-99 concentrations were found $10 \mathrm{~m}$ below the water table east of WMA T. The extent of the plume, maximum technetium-99 concentration, source for the contamination, and reason for the depth distribution remain to be explained. These issues are being addressed by the technetium-99 investigation conducted by Fluor Hanford, Inc. as part of the 200-ZP-1 Operable Unit. Several wells are scheduled to be drilled and sampled beginning in late 2006 and early 2007. Data generated by that investigation will be incorporated into interpretations of single-shell tank influences on vadose zone and groundwater contamination.

Surface geophysical exploration using high resolution resistivity (SGE/HRR) recently has been used to map contaminant plumes in the vadose zone at WMA T and WMA S-SX (Rucker et al. 2006a, b). Similar surveys are planned for all other single-shell tank WMAs. The early results appear promising for delineating vadose zone contamination that may have impacted groundwater or may impact groundwater in the future. An unexpected result of the SGE investigation at WMA T is the identification of two groundwater plumes around WMA T. One of these is to the southwest of the WMA where the presence of groundwater contamination is known through previous monitoring activities. The other plume is north of the WMA where groundwater contamination was not previously known. New wells are scheduled to be drilled in late 2006 through both plumes for characterization purposes.

The new SGE/HRR results also appear to be useful to pinpoint potential specific sources for groundwater contamination. At the southwest corner of WMA T, the SGE/HRR method mapped a vadose zone plume beneath specific past-practice liquid disposal facilities that extends all the way to groundwater. Thus, these facilities appear to be responsible for at least most of the groundwater contamination west and southwest of the WMA. A relatively shallow vadose zone plume was mapped beneath past-practice disposal facilities east of WMA T. This plume did not extend to groundwater and these facilities do not appear to have impacted groundwater downgradient of the WMA.

Future SGE/HRR work should contribute to our understanding of the extent of vadose zone contamination beneath the other single-shell tank WMAs and which facilities are the most likely sources for groundwater contamination. Once specific sources are pinpointed, specific remedial actions can be selected.

Most efforts to compare groundwater contamination with leaked tank fluids have used ratios of contaminant concentrations, particularly technetium- 99 and nitrate. These comparisons are complicated 
by differential retardation in the tank environment, the vadose zone, and aquifer sediments. Additional complications rise from interferences from existing, regional plumes.

Moderate success has been achieved at WMAs T and S-SX and less than desirable success has been obtained elsewhere using the ratio comparison method. However, additional information should be obtained before accepting or rejecting the ratio method. Recent direct push work (direct push is a method of obtaining vadose zone pore water samples representative of specific tank leaks) has yielded pore water samples from WMAs C, TX-TY, and T and future plans call for direct push work in all remaining singleshell tank WMAs. Analyses of these samples is ongoing and should add to our understanding of tank leaks, the movement of contaminants in the vadose zone, and the contribution of tank farm activities to groundwater contamination.

Also, vadose zone characterization is being implemented at many past-practice liquid disposal facilities by Fluor Hanford, Inc. and part of the characterization is borehole drilling and sampling. These samples will yield analyses of pore water from past-practice cribs and trenches for comparison with pore water from single-shell tank WMAs and with groundwater. These comparisons may help determine the sources for much of the groundwater contamination.

Recent and preliminary investigations using uranium isotopes to pinpoint a specific source for uranium contamination in groundwater beneath WMA B-BX-BY was described in the preceding paragraphs. Other isotopic systems are being studied in attempts to discern specific sources for groundwater contamination; these include isotopes of ruthenium, nitrogen, oxygen, and strontium.

Ruthenium isotopes have been studied in groundwater and pore water from WMAs B-BX-BY, T, and TX-TY. The ruthenium data are preliminary and analysis is ongoing, but the method shows promise in delineating different sources of groundwater contamination.

Nitrate is one of the most extensive contaminants in groundwater beneath the 200 Areas and nitrate (as nitric acid) was used in almost all major production processes. Preliminary analyses of stable isotopes of nitrogen and oxygen in nitrate show promise in distinguishing nitrate in groundwater resulting from tank waste from nitrate in groundwater resulting from past-practice liquid waste disposal to cribs and trenches.

Several investigations during the past five years have shown that vertical hydraulic gradients and vertical chemical gradients exist in the aquifer at some locations. The hydraulic gradients can move contamination through a well to previously uncontaminated parts of the aquifer, and this may be occurring east of WMA TX-TY. Conversely, upward movement of uncontaminated water into a contaminant plume occurs south of WMA S-SX such that contaminated water near the water table is diluted during sampling. Additional aquifer testing will be done as opportunities and resources allow to identify other areas where vertical hydraulic gradients may be influencing contaminant distributions.

The chemical gradients in the aquifer have a direct impact on the representativeness of groundwater samples collected during routine monitoring and on choosing remediation methods. Chemical gradients also affect interpretations of source areas and locations of contaminants entering the aquifer. Only during the past few years has groundwater been sampled vertically as new wells were drilled. These efforts have yielded much new valuable information about the depths of contamination in the aquifer. Continued investigations of vertical gradients are being done at appropriate locations when new wells are drilled. 
The uppermost aquifer beneath the 200 East and 200 West Areas has been monitored and characterized to one degree or another since the mid 1940s. As a result, significant advances have been made in understanding the groundwater and contaminant system beneath the single-shell tank WMAs. However, there are still unanswered questions about the hydrogeology of the unconfined aquifer and the distribution, mobility, and source of contaminants in the unconfined aquifer, work is continuing in order to answer those questions. 


\subsection{References}

Agnew SF, J Boyer, RA Corbin, TB Duran, JR FitzPatrick, KA Jurgensen, TP Ortiz, and BL Young. 1997. Hanford Tank Chemical and Radionuclide Inventories: HDW Model Rev. 4. LA-UR-96-3860, Los Alamos National Laboratory, Los Alamos, New Mexico.

Aldrich RC. 1984. Radioactive Liquid Wastes Discharged to Ground in the 200 Areas During 1983. RHO-HS-SR-83-3 4Q LIQ P, Rockwell Hanford Operations, Richland, Washington.

Aldrich RC. 1985. Radioactive Liquid Wastes Discharged to Ground in the 200 Areas During 1984. RHO-HS-SR-84-3 4Q LIQ P, Rockwell Hanford Operations, Richland, Washington.

Aldrich RC and GJ Sliger. 1981. Radioactive Liquid Wastes Discharged to Ground in the 200 Areas During 1980. RHO-CD-80-34 4Q, Rockwell Hanford Operations, Richland, Washington.

Anderson JD. 1976. Input and Decayed Values of Radioactive Liquid Wastes Discharged to the Ground in the 200 Areas through 1975. ARH-CD-745, Atlantic Richfield Hanford Company, Richland, Washington.

Anderson JD and BE Poremba. 1979. Radioactive Liquid Waste Discharged to Ground in the 200 Areas During 1977. RHO-CD-34 4Q, Rockwell Hanford Operations, Richland, Washington.

Anderson JD and BE Poremba. 1979. Radioactive Liquid Waste Discharged to Ground in the 200 Areas During 1978. RHO-CD-78 4Q, Rockwell Hanford Operations, Richland, Washington.

Atomic Energy Act. 1954. Public Law 83-703, as amended, 68 Stat. 919, 42 USC 2011 et seq.

Bergeron MP and SK Wurstner. 2000. Groundwater Flow and Transport Calculations Supporting the Immobilized Low-Activity Waste Disposal Facility Performance Assessment. PNNL-13400, Pacific Northwest National Laboratory, Richland, Washington.

Brown CF, RJ Serne, BN Bjornstad, DG Horton, DC Lanigan, RE Clayton, MM Valenta, TS Vickerman, IV Kutnyakov, KN Geiszler, SR Baum, KE Parker, and MJ Lindberg. 2006. Characterization of Vadose Zone Sediments Below the C Tank Farm: Borehole C4297 and RCRA Borehole 299-E27-22.

PNNL-15503, Pacific Northwest National Laboratory, Richland, Washington.

Caggiano JA. 1993. Hydrologic Testing of the Single-Shell Tanks. WHC-SD-EN-TI-147, Rev. 0, Westinghouse Hanford Company, Richland, Washington.

Cantrell KJ, RJ Serne, and GV Last. 2002. Hanford Contaminant Distribution Coefficient Database and Users Guide. PNNL-13895. Pacific Northwest National Laboratory, Richland, Washington.

CERCLA - Comprehensive Environmental Response, Compensation, and Liability Act. 1980. Public Law 96-150, as amended, 94 Stat. 2767, 42 USC 9601 et seq. 
Christensen JN, PE Dresel, ME Conrad, K Maher, and DJ DePaolo. 2004. "Identifying the Sources of Subsurface Contamination at the Hanford Site in Washington using High-Precision Uranium Isotopic Measurements." Environmental Science and Technology 38(12):3330-3337.

Connelly MP, BH Ford, and JV Borghese. 1992. Hydrogeologic Model for the 200 West Groundwater Aggregate Area. WHC-SD-EN-TI-014, Rev. 0., Westinghouse Hanford Company, Richland, Washington.

Corbin RA, BC Simpson, MJ Anderson, WF Danielson III, JG Field, TE Jones, and CT Kincaid. 2005. Hanford Soil Inventory Model, Rev. 1. RPP-26744, CH2M HILL Hanford Group, Inc., Richland, Washington.

DOE. 1988. Consultation Draft Site Characterization Plan. Reference Repository Location, Hanford Site, Washington. DOE/RW-0164, U.S. Department of Energy, Office of Civilian Radioactive Waste Management, Washington, D.C.

DOE. 1992a. T Plant Source Aggregate Area Management Study Report. DOE/RL-91-61, U.S. Department of Energy, Richland, Washington.

DOE. 1992b. Hanford Site Groundwater Background. DOE/RL-92-23, U.S. Department of Energy, Richland, Washington.

DOE. 1993. B Plant Source Aggregate Area management Study Report. DOE/RL-92-05, Rev. 0, U.S. Department of Energy, Richland, Washington.

DOE. 1997. Hanford Site Background: Part 3, Groundwater Background. DOE/RL-96-61, Rev. 0, U.S. Department of Energy, Richland, Washington.

DOE. 2002. Fiscal Year 2001 Annual Summary Report for the 200-UP-1 and 200-ZP-1 Operable Unit Pump-and-Treat Operations. DOE/RL-2001-53, Decisional Draft, U.S. Department of Energy, Richland, Washington.

Dresel PE, JC Evans, and OT Farmer. 2002. Investigations of Isotopic Signatures for Sources of Groundwater Contamination at the Hanford Site. PNNL-13763, Pacific Northwest National Laboratory, Richland, Washington.

Dresel PE, DB Barnett, DB Erb, and DG Horton. 2004. Chapter 2.8, “200-ZP-1 Operable Unit.” In Hanford Site Groundwater Monitoring for Fiscal Year 2003, MJ Hartman, LF Morasch, and WD Webber (eds.), PNNL-14548, Pacific Northwest National Laboratory, Richland, Washington.

Dresel PE, DG Horton, LC Swanson, DB Erb, and RF Raidl. 2006. Chapter 2.8, "200-ZP-1 Operable Unit." In Hanford Site Groundwater Monitoring for Fiscal Year 2005, MJ Hartman, LF Morasch, and WD Webber (eds.), PNNL-15670, Pacific Northwest National Laboratory, Richland, Washington.

Ecology - Washington State Department of Ecology, U.S. Environmental Protection Agency, and U.S. Department of Energy. 1989. Hanford Federal Facility Agreement and Consent Order. Document No. 89-10, as amended (The Tri-Party Agreement), Olympia, Washington. 
Eddy PA. 1979. Radiological Status of the Ground-Water Beneath the Hanford Project JanuaryDecember 1978. PNL-2899, Pacific Northwest Laboratory, Richland, Washington.

Fecht KR, GV Last, and KR Price. 1977. Evaluation of Scintillation Probe Profiles from 200 Area Crib Monitoring Wells. Volume III. ARH-ST-156, Atlantic Richfield Hanford Company, Richland, Washington.

Field JG and TE Jones. 2005. Tank Farm Vadose Zone Contamination Volume Estimates. RPP-23405, Rev. 1., CH2M HILL Hanford Group, Inc., Richland, Washington.

Hartman MJ (ed.). 1999. Hanford Site Groundwater Monitoring for Fiscal Year 1998. PNNL-12086, Pacific Northwest National Laboratory, Richland, Washington.

Hartman MJ (ed.). 2000. Hanford Site Groundwater Monitoring: Setting, Sources, and Methods. PNNL-13080, Pacific Northwest National Laboratory, Richland, Washington.

Hartman MJ, LF Morasch, and WD Webber (eds.). 2001. Hanford Site Groundwater Monitoring for Fiscal Year 2000. PNNL-13404, Pacific Northwest National Laboratory, Richland, Washington.

Hartman MJ, LF Morasch, and WD Webber (eds.). 2004. Hanford Site Groundwater Monitoring for Fiscal Year 2003. PNNL-14548, Pacific Northwest National Laboratory, Richland, Washington.

Hartman MJ, LF Morasch, and WD Webber (eds.). 2005. Hanford Site Groundwater Monitoring for Fiscal Year 2004. PNNL-15070, Pacific Northwest National Laboratory, Richland, Washington.

Hartman MJ, LF Morasch, and WD Webber (eds.). 2006. Hanford Site Groundwater Monitoring for Fiscal Year 2005. PNNL-15670, Pacific Northwest National Laboratory, Richland, Washington.

HEIS. 1994. Hanford Environmental Information System. Hanford Information Systems Department, Fluor Hanford, Inc., Richland, Washington.

Hodges FN. 1998. Results of Phase I Groundwater Quality Assessment for Single-Shell Tank Waste Management Areas T and TX-TY at the Hanford Site. PNNL-11809, Pacific Northwest National Laboratory, Richland, Washington.

Hodges FN and CJ Chou. 2000. Groundwater Quality Assessment for Single-Shell Tank Wastes Management Area U: First Determination. PNNL-13282, Pacific Northwest National Laboratory, Richland, Washington.

Hodges FN and CJ Chou. 2001. RCRA Assessment Plan for Single-Shell Tank Waste Management Area TX-TY at the Hanford Site. PNNL-12072, Pacific Northwest National Laboratory, Richland, Washington.

Horton DG. 2002. Groundwater Conditions at Single-Shell Tank Waste Management Area TX-TY (January 1998 through December 2001). PNNL-14099, Pacific Northwest National Laboratory, Richland, Washington. 
Horton DG. 2003. Data Package for Calendar Year 2002 RCRA Groundwater Monitoring Wells at Single-Shell Tank Waste Management Area TX-TY. PNNL-14249, Pacific Northwest National Laboratory, Richland, Washington.

Horton DG. 2006. RCRA Assessment Plan for Single-Shell Tank Waste Management Area T. PNNL-15301, Pacific Northwest National Laboratory, Richland, Washington.

Horton DG and FN Hodges. 1999. Borehole Data Package for 1998 Wells Installed at Single-Shell Tank Waste Management Area TX-TY. PNNL-12124, Pacific Northwest National Laboratory, Richland, Washington.

Horton DG and VG Johnson. 2000. Borehole Data Package for Wells 299-W22-48, 299-W22-49, and 299-W22-50 at Single-Shell Tank Waste Management Area S-SX. PNNL-13200, Pacific Northwest National Laboratory, Richland, Washington.

Horton DG and SM Narbutovskih. 2001. RCRA Groundwater Monitoring Plan for Single-Shell Tank Waste Management Area C at the Hanford Site. PNNL-13024, Pacific Northwest National Laboratory, Richland, Washington.

Horton DG, VG Johnson, FN Hodges, and CJ Chou. 2002. RCRA Groundwater Quality Assessment Report for Single-Shell Tank Waste management Area T (January 1998 through December 2001). PNNL-13929, Pacific Northwest National Laboratory, Richland, Washington.

Johnson VG and CJ Chou. 1998. Results of Phase I Groundwater Quality Assessment for Single-Shell Tank Waste Management Areas S-SX at the Hanford Site. PNNL-11810, Pacific Northwest National Laboratory, Richland Washington.

Johnson VG and CJ Chou. 2001. RCRA Groundwater Quality Assessment Report for Waste Management Area S-SX (November 1997 through April 2000). PNNL-13441, Pacific Northwest National Laboratory, Richland, Washington.

Johnson VG and CJ Chou. 2002. Groundwater Quality Assessment Report for Waste Management Area S-SX (April 2000 through December 2001). PNNL-13801, Pacific Northwest National Laboratory, Richland Washington.

Kipp RL and RD Mudd. 1974. Selected Water Table Contour Maps and Well Hydrographs for the Hanford Reservation, 1944-1973. BNWL-B-360, Pacific Northwest Laboratories, Richland, Washington.

Knepp AJ. 2002a. Field Investigation Report for Waste Management Area S-SX. RPP-7884, Rev. 0, CH2M HILL Hanford Group, Inc., Richland, Washington.

Knepp AJ. 2002b. Field Investigation Report for Waste Management Area B-BX-BY. RPP-10098, Rev. 0, CH2M HILL Hanford Group, Inc., Richland, Washington.

Lahee FH. 1961. Field Geology. Sixth Edition, McGraw-Hill Book Company, New York. 
Last GV, BN Bjornstad, MP Bergeron, DW Wassace, DR Newcomer, JA Schramke, MA Chamness, CS Cline, SP Airhart, and JS Wilbur. 1989. Hydrogeology of the 200 Areas Low-Level Burial Grounds An Interim Report, Volumes 1 and 2. PNL-6820, Pacific Northwest National Laboratory, Richland, Washington.

Last GV, DW Duncan, MJ Graham, MD Hall, VW Hall, DS Landeen, JG Leitz, and RM Mitchell. 1994. 216-U-10 Pond and 216-Z-19 Ditch Characterization Studies. WHC-EP-0707 (formerly FHO-ST-45). Westinghouse Hanford Company, Richland, Washington.

Lindberg JW. 1997. Combination RCRA Groundwater Monitoring Plan for the 216-A-10, 216-A-36B, and 216-A-37-1 PUREX cribs. PNNL-11523, Pacific Northwest National Laboratory, Richland, Washington.

Lindberg JW, SM Narbutovskih, MD Sweeney, DB Barnett, DG Horton, and EC Thornton. 2006. Chapter 2.11, "200-PO-1 Operable Unit." In Hanford Site Groundwater Monitoring for Fiscal Year 2005, MJ Hartman, LF Morasch, and WD Webber (eds.), PNNL-15670, Pacific Northwest National Laboratory, Richland, Washington.

Lindberg JW, EC Thornton, DB Barnett, JP McDonald, PE Dresel, SM Narbutovskih, and MD Sweeney. 2003. Chapter 2.9, "200 East Area." In Hanford Site Groundwater Monitoring for Fiscal Year 2002, MJ Hartman, LF Morasch, and WD Webber (eds.), PNNL-14187, Pacific Northwest National Laboratory, Richland, Washington.

Lindsey KA. 1995. Miocene-to Pliocene-Aged Suprabasalt Sediments of the Hanford Site, SouthCentral Washington. BHI-00184, Rev. 0, Bechtel Hanford, Inc., Richland, Washington.

Lindsey KA. 1996. The Miocene to Pliocene Ringold Formation and Associated Deposits of the Ancestral Columbia River System, South-Central Washington and North-Central Oregon. Open-File Report 96-8, Washington State Department of Natural Resources, Washington Division of Geology and Earth Resources, Olympia, Washington.

McDonald JP, MA Chamness, and DR Newcomer. 1999. Water Level Monitoring Plan for the Hanford Groundwater Monitoring Project. PNNL-13021, Pacific Northwest National Laboratory, Richland, Washington.

McDonald JP, DB Erb, RM Smith, RL Weiss, and BA Williams. 2004. Chapter 2.9, “200-ZP-1 Operable Unit." In Hanford Site Groundwater Monitoring for Fiscal Year 2003, MJ Hartman, LF Morasch, and WD Webber (eds.), PNNL-14548, Pacific Northwest National Laboratory, Richland, Washington.

McDonald JP, RM Smith, BA Williams, LC Swanson, SW Peterson, and RL Weiss. 2005. Chapter 2.9, “200-ZP-1 Operable Unit.” In Hanford Site Groundwater Monitoring for Fiscal Year 2004, MJ Hartman, LF Morasch, and WD Webber (eds.), PNNL-14548, Pacific Northwest National Laboratory, Richland, Washington.

McDonald JP, RM Smith, BA Williams, DB Erb, and RL Weiss. 2006. Chapter 2.9, “200-ZP-1 Operable Unit.” In Hanford Site Groundwater Monitoring for Fiscal Year 2005, MJ Hartman, LF Morasch, and WD Webber (eds.), PNNL-15670, Pacific Northwest National Laboratory, Richland, Washington. 
Mirabella JE. 1977. Radioactive Liquid Wastes Discharged to Ground in the 200 Areas During 1976. ARH-CD-743 4Q, Atlantic Richfield Hanford Company, Richland, Washington.

Myers DA. 2005. Field Investigation Report for Waste Management Areas T and TX-TY. RPP-23752, Rev. 0. CH2M HILL Hanford Group, Inc., Richland, Washington.

Narbutovskih SM and DG Horton. 2001. RCRA Groundwater Monitoring Plan for Single-Shell Tank Waste Management Area A-AX at the Hanford Site. PNNL-13023, Pacific Northwest National Laboratory, Richland, Washington.

Narbutovskih SM and CJ Chou. 2006. RCRA Assessment Plan for Single-Shell Tank Waste Management Area A-AX at the Hanford Site. PNNL-15315, Pacific Northwest National Laboratory, Richland, Washington.

Narbutovskih SM, JP McDonald, R Schalla, and MD Sweeney. 2002. "Application of the Collodial Borescope to Determine a Complex Groundwater Flow Pattern." Evaluation and Remediation of Low Permeability and Dual Porosity Environments, ASTM STP 1415, MN Sara and LG Everett (eds.), ASTM International, West Conshohocken, Pennsylvania.

RCRA - Resource Conservation and Recovery Act. 1976. Public Law 94-580, as amended, 90 Stat. 2795, 42 USC 6901 et seq.

Reidel SP, DG Horton, Y Chien, DB Barnett, and K Singleton. 2006. Geology, Hydrogeology, Geochemistry, and Mineralogy Data Package. RPP-23748, Rev. 0. CH2M HILL Hanford Group, Inc., Richland, Washington.

Rucker DF, FM Levitt, C Henderson, and K Williams. 2006a. Surface Geophysical Exploration of T Tank Farm at the Hanford Site. RPP-RPT-28955, CH2M HILL Hanford Group, Inc., Richland, Washington.

Rucker DF, FM Levitt, C Henderson, and K Williams. 2006b. Surface Geophysical Exploration of $S$ Tank Farm at the Hanford Site. RPP-RPT-30976, CH2M HILL Hanford Group, Inc., Richland, Washington.

Schalla R and SM Narbutovskih. 2006. "Determining Vertical Contaminant Distribution in Groundwater." In Proceedings of the 2006 North American Environmental Field Conference and Exposition, January 10 - 12, 2006, Tampa, Florida. The Nielsen Environmental Field School, Galena, Ohio.

Serne RJ, HT Schaef, BN Bjornstad, DC Lanigan, GW Gee, CW Lindenmeier, RE Clayton, VL LeGore, RD Orr, MJ O'Hara, CF Brown, GV Last, IV Kutnyakov, DS Burke, TC Wilson, and BA Williams. 2002a. Characterization of Vadose Zone Sediment: Borehole 299-W23-19 [SX-115] in the S-SX Waste Management Area. PNNL-13757-2, Pacific Northwest National Laboratory, Richland, Washington.

Serne RJ, GV Last, GW Gee, HT Schaef, DC Lanigan, CW Lindenmeier, MJ Lindberg, RE Clayton, VL LeGore, RD Orr, SR Baum, KN Geiszler, CF. Brown, MM Valenta, and TS Vickerman. 2002b. Characterization of Vadose Zone Sediment: Borehole 299-E33-45 Near BX-102 in the B-BX-BY Waste Management Area. PNNL-14083, Pacific Northwest National Laboratory, Richland, Washington. 
Serne RJ, BN Bjornstad, GW Gee, HT Schaef, DC Lanigan, RG McCain, CW Lindenmeier, RD Orr, VL LeGore, RE Clayton, MJ Lindberg, IV Kutnyakov, SR Baum, KN Geiszler, MM Valenta, TS Vickerman, and LJ Royack. 2002c. Characterization of Vadose Zone Sediment: Borehole 299-E33-46 Near B-110 in the B-BX-BY Waste Management Area. PNNL-14119, Pacific Northwest National Laboratory, Richland, Washington.

Serne RJ, MJ Lindberg, SR Baum, BN Bjornstad, RE Clayton, KN Geiszler, DG Horton, VL LeGore, MM Valenta, DC Lanigan, RD Orr, TS Vickerman, CW Lindenmeier, and IV Kutnyakov. 2004a. Characterization of Vadose Zone Sediment Below the TX Tank Farm: Boreholes C3830, C3831, C3832 and RCRA Borehole 299-W10-27. PNNL-14594, Pacific Northwest National Laboratory, Richland, Washington.

Serne RJ, BN Bjornstad, DG Horton, DC Lanigan, HT Schaef, CW Lindenmeier, MJ Lindberg, RE Clayton, VL LeGore, KN Geiszler, SR Baum, MM Valenta, IV Kutnyakov, TS Vickerman, RD Orr, and CF Brown. 2004b. Characterization of Vadose Zone Sediment Below the T Tank Farm: Boreholes C4104, C4105, 299-W10-196, and RCRA Borehole 299-W11-39. PNNL-14849, Pacific Northwest National Laboratory, Richland, Washington.

Sliger GJ. 1980. Radioactive Liquid Wastes Discharged to Ground in the 200 Areas During 1979. RHO-CD-79 4Q, Rockwell Hanford Operations, Richland, Washington.

Sliger GJ. 1982. Radioactive Liquid Wastes Discharged to Ground in the 200 Areas During 1981. RHO-HS-SR-81-3 4QLIQ, Rockwell Hanford Operations, Richland, Washington.

Sliger GJ. 1983. Radioactive Liquid Wastes Discharged to Ground in the 200 Areas During 1982. RHO-HS-SR-82-3 4Q LIQ P, Rockwell Hanford Operations, Richland, Washington.

Spane FA Jr and DR Newcomer. 2004. Results of Detailed Hydrologic Characterization Tests - Fiscal Year 2003. PNNL-14804, Pacific Northwest National Laboratory, Richland, Washington.

Spane FA Jr, P D Thorne, and DR Newcomer. 2001a. Results of Detailed Hydrologic Characterization Tests - Fiscal Year 1999. PNNL-13378, Pacific Northwest National Laboratory, Richland, Washington.

Spane FA Jr, PD Thorne, and DR Newcomer. 2001b. Results of Detailed Hydrologic Characterization Tests - Fiscal Year 2000. PNNL-13514, Pacific Northwest National Laboratory, Richland, Washington.

Spane FA Jr, DR Newcomer, and PD Thorne. 2002. Results of Detailed Hydrologic Characterization Tests - Fiscal Year 2001. PNNL-14113, Pacific Northwest National Laboratory, Richland, Washington.

Spane FA Jr, DR Newcomer, and PD Thorne. 2003. Results of Detailed Hydrologic Characterization Tests - Fiscal Year 2002. PNNL-14186, Pacific Northwest National Laboratory, Richland, Washington.

Stiff HA Jr. 1983. "The Interpretation of Chemical Water Analysis by Means of Patterns." In Chemical Hydrology, W Back and RA Freeze (eds.), Benchmark Papers in Geology, Volume 73, Hutchinson Ross Publishing Company, Stroudsburg, Pennsylvania. 
Thorne PD, MA Chamness, FA Spane Jr, VR Vermeul, and WD Webber. 1993. Three Dimensional Conceptual Model for the Hanford Site Unconfined Aquifer System, FY 93 Status Report. PNL-8971, Pacific Northwest Laboratory, Richland, Washington.

Thorne PD. 2004. Groundwater Data Package for the 2004 Composite Analysis. PNNL-14753, Rev. 0., Pacific Northwest National Laboratory, Richland, Washington.

Thornton EC, PE Dresel, SM Narbutovskih, MD Sweeney, and JP McDonald. 2006. Chapter 2.10, "200-BP-5 Operable Unit." In Hanford Site Groundwater Monitoring for Fiscal Year 2005, MJ Hartman, LF Morasch, and WD Webber (eds.), PNNL-15670, Pacific Northwest National Laboratory, Richland, Washington.

Thornton EC, GS Thomas, PE Dresel, SM Narbutovskih, and MD Sweeney. 2007. Chapter 2.10, “200-BP-5 Operable Unit." In Hanford Site Groundwater Monitoring for Fiscal Year 2006, MJ Hartman, LF Morasch, and WD Webber (eds.), PNNL-16346, Pacific Northwest National Laboratory, Richland, Washington.

Waldrop WR and HS Pearson. 2000. Results of Field Tests with the Electromagnetic Borehole Flowmeter at the Pacific Northwest National Laboratory, Richland, WA. QEC-T-132, Quantum Engineering Corporation, Loudon, Tennessee.

Williams BA and SM Narbutovskih. 2004. Borehole Data Package for Four CY 2003 RCRA Wells 299E27-4, 299-E27-21, 299-E27-22, and 299-E27-23 at Single-Shell Tank, Waste Management Area C, Hanford Site, Washington. PNNL-14656, Pacific Northwest National Laboratory, Richland, Washington.

Williams BA, BN Bjornstad, R Schalla, and WD Webber. 2000. Revised Hydrogeology for the Suprabasalt Aquifer System, 200-East Area and Vicinity, Hanford Site, Washington. PNNL-12261, Pacific Northwest National Laboratory, Richland, Washington.

Williams BA, BN Bjornstad, R Schalla, and WD Webber. 2002. Revised Hydrogeology for the Suprabasalt Aquifer System, 200-West Area and Vicinity, Hanford, Washington. PNNL-13858, Pacific Northwest National Laboratory, Richland, Washington.

Wood MI and TE Jones. 2003. Subsurface Conditions Description of the U Waste Management Area. RPP-15808, Rev. 0. CH2M Hill Hanford Group, Inc., Richland, Washington.

Wood MR, VG Johnson, SP Reidel, and TE Jones. 1999. Subsurface Conditions Description for the SSX Waste Management Area. HNF-4936, Lockheed Martin Hanford Corporation, Richland, Washington.

Wood MI, TE Jones, BN Bjornstad, DG Horton, SM Narbutovskih, and R Schalla. 2003. Subsurface Conditions Description of the C and A-AX Waste Management Area. RPP-14430, CH2M HILL Hanford Group, Inc., Richland, Washington. 


\section{Distribution}

No. of

Copies

DOE Office of River Protection

R. W. Lober H6-60

CH2M HILL Hanford Group, Inc.

F. M. Mann

H6-03
No. of

Copies

4 Pacific Northwest National Laboratory

R. W. Bryce

K6-75

K. M. Krupka

K6-81

Hanford Technical Library (2)

P8-55 